\title{
HYDROGEOLOGY AND CHEMICAL QUALITY OF WATER AND SOIL AT CARROLL ISLAND, ABERDEEN PROVING GROUND, MARYLAND
}

By Frederick J. Tenbus and Scott W. Phillips

\section{U.S. GEOLOGICAL SURVEY}

Water-Resources Investigations Report 96-4169

Prepared in cooperation with the

U.S. ARMY GARRISON, ABERDEEN PROVING GROUND

ENVIRONMENTAL CONSERVATION AND RESTORATION DIVISION ABERDEEN PROVING GROUND, MARYLAND

The contents of this report have been approved for public release and unlimited distribution by the U.S. Army-distribution number 1658-A-3

Towson, Maryland 


\section{U.S. DEPARTMENT OF THE INTERIOR BRUCE BABBITT, Secretary}

U.S. GEOLOGICAL SURVEY GORDON P. EATON, Director

For additional information write to:

District Chief U.S. Geological Survey, WRD 208 Carroll Building 8600 La Salle Road Towson, Maryland 21286
Copies of this report can be purchased from:

U.S. Geological Survey

Branch of Information Services

Box 25286

Denver Federal Center

Denver, Colorado 80225 


\section{CONTENTS}

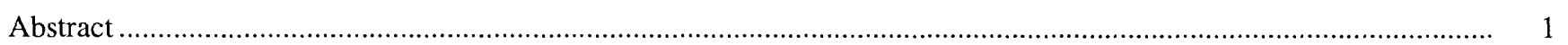

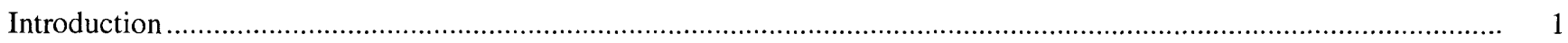

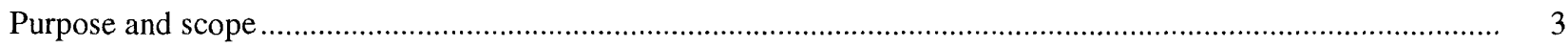

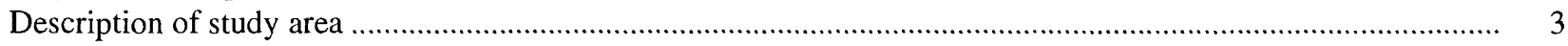

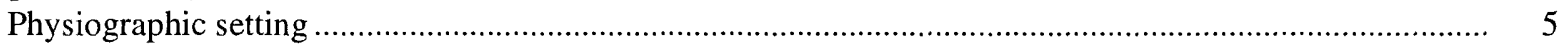

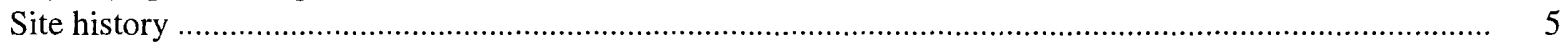

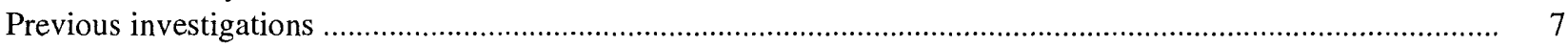

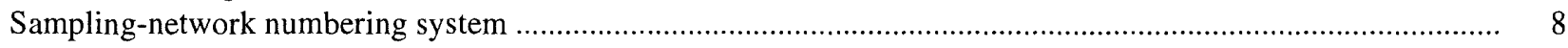

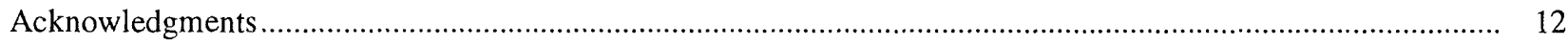

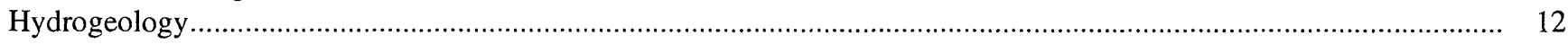

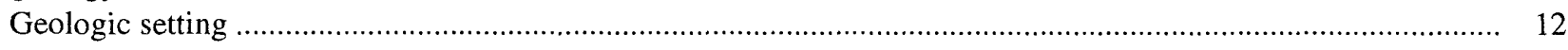

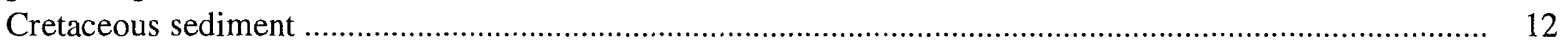

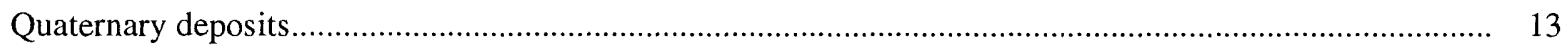

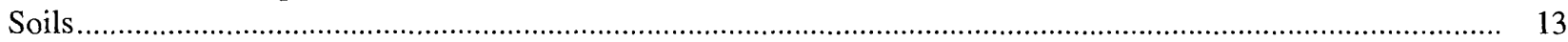

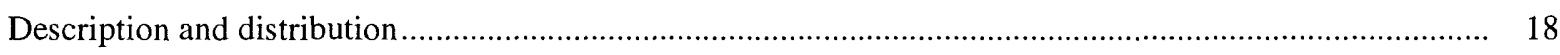

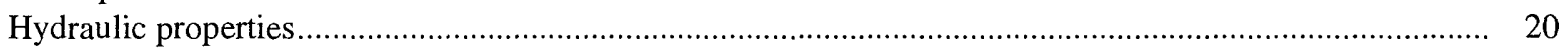

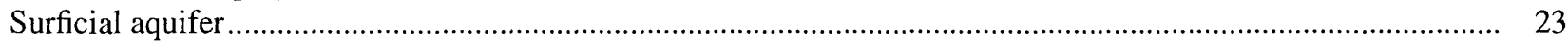

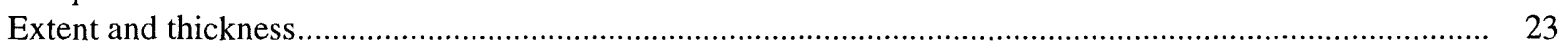

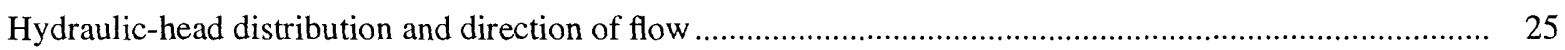

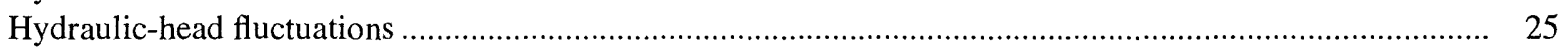

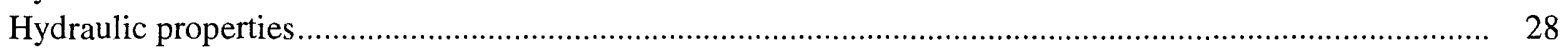

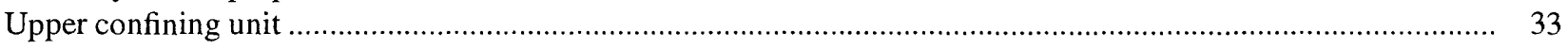

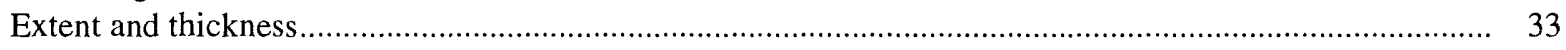

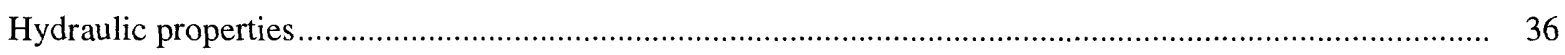

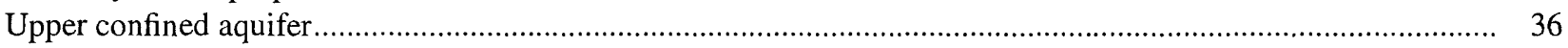

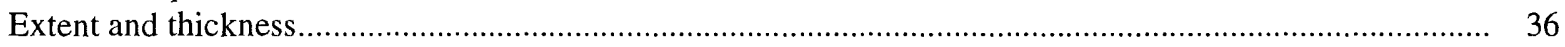

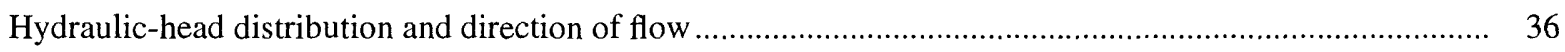

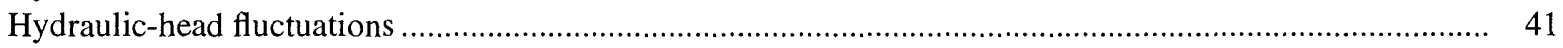

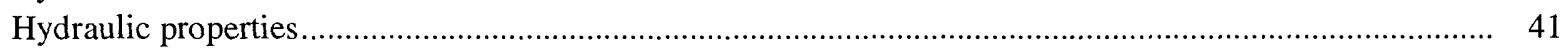

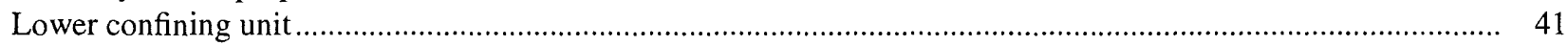

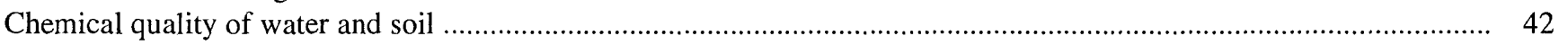

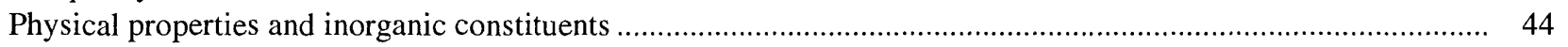

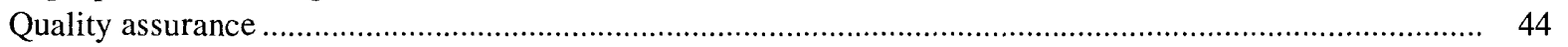

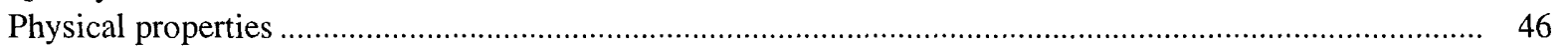

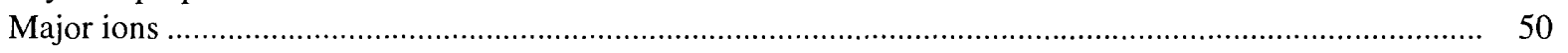

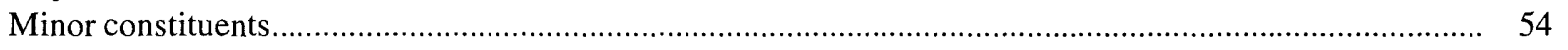

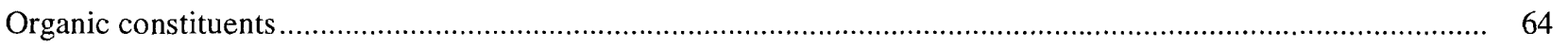

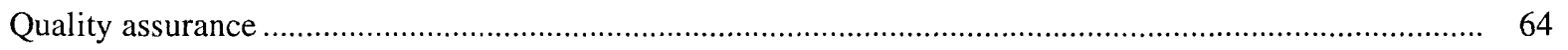

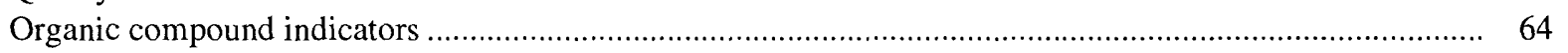

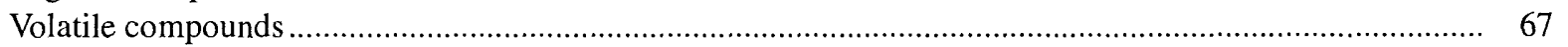

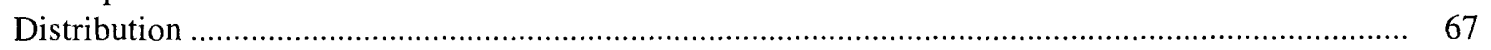

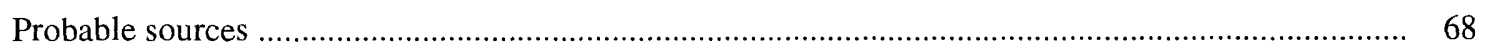

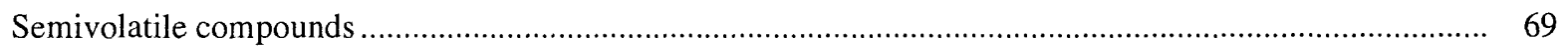

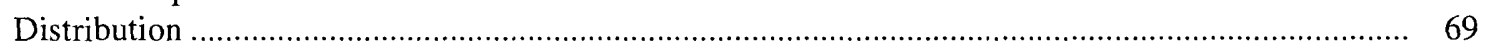

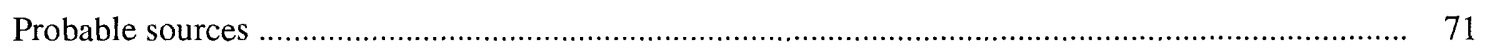

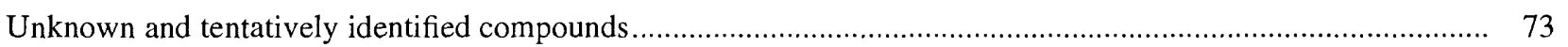

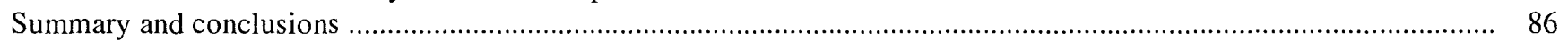

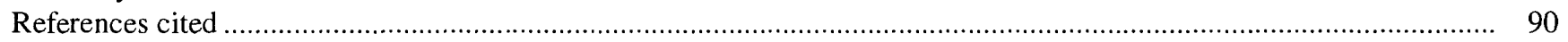

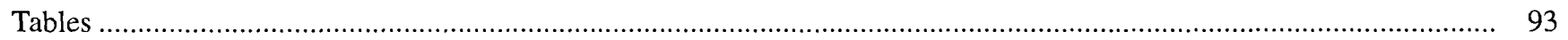




\section{FIGURES}

1-6. Maps showing:

1. Location of Carroll Island study area on Aberdeen Proving Ground near Baltimore, Md.

2. Locations of potential sources of environmental contamination on Carroll Island, Aberdeen Proving Ground, Md.

3. Location of observation wells and test holes on Carroll Island, Aberdeen Proving Ground, Md.

4. Location of surface-water sampling sites on Carroll Island, Aberdeen Proving Ground, Md.

5. Location of soil-sampling sites on Carroll Island, Aberdeen Proving Ground, Md.....

6. Traces of hydrogeologic sections through Carroll Island, Aberdeen Proving Ground, Md., and adjacent areas.

7. Hydrogeologic section A-A' through Carroll Island, Aberdeen Proving Ground, Md.

8. Hydrogeologic section B-B' through Carroll Island, Aberdeen Proving Ground, Md.

9. Hydrogeologic section C-C' through Carroll Island, Aberdeen Proving Ground, Md.

10-13. Maps showing:

10. Soil and land types on Carroll Island, Aberdeen Proving Ground, Md.

11. Thickness of surficial aquifer, Carroll Island, Aberdeen Proving Ground, Md

12. Hydraulic head in the surficial aquifer, Carroll Island, Aberdeen Proving Ground, Md., May 1988 ..

13. Hydraulic head in the surficial aquifer, Carroll Island, Aberdeen Proving Ground, Md., October 1988

14. Hydrograph showing water levels in wells I27B in the surficial aquifer and I27A in the confined aquifer, Carroll Island, Aberdeen Proving Ground, Md., November 1987 through September 1989

15. Hydrograph showing water levels in wells I54A in the surficial aquifer and I54B in the confined aquifer, Carroll Island, Aberdeen Proving Ground, Md., November 1987 through September 1989

16. Graph showing precipitation at Carroll Island, Aberdeen Proving Ground, Md., from October 1987 through October 1988

17-26. Maps showing:

17. Altitude of the top of the upper confining unit, Carroll Island, Aberdeen Proving Ground, Md.

18. Thickness of the upper confining unit, Carroll Island, Aberdeen Proving Ground, Md.

19. Altitude of the top of the upper confined aquifer, Carroll Island, Aberdeen Proving Ground, Md.

20. Thickness of the upper confined aquifer, Carroll Island, Aberdeen Proving Ground, Md.

21. Hydraulic head in the upper confined aquifer, Carroll Island, Aberdeen Proving Ground, Md., May 1988

22. Hydraulic head in the upper confined aquifer, Carroll Island, Aberdeen Proving Ground, Md., October 1988

23. Specific conductance in water samples from selected wells in the surficial aquifer, Carroll Island, Aberdeen Proving Ground, Md., May 1989.

24. Stiff diagrams for water-quality samples from selected wells in the surficial aquifer, Carroll Island, Aberdeen Proving Ground, Md., May 1989.

25. Stiff diagrams for water-quality samples from selected wells in the upper confined aquifer, Carroll Island, Aberdeen Proving Ground, Md., May 1989

26. Stiff diagrams for water-quality samples from selected surface-water sampling sites, Carroll Island, Aberdeen Proving Ground, Md., May 1989

\section{TABLES}

1. Known quantities of chemicals released on Carroll Island, Aberdeen Proving Ground, Md., from July 1964 through December 1971

2. Soil or land type at each solid waste management unit, chemical-agent test area, and well location,

Carroll Island, Aberdeen Proving Ground, Md. 


\section{TABLES--Continued}

3. Summary of slug-test results in the surficial aquifer, Carroll Island, Aberdeen Proving Ground, Md., May through September 1988

4. Summary of slug-test results in wells completed in the confined aquifer, Carroll Island, Aberdeen Proving Ground, Md., May through June 1988.

5. Range of selected physical properties and concentrations of major inorganic constituents in groundwater and surface-water samples, Carroll Island, Aberdeen Proving Ground, Md., spring 1989.

6. Range of concentrations of selected inorganic constituents in soil samples, Carroll Island, Aberdeen Proving Ground, Md., summer 1990

7. Range of concentrations of selected minor inorganic constituents in ground-water and surface-water samples, Carroll Island, Aberdeen Proving Ground, Md., spring 1989

8. Locations and concentrations of selected organic constituents detected in ground-water, surface-water, and soil samples, Carroll Island, Aberdeen Proving Ground, Md., spring 1989 and summer 1990

9. Locations and concentrations of selected unknown compounds detected in ground-water and surfacewater samples, Carroll Island, Aberdeen Proving Ground, Md., spring 1989

10. Locations and concentrations of selected unknown compounds detected in soil samples at Carroll Island, Aberdeen Proving Ground, Md., summer 1990

11. Results of inorganic-chemical analyses of water from selected wells in the surficial aquifer at Carroll Island, Aberdeen Proving Ground, Md., spring 1989

12. Results of inorganic-chemical analyses of water from wells in the confined aquifer at Carroll Island, Aberdeen Proving Ground, Md., spring 1989

13. Results of organic-chemical analyses of water from selected wells in the surficial aquifer at Carroll Island, Aberdeen Proving Ground, Md., spring 1989

14. Results of organic-chemical analyses of water from wells in the confined aquifer at Carroll Island, Aberdeen Proving Ground, Md., spring 1989

15. Results of inorganic-chemical analyses of surface water from selected sampling sites at Carroll Island, Aberdeen Proving Ground, Md., spring 1989

16. Results of organic-chemical analyses of surface water from selected sampling sites at Carroll Island, Aberdeen Proving Ground, Md., spring 1989.

17. Results of inorganic-chemical analyses of soil from selected sampling sites at Carroll Island, Aberdeen Proving Ground, Md., summer 1990.

18. Results of organic-chemical analyses of soil from selected sampling sites at Carroll Island, Aberdeen Proving Ground, Md., summer 1990.

19. Results of inorganic-chemical analyses of equipment blanks at Carroll Island, Aberdeen Proving Ground, Md., spring 1989

20. Results of organic-chemical analyses of equipment blanks at Carroll Island, Aberdeen Proving Ground, Md., spring 1989.

21. Tentative identification of unknown organic compounds in water from wells and blank samples at Carroll Island, Aberdeen Proving Ground, Md., spring 1989.

22. Tentative identification of unknown organic compounds in surface water from selected sampling sites at Carroll Island, Aberdeen Proving Ground, Md., spring 1989

23. Tentative identification of unknown organic compounds in soil from selected sampling sites at Carroll Island, Aberdeen Proving Ground, Md., summer 1990 


\section{CONVERSION FACTORS, VERTICAL DATUM, ACRONYMS, AND ABBREVIATIONS}

\begin{tabular}{rll}
\hline Multiply & \multicolumn{1}{c}{ By } & To obtain \\
acre & & square meter \\
acre & 4,047 & hectare \\
inch (in.) & 0.4047 & millimeter \\
mile(mi) & 25.4 & kilometer \\
foot (ft) & 1.609 & meter \\
foot per day (ft/d) & 0.3048 & meter per day \\
gallon & 0.3048 & liter \\
gallon per minute (gal/min) & 3.785 & liter per second \\
pound, avoirdupois (lb) & 0.06309 & kilogram \\
\hline
\end{tabular}

Temperature is degrees Fahrenheit $\left({ }^{\circ} \mathrm{F}\right)$ can be converted to degrees Celsius $\left({ }^{\circ} \mathrm{C}\right)$ by using the following equation:

$$
{ }^{\circ} \mathrm{C}=5 / 9 \times\left({ }^{\circ} \mathrm{F}-32\right)
$$

Sea level: In this report, "sea level" refers to the National Geodetic Vertical Datum of 1929--a geodetic datum derived from a general adjustment of the first-order level nets of the United States and Canada, formerly called Sea Level Datum of 1929.

Chemical concentrations and water temperature are given in metric units. Chemical concentration for water is given in milligrams per liter $(\mathrm{mg} / \mathrm{L})$ or micrograms per liter $(\mu \mathrm{g} / \mathrm{L})$. Chemical concentration for soil is given in micrograms per gram $(\mu \mathrm{g} / \mathrm{g})$. Milligrams per liter is a unit expressing the concentration of chemical constituents in solution as well as weight (milligrams) of solute per unit volume (liter) of water. One thousand micrograms per liter is equivalent to one milligram per liter. For concentrations less than $7,000 \mathrm{mg} / \mathrm{L}$, the numerical value is the same as for concentrations in parts per million.

Specific electrical conductance of water is expressed in microsiemens per centimeter at 25 degrees Celsius $(\mu \mathrm{S} / \mathrm{cm})$. This unit is equivalent to micromhos per centimeter at 25 degrees Celsius $(\mu \mathrm{mho} / \mathrm{cm})$, formerly used by the U.S. Geological Survey. 


\section{ACRONYMS AND ABBREVIATIONS}

APG:

AHEA:

ARAR:

BBC:

Bis:

BZ:

CERCLA:

CFC:

$\mathrm{CN}$ :

COE:

CS:

CS-1:

CS-2:

DANC:

DBHP:

DEHP:

DM:

DMHP:

EA 1356:

EA 3528:

EA 3834:

EA 3990:

EDA:

EPG:

FS:

FWA:

FWC:

GA:

GB:

GC/MS:

GD:

HC:

HD:

HGA:

MCL:

MCLG:

NWQL:

PAH

RCRA:

RFI:

SMCL:

SWMU:

TEA:

TOF:

TOH:

Aberdeen Proving Ground

U.S. Army Environmental Hygiene Agency

Applicable or Relevant and Appropriate Regulation

An irritant (bromobenzyl cyanide)

A simulant (bis-2-ethylhexyl hydrogen phosphite)

An incapacitating agent (3-quinuclidinyl benzilate)

Comprehensive Environmental Response, Compensation, and Liability Act

Chlorofluorocarbon

A tear agent (chloroacetophenone)

U.S. Army Corps of Engineers

A tear agent (o-chlorobenzylidene malononitrile)

CS blended with 5-percent silica aerogel

CS blended with a hydrophoric compound

Decontaminating agent, non-corrosive

A simulant (dibutyl hydrogen phosphite)

A simulant

Adamsite, a vomiting agent (diphenylamine-chloroarsine)

A simulant (dimethyl hydrogen phosphite)

An organophosphorus nerve agent

An incapacitating agent

An incapacitating agent (1-methyl-4-piperidyl isopropyl phenylglycolate)

A nerve agent

A simulant (ethylenediamine)

Edgewood Proving Ground

A screening smoke (sulfur trioxide and chlorosulfonic acid)

Fresh-water acute

Fresh-water chronic

The nerve agent tabun (ethyl N,N-dimethyl phosphoroamidocyanidate)

Sarin, a nerve agent (isopropyl methyl phosphonofluoridate)

Gas-chromatography mass spectroscopy

Soman, a nerve agent (pinacolyl methyl phosphonofluoridate)

A smoke mixture (hexachloroethane with various other materials)

Distilled mustard, a blister agent (bis(2-chloroethyl) sulfide)

Hydrogeologic assessment

Maximum Contaminant Level

Maximum Contaminant Level Goal

U.S. Geological Survey National Water Quality Laboratory

Polycyclic aromatic hydrocarbons

Resource Conservation Recovery Act

RCRA facility investigation

Secondary Maximum Contaminant Level

Solid waste management unit

An incendiary (triethyl aluminum)

A simulant (tri(2-ethylhexyl) phosphate)

Total organic halogens

USATHAMA: U.S. Army Toxic and Hazardous Materials Agency

USEPA:

U.S. Environmental Protection Agency 


\section{ACRONYMS AND ABBREVIATIONS--Continued}

USGS

$\mathrm{VX}$ :

WP:
U.S. Geological Survey

A nerve agent ( $\beta$-diisopropylaminoethyl-mercapto-O-ethyl methyl- phosphonothioate) White phosphorus, an incendiary or smoke munition 


\title{
Hydrogeology and Chemical Quality of Water and Soil at Carroll Island, Aberdeen Proving Ground, Maryland
}

\author{
By Frederick J. Tenbus and Scott W. Phillips
}

\section{ABSTRACT}

Carroll Island was used for open-air testing of chemical warfare agents from the late 1940's until 1971. Testing and disposal activities were suspected of causing environmental contamination at 16 sites on the island. The hydrogeology and chemical quality of ground water, surface water, and soil at these sites were investigated with borehole logs, environmental samples, water-level measurements, and hydrologic tests. A surficial aquifer, upper confining unit, and upper confined aquifer were defined. Ground water in the surficial aquifer generally flows from the east-central part of the island toward the surface-water bodies, but gradient reversals from low water levels caused by evapotranspiration can occur during dry seasons. In the confined aquifer, hydraulic gradients are low, and hydraulic head is affected by tidal loading and by seasonal pumpage from the west. Inorganic chemistry in the aquifers is affected by brackish-water intrusion from the gradient reversals and by dissolution of carboniferous shell material in the confining unit. The concentrations of most inorganic constituents probably resulted from natural processes, although some concentrations exceeded Federal water-quality regulations and criteria. Organic compounds were detected in water and soil samples at maximum concentrations of 138 micrograms per liter (thiodiglycol in surface water) and 12 micrograms per gram (octadecanoic acid in soil). Concentrations of organic compounds in ground water exceeded maximum levels specified in Federal drinking-water regulations at two sites. The organic compounds detected in environmental samples were attributed to natural processes, laboratory or field-sampling contamination, fallout from industrial air pollution, and historical military activities.

\section{INTRODUCTION}

The Edgewood Area of Aberdeen Proving Ground (APG), Maryland, has been used to develop, manufacture, and test chemical agents and munitions since World War I. These include smoke munitions such as white phosphorus (WP), nerve agents such as sarin (GB) and VX, blister agents such as mustard (HD) and lewisite, vomiting agents such as adamsite (DM), tear agents such as $\mathrm{CN}$ and $\mathrm{CS}$, and incapacitating agents such as BZ. An environmental survey of the Edgewood Area was conducted by the U.S. Army Toxic and Hazardous Materials Agency (USATHAMA) during 1977 and 1978 to determine the effect of past manufacturing and testing operations on the environment (Nemeth and others, 1983). The report from this environmental survey identified several areas that were contaminated to some degree, including Canal Creek, O-Field, J-Field, Graces Quarters, and Carroll Island (fig. 1).

In 1986, the U.S. Environmental Protection Agency (USEPA) issued a Resource Conservation and Recovery Act (RCRA) permit (MD3-21-002-1355) to address solid waste management units (SWMU's) in the Edgewood Area of APG. Solid waste management units are sites that contain hazardous materials and thus have a potential effect on the environment. The RCRA permit required that a hydrogeologic assessment (HGA) be performed at each of the areas that contained SWMU's; Carroll Island was identified as one of these areas.

In October 1986, at the request of the Environmental Management Office of APG, the U.S. Geological Survey (USGS) began an HGA of Carroll Island. The purpose of the HGA was to collect hydrologic data in the vicinity of SWMU's to provide a framework for characterizing any release and movement of contaminants. The HGA also would provide information about chemical-agent test sites, including the type of chemical agent tested and the period in which testing took place. 


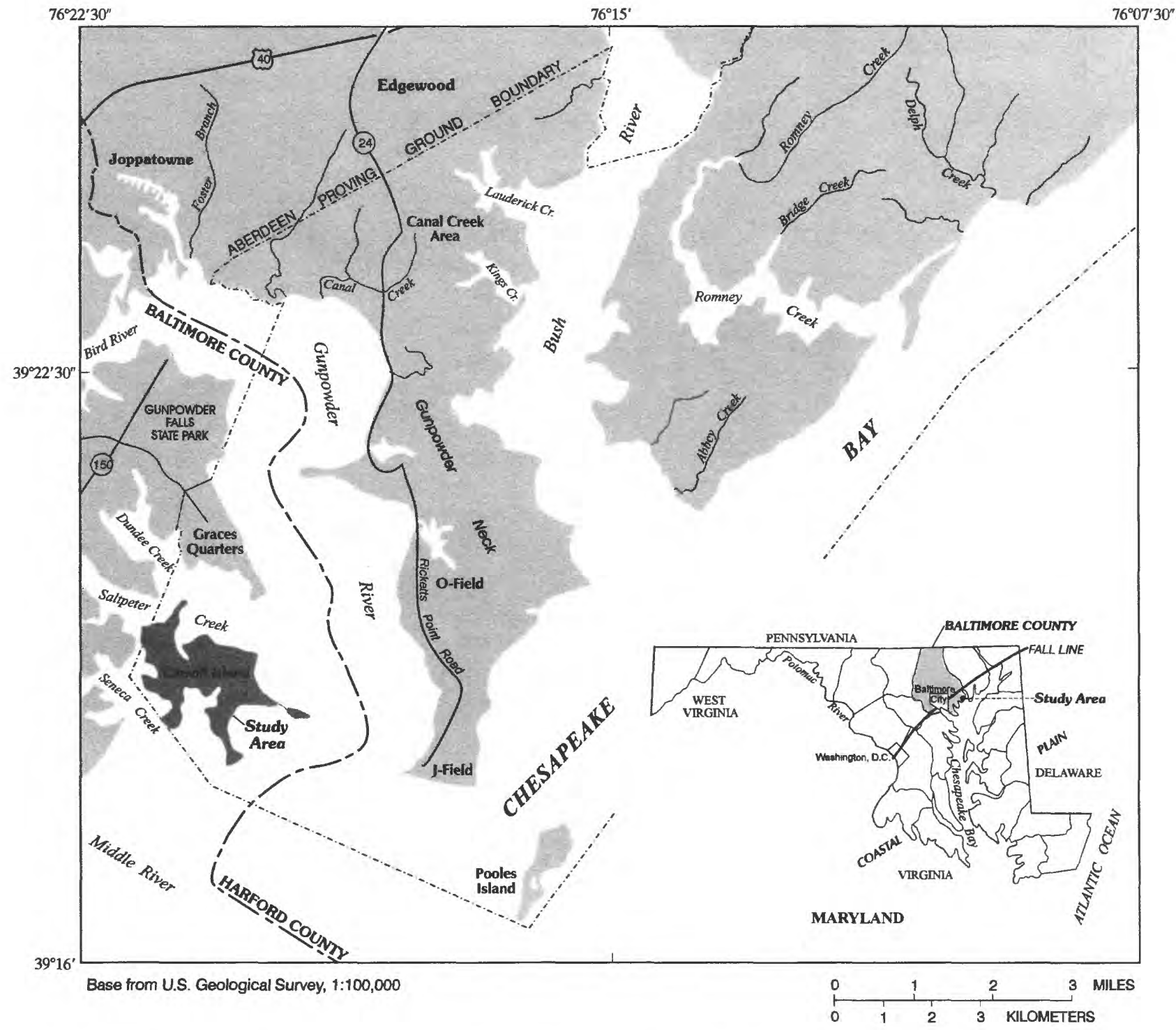

Figure 1. Location of Carroll Island study area on Aberdeen Proving Ground near Baltimore, Maryland. 
In 1988, the RCRA permit was renewed, the requirements for RCRA had changed, and the HGA became the RCRA Facility Investigation (RFI). The RFI required that an observation-well network be established to determine the directions and rates of ground-water movement, the concentrations and spatial distributions of selected chemical constituents, and the spatial distributions of selected compounds that may be considered indicators of ground-water contamination. These data were necessary so that predictive methods such as ground-water and solute-transport models could be developed to aid in the planning of any remediation efforts that may be needed. The RFI also required that a surface-water and soil-sampling network be developed to provide information on the concentrations and spatial distributions of constituents in these media.

In February 1990, the Edgewood Area of APG was placed on the USEPA National Priorities List. Since that time, the Edgewood Area studies have been under Comprehensive Environmental Response, Compensation, and Liability Act (CERCLA) guidelines. The data and reports from this study will be used to fulfill some of the CERCLA requirements for the remedial investigation at Carroll Island.

\section{Purpose and Scope}

The purpose of this report is to (1) describe the hydrogeologic system of Carroll Island, including the soils, aquifers, confining units, and ground-water flow paths; (2) describe the inorganic and organic constituents of the ground water, surface water, and soils in the Carroll Island area; and (3) make preliminary inferences as to the source of the inorganic and organic constituents in the water and soils.

Sixteen sites on Carroll Island have been identified as potential contaminant sources (fig. 2). Five of the sites were used for disposal of test materials and equipment, nine areas were used primarily for testing purposes, and two other areas were used as support facilities during the Carroll Island testing. The potential contamination sources were identified from aerial photos, site visits, and existing literature.

The lithology, distribution, and hydrologic properties of soils on Carroll Island were examined by comparing data from the county soil survey (Reybold and Matthews, 1976) with field observations and borehole logs. The lithology and hydrogeology of the aquifers and confining units were examined using test holes and observation wells that were drilled on the site. Slug tests were used to determine aquifer properties. Water levels in the wells were measured monthly from July 1987 through March 1989, and in June and August 1989. Automatic water-level recorders were installed on selected wells to record water levels continuously at 15-minute intervals. A tide gage was installed to help in the investigation of ground-water/surface-water interactions, and a rain gage was installed to help quantify recharge rates from precipitation. Two rounds of sampling for ground water and surface water were done, to compare the wet season (winter and spring) with the dry season (summer and fall). Surficial soil samples were collected within and near the potential contaminant sources.

\section{Description of Study Area}

Aberdeen Proving Ground is located on the western shore of the Chesapeake Bay in Harford and Baltimore Counties, Maryland. The land area of APG is approximately 30,000 acres (Nemeth, 1989, p. 1), and consists primarily of peninsulas and islands along the upper Chesapeake Bay. Carroll Island is an 855 -acre island located in the southwestern part of the Edgewood Area (fig. 1). The island is surrounded by estuaries, including the Gunpowder River and two tidal creeks. Carroll Island is not connected by land to any other part of APG.

The land areas near Carroll Island are not densely populated. Several small communities and some scattered houses are located nearby, but development in the immediate area has not been extensive. Some of the houses nearby obtain drinking water from wells, but the communities are generally connected to municipal water supplies. Two commercial groundwater users are in the area--a power plant, located directly west of Carroll Island, and a nursery, located to the northwest across Saltpeter Creek (fig. 1). The power plant has an aquaculture facility that draws water from a well at a rate of approximately $150 \mathrm{gal} / \mathrm{min}$ (gallon per minute) during the hottest part of the summer (Curry Woods, C.P. Crane Aquaculture Facility, written commun., 1988). The water is added to the estuary water in the fish tanks of the aquaculture facility for cooling purposes. The nursery uses ground water during the growing season to water plants and trees. 


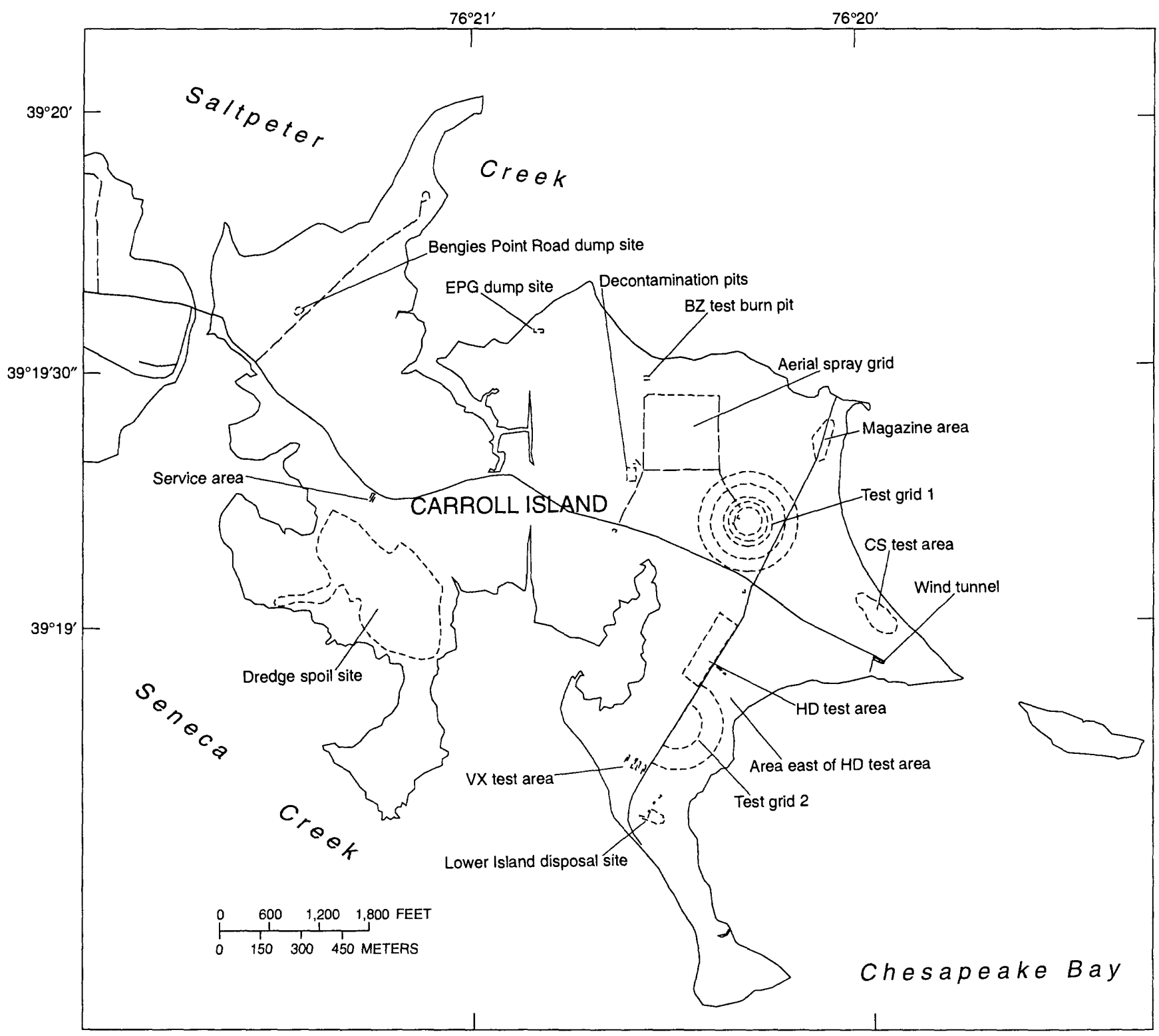

Base modified from U.S. Army, 1:4,800, 1970

Figure 2. Locations of potential sources of environmental contamination on Carroll Island, Aberdeen Proving Ground, Maryland. 
No military activities are currently conducted on Carroll Island. Access to Carroll Island is restricted, but surrounding water bodies are used for recreational purposes such as boating and fishing. The bridge between Carroll Island and the mainland also is used for recreational fishing.

\section{Physiographic Setting}

Carroll Island is within the Atlantic Coastal Plain physiographic province, which extends from Long Island, New York, to Texas (Fenneman, 1938). The Coastal Plain consists of unconsolidated deposits of sand, silt, and clay underlain by crystalline rock. These deposits begin at the Fall Line, which is the boundary between the Coastal Plain and the Piedmont Plateau, and thickens to the east in a wedge shape toward the Atlantic Ocean. The thickness of these sediments is greater than $500 \mathrm{ft}$ (feet) beneath Carroll Island (Otton and Mandle, 1984, p. 9).

The climate in this part of Maryland is temperate and moderately humid, with milder winters than areas farther inland because of the proximity to the Chesapeake Bay (Nemeth, 1989, p. 5). The mean annual precipitation is $45 \mathrm{in}$. (inches) and is distributed fairly uniformly throughout the year. The mean annual temperature is about 54 degrees Fahrenheit $\left({ }^{\circ} \mathrm{F}\right)$.

Altitude of land surface at Carroll Island ranges from sea level to about $13 \mathrm{ft}$. Land cover on Carroll Island consists mainly of marshes and open fields, along with wooded areas and areas of low brush. The distribution of land cover on Carroll Island is shown in Tenbus and Phillips (1990, p. 9).

\section{Site History}

Carroll Island was acquired by the U.S. Army in 1918 (Nemeth, 1989, p. 470). The early history of Army activity in the area is not well documented, but it is likely that Carroll Island was leased out as farm land until the 1940's (Nemeth, 1989, p. 470). In 1944, construction was initiated to prepare Carroll Island for use as a chemical-agent test site (Nemeth, 1989, p. 470). Roads and docks were built, trees and brush were removed, swamps were filled, and existing buildings were renovated. During the construction, parts of Carroll Island were designated as impact areas (Nemeth, 1989 , p. 470).

In the early 1950's, most of the testing of lethal chemical agents at APG was moved from other areas of the Proving Ground to Carroll Island and Graces Quarters (Nemeth, 1989, p. 141). Most testing on Carroll Island took place on the eastern part of the island (Ward, 1971) at four test areas, designated as test grid 1, test grid 2, the aerial spray grid, and the wind tunnel (fig. 2). Five other test areas have been identified from historical records; these areas include an HD test area, VX test area, CS test area, an area east of the HD test area, and the dredge spoil site (fig. 2).

Test grid 1 (fig. 2) was used for chemical-agent testing from the late 1940's through 1971 (Nemeth, 1989, p. 481). The grid consisted of a central testing area surrounded by sampling apparatus located in concentric circles out to 200 yards from the center (Nemeth, 1989, p. 481). Features of the grid that still exist (1993) include a 60-ft metal frame tower near the center of the grid, a sump that was part of the grid's drainage system at the south side of the tower, and remnants of some of the sampling apparatus, such as small concrete squares that were probably used as bases for air-sampling masts.

Test grid 2 (fig. 2) was arranged and used in a similar manner to test grid 1 , but there were no underground drainage, sampling, or control systems and the grid was slightly smaller (Nemeth, 1989, p. 487). The grid was semicircular, with air samplers arranged mainly to the east of the release point (Tenbus and Phillips, 1990, p. 20). Test grid 2 was used primarily for testing items containing smaller quantities of chemical agent than test grid 1, but the total quantity of agent released at test grid 2 was similar to quantities released at the other major test areas on Carroll Island (Nemeth, 1989, p. 487).

The aerial spray grid is located in the northcentral part of Carroll Island (fig. 2). This test area did not have any permanent facilities, such as sampling equipment, associated with it (Nemeth, 1989, p. 484). The feature shown on figure 2 in this area represents dirt roads and ditches that can be seen on aerial photographs. The extent of this test grid is not known exactly, but was believed to include the open field along with adjacent wooded and marshy areas (Nemeth, 1989, p. 484). Most of the chemical releases in this area were by aerial spraying, but other types of ground-contamination studies were probably conducted in this area.

The wind tunnel (fig. 2) was used for the testing of chemical agents from the early 1960's until 1971 (Nemeth, 1989, p. 485). It was a single-story 20 - by $90-\mathrm{ft}$ building constructed of corrugated metal. Fea- 
tures of the wind tunnel included an exhaust scrubber on the north side of the building that was installed at the end of the operational period of the facility, and an underground storage tank at the south end of the building that probably contained about 250 gallons of ethylene glycol and water for coolant (Nemeth, 1989, p. 485). The wind tunnel was dismantled and the underground storage tank was removed in 1994.

The HD test area (fig. 2) is a field in which HD (distilled mustard) and VX (a type of nerve agent) were used for ground-contamination studies (Nemeth, 1989, p. 488). The studies were conducted by contaminating the area and then measuring the persistence of the agent (Nemeth, 1989, p. 488). One series of tests in this area (conducted prior to 1964) involved the release of 1,500 to $2,500 \mathrm{lbs}$ (pounds) of mustard over a several month period by detonating land mines (Nemeth, 1989, p. 148). It is reported that the area was decontaminated using calcium hypochlorite or supertropical bleach after mustard was used (Nemeth 1989, p. 488). The exact dimensions of this test area are unknown.

Less information is available about most of the other areas that were used for testing on Carroll Island. Each of the areas was reportedly used for only a short period of time or for relatively small quantities of chemicals. The VX test area (fig. 2) was used for testing that involved above-ground release of $\mathrm{VX}$, and contamination and decontamination of four rectangular pads made of asphalt and concrete (Tenbus and Phillips, 1990, p. 23). Nemeth (1989, p. 148) reports that up to $600 \mathrm{lbs}$ of VX were released in this area during a several-day period in the early 1960's. The CS test area (fig. 2) was used for the testing of CS, a nonlethal tear agent. The area east of the HD test area (fig. 2) was reportedly used for miscellaneous testing within small wind tunnels and other small structures (Nemeth, 1989, p. 489). The dredge-spoil site (fig. 2) also was used for some testing.

Nemeth $(1989$, p. 146) reports that the history of testing activities is better known for Carroll Island (and Graces Quarters) than for any of the other ranges in the Edgewood Area. Ward (1971) found, however, that detailed records were available only for the testing period after July 1964 (Nemeth, 1989, p. 146). A summary of this information is available in Ward (1971), Ward and Pinkham (1973), and Nemeth (1989, p. 146150). The total amounts of the different types of agent and other chemicals disseminated during testing on Carroll Island from July 1964 through December 1971 are presented in table 1 .
Table 1. Known quantities of chemicals released on Carroll Island, Aberdeen Proving Ground, Md., from July 1964 through December 1971

[From Ward and Pinkham, 1973, p. 10]

\begin{tabular}{|c|c|c|}
\hline Material Released & Type & $\begin{array}{l}\text { Pounds } \\
\text { released }\end{array}$ \\
\hline Talcum powder & simulant $^{1}$ & $5,438.5$ \\
\hline $\mathrm{CS}-1$ & irritant & $3,608.7$ \\
\hline $\mathrm{CS}-2$ & irritant & 664.3 \\
\hline VX & anticholinesterase & 422.4 \\
\hline DBHP & simulant & 403.8 \\
\hline Telvar $^{2}$ & herbicide & 350.0 \\
\hline Furfural & simulant & 264.0 \\
\hline $\mathrm{BZ}$ & incapacitant & 260.4 \\
\hline TEA & incendiary & 221.0 \\
\hline Chloroform and dye & simulant & 208.0 \\
\hline $\mathrm{CN} / \mathrm{DM}$ & irritant & 181.2 \\
\hline $\mathrm{NaOH}$ & decontaminant & 180.0 \\
\hline GB & anticholinesterase & 148.1 \\
\hline WP & screening smoke & 147.5 \\
\hline CS/DM & irritant & 134.2 \\
\hline DMHP & simulant & 48.4 \\
\hline Isopropyl alcohol & simulant & 48.0 \\
\hline Combined nerve agents ${ }^{3}$ & anticholinesterase & 40.0 \\
\hline EDA & simulant & 33.8 \\
\hline GA & anticholinesterase & 31.5 \\
\hline TOF & simulant & 27.2 \\
\hline Signaling smokes & smokes & 26.4 \\
\hline DM & irritant & 15.8 \\
\hline FS & screening smoke & 12.0 \\
\hline 1,2,3-Trichloropropane & simulant & 11.2 \\
\hline Methylacetoacetate & simulant & 11.2 \\
\hline EA 1356 & anticholinesterase & 10.0 \\
\hline Bis & simulant & 9.8 \\
\hline HD & vesicant agent & 7.6 \\
\hline $\mathrm{BBC}$ & irritant & 5.7 \\
\hline $\mathrm{CN}$ & irritant & 4.0 \\
\hline GD & anticholinesterase & 3.0 \\
\hline EA 3834 & incapacitant & 2.3 \\
\hline EA 3528 & incapacitant & 1.0 \\
\hline EA 3990 & anticholinesterase & .7 \\
\hline \multirow[t]{2}{*}{ DEHP } & simulant & .04 \\
\hline & Total pounds & $12,981.74$ \\
\hline
\end{tabular}

\footnotetext{
${ }^{1}$ A substance used to simulate a chemical agent during testing.

${ }^{2}$ Use of firm/trade names in this report is for identification purposes only and does not constitute endorsement by the U.S. Geological Survey.

${ }^{3}$ Old stocks of agents taken to field, dumped, and detoxified on the ground with $\mathrm{NaOH}$.
} 
Wastes from testing operations on Carroll Island were disposed in burn pits and small dump areas (Nemeth and others, 1983, p. 3-6), and within small burial pits. Known disposal sites (fig. 2) include the Lower Island disposal site, Bengies Point Road dump site, the Edgewood Proving Ground (EPG) dump site, the BZ test burn pit, and the decontamination pits. Solid wastes typically generated during field testing included used equipment, protective clothing, and munitions fragments (Nemeth, 1989 , p. 144). Waste items were normally chemically decontaminated prior to disposal if lethal agents were involved in a test (Nemeth, 1989, p. 144).

The Lower Island disposal site (fig. 2) consists of approximately 10 shallow burial pits and a marsh dump site (Nemeth, 1989, p. 474). Disposal consisted of dumping waste items into a pit until it was almost full, then covering the pit with soil (Nemeth, 1989, p. 474). The area is located near a shoreline, and some of the items disposed in this area (probably in the marsh dump site) have been exposed to the estuary through beach erosion. One of the burial pits at the northeast end of the disposal site was left open when test activities on Carroll Island ceased.

The Bengies Point Road dump site is located on the western part of Carroll Island (fig. 2). This dump site is in a low-lying, marshy area; disposal consisted of test materials that were reportedly not contaminated by chemical agent (Nemeth, 1989, p. 477). Materials in this dump site are in direct contact with surface water throughout most of the year.

The EPG dump site (fig. 2) is located at the north end of a linear drainage ditch that extends from north to south in the center of the island. The dump site is believed to be about $30 \mathrm{ft}$ in length (Tenbus and Phillips, 1990 , p. 14; Nemeth, 1989, p. 471). Disposal was on a berm east of the drainage ditch and also within the ditch. Known disposal at this site includes construction material and containers of supertropical bleach. Material at the bottom of the ditch is at times submerged in brackish water.

The BZ test burn pit (fig. 2) is an open pit approximately $10 \mathrm{ft}$ in diameter that was used briefly during the 1960 's. The site was used to study the effectiveness of disposal of BZ (an incapacitating agent) by burning (Nemeth, 1989, p. 480). Adjacent to the pit on the north side is a mound that appears to be excavated soil material from the pit. Magnetometer surveys indicate that there is some buried metal near the pit away from the mound (Tenbus and Phillips, 1990, p. 15).
The decontamination pits (fig. 2) were used to burn items from facilities that had been used in chemical-agent testing at Carroll Island (Nemeth, 1989, p. 478). Both combustible and non-combustible items were burned; wood and fuel oil were used during the burning (Nemeth, 1989, p. 478). The pits were used in 1975 after chemical testing on Carroll Island had ceased. The pits are located in a rectangular area approximately 100 by $180 \mathrm{ft}$, and are 1 to $2 \mathrm{ft}$ deep (Nemeth, 1989, p. 478). Magnetometer surveys indicate that metal is buried in the pits.

Waste disposal on Carroll Island was not limited to the designated disposal sites. Miscellaneous testing debris can be found in several locations, including the service area and dredge-spoil site. In some test areas such as the wind tunnel and test grids 1 and 2 , some of the infrastructure was left in place when testing activities stopped. Information on recent (1990) conditions at each of the test sites and SWMU's is reported in Tenbus and Phillips (1990).

The service area and the magazine area (fig. 2) also were investigated in this study. The service area consisted of two Quonset huts and several small facilities for water supply and waste-water handling (Nemeth, 1989, p. 490). It supported testing operations on Carroll Island and housed various activities such as minor laboratory work and equipment maintenance. The service area had a drilled well for non-potable water uses, and had a small wastewater treatment unit. Some disposal of miscellaneous test equipment took place east of the service area.

The magazine area is a fenced area near the north shore of Carroll Island (fig. 2) at the site of a former dock. The area was used for temporary storage of chemical agents prior to use in test programs, and was used for the filling of chemical munitions prior to testing. Nemeth $(1989$, p. 490) indicates that the area was not used to manage solid waste, and that any chemical spills or leaks were not routine or deliberate.

\section{Previous Investigations}

A series of ecological investigations were performed by the Department of the Army during the 1970 's to determine the effects of chemical-agent testing on Carroll Island. The objectives and methodology of the studies are outlined by Ward (1971). The ecological investigations included concurrent studies of the ecology, toxicology, botany, and analytical techniques. Ecological studies of various organisms are reported in Smrchek (1971a, 1971b), which included investiga- 
tions of invertebrates and soil-litter invertebrate populations; Slack and others (1972) studied populations of reptiles and amphibians on Carroll Island; Roelle and Slack (1972) studied the bird population; and Speir (1972) inventoried the fish diversity. Pinkham and others (1976) compared the mammals on the eastern and western sections of Carroll Island. Weimer and others (1970) studied the acute toxicity of VX and Soman (GD) to three estuarine species taken from the waters of the Gunpowder River near Carroll Island, and Pearson and Bender (1975) investigated the effects of runoff from the Carroll Island dredge spoil site. These ecological investigations indicated that there generally were no discernible long-term effects of chemicalagent testing on the biota in and around the Carroll Island test areas (Nemeth, 1989, p. 210).

In 1977 and 1978, an environmental survey of the Edgewood Area was conducted by the USATHAMA (Nemeth and others, 1983). It was concluded that there was no significant threat to the environment from the contaminants that were found on Carroll Island, and that further ground-water monitoring was not necessary (Nemeth and others, 1983, p. 4-3). In 1986, however, the USEPA issued a RCRA permit for the Edgewood Area of APG. At that time, Gary Nemeth of the U.S. Army Environmental Hygiene Agency (AEHA) began work on the RCRA Facility Assessment of the Edgewood Area. The report from that study (Nemeth, 1989) included descriptions of the SWMU's and test areas on Carroll Island, along with all known information on the testing and disposal practices and types of materials used on Carroll Island.

Also in 1986, U.S. Geological Survey began a hydrogeologic assessment of Carroll Island. This report is one of the resulting products of that study. Previous reports from the study include Ham and others (1991), which presents the hydrogeologic data collected during the study, and Tenbus and Phillips (1990), which presents detailed descriptions of the methodology and sampling rationale for the hydrogeologic assessment.

\section{Sampling-Network Numbering System}

The observation-well network (fig. 3) on Carroll Island consists of 56 wells screened in the surficial or uppermost aquifer and 6 wells screened in confined aquifers. The network was designed to provide information on the hydrogeologic framework of Carroll
Island and to determine whether ground water from the SWMU's and test areas is contaminated.

Thirteen of the wells in the surficial aquifer were installed during an earlier study (Nemeth and others, 1983) that encompassed the entire Edgewood Area of APG, including Carroll Island. The wells drilled on Carroll Island during that study were designated with the letter "I" and are located at sites I01 through I13 (fig. 3).

The same well-numbering system was used for the wells installed during the present study. Each of the well sites was assigned a unique identifier that started with the letter "I" followed by a two-digit number. At some sites, more than one well was installed to allow the investigation of more than one aquifer, or of different sand layers within the uppermost aquifer. In these cases, an "A", " $\mathrm{B}$ ", or " $\mathrm{C}$ " designation was added as a suffix to each individual well at the site, depending on which well was drilled first. The suffix does not indicate the aquifer or part of an aquifer in which a particular well is screened.

At certain well sites, test holes were drilled to provide data about some of the deeper (140 to $180 \mathrm{ft}$ below land surface) aquifers and confining units. Test holes were located at sites I20, I31, I38, I47, and I50 (fig. 3) and are designated with a "T" after the well number. The purpose of the test holes was to collect core samples and geophysical logs (gamma, spontaneous potential, and resistivity). Test holes were sealed with cement grout immediately after these data were collected.

The surface-water sampling network (fig. 4) consisted of six sites in the estuaries around Carroll Island, and 15 sites in ponds, marshes, sumps, and ditches on Carroll Island. The numbering system used for the surface-water samples includes the designation "CI" (for Carroll Island), "SW" (for surface water), and a two-digit sample identifier. If a shorter identifier is desired (such as on fig. 4), the "CI" designation is dropped. Therefore a surface-water site on Carroll Island could be identified as CISW04 or simply SW04.

The 26 soil-sampling locations (fig. 5) on Carroll Island were designated with the prefix "CISOIL" to distinguish them from the other types of samples. The samples were numbered CISOIL1 through CISOIL29, with numbers 2,10 , and 26 left out because the planned samples at those sites were not collected. Replicate samples were collected at sites 1,6 , and 15 , and were labeled CISOIL101, CISOIL106, and CISOIL115, respectively. 


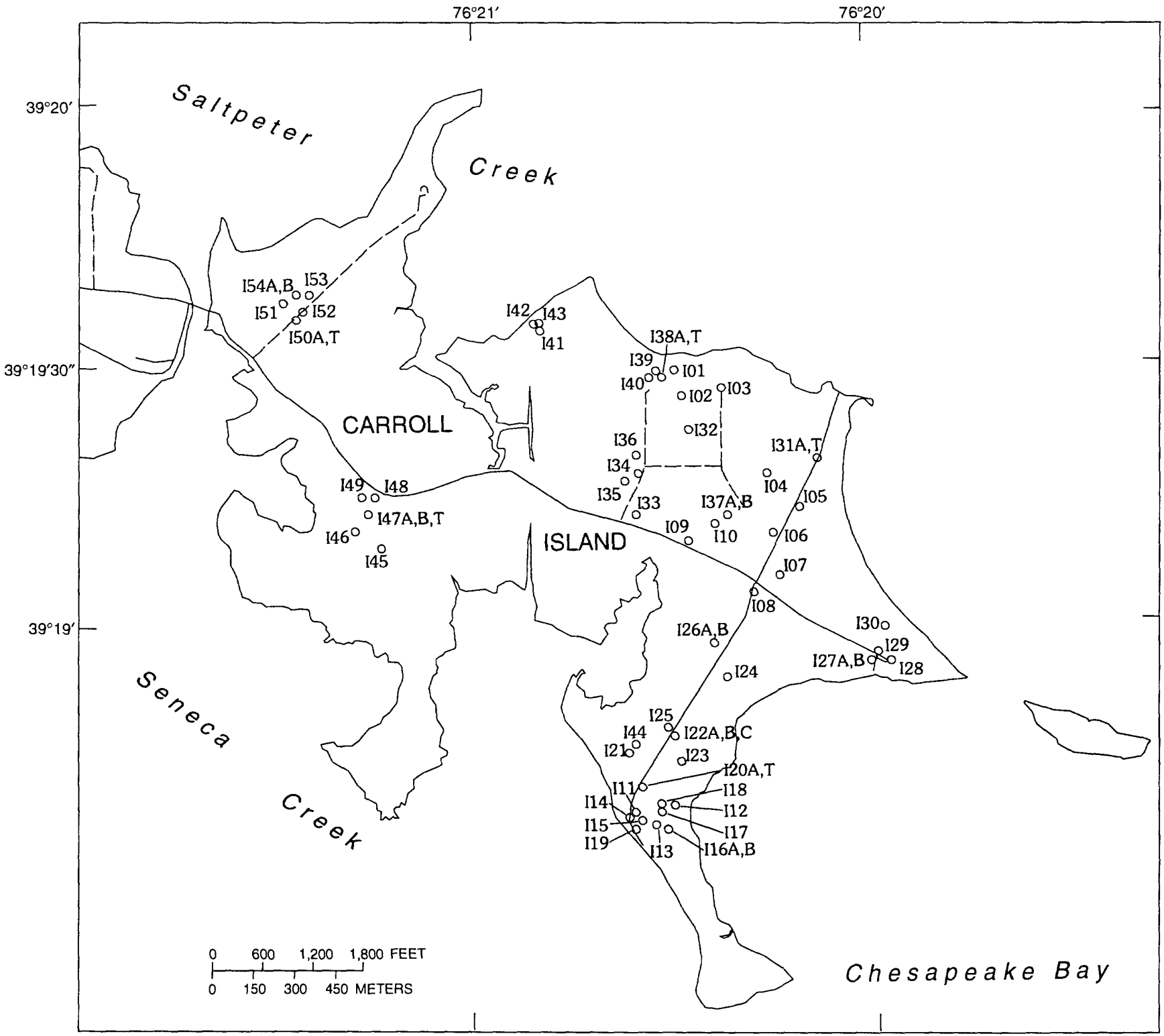

Base modified from U.S. Army, $1: 4,800,1970$

\section{EXPLANATION}

OBSERVATION WELL AND NUMBER--A,B OR $A, B, C$ designates well cluster. $A, T$ designates well and test hole. $A, B, T$ designates well cluster and test hole.

Figure 3. Location of observation wells and test holes on Carroll Island, Aberdeen Proving Ground, Maryland. 


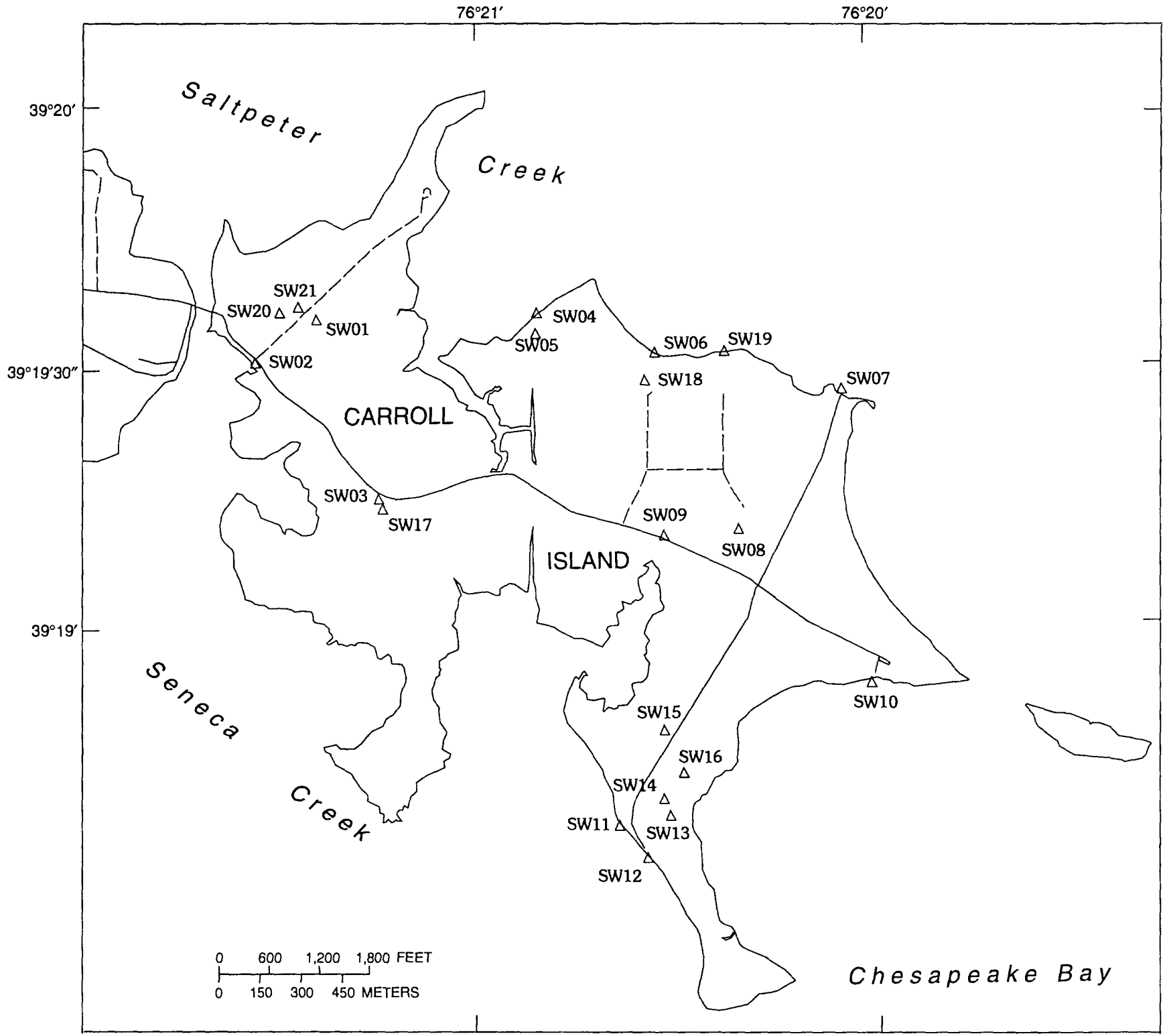

Base modified from U.S. Army, 1:4,800, 1970

\section{EXPLANATION \\ $\triangle$ SURFACE-WATER SAMPLING SITE SW12 AND NUMBER}

Figure 4. Location of surface-water sampling sites on Carroll Island, Aberdeen Proving Ground, Maryland. 


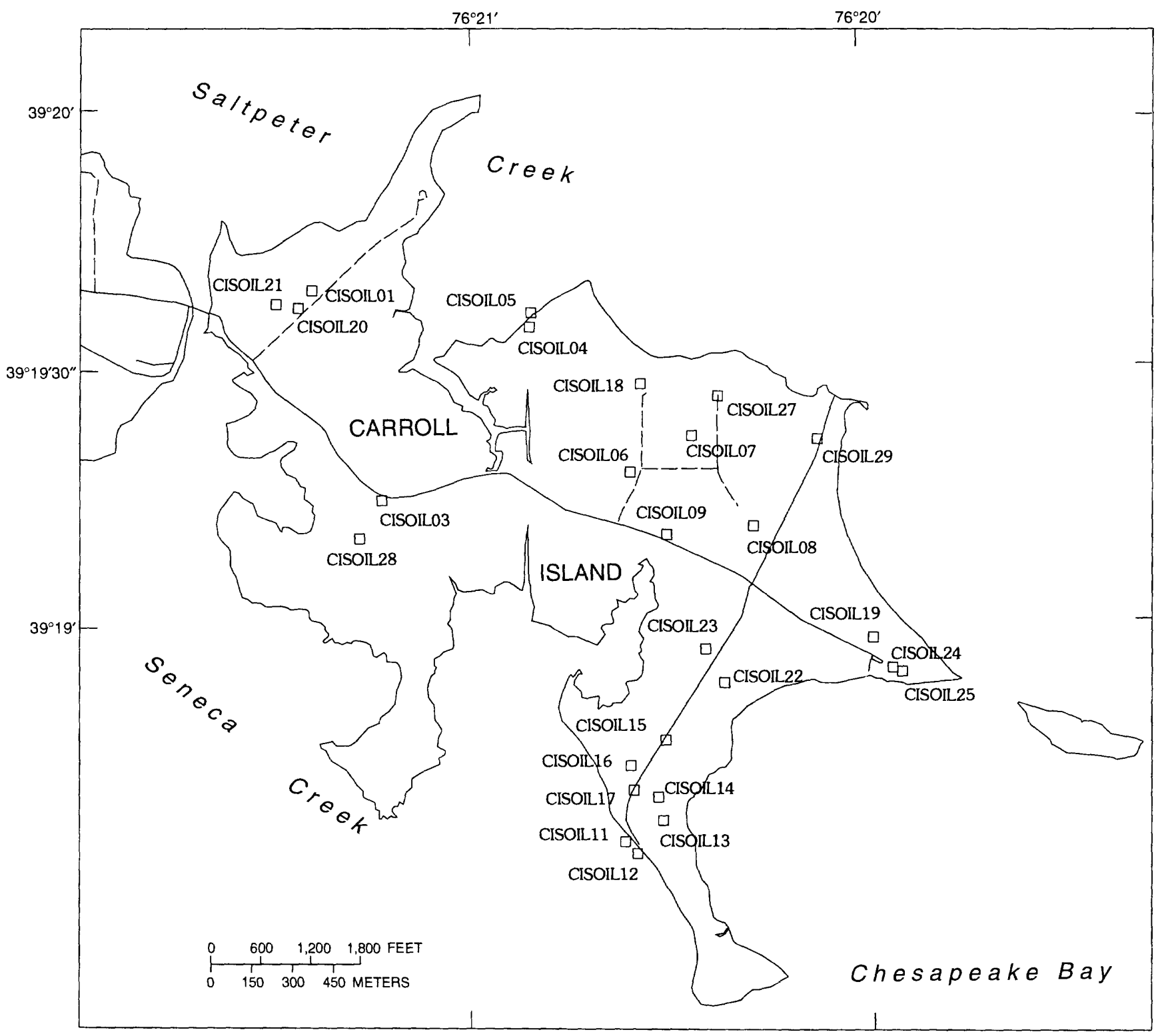

Base modified from U.S. Army, 1:4,800, 1970

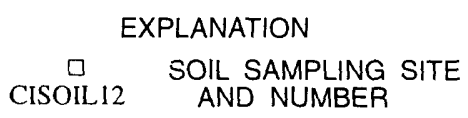

Figure 5. Location of soil-sampling sites on Carroll Island, Aberdeen Proving Ground, Maryland. 


\section{Acknowledgments}

The authors wish to thank the following people for their assistance with various aspects of this report. Gary Nemeth of AHEA provided background information on the history of Carroll Island. The U.S. Army Technical Escort Unit provided magnetometer surveys and visual searches of the study area for unexploded ordnance. They also provided logistical support, collected air samples, and performed field tests to detect chemical agent in drill cores during remote drilling.

The U.S. Army Corps of Engineers (COE) drilled the wells and test holes for this project, and also installed and developed the observation wells. James Stefano was the COE project geologist during the drilling. $\mathrm{He}$ helped direct the drillers, provided well-construction data, and ran and helped interpret most of the borehole geophysical logs.

Administrative assistance was provided by Cynthia Powels of the U.S. Army Directorate of Safety, Health, and the Environment during the early part of the study, and by Donald Green of the same organization during the later part. Douglas Stevenson, Ann Ryan, and Steven Krogsrud of USATHAMA provided assistance in securing laboratory contracts for chemical analysis of various samples. Eric Kauffman and Roxann Diehl of USATHAMA assisted in organizing the results of the chemical analyses of samples.

\section{HYDROGEOLOGY}

Characterization of the hydrogeologic system aids in the identification of potential pathways for contaminant migration. Evaluation of the shallow flow system (to a depth of $200 \mathrm{ft}$ below land surface) included characterization of geologic setting, definition of aquifers and confining units, determination of ground-water flow direction, and measurement and calculation of hydraulic properties in the study area.

The hydrogeologic framework was characterized by using lithologic and geophysical data to prepare cross sections to show the continuity of aquifers and confining units. The geologic setting was determined by comparing lithologic data from Carroll Island to existing data in the literature. The aquifers and confining units of the shallow hydrogeologic system include the surficial aquifer, the upper confining unit, the upper confined aquifer, and a lower confining unit. The boundaries of aquifers and confining units were based on the water-bearing properties of the sediment and was not directly related to geologic contacts.

Hydraulic-head distribution and hydraulic gradients within the surficial and the upper confined aquifers were determined from monthly synoptic water-level measurements of all the Carroll Island wells and from continuous water-level measurements at selected wells. The hydraulic properties of aquifers and confining units were obtained from both field and laboratory testing.

\section{Geologic Setting}

Carroll Island is within the Atlantic Coastal Plain physiographic province. The geologic units that comprise the Coastal Plain sediment in the study area include the Cretaceous Potomac Group, which can be subdivided into the Patuxent Formation, the Arundel Formation, and the Patapsco Formation; and Quaternary sediments, which include the Talbot Formation and Quaternary alluvium (Crowley and others, 1976).

\section{Cretaceous Sediment}

In Maryland, the Patuxent Formation consists of moderately sorted sand and gravel interbedded with gray silt and clay beds (Hansen, 1972, p. 19). The basal part of the formation is made up of coarse-grained material reworked from the underlying crystalline rock. The formation comprises an overall fining upward sequence with the upper sediment consisting of fine sand, silt, and clay (Chapelle, 1985, p. 6).

The Patuxent Formation crops out in a wide band along the Fall Line, which is about 5 miles (mi) west of Carroll Island. The depth to the top of the Patuxent Formation in the Carroll Island vicinity is between 300 and $400 \mathrm{ft}$ (Chapelle, 1985, p. 6). The thickness of the Patuxent Formation is between 150 and $300 \mathrm{ft}$ in the greater Baltimore area (Bennett and Meyer, 1952, p. 40).

The Patuxent Formation is overlain by the finegrained sediment of the Arundel Formation, which consists of multicolored clay and silt interbedded with sparse lenses of fine- to medium-grained sand. A geologic map prepared by Crowley and others (1976) indicates that the formation crops out about $3.5 \mathrm{mi}$ west of Carroll Island. The Arundel Formation is typically 75 to $100 \mathrm{ft}$ thick, but the thickness is variable because of 
erosion preceding the deposition of the Patapsco Formation (Bennett and Meyer, 1952, p. 59).

The Patapsco Formation consists of interbedded sand, silt, and clay. Silt- and clay-sized material typically makes up 40 to 60 percent of the total section (Chapelle, 1985, p. 10). Crowley and others (1976) divided the formation into a clay facies and a sand facies. The geologic map prepared by these authors indicates that the formation crops out along a wide band just west of Carroll Island. The Patapsco Formation was encountered at a depth of about $50 \mathrm{ft}$ below sea level at Carroll Island (figs. 6-9). The total thickness of the Patapsco Formation in the vicinity of Carroll Island is between 200 and $300 \mathrm{ft}$.

Two samples taken from cores collected in the Patapsco Formation underlying the J-Field area of APG were analyzed for mineralogy, major elements, and trace elements (Hughes, 1993, tables 2-4). The mineralogy of both samples was dominated by quartz. Other minerals present included kaolinite, illite, pyrite, and marcasite. The major elements in these samples included aluminum, iron, and potassium. Trace elements including arsenic, barium, cobalt, chromium, copper, manganese, nickel, lead, and zinc also were present.

\section{Quaternary Deposits}

Quaternary deposits lie unconformably over the Patapsco Formation in some areas along the shore of the Chesapeake Bay, including Carroll Island. These deposits consist of sand, gravel, silt, and clay, and probably are of fluvial origin (Bennett and Meyer, 1952, p. 71). The Quaternary deposits in the vicinity of Carroll Island are a result of the lowering of sea level during the Pleistocene Epoch and the subsequent downcutting of the ancestral Susquehanna River into underlying Cretaceous sediment (Bennett and Meyer, 1952, p. 72). A series of paleochannels were formed in the vicinity of the Chesapeake Bay due to the fluctuating sea levels during the different glacial episodes of the Pleistocene (Hack, 1957, p. 817). The channel-fill sediment that was deposited in the paleochannels subsequent to the erosion episodes consists of gravel, sand, silt, and clay (Chapelle, 1985, p. 21).

The Quaternary deposits underlying Carroll Island consist of three units. The basal unit, which is part of the Talbot Formation, is a coarse gravel and sand deposit that overlies the unconformity. Above this is a gray silty clay that is part of the Talbot Forma- tion and is similar to the Talbot deposits in the Sparrows Point area of Baltimore County described in Bennett and Meyer (1952, p. 69). The upper unit consists of interbedded tan to gray sand and silt from the Talbot Formation and Quaternary alluvium. There was no noticeable difference between the Talbot sediment and the alluvium in this unit, so the sediment in this upper unit is considered to be undifferentiated for the purposes of this report.

The Quaternary deposits are not continuous west of Carroll Island. The deposits underlying most of the island are over $60 \mathrm{ft}$ thick, but they appear to pinch out in the vicinity of Saltpeter Creek (fig. 7) and Seneca Creek (fig. 9). Marine seismic work conducted in the vicinity of Carroll Island indicates the Quaternary sediment was deposited in a paleochannel that trends north-south through Carroll Island (Brian Hughes, U.S. Geological Survey, oral commun, 1992).

Samples were collected from all three Quaternary units underlying J-Field ( $2 \mathrm{mi}$ east of Carroll Island) for mineralogical analysis and from Carroll Island for grain-size analysis. Hughes (1993, tables 2 and 4) reported that the upper and lower units (designated as units $\mathrm{C}$ and $\mathrm{A}$, respectively) are predominately composed of quartz with minor amounts of clay minerals, plagioclase, and potassium feldspar. The intervening clay unit (designated as unit B) contained higher relative quantities of clay minerals than the other units. Aragonite comprised 20 percent of a sample from unit $B$ because of the large amount of shell material present. Trace elements present in the Quaternary deposits at J-Field include barium, cobalt, chromium, copper, manganese, nickel, lead, and zinc. The grain-size distributions of samples collected and analyzed from the upper unit at Carroll Island (Ham and others, 1991, p. 51) were within the fine sand category, and all have at least a trace of silt. Some of the Carroll Island samples had a trace of gravel, while others had enough silt to be classified as a silty sand.

\section{Soils}

The soil component of the hydrogeologic system includes all of the soil horizons and the unsaturated part of the soil parent material above the surficial aquifer. Soils can be an important part of the hydrogeologic system of an area because they may affect water flow and the transport of contaminants. Two types of information were used to determine the soil characteristics at 


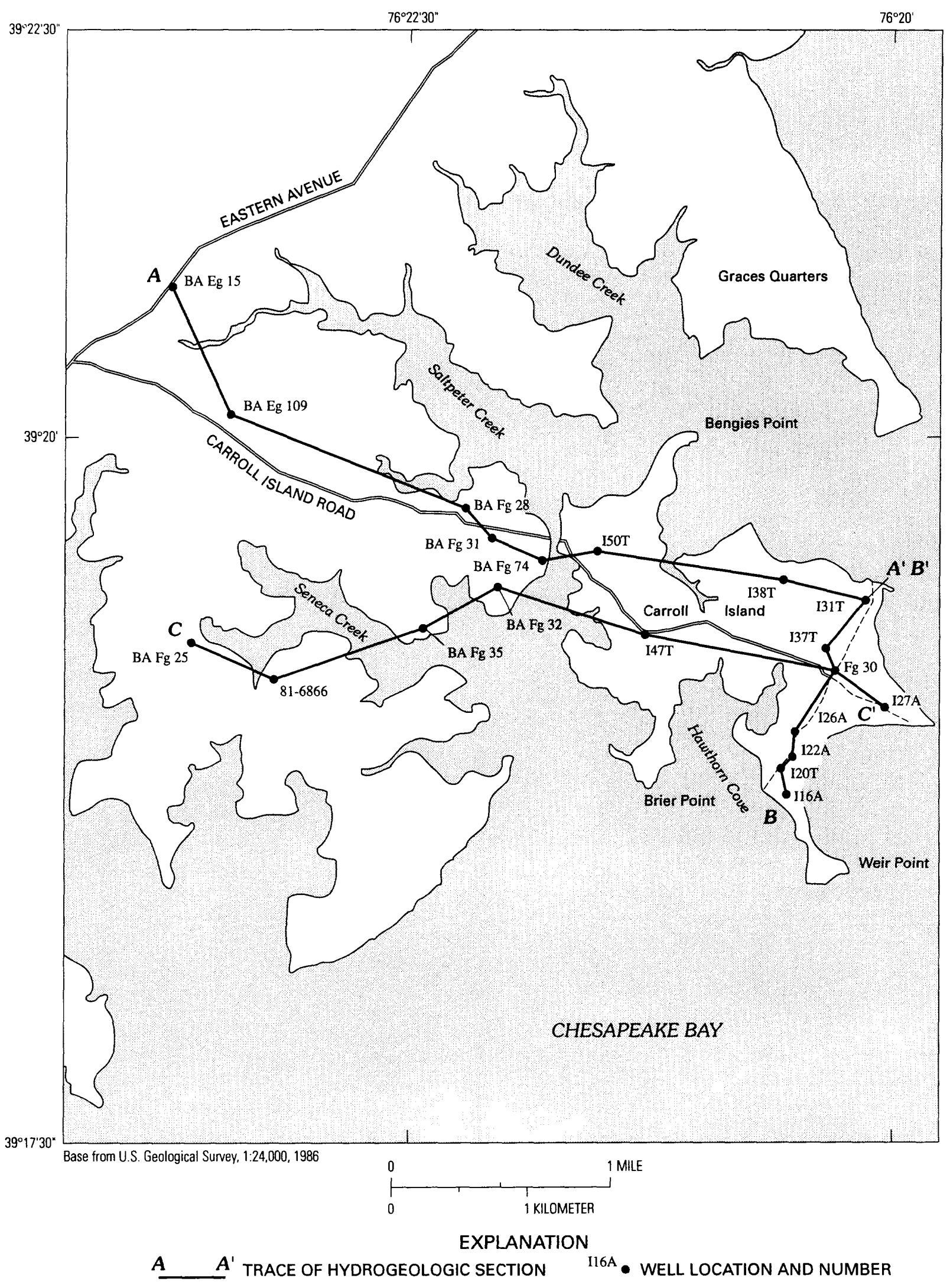

Figure 6. Traces of hydrogeologic sections through Carroll Island, Aberdeen Proving Ground, Maryland, and adjacent areas. 


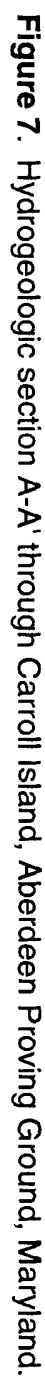

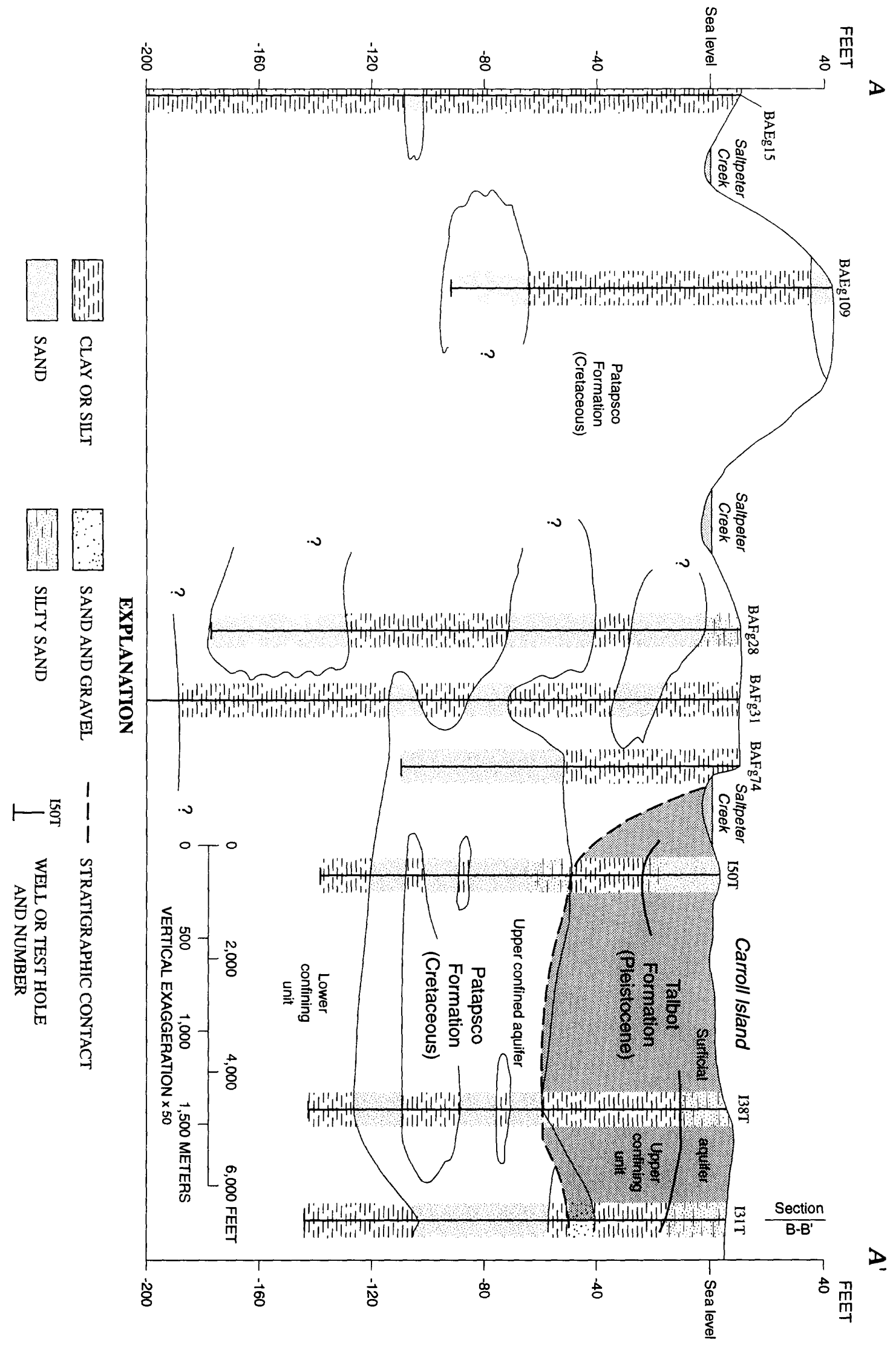




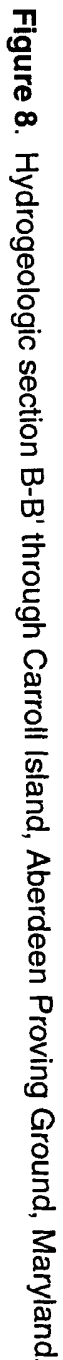

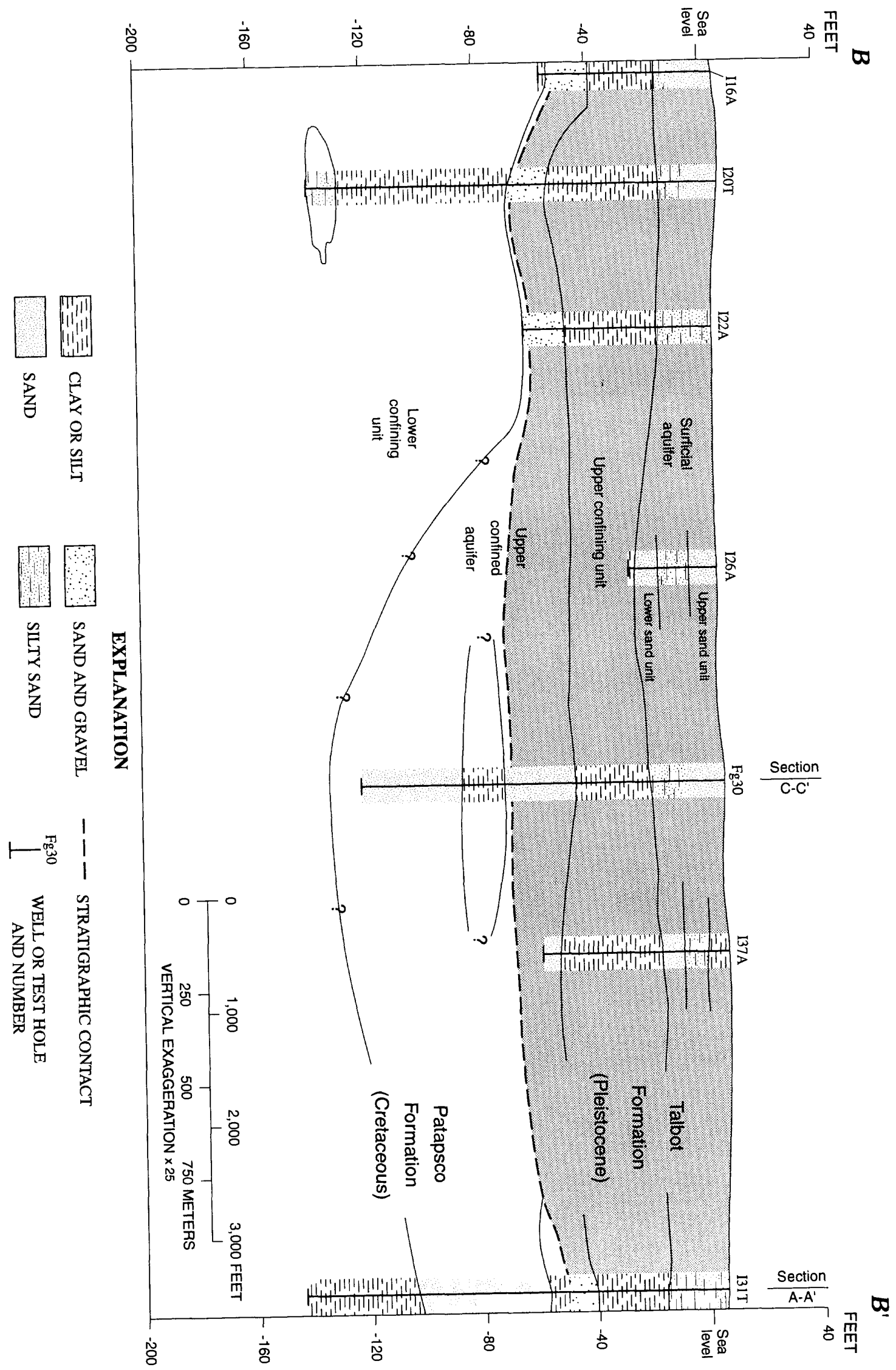




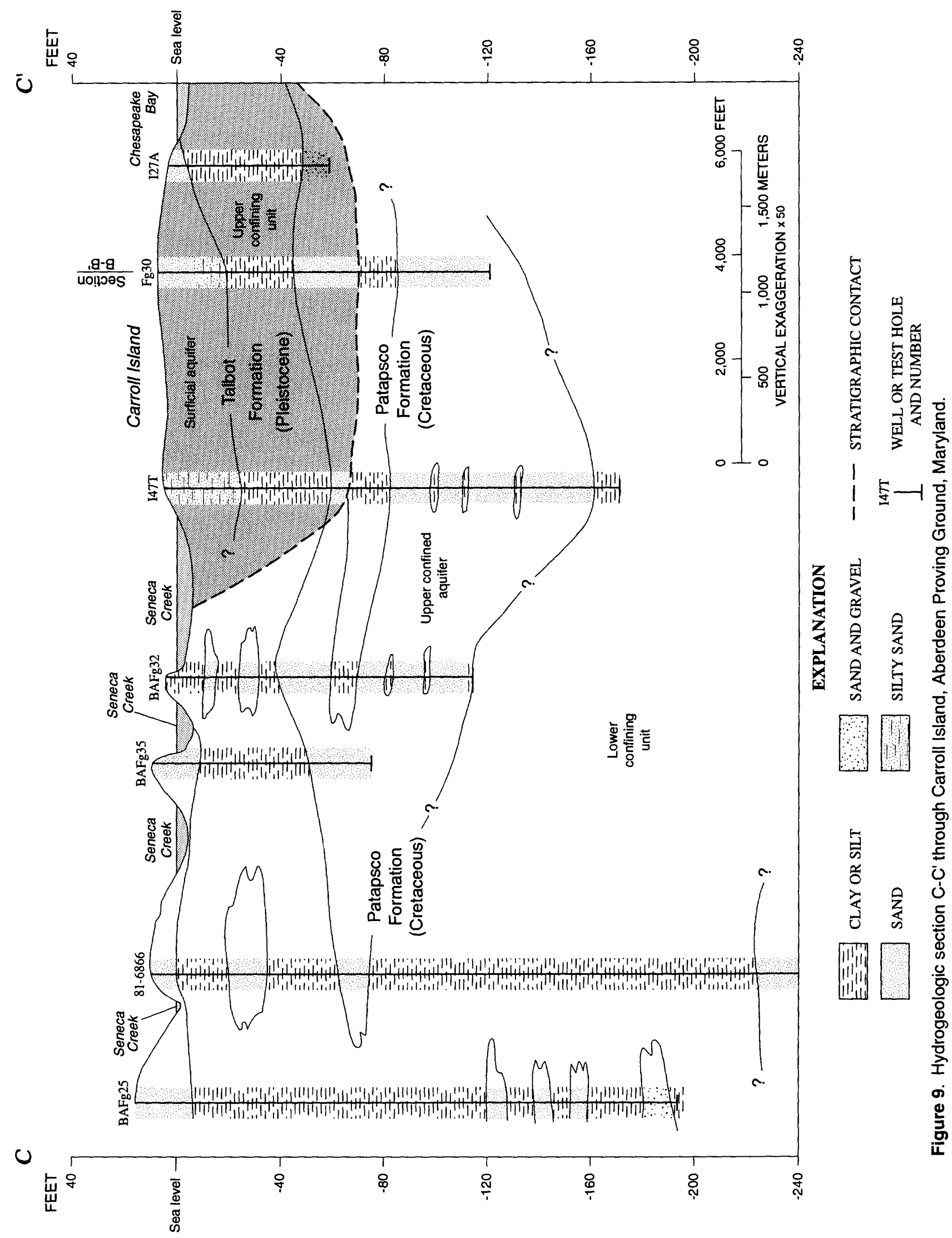


Carroll Island. General descriptions and the distribution of soils at Carroll Island were obtained from the soil survey of Baltimore County (Reybold and Matthews, 1976). Site-specific information about some of the hydraulic properties of Carroll Island soils was obtained by comparing the soil-survey information with notes and observations collected during drilling and other field activities associated with this study. The general and site-specific information was synthesized into the following sections to provide both a comprehensive and a site-by-site look at the Carroll Island soils.

Important characteristics of soils that are available from county-wide soil surveys include drainage class, reactivity, and permeability. Drainage class refers to the conditions of frequency and duration of periods of saturation or partial saturation that existed during the development of a soil (Reybold and Matthews, 1976, p. 148), and can be determined using characteristics such as soil texture and the presence or absence of mottling in the various soil horizons. Of the seven drainage classes recognized by soil scientists, four were represented in Carroll Island soils--welldrained, moderately well drained, somewhat poorly drained, or poorly drained. Reactivity in soils refers to the degree of acidity or alkalinity of a soil expressed in $\mathrm{pH}$ values (Reybold and Matthews, 1976, p. 148). The soils on Carroll Island were categorized as being strongly acidic ( $\mathrm{pH} 5.1$ to 5.5 ), very strongly acidic ( $\mathrm{pH}$ 4.5 to 5.0 ), or extremely acidic ( $\mathrm{pH}$ below 4.5 ). Permeability refers to the movement of water downward through undisturbed and uncompacted soil (Reybold and Matthews, 1976, p. 116). Permeability can be highly variable within a given area or soil type.

Because of this variability, permeability is described in qualitative terms in this report. Reybold and Matthews (1976, p 94-101) provide numerical permeability ranges (based on soil structure) for different layers in each of the soil series found in Baltimore County.

\section{Description and Distribution}

The basic soil units described below include soil associations, soil series, and soil phases. Soil associations are landscapes that have distinctive proportional patterns of soils (Reybold and Matthews, 1976, p. 2). Soil series describe soils that have major horizons that are similar in thickness, arrangement, and other important characteristics (Reybold and Matthews, 1976,

p. 2). Soil phases characterize the differences within a soil series that affect the use of the soils by humans, such as slope, texture of the surface soil, or stoniness (Reybold and Matthews, 1976, p. 2).

The soils on Carroll Island (fig. 10) belong to the Sassafras-Woodstown-Fallsington association. This soil association is characterized by well drained, moderately well drained, and poorly drained soils that have a subsoil of sandy clay loam (Reybold and Matthews, 1976, p. 6). The association usually consists of about 50 percent Sassafras soils, 22 percent Woodstown soils, 7 percent Fallsington soils, and 21 percent minor soils (Reybold and Matthews, 1976, p. 6). Minor soils include Fort Mott, Galestown, and Matapeake soils (none of which are mapped on Carroll Island), along with alluvial land and tidal marsh.

Soils from the Woodstown series cover a significant part of Carroll Island (fig. 10). They are characterized as deep, moderately well drained, nearly level to gently sloping, and very strongly acidic to extremely acidic (Reybold and Matthews, 1976, p. 59). The soils are formed in unconsolidated deposits of very old sandy materials containing moderate amounts of silt and clay (Reybold and Matthews, 1976, p. 59). The two Woodstown phases on Carroll Island are Woodstown sandy loam and Woodstown loam (both 0 to 2 percent slope).

Fallsington soils are located adjacent to the Woodstown soils on several parts of Carroll Island (fig. 10). The Fallsington series consists of deep, poorly drained, nearly level soils that are strongly acidic to extremely acidic (Reybold and Matthews, 1976, p. 29). Fallsington soils formed in old marine deposits of sandy materials that contain low to moderate amounts of silt and clay (Reybold and Matthews, 1976, p. 29).

Sassafras sandy loam is present on Carroll Island but covers a smaller area than the Woodstown and Fallsington soils (fig. 10). The Sassafras series consists of deep, well-drained, nearly level to steep soils that are strongly acidic to very strongly acidic (Reybold and Matthews, 1976, p. 56). Sassafras soils formed in unconsolidated deposits of very old, dominantly sandy sediment (Reybold and Matthews, 1976, p. 56).

Mattapex silt loam is another soil that is present on Carroll Island (fig. 10). Mattapex soils are deep, moderately well drained, nearly level to gently sloping, and strongly acidic to very strongly acidic (Reybold and Matthews, 1976, p. 48). The soils are formed in old deposits of silty material underlain by older, coarsertextured sediment (Reybold and Matthews, 1976, p. 48). 


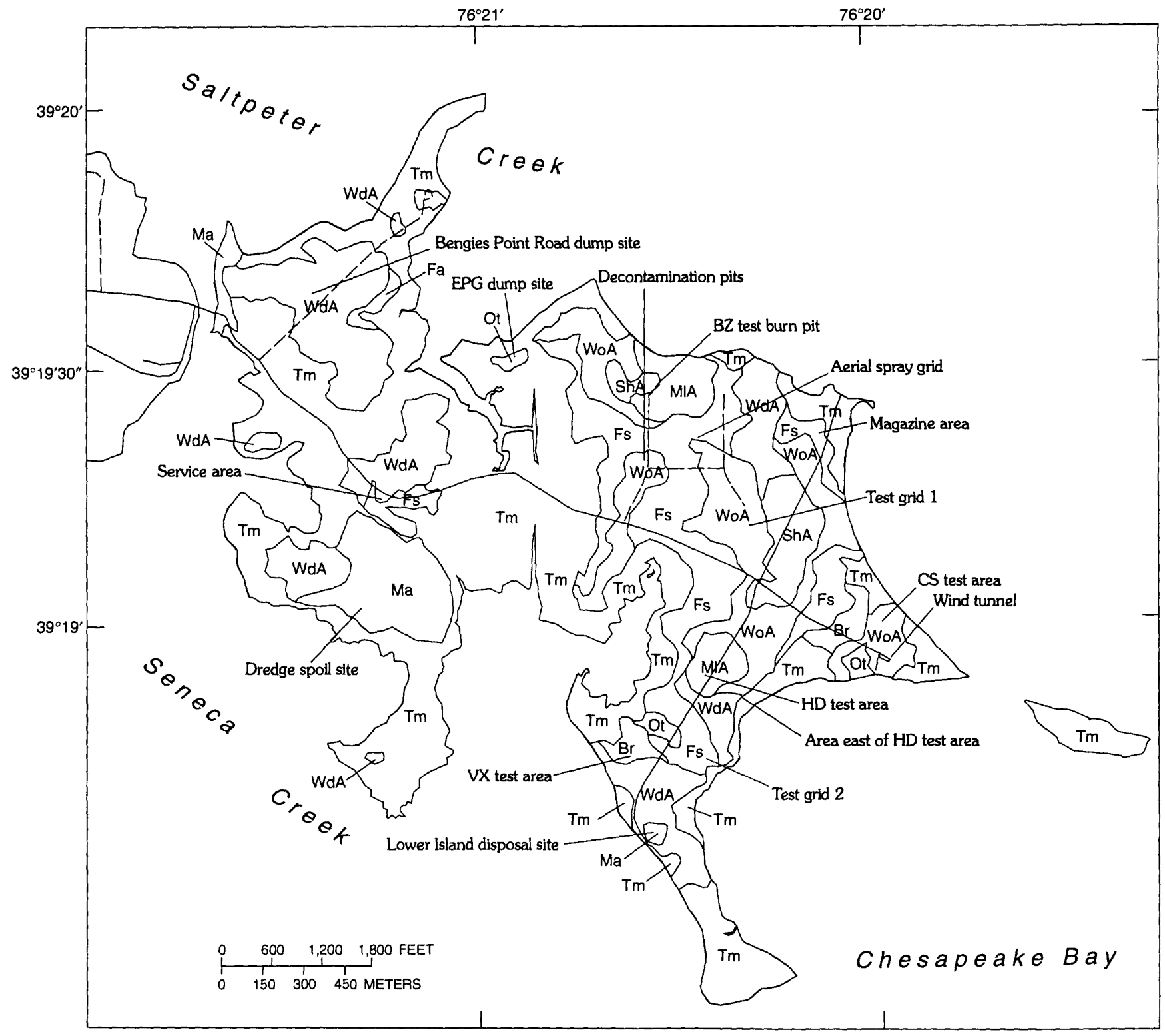

Base modified from U.S. Army, 1:4,800, 1970

\section{EXPLANATION}

SOIL TYPE

$\begin{array}{ll}\mathrm{Br} & \text { BARCALY SILT LOAM } \\ \text { Fa } & \text { FALLSINGTON SANDY LOAM } \\ \text { Fs } & \text { FALLSINGTON LOAM } \\ \text { MIA } & \text { MATTAPEX SILT LOAM-- } \\ \text { O-to 2-percent Slopes } \\ \text { Ot } & \text { OTHELLO SILT LOAM }\end{array}$

ShA SASSAFRAS SANDY LOAM--

0-to 2-percent slopes

WdA WOODSTOWN SANDY LOAM-

0 - to 2-percent siopes

WOA WOODSTOWN LOAM--

0 - to 2-percent slopes

LAND TYPE

Ma MADE LAND Tm TIDAL MARSH

Figure 10. Soil and land types on Carroll Island, Aberdeen Proving Ground,Maryland (from Reybold and Matthews, 1976). 
Othello silt loam and Barclay silt loam are important on some parts of Carroll Island (fig. 10). Othello soils are deep, poorly drained, nearly level, and very strongly acidic to extremely acidic (Reybold and Matthews, 1976, p. 53). The soils are formed in old deposits of silty material underlain by older sandy sediment (Reybold and Matthews, 1976, p. 53). The Barclay series consists of deep, somewhat poorly drained, nearly level silt loams (Reybold and Matthews, 1976, p. 14).

Tidal marsh and made land are two land types that do not fit into a soil series category but are mapped on Carroll Island. Tidal marsh consists of areas that are regularly covered by tidal water (Reybold and

Matthews, 1976, p. 58). The soil material in these areas ranges from sand to clay, and in some areas is peaty or mucky (Reybold and Matthews, 1976, p. 58). Tidal marsh is important because it covers a significant area on Carroll Island and because it is wetland.

Made land consists of land areas made by humans (Reybold and Matthews, 1976, p. 45). Made land is variable by definition and cannot be generalized on a county-wide scale. On Carroll Island, made land is mapped at the Lower Island disposal site and at the dredge spoil site (fig. 10). At the Lower Island disposal site, the made land probably consists of native soil cover over the disposal pits. Nemeth $(1989$, p. 474477) indicates that disposal practices included covering the pits with soil after they were full. There is no visual evidence of differences in soil between the disposal pits and their surroundings. At the dredge spoil site, the made land consists of dredge spoil from the channel between Carroll Island and the mainland west of the island. The spoil is primarily sand, and it covers an area that was most likely tidal marsh.

\section{Hydraulic Properties}

Hydraulic properties of the soils at Carroll Island were investigated qualitatively on a site-by-site basis during this study. Drainage class, permeability, and shrink-swell potential from the county soil survey (Reybold and Matthews, 1976) were noted for soils at each of the SWMU's and test areas on Carroll Island. When possible, this information and the general soil descriptions were compared to observations from lithologic logs (Ham and others, 1991, tables 4 and 5) and to various other field observations.

The Lower Island disposal site (fig. 2) is located on made land, tidal marsh, and Woodstown sandy loam (table 2). Ten wells are located around this site, and lithologic logs from seven of the wells were collected and reported by Ham and others (1991, p. 32-34).

All of the wells at the Lower Island disposal site were drilled in Woodstown sandy loam (table 2). Woodstown sandy loam is moderately well drained and moderately permeable (Reybold and Matthews, 1976, p. 59) with a low shrink-swell potential (Reybold and Matthews, 1976, p. 100-101). Moderately well drained soils usually have a slowly permeable layer in or immediately beneath the upper soil layers, with uniform color in the upper part of the soil and mottling in the lower part (Reybold and Matthews, 1976, p. 148). Borehole data from wells I14, I15, I16A, I17, I18, I19, and I20A show silt and sandy silt overlying sand (Ham and others, 1991, p. 32-34). Mottling was present in the lower soil horizons in some of these wells, indicating that the soils were moderately well drained. In general, the borehole data support the classification of this soil as Woodstown sandy loam.

The Bengies Point Road dump site (fig. 2) is located on Woodstown sandy loam and tidal marsh (table 2). Lithologic logs (Ham and others, 1991, p. 4446) are available from five well locations at this site (wells I50, I51, I52, I53, and I54), all of which are in the Woodstown sandy loam. The lower soil horizons in most of the boreholes were mottled, indicating moderately well drained soils. The upper part of the soils contained more silt than sand, but otherwise the soils are similar in character to Woodstown sandy loam.

The EPG dump site (fig. 2) is located on Woodstown loam and tidal marsh (table 2). The wells at this site (wells I41, I42, and I43) were drilled in the Woodstown loam. The soil texture, mottling, and color from the geologic logs (Ham and others, 1991, p. 42) are similar to the characteristics of Woodstown loam as described in Reybold and Matthews (1976, p. 59-60).

The BZ test burn pit (fig. 2) is located on Mattapex silt loam and Sassafras sandy loam (table 2). Mattapex silt loam is moderately well drained with a moderately slow permeability (Reybold and Matthews, 1976, p. 48) and low shrink-swell potential (Reybold and Matthews, 1976, p. 101). Sassafras sandy loam is well drained, has moderate permeability (Reybold and Matthews, 1976, p. 56) and low shrink-swell potential (Reybold and Matthews, 1976, p. 100-101). Lithologic logs (Ham and others, 1991, p. 41-42) are available for wells I38 (in the Mattapex soil) and I39 and I40 (in the Sassafras soil). The soil texture and mottling in the borehole at well I38 (Ham and others, 1991, p. 41) are 
Table 2. Soil or land type at each solid waste management unit, chemical-agent test area, and well location, Carroll Island, Aberdeen Proving Ground, Md.

[All soil phases on Carroll Island are 0 to 2 percent slope]

\begin{tabular}{|c|c|c|}
\hline $\begin{array}{l}\text { Location } \\
\text { (fig. 2) }\end{array}$ & $\begin{array}{l}\text { Soil or land type } \\
\text { (fig. 10) }\end{array}$ & $\begin{array}{l}\text { Wells in each soil or land type } \\
\text { (Well locations on fig. } 3 \text { ) }\end{array}$ \\
\hline $\begin{array}{l}\text { Lower Island } \\
\text { disposal site }\end{array}$ & $\begin{array}{l}\text { Made land } \\
\text { Tidal marsh } \\
\text { Woodstown sandy loam }\end{array}$ & $\begin{array}{l}\mathrm{I} 11, \mathrm{I12}, \mathrm{I13}, \mathrm{I14}, \mathrm{I15}, \mathrm{I16}, \mathrm{I} 17 \\
\mathrm{I} 18, \mathrm{I1}, \mathrm{I} 20\end{array}$ \\
\hline $\begin{array}{l}\text { Bengies Point Road } \\
\text { dump site }\end{array}$ & $\begin{array}{l}\text { Woodstown sandy loam } \\
\text { Tidal marsh }\end{array}$ & $\mathrm{I} 50, \mathrm{I} 51, \mathrm{I} 52, \mathrm{I} 53, \mathrm{I} 54$ \\
\hline EPG dump site & $\begin{array}{l}\text { Woodstown loam } \\
\text { Tidal marsh }\end{array}$ & $141,142,143$ \\
\hline BZ test burn pit & $\begin{array}{l}\text { Mattapex silt loam } \\
\text { Sassafras sandy loam }\end{array}$ & $\begin{array}{l}101,102,138 \\
103,139,140\end{array}$ \\
\hline Decontamination pits & Woodstown loam & $\mathrm{I} 34, \mathrm{I} 36, \mathrm{I} 35$ \\
\hline Test grid 1 & $\begin{array}{l}\text { Woodstown loam } \\
\text { Sassafras sandy loam } \\
\text { Woodstown sandy loam } \\
\text { Fallsington loam }\end{array}$ & $\begin{array}{l}\text { I10, I37 } \\
\text { I04, I05, I06, I07, } 108 \\
\text { I09 }\end{array}$ \\
\hline Aerial spray grid ${ }^{1}$ & $\begin{array}{l}\text { Fallsington loam } \\
\text { Mattapex silt loam } \\
\text { Sassafras sandy loam } \\
\text { Woodstown loam } \\
\text { Woodstown sandy loam } \\
\text { Tidal marsh }\end{array}$ & $\mathrm{I} 32, \mathrm{I} 33$ \\
\hline Wind tunnel/CS test area & $\begin{array}{l}\text { Woodstown loam } \\
\text { Tidal marsh }\end{array}$ & $\mathrm{I} 27, \mathrm{I} 28, \mathrm{I} 29, \mathrm{I} 30$ \\
\hline Test grid 2 & $\begin{array}{l}\text { Fallsington loam } \\
\text { Woodstown sandy loam } \\
\text { Othello silt loam } \\
\text { Barclay silt loam }\end{array}$ & $\begin{array}{l}\mathrm{I} 22, \mathrm{I} 23 \\
125\end{array}$ \\
\hline HD test area & $\begin{array}{l}\text { Mattapex silt loam } \\
\text { Woodstown sandy loam }\end{array}$ & 126 \\
\hline $\begin{array}{l}\text { Area east of HD } \\
\text { test area }\end{array}$ & $\begin{array}{l}\text { Mattapex silt loam } \\
\text { Woodstown loam } \\
\text { Woodstown sandy loam }\end{array}$ & I 24 \\
\hline Dredge spoil site & Made land & $\mathrm{I} 45, \mathrm{I} 46$ \\
\hline Service area & $\begin{array}{l}\text { Fallsington loam } \\
\text { Woodstown sandy loam } \\
\text { Tidal marsh }\end{array}$ & $\begin{array}{l}\mathrm{I} 47, \mathrm{I} 49 \\
\mathrm{I} 48\end{array}$ \\
\hline Magazine area & $\begin{array}{l}\text { Fallsington loam } \\
\text { Woodstown loam } \\
\text { Tidal marsh }\end{array}$ & I31 \\
\hline VX test area & $\begin{array}{l}\text { Barclay silt loam } \\
\text { Othello silt loam } \\
\text { Woodstown sandy loam } \\
\text { Tidal marsh }\end{array}$ & $\mathrm{I} 21, \mathrm{I} 44$ \\
\hline
\end{tabular}

\footnotetext{
${ }^{1}$ The $\mathrm{BZ}$ test burn pit and decontamination pits are also within this unit.
} 
similar to those in the Reybold and Matthews (1976, p. 48) description of Mattapex silt loam. Well-drained soils such as the Sassafras sandy loam are nearly free of mottling and are commonly of intermediate texture (Reybold and Matthews, 1976, p. 148). The soils from the boreholes at I39 and I40 exhibited some mottling (Ham and others, 1991, p. 42) but were otherwise similar to Sassafras soils.

The decontamination pits (fig. 2) are located on Woodstown loam (table 2), which is a moderately well drained soil. There is a silt layer at or near the top of the soil and mottling in the subsoil zones in wells 134 , I35, and I36 (Ham and others, 1991, p. 40) at this site. This is similar to the description in Reybold and Matthews (1976, p. 148) of moderately well drained soil. The coloring, texture, and mottling is similar to the Woodstown loam, which is how it is mapped.

Test grid 1 (fig. 2), is located on Woodstown loam and sandy loam, Sassafras sandy loam, and Fallsington loam (table 2). Each of these soils was formed from similar sediment (Reybold and Matthews, 1976, p. 60). As mentioned earlier, the Woodstown soils are moderately well drained, and the Sassafras sandy loam is well drained. Fallsington loam is poorly drained and moderately permeable (Reybold and Matthews, 1976, p. 29), with a low shrink-swell potential (Reybold and Matthews, 1976, p. 96-97). Poorly drained soils are wet for long periods and are light gray and generally mottled from the surface down, although the mottling may be absent (Reybold and Matthews, 1976, p. 148). Lithologic logs are available at one of the eight well locations (well I37) in or near test grid 1. Well I37 is located in an area mapped as Woodstown loam (table 2). The texture, mottling, and color of the soil at this well (Ham and others, 1991, p. 41) coincides with the drainage class and description of Woodstown loam given in Reybold and Matthews (1976, p. 59-60).

The aerial spray grid is located on Fallsington loam, Mattapex silt loam, Sassafras sandy loam, Woodstown loam and sandy loam, and tidal marsh (table 2). Wells I32 and I33 were drilled in an area mapped as Fallsington loam, which is a poorly drained soil. The lithologic descriptions from Ham and others (1991, p. 39) are consistent with those of a poorly drained soil. The color, texture, and mottling fit well with the description of Fallsington loam from Reybold and Matthews (1976, p. 29).

The wind tunnel and CS test area (fig. 2) are located on Woodstown loam and are adjacent to an area of tidal marsh (table 2). Lithologic logs are available for wells I27, I28, I29, and I30 (Ham and others, 1991, p. 37-38), which were drilled in Woodstown loam. The lithologic logs for wells I 28 and I29 agree fairly well with the description in Reybold and Matthews (1976, p. 59-60) of Woodstown loam, which is a moderately well drained soil. The mottling in the soil at wells I 27 and $\mathrm{I} 30$, however, indicates that the soil at these sites is poorly drained, but the texture of the soil is similar to Woodstown soils.

Test grid 2 is located on Fallsington loam, Woodstown sandy loam, and Othello and Barclay silt loams (table 2). Othello silt loam is poorly drained with a moderately slow permeability (Reybold and Matthews, 1976, p. 53). The shrink-swell potential for Othello soils is low throughout most of the soil profile, and low to moderate below about $4 \mathrm{ft}$ (Reybold and Matthews, 1976, p. 100-101). Barclay soils are somewhat poorly drained, have a moderate permeability (Reybold and Matthews, 1976, p. 14), and a low shrink-swell potential (Reybold and Matthews, 1976, p. 94-95). Soils that are somewhat poorly drained tend to be wet for significant periods and often have mottling below 6 to 16 in. (Reybold and Matthews, 1976, p. 148).

Lithologic logs are available for three wells in test grid 2 (Ham and others, 1991, p. 35-36). Wells I22 and I 23 are mapped in Fallsington loam, and well I25 is in Othello silt loam (table 2), both of which are poorly drained soils. The texture, drainage, color, and mottling of the soils at these wells matches the Reybold and Matthews (1976) descriptions of the soils.

The HD test area (fig. 2) is located on Mattapex silt loam and Woodstown sandy loam (table 2). Both of these soils are moderately well drained. Well I26 is located in Mattapex silt loam. The texture, color, and drainage described in the lithologic log from well I26A (Ham and others, 1991, p. 36-37) is consistent with the description of Mattapex soils in Reybold and Matthews (1976, p. 48-49).

The area east of the HD test area is located on Mattapex silt loam and Woodstown loam and sandy loam (table 2). Well I24 is located at this site in the Mattapex silt loam (table 2), which is a moderately well drained soil. The lithologic description of soil in the well $\log$ in Ham and others $(1991$, p. 36) is consistent with the drainage and texture of Mattapex silt loam as described in Reybold and Matthews (1976, p. 4849).

The dredge spoil site (fig. 2) is located on made land (table 2) which consists of sandy dredge spoils from the channel between Carroll Island and the main- 
land. Based on lithologic logs from wells I45 and I46 (Ham and others, 1991, p. 43), there has been no significant soil development in that area since the dredge spoil was deposited. The sandy material is approximately $7 \mathrm{ft}$ thick (Ham and others, 1991, p. 43), and overlies organic material (plant matter) and clay, silt, and sand.

The service area (fig. 2) is located on Fallsington loam and Woodstown sandy loam, and is adjacent to tidal marsh (table 2). Lithologic logs from wells I47, $\mathrm{I} 48$, and I49 are available for the service area (Ham and others, 1991, p. 43-44). Wells I47 and I49 were drilled in the Fallsington loam; well I48 was drilled in Woodstown sandy loam (table 2). The mottling and texture of the soil at well I47 indicates that it is moderately well drained and is probably a Woodstown soil. The lithologic log from well I48 describes the top $1.5 \mathrm{ft}$ of soil material as undifferentiated fill (Ham and others, 1991, p. 44). The description in lithologic log from 149 (Ham and others, 1991, p. 44) is consistent with the description of a poorly drained soil (Reybold and Matthews, 1976, p. 148).

The magazine area (fig. 2) is located on Fallsington loam and Woodstown loam, and is adjacent to tidal marsh (table 2). A lithologic log from well I31 near the magazine area is available in Ham and others (1991, p. 39). This well is located in an area mapped as Woodstown loam (table 2), but the site borders on an area of Fallsington loam. Mottling in the upper subsoil indicates that the soil is poorly drained, which best fits the description of Fallsington loam. The texture of the soil is consistent with either Fallsington loam or Woodstown loam.

The VX test area is located on Barclay silt loam, Othello silt loam, Woodstown sandy loam, and tidal marsh (table 2). Well logs are available at two sites within this test area, both of which are mapped in the Barclay soil (table 2). The texture and color of the soil in the lithologic log from well 121 (Ham and others, 1991, p. 34-35) is consistent with the description of the Barclay soil in Reybold and Matthews (1976, p. 14). The texture and mottling of the soil in the lithologic log from well I44 (Ham and others, 1991, p. 43), however, is not consistent with Barclay silt loam. The uppermost part of the soil is silty and underlain by sandy silt, and mottling is present throughout the soil profile. This description is very similar to that of Fallsington loam (Reybold and Matthews, 1976, p. 29).

\section{Surficial Aquifer}

The surficial aquifer on Carroll Island is defined as the uppermost layers of permeable material in which saturated conditions were encountered. The aquifer consists of Quaternary deposits of interbedded silt, sand, and clay that are variable in thickness and composition. The deposits represent the upper sedimentary sequence of the paleochannel that underlies Carroll Island.

\section{Extent and Thickness}

The extent of the surficial aquifer is constrained by the location of the paleochannel. The aquifer seems to be fairly continuous underlying Carroll Island, but it is discontinuous under the adjacent surface-water bodies and land masses. Little is known about the characteristics of the surficial aquifer in the tidal marsh areas of the west-central part of the island (fig. 10). The surficial aquifer was not present west of Carroll Island; therefore the unit probably pinches out in the vicinity of Saltpeter and Seneca Creeks (figs. 7 and 9).

Delineating the vertical extent of the aquifer is difficult because of the complex lithologic variation. On some areas of Carroll Island, the surficial aquifer is composed of two sand lenses (fig. 8). The uppermost sand unit is usually light-tan to orange sand, whereas the lower sand unit is usually a gray to dark-gray silty sand. The intervening unit is usually a dark-gray silt or sandy silt. Analysis of the lithologic logs presented in Ham and others (1991, p. 32-50) indicates that two sand lenses exist over much of the island, but the thickness and composition of the lenses are extremely variable. Examination of water-level data indicates that parts of the upper sand lens were not saturated during periods of high evapotranspiration. Because the lithology and saturated thickness of the sand lenses are extremely variable, both lenses were considered part of the surficial aquifer.

The top of the surficial aquifer is generally within $5 \mathrm{ft}$ of the land surface, and the thickness of the aquifer ranges from 7 to $32 \mathrm{ft}$ (fig. 11). Although in theory it is more accurate to describe the surficial aquifer as the saturated section of the sediment, the waterlevel fluctuations in the aquifer made it difficult to define an average saturated thickness. The top of the aquifer, therefore, was defined as the top of first sand lens, and the bottom of the aquifer was uniformly defined by the presence of a dark, silty clay that marked 


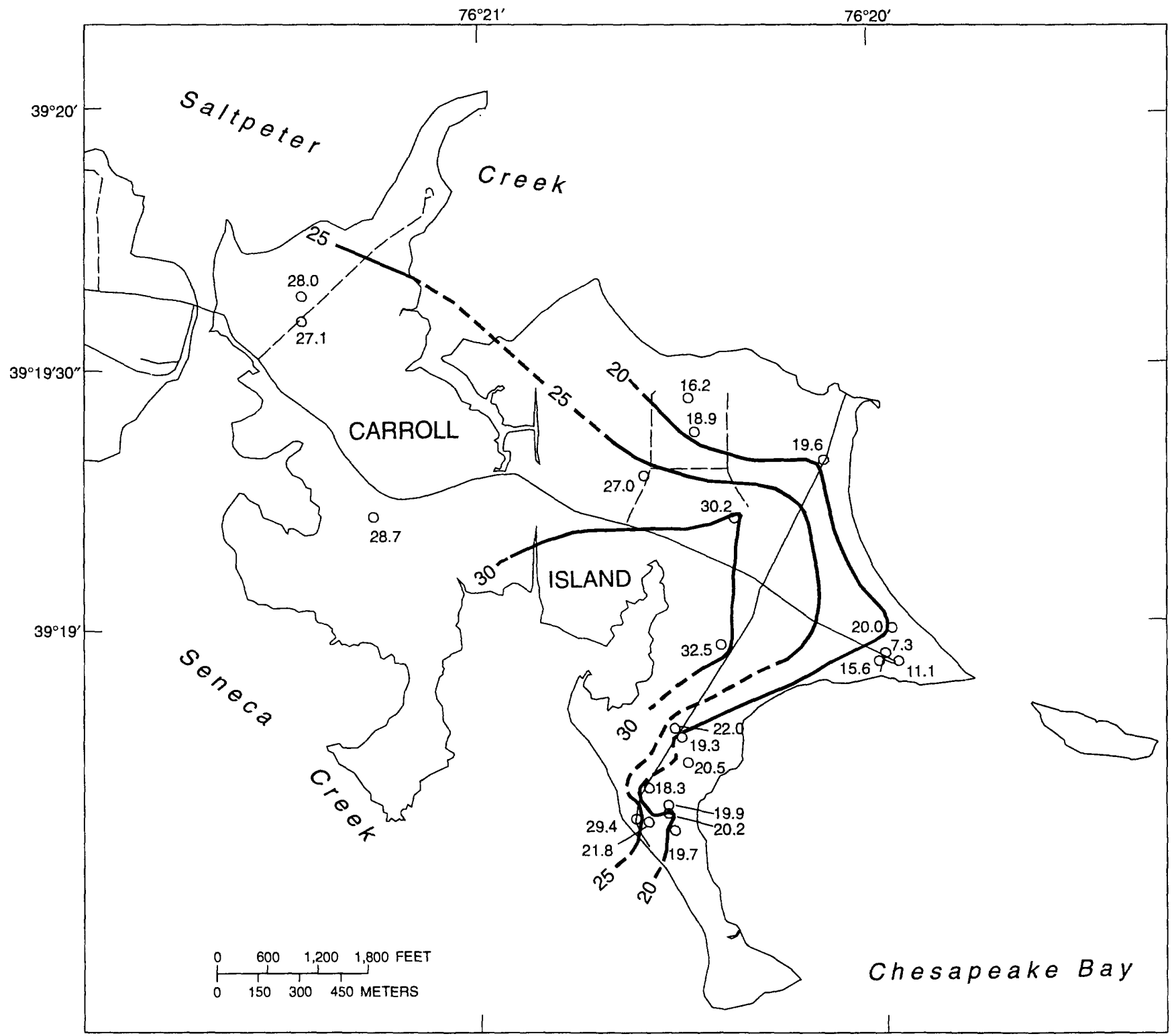

Base modified from U.S. Army, 1:4,800, 1970

EXPLANATION

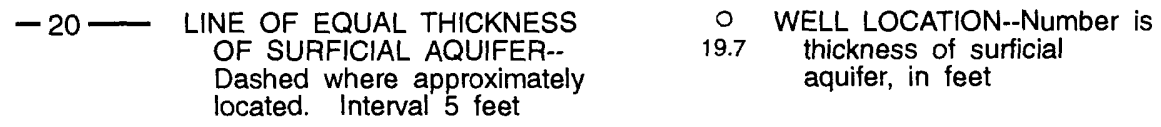

Figure 11. Thickness of surficial aquifer, Carroll Island, Aberdeen Proving Ground, Maryland. 
the top of the upper confining unit. The indicated thickness of the aquifer varies areally with the number and thickness of sand lenses encountered in each borehole.

\section{Hydraulic-Head Distribution and Direction of Flow}

Synoptic water levels were measured monthly to help determine the direction of ground-water flow and gradients in the surficial aquifer. The full set of data from these surveys is presented in Ham and others (1991, p. 52-67); a general discussion of the findings is presented here. Hydraulic head in the surficial aquifer during periods of high and low water levels is shown in figures 12 and 13, respectively. May 1988 represents a period that was influenced by high recharge (fig. 12), whereas October 1988 represents a period that was influenced by low recharge and high evapotranspiration (fig. 13). These maps illustrate typical groundwater conditions in the Carroll Island surficial aquifer during the recharge and evapotranspiration extremes that seasonally occur in this area.

Water-level contours from May 1988 are presented in figure 12. Water levels ranged from greater than $7 \mathrm{ft}$ above sea level near test grid 1 to less than $2 \mathrm{ft}$ above sea level at the EPG dump site. On the eastern half of the island, flow radiates from the ground-water high near test grid 1 toward the marshes or surface water bodies. The contours are elongated to the northwest and the southwest, and the steepest gradients are to the northeast and to the west. On the southeastern peninsula of the island, water levels were about $3 \mathrm{ft}$ above sea level, with less than $1 \mathrm{ft}$ difference across the peninsula. Consequently, the hydraulic gradient in this area is less steep than at test grid 1. Flow is generally west toward Hawthorn Cove and to the east in the direction of the Chesapeake Bay. The two 3-ft contours indicate the existence of a local ground-water divide in the middle of the peninsula. On the western part of the island near the EPG dump site, flow is to the northwest toward Saltpeter Creek. The flow direction near the dredge spoil site appears to be east into an adjacent marsh. Flow at the Bengies Point Road dump site is to the west.

Water-level contours from October, 1988 (fig. 13) show the effect of evapotranspiration on the ground-water system. Water levels in the surficial aquifer ranged from about $1 \mathrm{ft}$ above sea level to nearly $2 \mathrm{ft}$ below sea level, with a total difference of only about $3 \mathrm{ft}$ across the island. The decline in water levels within the aquifer caused a change in the ground-water flow direction and gradients in some areas. For example, at the Lower Island disposal area, the flow direction compared to May 1988 (fig. 12) has reversed. The water level is higher in the Bay and in Hawthorne Cove than it is in the aquifer. The ground-water flow direction at the dredge spoil site is now to the north and northwest. At other areas of the island, such as near test grid 1, the flow is still moving in a radial pattern from the center of the site toward the marshes and surface water. The hydraulic gradient, however, is less steep than the May 1988 conditions.

The vertical distribution of hydraulic head in the surficial aquifer was examined by comparing water levels at sites that have wells in both sand units of the surficial aquifer. Test grid 2 (wells I22B and C) and the HD test area (wells I26A and B) have wells screened in each sand unit. At well I26, water levels were higher in the well screened in the upper sand unit (I26B) during the period from December 1987 to July 1988 (Ham and others, 1991, p. 59). The maximum difference between hydraulic head in the two sand units was $1.35 \mathrm{ft}$ in May 1988. From August to December 1988, the head in the upper unit was less than the head in the lower unit, with a maximum difference in the water levels of about $1 \mathrm{ft}$ between the wells (Ham and others, 1991, p. 59). A similar relation was observed in wells I22B and C, but the difference between water levels was smaller than at I26. Water levels in the well screened in the upper sand (I22C) were lower than in the well screened in the lower sand (I22B) from March through October 1988, and higher in November and December 1987 and January, February, November, and December 1988 (Ham and others, 1991, p. 57-58).

\section{Hydraulic-Head Fluctuations}

The major influences on the water levels in the surficial aquifer are recharge, evapotranspiration, tides, and pumping. The seasonal changes in water levels caused by evapotranspiration and recharge were determined by comparing the monthly water-level data collected during the investigation. Hydrographs of water levels measured during the study were used to assess seasonal changes and short-term hydraulic head fluctuations due to tides and pumpage.

Monthly water-level data presented in Ham and others (1991, p. 52-67) were contoured to assess the seasonal changes in hydraulic head within the surficial aquifer across Carroll Island (May 1988 in fig. 12 and 


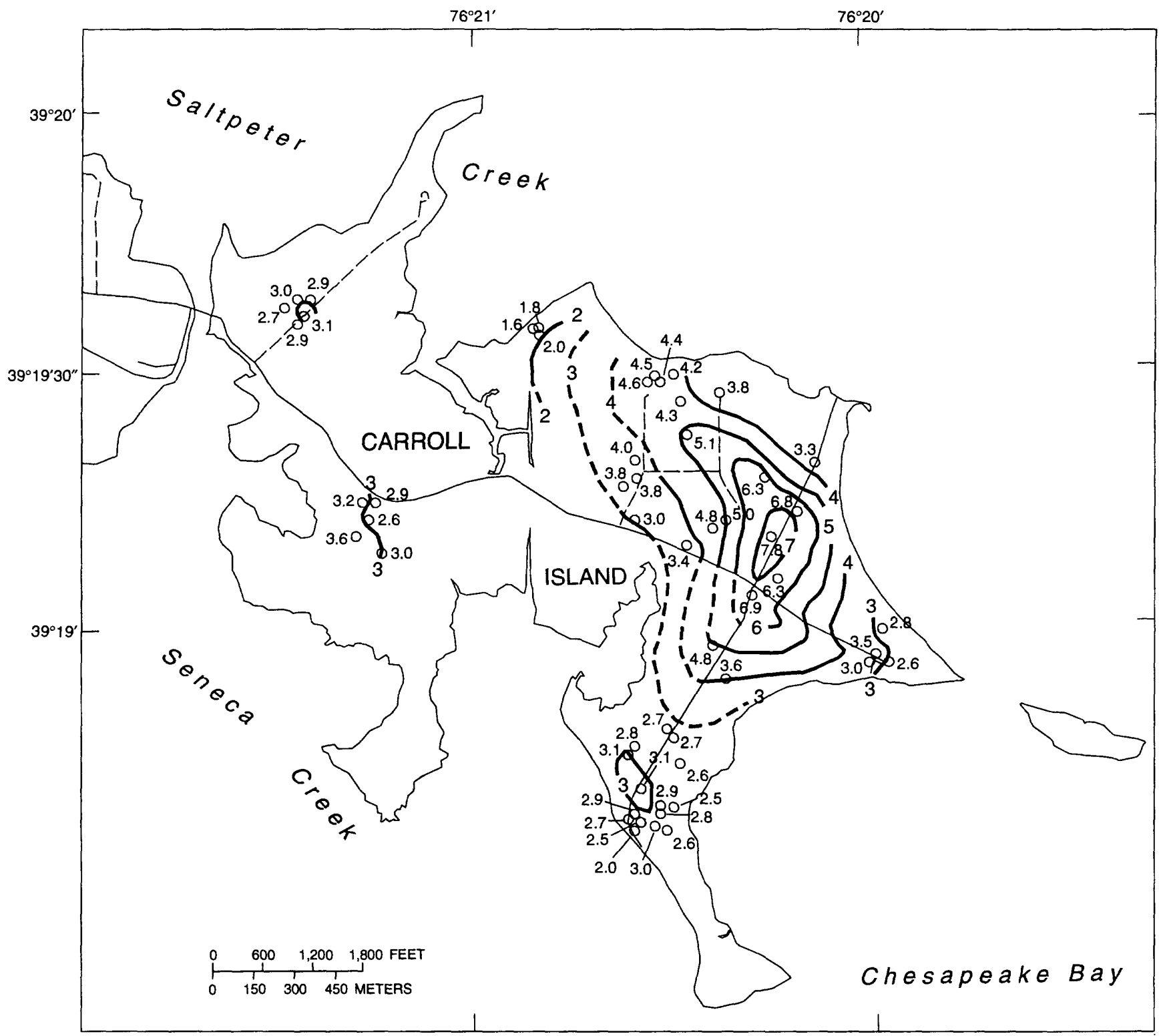

Base modified from U.S. Army, 1:4,800, 1970

\section{EXPLANATION}

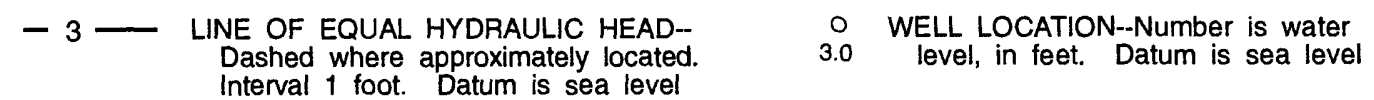

Figure 12. Hydraulic head in the surficial aquifer, Carroll Island, Aberdeen Proving Ground, Maryland, May 1988. 


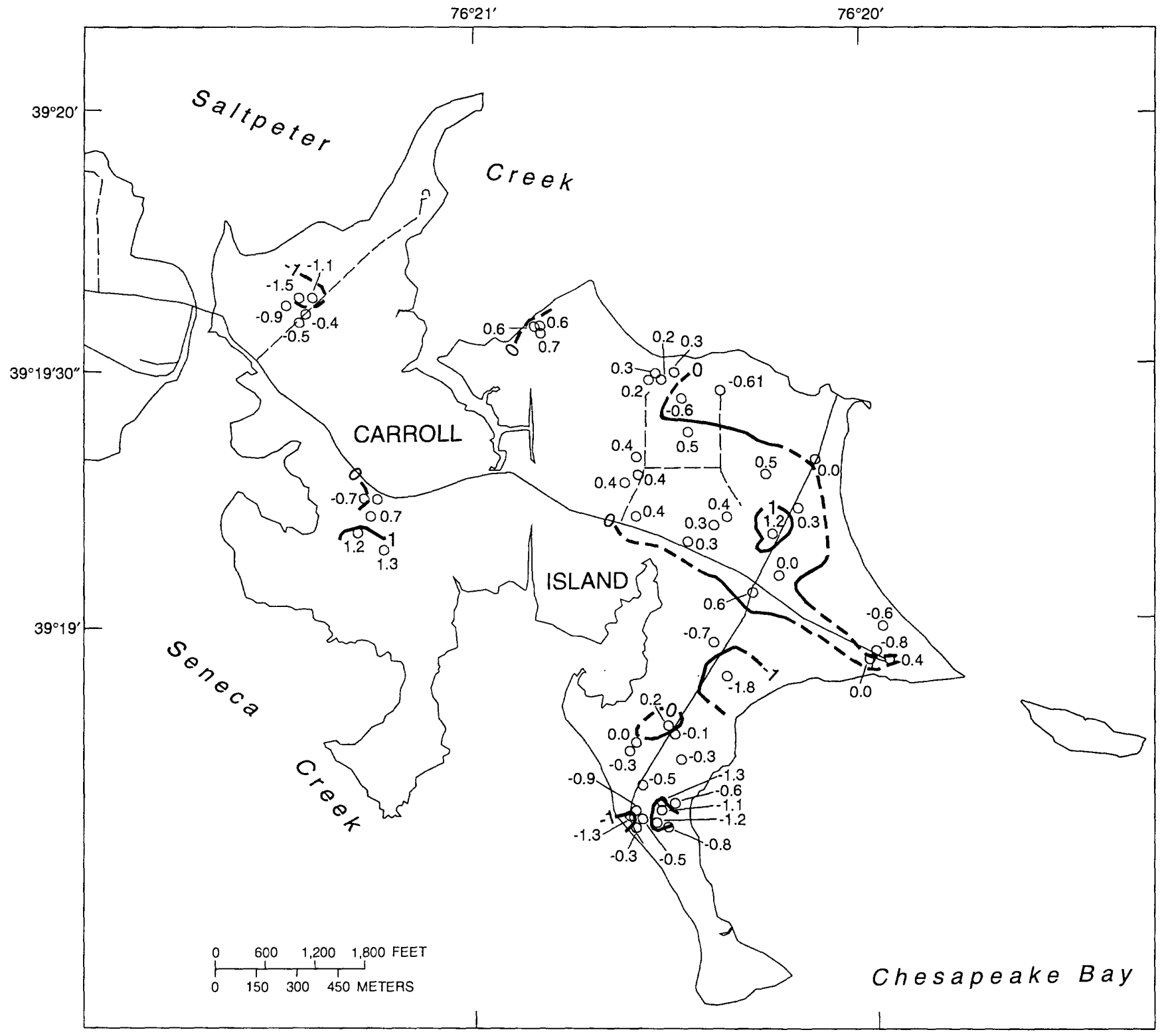

Base modified from U.S. Army, 1:4,800, 1970

EXPLANATION

-1 LINE OF EQUAL HYDRAULIC HEAD--
Dashed where approximately located.
Interval 1 foot. Datum is sea level

Figure 13. Hydraulic head in the surficial aquifer, Carroll Island, Aberdeen Proving Ground, Maryland, October 1988. 
October 1988 in fig. 13). The water levels measured in October 1988 were about 2 to $5 \mathrm{ft}$ lower than those measured in May 1988, which represent the largest difference in hydraulic head over the period of available record for all wells. An island-wide decline in water levels that begins in late spring and continues until the fall is apparent from data presented in Ham and others (1991, table 7). Conversely, water levels in the surficial aquifer begin to rise in the fall and continue to increase during the winter and spring. This variation coincides with seasonal changes in the rate of evapotranspiration.

Digital water-level recorders were installed on 14 wells on Carroll Island for various lengths of time during the study period. These wells included wells I01, I06, and I13 from the previous study (Nemeth and others, 1983); wells I19 and I33; and well clusters at I22 (A, B, and C), I27 (A and B), I47 (A and B), and I54 (A and B). Water levels were recorded at 15-minute intervals at each of these wells. Hydrographs of the water levels are available in Ham and others (1991, p. 98-104).

In addition to the recorders that were installed on wells, a tide gage and precipitation gage were set up during the study to help determine the response of ground-water levels to tidal stresses and recharge events. The tide gage recorded water levels in the Gunpowder River at 15-minute intervals; the precipitation gage recorded rainfall at 5-minute intervals.

The response of water levels in individual wells to recharge, tides, and pumping can be seen in figures 14-16. The hydrographs of water levels from wells screened in the surficial and upper confined aquifers near the wind tunnel on the eastern part of Carroll Island are shown in figure 14. Hydrographs of wells in the surficial and upper confined aquifers on the western part of Carroll Island are shown in figure 15. The water-level response in the surficial aquifer to individual recharge events can be seen by comparing the hydrographs to a graph of precipitation data (fig. 16). Precipitation of 0.5 to 1.0 in. generally resulted in a rise of 0.5 to $1.0 \mathrm{ft}$ in the surficial aquifer water levels. A rainfall of almost 3 in. that occurred in July 1988 (fig. 16) resulted in a 2-ft rise in water levels in both of the surficial aquifer wells (figs. 14 and 15). The strong influence of evapotranspiration in the surficial aquifer is evident based on the sharp decline in water levels near the end of May 1988 and the quick recovery in
November 1989. In times of high evapotranspiration, head in the surficial aquifer declines low enough for an upward hydraulic gradient to develop between the surficial and confined aquifers (figs. 14 and 15).

A strong influence of tides on hydraulic head in the surficial aquifer is not apparent in figures 14 and 15 . Hydrographs presented in Ham and others (1991, p. 98-105) of wells screened in the surficial aquifer show that with the exception of well I19, which is located near the shoreline, water levels in most wells were not strongly influenced by tidal fluctuations.

Only limited information is available to evaluate the effects of ground-water withdrawals on water levels in the surficial aquifer because the aquifer is not utilized for water supply on Carroll Island or the adjacent area. Water is withdrawn from the upper confined aquifer, however, and the closest withdrawal well (BA $\mathrm{Fg} 74$ ) is 2,000 ft west of site I54 (fig. 7). Hydraulic head in the confined aquifer at well I54B on the western part of Carroll Island declined during August 1988 (fig. 15). No corresponding decline of the water level in well I54A in the surficial aquifer was noted. This hydraulic head decline in the confined aquifer is directly attributable to pumping at well BA Fg 74 . The well is pumped during the hottest part of the summer to provide cooler water for fish breeding than is available from the estuaries, and in 1988, the only pumpage that was reported was during August (Curry Woods, C.P. Crane Aquaculture Facility, written commun., 1988). The water-level fluctuations in the shallow well are virtually the same as those for other wells in the surficial aquifer (Ham and others, 1991, p. 98-105), which are related to recharge and evapotranspiration.

\section{Hydraulic Properties}

During the summer of 1988 , slug tests were done on 21 wells in the surficial aquifer to determine the aquifer properties. A slug test is done by rapidly changing the water level in a well and observing the response as the aquifer adjusts to the change. The water-level response is a function of the hydraulic characteristics of the well and the properties of the aquifer in the area near the well. Local aquifer properties that can be determined fairly accurately from a slug test are transmissivity and horizontal hydraulic conductivity. 


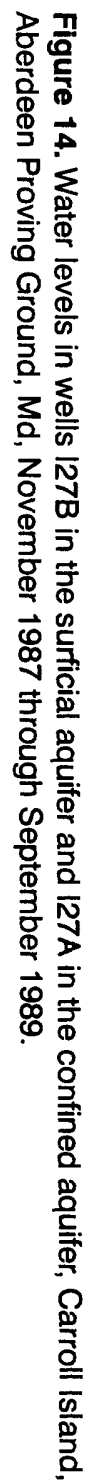

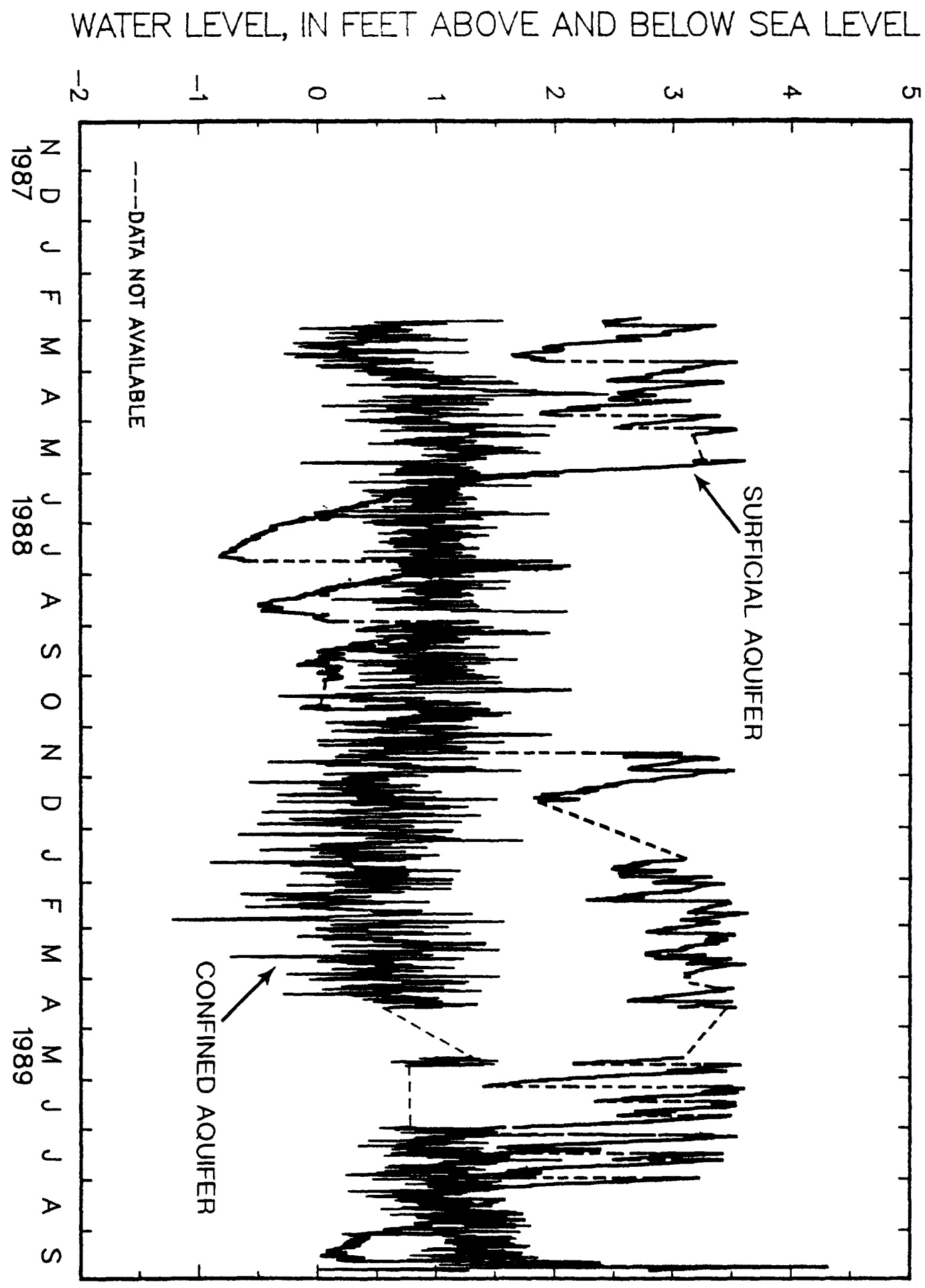




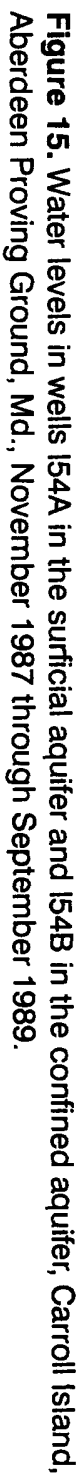

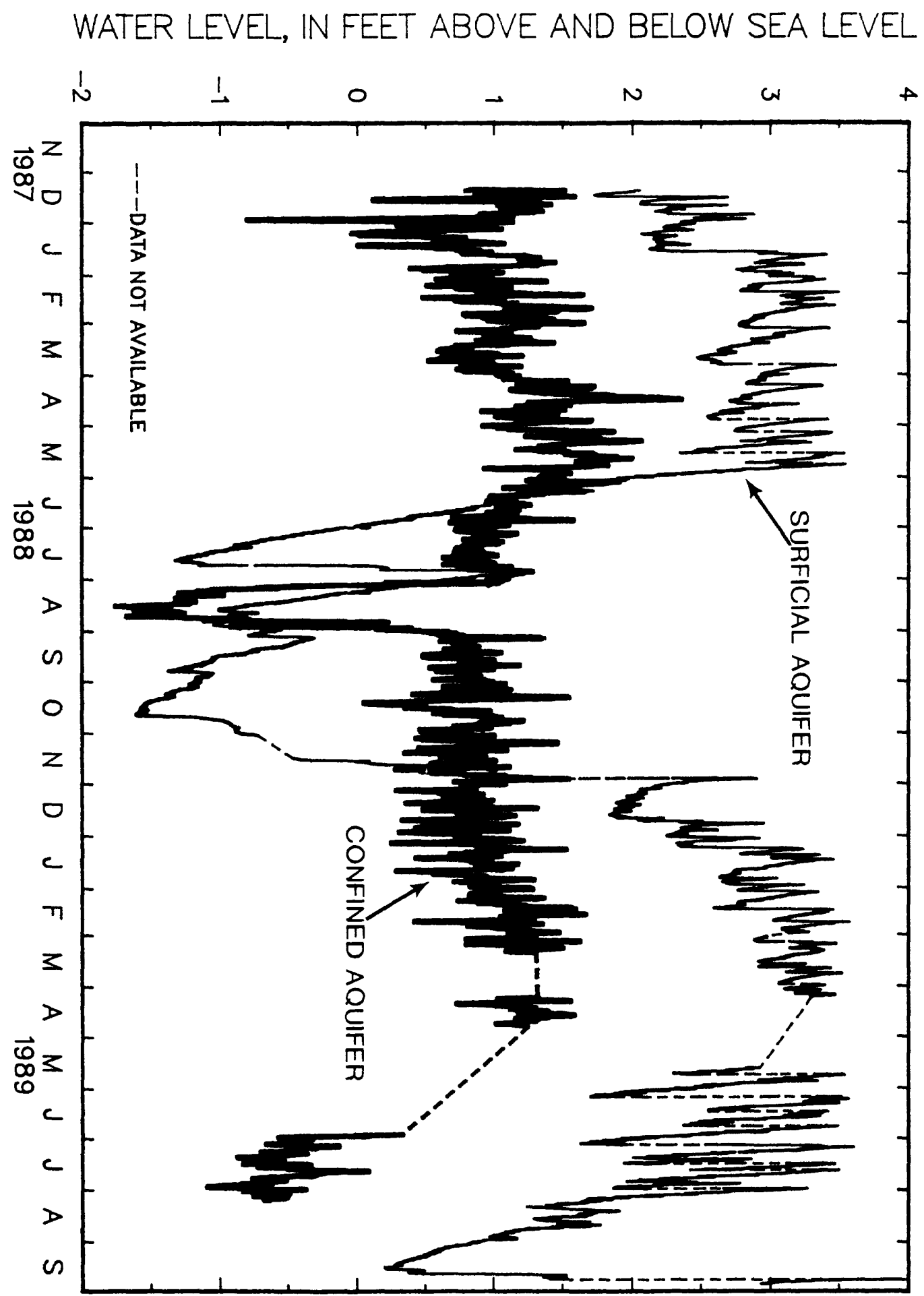



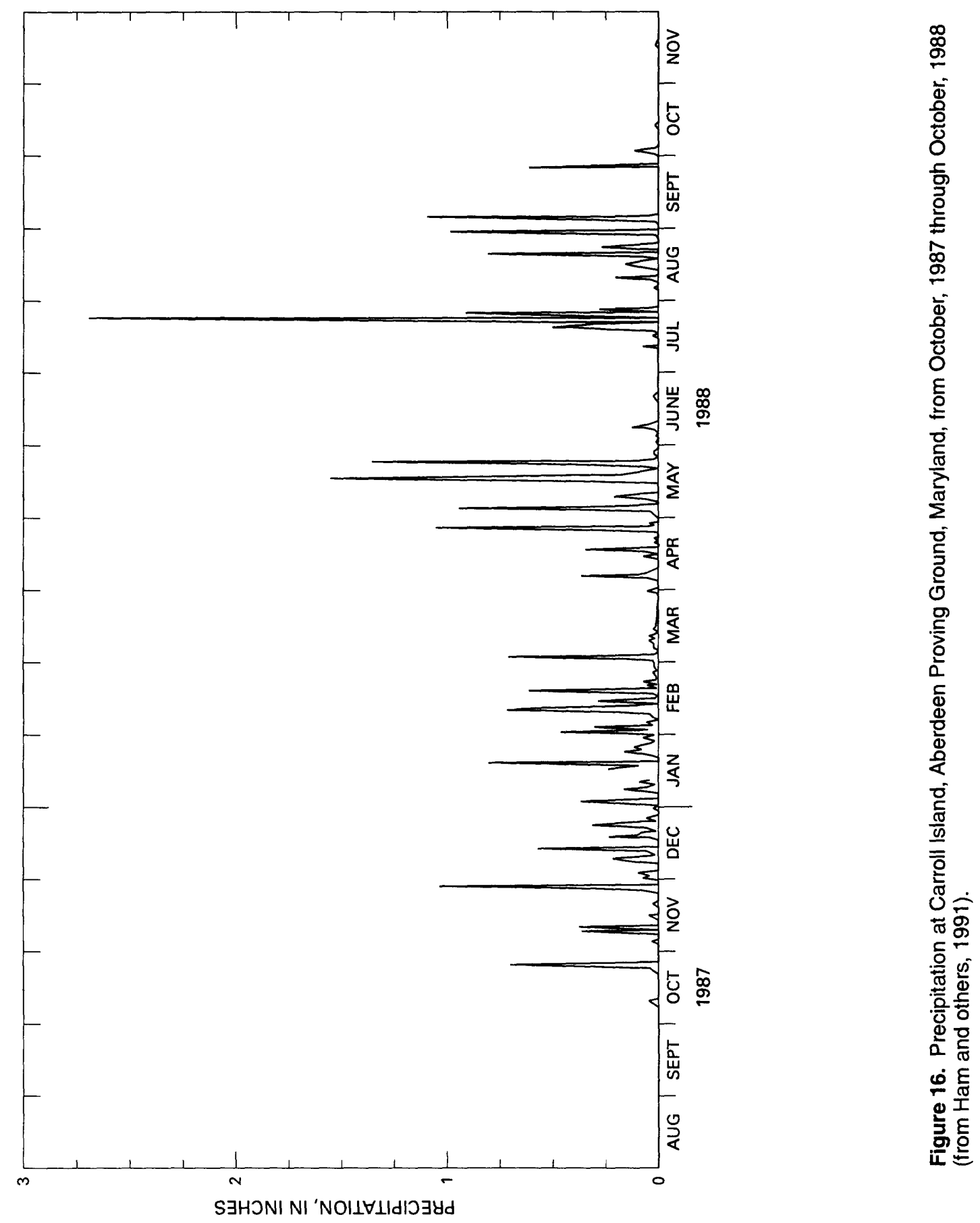
Several methods can be used to analyze slug tests. Each method is best applied to a particular well geometry and hydrogeologic setting. Well geometry refers to the dimensions of the casing and screen; hydrogeologic setting refers to the aquifer type, the relation of the well screen to the aquifer, and the stratigraphy near the well. Commonly-used methods for the analysis of slug tests (Chirlin, 1989, p. 131) include those of Hvorslev (1951), Bouwer and Rice (1976), and Cooper and others (1967).

The slug tests in the surficial aquifer on Carroll Island were analyzed using the methods of Cooper and others (1967) and Hvorslev (1951). The Bouwer and Rice (1976) method was not used at Carroll Island because the calculations are relatively difficult, and the results were not expected to be appreciably different from, or more accurate than, results that would be obtained by using other methods. The method of Cooper and others (1967) was used because the well geometry and hydrogeologic setting of the wells selected for slug testing on Carroll Island were similar to those in a confined aquifer. Each of the wells in the surficial aquifer that was tested contained 8 feet of water or more in the well casing above the screen. This was considered to be a sufficient criterion for application of the method of Cooper and others (1967), because the surficial aquifer on Carroll Island is highly stratified and usually contained clay and silt layers that somewhat isolated the sandier parts of the aquifer where the screen was placed. The validity of each of the Cooper and others (1967) analyses was then determined by a comparison of fit between the actual data and the type curves presented in Reed (1980). The Hvorslev (1951) method also was used to analyze the surficial-aquifer slug tests, and the results were compared to those from the Cooper and others (1967) analyses.

Horizontal hydraulic conductivities in the surficial aquifer (table 3 ) calculated with the method of Cooper and others (1967) ranged from less than 0.02 to $54 \mathrm{ft} / \mathrm{d}$ (feet per day), with a median of $1.6 \mathrm{ft} / \mathrm{d}$. Most of the hydraulic conductivity values were within the range that would be expected for the aquifer materials that were screened, and the values were log-normally distributed.

The lowest hydraulic conductivities determined were from slug tests in wells I37B, I40, and I44. Significant variability in hydraulic conductivity is common in unconsolidated aquifers. It is not obvious, however, from the grain sizes within the aquifer at the
Table 3. Summary of slug-test results in the surficial aquifer, Carroll Island, Aberdeen Proving Ground, Md., May through September 1988

$[<$, less than]

\begin{tabular}{|c|c|c|c|}
\hline \multirow[b]{2}{*}{$\begin{array}{c}\text { Well no. } \\
\text { (fig. 3) }\end{array}$} & \multicolumn{2}{|c|}{$\begin{array}{c}\text { Horizontal hydraulic } \\
\text { conductivity } \\
\text { (feet per day) }\end{array}$} & \multirow[b]{2}{*}{ Material screened ${ }^{3}$} \\
\hline & $\begin{array}{l}\text { Cooper } \\
\text { method }\end{array}$ & $\begin{array}{c}\text { Hvorslev }{ }^{2} \\
\text { method }\end{array}$ & \\
\hline I15 & 1.5 & 0.9 & silty sand, sandy silt \\
\hline I19 & 1.6 & .8 & silty sand \\
\hline $\mathrm{I} 20$ & .2 & .4 & fine-grained sand \\
\hline 121 & 48 & 21 & medium-grained sand, some clay \\
\hline I22B & 4.0 & 2.0 & silty sand \\
\hline $\mathrm{I} 23$ & 2.4 & 1.6 & fine-grained sand, silty sand \\
\hline $\mathrm{I} 25$ & 1.8 & 1.2 & silty sand \\
\hline $\mathrm{I} 26 \mathrm{~A}$ & 2.4 & 1.5 & medium-grained sand \\
\hline $\mathrm{I} 30$ & .4 & 1.0 & silty sand, clayey silt \\
\hline $\mathrm{I} 31$ & 1.2 & 1.0 & sandy silt, medium-grained sand \\
\hline $\mathrm{I} 32$ & 1.6 & 1.4 & sand, silt, clay \\
\hline $\mathrm{I} 33$ & 9.6 & 7.0 & medium-grained sand \\
\hline 134 & 5.0 & 3.4 & medium-grained sand \\
\hline I35 & .2 & .2 & silty sand \\
\hline I36 & 54 & 14 & fine-grained sand, running sand \\
\hline $\mathrm{I} 37 \mathrm{~B}$ & $<.02$ & $<.1$ & sandy silt, medium-grained sand \\
\hline I38 & 1.0 & .9 & sand, silt \\
\hline I39 & .4 & .4 & clay, silt \\
\hline I 40 & $<.02$ & .1 & silty sand \\
\hline I44 & $<.02$ & $<.1$ & medium-grained sand, some clay \\
\hline 150 & 12 & 8.4 & no sample collected \\
\hline
\end{tabular}

${ }^{1}$ Cooper and others (1967).

${ }^{2}$ Hvorslev (1951).

${ }^{3}$ From Ham and others (1991, table 4).

screened area (table 3) why these wells had lower hydraulic conductivities than the other wells. It is possible that the aquifer surrounding the well bore in the screened area was affected by the smearing of clay or silt from above during the drilling process. The hydraulic conductivities from slug tests in these wells therefore may not be representative of the true hydraulic conductivity within the aquifer.

The highest hydraulic conductivities were in wells I21 and I36. Running sand such as that encountered in the borehole at well $\mathrm{I} 36$ is usually a good indicator of high hydraulic conductivity. Well I21 is adja- 
cent to I44 (which had a low hydraulic conductivity) and is screened in what seems to be the same material (table 3). This indicates that the hydraulic conductivity in well I44 may be low because of factors other than grain size.

Hydraulic conductivities in the surficial aquifer calculated with the method of Hvorslev (1951) ranged from less than 0.1 to $21 \mathrm{ft} / \mathrm{d}$ (table 3), with a median of $1.0 \mathrm{ft} / \mathrm{d}$. Hydraulic conductivities calculated with this method also were log-normally distributed. The range of values is smaller than that of the hydraulic conductivities calculated by the method of Cooper and others (1967) for two reasons. First, the low value is not quite as low as in the Cooper method because of the precision to which each method could be calculated. Second, the high value (and the median value) is not quite as high as in the Cooper method because of the effects of compressive storage within the aquifer, which are accounted for by the method of Cooper and others (1967) but not by the Hvorslev (1951) method (Chirlin, 1989, p. 130-131).

A rough estimate of the storage coefficient of an aquifer in the area near the well screen can be determined from slug tests if the data are analyzed by the method of Cooper and others (1967). The shape of the curve that results from plotting the data is related to the aquifer storage coefficient (Cooper and others, 1967, p. 267). The storage coefficients estimated with this method for most of the wells in the surficial aquifer were between $10^{-5}$ and $10^{-3}$; however, for well 120 , the storage coefficient was about $10^{-2}$, and for well 130 , the storage coefficient was about $10^{-1}$.

Chirlin (1989, p. 134-136) contends that the accuracy of the Hvorslev (1951) method within the hydrogeologic setting in which the method of Cooper and others (1967) also is appropriate depends on the degree to which the well response can be attributed to compressive storage. Because compressive storage is not addressed by the Hvorslev (1951) model, it will underestimate hydraulic conductivity in hydrogeologic settings where compressive storage is important. The magnitude of the storage coefficient in most of the wells in the surficial aquifer indicates that compressive storage was an important factor in the response of the water level during the slug test, which means that the method of Cooper and others (1967) is more appropriate than the Hvorslev (1951) model. In wells I20 and I30, the magnitude of the storage coefficient indicates that the effects of compressive storage were negligible. In these wells, the hydraulic conductivities calculated with the Hvorslev (1951) method were somewhat higher than those calculated with the method of Cooper and others (1967), and may be more accurate. In a few wells where the storage coefficient was on the order of $10^{-3}$ (I31, I32, I35, I38, and I39), both models produced essentially equal hydraulic conductivities (table 3 ).

\section{Upper Confining Unit}

The upper confining unit in the Carroll Island area consists of fine-grained sediment from two geologic units--the Cretaceous Patapsco Formation and the Quaternary Talbot Formation. Beneath Carroll Island, the upper confining unit is composed of Quaternary dark-gray clay and silty clay (figs. 7-9). Because this Quaternary unit was deposited as part of a paleochannel, it is discontinuous to the west of the island where the paleochannel ends. West of Carroll Island, the upper confining unit consists of the fine-grained sediment of the Patapsco Formation (figs. 7 and 9).

\section{Extent and Thickness}

The confining unit underlying Carroll Island was encountered in all of the geologic borings drilled during this investigation. This suggests that the confining unit is continuous beneath the island. It is not known how far the confining unit extends into the estuaries to the north, east, and south of Carroll Island, but similar confining units are present in the O-Field and J-Field areas across the Gunpowder River from Carroll Island (fig. 1). West of Carroll Island, the confining unit is continuous across to well BA Fg 74 (figs. 6 and 7) even though the geologic formation is different. Less is known about the continuity and extent of the confining unit west of BA Fg 74, because less data are available, and because the stratigraphy of the Patapsco Formation is more complex than that of the Talbot Formation that underlies Carroll Island.

Lithologic data from the geologic borings were used to determine that the altitude of the top of the confining unit ranged from about $3 \mathrm{ft}$ to $27 \mathrm{ft}$ below sea level (fig. 17). The confining unit is shallowest on the eastern end of the island near the wind tunnel and in the area north of test grid 1 . The thickness of the confining unit underlying Carroll Island ranged from 19 to $41 \mathrm{ft}$ (fig. 18). The unit is generally thickest in the central area of the island. 


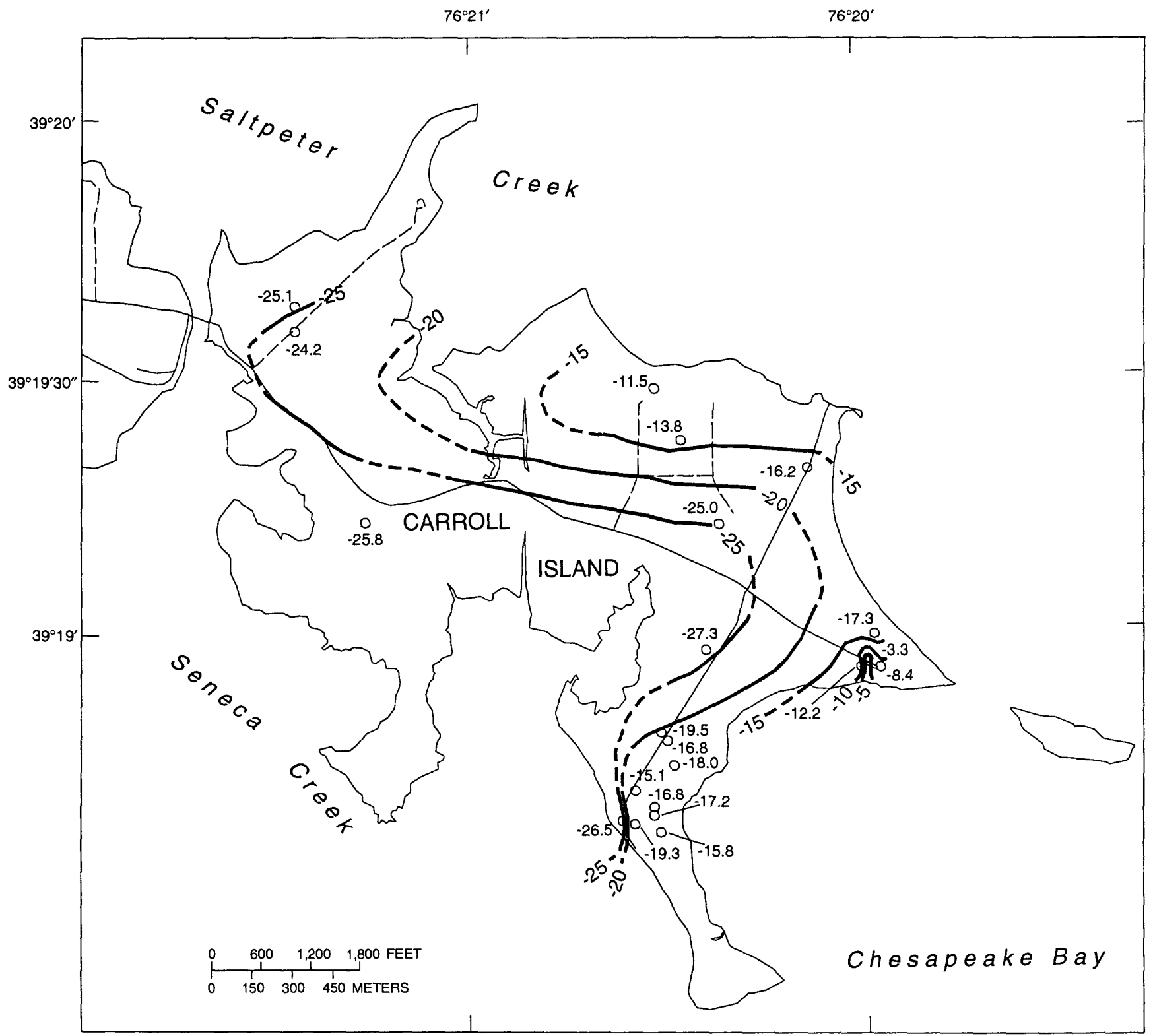

Base modified from U.S. Army, 1:4,800, 1970

\section{EXPLANATION}

$-25-$ STRUCTURE CONTOUR--Shows altitude
of the top of the upper confining unit. of the top of the upper confining unit. Dashed where approximately located. Interval 5 feet. Datum is sea level

O WELL LOCATION--Number is altitude

-19.3 of the top of the upper confining unit, in feet. Datum is sea level

Figure 17. Altitude of the top of the upper confining unit, Carroll Island, Aberdeen Proving Ground, Maryland. 


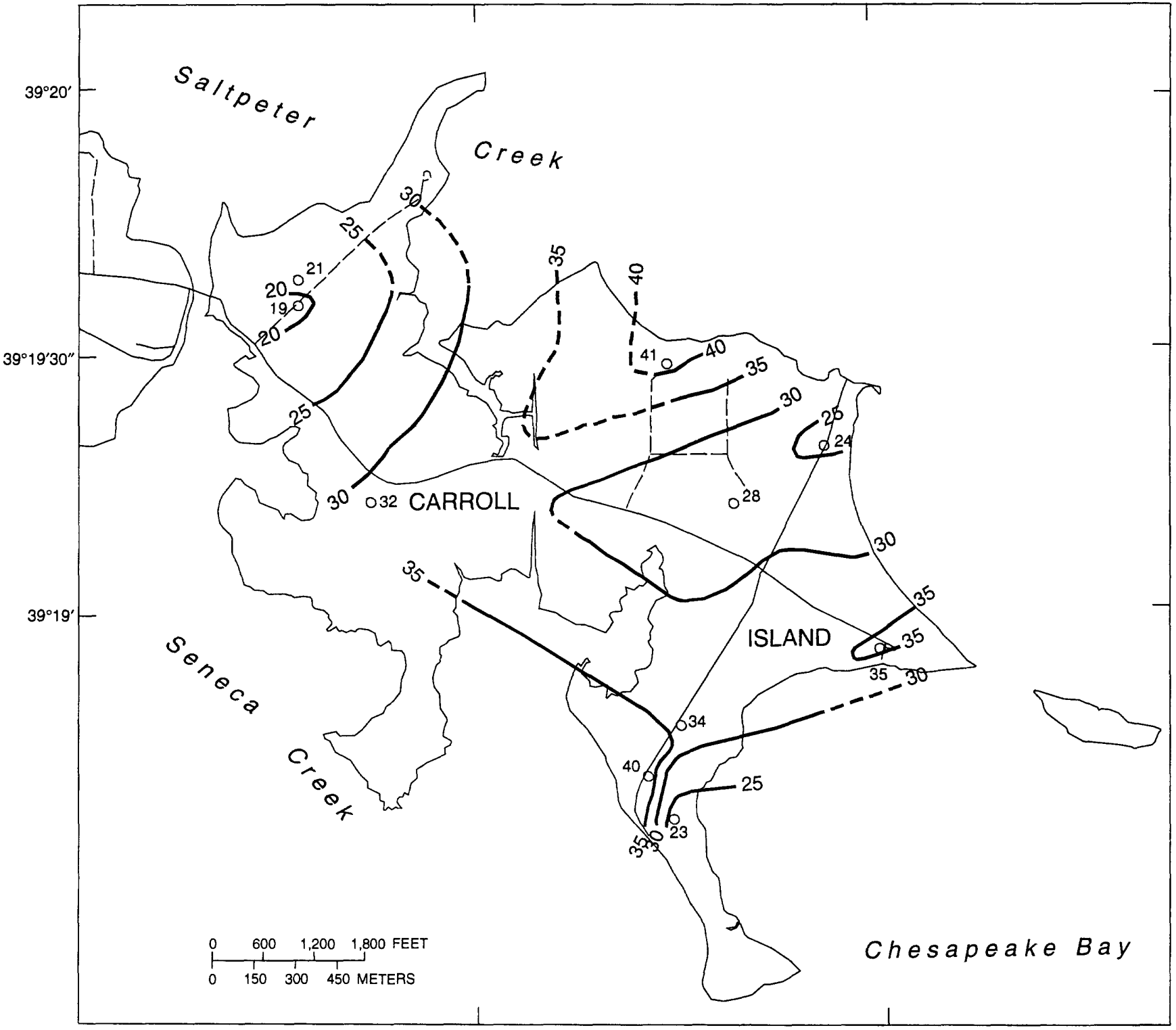

Base modified from U.S. Army, 1:4,800, 1970

\section{EXPLANATION}
- 35 - LINE OF EQUAL THICKNESS--
Dashed where approximately located.
- WELL LOCATION--Number is thickness of the upper confining unit, in feet Interval 5 feet. Datum is sea level

Figure 18. Thickness of the upper confining unit, Carroll Island, Aberdeen Proving Ground, Maryland. 


\section{Hydraulic Properties}

Hydraulic conductivity of the silty clay that comprises the upper confining unit beneath Carroll Island was determined in laboratory experiments on undisturbed core samples collected from four wells during the drilling phase of the study. Core samples were collected from wells I14 (at a depth of 30-32 ft below land surface), I17 (24.5-26.5 ft below land surface), I28 (15$17 \mathrm{ft}$ below land surface), and I31 (25-27 ft below land surface). These samples were collected in Shelby tubes, which are thin-walled samplers that are pushed into sediment with a constant pressure to minimize disturbance. The samples were sealed and sent to the USGS Branch of Geologic Risk Assessment for determination of hydraulic conductivity.

The analyses included measurements of hydraulic conductivity under constant-flow conditions with varying pressure stresses. The results indicated that under the laboratory conditions, hydraulic conductivities in the four samples ranged from $10^{-6}$ to $10^{-4} \mathrm{ft} / \mathrm{d}$ (Gill, 1989, Appendix A), which is several orders of magnitude lower than the horizontal hydraulic conductivities that were measured in the surficial aquifer (table 3). It is likely that the vertical hydraulic conductivity of the upper confining unit under natural conditions is higher than that measured in the laboratory because the laboratory samples may not be representative of the entire unit.

\section{Upper Confined Aquifer'}

Like the upper confining unit, the upper confined aquifer in the Carroll Island area consists of two different geologic formations. Beneath Carroll Island, the aquifer comprises sand and gravel from the Talbot Formation and coarse-grained sediment of the Patapsco Formation (figs. 7 and 8). West of Carroll Island, the unit is composed entirely of sediment of the Patapsco Formation.

\section{Extent and Thickness}

Analysis of lithologic data from borehole records indicates that the upper confined aquifer is continuous from Carroll Island across to the mainland west of the island. The unit thins to the west and becomes discontinuous between sites BA Fg 31 and BA Fg 28 (fig. 7). The aquifer also becomes discontinuous to the southwest, where the sand lenses of the Patapsco Formation become discontinuous (fig. 9). On the southern end of Carroll Island, no coarse-grained sediment from the Patapsco Formation was encountered in test hole I20T (fig. 8), which indicates that the aquifer might pinch out somewhere beneath the Chesapeake Bay, probably within several hundred feet of the shore of Carroll Island. In the area at I20T, the confined aquifer consists entirely of the sand and gravel of the Quaternary deposits, which represent the basal sequence of the paleochannel deposits.

The top of the upper confined aquifer underlying Carroll Island was encountered at altitudes between 38 and $58 \mathrm{ft}$ below sea level (fig. 19). Data from a few wells indicate that the thickness of the aquifer ranges from $13 \mathrm{ft}$ to greater than $100 \mathrm{ft}$ (fig. 20). The aquifer is thinnest in the southern tip of the island, where it consists only of Quaternary deposits (fig. 8). Elsewhere the aquifer is thicker than $50 \mathrm{ft}$ (fig. 20) because it is composed of both Quaternary deposits and coarsegrained Patapsco Formation sediment.

\section{Hydraulic-Head Distribution and Direction of Flow}

Within the upper confined aquifer, the hydraulic head in May and October 1988 (figs. 21 and 22, respectively) did not show much variation during either period. Hydraulic head in May 1988 (fig. 21) ranged from 1.7 to $1.2 \mathrm{ft}$ above sea level in the area underlying Carroll Island. Hydraulic head was slightly higher in the part of the aquifer that underlies the western part of the island. During October 1988, hydraulic head ranged from 0.4 to $0.8 \mathrm{ft}$ above sea level, and was lowest at the southern end of the island (fig. 22).

The ground-water flow direction is to the south, the east, and the southeast, but the hydraulic gradient is low (figs. 21 and 22). The hydrographs for two wells screened in the confined aquifer (figs. 14 and 15), however, indicate that the hydraulic head in the aquifer may vary by $1 \mathrm{ft}$ or more each day because of loading effects induced by tidal fluctuations in the estuaries. Depending on the tidal influences, the flow direction in the aquifer may reverse or change daily. 


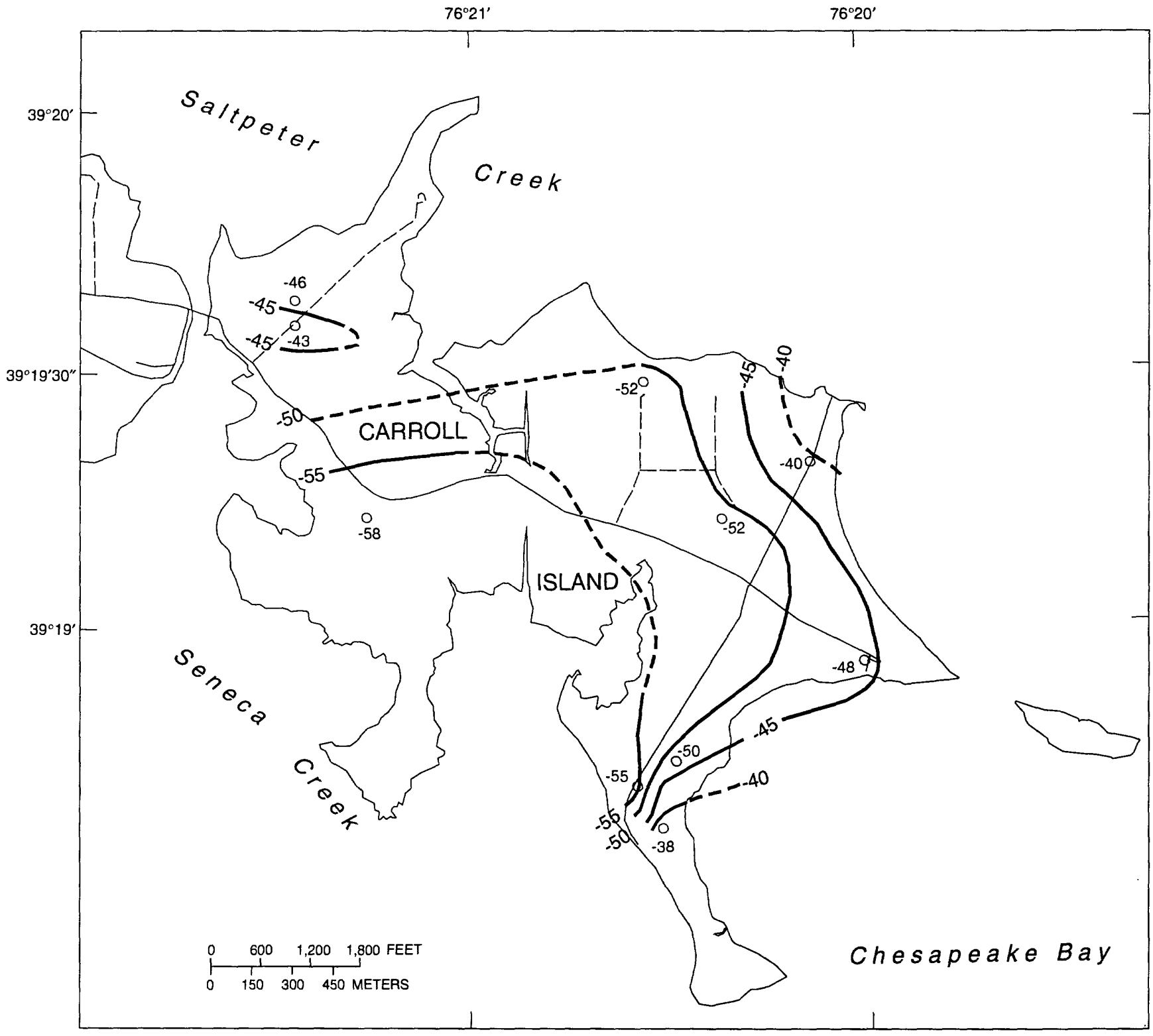

Base modified from U.S. Army, 1:4,800, 1970

\section{EXPLANATION} -50_-5TRUCTURE CONTOUR--shows altitude
of the top of the upper confined aquifer Dashed where approximately located.

WELL LOCATION--Number is altitude Interval 5 feet. Datum is sea level of the top of the upper confined aquifer, in feet. Datum is sea level

Figure 19. Altitude of the top of the upper confined aquifer, Carroll Island, Aberdeen Proving Ground, Maryland. 


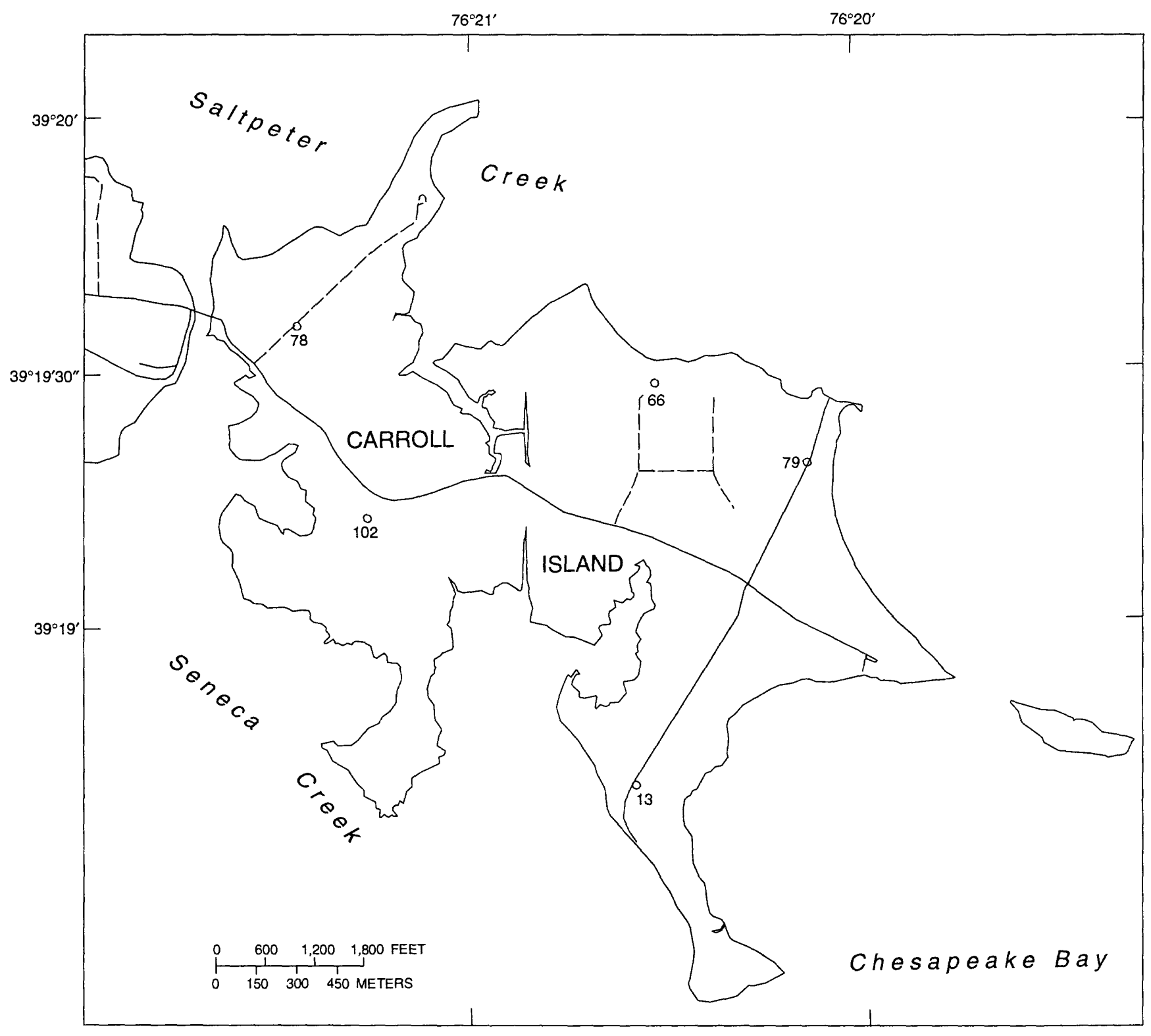

Base modified from U.S. Army, 1:4,800, 1970

\section{EXPLANATION}

TEST HOLE LOCATION--number is thickness

13 of the upper confined aquifer, in feet

Figure 20. Thickness of the upper confined aquifer, Carroll Island, Aberdeen Proving Ground, Maryland. 


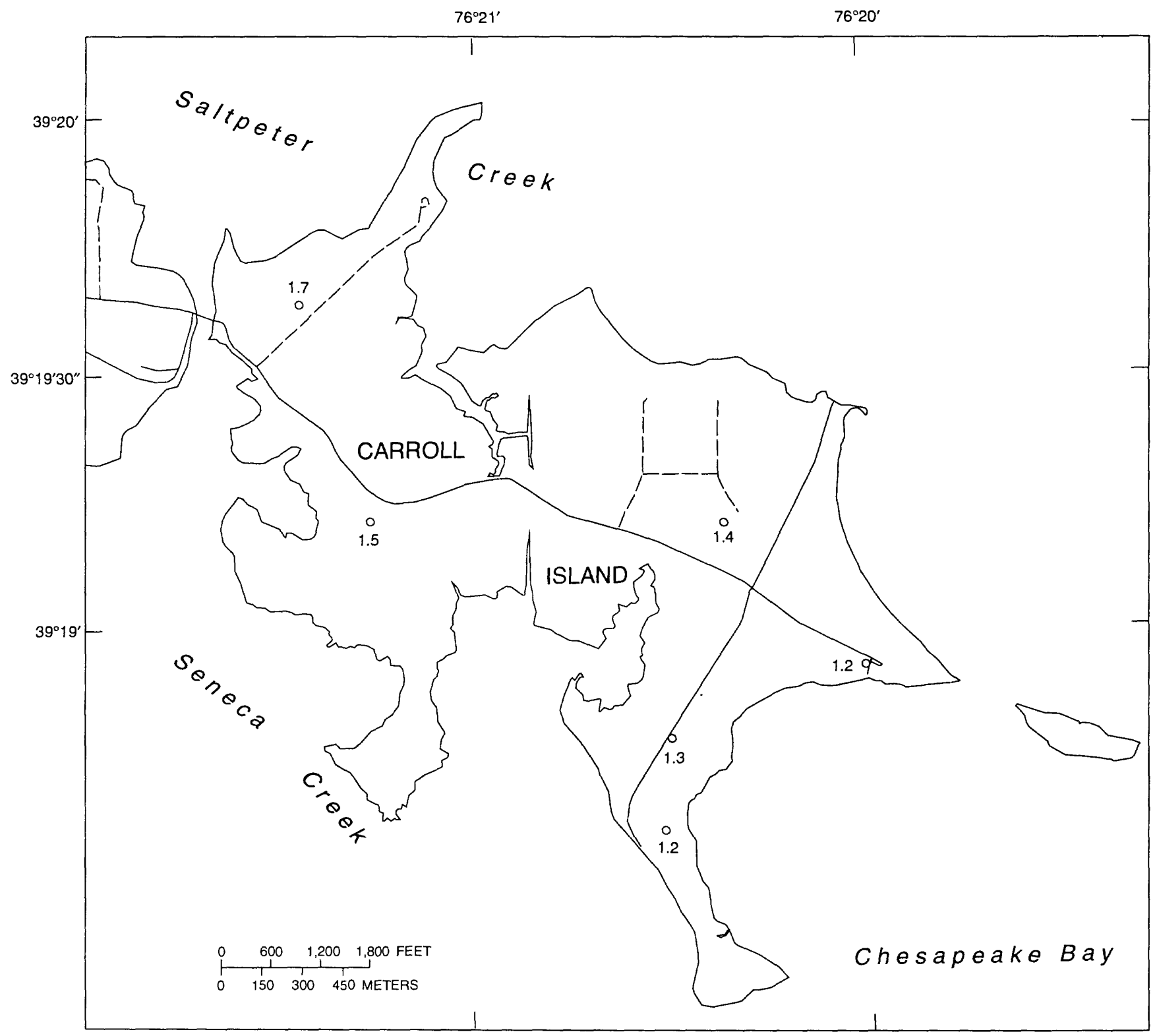

Base modified from U.S. Army, 1:4,800, 1970

\section{EXPLANATION}

- WELL LOCATION--Number is hydraulic head in the upper confined aquifer, in feet. Datum is sea level

Figure 21. Hydraulic head in the upper confined aquifer, Carroll Island, Aberdeen Proving Ground, Maryland, May 1988. 


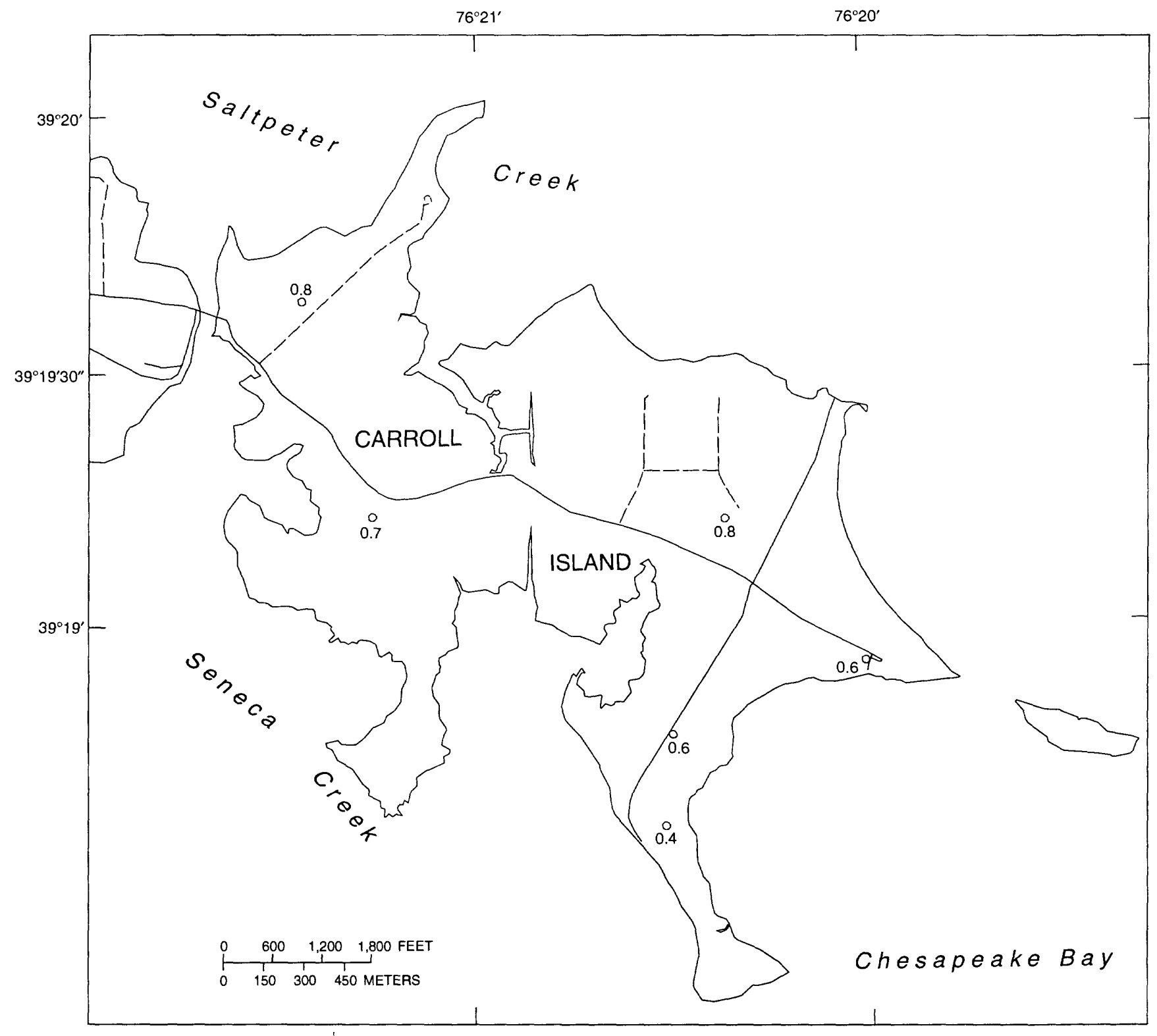

Base modified from U.S. Army, 1:4,800, 1970

\section{EXPLANATION}

$\circ$ WELL LOCATION--Number is hydraulic head in the upper confined aquifer.

in feet. Datum is sea level

Figure 22. Hydraulic head in the upper confined aquifer, Carroll Island, Aberdeen Proving Ground, Maryland, October 1988. 


\section{Hydraulic-Head Fluctuations}

Hydraulic head in the confined aquifer is controlled by loading effects induced by tidal fluctuations in the estuaries and is influenced on the western part of the island by ground-water withdrawals. Recharge and evapotranspiration do not have a noticeable influence on aquifer water levels.

Water levels in the estuaries near Carroll Island fluctuate between 0.5 to $2.0 \mathrm{ft}$ due to tidal influences (Ham and others, 1991, p. 105). A similar daily change in hydraulic head due to tidal loading is evident in the wells completed in the confined aquifer (figs. 14 and 15). The water levels in wells screened in the upper confined aquifer show very little seasonal change. The seasonal fluctuation of median daily water levels is less than $1 \mathrm{ft}$ over the period of record. This small seasonal change suggests that the recharge area for the aquifer is not in proximity to Carroll Island, or that the aquifer is isolated by confining units from local recharge. No relation could be discerned between hydraulic head in the surficial and the upper confined aquifer (figs. 14 and 15); this implies that there is no direct hydraulic connection between the two aquifers.

Hydraulic head in the upper confined aquifer underlying the western parts of the island declined in response to pumping at well BA Fg 74. The water level declined $3 \mathrm{ft}$ in well I54B during August 1988, but the level recovered quickly when the pumping was discontinued (fig. 14). The water-level decline was not observed in well I27A on the eastern part of the island (fig. 15), nor in the surficial aquifer at either site.

\section{Hydraulic Properties}

Slug tests were done in the summer of 1988 on each of the six wells completed in the confined aquifer. Results from the methods of Cooper and others (1967) and Hvorslev (1951) are shown in table 4. Those calculated with the Cooper and others (1967) method are more appropriate in this hydrogeologic setting. The results based on Hvorslev (1951) are consistently lower than those based on Cooper and others (1967), because the method of Cooper and others (1967) accounts for compressive storage in the calculation, and compressive storage is the dominant factor in the response of a confined aquifer to stresses.
Table 4. Summary of slug-test results in wells completed in the confined aquifer, Carroll Island, Aberdeen Proving Ground, Md., May through June 1988

\begin{tabular}{lccl}
\hline \multicolumn{4}{c}{$\begin{array}{c}\text { Horizontal hydraulic } \\
\text { conductivity } \\
\text { (feet per day) }\end{array}$} \\
\cline { 2 - 4 } $\begin{array}{c}\text { Well no. } \\
\text { (fig. 3) }\end{array}$ & $\begin{array}{c}\text { Cooper } \\
\text { method }^{1}\end{array}$ & $\begin{array}{c}\text { Hvorslev }^{2} \\
\text { method }^{-}\end{array}$ & Material screened \\
\hline I16A & 27 & 10 & gravel, running sand \\
I22A & 48 & 17 & gravel, running sand \\
I27A & 6.0 & 3.9 & sand, gravel \\
I37A & 4.8 & 4.2 & no sample collected \\
I47B & 10 & 8.4 & medium-grained sand \\
I54B & 3.5 & 2.8 & no sample collected \\
\hline & & & \\
I Cooper and others (1967). & & \\
${ }^{2}$ Hvorslev (1951). &
\end{tabular}

The horizontal hydraulic conductivity values for the confined aquifer calculated by the method of Cooper and others (table 4) range from 3.5 to $48 \mathrm{ft} / \mathrm{d}$, with a median of $8.0 \mathrm{ft} / \mathrm{d}$. This range is only one order of magnitude, as opposed to three in the surficial aquifer (table 3). The highest conductivity values were from wells I16A and I22A, which were both screened in gravel and running sand (table 4). Hydraulic conductivities in the confined aquifer (table 4) are all within the range that would be expected for the aquifer materials where they were screened.

\section{Lower Confining Unit}

The characteristics of the lower confining unit are poorly known in the study area. It is composed of fine-grained sediment of the Patapsco Formation. The top of the unit is about $120 \mathrm{ft}$ below sea level across the northern parts of Carroll Island (fig. 7), but the depth to the top varies over the southern parts of the island. The unit is about $65 \mathrm{ft}$ below sea level at well I16A, but is $100 \mathrm{ft}$ deeper near the center of the island (fig. 8). The depth of the confining unit varies with the thickness of the overlying confined aquifer. The thickness of the lower confining unit is not well defined. 


\section{CHEMICAL QUALITY OF WATER AND SOIL}

This section of the report presents chemicalquality data for ground water, surface water, and soils in the Carroll Island area and evaluates the chemical composition in terms of natural conditions and anthropogenic contamination. Where contamination was detected, preliminary inferences regarding the source, movement, and extent of contamination are given.

The occurrence and movement of contaminants within a hydrogeologic system depend on a number of factors, including the amount and type of material applied or buried at a site, the hydrogeologic framework, the presence and movement of surface water and ground water, and the chemical stability, solubility, and sorptive properties of the contaminant. On Carroll Island, the material that was disposed in burial pits and dump sites is commonly in direct contact with ground water because the water table is close to the surface and with surface water because several of the dump sites were within or near the marshes.

Water samples were collected at Carroll Island to characterize the chemistry of ground water and surface water in the area and to determine if the quality of the water has been adversely affected by the presence of SWMU's and by the historical testing activity. Many chemical compounds were used on Carroll Island during the historical testing period. These compounds included chemical-warfare agents, organic solvents, inorganic decontaminating agents, and various other chemicals. The sampling and analysis strategy was designed to detect releases of chemicals from SWMU's and test areas, and to analyze for the compounds that would most likely be present from anthropogenic contamination. Ground water and surface water were sampled twice, once during a dry season (August 1988) and once during a wet season (April and May 1989). Samples from the 1988 and 1989 sampling runs were analyzed by two different laboratories under contract to USATHAMA. The validity of the laboratory analyses for the August 1988 samples, however, was questioned by USATHAMA and the data were invalidated. For this reason, the August 1988 data are not presented in this report, and are not used for any of the interpretations that appear in later sections of the report.

Water samples from 61 wells and 21 surfacewater sites were collected at Carroll Island in April and May 1989 and analyzed for major ionic constituents, trace elements, nutrients, volatile and semivolatile organic compounds, and physical properties. The analytes are listed in Tenbus and Phillips (1991, p. 5358). One pre-existing well, I11, was not sampled because it seemed to be damaged below the ground surface.

Fifty-five of the 61 ground-water samples were collected from wells screened in the surficial aquifer and 6 were collected from wells screened in the upper confined aquifer. Results of these analyses are shown in tables 11 through 14 (at the end of the report), and sampling locations are shown in figure 3. Surfacewater samples were collected from various surface expressions of water including ponds, ditches, marshes, sumps, and estuaries. Surface-water site locations are shown in figure 4 and the results of the chemical analyses are presented in tables 15 and 16 (at the end of the report).

In addition to ground-water and surface-water samples, 29 surficial soil samples were collected from 26 sites at Carroll Island during the summer of 1990 and were analyzed for major ionic constituents, trace elements, and volatile and semivolatile organic constituents. Soil-sampling sites were chosen to be representative of likely areas of soil contamination. Samples were collected from the top 6 inches of soil with a steel shovel and placed in a stainless-steel pan. Three 40-mL (milliliter) amber vials were filled with soil for analysis of volatile organic compounds and tightly capped. After the vials were filled, each sample was mixed within the stainless-steel pan to homogenize the soil, and a $250-\mathrm{mL}$ and $1-\mathrm{L}$ (liter) bottle were filled with soil for the remaining analyses. The results of these chemical analyses are presented in tables 17 and 18 (at the end of the report). Soil-sampling site locations are shown in figure 5.

The chemistry data presented in this report were reviewed for accuracy and verified for quality by inspection of the data, computation of ion balances, and the collection and analysis of a number of qualitycontrol samples as described in Tenbus and Phillips (1991). The types of quality-control samples analyzed included replicate samples, split samples, trip blanks, and equipment (wash) blanks. Each sample type was useful for identifying different types of error in the sampling results.

Replicate samples were collected sequentially at the site, and analyzed for the same suite of constituents at the contract laboratory. They were collected at wells $\mathrm{I} 18, \mathrm{I} 22 \mathrm{~B}, \mathrm{I} 26 \mathrm{~A}, \mathrm{I} 34, \mathrm{I} 37 \mathrm{~B}$, and I53 (all in the surficial 
aquifer); at inland surface-water site SW09; and at estuarine surface-water site SW11. Replicate soil samples also were collected at sites CISOIL01, CISOIL06, and CISOIL15. Results from the replicate samples were used to determine the precision of the analyses from the USATHAMA contract laboratories.

Split samples were collected like replicates but were analyzed at the USGS National Water Quality Laboratory (NWQL). Split samples were collected at wells I17, I18, I26A, I33, and I34 in the surficial aquifer; at wells I16A, I22A, and I47B in the confined aquifer; and at inland surface-water site SW09. No split samples were collected during soil sampling. Results from the split samples were compared to determine if results from one laboratory were similar to those from another.

Trip blanks were shipped with samples to determine if the samples were contaminated by volatile organic compounds during the shipping and storage of samples and sample bottles. Trip blanks were included in each of the sample coolers that were shipped to the laboratory during surface-water, ground-water, and soil sampling. During the water sampling, trip blanks consisted of $40-\mathrm{mL}$ glass vials that were filled at the laboratory and sent with the empty sample bottles. These trip blanks were carried on each sampling trip and shipped back to the laboratory with the regular samples for analysis. During the soil sampling, trip blanks consisted of 40-mL glass vials that were filled with deionized water by sampling personnel at the end of each day and shipped along with the soil samples for analysis.

Equipment blanks were collected through the pumps and bailers used for sampling after decontamination of the sampling equipment during ground-water and surface-water sampling. Equipment blanks consisted of deionized water that was subjected to the same procedures as a standard ground-water or surfacewater sample. Results from these samples (tables 19 and 20 , at the end of the report) were used to determine if any analytical detections may have been caused by cross-contamination that resulted from inadequate decontamination of equipment.

Under the Safe Drinking Water Act of 1986, the USEPA (1989; 1990a; 1990b; 1990c; 1990d; 1990e; $1991 \mathrm{a} ; 1991 \mathrm{~b} ; 1991 \mathrm{c} ; 1992)$ established and updated two sets of regulations that set maximum levels for contaminants in treated drinking water. Primary drinking-water regulations include the Maximum Contaminant Levels (MCL), Maximum Contaminant Level Goals (MCLG), and Proposed Maximum Contaminant
Levels. Secondary drinking-water regulations include the Secondary Maximum Contaminant Levels (SMCL) and Proposed Secondary Maximum Contaminant Levels. The MCL's are enforceable health-based regulations with which public drinking-water supplies must be in compliance. The MCLG's are non-enforceable health goals set at the level at which no known or anticipated adverse effects to health occur. The SMCL's are non-enforceable levels which, when exceeded, pose no known health risk, but may be undesirable for aesthetic reasons. None of the other drinking-water regulations are enforceable; however, all of the regulations can be useful for determining the quality of a water resource.

In addition to the drinking-water regulations, water-quality criteria designed to protect aquatic life in the environment (U.S. Environmental Protection Agency, 1986) are applicable. These are known as Federal ambient water-quality criteria. The criteria that are appropriate to the Carroll Island sampling results are known as the fresh-water acute (FWA) and freshwater chronic (FWC) criteria. This report discusses the presence of inorganic and organic compounds in ground-water and surface-water samples in relation to these water-quality regulations and criteria.

Because ground water on Carroll Island cannot be ruled out as a potential future drinking-water source, the MCL's, SMCL's, and Proposed MCL's are the most appropriate regulations for comparison with results of ground-water analyses. Results of surface-water analyses are compared to the ambient water-quality criteria because surface water on and around Carroll Island is not likely to be used for human consumption. Surfacewater samples collected from Saltpeter Creek, Seneca Creek, and the Chesapeake Bay are brackish, but analyses from these samples are most appropriately compared to the fresh-water criteria because the estuarine waters in this area are considered by the State of Maryland to be fresh (Code of Maryland Regulations 26.08.02.03-1B). Surface-water samples collected within the land area of Carroll Island also are most appropriately compared to the fresh-water criteria (FWA and FWC).

Some compounds detected in water samples from Carroll Island are not regulated by water-quality regulations or criteria, and in some cases, natural geochemical processes can produce water that contains concentrations of constituents in excess of an applicable water-quality regulation. Because of this, it is desirable to have background samples from an uncontaminated area in a similar environment to compare to 
the analyses from the area in question. Offsite background samples were not collected in this study, but some water-quality analyses from similar environments are available in the published literature and from unpublished sources. Comparisons to these data sources are made in this report whenever possible. In addition, upgradient wells were installed at each of the SWMU's. Upgradient wells include site 120 at the Lower Island disposal site, sites I52 and I53 at the Bengies Point Road dump site, site I41 at the EPG dump site, site I38 at the BZ test burn pit, site I29 at the wind tunnel, and site I49 at the service area (figs. 2 and 3). These upgradient wells may not represent true background (upgradient) conditions because of the potential of contamination from sources further upgradient and the potential for gradient reversals causing changes in flow direction. Upgradient wells, however, are less likely to be contaminated than downgradient wells, so contaminant concentrations between upgradient and downgradient wells also are compared.

\section{Physical Properties and Inorganic Constituents}

Physical properties and inorganic constituents are used to describe the chemical quality of ground water and surface water. Physical properties including specific conductance, $\mathrm{pH}$, temperature, and alkalinity are indicators of the geochemical conditions that affect the stability of chemical species. Physical properties are measured onsite because $\mathrm{pH}$ and temperature change quickly when samples are removed from the natural environment. Major ions are those constituents that are present naturally, typically in concentrations greater than $1.0 \mathrm{mg} / \mathrm{L}$. Many trace elements (minor constituents) are present naturally in small concentrations (less than $1 \mathrm{mg} / \mathrm{L}$ ); however, increased concentrations of these elements can be derived from contamination sources or can be found in unique chemical environments.

The concentrations of inorganic constituents in ground water, surface water, and soil, and the values of physical properties in ground water and surface water were summarized with descriptive statistics for the discussions that follow. Because some of the constituents were below detection limits and the populations of constituent concentrations were not necessarily normally distributed, the median, maximum, and minimum were used to describe the central values and range of the sample populations. In addition, water samples were grouped so comparisons could be made between samples collected from different environments. The groups included samples collected from the confined aquifer (wells I16A, I22A, I27A, I37A, I47B, and I54B), samples collected from the surficial aquifer (all remaining wells), samples collected from estuarine surface-water sites (SW04, SW06, SW07, SW10, SW11, and SW19), and samples collected from inland sites (all remaining sites). Data sets were compared with the Wilcoxon-Mann-Whitney rank sum test (Iman and Conover, 1983, p. 280-287), a nonparametric test that uses ranked data to test the likelihood that the means of two populations are equal. The level of significance (two-tailed) used in these comparisons was 0.05 .

In addition to the above groupings, the upgradient wells (I20, I29, I38, I41, I49, I52, and I53) in the surficial aquifer were compared with all other wells in the surficial aquifer to determine if the means for the inorganic constituents were different. Significantly higher mean concentrations of constituents in the downgradient wells than in the upgradient wells would be a strong indication that the sources of these constituents were within the disposal pits or test areas.

Because this is a test in which one mean is assumed to be higher than the other, the more powerful one-tailed Wilcoxon-Mann-Whitney rank sum test was used, with the same 0.05 level of significance. The results of these comparisons indicated that none of the concentrations of inorganic constituents was significantly higher in the downgradient wells. These results support one of two conclusions: either the upgradient wells are as contaminated as the downgradient wells, or the downgradient wells are no more contaminated than background. The primary benefit of this exercise is that it does not show definitively that the downgradient wells are contaminated, which is useful information.

\section{Quality Assurance}

As part of the project quality-assurance program, the inorganic chemical data for each ground-water and surfacewater sample site were reviewed for accuracy using the ion balance method described by Hem (1989, p. 164). In this method, the total concentration (in milliequivalents per liter) of anions is compared to the total concentration of cations. In natural waters, the sum of cations and anions should be equal. Hem (1989, p. 164) suggests that the difference between the sums of cations and anions should 
not exceed 1 or 2 percent of the total of cations and anions in waters of moderate concentration (total ion concentration of $250-1000 \mathrm{mg} / \mathrm{L}$ ). In dilute waters (total anions and cations less than 5 milliequivalents per liter), however, a larger percentage of error may be acceptable.

The balance errors of ground-water and surfacewater data were checked, and very few fell within 1 to 2 percent of the total of cations and anions. Of 64 ground-water samples (including replicates) analyzed by the USATHAMA contract laboratory that were complete enough so that ion balances would not be adversely affected by missing data, 33 samples had balance errors greater than 10 percent. Only 18 of the 64 samples had balance errors less than 5 percent, and 9 of 64 had errors less than 2 percent. This contrasts with the surface-water results, in which 5 of 23 samples analyzed by the USATHAMA contract laboratory had errors greater than 10 percent, and 9 of the 23 samples had errors less than 5 percent.

Because of the relatively large balance errors in the ground-water data, attempts were made to determine if patterns existed in the data that would indicate the source of the errors. It was determined that the balance errors in ground-water samples analyzed by the USATHAMA contract laboratory were approximately normally distributed with a mean of -9.5 percent and a standard deviation of 7.7. This indicates that the analyses were biased toward higher concentrations of anions than cations. The balance errors in surfacewater samples were not normally distributed and exhibited a positive bias. The mean error was 2.6 percent, and the standard deviation of the error distribution was 11.2.

It was mentioned earlier that ion balances are commonly less accurate in dilute waters than in waters having moderate ionic concentrations (Hem, 1989, p. 164). To determine if this would explain some of the balance errors within the Carroll Island ground-water data, the percent error and the absolute value of the percent error were each regressed with specific conductance (which is an indicator of total ion concentrations in water) and with chloride concentration (which is a common ion in the ground water at this site). No significant correlations were identified in any of these linear regressions, which suggests that the magnitude of the balance error was not related to ionic strength in the water.

An analysis of replicate and split samples was useful to help determine possible causes of the balance errors. Balances were checked on the split samples to see if the errors from each laboratory were similar. Of seven split ground-water samples analyzed by the USGS NWQL, only one sample (from well I33) had a balance error greater than 10 percent. However, of the corresponding samples analyzed by the USATHAMA contract laboratory, four had balance errors greater than 10 percent. This indicates that the problem may have originated in the USATHAMA contract laboratory.

In addition, the relative percent difference in concentration for each inorganic constituent between a ground-water sample and its replicate was compared to determine which data were the least accurate. Analysis of the differences in concentration of constituents between corresponding analyses in the replicate ground-water samples revealed a median difference for all major ions of 2.7 percent, with a minimum of zero and a maximum greater than 37 percent. When calculated separately, none of the median differences for major ions exceeded 10 percent. The relative percent difference for minor constituents was greater than for major ions. The minimum difference in concentration of minor constituents between each sample and its replicate was zero, the median was 8.1 percent, and the maximum was greater than 36 percent. The median differences in replicates for several individual minor constituents (aluminum, arsenic, copper, nickel, and zinc) were greater than 10 percent. Censored data (a statistical term for values below a detection limit) were excluded from the calculation of differences, except in cases where a constituent was detected in one replicate but not the other.

The differences in concentrations of constituents in split ground-water samples also were investigated. The median difference in concentrations of major ions between analyses done by the USATHAMA contract laboratory and the NWQL was 8.1 percent. For minor constituents, the median difference was 13 percent. The concentrations in the NWQL analyses were higher in every case for calcium, magnesium, and silica, and in nearly every case for sodium. The differences were mixed for potassium and sulfate, and the concentrations in the NWQL analyses were lower every time for chloride. These data indicate that a probable cause for the balance errors was that the USATHAMA contract lab was consistently underestimating cations such as calcium, magnesium, and sodium, and overestimating anions such as chloride. This would account for the anion bias that was apparent in most of the balance errors. 
Two replicate surface-water samples were collected (sites SW09 and SW11). The median difference in replicate samples for major ions was 4.2 percent, whereas the median difference for minor constituents was 12 percent. Only one split surface-water sample was collected (site SW09). The median difference in concentration in this sample was 82 percent for major ions and 23 percent for minor constituents.

Although there are inaccuracies in some of the ground-water and surface-water data, some useful information can be derived from the results of these analyses. For graphical presentations such as Stiff diagrams, only sampling sites with balance errors less than 10 percent were included on the diagram. For statistical comparisons, all of the data were used (except replicates and splits), regardless of the balance error. For the comparisons of the concentrations of constituents to water-quality regulations and criteria, all data were used, but the possibilities of analytical error are included in the discussion.

In addition to the above quality checks, equipment blanks were collected during ground-water and surface-water sampling to determine if any detections of inorganic constituents resulted from contaminated equipment. Only limited data were returned from the laboratory (table 19, at the end of the report). No inorganic constituents were detected in the equipment blanks.

In soil samples, the primary check on data quality for inorganic constituents that was possible was a comparison of the differences between replicate samples for each constituent. Replicate samples were collected at sites CISOIL01 (CISOIL101), CISOIL06 (CISOIL106), and CISOIL15 (CISOIL115). The median difference between replicate samples was 3.9 percent. The range of differences was 0.1 to greater than 57 percent. Censored data were excluded from the calculation of differences, except in cases where a constituent was detected in one replicate but not the other.

\section{Physical Properties}

The specific conductance of a water sample is a physical property that is closely related to the concentration of dissolved ions. Specific conductance in ground-water samples at Carroll Island was highly variable, ranging from 77 to $7,720 \mu \mathrm{S} / \mathrm{cm}$ (microsiemens per centimeter at 25 degrees Celsius) with a median of $364 \mu \mathrm{S} / \mathrm{cm}$ (table 5). Conductance was more variable in the surficial aquifer than in the confined aquifer; the highest and lowest values were both measured in samples from the surficial aquifer (table 5). The causes of this variability are difficult to isolate, although much of the variability probably can be attributed to variations in the hydrogeologic conditions on Carroll Island. Many of the highest conductance values were found in samples from the surficial aquifer near the shoreline (fig. 23) or marshes. Values varied considerably among samples from adjacent wells, however, so no natural patterns to the conductance values are obvious. Because of the many possible sources of high conductance values in groundwater samples at Carroll Island, specific conductance by itself is not a good indicator of anthropogenic contamination at this site.

Specific conductance values in ground water at Carroll Island were similar to those at other locations at APG. No significant difference was found between the median specific conductance values in the Carroll Island ground water and in the surficial aquifer in the Canal Creek area of APG, which consists primarily of Talbot Formation sediment (Oliveros and Vroblesky, 1989 , p. 14) similar to that on Carroll Island. Specific conductance in samples from the surficial aquifer at Canal Creek (Lorah and Vroblesky, 1989, p. 27) had a median of $412 \mu \mathrm{S} / \mathrm{cm}$ and a range of 205 to 8,340 $\mu \mathrm{S} / \mathrm{cm}$. The highest conductance values at Carroll Island $(5,780$ to $7,720 \mu \mathrm{S} / \mathrm{cm})$ were located in an area on the northern shore of the island (fig. 23). These values were similar to conductances in the surficial aquifer near the shoreline at O-Field $(5,140$ and $6,190 \mu \mathrm{S} / \mathrm{cm})$, which were attributed to infiltration of brackish water from the nearby tidal creek (Vroblesky and others, 1989, p. 54).

The $\mathrm{pH}$ of water on Carroll Island varied among the ground-water and surface-water environments present on the island. The $\mathrm{pH}$ of water in the surficial aquifer generally was low, with a median of 5.77 and a range of 4.09 to 6.84 (table 5). The $\mathrm{pH}$ of water in the confined aquifer was significantly higher, ranging from 6.62 to 8.83 with a median of 7.03 (table 5). In surface water, the $\mathrm{pH}$ of inland samples was not significantly different from the $\mathrm{pH}$ of estuarine samples, but the median $\mathrm{pH}$ of all surface-water samples was higher than the median $\mathrm{pH}$ in ground-water samples. The $\mathrm{pH}$ in surface-water samples ranged from 5.53 to 7.45 , with a median of 6.92 (table 5). 
Table 5. Range of selected physical properties and concentrations of major inorganic constituents in ground-water and surface-water samples, Carroll Island, Aberdeen Proving Ground, Md., spring 1989

[Concentrations in milligrams per liter, $\mathrm{pH}$ in standard units, specific conductance in microsiemens per centimeter at 25 degrees Celsius; gw, ground water; sw, surface water; <, less than; MCL, maximum contaminant level; MCLG, maximum contaminant level goal; SMCL, secondary maximum contaminant level; *, contaminant level exceeded; replicate and split samples not included]

\begin{tabular}{|c|c|c|c|c|c|c|}
\hline \multirow{2}{*}{$\begin{array}{l}\text { Property or } \\
\text { constituent }\end{array}$} & \multirow{2}{*}{$\begin{array}{c}\text { Sample } \\
\text { type }\end{array}$} & \multirow{2}{*}{$\begin{array}{c}\text { Number of } \\
\text { samples }\end{array}$} & \multicolumn{3}{|c|}{ Range } & \multirow[b]{2}{*}{ Contaminant level ${ }^{1}$} \\
\hline & & & Maximum & Median & Minimum & \\
\hline \multirow{6}{*}{$\begin{array}{l}\text { Specific } \\
\text { conductance }\end{array}$} & all gw & 60 & 7,720 & 364 & 77 & \\
\hline & surficial gw & 54 & 7,720 & 345.5 & 77 & \\
\hline & confined gw & 6 & 1,270 & 578.5 & 414 & \\
\hline & all sw & 21 & 2,210 & 554 & 87 & \\
\hline & inland sw & 15 & 2,100 & 418 & 87 & \\
\hline & estuarine sw & 6 & 2,210 & 1,955 & 1,430 & \\
\hline \multirow[t]{6}{*}{$\mathrm{pH}$} & all gw & 61 & $8.83 *$ & $5.79 *$ & $4.09 *$ & $6.5-8.5(\mathrm{SMCL})$ \\
\hline & surficial gw & 55 & 6.84 & $5.77 *$ & $4.09 *$ & \\
\hline & confined gw & 6 & $8.83 *$ & 7.03 & 6.62 & \\
\hline & all sw & 21 & 7.45 & 6.92 & 5.53 & \\
\hline & inland sw & 15 & 7.45 & 6.88 & 5.53 & \\
\hline & estuarine sw & 6 & 7.35 & 6.995 & 6.81 & \\
\hline \multirow[t]{6}{*}{ Alkalinity } & all gw & 56 & 525 & 56.5 & 1 & \\
\hline & surficial gw & 50 & 525 & 35 & 1 & \\
\hline & confined gw & 6 & 253 & 213.5 & 111 & \\
\hline & all sw & 21 & 219 & 31 & 8 & \\
\hline & inland sw & 15 & 219 & 35 & 8 & \\
\hline & estuarine sw & 6 & 29 & 14.5 & 13 & \\
\hline \multirow[t]{6}{*}{ Calcium } & all gw & 61 & 85.0 & 12.6 & 3.33 & \\
\hline & surficial gw & 55 & 84.0 & 11.4 & 3.33 & \\
\hline & confined gw & 6 & 85.0 & 64.0 & 42.0 & \\
\hline & all sw & 21 & 82.0 & 17.4 & 3.99 & \\
\hline & inland sw & 15 & 82.0 & 16.1 & 3.99 & \\
\hline & estuarine sw & 6 & 25.0 & 17.6 & 15.8 & \\
\hline \multirow[t]{6}{*}{ Magnesium } & all gw & 61 & 180 & 6.78 & 1.53 & \\
\hline & surficial gw & 55 & 180 & 6.91 & 1.53 & \\
\hline & confined gw & 6 & 15.1 & 5.045 & 2.00 & \\
\hline & all sw & 21 & 47.0 & 14.4 & 2.52 & \\
\hline & inland sw & 15 & 40.0 & 10.0 & 2.52 & \\
\hline & estuarine sw & 6 & 47.0 & 38.5 & 29.0 & \\
\hline \multirow[t]{6}{*}{ Sodium } & all gw & 61 & 1,300 & 34.5 & 2.09 & \\
\hline & surficial gw & 55 & 1,300 & 34.3 & 2.09 & \\
\hline & confined gw & 6 & 160 & 31.5 & 9.95 & \\
\hline & all sw & 21 & 370 & 73.0 & 1.86 & \\
\hline & inland sw & 15 & 370 & 36.9 & 1.86 & \\
\hline & estuarine sw & 6 & 370 & 305 & 220 & \\
\hline \multirow[t]{6}{*}{ Potassium } & all gw & 61 & 39.0 & 2.78 & $<.375$ & \\
\hline & surficial gw & 55 & 33.0 & 2.78 & $<.375$ & \\
\hline & confined gw & 6 & 39.0 & 5.93 & 1.79 & \\
\hline & all sw & 21 & 16.0 & 6.03 & 1.80 & \\
\hline & inland sw & 15 & 14.0 & 4.60 & 1.80 & \\
\hline & estuarine sw & 6 & 16.0 & 13.8 & 10.5 & \\
\hline
\end{tabular}


Table 5. Range of selected physical properties and concentrations of major inorganic constituents in ground-water and surface-water samples, Carroll Island, Aberdeen Proving Ground, Md., spring 1989--Continued

\begin{tabular}{|c|c|c|c|c|c|c|}
\hline \multirow{2}{*}{$\begin{array}{l}\text { Property or } \\
\text { constituer.i }\end{array}$} & \multirow{2}{*}{$\begin{array}{c}\text { Sample } \\
\text { type }\end{array}$} & \multirow{2}{*}{$\begin{array}{c}\text { Number of } \\
\text { samples }\end{array}$} & \multicolumn{3}{|c|}{ Range } & \multirow[b]{2}{*}{ Contaminant level ${ }^{1}$} \\
\hline & & & Maximum & Median & Minimum & \\
\hline \multirow[t]{6}{*}{ Bromide } & all gw & 61 & 9.71 & $<1.00$ & $<1.00$ & \\
\hline & surficial gw & 55 & 9.71 & $<1.00$ & $<1.00$ & \\
\hline & confined gw & 6 & $<3.00$ & $<1.00$ & $<1.00$ & \\
\hline & all sw & 21 & 2.09 & $<1.00$ & $<1.00$ & \\
\hline & inland sw & 15 & 1.93 & $<1.00$ & $<1.00$ & \\
\hline & estuarine sw & 6 & 2.09 & 1.535 & $<1.00$ & \\
\hline \multirow[t]{6}{*}{ Chloride } & all gw & 61 & $3,100 *$ & 60.0 & 2.12 & 250 (SMCL) \\
\hline & surficial gw & 55 & $3,100 *$ & 60.0 & 2.12 & \\
\hline & confined gw & 6 & $360 *$ & 66.0 & 4.01 & \\
\hline & all sw & 21 & 770 & 140 & $<2.12$ & \\
\hline & inland sw & 15 & 710 & 71.0 & $<2.12$ & \\
\hline & estuarine sw & 6 & 770 & 655 & 440 & \\
\hline \multirow[t]{6}{*}{ Fluoride } & all gw & 61 & 3.04 & $<1.23$ & -- & $4.0(\mathrm{MCL})$ \\
\hline & surficial gw & 55 & 3.04 & $<1.23$ & -- & 2.0 (SMCL) \\
\hline & confined gw & 6 & $<1.23$ & $<1.23$ & $<1.23$ & \\
\hline & all sw & 21 & $<1.23$ & $<1.23$ & $<1.23$ & \\
\hline & inland sw & 15 & $<1.23$ & $<1.23$ & $<1.23$ & \\
\hline & estuarine sw & 6 & $<1.23$ & $<1.23$ & $<1.23$ & \\
\hline Nitrate plus & all gw & 61 & .191 & .013 & $<.010$ & 10 (MCL, MCLG) \\
\hline \multirow[t]{5}{*}{ Nitrite } & surficial gw & 55 & .191 & .014 & $<.010$ & \\
\hline & confined gw & 6 & .013 & -- & $<.010$ & \\
\hline & all sw & 21 & .880 & - & $<.010$ & \\
\hline & inland sw & 15 & .430 & -- & $<.010$ & \\
\hline & estuarine sw & 6 & .880 & .795 & .730 & \\
\hline \multirow[t]{6}{*}{ Silica } & all gw & 61 & 30.0 & 9.5 & 2.20 & \\
\hline & surficial gw & 55 & 23.8 & 8.00 & 2.20 & \\
\hline & confined gw & 6 & 30.0 & 18.35 & 12.8 & \\
\hline & all sw & 0 & & & & \\
\hline & inland sw & 0 & & & & \\
\hline & estuarine sw & 0 & & & & \\
\hline \multirow[t]{6}{*}{ Sulfate } & all gw & 61 & $730 *$ & 34.3 & $<10.0$ & $250(\mathrm{SMCL})$ \\
\hline & surficial gw & 55 & $730 *$ & 41.0 & $<10.0$ & 400/500 (Proposed MCL, \\
\hline & confined gw & 6 & 38.4 & $<10.0$ & $<10.0$ & MCLG) \\
\hline & all sw & 21 & 113 & 18.0 & $<10.0$ & \\
\hline & inland sw & 15 & 113 & 10.1 & $<10.0$ & \\
\hline & estuarine sw & 6 & 108 & 97.55 & 73.9 & \\
\hline
\end{tabular}

${ }^{1}$ Contaminant levels established by U.S. Environmental Protection Agency (1989, 1990a through e, 1991a through c, 1992). 


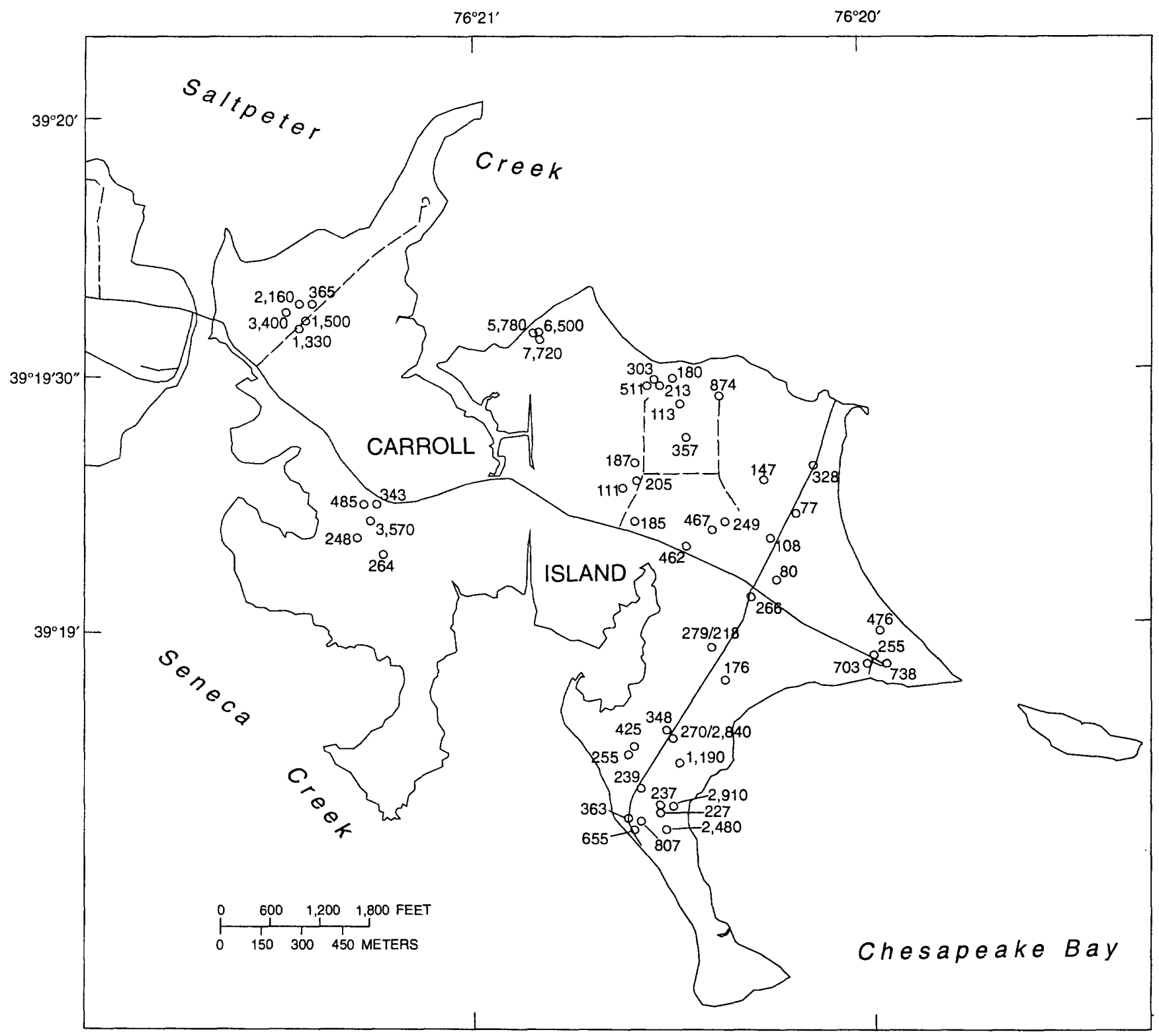

Base modified from U.S. Army, 1:4,800, 1970

\section{EXPLANATION}

655 WELL LOCATION--Single number is specific conductance of the water sample, in microsiemens per centimeter. Double numbers are specific conductance of samples from the deeper/shallower wells $270 / 2,840$ where two wells were screened in the surficial aquifer, in microsiemens per centimeter

Figure 23. Specific conductance in water samples from selected wells in the surficial aquifer, Carroll Island, Aberdeen Proving Ground, Maryland, May 1989. 
Most of the $\mathrm{pH}$ values in ground-water samples were outside the SMCL range (pH 6.5 to 8.5) for drinking water set by the USEPA. Roughly 93 percent of the $\mathrm{pH}$ values in water samples from the surficial aquifer were less than the SMCL (6.5-8.5) set by the USEPA. The maximum $\mathrm{pH}$ detected in a sample from the confined aquifer (8.83, at well I16A) was above the SMCL range of 6.5 to 8.5 .

Alkalinity distributions from the Carroll Island samples also varied somewhat among the different environments. Alkalinity in samples from the surficial aquifer was widely variable, ranging from a low of $1 \mathrm{mg} / \mathrm{L}$ to a high of $525 \mathrm{mg} / \mathrm{L}$, with a median of $35 \mathrm{mg} / \mathrm{L}$ (table 5). Alkalinity in samples from the confined aquifer was significantly higher than alkalinity in samples from the surficial aquifer. The range of alkalinity in samples from the confined aquifer was narrower than the range in samples from the surficial aquifer, with a low of $111 \mathrm{mg} / \mathrm{L}$, a high of $253 \mathrm{mg} / \mathrm{L}$, and a median of $213.5 \mathrm{mg} / \mathrm{L}$ (table 5). There was no significant difference in alkalinity between ground-water and surface-water samples. The alkalinity in estuarine surface water, however, was significantly lower than alkalinity in inland surface water.

Most of the $\mathrm{pH}$ and alkalinity values in water samples from Carroll Island probably result from natural processes. The low $\mathrm{pH}$ values in the surficial aquifer may be primarily due to the low $\mathrm{pH}$ of precipitation and the acidic soils on Carroll Island. The volume-weighted $\mathrm{pH}$ of precipitation in the area is approximately 4.3 (Rice and Bricker, 1992, fig. 2), and acidic soils would be unlikely to provide much buffering capacity to the water as it infiltrates into the aquifer. The upper confining unit between the surficial and confined aquifers contains shell material that was buried when the confiningunit sediment was deposited during the Pleistocene

Epoch. The higher $\mathrm{pH}$ and alkalinity values in the confined aquifer probably resulted from dissolution of calcium carbonate from this shell material as water passed through the confining unit into the confined aquifer.

\section{Major lons}

Laboratory analyses for major inorganic constituents in ground-water and surface-water samples included calcium, magnesium, sodium, potassium, bromide, chloride, fluoride, nitrate plus nitrite, and sulfate concentrations. Silica analyses were only available for ground-water samples. Bicarbonate concentrations were calculated from alkalinity titrations that were done in the field. The range of values for these constituents in ground-water and surface-water samples is shown in table 5 along with applicable water-quality regulations.

The distribution of major ions in selected water samples (those with ion-balance errors less than 10 percent) from the surficial aquifer is shown in Stiff diagrams (fig. 24). These diagrams show ion concentrations in milliequivalents per liter. Cation concentrations (sodium, potassium, calcium, and magnesium) are plotted to the left of the zero vertical axis, and anion concentrations (chloride, nitrate, bicarbonate, and sulfate) are plotted to the right of the zero vertical axis. In this figure, sodium and potassium are plotted together, as are chloride and nitrate. The shape of these diagrams show the dominant ions in the water sample.

Most of the water samples from wells in the surficial aquifer are of mixed composition (fig. 24). A few of the diagrams in figure 24 , however, indicate that the chemistry of some samples was dominated by individual constituents. The samples from wells I01 and I39 are of calcium-bicarbonate type, whereas the chemistry of the samples from wells I28, I30, and I31 is dominated by sodium and chloride. The sample from well 108 is a sodium-sulfate type water.

Some of the water samples from the surficial aquifer in the east-central part of Carroll Island were more dilute than samples near the shoreline (fig. 24). The water-level contour maps (figs. 12 and 13) from wells in the surficial aquifer show this area to be a recharge zone for the aquifer, and samples from wells in this area have low specific conductance values (fig. 23). The hydraulic heads in figure 13 indicate that there are gradient reversals in the aquifer caused by evapotranspiration during dry seasons, and these gradient reversals may cause brackish-water intrusion into some parts of the surficial aquifer from the estuaries.

Other evidence indicates that brackish-water intrusion or overwash is a dominant factor in the majorion chemistry of the surficial aquifer at Carroll Island. Sodium and chloride usually are the dominant ions in brackish water, and the ratio of the two would be expected to be relatively constant in most brackishwater samples collected from a limited area. This hypothesis was tested in the estuarine water samples collected around Carroll Island with a simple linear regression of chloride concentration with sodium concentration. Five of the six samples plotted on a straight line; the coefficient of determination was 0.69 , and the correlation was significant to a probability of 0.026 . 


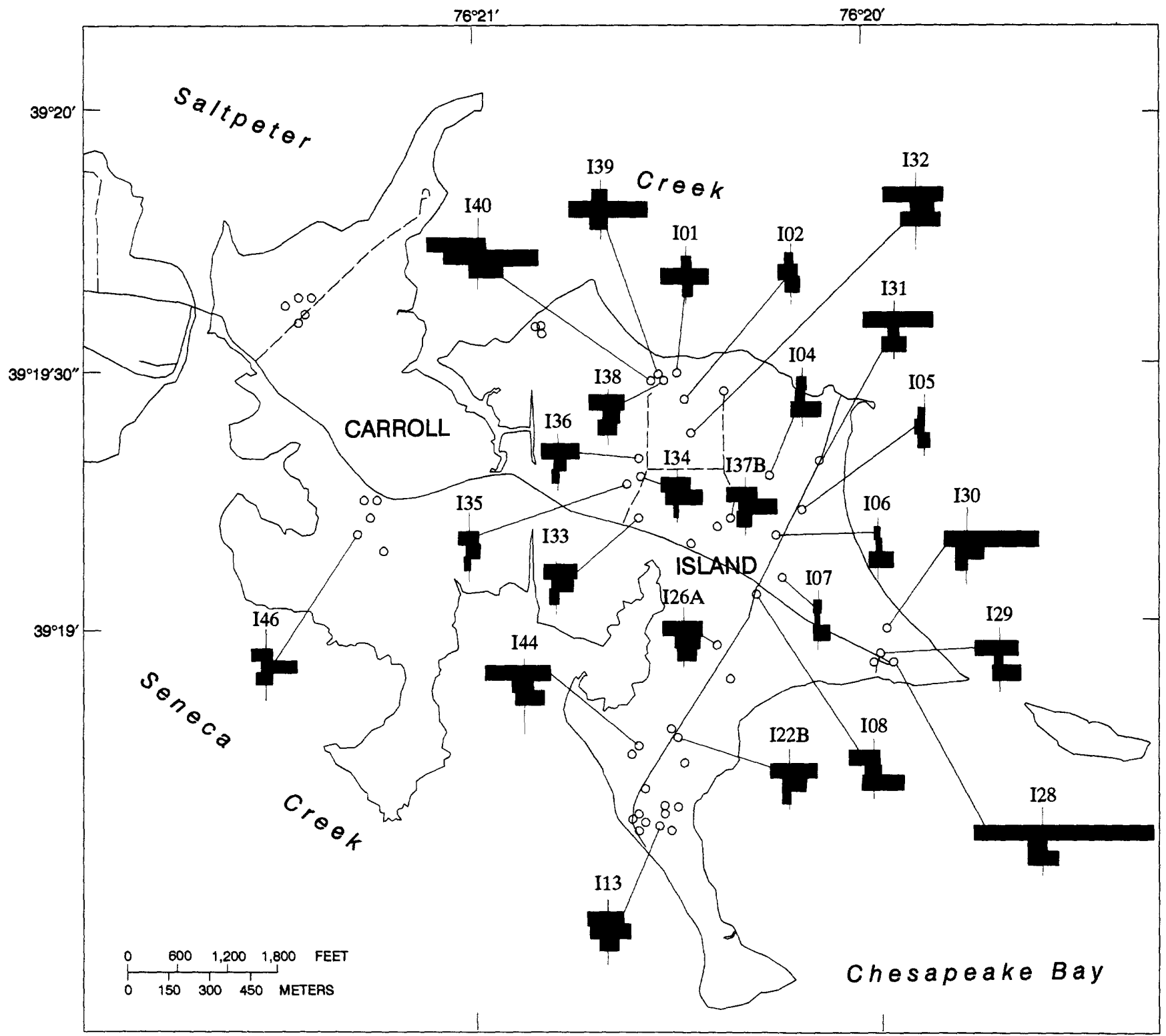

Base modified from U.S. Army, 1:4,800, 1970

EXPLANATION

113 Well number

Well location

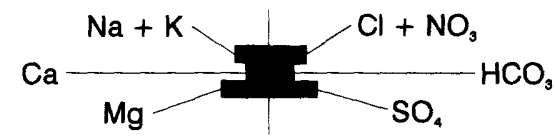

\begin{tabular}{rrrrr}
8 & 4 & 0 & 4 & 8 \\
\hline & 1 & 1 & 1 & 1 \\
\hline
\end{tabular}

Cations (Meq/Liter) Anions (Meq/Liter)

Figure 24. Stiff diagrams for water-quality samples from selected wells in the surficial aquifer, Carroll Island, Aberdeen Proving Ground, Maryland, May 1989. 
This indicates that the ratio of chloride to sodium is related, and that there is less than 3 percent chance that the apparent linear trend is due to random chance.

Linear regression also was performed on concentrations of sodium and chloride in water samples from the surficial aquifer at Carroll Island. The ratio of chloride to sodium plotted on a nearly straight line. The coefficient of determination was 0.96 , and was significant to a probability of 0.00000 , indicating that the ratio of chloride to sodium was nearly constant in these samples. As a check, the chloride to sodium ratio was regressed for data from the surficial aquifer at Graces Quarters, which is located near Carroll Island (fig. 1). The data from Graces Quarters were obtained from Tenbus and Blomquist (1995). The water in the surficial aquifer at Graces Quarters is not thought to be influenced by brackish-water intrusion or overwash, because a linear trend was not apparent in the Graces Quarters data. The coefficient of determination was 0.09 , indicating almost no linear trend; this coefficient was significant to a probability of 0.07 .

These statistical relations do not prove that ground water in the surficial aquifer at Carroll Island is influenced by brackish-water intrusion. They do, however, indicate that sodium and chloride in most of the ground-water samples probably came from the same source, and that it probably was a natural source. The sources of sodium and chloride that would have resulted from military activity on Carroll Island include decontaminating agents such as sodium hydroxide, chlorinated lime, and calcium hypochlorite (Lorah and Vroblesky, 1989, p. 43), along with chlorinated hydrocarbons. If sodium and chloride came from these sources rather than natural sources, it is unlikely that the ratio of the two ions would be as constant as it is in the ground-water samples.

The distribution of major ions in selected samples from the confined aquifer is shown with Stiff diagrams in figure 25. The samples from wells screened in the confined aquifer are either calcium-bicarbonate water or mixed calcium-bicarbonate and sodium-chloride waters. It is believed that the chemistry of the water in the confined aquifer results from the dissolution of the shell material in the Pleistocene sediment of the upper confining unit. The sodium and chloride in the water may have been present in the sediment when it was deposited, or may have come from subsequent seepage of water from the bay into the aquifer.

Of the major ionic constituents in ground water, chloride, sulfate, and fluoride were detected in concen- trations that exceeded non-enforceable drinking-water regulations set by USEPA (table 5). Chloride concentrations in ground-water samples exceeded the SMCL of $250 \mathrm{mg} / \mathrm{L}$ at wells I12, I16B, I22C, I23, I41, I42, I43, I45, I47A, I50, I51, I52, I53, and I54A in the surficial aquifer (see fig. 3 for well locations, and table 11 at the end of the report for chloride concentrations), and at well I16A (chloride concentration $360 \mathrm{mg} / \mathrm{L}$ ) in the confined aquifer. Sulfate concentrations exceeded the $\mathrm{SMCL}$ of $250 \mathrm{mg} / \mathrm{L}$ at wells $112(460 \mathrm{mg} / \mathrm{L}), \mathrm{I} 22 \mathrm{C}$ (730 mg/L), I41 (400 mg/L), I43 (300 mg/L), and I51 $(390 \mathrm{mg} / \mathrm{L})$ in the surficial aquifer. Fluoride concentrations exceeded the SMCL of $2.0 \mathrm{mg} / \mathrm{L}$ at wells $\mathrm{I} 41$ (3.04 mg/L), I42 (2.17 mg/L), and I43 (2.56 mg/L) in the surficial aquifer. Fluoride was not detected in the confined aquifer.

The sources of the high concentrations of major ionic constituents in most of the ground-water samples are thought to be brackish-water intrusion or overwash. The concentrations detected in wells I41, I42, and I43 in the surficial aquifer at the EPG dump site, however, were unusually high when compared to other groundwater samples and even to the estuarine surface-water samples. For example, the chloride concentrations in these three ground-water samples were 3,100, 2,300, and 2,600 $\mathrm{mg} / \mathrm{L}$, respectively (table 11 , at the end of the report). These concentrations are an order of magnitude higher than the maximum chloride concentration in the estuarine surface-water samples (table 5), and are significantly higher than the chloride concentrations in other ground-water samples (table 11, at the end of the report). Similarly, concentrations of magnesium, sodium, sulfate, fluoride, and bromide in the three wells (table 11, at the end of the report) were significantly higher than the maximum concentrations detected in estuarine surfacewater samples (table 5). It should be noted that the concentrations of major ions in the estuaries fluctuates, and the samples used in these comparisons were collected during a month where fresh-water influx to the estuaries was probably relatively high. Vroblesky and others (1989, p. 61) report a concentration of chloride in the shallow aquifer at $\mathrm{O}$-Field of $2,150 \mathrm{mg} / \mathrm{L}$, which is attributed to infiltration of brackish water as overwash from an adjacent tidal creek. The EPG dump site also is adjacent to a tidal creek, which indicates that a natural process such as overwash may have caused the elevated levels of major constituents in the ground water at the site. It is also possible, however, that an anthropogenic source (such as brine disposal) caused the elevated levels of these constituents at this site. 


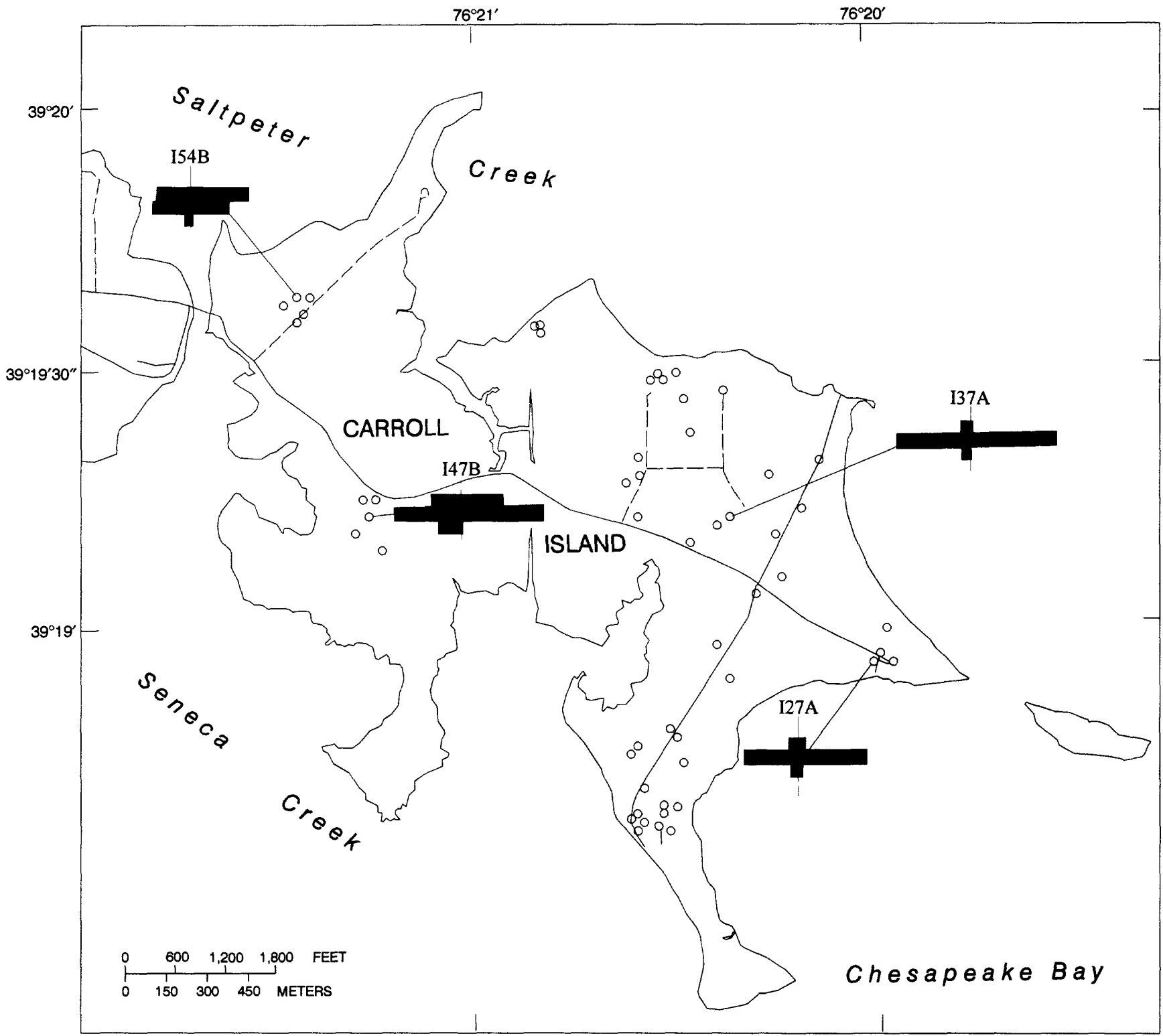

Base modified from U.S. Army, 1:4,800, 1970

\section{EXPLANATION}

I27A Well number

- Well location
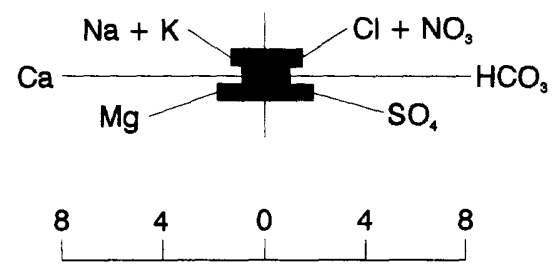

Cations (Meq/Liter) Anions (Meq/Liter)

Figure 25. Stiff diagrams for water-quality samples from selected wells in the upper confined aquifer, Carroll Island, Aberdeen Proving Ground, Maryland, May 1989. 
Stiff diagrams (fig. 26) show that most of the surface-water sample analyses (both inland and estuarine) are sodium-chloride type waters or mixed waters. The exceptions are SW03 (near the service area) and SW08 (in the central area of test grid 1), which are calciumbicarbonate type waters. Sample SW17, which is near SW03, also shows relatively high levels of calcium and bicarbonate. Each of the samples with high calcium and bicarbonate were collected from within or near underground concrete sumps, and it is likely that prolonged contact with the concrete increased the levels of calcium and bicarbonate in these waters above what they would have otherwise contained. Decontaminating agents that contained calcium are another possible source of these constituents.

The distribution of major constituents in the soil samples can help determine some possible sources of major constituents in water samples. Laboratory analyses of major inorganic constituents in soil included calcium, magnesium, sodium, sulfate, chloride, bromide, silica, nitrate plus nitrite, and phosphate. Summary statistics for inorganic constituents in soil samples are shown in table 6.

The concentration ranges of major constituents shown in table 6 indicate that the maximum values are commonly one to two orders of magnitude greater than the median values. For several constituents, this is a result of very high values in one or two samples that skew the distribution.

The inorganic chemistry data for the soil samples collected at Carroll Island in 1990 are presented in table 17 (at the end of the report). High levels of calcium were detected at sites CISOIL03 $(48,500 \mu \mathrm{g} / \mathrm{g}$ [micrograms per gram]) near the service area and CISOIL08 $(48,900 \mu \mathrm{g} / \mathrm{g})$ in the center of test grid 1 . These sites are close to surface-water sampling sites SW03 and SW08, which also exhibited high levels of calcium. Because calcium was a component of several inorganic decontaminating agents that were probably used on Carroll Island, it is possible that inorganic decontaminants were the source of the elevated calcium levels in both soil and surface water at these sites.

An elevated level of magnesium also was noted at site CISOIL08. This site is in test grid 1, where much of the testing was done on Carroll Island. A possible source of the magnesium in CISOIL08 is talcum powder. More than 5,000 lbs of talcum powder was released on Carroll Island from 1964 to 1971 (table 1). Talcum powder is a harmless substance that was used as a chemical-agent simulant during dispersal tests.
Test grid 1 was extensively instrumented with cameras and sampling systems (Ward, 1971, p. 38) and would have been ideal for dispersal tests, so it is likely that most of the talcum powder that was released on Carroll Island was released at test grid 1.

Elevated levels of sodium and chloride were detected in soil samples CISOIL09 and CISOIL12 (table 17, at the end of the report). These sites were located in marsh areas that are subject to flooding during storms and high tides, so it is likely that these levels resulted from overwash of brackish water. Although sodium and chloride in other marsh-area soil samples (such as CISOIL04, 05, 13, and 11) were not as high as in CISOIL09 and CISOIL12 (table 17, at the end of the report), the mobility of these ions in water means that man-made sources are unlikely. There had been no military testing activity on Carroll Island for nearly 20 years before the soil sampling, so residual sodium and chloride from test activities probably would have been washed out of the soil.

The maximum values of sulfate in soil samples were detected at sites CISOIL09 $(517 \mu \mathrm{g} / \mathrm{g})$ and CISOIL27 $(402 \mu \mathrm{g} / \mathrm{g})$, located in the central area of Carroll Island. Both of these sites were located in ditches that drain the aerial spray grid and test grid 1 . Sulfate was not detected in the surface-water sample (SW09) collected near CISOIL09. The source of the sulfate in these soil samples is not known.

\section{Minor Constituents}

Minor constituents analyzed in ground-water and surface-water samples include those inorganic compounds that usually occur in only trace concentrations except where contamination or unique geochemical conditions exist. The presence of minor constituents in water samples from Carroll Island is summarized in table 7 . The ground-water samples were filtered through a 0.45 micron filter prior to analysis, so the metals detected would be present in the dissolved phase and not complexed with any organic matter or in a larger colloidal suspension. The surfacewater samples, however, were unfiltered, because the applicable water-quality criteria call for unfiltered samples. Thus, trace element concentrations in surfacewater samples represent the combination of dissolved metals, and complexes of metals with dissolved and suspended organic carbon and possibly suspended sediment. 


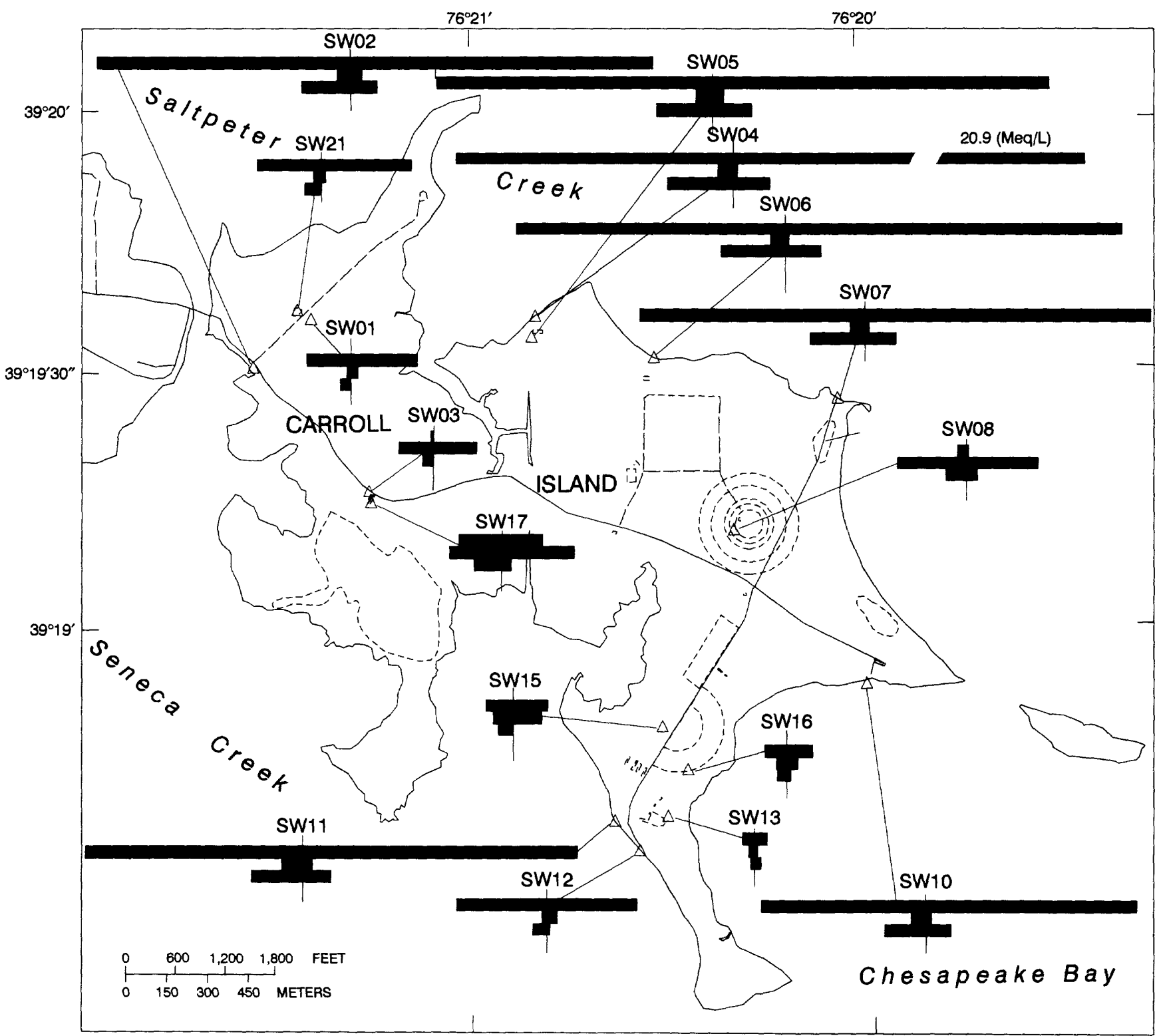

Base modified from U.S. Army, 1:4,800, 1970

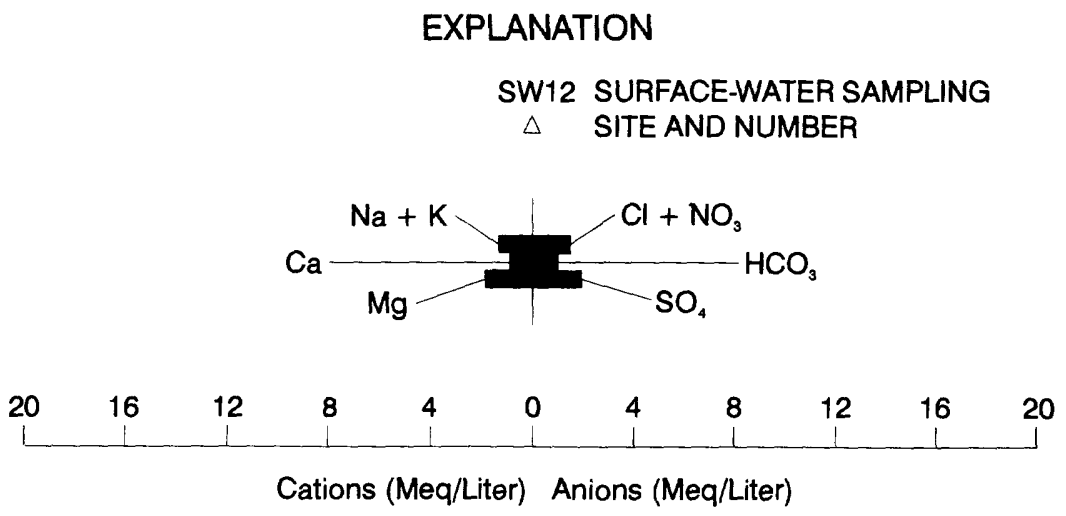

Figure 26. Stiff diagrams for water-quality samples from selected surface-water sampling sites, Carroll Island, Aberdeen Proving Ground, Maryland, May 1989. 
Table 6. Range of concentrations of selected inorganic constituents in soil samples, Carroll Island, Aberdeen Proving Ground, Md., summer 1990

[Concentrations in micrograms per gram, except silica, which is in milligrams per gram; <, less than; --, value cannot be determined because of variable reporting limit; replicate samples not included]

\begin{tabular}{|c|c|c|c|c|}
\hline \multirow[b]{2}{*}{ Constituent } & \multirow{2}{*}{$\begin{array}{l}\text { Number of } \\
\text { samples }\end{array}$} & \multicolumn{3}{|c|}{ Concentration range } \\
\hline & & Maximum & Median & Minimum \\
\hline Calcium & 16 & 48,900 & 520 & 132 \\
\hline Magnesium & 16 & 15,100 & 652.5 & $<329$ \\
\hline Sodium & 16 & 1,700 & 173 & 77.0 \\
\hline Sulfate & 26 & 517 & 44.2 & $<14.4$ \\
\hline Chloride & 26 & 1,400 & 57.4 & $<39.6$ \\
\hline Bromide & 26 & $<88.3$ & $<8.83$ & $<8.83$ \\
\hline Silica & 24 & 1,010 & 699 & 504 \\
\hline Total Kjeldahl Nitrogen & 26 & 8,210 & 883 & 80.6 \\
\hline Phosphate & 26 & 1,930 & 142 & 3.93 \\
\hline Antimony & 16 & $<19.6$ & $<7.92$ & $<7.92$ \\
\hline Arsenic & 26 & 23 & 10.45 & $<2.2$ \\
\hline Boron & 25 & 107 & $<7.37$ & $<6.64$ \\
\hline Cadmium & 16 & $<1.20$ & $<.447$ & $<.447$ \\
\hline Chromium & 16 & 26.2 & 9.65 & $<3.87$ \\
\hline Copper & 16 & 55.2 & 4.525 & - \\
\hline Iron & 16 & 22,800 & 6,810 & 1,520 \\
\hline Lead & 25 & 164 & 19.6 & 3.11 \\
\hline Manganese & 16 & 169 & 46.7 & 4.38 \\
\hline Mercury & 25 & .79 & $<.026$ & $<.026$ \\
\hline Selenium & 24 & $<5.76$ & $<5.76$ & $<.576$ \\
\hline Zinc & 16 & -- & -- & -- \\
\hline
\end{tabular}


Table 7. Range of concentrations of selected minor inorganic constituents in ground-water and surface-water samples, Carroll Island, Aberdeen Proving Ground, Md., spring 1989

[Concentrations in milligrams per liter; gw, ground water; sw, surface water; <, less than; MCL, maximum contaminant level; MCLG, maximum contaminant level goal; SMCL, secondary maximum contaminant level; FWA, fresh-water acute; FWC, fresh-water chronic; *, contaminant level exceeded; replicate and split samples not included]

\begin{tabular}{|c|c|c|c|c|c|c|}
\hline \multirow[b]{2}{*}{ Constituent } & \multirow{2}{*}{$\begin{array}{l}\text { Sample } \\
\text { type }\end{array}$} & \multirow{2}{*}{$\begin{array}{l}\text { Number of } \\
\text { samples }\end{array}$} & \multicolumn{3}{|c|}{ Range } & \multirow[b]{2}{*}{ Contaminant level ${ }^{1}$} \\
\hline & & & Maximum & Median & Minimum & \\
\hline \multirow[t]{6}{*}{ Aluminum } & all gw & 61 & $23.2 *$ & $<0.141 *$ & $<0.141 *$ & \multirow[t]{3}{*}{0.05 to 0.20 (SMCL) } \\
\hline & surficial gw & 55 & $23.2 *$ & $<.141 *$ & $<.141 *$ & \\
\hline & confined gw & 6 & $<.141 *$ & $<.141 *$ & $<.141 *$ & \\
\hline & all sw & 21 & $2.32 *$ & $.402 *$ & $<.141 *$ & \multirow[t]{3}{*}{.75 (FWA), .087 (FWC) } \\
\hline & inland sw & 15 & $2.32 *$ & $.354 *$ & $<.141 *$ & \\
\hline & estuarine sw & 6 & $2.11 *$ & $.6335 *$ & $.384 *$ & \\
\hline \multirow[t]{6}{*}{ Antimony } & all gw & 61 & $<.038 *$ & $<.038 *$ & $<.038 *$ & \multirow{3}{*}{$\begin{array}{l}.01 / .005 \text { (Proposed MCL) } \\
.003 \text { (MCLG) }\end{array}$} \\
\hline & surficial gw & 55 & $<.038 *$ & $<.038 *$ & $<.038 *$ & \\
\hline & confined gw & 6 & $<.038 *$ & $<.038 *$ & $<.038 *$ & \\
\hline & all sw & 21 & .147 & $<.038$ & $<.038$ & \multirow{3}{*}{9.0 (FWA), 1.6 (FWC) } \\
\hline & inland sw & 15 & .147 & $<.038$ & $<.038$ & \\
\hline & estuarine sw & 6 & $<.038$ & $<.038$ & $<.038$ & \\
\hline \multirow[t]{6}{*}{ Arsenic } & all gw & 61 & .00874 & $<.00254$ & $<.00254$ & \multirow[t]{6}{*}{.05 (MCL) } \\
\hline & surficial gw & 55 & .00874 & $<.00254$ & $<.00254$ & \\
\hline & confined gw & 6 & .00544 & .00410 & $<.00254$ & \\
\hline & all sw & 0 & & & & \\
\hline & inland sw & 0 & & & & \\
\hline & estuarine sw & 0 & & & & \\
\hline \multirow[t]{6}{*}{ Barium } & all gw & 61 & .274 & .038 & .007 & \multirow[t]{6}{*}{$2.0(\mathrm{MCL}, \mathrm{MCLG})$} \\
\hline & surficial gw & 55 & .274 & .042 & .007 & \\
\hline & confined gw & 6 & .037 & .0265 & .013 & \\
\hline & all sw & 21 & .0406 & .0201 & .00935 & \\
\hline & inland sw & 15 & .0406 & .0223 & .00935 & \\
\hline & estuarine sw & 6 & .0201 & .01715 & .0142 & \\
\hline \multirow[t]{6}{*}{ Beryllium } & all $\mathrm{gw}$ & 61 & $<.00500^{*}$ & $<.00500^{*}$ & $<.00500 *$ & \multirow{3}{*}{$\begin{array}{l}.001 \text { (Proposed MCL), } \\
0 \text { (MCLG) }\end{array}$} \\
\hline & surficial gw & 55 & $<.00500^{*}$ & $<.00500^{*}$ & $<.00500^{*}$ & \\
\hline & confined gw & 6 & $<.00500^{*}$ & $<.00500^{*}$ & $<.00500 *$ & \\
\hline & all sw & 21 & $.00594 *$ & $<.00500^{*}$ & $<.00500^{*}$ & \multirow[t]{3}{*}{.130 (FWA), .0053 (FWC) } \\
\hline & inland sw & 15 & $.00594 *$ & $<.00500^{*}$ & $<.00500^{*}$ & \\
\hline & estuarine sw & 6 & $<.00500^{*}$ & $<.00500^{*}$ & $<.00500^{*}$ & \\
\hline \multirow[t]{6}{*}{ Cadmium } & all gw & 61 & $<.00401$ & $<.00401$ & $<.00401$ & \multirow{3}{*}{$\begin{array}{l}.005(\mathrm{MCL} \text {, } \\
\mathrm{MCLG})\end{array}$} \\
\hline & surficial gw & 55 & $<.00401$ & $<.00401$ & $<.00401$ & \\
\hline & confined gw & 6 & $<.00401$ & $<.00401$ & $<.00401$ & \\
\hline & all sw & 21 & $.0112 *$ & $<.00401 *$ & $<.00401 *$ & \multirow[t]{3}{*}{.0039 (FWA), .0011 (FWC) } \\
\hline & inland sw & 15 & $.0112 *$ & $<.00401 *$ & $<.00401 *$ & \\
\hline & estuarine sw & 6 & $<.00401 *$ & $<.00401^{*}$ & $<.00401^{*}$ & \\
\hline \multirow[t]{6}{*}{ Chromium } & all gw & 61 & .00707 & $<.00602$ & $<.00602$ & \multirow[t]{3}{*}{.1 (MCL, MCLG) } \\
\hline & surficial gw & 55 & .00707 & $<.00602$ & $<.00602$ & \\
\hline & confined gw & 6 & $<.00602$ & $<.00602$ & $<.00602$ & \\
\hline & all sw & 21 & $.020 *$ & $<.00602$ & $<.00602$ & \multirow[t]{3}{*}{.016 (FWA), .011 (FWC) } \\
\hline & inland sw & 15 & $.020 *$ & $<.00602$ & $<.00602$ & \\
\hline & estuarine sw & 6 & $<.00602$ & $<.00602$ & $<.00602$ & \\
\hline
\end{tabular}


Table 7. Range of concentrations of selected minor inorganic constituents in ground-water and surface-water samples, Carroll Island, Aberdeen Proving Ground, Md., spring 1989--Continued

\begin{tabular}{|c|c|c|c|c|c|c|}
\hline \multirow[b]{2}{*}{ Constituent } & \multirow{2}{*}{$\begin{array}{c}\text { Sample } \\
\text { type }\end{array}$} & \multirow{2}{*}{$\begin{array}{l}\text { Number of } \\
\text { samples }\end{array}$} & \multicolumn{3}{|c|}{ Range } & \multirow[b]{2}{*}{ Contaminant level ${ }^{1}$} \\
\hline & & & Maximum & Median & Minimum & \\
\hline \multirow[t]{6}{*}{ Copper } & all gw & 61 & 0.0497 & 0.00879 & $<0.00809$ & 1.3 (Proposed MCL, MCLG) \\
\hline & surficial gw & 55 & .0497 & $<.00809$ & $<.00809$ & \\
\hline & confined gw & 6 & .0172 & .0116 & $<.00809$ & \\
\hline & all sw & 21 & $.0442 *$ & $.0149 *$ & $<.00809$ & $.018(\mathrm{FWA}), .012(\mathrm{FW})$ \\
\hline & inland sw & 15 & $.0377 *$ & $.0159 *$ & $<.00809$ & \\
\hline & estuarine sw & 6 & $.0442 *$ & $<.00809$ & $<.00809$ & \\
\hline \multirow[t]{6}{*}{ Iron } & all gw & 61 & $83.0 *$ & $5.34 *$ & $<.043$ & .300 (SMCL) \\
\hline & surficial gw & 55 & $83.0 *$ & $6.03 *$ & $<.043$ & \\
\hline & confined gw & 6 & $8.25 *$ & $3.04 *$ & $<.043$ & \\
\hline & all sw & 21 & 16.4 & 1.42 & .334 & \\
\hline & inland sw & 15 & 16.4 & 3.21 & .334 & \\
\hline & estuarine sw & 6 & 2.89 & .913 & .551 & \\
\hline \multirow[t]{6}{*}{ Lead } & all gw & 61 & $.0314 *$ & $<.00126$ & $<.00126$ & .015 (MCL), 0 (MCLG) \\
\hline & surficial gw & 54 & $.0314 *$ & $<.00126$ & $<.00126$ & \\
\hline & confined gw & 6 & $.00195 *$ & $<.00126$ & $<.00126$ & \\
\hline & all sw & 0 & & & & \\
\hline & inland sw & 0 & & & & \\
\hline & estuarine sw & 0 & & & & \\
\hline \multirow[t]{6}{*}{ Manganese } & all gw & 61 & $7.60 *$ & $.511 *$ & .00775 & .050 (SMCL) \\
\hline & surficial gw & 55 & $7.60 *$ & $.506 *$ & .00775 & \\
\hline & confined gw & 6 & $1.46 *$ & $.5895 *$ & .0475 & \\
\hline & all sw & 21 & 1.21 & .128 & .0122 & \\
\hline & inland sw & 15 & 1.21 & .128 & .0122 & \\
\hline & estuarine sw & 6 & .237 & .133 & .110 & \\
\hline \multirow[t]{6}{*}{ Mercury } & all gw & 45 & .000403 & $<.000243$ & $<.000243$ & .002 (MCL, MCLG) \\
\hline & surficial gw & 39 & .000403 & $<.000243$ & $<.000243$ & \\
\hline & confined gw & 6 & $<.000243$ & $<.000243$ & $<.000243$ & \\
\hline & all sw & 0 & & & & \\
\hline & inland sw & 0 & & & & \\
\hline & estuarine sw & 0 & & & & \\
\hline \multirow[t]{6}{*}{ Nickel } & all $\mathrm{gw}$ & 61 & .0657 & $<.0343$ & $<.0343$ & .100 (Proposed MCL, \\
\hline & surficial gw & 55 & .0657 & $<.0343$ & $<.0343$ & MCLG) \\
\hline & confined gw & 6 & $<.0343$ & $<.0343$ & $<.0343$ & \\
\hline & all $\mathrm{sw}$ & 21 & .0663 & $<.0343$ & $<.0343$ & 1.80 (FWA), .096 (FWC) \\
\hline & inland sw & 15 & .0663 & $<.0343$ & $<.0343$ & \\
\hline & estuarine sw & 6 & $<.0343$ & $<.0343$ & $<.0343$ & \\
\hline \multirow[t]{6}{*}{ Selenium } & all gw & 61 & $<.00302$ & $<.00302$ & $<.00302$ & .05 (MCL, MCLG) \\
\hline & surficial gw & 55 & $<.00302$ & $<.00302$ & $<.00302$ & \\
\hline & confined gw & 6 & $<.00302$ & $<.00302$ & $<.00302$ & \\
\hline & all sw & 0 & & & & \\
\hline & inland sw & 0 & & & & \\
\hline & estuarine sw & 0 & & & & \\
\hline
\end{tabular}


Table 7. Range of concentrations of selected minor inorganic constituents in ground-water and surface-water samples, Carroll Island, Aberdeen Proving Ground, Md., spring 1989--Continued

\begin{tabular}{|c|c|c|c|c|c|c|}
\hline \multirow[b]{2}{*}{ Constituent } & \multirow{2}{*}{$\begin{array}{c}\text { Sample } \\
\text { type }\end{array}$} & \multirow{2}{*}{$\begin{array}{c}\text { Number of } \\
\text { samples }\end{array}$} & \multicolumn{3}{|c|}{ Range } & \multirow[b]{2}{*}{ Contaminant level $^{1}$} \\
\hline & & & Maximum & Median & Minimum & \\
\hline \multirow[t]{6}{*}{ Silver } & all gw & 61 & 0.0253 & $<0.00460$ & $<0.00460$ & $0.050(\mathrm{MCL})$ \\
\hline & surficial gw & 55 & .0253 & $<.00460$ & $<.00460$ & $.100(\mathrm{SMCL})$ \\
\hline & confined gw & 6 & $<.00460$ & $<.00460$ & $<.00460$ & \\
\hline & all sw & 21 & $.00564 *$ & $<.00460^{*}$ & $<.00460 *$ & .0041 (FWA), .00012 (FWC) \\
\hline & inland sw & 15 & $.00564 *$ & $<.00460 *$ & $<.00460 *$ & \\
\hline & estuarine sw & 6 & $<.00460^{*}$ & $<.00460^{*}$ & $<.00460 *$ & \\
\hline \multirow[t]{6}{*}{ Thallium } & all gw & 61 & $.259 *$ & $<.0814 *$ & $<.0814 *$ & .0005 (MCLG), \\
\hline & surficial gw & 55 & $.259 *$ & $<.0814 *$ & $<.0814 *$ & $.002 / .001$ (Proposed MCL) \\
\hline & confined gw & 6 & $<.0814 *$ & $<.0814 *$ & $<.0814 *$ & \\
\hline & all sw & 21 & $.113 *$ & $<.0814 *$ & $<.0814 *$ & 1.40 (FWA), .040 (FWC) \\
\hline & inland sw & 15 & $.113 *$ & $<.0814 *$ & $<.0814 *$ & \\
\hline & estuarine sw & 6 & $<.0814 *$ & $<.0814 *$ & $<.0814 *$ & \\
\hline \multirow[t]{6}{*}{ Zinc } & all gw & 61 & .407 & $<.0211$ & $<.0211$ & $5.0(\mathrm{SMCL})$ \\
\hline & surficial gw & 55 & .213 & $<.0211$ & $<.0211$ & \\
\hline & confined gw & 6 & .0348 & $<.0211$ & $<.0211$ & \\
\hline & all sw & 21 & $.800 *$ & $<.0211$ & $<.0211$ & .320 (FWA), .047 (FWC) \\
\hline & inland sw & 15 & $.800 *$ & .0293 & $<.0211$ & \\
\hline & estuarine sw & 6 & $<.0211$ & $<.0211$ & $<.0211$ & \\
\hline
\end{tabular}

${ }^{1}$ Contaminant levels established by U.S. Environmental Protection Agency (1986, 1989, 1990a through e, 1991 a through c, 1992).

Ground-water samples were analyzed for 17 trace elements. Antimony, beryllium, cadmium, and selenium either were not present in ground-water samples, or were present in concentrations below the analytical method reporting limit. Barium and manganese were the only minor constituents detected in all ground-water samples; iron was present in a majority of the samples.

Results of laboratory analyses of surface-water samples were available for 13 of the 17 trace elements analyzed in ground-water samples. Missing trace element analyses include arsenic, lead, mercury, and selenium. All of the trace elements analyzed in surfacewater samples were detected in one or more samples.

Water-quality regulations and criteria for minor constituents were exceeded in several water samples. The concentrations of some of the minor constituents probably reflect natural hydrochemical conditions rather than ground-water contamination. The presence of minor constituents in each of the sampled environments is discussed in the following paragraphs.

Aluminum was detected in 14 ground-water samples (excluding replicates) in concentrations greater than the reporting level of $0.141 \mathrm{mg} / \mathrm{L}$ (tables 11 and 12, at the end of the report). All of the samples in which aluminum was detected were from wells screened within the surficial aquifer (table 7). The SMCL of aluminum ranges from 0.05 to $0.20 \mathrm{mg} / \mathrm{L}$, depending on the $\mathrm{pH}$ of the water. The analytical reporting level for the water samples was greater than the lower SMCL of $0.05 \mathrm{mg} / \mathrm{L} ; 13$ of the 14 detections in ground water were above $0.20 \mathrm{mg} / \mathrm{L}$. The maximum concentration in ground-water $(23.2 \mathrm{mg} / \mathrm{L})$ occurred in well I43. Another high concentration of aluminum $(14.2 \mathrm{mg} / \mathrm{L}$ ) occurred in well $\mathrm{I} 41$, which is adjacent to I43. These wells are located at the EPG dump site (fig. 2) on the northern shore of Carroll Island.

Several possible sources of aluminum in the ground water exist at Carroll Island. Aluminum is abundant in feldspars and aluminosilicate minerals, which are likely to be present in the aquifer material at Carroll Island. Hughes (1993, table 3) indicates that aluminum is present in the Talbot Formation sediments at J-Field, which is across the Gunpowder River from Carroll Island (fig. 1). Possible military sources of aluminum include the incendiary compound TEA (triethyl aluminum), which was used on Carroll Island (table 1); thermite, which is an incendiary mixture of aluminum 
powder and an oxidizing agent (Nemeth, 1989, p. 132); and HC, which is a smoke mixture that sometimes contained granular aluminum (Nemeth, 1989, p. 135).

The solubility of aluminum is largely $\mathrm{pH}$ dependent. Waters with lower $\mathrm{pH}$ may tend to contain more aluminum in solution (Hem, 1989, p. 74) than waters with higher $\mathrm{pH}$. Nine of the 14 ground-water samples with detectable aluminum concentrations had $\mathrm{pH}$ values below 5.0 (only 10 out of all the groundwater samples had $\mathrm{pH}$ values below 5.0). Aluminum has a high affinity to complex with natural organic acids. A high percentage of ground-water samples from the surficial aquifer had total organic carbon concentrations greater than $1 \mathrm{mg} / \mathrm{L}$. Aluminum-organic complexes in these samples may have passed through the filter and been measured as dissolved aluminum.

In surface water, aluminum was present at concentrations greater than the reporting level of $0.141 \mathrm{mg} / \mathrm{L}$ for 15 of the 20 sites where it was analyzed (table 15, at the end of the report). Because surfacewater samples were unfiltered, the high levels of aluminum were most likely the result of measurement of aluminum-organic complexes or aluminum that was sorbed onto suspended sediments.

The most appropriate water-quality criteria for aluminum in surface water at Carroll Island are the FWA and FWC criteria of 0.75 and $0.087 \mathrm{mg} / \mathrm{L}$, respectively. Of the 14 inland surface-water samples, one (SW21, aluminum concentration $2.32 \mathrm{mg} / \mathrm{L}$ ) exceeded the FWA criterion. Two of the six estuarine sites exceeded the FWA criterion for aluminum. Site SW07 had an aluminum concentration of $0.866 \mathrm{mg} / \mathrm{L}$ (table 15, at the end of the report), and site SW11 contained $2.11 \mathrm{mg} / \mathrm{L}$ (the replicate sample at SW11 contained $1.36 \mathrm{mg} / \mathrm{L}$ ). Because the reporting level for aluminum was higher than the FWC criterion, all of the surface-water sites potentially exceeded the criterion.

Antimony was not detected in ground-water samples at the reporting limit of $0.038 \mathrm{mg} / \mathrm{L}$, which was higher than the Proposed MCL of 0.01 or $0.005 \mathrm{mg} / \mathrm{L}$, and higher than the Proposed MCLG of $0.003 \mathrm{mg} / \mathrm{L}$. Antimony was detected at two inland surface-water sites. The sample at site SW02 (near Bengies Point Road) contained $0.147 \mathrm{mg} / \mathrm{L}$ antimony, and the sample at site SW14 (at the Lower Island disposal site) contained $0.090 \mathrm{mg} / \mathrm{L}$. These detections were below the FWA and FWC criteria for antimony (table 7). The source of antimony in these samples is unknown; the only likely military source would be impurities in some of the metallic oxides used in smoke mixtures, incendiaries, and other munitions. Antimony was not detected in any soil samples in concentrations above the reporting limits of 7.92 and $19.6 \mu \mathrm{g} / \mathrm{g}$.

Arsenic was detected in ground-water samples in both the surficial and confined aquifers. The highest concentration at any of the wells $(0.009 \mathrm{mg} / \mathrm{L}$, well I45) was lower than the MCL of $0.05 \mathrm{mg} / \mathrm{L}$. Arsenic was detected at nine wells in the surficial aquifer and at four out of six wells in the confined aquifer. The source of arsenic in these samples is not known. Arsenic was present in 20 of 26 soil samples collected on Carroll Island at concentrations up to $23 \mu \mathrm{g} / \mathrm{g}$. Brady (1974, p. 564) indicates that arsenic commonly occurs in soils in concentrations of 0.1 to $40 \mu \mathrm{g} / \mathrm{g}$. This means that naturally-occurring arsenic in the soils could be a source of the arsenic detected in ground water. Arsenic also is a component of chemical agents such as adamsite (Nemeth, 1989, p. 84-85), and lewisite (Nemeth, 1989, p. 81). These chemical agents could be a source of arsenic in ground water.

Barium was present in ground-water and surface-water samples at concentrations ranging from 0.007 to $0.274 \mathrm{mg} / \mathrm{L}$ (table 7 ), which is much less than the $\mathrm{MCL}$ of $2.0 \mathrm{mg} / \mathrm{L}$. The barium concentrations in the samples probably can be attributed to natural geochemical processes. Hughes (1993, table 4) found barium within the Talbot Formation sediments at J-Field near Carroll Island (fig. 1).

Beryllium was not detected in ground-water samples at the reporting limit of $0.00500 \mathrm{mg} / \mathrm{L}$. This reporting limit was higher than the proposed MCL of 0.001 and MCLG of $0 \mathrm{mg} / \mathrm{L}$. Beryllium was detected in one surface-water sample (SW02) at a concentration of $0.00594 \mathrm{mg} / \mathrm{L}$. This detection was below the FWA of $0.130 \mathrm{mg} / \mathrm{L}$, but the reporting limit and therefore the detection were above the FWC of $0.0053 \mathrm{mg} / \mathrm{L}$ (table 7).

Although boron was not analyzed in groundwater or surface-water samples, it was, however, analyzed in the soil samples at Carroll Island. Boron was detected in eight samples at concentrations above the reporting limits of 6.64 and $7.37 \mu \mathrm{g} / \mathrm{g}$. The detections were at CISOIL03 $(107 \mu \mathrm{g} / \mathrm{g})$ at the service area; CISOIL11 $(9.04 \mu \mathrm{g} / \mathrm{g})$ on the shore near the Lower Island disposal site; CISOIL $15(9.75 \mu \mathrm{g} / \mathrm{g} ; 12.3 \mu \mathrm{g} / \mathrm{g}$ in the duplicate sample) at test grid 2; CISOIL16 $(14.3 \mu \mathrm{g} / \mathrm{g})$ at the VX test area; CISOIL17 $(15.6 \mu \mathrm{g} / \mathrm{g})$ north of the Lower Island disposal site; CISOIL20 $(16.4 \mu \mathrm{g} / \mathrm{g})$ at Bengies Point Road dump site; CISOIL22 $(20.7 \mu \mathrm{g} / \mathrm{g})$ east of the HD test area; and 
CISOIL29 $(22.2 \mu \mathrm{g} / \mathrm{g})$ in the magazine area. Brady (1974, p. 564) indicates that boron levels of 2 to $100 \mu \mathrm{g} / \mathrm{g}$ are common in soils.

Cadmium was not detected in any ground-water samples at a reporting limit of $0.00401 \mathrm{mg} / \mathrm{L}$, or in any soil samples at reporting limits of 0.447 and $1.20 \mu \mathrm{g} / \mathrm{g}$. The reporting limit for ground-water samples was less than the MCL and MCLG of $0.005 \mathrm{mg} / \mathrm{L}$ (table 7). In surface-water samples, cadmium was detected at site SW01 (0.0112 mg/L) and site SW14 (0.00617 mg/L). Both of these were inland sites. The source of cadmium in these samples may have been anthropogenic. Site SW01 was near the Bengies Point Road dump site, where metallic munitions fragments are likely; site SW14 was in the open disposal pit at the Lower Island disposal site. The fresh-water criteria $($ FWA $=0.0039 \mathrm{mg} / \mathrm{L} ; \mathrm{FWC}=0.0011 \mathrm{mg} / \mathrm{L}$ ) for cadmium were lower than the $0.00401 \mathrm{mg} / \mathrm{L}$ reporting limit in surface-water samples.

Chromium was detected in concentrations greater than the reporting limit of $0.00602 \mathrm{mg} / \mathrm{L}$ in one ground-water sample (well I26A, $0.007 \mathrm{mg} / \mathrm{L}$ ), and one surface-water sample (SW01, $0.020 \mathrm{mg} / \mathrm{L}$ ). The concentration in the sample at well I26A did not exceed the $0.1 \mathrm{mg} / \mathrm{L} \mathrm{MCL}$ and MCLG. The concentration of chromium in the sample at surface-water site SW01, however, exceeded the FWA and FWC criteria of 0.016 and $0.011 \mathrm{mg} / \mathrm{L}$. In soils, chromium was detected in 15 of the 16 samples that analyses were available for (table 17, at the end of the report), with detections of up to $26.2 \mu \mathrm{g} / \mathrm{g}$.

Chromium commonly leaches from deposits of industrial metals. Concentrations of chromium in natural waters that have not been affected by waste disposal are commonly less than $0.01 \mathrm{mg} / \mathrm{L}$ (Hem, 1989, p. 138). On Carroll Island, sources of chromium may include buried shell fragments, agent containers, and equipment. Hughes (1993) indicates that chromium is present in Quaternary deposits at J-Field (fig. 1), so it is likely to be present in similar deposits on Carroll Island. No known burial of any of these sources exists in the HD test area where chromium was detected in ground water. In addition, well I26A is the deeper of two wells screened in the surficial aquifer at this site, and chromium was not detected in the shallower well (I26B). The sources of chromium in the soil samples are unknown, but the chromium might be naturally occurring. Some of the detections that are at or near disposal sites may have resulted from disposal of munition fragments or personal protective equipment (such as respirator filters) that may have contained chromium. The highest concentration of chromium in soil $(26.2 \mu \mathrm{g} / \mathrm{g})$ occurred at site CISOIL03, which is near the service area.

Copper was detected in ground water above the reporting limit of $0.00809 \mathrm{mg} / \mathrm{L}$ at 31 of the 61 wells that were sampled. The maximum copper concentration in a ground-water sample was $0.0497 \mathrm{mg} / \mathrm{L}$, which is much lower than the SMCL of $1.0 \mathrm{mg} / \mathrm{L}$, and the Proposed MCL and MCLG of $1.3 \mathrm{mg} / \mathrm{L}$ (table 7).

Concentrations of copper in surface-water samples were similar to those in ground-water samples. The ambient water-quality criteria for copper in surface water, however, are much more stringent than the regulations for copper in drinking water. Of the inland sites, copper concentrations in the samples at SW01 (0.0377 mg/L), SW09 (0.0200 mg/L), SW13 (0.0180 $\mathrm{mg} / \mathrm{L}), \mathrm{SW} 14$ (0.0341 mg/L), SW15 (0.0270 mg/L), SW20 (0.0226 mg/L), and SW21 (0.0193 mg/L) exceeded or equaled the FWA criterion of $0.018 \mathrm{mg} / \mathrm{L}$; copper concentrations at the above sites plus SW 12 $(0.016 \mathrm{mg} / \mathrm{L}), \mathrm{SW} 16(0.015 \mathrm{mg} / \mathrm{L})$, and the replicate sample at SW09 $(0.0152 \mathrm{mg} / \mathrm{L})$ exceeded the FWC criterion of $0.012 \mathrm{mg} / \mathrm{L}$. The copper in these waters probably results from the leaching of naturally-occurring copper in the soils and sediments. A possible military source of copper is respirator filters, which contained activated charcoal that was commonly impregnated with copper (Nemeth, 1989, p. 64). This military source is most likely at sites SW01, SW20, SW21, and SW14, which are located in areas where the surface water is in direct contact with solid waste from military testing activities (Bengies Point Road dump site and the open disposal pit at the Lower Island disposal site). Both fresh-water criteria were exceeded at one estuarine sampling site near the Lower Island disposal site (SW11, $0.0442 \mathrm{mg} / \mathrm{L}$ ). Copper, however, was not detected at a reporting limit of $0.00809 \mathrm{mg} / \mathrm{L}$ in the replicate sample at site SW11.

In soil, the maximum copper concentration was $55.2 \mu \mathrm{g} / \mathrm{g}$ (table 6). This concentration falls within the range reported as commonly occurring within soils (Brady, 1974, p. 564), indicating that the concentrations may occur naturally.

Iron concentrations in ground-water samples ranged from less than 0.043 to $83.0 \mathrm{mg} / \mathrm{L}$ (table 7). Iron was detected in 56 of the 61 ground-water sampling sites. Iron concentrations exceeded the SMCL of $0.300 \mathrm{mg} / \mathrm{L}$ in 44 ground-water samples. These iron concentrations may occur naturally. Vroblesky and 
others $(1989$, p. 70$)$ indicate that the dominant source of iron in ground-water at O-Field (fig. 1) is probably related to leaching and dissolution of naturallyoccurring iron-rich grain coatings under the reducing conditions present in the ground water. The hydrogeologic setting at O-Field is similar to that of Carroll Island.

Iron concentration in surface-water samples ranged from 0.334 to $16.4 \mathrm{mg} / \mathrm{L}$ (table 7). These relatively high values probably result from the fact that the samples were not filtered prior to analysis because surface water quality criteria are for unfiltered water. The iron was most likely complexed with organic material in the water or associated with suspended sediment. Iron concentrations in soil samples ranged from 1,520 to $22,800 \mu \mathrm{g} / \mathrm{g}$. The range of iron concentrations commonly found in soils is 5,000 to $50,000 \mu \mathrm{g} / \mathrm{g}$ (Brady, 1974, p. 23).

Lead was detected in 12 of 60 ground-water samples at levels above the reporting limit of $0.00126 \mathrm{mg} / \mathrm{L}$. The concentration of lead in ground water was above the USEPA MCL action level of $0.015 \mathrm{mg} / \mathrm{L}$ at one site (well I54A, $0.0314 \mathrm{mg} / \mathrm{L}$ ) in the surficial aquifer. Lead was detected at one site (well I16A, $0.00195 \mathrm{mg} / \mathrm{L}$ ) in the confined aquifer. The MCLG for lead in drinking water is zero. Lead concentrations in soil samples ranged from 3.11 to $164 \mu \mathrm{g} / \mathrm{g}$. Lead was detected at all 25 of the soil sites for which it was analyzed.

The sources of lead in the ground-water and soil samples are unknown. The $\mathrm{pH}$ of the ground-water sample that exceeded the MCL (well I54A) was relatively low, which can increase the solubility of lead in water (Hem, 1989, p. 144). The $\mathrm{pH}$ of seven of the 12 ground-water samples in which lead was detected was lower than 5.0, and the detection of lead in all of the soil samples indicates that the source of lead in the system is widespread. It is possible that practices during the historical testing period increased the lead concentrations in ground water at Carroll Island. It also is possible, however, that lead concentrations in the ground-water and soil samples are not significantly different from background concentrations of lead. Hem (1989, p. 144) indicates that concentrations of lead in rain and snow can be more than $0.1 \mathrm{mg} / \mathrm{L}$ in areas subject to substantial air pollution. Brady (1974, p. 564) indicates that the range of lead commonly found in soil is 2 to $200 \mu \mathrm{g} / \mathrm{g}$.

Manganese was detected in all ground-water, surface-water, and soil samples for which analyses were available (tables 6 and 7). The concentration of manganese in 53 of 60 ground-water samples exceeded the SMCL of $0.05 \mathrm{mg} / \mathrm{L}$. The chemistry of manganese is similar to that of iron (Hem, 1989, p. 85), in that the speciation of the oxides of manganese is sensitive to $\mathrm{pH}$ and oxidation-reduction conditions, so it is likely that the concentrations in water and soil samples are naturally occurring. The maximum concentration of manganese in soil at Carroll Island $(169 \mu \mathrm{g} / \mathrm{g})$ is lower than the range of manganese described by Brady (1974, p. 23) as commonly found in soils (200 to $10,000 \mu \mathrm{g} / \mathrm{g}$ ). Hughes (1993, table 4) found manganese in the Quaternary sediments at J-Field, near Carroll Island (fig. 1).

Mercury was detected at two ground-water sites in the surficial aquifer at concentrations close to the reporting limit of $0.000243 \mathrm{mg} / \mathrm{L}$. Mercury was detected at well $\mathrm{I} 28$ at a concentration of $0.000268 \mathrm{mg} / \mathrm{L}$, and at well I47A at a concentration of $0.000403 \mathrm{mg} / \mathrm{L}$. The concentrations of the two detections in the surficial aquifer were lower than the MCL and MCLG of $0.002 \mathrm{mg} / \mathrm{L}$ (table 7). Mercury was not detected in the confined aquifer.

Mercury was detected above a reporting limit of $0.026 \mu \mathrm{g} / \mathrm{g}$ in 11 soil samples. The maximum concentration was at site CISOIL03 $(0.786 \mu \mathrm{g} / \mathrm{g})$. The sources of mercury in water and soil samples are unknown. Hem $(1989$, p. 143) indicates that mercury has numerous cultural uses and that the natural tendency of the element to volatilize acts to disperse it widely.

Nickel was detected above the reporting level of $0.0343 \mathrm{mg} / \mathrm{L}$ in wells $\mathrm{I03}(0.0481 \mathrm{mg} / \mathrm{L}), \mathrm{I} 12$ $(0.0527 \mathrm{mg} / \mathrm{L}), \mathrm{I} 22 \mathrm{C}(0.0591 \mathrm{mg} / \mathrm{L}), \mathrm{I} 41(0.0657 \mathrm{mg} / \mathrm{L})$, I43 (0.0657 mg/L), and I53 (0.0442 mg/L). These wells are screened in the surficial aquifer, and are located throughout the study area. The Proposed MCL and MCLG for nickel is $0.10 \mathrm{mg} / \mathrm{L}$ (table 7). Nickel is commonly associated with iron and manganese oxides (Hem, 1989, p. 159) but also is commonly used in stainless steel and in numerous alloys. Potential anthropogenic sources exist for the nickel in wells I12, I41, I43, and I53. Samples from these wells exhibited low $\mathrm{pH}$ values (below 5.0), and the wells were each located near dump sites or burial pits that contained metal fragments. The sources of nickel at the other well sites are not known. Hughes (1993, table 4) indicates that nickel is present at parts per million levels within the Quaternary sediments at J-Field, which are similar to the sediments underlying Carroll Island. The constituent could therefore be present naturally in the ground water.

Nickel was detected in one surface-water sample (SW01, $0.0663 \mathrm{mg} / \mathrm{L}$ ) above the reporting limit of 
$0.0343 \mathrm{mg} / \mathrm{L}$. This sample was at the Bengies Point Road dump site, which could contain sources of nickel and other trace metals such as copper and chromium. Neither of the fresh-water criteria for nickel (table 7) were exceeded in surface-water samples.

Selenium was not detected in ground-water samples at or above the reporting limit of $0.00302 \mathrm{mg} / \mathrm{L}$ (table 7). The MCL and MCLG for selenium is $0.05 \mathrm{mg} / \mathrm{L}$ (table 7). Selenium was not detected in soil samples at reporting limits of $5.76 \mu \mathrm{g} / \mathrm{g}$ and $0.576 \mu \mathrm{g} / \mathrm{g}$ (table 6).

Silver was detected in 14 ground-water samples (all from the surficial aquifer) above the reporting limit of $0.00460 \mathrm{mg} / \mathrm{L}$. The highest concentration of silver was $0.0253 \mathrm{mg} / \mathrm{L}$ (at well I50); this concentration was below the MCL of $0.50 \mathrm{mg} / \mathrm{L}$ and the SMCL of $0.100 \mathrm{mg} / \mathrm{L}$.

Silver was detected above the reporting limit of $0.00460 \mathrm{mg} / \mathrm{L}$ at two surface-water sites (SW12, $0.00564 \mathrm{mg} / \mathrm{L} ; \mathrm{SW} 20,0.00546 \mathrm{mg} / \mathrm{L}$ ). The applicable water-quality criteria, however, are lower than the reporting limit for the silver analyses in surface water (table 7). Meaningful comparisons of silver concentrations in surface water to the water-quality criteria are therefore not possible. A possible military source for silver is respirator filters, which contained activated charcoal that was sometimes impregnated with silver (Nemeth, 1989, p. 64).

Thallium was detected in 10 ground-water samples (all in the surficial aquifer) above the reporting limit of $0.0814 \mathrm{mg} / \mathrm{L}$. The MCLG of $0.0005 \mathrm{mg} / \mathrm{L}$ and Proposed MCL of $0.002 / 0.001 \mathrm{mg} / \mathrm{L}$ are much lower than the reporting limit for thallium. The thallium detections include well $\mathrm{I} 23(0.104 \mathrm{mg} / \mathrm{L})$ in test grid 2 ; wells I27B $(0.124 \mathrm{mg} / \mathrm{L})$ and $\mathrm{I} 28(0.169 \mathrm{mg} / \mathrm{L})$ at the wind tunnel; well $\mathrm{I} 30(0.145 \mathrm{mg} / \mathrm{L})$ at the CS test area; wells I41 $(0.251 \mathrm{mg} / \mathrm{L})$ and $I 43(0.160 \mathrm{mg} / \mathrm{L})$ at the EPG dump site; well I47A (0.233 mg/L) at the service area; and wells $I 50(0.200 \mathrm{mg} / \mathrm{L}), \mathrm{I} 51(0.259 \mathrm{mg} / \mathrm{L})$, and $152(0.113 \mathrm{mg} / \mathrm{L})$ at Bengies Point Road dump site.

Thallium was detected above the reporting limit of $0.0814 \mathrm{mg} / \mathrm{L}$ in one surface-water sample on Carroll Island, site SW17 at the service area $(0.113 \mathrm{mg} / \mathrm{L})$. The FWA for thallium is $1.4 \mathrm{mg} / \mathrm{L}$; however, the FWC $(0.040 \mathrm{mg} / \mathrm{L})$ is lower than the reporting limit (table 7$)$.

Thallium is relatively insoluble in water and is highly toxic. The use of thallium in chemical agents is not documented; however, it has been used in rodenticides, fungicides, insecticides, and as catalyzing agents for organic reactions (Lucius and others, 1989, p. 434).
Because the chemical compositions of many warfare agents are similar to those of pesticides, any number of these products could be the source of thallium on Carroll Island. It is present in the Quaternary deposits at J-Field (Hughes, 1993, table 4), so it is likely to occur naturally in the sediment and aquifers at Carroll Island.

Zinc was detected above the reporting limit of $0.0211 \mathrm{mg} / \mathrm{L}$ in ground-water samples from 20 wells screened in the surficial aquifer and 2 wells screened in the confined aquifer. The highest concentration of zinc was $0.213 \mathrm{mg} / \mathrm{L}$ at well $\mathrm{I} 28$ near the wind tunnel. This concentration was below the SMCL of $5.0 \mathrm{mg} / \mathrm{L}$ (table 7).

Zinc was detected above the reporting level of $0.0211 \mathrm{mg} / \mathrm{L}$ in eight surface-water samples (all were inland sites). Of these, four samples (SW01, $0.0645 \mathrm{mg} / \mathrm{L} ; \mathrm{SW} 03,0.0854 \mathrm{mg} / \mathrm{L} ; \mathrm{SW} 13,0.0787 \mathrm{mg} / \mathrm{L}$; and $S W 14,0.800 \mathrm{mg} / \mathrm{L}$ ) had concentrations above the FWC of $0.047 \mathrm{mg} / \mathrm{L}$, and one (SW14) had a concentration above the FWA of $0.320 \mathrm{mg} / \mathrm{L}$.

In soil samples, zinc was detected at 12 of 16 sites for which analyses were available. There were, however, problems with the reporting limit for zinc. In various samples, the reporting limit was 7.96 , 79.6 , and $796 \mu \mathrm{g} / \mathrm{g}$, and three reported values were below the $7.96 \mu \mathrm{g} / \mathrm{g}$ reporting limit (table 17 , at the end of the report). This makes summary statistics and data comparisons nearly meaningless. The highest reported detection for zinc was $39.5 \mu \mathrm{g} / \mathrm{g}$ at site CISOIL08 in test grid 1.

The sources of zinc in the ground-water, surfacewater, and soil samples are probably natural. A possible military source is smoke mixtures (HC), which reportedly contained zinc oxide (Vroblesky and others, 1989 , p. 71). Zinc, however, is a relatively common element in the environment (Vroblesky and others, 1989 , p. 71). Hem (1989, p. 142) indicates that industrial processes have tended to disperse the element widely in the environment, and have greatly enhanced the availability of zinc for solution in water. Hughes (1993, table 4) found concentrations of zinc up to $83 \mu \mathrm{g} / \mathrm{g}$ in the Quaternary sediment at J-Field, so it is likely that zinc is naturally occurring in similar sediment at Carroll Island. Brady (1974, p. 564) indicates that the common concentration range for zinc in soil is from 10 to $300 \mu \mathrm{g} / \mathrm{g}$. 


\section{Organic Constituents}

The distribution of organic compounds on Carroll Island was determined by the collection and analysis of organic-compound indicators such as total organic halogens and total organic carbon in water samples and volatile and semivolatile compounds in water and soil samples. The volatile compounds, semivolatile compounds, and unknown organic compounds that were detected in water and soil samples at Carroll Island during the 1989 and 1990 sampling runs are summarized in table 8. Organic-chemical data for ground-water samples collected in spring 1989 from the surficial and confined aquifers are presented in tables 13 and 14 (at the end of the report). Organic-chemical data for surfacewater samples, also collected in spring 1989 , are presented in table 16 (at the end of the report), and organicchemical data for soil samples collected in summer 1990 from Carroll Island are presented in table 18 (at the end of the report). Unknown organic compounds detected in ground-water, surface-water, and soil samples, along with tentative identifications of the compounds are presented in tables 21,22 , and 23 (at the end of the report).

\section{Quality Assurance}

Quality-control samples included equipment and trip blanks along with replicate and split samples. Several organic compounds were identified in equipment blanks collected during the Carroll Island ground-water and surface-water sampling effort (table 20, at the end of the report). These detections include $8.46 \mu \mathrm{g} / \mathrm{L}$ (micrograms per liter) total phenolic compounds and $8 \mu \mathrm{g} / \mathrm{L}$ of an unknown compound (UNK591; see table 21 at the end of the report for unknown compounds in groundwater equipment blanks) in an equipment blank on April 27,$1989 ; 9 \mu \mathrm{g} / \mathrm{L}$ total organic halogens and $8 \mu \mathrm{g} / \mathrm{L}$ of UNK591 on May 2,$1989 ; 21 \mu \mathrm{g} / \mathrm{L}$ of UNK591 on May 4,$1989 ; 116 \mu \mathrm{g} / \mathrm{L}$ total organic halogens and $12 \mu \mathrm{g} / \mathrm{L}$ of UNK591 on May 9, 1989; and $5 \mu \mathrm{g} / \mathrm{L}$ UNK646 on May 18,1989 . No trip-blank data from ground-water or surface-water samples were returned from the laboratory.

During soil sampling, the only trip-blank results that were received from the laboratory came with the tentative identifications of unknown organic compounds. The tentative identification data received from the laboratory contained no information about the concentrations of constituents. Most of the detections in trip blanks were unknown compounds; however, ace- tone, meta/para xylene, and 1-bromo-3-fluorobenzene were detected in a trip blank that was sent June 19, 1990. Unknown compounds detected in this trip blank included UNK257 and UNK284. Unknown compounds UNK019, UNK020, UNK250, and UNK276 were detected in the trip blank sent on May 23, 1990. Unknown compounds UNK023 and UNK197 were detected in the trip blank sent on October 16, 1990.

No organic chemicals were detected in any of the replicate or split ground-water or surface-water samples. Organic chemicals were, however, detected in several replicate soil samples. This information can be used to give some idea about the reliability of the organic-chemistry data for soils. Replicate samples were collected at sites CISOIL01 (CISOIL101), CISOIL06 (CISOIL106), and CISOIL15 (CISOIL115). Comparisons were possible for five cases; the median difference in concentration of organic constituents between replicate samples was 31.8 percent. The range of differences was 0.8 to 46.4 percent. Censored data (a statistical term for values below a detection limit) were excluded from the calculation of differences.

Volatile and semivolatile organic compounds were detected in ground-water, surface-water, and soil samples. For ground-water data, all of the detections were in samples collected from the surficial aquifer. A significant percentage (about 65 percent) of the analyses of organic compounds in the confined aquifer were not available. Most of the missing results from the confined-aquifer samples were from semivolatilecompound analyses.

\section{Organic Compound Indicators}

In addition to direct analysis of organic compounds, other potential indicators of contamination from volatile organic compounds were measured in ground-water and surface-water samples. These indicator analyses included those for total organic halogens (TOH) and total organic carbon. The $\mathrm{TOH}$ analysis measures the concentration of halogen (chlorine, bromine, and fluorine) associated with volatile organic compounds present in a water sample (Lorah and Vroblesky, 1989, p. 53). This analysis therefore measures a broad spectrum of the primary types of organic compounds identified by the more compound-specific gas-chromatography mass spectroscopy (GC/MS) analysis of volatile organic compounds. In contrast to the GC/MS results, TOH analysis was greater than the detection level of $5.00 \mu \mathrm{g} / \mathrm{L}$ in 44 of 51 ground-water 
Table 8. Locations and concentrations of selected organic constituents detected in ground-water, surface-water, and soil samples, Carroll Island, Aberdeen Proving Ground, Md., spring 1989 and summer 1990

[Concentrations for water samples in micrograms per liter; concentrations for soil samples in micrograms per gram; MCL, maximum contaminant level; MCLG, maximum contaminant level goal; FWA, fresh-water acute; * denotes sites where MCL or FWA was exceeded;

** denotes compounds that were not routinely analyzed and were only reported when detected; replicates not included]

\begin{tabular}{llcc}
\hline Compound & $\begin{array}{c}\text { Number of } \\
\text { detections }\end{array}$ & $\begin{array}{c}\text { Concentration } \\
\text { range }\end{array}$ & $\begin{array}{c}\text { Location and site number where detected } \\
\text { (figs. 2, 3, 4, and 5) }\end{array}$ \\
\hline & Ground-water samples
\end{tabular}

Ground-water samples

\section{Volatile compounds:}

1,2-Dichloroethane

$(5.0 \mu \mathrm{g} / \mathrm{L} \mathrm{MCL}$;

$0 \mu \mathrm{g} / \mathrm{L}$ MCLG) ${ }^{1}$

Methylene chloride

(5.0 $\mu \mathrm{g} / \mathrm{L} \mathrm{MCL;}$

$0 \mu \mathrm{g} / \mathrm{L} \mathrm{MCLG})$

Trichlorofluoromethane

Semivolatile compounds:

Acetone
Diacetone alcohol**
1,2-Epoxycyclohexene**
2-methyl naphthalene
Naphthalene

$1-31$

$34.0-7.0$

$6 \quad 3.0-5.0$

1

1

15

Lower Island disposal site (113)

Lower Island disposal site (117, I20);

$\mathrm{VX}$ test area (I44)

Lower Island disposal site (I16B); Test grid 2

(I22C); HD test area (I26A,B); Bengies Point Rd. dump site (I51, I54A)

Test grid 1 (108)

Test grid 1 (108)

Surface-water samples

Volatile compounds:

Benzene

$(5,300 \mu \mathrm{g} / \mathrm{L}$ FWA $)$

Toluene

$(17,500 \mu \mathrm{g} / \mathrm{L}$ FWA $)$

.56

Test grid 2 (SW16)

$90 \quad$ Test grid 2 (SW16)

Semivolatile compounds:

Hexadecanoic acid**

Lower Island disposal site (SW 14, SW12);

Test grid 2 (SW16); Service area (SW17);

Bengies Point Rd. dump site (SW20, SW21)

Pentadecanoic acid**

1

3.0

Lower Island disposal site (SW14)

Tetradecanoic acid**

Lower Island disposal site (SW14)

Thiodiglycol

138

Lower Island disposal site (SW12)

Soil samples

Volatile compounds:

Methylene chloride

Lower Island disposal site (CISOIL11)

1,1,2,2-Tetrachloroethane**

EPG dump site (CISOIL04); Lower Island disposal site (CISOIL17); CS test area (CISOIL19); Wind tunnel (CISOIL25); 
Table 8. Locations and concentrations of selected organic constituents detected in ground-water, surface-water, and soil samples, Carroll Island, Aberdeen Proving Ground, Md., spring 1989 and summer 1990--Continued

\begin{tabular}{|c|c|c|c|}
\hline Compound & $\begin{array}{l}\text { Number of } \\
\text { detections }\end{array}$ & $\begin{array}{l}\text { Concentration } \\
\text { range }\end{array}$ & $\begin{array}{l}\text { Location and site number where detected } \\
\text { (figs. } 2,3,4 \text {, and } 5 \text { ) }\end{array}$ \\
\hline \multicolumn{4}{|c|}{ Soil samples--continued } \\
\hline \multicolumn{4}{|c|}{ Semivolatile compounds: } \\
\hline Acetone & 13 & $0.013-0.26$ & $\begin{array}{l}\text { Bengies Point Rd. dump site (CISOIL01, 20); } \\
\text { EPG dump site (CISOIL05); BZ test burn pit } \\
\text { (CISOIL08); Lower Island disposal site } \\
\text { (CISOIL11,12,13,14,17); Test grid } 2 \\
\text { (CISOIL15); VX test area (CISOIL16); } \\
\text { Area east of HD test area (CISOIL22); } \\
\text { Magazine area (CISOIL29) }\end{array}$ \\
\hline Benzoic acid & 16 & $.062-6.9$ & $\begin{array}{l}\text { Bengies Point Rd. dump site (CISOIL01, 20, 21); } \\
\text { EPG dump site (CISOIL04, 05); Decontamination } \\
\text { pits (CISOIL06); Aerial spray grid (CISOIL07, 27); } \\
\text { Lower Island disposal site (CISOIL11, 13, 14); VX } \\
\text { test area (CISOIL16); Wind tunnel (CISOIL24, 25); } \\
\text { Dredge spoil site (CISOIL28); Magazine area } \\
\text { (CISOIL29) }\end{array}$ \\
\hline Butylbenzyl phthalate & 18 & $.049-.70$ & $\begin{array}{l}\text { Bengies Point Rd. dump site (CISOIL01, 20, 21); } \\
\text { EPG dump site (CISOIL04, 05); Decontamination } \\
\text { pits (CISOIL06); Aerial spray grid (CISOIL07, 27); } \\
\text { Test grid 1 (CISOIL09); Lower Island disposal site } \\
\text { (CISOIL11, 13, 14); VX test area (CISOIL16); HD } \\
\text { test area (CISOIL23); Wind tunnel (CISOIL24, 25); } \\
\text { Dredge spoil site (CISOIL28); Magazine area } \\
\text { (CISOIL29) }\end{array}$ \\
\hline Heptadecanoic acid** & 1 & .64 & Lower Island disposal site (CISOIL14) \\
\hline Hexadecanoic acid** & 11 & $.26-13$ & $\begin{array}{l}\text { Bengies Point Rd. dump site (CISOIL01, 21); } \\
\text { EPG dump site (CISOIL04, 05); } \\
\text { Decontamination pits (CISOIL06); Aerial } \\
\text { spray grid (CISOIL07, 27); Lower Island } \\
\text { disposal site (CISOIL13, 14); Wind tunnel } \\
\text { (CISOIL24, 25); Dredge spoil site } \\
\text { (CISOIL28) }\end{array}$ \\
\hline Methylethyl ketone & 1 & .13 & Bengies Point Rd. dump site (CISOIL20) \\
\hline 4-Methylphenol & 1 & .98 & Bengies Point Rd. dump site (CISOIL20) \\
\hline Octadecanoic acid** & 1 & 12 & Lower Island disposal site (CISOIL14) \\
\hline Pentadecanoic acid** & 1 & .39 & Lower Island disposal site (CISOIL14) \\
\hline Tetradecanoic acid** & 1 & 1.2 & Lower Island disposal site (CISOIL14) \\
\hline
\end{tabular}

${ }^{1}$ Contaminant levels established by U.S. Environmental Protection Agency $(1989,1990 \mathrm{a}, \mathrm{b}, \mathrm{c}$ and e, 1991a, 1992). 
samples in the surficial aquifer (four samples were missing, and replicates and splits were not included), in four of five samples from the confined aquifer (one analysis was missing) and in all of the surface-water samples for which analyses were available. The maximum TOH concentrations were $354 \mu \mathrm{g} / \mathrm{L}$ in the surficial aquifer (well I13), $26.4 \mu \mathrm{g} / \mathrm{L}$ in the confined aquifer (well I16A), $108 \mu \mathrm{g} / \mathrm{L}$ in an inland surface-water sample (SW03), and $182 \mu \mathrm{g} / \mathrm{L}$ in an estuarine sample (SW11).

The high concentrations of $\mathrm{TOH}$ are difficult to explain in light of the relatively few detections and low concentrations of volatile organic compounds in water samples (table 8). The highest TOH concentrations in ground water were detected in samples from wells $\mathrm{I04}$ $(118 \mu \mathrm{g} / \mathrm{L}), \mathrm{I} 13(354 \mu \mathrm{g} / \mathrm{L}), \mathrm{I} 22 \mathrm{C}(122 \mu \mathrm{g} / \mathrm{L}), \mathrm{I} 45$ $(149 \mu \mathrm{g} / \mathrm{L})$, I $46(331 \mu \mathrm{g} / \mathrm{L})$, I47A $(109 \mu \mathrm{g} / \mathrm{L})$, and I51 $(100 \mu \mathrm{g} / \mathrm{L})$. Only four of these samples (I22C, I45, I46, and I51) contained measurable concentrations of volatile organic compounds. In surface-water samples, no halogenated volatile organic compounds were detected (table 8), and yet relatively high concentrations (13.3 to $182 \mu \mathrm{g} / \mathrm{L}$ ) of TOH were reported (table 16 , at the end of the report). Possible explanations for the lack of correlation between $\mathrm{TOH}$ and volatile organic compound concentrations are that the $\mathrm{TOH}$ values were too high because of field or lab contamination or interferences from other compounds (such as inorganic halides in the water), or that the volatile compounds that caused the high $\mathrm{TOH}$ values were lost during sampling or analysis from the samples analyzed by GC/MS.

Total organic carbon is a gross measure of the total organic material dissolved and suspended in solution. Total organic carbon is measured by converting all of the organic material in an unfiltered water sample into carbon dioxide, and then measuring the carbon dioxide produced (Drever, 1988, p. 37). This analysis measures the organic carbon in water from chlorinated hydrocarbons as well as oil, grease, and natural organic material such as tannic and fulvic acids. In these shallow ground-water and surface-water systems, the natural compounds are probably present in much greater concentrations than anthropogenic carbon. Thurman (1985, p. 14) indicates that dissolved organic carbon (which is total minus suspended organic carbon) is generally present in ground water in the range of 200 to $15,000 \mu \mathrm{g} / \mathrm{L}$, with a median of $700 \mu \mathrm{g} / \mathrm{L}$. Natural sources of organic carbon in ground water are the dissolution of surficial organic material or fossilized organic matter that is present in the geologic material of the aquifer (Thurman, 1985, p. 15). Out of 55 groundwater samples from the surficial aquifer (replicates and splits not included), 22 contained total organic carbon in concentrations greater than $1,000 \mu \mathrm{g} / \mathrm{L}$, with a maximum value of $10,300 \mu \mathrm{g} / \mathrm{L}$ in well 140 . Total organic carbon in the confined aquifer ranged from 1,370 to $5,200 \mu \mathrm{g} / \mathrm{L}$. Total organic carbon concentrations in surface-water samples were all well below $1,000 \mu \mathrm{g} / \mathrm{L}$.

\section{Volatile Compounds}

The volatile organic compounds detected in ground-water samples at Carroll Island during spring 1989 include 1,2-dichloroethane, methylene chloride, and trichlorofluoromethane (table 8). Methylene chloride was the only compound to be detected in more than one ground-water sample, and no ground-water samples contained more than one volatile compound. The volatile organic compounds detected in surface water (table 8) were benzene and toluene. Both compounds were detected in the same sample, and no other volatile compounds were detected in any other surface-water samples. The volatile compounds detected in soils (table 8) were 1,1,2,2-tetrachloroethane (detected in four samples) and methylene chloride (detected in one sample).

\section{Distribution}

The sites in which volatile organic compounds were detected include three test areas and four SWMU's. Volatile organic compounds were detected in ground water at test grid 2 (well I22C), the wind tunnel (well I28), the Bengies Point Road dump site (well I51), and the dredge spoil site (wells I45 and I46). In surface water, volatile compounds were detected at only one location, site SW16 at the southeastern end of test grid 2 . In soil, volatile compounds were detected at the wind tunnel (CISOIL25), the CS test area (CISOIL19), the Lower Island disposal site (CISOIL11 and CISOIL17), and the EPG dump site (CISOIL04).

Trichlorofluoromethane was detected in the ground water at test grid 2 . The compound was detected in well $\mathrm{I} 22 \mathrm{C}$ in test grid 2 at a concentration of $2.1 \mu \mathrm{g} / \mathrm{L}$. Trichlorofluoromethane is not regulated by primary or secondary drinking-water standards. Well I22C is in a well cluster with another well (I22B) in the surficial aquifer and one (well I22A) in the confined aquifer. Well $\mathrm{I} 22 \mathrm{C}$ is the shallowest well in the cluster, screened at 5 to $10 \mathrm{ft}$ below land surface (Ham and oth- 
ers, 1991, p. 26-27). Well I22B is screened below a thin silt layer in the surficial aquifer at a depth of 14 to $19 \mathrm{ft}$, and $\mathrm{I} 22 \mathrm{~A}$ is screened in the confined aquifer at 55 to $65 \mathrm{ft}$ (Ham and others, 1991, p. 26-27). Trichlorofluoromethane was not detected in either of the other wells in the cluster (tables 13 and 14, at the end of the report).

Benzene and toluene were detected in one surface-water sample (SW16) at the southeast end of test grid 2. Benzene was detected at a concentration of $0.56 \mu \mathrm{g} / \mathrm{L}$, and toluene was detected at $0.90 \mu \mathrm{g} / \mathrm{L}$. The detections were well below the FWA criteria for these substances in surface water, which are $5,300 \mu \mathrm{g} / \mathrm{L}$ for benzene and $17,500 \mu \mathrm{g} / \mathrm{L}$ for toluene. No other volatile organic compounds were detected in surface-water samples at any site.

At the wind tunnel, volatile compounds were detected in ground water and in soil. The compound 1,2-dichloroethane was detected in a ground-water sample (well I28) in the surficial aquifer at a concentration of $1.4 \mu \mathrm{g} / \mathrm{L}$. The MCL for 1,2-dichloroethane is $5.0 \mu \mathrm{g} / \mathrm{L}$, and the MCLG is zero. In soil, 1,1,2,2-tetrachloroethane was detected at site CISOIL25 at a concentration of $0.39 \mu \mathrm{g} / \mathrm{g}$, and at the nearby CS test area at site CISOIL19 at a concentration of $0.26 \mu \mathrm{g} / \mathrm{g}$.

Methylene chloride was detected in ground water at the Bengies Point Road dump site. This compound was detected at a concentration of $50 \mu \mathrm{g} / \mathrm{L}$ in well I51 in the surficial aquifer. Methylene chloride also was detected in two ground-water samples from the dredge spoil site, well I45 (50 $\mu \mathrm{g} / \mathrm{L})$ and well I46 $(9.3 \mu \mathrm{g} / \mathrm{L})$. Methylene chloride is regulated by USEPA drinkingwater standards. These detections exceeded the MCL of $5.0 \mu \mathrm{g} / \mathrm{L}$ and the MCLG of zero.

At the Lower Island disposal site, methylene chloride and 1,1,2,2-tetrachloroethane were detected in two different soil samples. Methylene chloride was detected at site CISOIL11, at a concentration of $0.016 \mu \mathrm{g} / \mathrm{g} ; 1,1,2,2$-tetrachloroethane was detected at CISOIL17 at a concentration of $0.24 \mu \mathrm{g} / \mathrm{g}$. The compound 1,1,2,2-tetrachloroethane also was detected in one soil sample at the EPG dump site (CISOIL04, $0.23 \mu \mathrm{g} / \mathrm{g})$.

\section{Probable Sources}

Several possible sources may have caused detections of volatile organic compounds in the samples from Carroll Island. Potential sources of organic chemicals in water samples that are related to historical military activity include the leaching of chemical residues from items disposed in SWMU's, the leakage of chemicals from containers that may have been disposed in SWMU's, and the leaching of chemicals, applied to the ground surface at test areas, into the ground water or surface water. In soil samples, potential sources related to military activities include the adsorption of chemicals that were applied to the ground surface in test areas or chemicals that were washed there by surface-water runoff. Another potential source of the chemicals that were detected in water and soil samples is from degradation of other chemicals by natural processes or chemical decontamination. Contamination during the sampling or analysis process is another possible source of the organic constituents in the samples.

The organic decontaminant (decontaminating agent, non-corrosive (DANC)) is a possible source for at least two of the volatile organic compounds detected at Carroll Island. Solutions of DANC contained a large amount of 1,1,2,2-tetrachloroethane (Nemeth, 1989, p. 177). This chemical was detected in four soil samples (table 8). In addition, 1,2-dichloroethane, which was detected in a ground-water sample at the wind tunnel (table 8 ), is believed to be a degradation product of 1,1,2,2-tetrachloroethane (Vroblesky and others, 1989, p. 89).

Nemeth (1989, p. 145) indicates that DANC was not used routinely after chemical tests, because it was expensive and very corrosive. It was, however, used in decontamination studies at many sites on Carroll Island, primarily in the commonly used test areas such as the test grids (Nemeth, 1989, p. 145). The detections of 1,1,2,2-tetrachloroethane in one soil sample at the wind tunnel (CISOIL25, $0.39 \mu \mathrm{g} / \mathrm{g}$ ) and 1,2-dichloroethane in one ground-water sample at the wind tunnel $(\mathrm{I} 28,1.4 \mu \mathrm{g} / \mathrm{L}$ ) were probably related to the decontamination studies.

Two other detections of 1,1,2,2-tetrachloroethane in soil samples may have been related to decontamination studies. The detections at site CISOIL19 in the CS test area $(0.26 \mu \mathrm{g} / \mathrm{g})$ and at CISOIL17 north of the Lower Island disposal site $(0.24 \mu \mathrm{g} / \mathrm{g})$ may have resulted from decontamination tests in these areas, which were reportedly used for limited testing (Nemeth, 1989, p. 474, 489).

At the EPG dump site, 1,1,2,2-tetrachloroethane was detected in one soil sample (CISOIL04, $0.23 \mu \mathrm{g} / \mathrm{g}$ ). It is unlikely that decontamination tests were performed in this area. It is conceivable, however, that DANC was either disposed at this site (other decontaminants such as bleach were disposed there) or 
that it was used to decontaminate items that were contaminated during test activities in other areas.

The source of methylene chloride, which was detected on Carroll Island in two ground-water samples from the dredge spoil site (wells 145 and I46), one ground-water sample from the Bengies Point Road dump site (well 151), and one soil sample from near the shore at the Lower Island disposal site (CISOIL11), may or may not be related to military activities. Vroblesky and others $(1989$, p. 89) indicate that methylene chloride can be a breakdown product of many other organic chemicals, such as those in organic-based decontaminating agents. Methylene chloride also is a common laboratory contaminant, so the detections may have resulted from contamination of samples during the analysis process. This possibility was not confirmed because the compound was not reported in any qualitycontrol samples.

Trichlorofluoromethane was detected in one ground-water sample in test grid 2. This compound is a chlorofluorocarbon (CFC), which is a type of stable synthetic organic compound commonly used as a refrigerant and once commonly used as a propellant in aerosol cans. Nemeth and others (1983) detected trichlorofluoromethane in several ground-water samples collected in 1977 at Carroll Island, but these detections were suspected to have been caused by laboratory or sampling contamination (Nemeth, 1989, p. 227-232). Military use of CFC's at Carroll Island during the historical testing period, however, is very likely. Chlorofluorocarbons were first manufactured in the 1930's (Busenberg and Plummer, 1992, p. 2,257), and their chemical properties would have made them ideal propellants for experimental chemical-agent dissemination. The stability of CFC's in the environment makes it likely that they could have been present at detectable concentrations in ground-water samples from Carroll Island in 1977 and 1989.

Benzene and toluene, which were detected in one surface-water sample in a shallow ditch in test grid 2 , are two aromatic volatile compounds that are commonly associated with fuels such as gasoline. The source of these compounds may have been related to historical use of test grid 2.

\section{Semivolatile Compounds}

Semivolatile organic compounds are those compounds that do not readily evaporate under atmospheric conditions. Several different semivolatile compounds were identified in six ground-water samples, six surface-water samples, and 23 soil samples on Carroll Island. The compounds 2-methyl naphthalene, acetone, naphthalene, 1,2-epoxycyclohexene, and diacetone alcohol were detected in ground-water samples collected in spring 1989. In surface-water samples (also collected in spring 1989), thiodiglycol and three organic acids were detected. Acetone, 4-methylphenol, butylbenzyl phthalate, methylethyl ketone, and seven organic acids were detected in soil samples that were collected in summer 1990.

\section{Distribution}

Semivolatile compounds were detected in ground-water samples at one SWMU (the Lower Island disposal site) and four test areas (test grids 1 and 2, the wind tunnel, and the VX test area). Concentrations that were detected ranged from $2.1 \mu \mathrm{g} / \mathrm{L}$ for 2-methyl naphthalene to $31 \mu \mathrm{g} / \mathrm{L}$ for acetone. All of the detections of semivolatile compounds in ground water were from samples collected in the surficial aquifer. The semivolatile compounds detected in ground-water samples were not regulated by USEPA drinking-water standards.

The semivolatile compounds that were detected in surface-water samples were all at inland sites. These compounds were detected at two SWMU's (the Lower Island disposal site and Bengies Point Road dump site), one test area (test grid 2), and the service area. Concentrations of organic acids (tetradecanoic, pentadecanoic, and hexadecanoic acid), which were not routinely analyzed and only reported where detected, were from 2 to $5 \mu \mathrm{g} / \mathrm{L}$. The concentration of thiodiglycol was $138 \mu \mathrm{g} / \mathrm{L}$. None of these compounds were subject to FWA or FWC water-quality criteria.

More semivolatile compounds were detected in soil samples than in ground-water and surface-water samples combined. Semivolatile compounds were detected at the four major test areas (test grids 1 and 2, the aerial spray grid, and the wind tunnel), along with the HD test area, the VX test area, and the area east of the HD test area. These compounds also were detected in most of the SWMU's, including the Lower Island disposal site, the Bengies Point Road dump site, the EPG dump site, the BZ test burn pit, the decontamination pits, and the dredge spoil site. In addition, semivolatile compounds were found in the soil sample from the magazine area. Concentrations of semivolatile compounds detected in soil samples ranged from $0.013 \mu \mathrm{g} / \mathrm{g}$ for acetone to $13 \mu \mathrm{g} / \mathrm{g}$ for hexadecanoic acid. 
The semivolatile compounds 2-methyl naphthalene $(2.1 \mu \mathrm{g} / \mathrm{L})$ and naphthalene $(15 \mu \mathrm{g} / \mathrm{L})$ were detected in one well (I08) at test grid 1. No semivolatile compounds were detected in the surface-water samples from this site, although $0.70 \mu \mathrm{g} / \mathrm{g}$ of butylbenzyl phthalate was detected at site CISOIL09, located southwest of test grid 1 along a potential ephemeral surface-water drainage from the test grid.

At test grid 2, the compound 1,2-epoxycyclohexene was detected at a concentration of $4.0 \mu \mathrm{g} / \mathrm{L}$ in the ground-water sample at well $\mathrm{I} 22 \mathrm{C}$, the shallowest well of a three-well cluster in the center of the test grid.

Hexadecanoic acid was detected at surface-water site $\mathrm{SW} 16(2.0 \mu \mathrm{g} / \mathrm{L})$, in the southeastern part of test grid 2 . Acetone was detected at a concentration of $0.19 \mu \mathrm{g} / \mathrm{g}$ at site CISOIL15 near the center of test grid 2 (the concentration of acetone in the replicate sample, CISOIL115, was $0.18 \mu \mathrm{g} / \mathrm{g}$ ).

No semivolatile compounds were detected in ground-water or surface-water samples within the aerial spray grid, although benzoic acid, butylbenzyl phthalate, and hexadecanoic acid were detected in the two soil samples from the aerial spray grid. The concentrations of benzoic acid were $0.31 \mu \mathrm{g} / \mathrm{g}$ in CISOIL07, and $0.21 \mu \mathrm{g} / \mathrm{g}$ in CISOIL 27 ; the concentrations of butylbenzyl phthalate were $0.10 \mu \mathrm{g} / \mathrm{g}$ in CISOIL07, and $0.10 \mu \mathrm{g} / \mathrm{g}$ in CISOIL 27; and the concentrations of hexadecanoic acid were $0.61 \mu \mathrm{g} / \mathrm{g}$ in CISOIL07, and $0.48 \mu \mathrm{g} / \mathrm{g}$ in CISOIL27.

As in the aerial spray grid, no semivolatile compounds were detected in ground-water or surface-water samples within the HD test area or east of the area where some testing took place. Butylbenzyl phthalate, however, was detected within the HD test area at site CISOIL 23 at a concentration of $0.51 \mu \mathrm{g} / \mathrm{g}$. In the area east of the HD test area, acetone was detected at a concentration of $0.025 \mu \mathrm{g} / \mathrm{g}$ at site CISOIL 22 .

Diacetone alcohol was detected in one groundwater sample (I44) in the VX test area at a concentration of $4.0 \mu \mathrm{g} / \mathrm{L}$. In the soil sample within this area (CISOIL16), acetone was detected at a concentration of $0.027 \mu \mathrm{g} / \mathrm{g}$, benzoic acid was detected at a concentration of $0.13 \mu \mathrm{g} / \mathrm{g}$, and butylbenzyl phthalate was detected at a concentration of $0.20 \mu \mathrm{g} / \mathrm{g}$. No semivolatile compounds were detected in the ground-water or soil sample collected from the CS test area, and no surface-water samples were collected from this area.

Semivolatile compounds were detected in ground-water, surface-water, and soil samples at the Lower Island disposal site. Acetone was detected in well I13 $(31 \mu \mathrm{g} / \mathrm{L})$, and diacetone alcohol was detected in well I20 $(4.0 \mu \mathrm{g} / \mathrm{L})$. In surface water, tetradecanoic acid $(5.0 \mu \mathrm{g} / \mathrm{L})$, pentadecanoic acid $(3.0 \mu \mathrm{g} / \mathrm{L})$, and hexadecanoic acid $(4.0 \mu \mathrm{g} / \mathrm{L})$ were detected in one sample (SW14) within an open disposal pit. Hexadecanoic acid $(2.0 \mu \mathrm{g} / \mathrm{L})$ and thiodiglycol $(138 \mu \mathrm{g} / \mathrm{L})$ were detected at another surface-water sample taken at a marsh seep near the shoreline. In soil samples, acetone was detected at five sites (CISOIL11, $0.0220 \mu \mathrm{g} / \mathrm{g}$; CISOIL12, $0.016 \mu \mathrm{g} / \mathrm{g}$; CISOIL13, $0.014 \mu \mathrm{g} / \mathrm{g}$; CISOIL14, $0.013 \mu \mathrm{g} / \mathrm{g}$; and CISOIL17, $0.017 \mu \mathrm{g} / \mathrm{g}$ ). Benzoic acid was detected at CISOIL11 $(0.062 \mu \mathrm{g} / \mathrm{g})$, CISOIL13 $(2.0 \mu \mathrm{g} / \mathrm{g})$, and CISOIL14 $(1.5 \mu \mathrm{g} / \mathrm{g})$. Butylbenzyl phthalate was detected at CISOIL11 $(0.049 \mu \mathrm{g} / \mathrm{g})$, CISOIL13 $(0.20 \mu \mathrm{g} / \mathrm{g})$, and CISOIL14 $(0.19 \mu \mathrm{g} / \mathrm{g})$. Tetradecanoic acid $(1.2 \mu \mathrm{g} / \mathrm{g})$, pentadecanoic acid $(0.39 \mu \mathrm{g} / \mathrm{g})$, heptadecanoic acid $(0.64 \mu \mathrm{g} / \mathrm{g})$, and octadecanoic acid $(12 \mu \mathrm{g} / \mathrm{g})$ were detected at CISOIL14. Hexadecanoic acid was detected at CISOIL13 $(0.26 \mu \mathrm{g} / \mathrm{g})$ and CISOIL14 $(13 \mu \mathrm{g} / \mathrm{g})$.

At Bengies Point Road dump site, semivolatile compounds were detected in surface-water and soil samples. Hexadecanoic acid was detected in surfacewater samples SW20 $(2.0 \mu \mathrm{g} / \mathrm{L})$ and SW21 $(3.0 \mu \mathrm{g} / \mathrm{L})$. In soil samples, 4-methylphenol was detected at site CISOIL20 $(0.98 \mu \mathrm{g} / \mathrm{g})$; Acetone was detected at sites CISOIL01 $(0.014 \mu \mathrm{g} / \mathrm{g}$; less than 0.010 at the duplicate sample CISOIL101) and CISOIL20 $(0.26 \mu \mathrm{g} / \mathrm{g})$. Benzoic acid was detected at sites CISOIL01 $(4.6 \mu \mathrm{g} / \mathrm{g}$; $2.9 \mu \mathrm{g} / \mathrm{g}$ at CISOIL101), CISOIL20 $(6.9 \mu \mathrm{g} / \mathrm{g})$, and CISOIL21 $(5.0 \mu \mathrm{g} / \mathrm{g})$. Butylbenzyl phthalate was detected at sites CISOIL01 $(0.13 \mu \mathrm{g} / \mathrm{g} ; 0.095 \mu \mathrm{g} / \mathrm{g}$ at CISOIL101), CISOIL20 $(0.26 \mu \mathrm{g} / \mathrm{g})$, and CISOIL21 $(0.27 \mu \mathrm{g} / \mathrm{g})$; methylethyl ketone was detected at CISOIL20 $(0.13 \mu \mathrm{g} / \mathrm{g})$; and hexadecanoic acid was detected at sites CISOIL01 $(0.26 \mu \mathrm{g} / \mathrm{g} ; 0.41 \mu \mathrm{g} / \mathrm{g}$ at duplicate sample CISOIL101) and CISOIL21 $(0.40 \mu \mathrm{g} / \mathrm{g})$.

At the EPG dump site, semivolatile compounds were detected only in soil samples. Benzoic acid was detected at CISOIL04 $(1.1 \mu \mathrm{g} / \mathrm{g})$ and CISOIL05 $(0.14 \mu \mathrm{g} / \mathrm{g})$. Butylbenzyl phthalate was detected at CISOIL05 $(0.21 \mu \mathrm{g} / \mathrm{g})$.

Acetone was detected in soil at the BZ test burn pit (CISOIL08, $0.018 \mu \mathrm{g} / \mathrm{g}$ ). At site CISOIL06 in the decontamination pits area, benzoic acid $(0.12 \mu \mathrm{g} / \mathrm{g}$ in the sample and replicate), butylbenzyl phthalate $(0.08 \mu \mathrm{g} / \mathrm{g}$; less than 0.33 in the replicate), and hexadecanoic acid $(0.49 \mu \mathrm{g} / \mathrm{g}$; the replicate was missing) were 
detected. These same three compounds (benzoic acid, $0.063 \mu \mathrm{g} / \mathrm{g}$; butylbenzyl phthalate, $0.15 \mu \mathrm{g} / \mathrm{g}$; and hexadecanoic acid, $0.32 \mu \mathrm{g} / \mathrm{g}$ ), were detected at site CISOIL28 in the dredge spoil site.

In the service area, hexadecanoic acid was detected in one surface-water sample (SW17) at a concentration of $3.0 \mu \mathrm{g} / \mathrm{L}$. No other semivolatile compounds were detected in ground-water, surface-water, or soil samples at this site. At the magazine area, acetone $(0.019 \mu \mathrm{g} / \mathrm{g})$, benzoic acid $(0.12 \mu \mathrm{g} / \mathrm{g})$, and butylbenzyl phthalate $(0.060 \mu \mathrm{g} / \mathrm{g})$ were detected in soil sample CISOIL29.

\section{Probable Sources}

Some of the semivolatile organic chemicals detected in ground-water, surface-water, and soil samples at Carroll Island are thought to be degradation products that have resulted from the historical testing and decontamination of chemical warfare agents. Other semivolatile compounds are believed to occur naturally, and others probably came from atmospheric fallout that resulted from ambient anthropogenic influences in the Baltimore metropolitan area. For some chemicals, a source could not be identified. Because the most important chemicals in this study are those that may have been caused by historical testing and disposal activities, these chemicals are discussed first.

Thiodiglycol is a semivolatile chemical detected at surface-water sample SW 12 (table 8) in a marsh seep at the shoreline south of the Lower Island disposal site. Thiodiglycol is a hydrolysis product of the chemical agent mustard (Nemeth, 1989, p. 183). It is believed that the principal source of thiodiglycol in the Edgewood Area of APG is the hydrolysis of mustard (Nemeth, 1989, p. 189). It is unlikely that another source of thiodiglycol would exist on Carroll Island.

There is some question about the validity of the detection of thiodiglycol $(138 \mu \mathrm{g} / \mathrm{L})$ at site SW12, because the reporting limit for thiodiglycol in all of the other surface-water samples was $187 \mu \mathrm{g} / \mathrm{L}$ (table 16, at the end of the report). In ground-water samples, the reporting limit varied between $65.5 \mu \mathrm{g} / \mathrm{L}$ and $187 \mu \mathrm{g} / \mathrm{L}$. The ground-water and surface-water samples were analyzed by the same USATHAMA contract lab (under the same contract), and all analyses were done within a several-week period.

If the detection of thiodiglycol at Carroll Island is accurate, it is indicative of some source of mustard within the marsh area at the Lower Island disposal site.
Mustard is not readily soluble in water, but when it does dissolve, it is rapidly hydrolyzed (Nemeth, 1989, p. 184). This means that the thiodiglycol, which is miscible in water and therefore readily transported by water flow, would probably have resulted from the fairly recent dissolution and subsequent hydrolysis of undissolved mustard. The amount of undissolved mustard required for a thiodiglycol detection of $138 \mu \mathrm{g} / \mathrm{L}$ is unknown, and the exact location of the source of the mustard also is unknown.

The other detections of semivolatile organic compounds thought to be related to historical testing and disposal involve chemicals not as readily traceable to warfare agents as thiodiglycol. Acetone and diacetone alcohol are two such compounds. Acetone was detected in one ground-water sample (well I13) at the Lower Island disposal site (table 8), and in 13 soil samples (table 8) at the Bengies Point Road dump site (CISOIL01, CISOIL20), EPG dump site (CISOIL05), $\mathrm{BZ}$ test burn pit (CISOIL08), Lower Island disposal site (CISOIL11, CISOIL12, CISOIL13, CISOIL14, and CISOIL17), test grid 2 (CISOIL15), the VX test area (CISOIL16), the area east of the HD test area (CISOIL22), and the magazine area (CISOIL29). Diacetone alcohol was detected in three ground-water samples (table 8) at the wind tunnel (well I28), the Lower Island disposal site (well I20), and the VX test area (well I44).

Acetone is a common solvent, and it is likely that there would be many uses for solvents in the chemicalagent test activities at Carroll Island. The detection in ground water (well I13, fig. 3) is down gradient from one or more of the burial pits in the Lower Island disposal site, so leachate from one of the disposal pits is a probable source. The widespread occurrence of acetone in soil samples may have resulted from contamination during sampling or analysis. Acetone was detected in a trip blank that was shipped along with samples CISOIL08, $11,15,115,16,17,22$, and 29, and it also was detected in each of those samples. The presence of acetone in other samples, however, indicates that some of the detections in environmental samples may be accurate.

Diacetone alcohol is a solvent, and it is found in some antifreeze solutions and hydraulic fluids (Windholz and others, 1983, p. 429). Diacetone alcohol is formed by a reaction of barium hydroxide, calcium hydroxide, or potassium hydroxide with acetone (Windholz and others, 1983, p. 428). Because calcium hydroxide was commonly used on Carroll Island as a 
decontaminant for chemical agents, a reaction between acetone and calcium hydroxide is a plausible source of diacetone alcohol in ground water. Acetone was detected in soil samples at or near each of the wells in which diacetone alcohol was detected in ground water.

Methylethyl ketone is another solvent detected on Carroll Island. This compound was detected at one soil site (CISOIL20) at the Bengies Point Road dump site. The source of this compound within the soil sample may have been contamination from disposal at the dump site, or it may have been sampling or laboratory contamination.

The compound 4-methylphenol (also known as 4-cresol or p-cresol) was detected at the Bengies Point Road dump site in the same soil sample (CISOIL20) as the methylethyl ketone. The source of the 4-methylphenol in this sample is unknown. Phenolic compounds can occur naturally; however, the sediment residues of phenols rarely exceed the micrograms-perkilogram range (Smith and others, 1988, p. 50). The 4-methylphenol detected at CISOIL20 was $0.98 \mu \mathrm{g} / \mathrm{g}$ (table 8 ), which is nearly one milligram per kilogram. The compound is apparently obtained from coal tar (Windholz and others, 1983, p. 369); however, possible sources of this compound on Carroll Island are unclear.

The compound 1,2-epoxycyclohexene was detected in ground-water samples at the Lower Island disposal site (well I16B), test grid 2 (well I22C), the $\mathrm{HD}$ test area (wells I26A,B), and Bengies Point Road dump site (wells I51 and I54A). The concentrations ranged from 3.0 to $5.0 \mu \mathrm{g} / \mathrm{L}$ (table 8 ). Cyclohexene is a derivative of coal tar (Windholz and others, 1983, p. 391), and 1,2-epoxycyclohexene may be a cyclohexene degradation product. The source of 1,2-epoxycyclohexene in the ground water is unknown. Tenbus and Blomquist (1995, p. 74) report detections of 1,2-epoxycyclohexene in five wells in concentrations of 1.0 to $2.0 \mu \mathrm{g} / \mathrm{L}$ on Graces Quarters, but the source of this compound was not determined.

Some of the semivolatile constituents that are thought to occur naturally include the organic acids detected in several of the surface-water and soil samples. These include aromatic acids such as benzoic acid, and nonvolatile fatty acids such as tetradecanoic acid (also known as myristic acid), pentadecanoic acid, hexadecanoic acid (palmitic acid), heptadecanoic acid, and octadecanoic acid (stearic acid). Benzoic acid was detected in 16 soil samples in various areas of Carroll Island (table 8). Hexadecanoic acid was detected in 11 soil samples and 6 surface-water samples. The other organic acids were detected in the soil and water at the Lower Island disposal site.

Although benzoic acid was only detected in soil samples, it is a naturally-occurring substance in water (Thurman, 1985, p. 141). Aromatic acids such as benzoic acid enter the aquatic environment through the degradation of plant matter, such as lignin and other plant tissues (Thurman, 1985, p. 141). Of the nonvolatile fatty acids, Thurman (1985, p. 114) indicates that palmitic acid and stearic acid are the most abundant. The nonvolatile fatty acids originate from the degradation of lipids and triglycerols, which are derived from algal and terrestrial plants. When algal cells decompose, fats enter the water, and their subsequent oxidation yields fatty acids such as myristic, palmitic, and stearic acids (Thurman, 1985, p. 124).

Naphthalene and 2-methyl naphthalene, detected in the ground-water sample from well 108 , are possibly natural or ambient in origin. In this sample, naphthalene was detected at $15 \mu \mathrm{g} / \mathrm{L}$ and 2-methyl naphthalene was detected at $2.1 \mu \mathrm{g} / \mathrm{L}$ (table 8 ). Naphthalene compounds are part of a large group of environmentally important compounds known as polycyclic aromatic hydrocarbons (PAH's) (Smith and others, 1988, p. 64).

Smith and others (1988, p. 64) indicate that PAH's are derived from natural or anthropogenic sources, but their occurrence in aquatic systems usually is anthropogenic in origin. The compounds are formed in high temperature (greater than $700^{\circ} \mathrm{C}$ ) pyrolytic reactions such as municipal incineration or forest fires; they also are present in fossil fuels, and are used in some chemical manufacturing processes (Smith and others, 1988, p. 64).

On the afternoon and evening of April 24, 1989, a brush and forest fire started at the western entrance of Carroll Island and burned almost all of the vegetation on the island. Observation wells on the island were not damaged, but because the fire occurred on the second day of the ground-water sampling run, it may have had some effect on the results of the ground-water and surface-water sampling. Samples from wells I16A, I22A, and $\mathrm{I} 37 \mathrm{~A}$ in the confined aquifer and I27B, I28, I29, $\mathrm{I} 30$, and I37B in the surficial aquifer were collected before the fire. All other ground-water and surfacewater samples were collected within a one-month period after the fire.

The naphthalene compounds in well I08 could have resulted from the brush fire on Carroll Island, which occurred 9 days before the sample was collected. The fire, however, may not have reached temperatures 
sufficient to cause the pyrolytic reactions that create PAH's. It also is likely that PAH's would have been detected elsewhere on the island if the fire were the cause, because the fire burned almost all of Carroll Island. Another possible pyrolytic source of the naphthalenes could be the coal- and oil-burning power plant adjacent to Carroll Island. If atmospheric fallout from the power plant were the cause, however, it would be likely that the naphthalene compounds would be detected in more than one sample. The exact source of naphthalene and 2-methyl naphthalene in the sample from well $\mathrm{I} 08$ is therefore unknown.

Although plasticizers such as phthalate esters are not found in natural waters and soils, these compounds can enter water and soil from many sources (Thurman, 1985, p. 270). Butylbenzyl phthalate is a common plasticizer (Thurman, 1985, p. 271) that was detected in 18 soil samples at Carroll Island at locations all over the island. The maximum concentration was less than $1 \mu \mathrm{g} / \mathrm{g}$. The most likely source of this compound was airborne deposition onto the soil from industrial sources in the Baltimore metropolitan area.

\section{Unknown and Tentatively Identified Compounds}

Although the list of organic compounds that were analyzed in ground-water, surface-water, and soil samples from Carroll Island was extensive, some compounds detected were not on the list of compounds to be analyzed. Some of these compounds were quickly identified by the laboratory and were included in tables $13,14,16$, and 18 . Others that could not be readily identified were listed as unknowns.

Unknown compounds detected by laboratories under USATHAMA contract are given unique identifiers that are related to the retention times in the analytical instruments. These identifiers begin with the prefix UNK (for unknown) and are followed by a three-digit number (UNK561, for example). Volatile compounds generally are given numbers less than 500 , and semivolatile compounds are given numbers greater than 500 (D. Scarborough, U.S. Army Toxic and Hazardous Materials Agency, oral commun., 1992). The concentrations of unknown compounds can only be approximated, because the analytical instruments cannot be calibrated to the compounds. A summary of the locations and concentration ranges of unknown compounds detected in ground-water and surface-water samples at Carroll Island is given in table 9.
Unknown compounds can be tentatively identified through a computer program known as a library search. The library-search program compares the chromatogram from the mass spectrometer for the unknown compound with chromatograms of known compounds that are stored in a database. The computer will usually provide the three best-matched compounds from its library database. The investigator then uses these data to tentatively identify the unknown compounds.

It should be noted that tentatively identified compounds may not be correctly identified. In many cases, however, a tentative identification is preferable to no identification, because it can be used as a guide during further sampling efforts. Potential sources and other information about the compounds below are provided under the assumption that the tentative identifications are correct. The unknown compounds detected in ground-water and surface-water samples from spring 1989 and their tentative identifications are provided in tables 21 and 22 (at the end of the report).

One of the most commonly detected unknown compounds in ground-water samples was UNK561, tentatively identified as iodocyclohexanol (table 21, at the end of the report). This compound was detected in samples from 27 wells areally distributed on Carroll Island, including one well completed in the confined aquifer (I37A, $2 \mu \mathrm{g} / \mathrm{L})$. The range of concentrations was $2 \mu \mathrm{g} / \mathrm{L}$ (well I37A) to $67 \mu \mathrm{g} / \mathrm{L}$ (well I28). The compound was not detected in any trip blanks or equipment blanks.

Iodocyclohexanol does not appear in standard literature references such as the Merck Index (Windholz and others, 1983). It probably results from the substitution of iodine into the cyclohexanol molecule. Unknown compounds that were detected in groundwater samples at Carroll Island that are similar to iodocyclohexanol include UNK565 (tentatively identified as chloroiodocyclohexanol) and UNK552 (tentatively identified as cis-2-bromocyclohexanol). One other unknown compound, UNK511, was tentatively identified as chloroiodomethane (table 21, at the end of the report).

The sources of iodocyclohexanol and the related compounds are not known, but its widespread occurrence suggests that it might be a natural compound. Cyclohexanol is reportedly obtained by the oxidation of cyclohexane or hydrogenation of phenol (Windholz and others, 1983, p. 391). Iodine was not one of the inorganic constituents that was analyzed in Carroll Island samples. Hem (1989, p. 146) indicates that the 
Table 9. Locations and concentrations of selected unknown compounds detected in ground-water and surface-water samples, Carroll Island, Aberdeen Proving Ground, Md., spring 1989

[Concentrations in micrograms per liter; all concentrations are approximate; UNK number is a laboratory designation for unknown compounds; replicate samples not included; see tables 21 and 22 for tentative identifications of unknown compounds]

\begin{tabular}{|c|c|c|c|}
\hline $\begin{array}{l}\text { Unknown } \\
\text { compound }\end{array}$ & $\begin{array}{l}\text { Number of } \\
\text { detections }\end{array}$ & $\begin{array}{l}\text { Concentration } \\
\text { range }\end{array}$ & $\begin{array}{l}\text { Location and site number where detected } \\
\text { (figs. 2, 3, and 4) }\end{array}$ \\
\hline \multicolumn{4}{|c|}{ Ground-water samples } \\
\hline UNK511 & 3 & $3-10$ & Wind tunnel (I28); CS test area (I30), EPG dump site (I41) \\
\hline UNK533 & 17 & $3-7$ & $\begin{array}{l}\text { Aerial spray grid (I03); Lower Island disposal site (I14, } \\
\text { I16B, I17); VX test area (I21); Test grid } 2 \text { (I22C, I23, I25) } \\
\text { Wind tunnel (I27B, I29); Decontamination pits (I35); EPG } \\
\text { dump site (I41, I43); Service area (I49); Bengies Point Rd. } \\
\text { dump site (I50, I53, I54A) }\end{array}$ \\
\hline UNK534 & 5 & $4-8$ & $\begin{array}{l}\text { Lower Island disposal site (I16B, I17); Test grid } 2 \text { (I23); } \\
\text { Bengies Point Rd. dump site (I53, I54A) }\end{array}$ \\
\hline UNK547 & 2 & $7-10$ & Lower Island disposal site (I15); Test grid 2 (I22C) \\
\hline UNK548 & 1 & 5 & Test grid 2 (I22C) \\
\hline UNK552 & 5 & $3-7$ & $\begin{array}{l}\text { Lower Island disposal site (I12, I16B) Service area (147A); } \\
\text { Bengies Point Rd. dump site (150, I53) }\end{array}$ \\
\hline UNK555 & 1 & 2 & Bengies Point Rd. dump site (I54B) \\
\hline UNK557 & 1 & 9 & Lower Island disposal site (I16A) \\
\hline UNK561 & 27 & $2-67$ & $\begin{array}{l}\text { Aerial spray grid (I03, I32); Test grid } 1 \text { (I08, I09, I10, I37A, } \\
\text { I37B); Lower Island disposal site (I12, I15, I16B, I17, I19); } \\
\text { Test grid } 2 \text { (I22C, I23, I25); HD test area (I26A); Wind } \\
\text { tunnel (I28); BZ test burn pit (I38A, I39); EPG dump site } \\
\text { (I41, I42); VX test area (I44); Service area (I47A, I49); } \\
\text { Bengies Point Rd. dump site (I50, I53, I54A) }\end{array}$ \\
\hline UNK565 & 6 & $2-8$ & $\begin{array}{l}\text { Aerial spray grid (I03); Wind tunnel (I28); EPG dump site } \\
(\mathrm{I} 41, \mathrm{I} 42,143) \text {; Service area (I47A) }\end{array}$ \\
\hline UNK581 & 1 & 5 & Service area $(\mathrm{I} 47 \mathrm{~A})$ \\
\hline UNK587 & 1 & 7 & Service area $(147 \mathrm{~A})$ \\
\hline UNK588 & 2 & $2-20$ & $\begin{array}{l}\text { Lower Island disposal site (120); Test grid } 2 \text { (123); VX test } \\
\text { area (I44) }\end{array}$ \\
\hline UNK589 & 1 & 3 & Dredge spoil site (I45) \\
\hline UNK599 & 5 & $2-70$ & $\begin{array}{l}\text { Test grid } 2 \text { (I22B); Wind tunnel (I27A); CS test area (I30); } \\
\text { Test grid } 1 \text { (I37A); VX test area (I44) }\end{array}$ \\
\hline UNK602 & 1 & 3 & Service area $(\mathrm{I} 47 \mathrm{~A})$ \\
\hline UNK616 & 12 & $2-4$ & $\begin{array}{l}\text { Test grid } 1 \text { (I07, I09, I37A); Lower Island disposal site }(114, \\
\text { I15, I16A, I19); Test grid } 2 \text { (I22A); Wind tunnel (I27A); } \\
\text { Service area (I47B); Bengies Point Rd. dump site (I52, } \\
\text { I54B) }\end{array}$ \\
\hline UNK637 & 2 & $3-4$ & Test grid 1 (107); Service area (I47B) \\
\hline UNK642 & 1 & 3 & Wind tunnel (I27A) \\
\hline UNK648 & 2 & $4-5$ & Lower Island disposal site (115); Decontamination pits (136) \\
\hline UNK650 & 1 & 6 & Wind tunnel (I27A) \\
\hline \multicolumn{4}{|c|}{ Surface-water samples } \\
\hline UNK512 & 1 & 5 & Test grid 1 (SW09) \\
\hline UNK588 & 1 & 2 & Bengies Point Rd. dump site (SW21) \\
\hline UNK593 & 1 & 3 & Lower Island disposal site (SW14) \\
\hline
\end{tabular}


Table 9. Locations and concentrations of selected unknown compounds detected in ground-water and surface-water samples, Carroll Island, Aberdeen Proving Ground, Md., spring 1989--Continued

\begin{tabular}{lccl}
\hline $\begin{array}{c}\text { Unknown } \\
\text { compound }\end{array}$ & $\begin{array}{c}\text { Number of } \\
\text { detections }\end{array}$ & $\begin{array}{c}\text { Concentration } \\
\text { range }\end{array}$ & \multicolumn{1}{c}{$\begin{array}{c}\text { Location and site number where detected } \\
\text { (figs. 2, 3, and 4) }\end{array}$} \\
\hline UNK603 & 2 & Surface-water samples--continued \\
UNK614 & 2 & $2-3$ & Lower Island disposal site (SW11, SW14) \\
UNK615 & 1 & $2-4$ & Lower Island disposal site (SW11, SW14) \\
UNK616 & 1 & 5 & Lower Island disposal site (SW14) \\
UNK617 & 1 & 2 & Test grid 2 (SW16) \\
UNK646 & 1 & 30 & Lower Island disposal site (SW14) \\
UNK666 & 1 & 6 & Lower Island disposal site (SW12) \\
UNK674 & 1 & 20 & Lower Island disposal site (SW11) \\
UNK679 & 1 & 9 & Lower Island disposal site (SW14) \\
\hline
\end{tabular}

element is widely distributed and common in seawater. It is possible that iodocyclohexanol originated from naturally-occurring inorganic and organic compounds present in the ground water at Carroll Island.

The unknown compound UNK599, tentatively identified as tris(2-chloroethyl)ester phosphoric acid, was detected in ground-water samples at well I22B (in test grid 2), I27A (wind tunnel), I30 (in the CS test area), and $\mathrm{I} 44$ (in the VX test area) in concentrations ranging from $2 \mu \mathrm{g} / \mathrm{L}$ (well I27A) to $70 \mu \mathrm{g} / \mathrm{L}$ (well I22B). No information on this particular compound could be found, but it seems similar to the military compound tris(2-chloroethyl)amine, described in Nemeth (1989, p. 100) as a nitrogen mustard. The three areas in which this compound was detected in ground-water samples are known to have been test areas, so the compound may have been related to chemical testing.

A few other unknown compounds were tentatively identified in ground-water samples (table 21, at the end of the report). The unknown UNK648 was tentatively identified as 10-demethylsqualene, and was detected in well $\mathrm{I} 36$ at a concentration of $4 \mu \mathrm{g} / \mathrm{L}$. This compound could be a degradation product of squalene, which is a branched alkene that is common in phytoplankton, bacteria, and zooplankton (Thurman, 1985, p. 216), and is probably naturally occurring. UNK589, tentatively identified as 2-methyl,1-(1,1-dimethylethyl)2-methyl-1,3-propanediylester propanoic acid was detected in well I45 at a concentration of $3 \mu \mathrm{g} / \mathrm{L}$. No information could be found in the literature on this compound. In well I47A, UNK581 was detected at a concentration of $5 \mu \mathrm{g} / \mathrm{L}$. This compound was tentatively identified as dodecanol. The source of this alcohol is not known.

One compound, UNK591, was detected in several equipment blanks during ground-water sampling (table 21, at the end of the report). This compound was tentatively identified as diphenylmethanone. It was not detected in any of the ground-water or surface-water samples.

Only three of the unknown compounds detected in surface water were tentatively identified (table 22, at the end of the report). These compounds were UNK646, which was tentatively identified as 4,4'-thiobis[(2-(1,1dimethylethyl)]-5-methylphenol; UNK593, which was tentatively identified as tridecanoic acid; and UNK674, which was tentatively identified as stigmasta-5,22dien-3 $\beta$-ol.

The unknown compound UNK646 was detected in two samples (SW12 at the Lower Island disposal site, $27 \mu \mathrm{g} / \mathrm{L}$; and one of the replicates at SW18, which is in the BZ test burn pit, $12 \mu \mathrm{g} / \mathrm{L}$ ). The compound also was detected in an equipment blank $(5 \mu \mathrm{g} / \mathrm{L})$ collected on the same day as the sample at SW18. The sample at SW12 had been collected one day before. Because of the detection in the equipment blank and the non-detection in one replicate at SW18, the detection in the sample at SW18 is suspected to be false, but the detection at SW12 is probably accurate.

The compound 4,4'-thiobis[(2-(1,1-dimethylethyl)]-5-methylphenol, which is the tentative identification of UNK646, is a substituted cresol compound. Cresol compounds can occur naturally, but they are usually found at concentrations less than $1 \mu \mathrm{g} / \mathrm{L}$ in water 
(Thurman, 1985, p. 143). It is possible that this compound is naturally occurring, because sample SW 12 was collected in a marsh seep, and marsh waters can contain unusual compounds. It also is possible, however, that the compound is somehow related to chemicals disposed by the military, because this site is the one in which thiodiglycol, a mustard degradation product, was detected. Another possible source of the chemical could have been some of the debris that commonly washes up into the marsh from the Chesapeake Bay during storms.

The unknown compound UNK593 was detected in SW14 at the Lower Island disposal site at a concentration of $3 \mu \mathrm{g} / \mathrm{L}$. This compound was identified as tridecanoic acid. It is very likely that this compound is another of the naturally occurring organic acids detected at this site (see table 8).

The unknown UNK674 (tentatively identified as stigmasta-5,22-dien-3 $\beta$-ol) also was detected at site SW14 in the Lower Island disposal site. The compound also is known as stigmasterol (Windholz and others, 1983, p. 1260). This compound was detected at a concentration of $20 \mu \mathrm{g} / \mathrm{L}$. It is thought to occur naturally.

Information about the unknown compounds detected in soil samples in summer 1990 and the tentative identifications of these compounds is provided in table 23 (at the end of the report). The soil samples were analyzed by a different USATHAMA contract laboratory than the one that analyzed the water samples. The tentative identifications provided for the soil samples were different from those provided for water samples. The data from which table 23 was derived consisted of photocopied printouts from the computer library search that was undertaken by the contract lab. The sheets consisted of the sample number, the chromatogram of the unknown compound with its identifier, and three chromatograms of the best-matched compounds chosen by the computer during the library search. The tentative identifications on table 23 are the first compounds chosen by the computer during the search. Along with the tentative identifications, an " $R$ " value is provided on table 23 . This number is a value given by the computer as a way to evaluate the closeness of the match to the chromatogram of the unknown compound. The exact statistical meaning of this value is not clear, but it appears that numbers closer to 1 are a better fit than numbers closer to 0 . The "R" value may be useful as a qualitative method to evaluate the goodness-of-fit of the tentatively identified compounds.
Discussion of the tentatively identified compounds in the soil samples is somewhat more difficult than for the compounds in the water samples. Many more unknown compounds were detected in the soil samples than in ground-water and surface-water samples. This is probably a result of soils naturally containing more organic material (especially in the surface layers) than natural waters. It also may be a result of anthropogenic organic compounds tending to sorb onto soils rather than go into solution in water. Another reason that discussion is difficult is that the best-matched compound chosen by the computer for a given unknown compound was not always consistent from sample to sample, even between replicate samples. This means that the tentative identifications for the compounds in soil may not be as accurate as the tentative identifications of the compounds in water. In addition, some of the names of the tentatively identified compounds were too long to fit on the computer printout from the library search. This occurred in certain cases for UNK334, UNK541, UNK548, UNK576, UNK577, UNK581, UNK590, UNK591, UNK605, UNK625, UNK630, UNK636, and UNK740 (table 23, at the end of the report).

Because of the large number of unknown compounds in soil samples and the inconsistency in the tentative identifications, the unknown compounds will be discussed below in order of the UNK numbers. In this way, some of the unknowns that have more than one tentative identification can be shown, and related compounds can be compared. The unknown compounds, the soil samples and concentrations in which they were detected, and their tentative identifications can be found in table 23, at the end of the report. A summary of the concentration ranges and the locations of unknown compounds detected in soil samples is given in table 10.

A few unknown compounds were detected in the soil sample trip blanks, but the concentrations are not available. Tentative identifications of these unknown compounds were provided with the photocopies of the library-search printouts. Trip blanks collected on four different dates contained unknown compounds. These trip blanks coincided with the various samples collected on the same dates.

Four trip blanks were sent to the laboratory on May 23, 1990. The samples sent that day include CISOIL04, 05, 06, 106, 07, 18, 19, 24, 25, 27, and 28. The unknown and tentatively identified compounds detected in the trip blanks from May 23 include 
UNK019 and UNK020 (both tentatively identified as methylhydrazine oxalate (1:1)), UNK250 (tentatively identified as octanal and 2-chloroheptane), and UNK276 (decanal). Unknown compounds UNK019 or UNK020 were detected in eight of the 11 samples sent on May 23 (CISOIL06, 106, 07, 18, 19, 24, 25, and 27). Unknown compound UNK250 was detected in samples CISOIL04, 05, 06, 07, 18, 19, 24, 27, and 28. all of which were collected on May 23. Unknown compound UNK276 was detected in samples CISOIL04, $05,06,07,18$, and 24 , all of which also were collected on May 23.

Four trip blanks were sent on June 19, 1990. The samples that were sent on June 19 were CISOIL08, 11, $15,115,16,17,22$, and 29. Unknown compounds detected in this trip blank include UNK257 (nonanal) and UNK284 (decanal). Unknown compound UNK257 was detected in samples CISOIL08, 11, 15, $115,16,17$, and 29. Unknown compound UNK284 was detected in samples CISOIL08, 11, 115, 16, 17, and 22. Neither of the unknowns was detected in any other sample, which makes them highly suspect. Other detections that may be related to this trip blank include UNK258, which was tentatively identified as nonanal in CISOIL22, and UNK283, which was tentatively identified as decanal in CISOIL29. Both of these samples were collected June 19.

Four trip blanks were shipped on July 25, 1990, along with samples CISOIL01, 101, 13, 14, 20, and 21. No data about detections of unknown compounds in this blank are available. Either no unknowns were detected in the trip blank, or the data are missing.

Two trip blanks were shipped to the laboratory on October 16, 1990. The samples from Carroll Island that were collected that day were CISOIL03, 09, 12 , and 23. Unknown compounds UNK023 (tentatively identified as N,N-dimethylacetamide) and UNK197 (tentatively identified as 1-bromo-2-fluorobenzene) were detected in the trip blank. Unknown compound UNK023 was detected in only one sample, CISOIL 23. Unknown compound UNK197 was not detected in any environmental samples.

Relatively few unknown compounds with UNK numbers between zero and 100 were found in soil samples (table 10). The compounds UNK013, UNK014, UNK019, and UNK020 were all tentatively identified in various samples as methylhydrazine oxalate (1:1) (table 23, at the end of the report). All of these detections are suspect because two unknown compounds in a trip blank were tentatively identified as methylhydrazine oxalate $(1: 1)$. Some of the unknown compounds in this range had more than one tentative identification. For example, UNK019 (which was detected in the trip blank as well as in environmental samples) also was tentatively identified as 4-pentyn-2-ol, cyanoacetic acid, and trinitro-methane. Unknown compound UNK022 was tentatively identified as 3-hydroxy-butanal and amphetamine, and UNK034 was identified as carbamic acid 2-propenyl ester and pentanal. Other unknown compounds in this range that were detected in soil samples include UNK023, which also was detected in a trip blank and is suspect, UNK025, which was tentatively identified as N,3-dimethyl 1-butanamine, and UNK078, tentatively identified as acetamide.

The occurrence of methylhydrazine oxalate $(1: 1)$ in these samples is unlikely. Methylhydrazine is a component of rocket fuel (Windholz and others, 1983, p. 872). It might be possible for rocket fuel to be found on Carroll Island, but because of the detection of UNK019 and UNK020 in a trip blank, the detection of this compound in environmental samples is unlikely to have been related to military activity. No information could be found on 4-pentyn-2-ol, N,3-dimethyl 1butanamine, or carbamic acid 2-propenyl ester. Trinitromethane is used in the manufacture of explosives and propellants (Windholz and others, 1983, p. 1390), so its detection on Carroll Island (CISOIL19, in the CS test area) is possible, but the detection of UNK019 in the trip blank makes it suspect. Pentanal is described by Windholz and others (1983, p. 1416) as used in resin chemistry. Acetamide is used as a solvent, plasticizer, and stabilizer (Windholz and others, 1983, p. 6), so it may have been used on Carroll Island. Cyanoacetic acid was listed in the Merck Index (Windholz and others, 1983, p. 385), but the detection may have been spurious.

Relatively few unknown compounds with UNK numbers between 100 and 200 were detected (table 10). The compounds UNK135 and 136 were tentatively identified as cyanoacetic acid (table 23, at the end of the report), which was the tentative identification for UNK019 in another sample; UNK135 also was tentatively identified as cyclobutanol in another sample. The tentative identification for UNK127 was 3-methyl-2-butanone; UNK163 was tentatively identified as hexanal; and UNK186 was tentatively identified as $\alpha$-pinene. 
Table 10. Locations and concentrations of selected unknown compounds detected in soil samples at Carroll Island, Aberdeen Proving Ground, Md., summer 1990

[Concentrations in micrograms per gram; all concentrations are approximate; UNK number is a laboratory code to designate unknown compounds;

*, unknown compound listed more than once per sample; see table 23 for tentative identifications of unknown compounds]

\begin{tabular}{|c|c|c|c|}
\hline $\begin{array}{l}\text { Unknown } \\
\text { compound }\end{array}$ & $\begin{array}{l}\text { Number of } \\
\text { detections }\end{array}$ & $\begin{array}{c}\text { Range of } \\
\text { detections }\end{array}$ & $\begin{array}{l}\text { Location and site number of detections } \\
\text { (figs. } 2 \text { and } 5 \text { ) }\end{array}$ \\
\hline UNK013 & 1 & 0.002 & Dredge spoil site (CISOIL28) \\
\hline UNK014 & 1 & .005 & Aerial spray grid (CISOIL07) \\
\hline UNK017 & 1 & .004 & Lower Island disposal site (CISOIL14) \\
\hline UNK019 & 6 & $.003-.006$ & $\begin{array}{l}\text { Decontamination pits (CISOIL06); Lower Island disposal site } \\
\text { (CISOIL13); BZ test burn pit (CISOIL18); CS test area } \\
\text { (CISOIL19); Wind tunnel (CISOIL24, 25) }\end{array}$ \\
\hline UNK020 & 4 & $.005-.007$ & $\begin{array}{l}\text { EPG dump site (CISOIL05); Decontamination pits } \\
\text { (CISOIL106); Aerial spray grid (CISOIL07, 27) }\end{array}$ \\
\hline UNK022 & 2 & $.008-.014$ & Test grid 1 (CISOIL09); Lower Island disposal site (CISOIL12) \\
\hline UNK023 & 1 & .010 & HD test area (CISOIL23) \\
\hline UNK025 & 1 & .002 & Dredge spoil site (CISOIL28) \\
\hline UNK034 & 6 & $.002-.005$ & $\begin{array}{l}\text { Lower Island disposal site (CISOIL11, 17); Test grid } 2 \\
\text { (CISOIL15, 115); VX test area (CISOIL16); Magazine area } \\
\text { (CISOIL29) }\end{array}$ \\
\hline UNK078 & 2 & .004 & $\begin{array}{l}\text { Lower Island disposal site (CISOIL11); Magazine area } \\
\text { (CISOIL29) }\end{array}$ \\
\hline UNK 127 & 1 & .007 & Bengies Point Rd. dump site (CISOIL20) \\
\hline UNK135 & 2 & $.002-.003$ & BZ test burn pit (CISOIL18); Wind tunnel (CISOIL24) \\
\hline UNK136 & 1 & .003 & EPG dump site (CISOIL04) \\
\hline UNK163 & 1 & .002 & Magazine area (CISOIL29) \\
\hline UNK 186 & 1 & .012 & HD test area (CISOIL23) \\
\hline UNK217 & 3 & $.005-.272$ & Bengies Point Rd. dump site (CISOIL01, 101, 20) \\
\hline UNK223 & 2 & $.005-.014$ & Bengies Point Rd. dump site (CISOIL101, 20) \\
\hline UNK227 & 1 & .082 & Bengies Point Rd. dump site (CISOIL20) \\
\hline UNK228 & 1 & .004 & Magazine area (CISOIL29) \\
\hline UNK234 & 1 & .004 & Bengies Point Rd. dump site (CISOIL101) \\
\hline UNK249 & 2 & $.004-.005$ & Decontamination pits (CISOIL106); Wind tunnel (CISOIL25) \\
\hline UNK250 & 9 & $.002-.010$ & $\begin{array}{l}\text { EPG dump site (CISOIL04, 05);Decontamination pits } \\
\text { (CISOIL06); Aerial spray grid (CISOIL07, 27); BZ test burn pit } \\
\text { (CISOIL18); CS test area (CISOIL19); Wind tunnel } \\
\text { (CISOIL24); Dredge spoil site (CISOIL28) }\end{array}$ \\
\hline UNK253 & 1 & .004 & Bengies Point Rd. dump site (CISOIL101) \\
\hline UNK254 & 1 & .033 & Bengies Point Rd. dump site (CISOIL20) \\
\hline UNK257 & 7 & $.004-.012$ & $\begin{array}{l}\text { Test grid } 1 \text { (CISOIL08); Lower Island disposal site (CISOIL11, } \\
\text { 17); Test grid } 2 \text { (CISOIL15, 115); VX test area (CISOIL16); } \\
\text { Magazine area (CISOIL29) }\end{array}$ \\
\hline UNK258 & 2 & $.005-.016$ & $\begin{array}{l}\text { Bengies Point Rd. dump site (CISOIL20); Area east of HD test } \\
\text { area (CISOIL22) }\end{array}$ \\
\hline UNK275 & 4 & $.004-.011$ & $\begin{array}{l}\text { Decontamination pits (CISOIL106); CS test area (CISOIL19); } \\
\text { Wind tunnel (CISOIL25); Aerial spray grid (CISOIL27) }\end{array}$ \\
\hline
\end{tabular}


Table 10. Locations and concentrations of selected unknown compounds detected in soil samples at Carroll Island, Aberdeen Proving Ground, Md., summer 1990--Continued

\begin{tabular}{|c|c|c|c|}
\hline $\begin{array}{l}\text { Unknown } \\
\text { compound }\end{array}$ & $\begin{array}{l}\text { Number of } \\
\text { detections }\end{array}$ & $\begin{array}{l}\text { Range of } \\
\text { detections }\end{array}$ & $\begin{array}{l}\text { Location and site number of detections } \\
\text { (figs. } 2 \text { and 5) }\end{array}$ \\
\hline UNK276 & 6 & $0.005-0.012$ & $\begin{array}{l}\text { EPG dump site (CISOIL04, 05); Decontamination pits } \\
\text { (CISOIL06); Aerial spray grid (CISOIL07); BZ test burn pit } \\
\text { (CISOIL18); Wind tunnel (CISOIL24) }\end{array}$ \\
\hline UNK283 & 2 & $.012-.024$ & Test grid 2 (CISOIL15); Magazine area (CISOIL29) \\
\hline UNK284 & 6 & $.006-.011$ & $\begin{array}{l}\text { Test grid } 1 \text { (CISOILO8); Lower Island disposal site (CISOIL11, } \\
\text { 17); Test grid } 2 \text { (CISOIL115); VX test area (CISOIL16); Area } \\
\text { east of HD test area (CISOIL22) }\end{array}$ \\
\hline UNK319 & 3 & $.003-.010$ & $\begin{array}{l}\text { Lower Island disposal site (CISOIL13, 14); Bengies Point Rd. } \\
\text { dump site (CISOIL20) }\end{array}$ \\
\hline UNK320 & 3 & $.004-.005$ & Bengies Point Rd. dump site(CISOIL01, 101, 21) \\
\hline UNK334 & 3 & $.005-.131$ & Bengies Point Rd. dump site (CISOIL101, 20, 21) \\
\hline UNK528 & 26 & $.248-22.4$ & $\begin{array}{l}\text { Bengies Point Rd. dump site (CISOIL01, 101, 20, 21); Service } \\
\text { area (CISOIL03*); EPG dump site (CISOIL04); } \\
\text { Decontamination pits (CISOILO6); Test grid } 1 \text { (CISOIL08, 09*); } \\
\text { Lower Island disposal site (CISOIL11, 12*,13,17); Test grid } 2 \\
\text { (CISOIL15, 115); VX test area (CISOIL16); BZ test burn pit } \\
\text { (CISOIL18); CS test area (CISOIL19); Area east of HD test area } \\
\text { (CISOIL22); HD test area (CISOIL23*); Aerial spray grid } \\
\text { (CISOIL27); Magazine area (CISOIL29) }\end{array}$ \\
\hline UNK529 & 9 & $.124-3.86$ & $\begin{array}{l}\text { EPG dump site (CISOIL05); Decontamination pits } \\
\text { (CISOIL106); Aerial spray grid (CISOIL07); CS test area } \\
\text { (CISOIL19*); Area east of HD test area (CISOIL22); Wind } \\
\text { tunnel (CISOIL24, 25); Dredge spoil site (CISOIL28) }\end{array}$ \\
\hline UNK530 & 18 & $.248-5.22$ & $\begin{array}{l}\text { Bengies Point Rd. dump site (CISOIL01, 101*, 21); Service area } \\
\text { (CISOIL03*); Test grid } 1 \text { (CISOIL09*); Lower Island disposal } \\
\text { site (CISOIL12*, 13,14); HD test area (CISOIL23*) }\end{array}$ \\
\hline UNK531 & 5 & $.371-1.12$ & $\begin{array}{l}\text { Service area (CISOIL03); Test grid } 1 \text { (CISOIL09); Lower Island } \\
\text { disposal site (CISOIL12); Bengies Point Rd. dump site } \\
\text { (CISOIL20); HD test area (CISOIL23) }\end{array}$ \\
\hline UNK535 & 4 & $.141-.82$ & $\begin{array}{l}\text { Lower Island disposal site (CISOIL12); CS test area } \\
\text { (CISOIL19*); Bengies Point Rd. dump site (CISOIL20) }\end{array}$ \\
\hline UNK536 & 28 & $.214-2.79$ & $\begin{array}{l}\text { Bengies Point Rd. dump site (CISOIL01); Service area } \\
\text { (CISOIL03*); EPG dump site (CISOIL04, 05); } \\
\text { Decontamination pits (CISOIL06, 106); Aerial spray grid } \\
\text { (CISOIL07, 27); Test grid } 1 \text { (CISOIL08, 09*); Lower Island } \\
\text { disposal site (CISOIL11, 12*, 17); Test grid 2 (CISOIL15, 115); } \\
\text { VX test area (CISOIL16); CS test area (CISOIL19*); Area east } \\
\text { of HD test area (CISOIL22); HD test area (CISOIL23); Wind } \\
\text { tunnel (CISOIL24, 25); Dredge spoil site (CISOIL28); } \\
\text { Magazine area (CISOIL29) }\end{array}$ \\
\hline UNK537 & 9 & $.539-1.64$ & $\begin{array}{l}\text { Bengies Point Rd. dump site (CISOIL01, 101, 20*, 21); Test grid } \\
1 \text { (CISOIL09); Lower Island disposal site (CISOIL13, 14); HD } \\
\text { test area (CISOIL23) }\end{array}$ \\
\hline UNK538 & 25 & $.124-3.36$ & $\begin{array}{l}\text { Bengies Point Rd. dump site (CISOIL101); Service area } \\
\text { (CISOIL03); EPG dump site (CISOIL04, 05); Decontamination } \\
\text { pits (CISOIL06, 106); Aerial spray grid (CISOIL07, 27); Test } \\
\text { grid 1 (CISOIL08, 09); Lower Island disposal site (CISOIL11, } \\
\left.12^{*}, 13,17\right) ; \text { Test grid } 2 \text { (CISOIL15, 115); VX test area } \\
\text { (CISOIL16); CS test area (CISOIL19); Area east of HD test area } \\
\text { (CISOIL22); HD test area (CISOIL23); Wind tunnel } \\
\text { (CISOIL24, 25); Dredge spoil site (CISOIL28); Magazine area } \\
\text { (CISOIL29) }\end{array}$ \\
\hline
\end{tabular}


Table 10. Locations and concentrations of selected unknown compounds detected in soil samples at Carroll Island, Aberdeen Proving Ground, Md., summer 1990--Continued

\begin{tabular}{|c|c|c|c|}
\hline $\begin{array}{l}\text { Unknown } \\
\text { compound }\end{array}$ & $\begin{array}{l}\text { Number of } \\
\text { detections }\end{array}$ & $\begin{array}{l}\text { Range of } \\
\text { detections }\end{array}$ & $\begin{array}{l}\text { Location and site number of detections } \\
\text { (figs. } 2 \text { and } 5 \text { ) }\end{array}$ \\
\hline UNK539 & 6 & $0.214-1.18$ & $\begin{array}{l}\text { Bengies Point Rd. dump site (CISOIL01, 101, 21); Lower Island } \\
\text { disposal site (CISOIL13, 14); Dredge spoil site (CISOIL28) }\end{array}$ \\
\hline UNK540 & 5 & $.261-.394$ & $\begin{array}{l}\text { Bengies Point Rd. dump site (CISOIL01, 21); EPG dump site } \\
\text { (CISOIL04); Test grid } 1 \text { (CISOIL09); Lower Island disposal site } \\
\text { (CISOIL13) }\end{array}$ \\
\hline UNK541 & 18 & $.24-3.36$ & $\begin{array}{l}\text { Service area (CISOIL03); EPG dump site (CISOIL04, 05); } \\
\text { Decontamination pits (CISOIL106); Test grid } 1 \text { (CISOIL08, 09); } \\
\text { Lower Island disposal site (CISOIL11, 12, 14, 17); Test grid } 2 \\
\text { (CISOIL15, 115); VX test area (CISOIL16); BZ test burn pit } \\
\text { (CISOIL18); CS test area (CISOIL19); Area east of HD test area } \\
\text { (CISOIL22); HD test area (CISOIL23); Magazine area } \\
\text { (CISOIL29) }\end{array}$ \\
\hline UNK542 & 12 & $.369-3.67$ & $\begin{array}{l}\text { Bengies Point Rd. dump site (CISOIL01, 21); EPG dump site } \\
\text { (CISOIL05); Decontamination pits (CISOIL06, 106); Aerial } \\
\text { spray grid (CISOIL07, 27); Lower Island disposal site } \\
\text { (CISOIL13, 14); Wind tunnel (CISOIL24, 25); Dredge spoil site } \\
\text { (CISOIL28) }\end{array}$ \\
\hline UNK543 & 4 & $.238-.543$ & $\begin{array}{l}\text { Bengies Point Rd. dump site (CISOIL101); Decontamination } \\
\text { pits (CISOIL106); Aerial spray grid (CISOIL07, 27) }\end{array}$ \\
\hline UNK547 & 15 & $.24-2.63$ & $\begin{array}{l}\text { Service area (CISOIL03); EPG dump site (CISOIL05); } \\
\text { Decontamination pits (CISOIL106); Test grid } 1 \text { (CISOIL08, 09); } \\
\text { Lower Island disposal site (CISOIL } 11,12,17) \text {; Test grid } 2 \\
\text { (CISOIL15, 115); VX test area (CISOIL16); CS test area } \\
\text { (CISOIL19); Area east of HD test area (CISOIL22); HD test } \\
\text { area (CISOIL23); Magazine area (CISOIL29) }\end{array}$ \\
\hline UNK548 & 2 & $.279-.386$ & Wind tunnel (CISOIL24, 25) \\
\hline UNK549 & 1 & 2.57 & Lower Island disposal site (CISOIL14) \\
\hline UNK551 & 1 & .141 & Lower Island disposal site (CISOIL12) \\
\hline UNK552 & 2 & $.135-.261$ & Bengies Point Rd. dump site (CISOIL01, 21) \\
\hline UNK556 & 1 & 64.3 & Lower Island disposal site (CISOIL14) \\
\hline UNK557 & 1 & .129 & Lower Island disposal site (CISOIL14) \\
\hline UNK560 & 1 & .386 & Lower Island disposal site (CISOIL14) \\
\hline UNK568 & 2 & $.122-.257$ & $\begin{array}{l}\text { Aerial spray grid (CISOIL07); Lower Island disposal site } \\
\text { (CISOIL14) }\end{array}$ \\
\hline UNK569 & 2 & $.135-.82$ & Bengies Point Rd. dump site (CISOIL20, 21) \\
\hline UNK576 & 2 & $.261-.272$ & Bengies Point Rd. dump site (CISOIL01, 101) \\
\hline UNK577 & 4 & $.135-1.09$ & Bengies Point Rd. dump site (CISOIL01, 101*, 21) \\
\hline UNK580 & 1 & .392 & Bengies Point Rd. dump site (CISOIL01) \\
\hline UNK581 & 2 & $.2729-.371$ & $\begin{array}{l}\text { Bengies Point Rd. dump site (CISOIL101,); HD test area } \\
\text { (CISOIL23) }\end{array}$ \\
\hline UNK583 & 3 & $.136-.82$ & $\begin{array}{l}\text { Bengies Point Rd. dump site (CISOIL101, 20); Lower Island } \\
\text { disposal site (CISOIL14) }\end{array}$ \\
\hline UNK590 & 1 & 4.92 & Bengies Point Rd. dump site (CISOIL20) \\
\hline UNK591 & 3 & $.135-1.64$ & Bengies Point Rd. dump site (CISOIL101, 20, 21) \\
\hline UNK598 & 1 & .82 & Bengies Point Rd. dump site (CISOIL20) \\
\hline UNK599 & 1 & .166 & Test grid 1 (CISOIL09) \\
\hline
\end{tabular}


Table 10. Locations and concentrations of selected unknown compounds detected in soil samples at Carroll Island, Aberdeen Proving Ground, Md., summer 1990--Continued

\begin{tabular}{|c|c|c|c|}
\hline $\begin{array}{l}\text { Unknown } \\
\text { compound }\end{array}$ & $\begin{array}{l}\text { Number of } \\
\text { detections }\end{array}$ & $\begin{array}{l}\text { Range of } \\
\text { detections }\end{array}$ & $\begin{array}{l}\text { Location and site number of detections } \\
\text { (figs. } 2 \text { and } 5 \text { ) }\end{array}$ \\
\hline UNK602 & 1 & 0.612 & Aerial spray grid (CISOIL07) \\
\hline UNK604 & 1 & .371 & HD test area (CISOIL23) \\
\hline UNK605 & 1 & .248 & HD test area (CISOIL23) \\
\hline UNK610 & 1 & .119 & Aerial spray grid (CISOIL27) \\
\hline UNK613 & 1 & .129 & Lower Island disposal site (CISOIL14*) \\
\hline UNK614 & 2 & $.129-.248$ & $\begin{array}{l}\text { Lower Island disposal site (CISOIL14); HD test area } \\
\text { (CISOIL23) }\end{array}$ \\
\hline UNK615 & 4 & $.238-.279$ & Aerial spray grid (CISOIL07, 27); Wind tunnel (CISOIL24, 25) \\
\hline UNK616 & 5 & $.129-.344$ & EPG dump site (CISOIL04,05*); Wind tunnel (CISOIL24, 25) \\
\hline UNK617 & 1 & .344 & EPG dump site (CISOIL04) \\
\hline UNK621 & 1 & .272 & Bengies Point Rd. dump site (CISOIL101) \\
\hline UNK622 & 3 & $.238-.27$ & $\begin{array}{l}\text { Bengies Point Rd. dump site (CISOIL21); Aerial spray grid } \\
\left(\text { CISOIL } 27^{*}\right)\end{array}$ \\
\hline UNK623 & 3 & $.238-3.28$ & $\begin{array}{l}\text { Lower Island disposal site (CISOIL14); Bengies Point Rd. dump } \\
\text { site (CISOIL20); Aerial spray grid (CISOIL27) }\end{array}$ \\
\hline UNK624 & 2 & $.129-.954$ & $\begin{array}{l}\text { Lower Island disposal site (CISOIL14); Aerial spray grid } \\
\text { (CISOIL27) }\end{array}$ \\
\hline UNK625 & 3 & $.262-.715$ & EPG dump site (CISOIL05); Aerial spray grid (CISOIL27*) \\
\hline UNK626 & 2 & $.115-.596$ & EPG dump site (CISOIL04); Aerial spray grid (CISOIL27) \\
\hline UNK629 & 1 & .333 & Test grid 1 (CISOIL09) \\
\hline UNK630 & 3 & $.262-6.56$ & $\begin{array}{l}\text { EPG dump site (CISOIL05); Bengies Point Rd. dump site } \\
\text { (CISOIL20); HD test area (CISOIL23) }\end{array}$ \\
\hline UNK631 & 2 & $.788-1.31$ & $\begin{array}{l}\text { Bengies Point Rd. dump site (CISOIL01); Lower Island disposal } \\
\text { site (CISOIL13) }\end{array}$ \\
\hline UNK633 & 7 & $.344-11.5$ & $\begin{array}{l}\text { Bengies Point Rd. dump site (CISOIL01, 20, 21); Service area } \\
\text { (CISOIL03); EPG dump site (CISOIL04); Lower Island disposal } \\
\text { site (CISOIL12, 14) }\end{array}$ \\
\hline UNK634 & 4 & $.263-2.27$ & $\begin{array}{l}\text { Bengies Point Rd. dump site (CISOIL101*, 20); Lower Island } \\
\text { disposal site (CISOIL13) }\end{array}$ \\
\hline UNK636 & 1 & .393 & EPG dump site (CISOIL05) \\
\hline UNK637 & 1 & 2.45 & Aerial spray grid (CISOIL07) \\
\hline UNK638 & 2 & $.131-.424$ & $\begin{array}{l}\text { Bengies Point Rd. dump site (CISOIL01); Lower Island disposal } \\
\text { site (CISOIL12) }\end{array}$ \\
\hline UNK639 & 1 & 1.64 & Bengies Point Rd. dump site (CISOIL20) \\
\hline UNK641 & 2 & $.257-.263$ & Lower Island disposal site (CISOIL14); CS test area (CISOIL19) \\
\hline UNK642 & 1 & .248 & HD test area (CISOIL23) \\
\hline UNK646 & 1 & 4.24 & Lower Island disposal site (CISOIL12) \\
\hline UNK647 & 2 & $.229-32.8$ & $\begin{array}{l}\text { EPG dump site (CISOIL04); Bengies Point Rd. dump site } \\
\text { (CISOIL20) }\end{array}$ \\
\hline UNK649 & 2 & .257 & Lower Island disposal site (CISOIL14*) \\
\hline UNK650 & 5 & $.237-2.7$ & $\begin{array}{l}\text { Bengies Point Rd. dump site (CISOIL01, 101, 21); Lower Island } \\
\text { disposal site (CISOIL13); Test grid } 2 \text { (CISOIL115) }\end{array}$ \\
\hline
\end{tabular}


Table 10. Locations and concentrations of selected unknown compounds detected in soil samples at Carroll Island, Aberdeen Proving Ground, Md., summer 1990--Continued

\begin{tabular}{|c|c|c|c|}
\hline $\begin{array}{l}\text { Unknown } \\
\text { compound }\end{array}$ & $\begin{array}{l}\text { Number of } \\
\text { detections }\end{array}$ & $\begin{array}{l}\text { Range of } \\
\text { detections }\end{array}$ & $\begin{array}{l}\text { Location and site number of detections } \\
\text { (figs. } 2 \text { and } 5 \text { ) }\end{array}$ \\
\hline UNK653 & 2 & $0.566-0.82$ & $\begin{array}{l}\text { Lower Island disposal site (CISOIL12); Bengies Point Rd. dump } \\
\text { site (CISOIL20) }\end{array}$ \\
\hline UNK655 & 1 & 1.48 & Bengies Point Rd. dump site (CISOIL20) \\
\hline UNK656 & 1 & 1.48 & Bengies Point Rd. dump site (CISOIL20) \\
\hline UNK657 & 1 & .392 & Bengies Point Rd. dump site (CISOIL01) \\
\hline UNK660 & 3 & $.248-1.64$ & $\begin{array}{l}\text { Service area (CISOIL03); Bengies Point Rd. dump site } \\
\text { (CISOIL20); HD test area (CISOIL23) }\end{array}$ \\
\hline UNK662 & 2 & $.129-.514$ & Lower Island disposal site (CISOIL14*) \\
\hline UNK666 & 1 & .849 & Lower Island disposal site (CISOIL12) \\
\hline UNK667 & 4 & $.248-32.8$ & $\begin{array}{l}\text { Service area (CISOIL03); Bengies Point Rd. dump site } \\
\text { (CISOIL20*); HD test area (CISOIL23) }\end{array}$ \\
\hline UNK669 & 1 & 1.64 & Bengies Point Rd. dump site (CISOIL20) \\
\hline UNK672 & 1 & .129 & Lower Island disposal site (CISOIL14) \\
\hline UNK680 & 1 & 1.64 & Bengies Point Rd. dump site (CISOIL20) \\
\hline UNK683 & 2 & .129 & Lower Island disposal site (CISOIL14*) \\
\hline UNK687 & 2 & $.373-16.4$ & $\begin{array}{l}\text { Service area (CISOIL03); Bengies Point Rd. dump site } \\
\text { (CISOIL20) }\end{array}$ \\
\hline UNK697 & 3 & $.124-6.56$ & $\begin{array}{l}\text { Lower Island disposal site (CISOIL12); Bengies Point Rd. dump } \\
\text { site (CISOIL20); HD test area (CISOIL23) }\end{array}$ \\
\hline UNK698 & 1 & 1.64 & Bengies Point Rd. dump site (CISOIL20) \\
\hline UNK728 & 1 & 1.64 & Bengies Point Rd. dump site (CISOIL20) \\
\hline UNK729 & 1 & .283 & Lower Island disposal site (CISOIL12) \\
\hline UNK740 & 1 & .743 & HD test area (CISOIL23) \\
\hline UNK742 & 1 & 1.48 & Bengies Point Rd. dump site (CISOIL20) \\
\hline UNK747 & 1 & 3.65 & Lower Island disposal site (CISOIL17) \\
\hline UNK750 & 1 & 1.48 & Bengies Point Rd. dump site (CISOIL20) \\
\hline
\end{tabular}


No information could be found on 3-methyl2-butanone or cyclobutanol. Hexanal was listed in the Merck Index (Windholz and others, 1983, p. 243). The compound $\alpha$-pinene is a constituent of many volatile oils (Windholz and others, 1983, p. 1073), and is a naturally-occurring terpene compound.

Many unknown compounds with UNK numbers between 200 and 300 were detected. The unknown compound UNK 217 was tentatively identified as 4-methyl-1-(1-methylethyl)bicyclo[3.1.0]hexane, $\alpha$-pinene, and 2-methyl-5-(1-methylethyl)bicyclo[3.1.0]hex-2-ene in various samples. These compounds are thought to be naturally-occurring terpenes. Two other unknown compounds, UNK223 (tentatively identified as camphene or 2-propyl benzene) and UNK234 (tentatively identified as $\beta$-myrcene) also are thought to be terpenes (Windholz and others, 1983, p. 238,907$)$.

The compound UNK249 was tentatively identified as 5-methyl-1-hexene. No information on this compound was available in the Merck Index (Windholz and others, 1983). Unknown compounds UNK253 (tentatively identified as 1,2-diethenyl3-methyl-cyclobutane), UNK254 (tentatively identified as 1-methyl-3-(1-methylethyl)-benzene), and UNK258 (tentatively identified as 1,1'-(1-ethenyl1,3-propanediyl)bis-benzene, or as nonanal) were detected in various samples. No information could be found on these compounds or for the tentative identifications of unknown compounds UNK275 (2-octen1-ol, decanal) and UNK283 (dimethyl-1-octanol, decanal). The unknown compounds UNK250, UNK257, UNK276, and UNK284 had several tentative identifications, but were detected in trip blanks and are therefore suspect.

Between UNK300 and UNK500, there were very few compounds detected. Unknown compounds UNK319 and UNK320 were both tentatively identified as decanal. Unknown compound UNK334 had two tentative identifications. One was $(Z, E)$ 3,7,1-trimethyl-1,3,6,10-dodecatetraene; the other was too long for the computer printout to provide a complete name. The compound $(Z, E)$ 3,7,1-trimethyl-1,3,6,10-dodecatetraene is naturally occurring; it is a component of aphid alarm pheromones (Windholz and others, 1983, p. 567-568).

Unknown compounds with UNK numbers greater than 500 are generally semivolatile compounds. Detections of these compounds were numerous, and some of the compounds had multiple tentative identifi- cations. Unknown compound UNK528 was detected at 20 different sampling locations on Carroll Island. The compound was tentatively identified in various samples as nine different chemicals--acetic acid methyl ester; acetic acid 1-methylethyl ester; 1,1-dipropoxypropane; 3-hydroxy-3,5-dimethyl-2-hexanone; 2,4-dimethyl-1,3-dioxolane-2-methanol; 5,5-dimethyl-2-hexene; (Z)-5,5-dimethyl-2-hexene; 2,6,8-trimethyl decane; and 2,4-dimethyl-2-pentanol. Unknown compound UNK529 (detected at eight sampling sites) also was tentatively identified as 2,4-dimethyl-2-pentanol, as well as 2-methyl heptane, and 3,4-dimethyl heptane. None of these compounds were listed in the Merck Index (Windholz and others, 1983). The large number of detections of UNK528 and UNK529 indicate that the compounds may occur naturally or that they may have been fallout from industrial air pollution from the Baltimore metropolitan area.

The unknown compound UNK530 was detected at eight soil sampling sites and was tentatively identified in various samples as five different chemicals-2,4-dimethyl-1,3-dioxolane-2-methanol; 2,3-dimethyl heptane; 4-methyl octane; 3,4-dimethyl heptane; and 2 -methyl octane. No information could be found on these compounds; however, octane and $n$-heptane are both found in petroleum (Windholz and others, p. 674 and 970, 1983).

Unknown compound UNK531 was detected at five sites, and was tentatively identified as 3-methyl octane, 6-methyl undecane, and heptanoic acid. Heptanoic acid is a substance found in rancid oils (Windholz and others, 1983, p. 674). This could mean that it is naturally occurring. No information could be found about 3-methyl octane or 6-methyl undecane, but they may be fuel-related products.

Unknown compound UNK535 was tentatively identified as (E)-2-methyl-2-butenoic acid; 1,1,2,2-tetrachloroethane; and 4-chloro-4,4-difluoro-4-butanone in various samples. This compound was detected at sites CISOIL12, CISOIL19, and CISOIL20. One of the tentative identifications, $(E)$-2-methyl-2-butenoic acid, also is known as tiglic acid (Windholz and others, 1983 , p. 1352) and is probably naturally occurring. One of the tentative identifications for UNK535 at site CISOIL19 was 1,1,2,2-tetrachloroethane; this compound also was detected in CISOIL19 during the routine organics analysis and is probably identified accurately. No information could be found about the third compound, 4-chloro-4,4-difluoro-4-butanone. 
The unknown compound UNK536 was reported 28 times in 23 samples (including replicates). This unknown was tentatively identified as hexanedioic acid; 2-bromo hexane, 1-(ethenyloxy)-pentane; 2,4-pentanedione; 2,5-hexanedione; 2,7-dimethyl octane; 5,5-dimethyl-2(5H)-furanone; and 1-(3-ethyloxyranyl). The large number of detections indicates that the compound may occur naturally or may have come from industrial fallout.

Information was available for some of the tentative identifications of UNK536. Hexanedioic acid (also known as adipic acid) is a dicarboxylic acid that is most likely naturally occurring. It has been found in natural waters, and originates from the decomposition of soil and plant organic matter and bacteria (Thurman, 1985, p. 139). The compounds 2,4-pentanedione (also known as acetylacetone) and 2,5-hexanedione (acetonylacetone) were listed in the Merck Index (Windholz and others, 1983 , p. 10, 12), but it was not clear whether the compounds were naturally occurring. One of the compounds, 2,4-pentanedione, is used to form organometallic complexes which are then used as gasoline additives, lubricant additives, fungicides, and insecticides (Windholz and others, 1983, p. 12). No information on the other tentative identifications of UNK536 was found.

The unknown compound UNK537 was tentatively identified as 2,4-pentanedione; 2-bromo hexane; 5-methyl-3-hexen-2-one; 3,6,6-trimethylbicyclo[3.1.1]hept-2-ene; and 1-(3-ethyloxyranyl)-ethanone. Of these compounds, 2,4-pentanedione and 2-bromo hexane were tentative identifications for UNK236, and 5-methyl-3-hexen-2-one was one of the tentative identifications of UNK538, UNK539, and UNK540. The Merck Index contained information on 2,6,6-trimethylbicyclo[3.1.1]hept-2-ene, which is similar to one of the tentative identifications of UNK537. This compound also is known as $\alpha$-pinene (Windholz and others, 1983, p. 1073), which is a terpene and is most likely naturally occurring.

Unknown compound UNK538 was reported 25 times in 24 soil samples, and UNK539 was reported in 6 soil samples (table 10). Tentative identifications for UNK538 included 3,6,6-trimethylbicyclo[3.1.1] hept2-ene and 2,5-dihydro-2,4,4-trimethyl furan. In addition, UNK538 and UNK539 were both tentatively identified as 5-methyl-5-hexen-2-one and 5-methyl3-hexen-2-one. No information on these compounds was found.
The unknown compound UNK540 was tentatively identified as 5-methyl-5-hexen-2-one; acetate 7-oxabicyclo[4.1.0]heptan-1-ol; octyl silane; and 5-methyl-3-hexen-2-one. Unknown compounds UNK541, UNK542, and UNK543 were each tentatively identified as trans-diacetate tetrahydro$2 \mathrm{H}$-pyran-2,3-diol. Another tentative identification for UNK541 was 2,4-dimethyl-3-heptanone. The tentatively identified compounds for UNK547 were $\mathrm{N}$-acetyl-dl-alloisoleucine; 2-methyl-3-heptanone; 1-(trimethyloxiranyl)-ethanone; 5-hexyldihydro2(3H)-furanone; hydroxy-hexanoic acid methyl ester; and 1-oxiranyl-ethanone. The unknown compound UNK548 was tentatively identified as 1,2-ethane diol monoacetate. For UNK549, UNK552, and UNK556, the tentative identification was 2-ethyl hexanoic acid. Other tentative identifications included 2-methyl-2-hexenoic acid methyl ester (for UNK557), 2-dodecenal (for UNK560), 2-methyl-2-propenoic acid propyl ester (for UNK568), and (2-hydroxy-5-methylphenyl)-ethanone (for UNK569). Of all these compounds, the only one for which information could be found was 1,2-ethane diol monoacetate. This compound also is called ethylene glycol monoacetate. It was detected in the soil at the wind tunnel; ethylene glycol was used as a cooling fluid in the wind tunnel (Nemeth, 1989, p. 485).

Unknown compound UNK577 was tentatively identified as caryophyllene, which is a terpene compound (Windholz and others, 1983, p. 262), and is probably naturally occurring. Unknown compound UNK580 was tentatively identified as 2,3-octanediol, and UNK583 was tentatively identified as 1,2,4a,5,8,8a-hexahydro-4,7-dimethyl naphthalene and as N,N-bis(2-hydroxyethyl) dodecanamide. The naphthalene compound is a polycyclic aromatic hydrocarbon, which usually come from combustion sources (Smith and others, 1988, p. 64). Unknown compound UNK591 was tentatively identified as 2-dodecenal, which also was the tentative identification of UNK560. Unknown compound UNK599 was tentatively identified as benzene sulfonamide.

Unknown compound UNK602 was detected in one sample in the aerial spray grid (table 10). The compound was tentatively identified as 3-pentadecyl phenol. Phenols are commonly used in industry (Smith and others, 1988, p. 44).

Unknown compounds UNK604 and UNK605 were each detected once in the same sample, CISOIL23 in the HD test area. The tentative identifi- 
cation for UNK604 was 10-octadecenoic acid methyl ester, which also is known as methyl oleate (Windholz and others, 1983, p. 980). Methyl oleate is an ester of oleic acid, which is a fatty acid that results from the hydrolysis of various animal and vegetable fats and oils (Windholz and others, 1983, p. 979). This indicates that UNK604 may have been a naturally-occurring compound. The tentative identification for UNK605 appeared to be similar, but was truncated on the library-search printout.

Other unknown compounds had tentative identifications that were similar to that of UNK604. One of the tentative identifications of UNK 615 and UNK616 was (Z)-9-octadecenoic acid, which is a stereoisomer of oleic acid (Windholz and others, 1983, p. 510). The unknown compound UNK614 was tentatively identified as (Z)-9-octadecenoic acid methyl ester, which is again probably related to oleic acid. In addition, UNK616 and UNK617 were tentatively identified as octadecanoic acid (or stearic acid), which is a naturally occurring fatty acid.

There were other tentative identifications for UNK615 and UNK616. For UNK615, the other tentative identifications were phosphonic acid dioctadecyl ester and 1,1'-(2-ethyl-1,3-propanediyl)biscyclohexane. For UNK616, the other tentative identifications were $(E)$-9-eicosene and $\mathrm{N}$-methyl-N(1-oxodecyl) glycine. The compound N-methyl-N(1-oxodecyl) glycine is a component of a salt that is used in detergents (Windholz and others, 1983, p. 623), so it may have resulted from laboratory contamination. No information was available for $(E)-9$ eicosene, which also was a tentative identification of UNK633, UNK634, UNK647, and UNK650.

Phosphonic acid dioctadecyl ester was a tentative identification for UNK615, UNK623, UNK633, UNK639, UNK647, and UNK656. This tentative identification appeared in samples CISOIL04 at the EPG dump site (twice), CISOIL07 in the aerial spray grid (once), and CISOIL20 at the Bengies Point Road dump site (three times). The compound may be a breakdown product from one of the chemical warfare agents such as GB or VX. A phosphonic acid compound (isopropylmethylphosphonic acid) is a hydrolysis product of the nerve agent GB (Nemeth, 1989, p. 195). Nemeth (1989, p. 199-200) also indicates that phosphonic acid compounds are expected products of the degradation of VX in soil.

Unknown compound UNK621 was tentatively identified as 4-methyl-1-phenyl-1-penten-3-one;
UNK622 was tentatively identified as 1,2-octanediol. Bis(4-methylpentyl) 1,2-benzenedicarboxylic acid was a tentative identification for UNK624, UNK625, and UNK626. The other tentative identification of UNK626 was (1-propylheptadecyl)-cyclohexane. The unknown compound UNK629 was tentatively identified as hexadecanal. None of these tentatively identified compounds were listed in the Merck Index (Windholz and others, 1983).

The unknown compound UNK630 was tentatively identified as (2-methyl-1-methylenepropyl)benzene. Unknown compound UNK631 was tentatively identified as 1,2,3,4-tetrahydro-1-methylnaphthalene and 1-(chloromethyl)-4-(2-propenyl)benzene. None of these compounds were listed in the Merck Index (Windholz and others, 1983).

Unknown compound UNK633 was detected seven times, and had five different tentative identifications. These tentative identifications included 1-cyclopentyl-4-(3-cyclopentylpropyl)-dodecane; 2-(octadecyloxy)-ethanol; and 11-decyl tetracosane, for which no information could be found; and (E)-9-eicosene and phosphonic acid dioctadecyl ester, which were discussed earlier.

The tentative identification for UNK637 was a compound known as 1 benzothieno 3,2-b 1 benzothiophene. This compound was not in the Merck Index (Windholz and others, 1983), but a similar compound, benzo[b]thiophene, is a PAH (Windholz and others, 1983, p. 1332-1333). This indicates that the tentatively identified compound for UNK637 is probably a substituted PAH. Unknown compound UNK638 was tentatively identified as the fatty acid ester octanoic acid 1-methyltridecyl ester and as 1 hexadecanol. Fatty acid esters are most likely naturally occurring. Cetyl alcohol, another name for 1 hexadecanol (Windholz and others, 1983, p. 282), is apparently related to palmitic acid, which is naturally occurring.

One of the tentative identifications of UNK641 was 2'-dodecyl-1,1'3'1'-tercyclopentane. This compound also was the tentative identification for UNK649. The other tentative identification for UNK641 was octadecanal, which also was the tentative identification for UNK642. Unknown compound UNK646 was tentatively identified as docosane. None of these compounds were listed in the Merck Index (Windholz and others, 1983).

Unknown compound UNK653 was tentatively identified as 2-methyl-1-hexadecanol. Unknown com- 
pound UNK655 was tentatively identified as decanedioic acid didecyl ester. Unknown compound UNK657 was tentatively identified as decanoic acid decyl ester. None of these compounds was listed in the Merck Index (Windholz and others, 1983). The decanedioic and decanoic acid esters, however, are probably naturally occurring because the parent acids are relatively common.

The tentative identifications for UNK660 were (Z)-2-(9-octadecenyloxy)-ethanol and $(Z, Z)-9,12$ octadecadienoic acid, which also is known as linoleic acid, a naturally-occurring fatty acid (Windholz and others, 1983, p. 790). The tentative identification for UNK666 was 11-decyl-tetracosane. Unknown compound UNK667 had four tentative identifications. These compounds were pentatriacontane, tricarbonyl n-(phenyl-2-pyridinylmethylene) iron, 5-cyclohexyl5-cyclohexyl-dodecane, and heptacosane. Unknown compound UNK669 was tentatively identified as 5-cyclohexyl-5-cyclohexyl-undecane. None of the compounds (except linoleic acid) were listed in the Merck Index (Windholz and others, 1983).

Unknown compounds UNK680 and UNK698 were tentatively identified as decanedioic acid decyl ester. Unknown compound UNK687 was tentatively identified as hexadecanal. The tentative identifications of UNK697 were heptacosane and tetratetracontane. Unknown compound UNK728 was tentatively identified as octadecanal, and UNK729 was tentatively identified as 11-octadecanal. Unknown compound UNK740 was the highest UNK number detected. The tentative identification for this compound was truncated on the library-search printout.

\section{SUMMARY AND CONCLUSIONS}

Carroll Island was used for open-air testing of chemical warfare agents from the late 1940's through 1971. Most of the testing was on the eastern part of the island at four areas, designated as test grid 1, test grid 2, the aerial spray grid, and the wind tunnel. Five other test areas also have been identified; these include an HD test area, VX test area, CS test area, an area east of the HD test area, and the dredge spoil site. Waste from testing operations on Carroll Island was disposed in burning pits, dump areas, and small burial pits. Known disposal sites include the Lower Island disposal site, Bengies Point Road dump site, the EPG dump site, the BZ test burn pit, and the decontamina- tion pits. Solid wastes typically generated during field testing included used equipment and protective clothing, and munitions fragments; these were normally chemically decontaminated prior to disposal if lethal agents were involved in a test.

Carroll Island is in the Atlantic Coastal Plain Physiographic Province and is underlain by Cretaceous and Quaternary sediment. The Cretaceous sediment includes the Patuxent Formation, the Arundel Formation, and the Patapsco Formation of the Potomac Group. The Quaternary sediment includes the Talbot Formation and Quaternary alluvium.

Surface water in the Carroll Island area includes the Chesapeake Bay and its estuarine tributaries surrounding the island, along with the marshes and the perennial and intermittent ponds on the island. Soils on the island are part of the Sassafras-WoodstownFallsington association. These soils range from poorly drained to well drained, and are strongly acidic to extremely acidic. The hydrogeologic units defined on Carroll Island during this study include the surficial aquifer, the upper confining unit, the upper confined aquifer, and the lower confining unit. The aquifers and confining units defined during this study are all within the Quaternary deposits and the Patapsco Formation.

Ground-water flow directions in the surficial aquifer on Carroll Island vary in response to seasonal recharge and evapotranspiration. During periods of high recharge and low evapotranspiration, the general hydraulic gradient is from the test grid 1 area in the east-central part of Carroll Island toward the marsh areas west of the aerial spray grid and the shorelines to the east, north, and south. Some areas of the island have localized flow patterns that discharge into the nearest marsh or surface-water body. During periods of low recharge and high evapotranspiration, hydraulic gradient reversals develop in which the water level in the estuaries is higher than the water levels within many of the wells in the surficial aquifer.

Horizontal hydraulic conductivity in the surficial aquifer ranged from less than 0.02 to $54 \mathrm{ft} / \mathrm{d}$, with a median of $1.6 \mathrm{ft} / \mathrm{d}$. Most of the hydraulic conductivity values were within the range that would be expected for the aquifer materials in which they were screened, but values at the low end of the range may not represent the true hydraulic conductivity within the aquifer because of the smearing of clay during drilling. 
Hydraulic-head gradients in the upper confined aquifer are small. The ground-water flow direction in this aquifer are generally to the south, east, and southeast throughout most of the year, but loading effects from tidal variations may cause the hydraulic gradient to change daily. Head in the upper confined aquifer exhibits only limited seasonal fluctuations, and little or no relation between the hydraulic head in the surficial aquifer and upper confined aquifer is apparent. Hydraulic head in the western part of the upper confined aquifer at Carroll Island is affected by pumping from a well at a nearby power plant. This well is pumped for a short period during the summer months, and produces noticeable drawdown (approximately $3 \mathrm{ft}$ ) in one well. The hydraulic head in this well recovers quickly after the pumped well is shut off.

The horizontal hydraulic conductivity values in the confined aquifer range from 3.5 to $48 \mathrm{ft} / \mathrm{d}$, with a median of $8.0 \mathrm{ft} / \mathrm{d}$. This range is only one order of magnitude, as opposed to three in the surficial aquifer. Hydraulic conductivity values in the confined aquifer fall within the range that would be expected for the aquifer materials in which they were screened.

Water from 61 wells and 21 surface-water sites was sampled to determine the extent of contamination at Carroll Island. Of the 61 wells, 55 were screened in the surficial aquifer and 6 were screened in the upper confined aquifer. Surface-water samples were collected from ponds, ditches, marshes, sumps, and estuaries. In addition to ground-water and surfacewater samples, 29 surficial soil samples were collected at Carroll Island.

The physical properties measured in water samples included specific conductance, $\mathrm{pH}$, temperature, and alkalinity. Specific conductance in ground-water samples was relatively high, with a median of $364 \mu \mathrm{S} / \mathrm{cm}$ (at 25 degrees Celsius) and a range of 77 to $7,720 \mu \mathrm{S} / \mathrm{cm}$. This was similar to specific conductance in surface-water samples, which had a median of $554 \mu \mathrm{S} / \mathrm{cm}$, and a range of 87 to $2,210 \mu \mathrm{S} / \mathrm{cm}$. The surficial aquifer on Carroll Island is believed to be hydraulically connected to the estuaries surrounding the island, and much of the ground water in this aquifer is probably influenced by brackish-water intrusion or overwash.

The $\mathrm{pH}$ of water on Carroll Island varied among the ground-water and surface-water environments present on the island. The $\mathrm{pH}$ of ground water in the surficial aquifer generally was low, with a median of 5.77 and a range of 4.09 to 6.84 . The $\mathrm{pH}$ of ground water in the confined aquifer was significantly higher, with a range of 6.62 to 8.83 and a median of 7.03. In surface water, the $\mathrm{pH}$ of inland samples was not significantly different from the $\mathrm{pH}$ of estuarine samples, but the median $\mathrm{pH}$ of all surface-water samples was higher than the median $\mathrm{pH}$ in ground-water samples. The $\mathrm{pH}$ in surface-water samples ranged from 5.53 to 7.45 , with a median of 6.92 .

Alkalinity distributions from the Carroll Island samples also varied somewhat among the different environments. Alkalinity in samples from the surficial aquifer was widely variable, ranging from a low of $1 \mathrm{mg} / \mathrm{L}$ to a high of $525 \mathrm{mg} / \mathrm{L}$, with a median of $35 \mathrm{mg} / \mathrm{L}$. Alkalinity in samples from the confined aquifer was significantly higher than alkalinity in samples from the surficial aquifer. The range of alkalinity in samples from the confined aquifer was narrower than the range in samples from the surficial aquifer, with a minimum of $111 \mathrm{mg} / \mathrm{L}$, a maximum of $253 \mathrm{mg} / \mathrm{L}$, and a median of $213.5 \mathrm{mg} / \mathrm{L}$. There was no significant difference in alkalinity between groundwater and surface-water samples.

Most of the $\mathrm{pH}$ values in ground-water samples were outside the Secondary Maximum Contaminant Level (SMCL) range (pH 6.5 to 8.5) for drinking water set by the U.S. Environmental Protection Agency (USEPA). The low $\mathrm{pH}$ values in the surficial aquifer may be due primarily to the acidic soils on Carroll Island, which would be unlikely to provide much buffering capacity to the water as it infiltrates into the aquifer. The higher $\mathrm{pH}$ and alkalinity values in the confined aquifer probably resulted from dissolution of calcium carbonate from shell material in the upper confining unit as water passed through the confining unit into the confined aquifer.

Brackish-water intrusion or overwash is a dominant factor in the major-ion chemistry of the surficial aquifer at Carroll Island. Ground-water samples from the surficial aquifer in the east-central part of Carroll Island were more dilute than samples near the shoreline. The ratio of sodium to chloride in ground-water samples from the surficial aquifer is highly correlated, which would be expected for brackish water. This correlation would not be likely if the sources of sodium and chloride were primarily the chemical decontaminants applied during the military testing on the island.

Of the major ionic constituents in ground water, chloride, sulfate, and fluoride were detected in concentrations that exceeded non-enforceable drinking- 
water regulations set by USEPA. Chloride concentrations in ground-water samples exceeded the SMCL of $250 \mathrm{mg} / \mathrm{L}$ at 14 sites in the surficial aquifer, and at one site in the confined aquifer. Sulfate concentrations exceeded the SMCL of $250 \mathrm{mg} / \mathrm{L}$ at five sites in the surficial aquifer. Fluoride concentrations exceeded the SMCL of $2.0 \mathrm{mg} / \mathrm{L}$ at three sites in the surficial aquifer, and fluoride was not detected in the confined aquifer. The sources of the high concentrations of major ionic constituents in most of the ground-water samples apparently are brackish-water intrusion or overwash.

The concentrations of minor constituents in water samples exceeded water-quality standards and criteria in several instances. The concentrations of some of the minor constituents probably reflect natural hydrochemical conditions, and may not be indicative of ground-water contamination.

In ground water, the health-based Maximum Contaminant Level (MCL) drinking-water action level for lead was exceeded in one sample (in the surficial aquifer at the Bengies Point Road dump site). No other MCL's were exceeded. The SMCL regulations, which are aesthetically based, were exceeded in at least 14 samples for aluminium, in 44 samples for iron, and in 53 samples for manganese. The MCL goals and proposed MCL's (also health-based, but not enforceable) were lower than the reporting limit for antimony, beryllium, and thallium. It is thought that the concentrations of lead found in ground water are not significantly different from background concentrations, and that the concentrations of aluminum, iron, and manganese in ground water are naturally occurring.

In surface water, freshwater acute (FWA) and chronic (FWC) criteria were exceeded for several of the minor constituents. The FWA criterion for aluminum was exceeded in one of the 14 inland sites and two of the six estuarine sites. The FWC criterion for aluminum was lower than the reporting limit. Beryllium was detected at one inland sample. The concentration of beryllium in this sample was lower than the FWA criterion, but the FWC criterion was lower than the reporting limit. Cadmium was detected at two inland surface-water sites. The FWA and FWC criteria were lower than the reporting limit for cadmium. Chromium was detected at one inland surface-water sample at a concentration that exceeded both criteria.

Copper concentrations in six inland surfacewater samples exceeded or equaled the FWA crite- rion. Copper concentrations at these and three other inland sites exceeded the FWC criterion. The copper in these samples probably results from the leaching of naturally-occurring copper in the soil and sediment. The copper concentration exceeded both of the freshwater criteria in one estuarine sample near the Lower Island disposal site, but it was not detected in the replicate. Silver was detected at two inland samples. Both fresh-water criteria for silver were lower than the reporting limit. Thallium was detected in one inland surface-water site. The concentration of thallium in this sample was lower than the FWA criterion, but the FWC criterion was lower than the reporting limit for thallium. Zinc was detected in eight inland surface-water samples. Of these, four had concentrations above the FWC, and one had a zinc concentration above the FWA. The sources of zinc in these samples are probably natural.

In soil samples, minor constituents such as arsenic, boron, chromium, copper, iron, lead, manganese, mercury, and zinc were detected at various concentrations. Most of these constituents were detected at levels within the ranges commonly found in soils. Antimony, cadmium, and selenium were not detected in soil samples.

Volatile and semivolatile organic compounds were detected in ground-water, surface-water, and soil samples collected from Carroll Island. Volatile compounds were detected in five ground-water samples collected from four sites, in one surface-water sample, and in five soil samples from four sites. Semivolatile compounds were detected in six groundwater samples from five sites, in seven surface-water samples from four sites, and in 24 soil samples (not including replicates) from all over the island.

The volatile compounds detected in groundwater samples were 1,2-dichloroethane, methylene chloride, and trichlorofluoromethane. Two of the compounds, 1,2-dichloroethane and methylene chloride, were regulated by MCL's of $5.0 \mu \mathrm{g} / \mathrm{L}$ and MCLG's of zero. The concentration of 1,2-dichloroethane was below the MCL in the sample from a well at the wind tunnel. The concentration of methylene chloride exceeded the MCL in the two samples at the dredge spoil site and the sample at the Bengies Point Road dump site in which the compound was detected. The maximum concentration of methylene chloride was $47.2 \mu \mathrm{g} / \mathrm{L}$. Trichlorofluoromethane, which was unregulated by drinking-water standards, was detected at $2.10 \mu \mathrm{g} / \mathrm{L}$ in a well at test grid 2 . 
The volatile compounds detected in surface water were benzene and toluene, which were detected at very low levels (less than $1 \mu \mathrm{g} / \mathrm{L}$ ) at one site at test grid 2. The concentrations were well below the applicable water-quality criteria for the compounds. The FWA for benzene was $5,300 \mu \mathrm{g} / \mathrm{L}$, and the FWA for toluene was $17,500 \mu \mathrm{g} / \mathrm{L}$.

Two volatile compounds were detected in soil samples. One compound, 1,1,2,2-tetrachloroethane, was detected at the EPG dump site, the Lower Island disposal site, the CS test area, and the wind tunnel.

Methylene chloride was detected in soil at the Lower Island disposal site. The highest concentration of any volatile compound in soil was $0.39 \mu \mathrm{g} / \mathrm{g}$ of $1,1,2,2-$ tetrachloroethane.

Semivolatile organic compounds were detected in six ground-water samples, six surface-water samples, and 23 soil samples on Carroll Island. The compounds 3-methyl naphthalene, acetone, naphthalene, 1,2-epoxycyclohexene, and diacetone alcohol were detected in ground-water samples. In surface-water samples, thiodiglycol and three organic acids were detected. Acetone, 4-methylphenol, butylbenzyl phthalate, methylethyl ketone, and seven organic acids were detected in soil samples.

Semivolatile compounds were detected in ground-water samples at the Lower Island disposal site, test grids 1 and 2, the wind tunnel, and the VX test area. Concentrations ranged from $2.1 \mu \mathrm{g} / \mathrm{L}$ for 2-methyl naphthalene to $31 \mu \mathrm{g} / \mathrm{L}$ for acetone. All of the detections of semivolatile compounds in ground water were within the surficial aquifer, and none of the detected compounds were regulated by USEPA drinking-water standards.

The semivolatile compounds that were detected in surface-water samples were all at inland sites. These compounds were detected at the Lower Island disposal site and Bengies Point Road dump site, at test grid 2, and at the service area. Concentrations of organic acids (tetradecanoic, pentadecanoic, and hexadecanoic acid) were from 2.0 to $5.0 \mu \mathrm{g} / \mathrm{L}$; the concentration of thiodiglycol was $138 \mu \mathrm{g} / \mathrm{L}$. None of these compounds were subject to FWA or FWC water-quality criteria.

There were more semivolatile compounds detected in soil samples than there were in groundwater and surface-water samples combined. Semivolatile compounds were detected at the four major test areas (test grids 1 and 2, the aerial spray grid, and the wind tunnel), the HD test area, the VX test area, and the area east of the HD test area. These compounds also were detected in the Lower Island disposal site, Bengies Point Road dump site, EPG dump site, BZ test burn pit, decontamination pits, and dredge spoil site, and magazine area. Concentrations of semivolatile compounds detected in soil samples ranged from 0.013 for acetone to $12 \mu \mathrm{g} / \mathrm{g}$ for octadecanoic acid.

Some of the semivolatile organic chemicals that were detected in ground-water, surface-water, and soil samples at Carroll Island are thought to be degradation products that have resulted from the historical testing and decontamination of chemical warfare agents. One such chemical is thiodiglycol, which was detected in a marsh seep at the shoreline south of the Lower Island disposal site. Thiodiglycol is a hydrolysis product of the chemical agent mustard. The detection of thiodiglycol at this site is somewhat suspect because it was lower than the reporting limit for this chemical in the other surface-water samples, but if it is accurate, it is indicative of some source of mustard within the marsh area at the Lower Island disposal site. Other semivolatile constituents are thought to occur naturally or as a result of ambient conditions in the area. These include the organic acids detected in several of the surface-water and soil samples, the naphthalene compounds detected in one ground-water sample at test grid 1, and the phthalate esters detected in soil.

Although the list of organic compounds that were analyzed in ground-water, surface-water, and soil samples from Carroll Island was extensive, some compounds were detected that were not on the list of compounds to be analyzed. These compounds were listed as unknowns. One of the most commonly detected unknowns in ground-water samples was UNK561, tentatively identified as iodocyclohexanol. This compound was detected in samples from 27 wells on Carroll Island, including one well in the confined aquifer. The range of concentrations was 2 to $67 \mu \mathrm{g} / \mathrm{L}$. The compound was not detected in any trip blanks or equipment blanks. The source of iodocyclohexanol is not known, but it is possible that iodocyclohexanol originated from naturally-occurring inorganic and organic compounds present in the ground water at Carroll Island.

The unknown compound UNK599, tentatively identified as tris(2-chloroethyl)ester phosphoric acid, was detected in ground-water samples at test grid 2 , the wind tunnel, the CS test area, and the VX test area in concentrations ranging from 2 to $70 \mu \mathrm{g} / \mathrm{L}$. The 
compound seems similar to the military compound tris(2-chloroethyl)amine, which is a nitrogen mustard. The three areas where this compound was detected in ground-water samples are known to have been test areas, so the compound may have been related to chemical testing.

There were a few other unknown and tentatively identified compounds in ground-water samples. The sources of these compounds are believed to be natural or are unknown.

Only three of the unknown compounds detected in surface water were tentatively identified. These compounds were UNK646, which was tentatively identified as 4,4'-thiobis[(2-(1,1-dimethylethyl)]5-methylphenol; UNK593, which was tentatively identified as tridecanoic acid; and UNK674, which was tentatively identified as stigmasta-5,22-dien$3 \mathrm{~b}-\mathrm{ol}$. The compounds are thought to be naturally occurring, but military sources are possible.

There were many more unknown compounds in the soil samples than in ground-water and surfacewater samples, probably because soils naturally contain more organic material (especially in the surface layers) than natural waters. It also may be a result of anthropogenic organic compounds tending to sorb onto soils rather than go into solution in water.

The most commonly detected unknown compounds in soil samples include UNK536 (reported 28 times in 23 samples), UNK528 (reported 26 times in 22 samples), UNK538 (reported 25 times in 24 samples), UNK541 (reported 18 times in 18 samples), UNK530 (reported 18 times in 9 samples), UNK547 (reported 15 times in 15 samples), and UNK542 (reported 12 times in 12 samples). These unknown compounds had various tentative identifications. Many of these compounds could have occurred naturally or resulted from fallout from industrial air pollution. Tentative identifications of some of the less commonly detected unknown compounds indicate that they may have had a military source. The tentative identification of UNK615, UNK623, UNK633, UNK639, UNK647, and UNK656 was a phosphonic acid, which is a type of compound that can result from nerve agent degradation. The tentative identification of UNK548 indicates that its source may have been a cooling fluid used in the wind tunnel.

\section{REFERENCES CITED}

Bennett, R.R., and Meyer, R.R., 1952, Geology and groundwater resources of the Baltimore Area: State of Maryland, Board of Natural Resources, Department of Geology, Mines, and Water Resources, Bulletin 4, 573 p.

Bouwer, Herman, and Rice, R.C., 1976, A slug test for determining hydraulic conductivity of unconfined aquifers with completely or partially penetrating wells: Water Resources Research, v. 12, no. 3, p. 423-428.

Brady, N.C., 1974, The nature and properties of soils, 8 th ed: New York, MacMillan, 639 p.

Busenberg, Eurybiades, and Plummer, L.N., 1992, Use of chlorofluorocarbons $\left(\mathrm{CCl}_{3} \mathrm{~F}\right.$ and $\left.\mathrm{CCl}_{3} \mathrm{~F}_{2}\right)$ as hydrologic tracers and age-dating tools--the alluvium and terrace system of central Oklahoma: Water Resources Research, v. 28, no. 9, p. 2,257-2,283.

Chapelle, F.H., 1985, Hydrogeology, digital solute-transport simulation, and geochemistry of the lower Cretaceous aquifer system near Baltimore, Maryland: Maryland Geological Survey Report of Investigations No. 43, $120 \mathrm{p}$.

Chirlin, G.R., 1989, A critique of the Hvorslev method for slug test analysis--the fully penetrating well: Ground Water Monitoring Review, v. 9, no. 2, p. 130-138.

Cooper, H.H., Bredehoeft, J.D., and Papadopulos, I.S., 1967, Response of a finite-diameter well to an instantaneous charge of water: Water Resources Research, v. 3, no. 1, p. 263-269.

Crowley, W.P., Reinhardt, Juergen, and Cleaves, E.T., 1976, Geologic map of Baltimore County and City, Maryland: Baltimore, Maryland Geological Survey, scale 1:62,500.

Drever, J.I., 1988, The geochemistry of natural waters, 2nd ed: Englewood Cliffs, N.J., Prentice Hall, 437 p.

Fenneman, N.M., 1938, Physiography of eastern United States: New York, McGraw-Hill, 714 p.

Fetter, C.W., 1980, Applied hydrogeology: Columbus, Ohio, Charles E. Merrill, 488 p.

Freeze, R.A., and Cherry, J.A., 1979, Groundwater: Englewood Cliffs, N.J., Prentice Hall, 604 p.

Gill, J.D., 1989, Simultaneous measurement of compressibility and hydraulic conductivity using volume controlled methods: Golden, Colorado, Colorado School of Mines, Master's thesis, $184 \mathrm{p}$.

Hack, J.T., 1957, Submerged river system of Chesapeake Bay: Bulletin of the Geological Society of America, v. 68, p. $817-830$. 
Ham, L.K., Phillips, S.W., Sears, L.N., and Tenbus, F.J., 1991, Hydrogeologic data for Carroll Island, Aberdeen Proving Ground, Maryland: U.S. Geological Survey Open-File Report 89-388, 105 p.

Hansen, H.J., 1972, A user's guide for the artesian aquifers of the Maryland Coastal Plain--Part two, aquifer characteristics: Maryland Geological Survey Miscellaneous Open-File Report, 123 p.

Hem, J.D., 1989, Study and interpretation of the chemical characteristics of natural water ( $3 \mathrm{~d}$ ed.): U.S. Geological Survey Water-Supply Paper 2254, 263 p.

Hughes, W.B., 1993, Hydrogeology and soil gas at J-field, Aberdeen Proving Ground, Maryland: U.S. Geological Survey Water Resources Investigations Report 92-4087, 83 p.

Hvorslev, M.J., 1951, Time lag and soil permeability in groundwater observations: U.S. Army Corps of Engineers Waterways Experimental Station Bulletin No. 36, $50 \mathrm{p}$.

Iman, R.L., and Conover, W.J., 1983, A modern approach to statistics: New York, John Wiley, 497 p.

Lorah, M.M., and Vroblesky, D.A., 1989, Inorganic and organic ground-water chemistry in the Canal Creek area of Aberdeen Proving Ground, Maryland: U.S. Geological Survey Water Resources Investigations Report 89-4022, 97 p.

Lucius, J.E., Olhoeft, G.R., Hill, P.J., and Duke, S.K., 1989, Properties and hazards of 108 selected substances: U.S. Geological Survey Open-File Report 89-491, 538 p.

Nemeth, Gary, 1989, Resource Conservation and Recovery Act (RCRA) facility assessment, Edgewood Area, Aberdeen Proving Ground, Maryland: Aberdeen Proving Ground, Maryland, Report No. 39-26-0490-90, $1,158 \mathrm{p}$.

Nemeth, Gary, Murphy, J.M. Jr., and Zarzycki, J.H., 1983, Environmental survey of the Edgewood Area of Aberdeen Proving Ground, Maryland: Aberdeen Proving Ground, Maryland, Report No. DRXTH-ASFR-82185, variously paged.

Oliveros, J.P., and Vroblesky, D.A., 1989, Hydrogeology of the Canal Creek area, Aberdeen Proving Ground, Maryland: U.S. Geological Survey Water Resources Investigations Report 89-4021, $50 \mathrm{p}$.

Otton, E.G., and Mandle, R.J., 1984, Hydrology of the upper Chesapeake Bay area, Maryland, with emphasis on the aquifers of the Potomac Group: Maryland Geological Survey Report of Investigations No. 39, 62 p.

Pearson, J.G., and Bender, E.S., 1975, Effects of discharge from a dredge spoils site on Carroll Island, Maryland: Aberdeen Proving Ground, Maryland, Edgewood Arsenal Technical Report No. EB-TR-75030, 21 p.
Pinkham, C.F., Braid, M.R., Roelle, J.E., and Slack, R.S., 1976, Effects of tests with military chemicals on the mammals of Carroll Island: Aberdeen Proving Ground, Maryland, Edgewood Arsenal Technical Report EO-TR-76071, 68 p.

Reed, J.E., 1980, Type curves for selected problems of flow to wells in confined aquifers: U.S. Geological Survey Techniques of Water-Resources Investigations, book 3 , chap. B3, 106 p.

Reybold, R.U., III, and Matthews, E.D., 1976, Soil survey of Baltimore County, Maryland: Washington, D.C., U.S. Department of Agriculture, Soil Conservation Service, $149 \mathrm{p}$.

Rice, K.C, and Bricker, O.P., 1992, Acid rain and its effect on streamwater quality on Catoctin Mountain, Maryland: U.S. Geological Survey Open-File Report 92-168, $2 \mathrm{p}$.

Roelle, J.E., and Slack, R.S., 1972, The distribution, abundance, and diversity of birds on the Edgewood Arsenal's chemical agent test area: Aberdeen Proving Ground, Maryland, Edgewood Arsenal Technical Report EATR 4646, 37 p.

Slack, R.S., Roelle, J.E., Ward, F.P., and Pinkham, C.F., 1972, Reptiles and amphibians on Edgewood Arsenal's chemical agent test area: Aberdeen Proving Ground, Maryland, Edgewood Arsenal Technical Report EATR 4593, $29 \mathrm{p}$.

Smith, J.A., Witkowski, P.J., and Fusillo, T.V., 1988, Manmade organic compounds in the surface waters of the United States--A review of current understanding: U.S. Geological Survey Circular 1007, 92 p.

Smrchek, J.C., 1971a, Invertebrates collected on and around Carroll Island, Maryland: Aberdeen Proving Ground, Maryland, Edgewood Arsenal Technical Report EATR 4552, $27 \mathrm{p}$.

1971b, Populations of soil-litter invertebrates on Edgewood Arsenal's chemical agent test area: Aberdeen Proving Ground, Maryland, Edgewood Arsenal Technical Report EATR 4600, 21 p.

Speir, H.J., 1972, Fish populations around Edgewood Arsenal's chemical agent test area: Aberdeen Proving Ground, Maryland, Edgewood Arsenal Technical Report EATR 4609, 27 p.

Tenbus, F.J., and Blomquist, J.D., 1995, Hydrogeology and water quality in the Graces Quarters area of Aberdeen Proving Ground, Maryland: U.S. Geological Survey Water Resources Investigations Report 94-4175, $115 \mathrm{p}$.

Tenbus, F.J., and Phillips, S.W., 1990, Study approach for the hydrogeologic assessment of Carroll Island and Graces Quarters, Aberdeen Proving Ground, Maryland: U.S. Geological Survey Open-File Report 90-181, 110 p. 
Thurman, E.M., 1985, Organic geochemistry of natural waters: Dordrecht, The Netherlands, Martinus Nijhoff/Dr W. Junk, 497 p.

U.S. Environmental Protection Agency, 1986, Quality Criteria for Water, U.S. Environmental Protection Agency440/5-86-001: Washington, D.C., U.S. Environmental Protection Agency Office of Water Regulations and Standards, variously paged.

1989, Proposed rule, National primary and secondary drinking water regulations (sections 141.50, 141.51, 141.61, and 141.62 of part 141 and 143.3 of part 143) U.S. Federal Register, v 54, no. 97, May 22, 1989, p. 22,062-22,160.

1990a, Proposed rule, National primary and secondary drinking water regulations--Synthetic organic compounds and inorganic chemicals (sections 141.50, 141.51, 141.61, and 141.62 of part 141 and 143.3 of part 143) U.S. Federal Register, v. 55, no. 143, July 25, 1990, p. 30,370-30,448.

1990b, Maximum contaminant levels (subpart B of part 141, National primary drinking water regulations): U.S. Code of Federal Regulations, Title 40, Parts 100 to 149 , revised as of July 1,1990 , p. 559-563.

1990c, Maximum contaminant level goals (subpart $F$ of part 141, National primary drinking water regulations): U.S. Code of Federal Regulations, Title 40, Parts 100 to 149 , revised as of July 1, 1990, p. 620-621.

1990d, National revised primary drinking water regulations: maximum contaminant levels (subpart $\mathrm{G}$ of part 141, National primary drinking water regulations): U.S. Code of Federal Regulations, Title 40, Parts 100 to 149, revised as of July 1, 1990, p. 621-622.

$1990 \mathrm{e}$, Secondary maximum contaminant levels (section 143.3 of part 143, National secondary drinking water regulations): U.S. Code of Federal Regulations, Title 40, Parts 100 to 149 , revised as of July 1, 1990, p. 674 .

1991a, Final rule, National primary and secondary drinking water regulations--Synthetic organic chemicals and inorganic chemicals (sections 141.11, 141.12, $141.32,141.50,141.51,141.61$, and 141.62 of part 141 and 143.3 of part 143) U.S. Federal Register, v. 56, no. 20, January 30,1991 , p. 3,526-3,597.

1991b, Final rule, Maximum contaminant level goals and national primary drinking water regulations for lead and copper (sections 141.11, 141.32, and 141.51 of part 141) U.S. Federal Register, v 56, no. 110, June 7, 1991, p. 26,460-26,564. 1991c, Final rule, National primary drinking water regulations--MCLG's and MCL's for aldicarb, aldicarb sulfoxide, aldicarb sulfone, pentachlorophenol, and barium (sections 141.50, 141.51, 141.61, and 141.62 of part 141) U.S. Federal Register, n. 56, no. 126, July 1, 1991, p. 30,266-33,124.

1992, Final rule, National primary and secondary drinking water regulations--Synthetic organic chemicals and inorganic chemicals (sections 141.12, 141.32, $141.50,141.51,141.61$, and 141.62 of part 141 and 143.3 of part 143) U.S. Federal Register, v. 57 , no. 138, July 17, 1992, p. 31,776-31,849.

Vroblesky, D.A., Lorah, M.M., and Oliveros, J.P., 1989, Ground-water, surface-water, and bottom-sediment contamination in the O-field area, Aberdeen Proving Ground, Maryland, and the possible effects of selected remedial actions on ground water: U.S. Geological Survey Open-File Report 89-399, 162 p.

Ward, F.P., 1971, A summary of ecological investigations at Edgewood Arsenal, Maryland, fiscal year 1970: Aberdeen Proving Ground, Maryland, Edgewood Arsenal Special Publication EASP 100-101, 87 p.

Ward, F.P., and Pinkham, C.F., 1973, An analysis of chemical agent tests at Carroll Island, Maryland, in recent years: Aberdeen Proving Ground, Maryland, Edgewood Arsenal Technical Report EATR 4709, 16 p.

Weimer, J.T., Owens, E.J., Samuel, J.B., Olson, J.S., and Merky, R.P., 1970, Toxicity of VX and GD in the aquatic animals indigenous to the Carroll Island test area water: Aberdeen Proving Ground, Maryland, Edgewood Arsenal Technical Report EATR 4441, 39 p.

Windholz, Martha, Budavari, Susan, Blumetti, R.F., and Otterbein, E.S., eds., 1983, The Merck index--An encyclopedia of chemicals, drugs, and biologicals (10th ed.): Rahway, N.J., Merck and Co., 1,463 p. plus appendixes. 
TABLES 11 - 23 
Table 11. Results of inorganic-chemical analyses of water from selected wells in the surficial aquifer at Carroll Island, Aberdeen Proving Ground, Md., spring 1989

[All concentrations are for dissolved constituents in units of milligrams per liter; deg $\mathrm{C}$, degrees Celsius; $\mu \mathrm{S} / \mathrm{cm}$, microsiemens per centimeter; (R), replicate sample; (S), split sample; --, missing data; <, less than]

\begin{tabular}{|c|c|c|c|c|c|c|c|c|}
\hline $\begin{array}{c}\text { Well } \\
\text { number } \\
\text { (fig. 3) }\end{array}$ & $\begin{array}{c}\text { Sampling } \\
\text { date }\end{array}$ & $\begin{array}{c}\text { Specific } \\
\text { conductance, } \\
\text { field } \\
(\mu \mathrm{S} / \mathrm{cm})\end{array}$ & $\begin{array}{c}\mathrm{pH}, \\
\text { field } \\
\text { (units) }\end{array}$ & $\begin{array}{c}\text { Temperature, } \\
\text { field } \\
\text { (deg C) }\end{array}$ & $\begin{array}{c}\text { Dissolved } \\
\text { oxygen, } \\
\text { field }\end{array}$ & $\begin{array}{l}\text { Calcium } \\
\text { (as Ca) }\end{array}$ & $\begin{array}{c}\text { Magnesium } \\
\text { (as Mg) }\end{array}$ & $\begin{array}{l}\text { Sodium } \\
\text { (as } \mathrm{Na} \text { ) }\end{array}$ \\
\hline 101 & $04-26-89$ & 180 & 6.23 & 11 & 8.4 & 28.0 & 1.56 & 4.87 \\
\hline 102 & $04-26-89$ & 113 & 5.90 & 10 & 6.5 & 12.0 & 2.21 & 3.38 \\
\hline I03 & $04-26-89$ & 874 & 5.69 & 11 & 5.0 & 21.0 & 26.0 & 95.0 \\
\hline I04 & $05-03-89$ & 147 & 5.17 & 10 & 10.3 & 6.63 & 6.91 & 5.28 \\
\hline 105 & $05-03-89$ & 77 & 5.52 & 11 & 18.6 & 7.06 & 1.60 & 2.09 \\
\hline I06 & $05-03-89$ & 108 & 4.78 & 10 & 10.0 & 4.33 & 6.03 & 2.84 \\
\hline 107 & $05-03-89$ & 80 & 5.22 & 11 & 9.0 & 3.78 & 3.37 & 3.83 \\
\hline 108 & $05-03-89$ & 266 & 5.37 & 10 & 2.0 & 8.64 & 7.25 & 12.9 \\
\hline 109 & $04-25-89$ & 462 & 5.69 & 12 & 2.1 & 8.54 & 10.5 & 35.8 \\
\hline 110 & $04-25-89$ & 467 & 5.96 & 11 & 1.9 & 14.4 & 14.8 & 37.3 \\
\hline $\mathrm{I} 12$ & $05-09-89$ & 2,910 & 4.63 & 11 & 1.7 & 40.0 & 80.0 & 370 \\
\hline I13 & $05-08-89$ & - & 6.48 & 10 & 1.0 & 20.1 & 5.25 & 24.2 \\
\hline I14 & $05-08-89$ & 363 & 6.22 & 10 & 5.1 & 12.6 & 6.32 & 40.8 \\
\hline I15 & $05-08-89$ & 807 & 5.77 & 11 & 1.5 & 31.0 & 20.0 & 70.0 \\
\hline I16B & $05-08-89$ & 2,480 & 5.46 & 10 & 1.9 & 57.0 & 45.0 & 270 \\
\hline I17 & $05-08-89$ & 227 & 6.23 & 11 & 5.3 & 8.70 & 2.33 & 25.7 \\
\hline $117(\mathrm{~S})$ & $05-08-89$ & 227 & 6.23 & 11 & 5.3 & 11.0 & 2.70 & 29.0 \\
\hline I18 & $05-08-89$ & 237 & 5.53 & 10 & 3.1 & 4.11 & 3.90 & 24.0 \\
\hline I18 (R) & $05-08-89$ & 237 & 5.53 & 10 & 3.1 & 4.86 & 4.17 & 27.7 \\
\hline II 8 (S) & $05-08-89$ & 237 & 5.53 & 10 & 3.1 & 5.40 & 4.80 & 28.0 \\
\hline I19 & $05-08-89$ & 655 & 5.89 & 12 & 1.3 & 10.5 & 9.23 & 66.0 \\
\hline 120 & $05-09-89$ & 239 & 5.39 & 11 & 1.9 & 4.65 & 4.55 & 25.5 \\
\hline I 21 & $05-09-89$ & 255 & 5.15 & 11 & 1.6 & 3.33 & 4.30 & 34.5 \\
\hline I $22 \mathrm{~B}$ & $05-04-89$ & 270 & 6.04 & 12 & 1.8 & 6.89 & 4.12 & 23.5 \\
\hline I22B (R) & $05-04-89$ & 270 & 6.04 & 12 & 1.8 & 7.93 & 4.47 & 27.1 \\
\hline $\mathrm{I} 22 \mathrm{C}$ & $05-04-89$ & 2,840 & 5.91 & 12 & 5.0 & 73.0 & 68.0 & 320 \\
\hline 123 & $05-09-89$ & 1,190 & 5.74 & 11 & 1.9 & 14.5 & 14.1 & 150 \\
\hline $\mathrm{I} 24$ & $05-02-89$ & 176 & 5.34 & 11 & 9.3 & 6.12 & 5.06 & 10.8 \\
\hline I25 & $05-04-89$ & 348 & 6.28 & 11 & 2.2 & 4.82 & 5.83 & 27.6 \\
\hline $126 \mathrm{~A}$ & $04-27-89$ & 279 & 6.06 & 13 & 1.3 & 8.39 & 3.43 & 27.4 \\
\hline I26A (R) & $04-27-89$ & 279 & 6.06 & 13 & 1.3 & -- & -. & -- \\
\hline $126 \mathrm{~A}(\mathrm{~S})$ & $04-27-89$ & 279 & 6.06 & 13 & 1.3 & 8.50 & 3.60 & 28.0 \\
\hline I26B & $05-02-89$ & 218 & 4.73 & 10 & 2.5 & 5.37 & 11.1 & 16.0 \\
\hline I $27 \mathrm{~B}$ & $04-20-89$ & 703 & 4.39 & 9 & 1.8 & 10.2 & 20.0 & 89.0 \\
\hline 128 & $04-20-89$ & 738 & 4.80 & 9 & 2.7 & 16.7 & 10.8 & 94.0 \\
\hline 129 & $04-20-89$ & 255 & 5.01 & 9 & 3.2 & 4.95 & 4.35 & 32.3 \\
\hline 130 & $04-20-89$ & 476 & 5.75 & 10 & 2.1 & 11.4 & 6.83 & 28.6 \\
\hline 131 & $05-04-89$ & 328 & 5.51 & 12 & 3.0 & 6.27 & 7.82 & 40.0 \\
\hline I32 & $05-01-89$ & 357 & 6.08 & 11 & 1.6 & 4.70 & 10.0 & 40.8 \\
\hline 133 & $05-01-89$ & 185 & 6.04 & 12 & 2.1 & 4.17 & 4.05 & 15.1 \\
\hline I33 (S) & $05-01-89$ & 185 & 6.04 & 12 & 2.1 & 4.40 & 4.30 & 15.0 \\
\hline 134 & $05-01-89$ & 205 & 6.33 & 13 & 2.2 & 12.6 & 1.53 & 17.8 \\
\hline $134(\mathrm{R})$ & $05-01-89$ & 205 & 6.33 & 13 & 2.2 & 14.3 & 1.67 & 17.7 \\
\hline I34 (S) & $05-01-89$ & 205 & 6.33 & 13 & 2.2 & 15.0 & 1.90 & 19.0 \\
\hline I 35 & $05-02-89$ & 111 & 6.05 & 12 & 1.9 & 3.41 & 3.36 & 14.2 \\
\hline I36 & $05-02-89$ & 187 & 5.79 & 12 & 1.5 & 3.78 & 3.76 & 21.0 \\
\hline I37B & $04-24-89$ & 249 & 6.41 & 11 & 1.3 & 6.58 & 5.37 & 24.3 \\
\hline I37B (R) & $04-24-89$ & 249 & 6.41 & 11 & 1.3 & 6.57 & 5.38 & 23.7 \\
\hline 138 & $04-26-89$ & 213 & 5.68 & 11 & 2.2 & 3.96 & 6.13 & 23.3 \\
\hline I39 & $04-26-89$ & 303 & 6.42 & 12 & 2.0 & 36.0 & 6.78 & 8.87 \\
\hline I 40 & $04-26-89$ & 511 & 6.84 & 12 & 2.5 & 39.0 & 5.23 & 65.0 \\
\hline 141 & $04-26-89$ & 7,720 & 4.56 & 10 & 3.5 & 84.0 & 180 & 1,300 \\
\hline 142 & $04-26-89$ & 5,780 & 5.77 & 10 & 2.8 & 60.0 & 110 & 850 \\
\hline I 43 & $04-26-89$ & 6,500 & 4.09 & 10 & 3.2 & 52.0 & 140 & 1,200 \\
\hline I 44 & $05-09-89$ & 425 & 5.78 & 10 & 2.7 & 13.9 & 5.92 & 51.4 \\
\hline 145 & $05-15-89$ & 264 & 6.58 & 12 & 2.3 & 23.0 & 48.0 & 410 \\
\hline 146 & $05-15-89$ & 248 & 6.58 & 12 & 2.4 & 6.68 & 7.81 & 17.9 \\
\hline I $47 \mathrm{~A}$ & $05-09-89$ & 3,570 & 4.42 & 10 & 2.8 & 24.0 & 44.0 & 390 \\
\hline I 48 & $05-09-89$ & 343 & 5.54 & 11 & 2.7 & 9.64 & 4.33 & 34.1 \\
\hline 149 & $05-09-89$ & 485 & 6.52 & 11 & 2.5 & 13.1 & 11.7 & $\begin{array}{l}54.1 \\
50.3\end{array}$ \\
\hline I50 & $05-15-89$ & 1,330 & 5.80 & 12 & 2.4 & 27.0 & 12.1 & 88.0 \\
\hline I51 & $05-15-89$ & 3,400 & 5.90 & 11 & 2.0 & 27.0 & 55.0 & 420 \\
\hline I52 & $05-15-89$ & 1,500 & 6.18 & 12 & 2.1 & 12.1 & 15.5 & $\begin{array}{l}420 \\
180\end{array}$ \\
\hline I53 & $05-15-89$ & 365 & 4.78 & 11 & 3.7 & 24.0 & 75.0 & 430 \\
\hline $153(\mathrm{R})$ & $05-15-89$ & 365 & 4.78 & 11 & 3.7 & 31.0 & 97.0 & 570 \\
\hline \multirow[t]{2}{*}{ I54A } & $05-15-89$ & 2,160 & 4.43 & 11 & 5.1 & 20.0 & 34.0 & 220 \\
\hline & & & & & & & \multicolumn{2}{|c|}{ TABLES } \\
\hline
\end{tabular}


Table 11. Results of inorganic-chemical analyses of water from selected wells in the surficial aquifer at Carroll Island, Aberdeen Proving Ground, Md., spring 1989--Continued

\begin{tabular}{|c|c|c|c|c|c|c|c|c|c|}
\hline $\begin{array}{c}\text { Well } \\
\text { number } \\
\text { (fig. 3) }\end{array}$ & $\begin{array}{c}\text { Potas- } \\
\text { sium } \\
\text { (as K) }\end{array}$ & $\begin{array}{c}\text { Alkalinity, } \\
\text { field } \\
\text { (as } \\
\mathrm{CaCO}_{3} \text { ) } \\
\end{array}$ & $\begin{array}{c}\text { Bicar- } \\
\text { bonate, } \\
\text { field } \\
\left(\text { as } \mathrm{HCO}_{3}\right)\end{array}$ & $\begin{array}{c}\text { Sulfate } \\
(\text { as SO } \\
\end{array}$ & $\begin{array}{c}\text { Chloride } \\
\text { (as Cl) }\end{array}$ & $\begin{array}{c}\text { Fluoride } \\
\text { (as F) }\end{array}$ & $\begin{array}{c}\text { Bromide } \\
\text { (as Br) }\end{array}$ & $\begin{array}{c}\text { Silica } \\
\text { (as SiO } \\
\text { (a) }\end{array}$ & $\begin{array}{c}\text { Nitrogen } \\
\mathrm{NO}_{2}+\mathrm{NO}_{3} \\
(\text { as N) } \\
\end{array}$ \\
\hline I01 & 0.444 & 67 & 82 & 19.7 & 9.97 & $<1.23$ & $<3.00$ & 2.94 & 0.041 \\
\hline $\mathrm{I} 02$ & 2.78 & 19 & 23 & 23.9 & 2.54 & $<1.23$ & $<3.00$ & 5.00 & .015 \\
\hline I03 & 1.64 & 54 & 65 & 96.9 & 240 & $<1.23$ & $<3.00$ & 15.0 & $<.010$ \\
\hline 104 & .760 & 4 & 5 & 52.2 & 5.31 & $<1.23$ & $<1.00$ & 9.50 & .129 \\
\hline I05 & .866 & 4 & 5 & 21.3 & $<2.12$ & $<1.23$ & $<1.00$ & 2.95 & .038 \\
\hline I06 & 1.51 & 2 & 2 & 40.5 & 2.78 & $<1.23$ & $<1.00$ & 4.35 & .191 \\
\hline 107 & 1.63 & 4 & 5 & 27.3 & $<2.12$ & $<1.23$ & $<1.00$ & 6.50 & .037 \\
\hline I08 & 33.0 & 20 & 24 & 84.4 & 10.4 & $<1.23$ & $<1.00$ & 8.90 & .041 \\
\hline I09 & 1.77 & 35 & 43 & 24.1 & 140 & $<1.23$ & $<1.00$ & 13.0 & .025 \\
\hline 110 & 1.45 & 115 & 140 & 142 & 31.7 & $<1.23$ & $<1.00$ & 18.2 & .014 \\
\hline I12 & 6.40 & 2 & 2 & 460 & 930 & $<1.23$ & 2.08 & 8.00 & .021 \\
\hline I13 & 4.24 & 64 & 78 & 26.8 & 30.0 & $<1.23$ & $<1.00$ & 3.55 & .050 \\
\hline I14 & 3.13 & 38 & 46 & 48.4 & 71.0 & $<1.23$ & $<1.00$ & 4.85 & .106 \\
\hline I15 & 2.80 & 28 & 34 & 50.6 & 130 & $<1.23$ & $<1.00$ & 9.50 & $<.010$ \\
\hline $116 \mathrm{~B}$ & 11.7 & 21 & 26 & 196 & 830 & $<1.23$ & 2.34 & 2.80 & .023 \\
\hline 117 & 2.11 & 29 & 36 & 26.7 & 39.0 & $<1.23$ & $<1.00$ & 5.50 & .012 \\
\hline I17 (S) & 1.30 & 29 & 36 & 28.0 & 32.0 & .10 & .13 & 12.0 & .. \\
\hline I18 & 4.38 & 3 & 4 & 27.7 & 60.0 & $<1.23$ & $<1.00$ & 6.00 & .084 \\
\hline $\mathrm{I} 18(\mathrm{R})$ & 3.80 & 3 & 4 & 26.3 & 60.0 & $<1.23$ & $<1.00$ & 6.00 & .081 \\
\hline I18 (S) & 3.80 & 3 & 4 & 28.0 & 50.0 & .10 & .17 & 13.0 & -- \\
\hline I19 & 2.86 & 30 & 37 & $<10.0$ & 220 & $<1.23$ & $<1.00$ & 15.0 & .010 \\
\hline $\mathrm{I} 20$ & 1.68 & 12 & 15 & 31.4 & 60.0 & $<1.23$ & $<1.00$ & 11.0 & $<.010$ \\
\hline I 21 & 2.78 & 5 & 7 & 63.7 & 44.0 & $<1.23$ & $<1.00$ & 11.0 & .120 \\
\hline I $22 \mathrm{~B}$ & 2.48 & 46 & 56 & $<10.0$ & 55.0 & $<1.23$ & $<1.00$ & 14.8 & .013 \\
\hline I22B (R) & 1.35 & 46 & 56 & $<10.0$ & 54.0 & $<1.23$ & $<1.00$ & 15.2 & .013 \\
\hline $\mathrm{I} 22 \mathrm{C}$ & 6.29 & 63 & 77 & 730 & 520 & $<1.23$ & 1.60 & 7.50 & .012 \\
\hline 123 & 2.41 & 53 & 65 & $<10.0$ & 470 & $<1.23$ & $<1.00$ & 11.0 & .019 \\
\hline I 24 & 3.06 & 8 & 9 & 60.2 & 11.8 & $<1.23$ & $<3.00$ & 11.5 & .068 \\
\hline I 25 & 2.94 & 48 & 59 & $<10$ & 88.0 & $<1.23$ & $<1.00$ & 15.8 & $<.010$ \\
\hline $\mathrm{I} 26 \mathrm{~A}$ & 1.43 & 48 & 59 & 34.3 & 37.0 & $<1.23$ & $<3.00$ & 13.8 & $<.010$ \\
\hline I26A (R) & -- & 48 & 59 & -- & -- & - & .. & -- & .. \\
\hline $\mathrm{I} 26 \mathrm{~A}(\mathrm{~S})$ & 1.30 & 48 & 59 & 34.0 & 32 & .10 & .13 & 26.0 & -- \\
\hline $126 \mathrm{~B}$ & 1.43 & 1 & 1 & 90.6 & 7.64 & $<1.23$ & $<3.00$ & 12.0 & .115 \\
\hline I $27 \mathrm{~B}$ & .882 & -- & .. & 49.1 & 240 & $<1.23$ & $<1.00$ & 11.0 & .021 \\
\hline 128 & 1.02 & 6 & 7 & 40.8 & 230 & $<1.23$ & $<1.00$ & 6.50 & $<.010$ \\
\hline 129 & $<.375$ & 5 & 6 & 59.2 & 36.0 & $<1.23$ & $<1.00$ & 6.50 & .011 \\
\hline 130 & .713 & 51 & 62 & $<10.0$ & 150 & $<1.23$ & $<1.00$ & 11.0 & $<.010$ \\
\hline I31 & .982 & 10 & 13 & 30.2 & 81.0 & $<1.23$ & $<1.00$ & 7.25 & $<.010$ \\
\hline I32 & 5.24 & 50 & 61 & 66.9 & 55.0 & $<1.23$ & $<3.00$ & 18.8 & $<.010$ \\
\hline I33 & $<.375$ & 47 & 57 & $<10.0$ & 40.0 & $<1.23$ & $<3.00$ & 14.0 & $<.010$ \\
\hline I33 (S) & .800 & 47 & 57 & $<1.0$ & 31.0 & .10 & .13 & 31.0 & -- \\
\hline I34 & 5.41 & 71 & 87 & $<10.0$ & 26.1 & $<1.23$ & $<3.00$ & 15.2 & $<.010$ \\
\hline I34 (R) & 5.73 & 71 & 87 & $<10.0$ & 26.9 & $<1.23$ & $<3.00$ & 15.0 & $<.010$ \\
\hline 134 (S) & 5.70 & 71 & 87 & $<1.0$ & 19.0 & .10 & .09 & 33.0 & -- \\
\hline I35 & 1.70 & 28 & 34 & $<10.0$ & 16.9 & $<1.23$ & $<3.00$ & 15.0 & .016 \\
\hline I36 & 1.35 & 20 & 24 & $<10.0$ & 43.0 & $<1.23$ & $<3.00$ & 16.8 & .010 \\
\hline $137 \mathrm{~B}$ & $<.375$ & 89 & 109 & 14.8 & 22.5 & $<1.23$ & $<1.00$ & 22.8 & $<.010$ \\
\hline I37B (R) & .818 & 89 & 109 & -- & -. & -- & -- & 22.0 & $<.010$ \\
\hline I38 & .713 & 33 & 40 & 22.9 & 32.0 & $<1.23$ & $<3.00$ & 23.8 & .012 \\
\hline I39 & 1.44 & 134 & 163 & 16.7 & 10.4 & $<1.23$ & $<3.00$ & 22.5 & .019 \\
\hline 140 & 6.20 & 181 & 221 & 72.3 & 15.5 & $<1.23$ & $<3.00$ & 12.0 & .051 \\
\hline I 41 & 13.4 & - & -- & 400 & 3,100 & 3.04 & 9.71 & 6.00 & .014 \\
\hline I42 & 28.0 & 54 & 66 & 169 & 2,300 & 2.17 & 7.98 & 2.40 & .012 \\
\hline 143 & 7.28 & - & -. & 300 & 2,600 & 2.56 & 7.35 & 4.80 & .012 \\
\hline 144 & 2.10 & 26 & 32 & 54.6 & 82.0 & $<1.23$ & $<1.00$ & 6.50 & .020 \\
\hline 145 & 10.3 & 525 & 640 & 68.4 & 740 & 1.21 & 3.41 & 8.00 & .013 \\
\hline 146 & 5.28 & 91 & 111 & 19.0 & 13.1 & $<1.23$ & $<1.00$ & 5.50 & .010 \\
\hline I47A & 5.97 & - & ... & 128 & 1,500 & 1.38 & 4.43 & 6.50 & $<.010$ \\
\hline I 48 & 4.02 & 48 & 59 & 41.3 & 60.0 & $<1.23$ & $<1.00$ & 3.65 & $<.010$ \\
\hline I 49 & 3.63 & 70 & 85 & 64.9 & 93.0 & $<1.23$ & $<1.00$ & 2.20 & .011 \\
\hline 150 & 3.53 & 35 & 43 & $<10.0$ & 470 & $<1.23$ & $<1.00$ & 15.0 & $<.050$ \\
\hline I5I & 13.7 & 53 & 65 & 390 & 1,200 & 1.19 & 2.75 & 3.25 & .020 \\
\hline 152 & 6.25 & 99 & 121 & 21.2 & 510 & $<1.23$ & $<1.00$ & 6.00 & .023 \\
\hline 153 & 3.30 & 3 & 3 & 141 & 1,300 & 1.52 & 3.31 & 4.65 & .117 \\
\hline $\mathrm{I} 53(\mathrm{R})$ & 3.37 & 3 & 3 & 146 & 1,400 & 1.52 & 2.84 & 4.50 & .126 \\
\hline I54A & 1.70 & -- & -- & 152 & 780 & $<1.23$ & $<1.00$ & 6.00 & .016 \\
\hline
\end{tabular}


Table 11. Results of inorganic-chemical analyses of water from selected wells in the surficial aquifer at Carroll Island, Aberdeen Proving Ground, Md., spring 1989--Continued

\begin{tabular}{|c|c|c|c|c|c|c|c|c|}
\hline $\begin{array}{c}\text { Well } \\
\text { number } \\
\text { (fig. 3) }\end{array}$ & $\begin{array}{c}\text { Aluminum } \\
\text { (as Al) }\end{array}$ & $\begin{array}{c}\text { Antimony } \\
\text { (as Sb) }\end{array}$ & $\begin{array}{l}\text { Arsenic } \\
\text { (as As) }\end{array}$ & $\begin{array}{l}\text { Barium } \\
\text { (as Ba) }\end{array}$ & $\begin{array}{c}\text { Beryllium } \\
\text { (as Be) }\end{array}$ & $\begin{array}{c}\text { Cadmium } \\
\text { (as Cd) }\end{array}$ & $\begin{array}{c}\text { Chromium } \\
\text { (as Cr) }\end{array}$ & $\begin{array}{l}\text { Copper } \\
\text { (as Cu) }\end{array}$ \\
\hline $\begin{array}{l}\mathrm{I} 01 \\
\mathrm{I} 02 \\
\mathrm{I} 03 \\
\mathrm{I} 04 \\
\mathrm{I} 05 \\
\mathrm{I} 06 \\
\mathrm{I} 07 \\
\mathrm{I} 08 \\
\mathrm{I} 09 \\
\mathrm{I} 10\end{array}$ & $\begin{array}{r}0.199 \\
<.141 \\
<.141 \\
<.141 \\
.237 \\
<.141 \\
<.141 \\
<.141 \\
<.141 \\
<.141\end{array}$ & $\begin{array}{l}<0.038 \\
<.038 \\
<.038 \\
<.038 \\
<.038 \\
<.038 \\
<.038 \\
<.038 \\
<.038 \\
<.038\end{array}$ & $\begin{array}{r}0.00341 \\
<.00254 \\
<.00254 \\
.00544 \\
<.00254 \\
<.00254 \\
<.00254 \\
<.00254 \\
.00341 \\
.00480\end{array}$ & $\begin{array}{l}0.012 \\
.016 \\
.085 \\
.032 \\
.011 \\
.037 \\
.035 \\
.024 \\
.105 \\
.031\end{array}$ & $\begin{array}{r}<0.00500 \\
<.00500 \\
<.00500 \\
<.00500 \\
<.00500 \\
<.00500 \\
<.00500 \\
<.00500 \\
<.00500 \\
<.00500\end{array}$ & $\begin{array}{r}<0.00401 \\
<.00401 \\
<.00401 \\
<.00401 \\
<.00401 \\
<.00401 \\
<.00401 \\
<.00401 \\
<.00401 \\
<.00401\end{array}$ & $\begin{array}{r}<0.00602 \\
<.00602 \\
<.00602 \\
<.00602 \\
<.00602 \\
<.00602 \\
<.00602 \\
<.00602 \\
<.00602 \\
<.00602\end{array}$ & $\begin{array}{c}0.0162 \\
.0152 \\
.0102 \\
<.00809 \\
<.00809 \\
.0112 \\
.00889 \\
<.00809 \\
.0137 \\
.0115\end{array}$ \\
\hline $\begin{array}{l}\text { I12 } \\
\text { II3 } \\
\text { II4 } \\
\text { I15 } \\
\text { I16B } \\
\text { I17 } \\
\text { I17 (S) } \\
\text { I18 } \\
\text { I18 (R) } \\
\text { I18 (S) }\end{array}$ & $\begin{array}{l}2.08 \\
.673 \\
<.141 \\
<.141 \\
<.141 \\
<.141 \\
<.010 \\
<.141 \\
<.141 \\
.070\end{array}$ & $\begin{array}{l}<.038 \\
<.038 \\
<.038 \\
<.038 \\
<.038 \\
<.038 \\
<.001 \\
<.038 \\
<.038 \\
<.001\end{array}$ & $\begin{array}{l}<.00254 \\
<.00254 \\
<.00254 \\
<.00254 \\
<.00254 \\
<.00254 \\
- \\
<.00254 \\
<.00254 \\
--\end{array}$ & $\begin{array}{l}.018 \\
.030 \\
.017 \\
.103 \\
.036 \\
.026 \\
.034 \\
.042 \\
.046 \\
.055\end{array}$ & $\begin{array}{l}<.00500 \\
<.00500 \\
<.00500 \\
<.00500 \\
<.00500 \\
<.00500 \\
<.0005 \\
<.00500 \\
<.00500 \\
<.0005\end{array}$ & $\begin{array}{l}<.00401 \\
<.00401 \\
<.00401 \\
<.00401 \\
<.00401 \\
<.00401 \\
<.0010 \\
<.00401 \\
<.00401 \\
<.0010\end{array}$ & $\begin{array}{l}<.00602 \\
<.00602 \\
<.00602 \\
<.00602 \\
<.00602 \\
<.00602 \\
<.005 \\
<.00602 \\
<.00602 \\
<.005\end{array}$ & $\begin{array}{c}<.00809 \\
<.00809 \\
<.00809 \\
<.00809 \\
.0152 \\
<.00809 \\
<.010 \\
<.00809 \\
.0104 \\
<.010\end{array}$ \\
\hline $\begin{array}{l}\mathrm{I} 19 \\
\mathrm{I} 20 \\
\mathrm{I} 21 \\
\mathrm{I} 22 \mathrm{~B} \\
\mathrm{I} 22 \mathrm{~B}(\mathrm{R}) \\
\mathrm{I} 22 \mathrm{C} \\
\mathrm{I} 23 \\
\mathrm{I} 24 \\
\mathrm{I} 25 \\
\mathrm{I} 26 \mathrm{~A}\end{array}$ & $\begin{array}{l}<.141 \\
<.141 \\
<.141 \\
<.141 \\
<.141 \\
<.141 \\
<.141 \\
<.141 \\
<.141 \\
<.141\end{array}$ & $\begin{array}{l}<.038 \\
<.038 \\
<.038 \\
<.038 \\
<.038 \\
<.038 \\
<.038 \\
<.038 \\
<.038 \\
<.038\end{array}$ & $\begin{array}{r}<.00254 \\
<.00254 \\
<.00254 \\
<.00254 \\
<.00254 \\
.00672 \\
<.00254 \\
.00277 \\
<.00254 \\
.00309\end{array}$ & $\begin{array}{l}.070 \\
.038 \\
.046 \\
.048 \\
.057 \\
.021 \\
.206 \\
.020 \\
.055 \\
.081\end{array}$ & $\begin{array}{l}<.00500 \\
<.00500 \\
<.00500 \\
<.00500 \\
<.00500 \\
<.00500 \\
<.00500 \\
<.00500 \\
<.00500 \\
<.00500\end{array}$ & $\begin{array}{l}<.00401 \\
<.00401 \\
<.00401 \\
<.00401 \\
<.00401 \\
<.00401 \\
<.00401 \\
<.00401 \\
<.00401 \\
<.00401\end{array}$ & $\begin{array}{r}<.00602 \\
<.00602 \\
<.00602 \\
<.00602 \\
<.00602 \\
<.00602 \\
<.00602 \\
<.00602 \\
<.00602 \\
.00707\end{array}$ & $\begin{array}{c}<.00809 \\
<.00809 \\
<.00809 \\
<.00809 \\
<.00809 \\
<.00809 \\
<.00809 \\
<.00809 \\
<.00809 \\
.0314\end{array}$ \\
\hline $\begin{array}{l}\mathrm{I} 26 \mathrm{~A}(\mathrm{R}) \\
\mathrm{I} 26 \mathrm{~A}(\mathrm{~S}) \\
\mathrm{I} 26 \mathrm{~B} \\
\mathrm{I} 27 \mathrm{~B} \\
\mathrm{I} 28 \\
\mathrm{I} 29 \\
\mathrm{I} 30 \\
\mathrm{I} 31 \\
\mathrm{I} 32 \\
\mathrm{I} 33\end{array}$ & $\begin{array}{r}-- \\
<.010 \\
.311 \\
.695 \\
.162 \\
<.141 \\
<.141 \\
<.141 \\
<.141 \\
<.141\end{array}$ & $\begin{array}{l}- \\
<.001 \\
<.038 \\
<.038 \\
<.038 \\
<.038 \\
<.038 \\
<.038 \\
<.038 \\
<.038\end{array}$ & $\begin{array}{l}-- \\
-- \\
<.00254 \\
<.00254 \\
<.00254 \\
<.00254 \\
<.00254 \\
<.00254 \\
<.00254 \\
<.00254\end{array}$ & $\begin{array}{l}. .081 \\
.033 \\
.063 \\
.085 \\
.030 \\
.124 \\
.066 \\
.094 \\
.049\end{array}$ & $\begin{array}{l}-- \\
<.0005 \\
<.00500 \\
<.00500 \\
<.00500 \\
<.00500 \\
<.00500 \\
<.00500 \\
<.00500 \\
<.00500\end{array}$ & $\begin{array}{l}- \\
<.0010 \\
<.00401 \\
<.00401 \\
<.00401 \\
<.00401 \\
<.00401 \\
<.00401 \\
<.00401 \\
<.00401\end{array}$ & $\begin{array}{l}- \\
<.005 \\
<.00602 \\
<.00602 \\
<.00602 \\
<.00602 \\
<.00602 \\
<.00602 \\
<.00602 \\
<.00602\end{array}$ & $\begin{array}{c}-- \\
<.010 \\
.00879 \\
.0238 \\
.0497 \\
.0262 \\
<.00809 \\
.0117 \\
.0324 \\
.0172\end{array}$ \\
\hline $\begin{array}{l}\text { I33 (S) } \\
\text { I34 } \\
\text { I34 (R) } \\
\text { I34 (S) } \\
\text { I35 } \\
\text { I36 } \\
\text { I37B } \\
\text { I37B (R) } \\
\text { I38 } \\
\text { I39 }\end{array}$ & $\begin{array}{l}<.010 \\
<.141 \\
<.141 \\
<.010 \\
<.141 \\
<.141 \\
<.141 \\
<.141 \\
<.141 \\
<.141\end{array}$ & $\begin{array}{l}<.001 \\
<.038 \\
<.038 \\
<.001 \\
<.038 \\
<.038 \\
<.038 \\
<.038 \\
<.038 \\
<.038\end{array}$ & $\begin{array}{r}-- \\
.00330 \\
<.00254 \\
-- \\
.00277 \\
<.00254 \\
.00373 \\
<.00254 \\
.00426 \\
<.00254\end{array}$ & $\begin{array}{l}.056 \\
.045 \\
.067 \\
.073 \\
.039 \\
.044 \\
.034 \\
.035 \\
.044 \\
.038\end{array}$ & $\begin{array}{l}<.0005 \\
<.00500 \\
<.00500 \\
<.0005 \\
<.00500 \\
<.00500 \\
<.00500 \\
<.00500 \\
<.00500 \\
<.00500\end{array}$ & $\begin{array}{l}<.0010 \\
<.00401 \\
<.00401 \\
<.0010 \\
<.00401 \\
<.00401 \\
<.00401 \\
<.00401 \\
<.00401 \\
<.00401\end{array}$ & $\begin{array}{l}<.005 \\
<.00602 \\
<.00602 \\
<.005 \\
<.00602 \\
<.00602 \\
<.00602 \\
<.00602 \\
<.00602 \\
<.00602\end{array}$ & $\begin{array}{c}<.010 \\
.0117 \\
<.00809 \\
<.010 \\
.0248 \\
.0107 \\
<.00809 \\
.0111 \\
.0165 \\
.0155\end{array}$ \\
\hline $\begin{array}{l}\mathrm{I} 40 \\
\mathrm{I} 41 \\
\mathrm{I} 42 \\
\mathrm{I} 43 \\
\mathrm{I} 44 \\
\mathrm{I} 45 \\
\mathrm{I} 46 \\
\mathrm{I} 47 \mathrm{~A} \\
\mathrm{I} 48 \\
\mathrm{I} 49\end{array}$ & $\begin{array}{l}<.141 \\
14.2 \\
<.141 \\
23.2 \\
<.141 \\
<.141 \\
<.141 \\
2.15 \\
<.141 \\
<.141\end{array}$ & $\begin{array}{l}<.038 \\
<.038 \\
<.038 \\
<.038 \\
<.038 \\
<.038 \\
<.038 \\
<.038 \\
<.038 \\
<.038\end{array}$ & $\begin{array}{r}<.00254 \\
<.00254 \\
<.00254 \\
<.00254 \\
<.00254 \\
.00874 \\
<.00254 \\
<.00254 \\
.00725 \\
<.00254\end{array}$ & $\begin{array}{l}.052 \\
.047 \\
.068 \\
.042 \\
.024 \\
.150 \\
.024 \\
.047 \\
.007 \\
.030\end{array}$ & $\begin{array}{l}<.00500 \\
<.00500 \\
<.00500 \\
<.00500 \\
<.00500 \\
<.00500 \\
<.00500 \\
<.00500 \\
<.00500 \\
<.00500\end{array}$ & $\begin{array}{l}<.00401 \\
<.00401 \\
<.00401 \\
<.00401 \\
<.00401 \\
<.00401 \\
<.00401 \\
<.00401 \\
<.00401 \\
<.00401\end{array}$ & $\begin{array}{l}<.00602 \\
<.00602 \\
<.00602 \\
<.00602 \\
<.00602 \\
<.00602 \\
<.00602 \\
<.00602 \\
<.00602 \\
<.00602\end{array}$ & $\begin{array}{c}.0321 \\
.0158 \\
.0114 \\
.0124 \\
<.00809 \\
<.00809 \\
.0177 \\
<.00809 \\
<.00809 \\
<.00809\end{array}$ \\
\hline $\begin{array}{l}\text { I50 } \\
\text { I51 } \\
\text { I52 } \\
\text { I53 } \\
\text { I53 (R) } \\
\text { I54A }\end{array}$ & $\begin{array}{c}<.141 \\
.221 \\
.288 \\
4.49 \\
5.63 \\
2.60\end{array}$ & $\begin{array}{l}<.038 \\
<.038 \\
<.038 \\
<.038 \\
<.038 \\
<.038\end{array}$ & $\begin{array}{r}<.00254 \\
.00565 \\
.00437 \\
<.00254 \\
<.00254 \\
<.00254\end{array}$ & $\begin{array}{l}.274 \\
.066 \\
.082 \\
.062 \\
.076 \\
.023\end{array}$ & $\begin{array}{l}<.00500 \\
<.00500 \\
<.00500 \\
<.00500 \\
<.00500 \\
<.00500\end{array}$ & $\begin{array}{l}<.00401 \\
<.00401 \\
<.00401 \\
<.00401 \\
<.00401 \\
<.00401\end{array}$ & $\begin{array}{l}<.00602 \\
<.00602 \\
<.00602 \\
<.00602 \\
<.00602 \\
<.00602\end{array}$ & $\begin{array}{c}<.00809 \\
<.00809 \\
<.00809 \\
<.00809 \\
.0172 \\
.0137\end{array}$ \\
\hline
\end{tabular}


Table 11. Results of inorganic-chemical analyses of water from selected wells in the surficial aquifer at Carroll Island, Aberdeen Proving Ground, Md., spring 1989--Continued

\begin{tabular}{|c|c|c|c|c|c|c|c|c|c|}
\hline $\begin{array}{c}\text { Well } \\
\text { number } \\
\text { (fig. 3) }\end{array}$ & $\begin{array}{c}\text { Iron } \\
\text { (as Fe) }\end{array}$ & $\begin{array}{c}\text { Lead } \\
\text { (as Pb) }\end{array}$ & $\begin{array}{c}\text { Manganese } \\
\text { (as Mn) }\end{array}$ & $\begin{array}{c}\text { Mercury } \\
\text { (as Hg) }\end{array}$ & $\begin{array}{l}\text { Nickel } \\
\text { (as Ni) } \\
\end{array}$ & $\begin{array}{c}\text { Selenium } \\
\text { (as Se) }\end{array}$ & $\begin{array}{c}\text { Silver } \\
\text { (as Ag) }\end{array}$ & $\begin{array}{l}\text { Thallium } \\
\text { (as TI) }\end{array}$ & $\begin{array}{c}\text { Zinc } \\
\text { (as Zn) }\end{array}$ \\
\hline $\begin{array}{l}101 \\
102 \\
103 \\
104 \\
105 \\
106 \\
107 \\
108 \\
109 \\
110\end{array}$ & $\begin{array}{c}0.153 \\
<.043 \\
.429 \\
.047 \\
.222 \\
<.043 \\
<.043 \\
3.52 \\
23.9 \\
19.2\end{array}$ & $\begin{array}{r}0.00260 \\
.00358 \\
<.00126 \\
<.00126 \\
<.00126 \\
<.00126 \\
<.00126 \\
<.00126 \\
<.00126 \\
<.00126\end{array}$ & $\begin{array}{l}0.0101 \\
.0188 \\
1.13 \\
.0737 \\
.00775 \\
.0374 \\
.0158 \\
.535 \\
1.09 \\
1.02\end{array}$ & $\begin{array}{l}<0.000243 \\
<.000243 \\
<.000243 \\
-- \\
-- \\
-- \\
-- \\
- \\
<.000243 \\
<.000243\end{array}$ & $\begin{array}{r}<0.0343 \\
<.0343 \\
.0481 \\
<.0343 \\
<.0343 \\
<.0343 \\
<.0343 \\
<.0343 \\
<.0343 \\
<.0343\end{array}$ & $\begin{array}{l}<0.00302 \\
<.00302 \\
<.00302 \\
<.00302 \\
<.00302 \\
<.00302 \\
<.00302 \\
<.00302 \\
<.00302 \\
<.00302\end{array}$ & $\begin{array}{r}<0.00460 \\
<.00460 \\
<.00460 \\
<.00460 \\
<.00460 \\
<.00460 \\
<.00460 \\
<.00460 \\
.00772 \\
.00536\end{array}$ & $\begin{array}{r}<0.0814 \\
<.0814 \\
<.0814 \\
<.0814 \\
<.0814 \\
<.0814 \\
<.0814 \\
<.0814 \\
<.0814 \\
<.0814\end{array}$ & $\begin{array}{l}<0.0211 \\
<.0211 \\
<.0211 \\
<.0211 \\
<.0211 \\
<.0211 \\
<.0211 \\
<.0211 \\
<.0211 \\
<.0211\end{array}$ \\
\hline $\begin{array}{l}\text { I12 } \\
\text { I13 } \\
\text { II4 } \\
\text { I15 } \\
\text { I16B } \\
\text { I17 } \\
117(\text { S) } \\
\text { I18 } \\
\text { I18 (R) } \\
\text { I18 (S) }\end{array}$ & $\begin{array}{l}1.84 \\
1.49 \\
.229 \\
8.81 \\
.321 \\
.366 \\
.480 \\
.258 \\
.245 \\
.270\end{array}$ & $\begin{aligned} .00358 \\
.00184 \\
<.00126 \\
<.00126 \\
<.00126 \\
<.00126 \\
<.010 \\
<.00126 \\
<.00126 \\
<.010\end{aligned}$ & $\begin{array}{c}1.84 \\
.206 \\
.307 \\
.688 \\
7.60 \\
.499 \\
.570 \\
.183 \\
.194 \\
.210\end{array}$ & $\begin{array}{c}<.000243 \\
<.000243 \\
<.000243 \\
<.000243 \\
<.000243 \\
<.000243 \\
.0001 \\
<.000243 \\
<.000243 \\
.00070\end{array}$ & $\begin{array}{c}.0527 \\
<.0343 \\
<.0343 \\
<.0343 \\
<.0343 \\
<.0343 \\
<.010 \\
<.0343 \\
<.0343 \\
.010\end{array}$ & $\begin{array}{l}<.00302 \\
<.00302 \\
<.00302 \\
<.00302 \\
<.00302 \\
<.00302 \\
<.001 \\
<.00302 \\
<.00302 \\
<.001\end{array}$ & $\begin{array}{l}<.00460 \\
<.00460 \\
<.00460 \\
<.00460 \\
<.00460 \\
<.00460 \\
<.0010 \\
<.00460 \\
<.00460 \\
<.0010\end{array}$ & $\begin{array}{l}<.0814 \\
<.0814 \\
<.0814 \\
<.0814 \\
<.0814 \\
<.0814 \\
-- \\
<.0814 \\
<.0814 \\
--\end{array}$ & $\begin{array}{c}.100 \\
<.0211 \\
<.0211 \\
.0407 \\
<.0211 \\
<.0211 \\
.008 \\
<.0211 \\
.0336 \\
.028\end{array}$ \\
\hline $\begin{array}{l}119 \\
\text { I20 } \\
\text { I21 } \\
\text { I22B } \\
\text { I22B (R) } \\
\text { I22C } \\
123 \\
124 \\
125 \\
\text { I26A }\end{array}$ & $\begin{array}{l}14.3 \\
4.92 \\
.129 \\
12.8 \\
14.9 \\
10.9 \\
33.5 \\
<.043 \\
17.5 \\
21.9\end{array}$ & $\begin{array}{l}<.00126 \\
<.00126 \\
<.00126 \\
<.00126 \\
<.00126 \\
<.00126 \\
<.00126 \\
<.00126 \\
<.00126 \\
<.00126\end{array}$ & $\begin{array}{l}.519 \\
.400 \\
.308 \\
.287 \\
.319 \\
.842 \\
.813 \\
.0438 \\
.522 \\
.511\end{array}$ & $\begin{array}{l}<.000243 \\
<.000243 \\
<.000243 \\
-- \\
-- \\
-- \\
<.000243 \\
-- \\
-- \\
<.000243\end{array}$ & $\begin{array}{r}<.0343 \\
<.0343 \\
<.0343 \\
<.0343 \\
<.0343 \\
.0591 \\
<.0343 \\
<.0343 \\
<.0343 \\
<.0343\end{array}$ & $\begin{array}{l}<.00302 \\
<.00302 \\
<.00302 \\
<.00302 \\
<.00302 \\
<.00302 \\
<.00302 \\
<.00302 \\
<.00302 \\
<.00302\end{array}$ & $\begin{array}{r}<.00460 \\
<.00460 \\
<.00460 \\
<.00460 \\
<.00460 \\
<.00460 \\
.00665 \\
<.00460 \\
<.00460 \\
.00920\end{array}$ & $\begin{array}{l}<.0814 \\
<.0814 \\
<.0814 \\
<.0814 \\
<.0814 \\
<.0814 \\
.104 \\
<.0814 \\
<.0814 \\
<.0814\end{array}$ & $\begin{array}{r}<.0211 \\
<.0211 \\
<.0211 \\
<.0211 \\
<.0211 \\
.0353 \\
<.0211 \\
<.0211 \\
<.0211 \\
.0515\end{array}$ \\
\hline $\begin{array}{l}\mathrm{I} 26 \mathrm{~A}(\mathrm{R}) \\
\mathrm{I} 26 \mathrm{~A}(\mathrm{~S}) \\
\mathrm{I} 26 \mathrm{~B} \\
\mathrm{I} 27 \mathrm{~B} \\
\mathrm{I} 28 \\
\mathrm{I} 29 \\
\mathrm{I} 30 \\
\mathrm{I} 31 \\
\mathrm{I} 32 \\
\mathrm{I} 33\end{array}$ & $\begin{array}{c}-. \\
20.0 \\
.060 \\
.099 \\
29.2 \\
2.07 \\
48.3 \\
1.58 \\
20.4 \\
17.2\end{array}$ & $\begin{array}{l}-- \\
<.010 \\
<.00126 \\
.0133 \\
<.00126 \\
<.00126 \\
<.00126 \\
<.00126 \\
<.00126 \\
<.00126\end{array}$ & $\begin{array}{l}. . \\
.490 \\
.140 \\
.531 \\
.596 \\
.823 \\
1.19 \\
.416 \\
1.35 \\
.388\end{array}$ & $\begin{array}{l}-- \\
<.0001 \\
-- \\
<.000243 \\
.000268 \\
<.000243 \\
<.000243 \\
-- \\
-- \\
--\end{array}$ & $\begin{array}{l}-.020 \\
<.0343 \\
<.0343 \\
<.0343 \\
<.0343 \\
<.0343 \\
<.0343 \\
<.0343 \\
<.0343\end{array}$ & $\begin{array}{l}-- \\
<.001 \\
<.00302 \\
<.00302 \\
<.00302 \\
<.00302 \\
<.00302 \\
<.00302 \\
<.00302 \\
<.00302\end{array}$ & $\begin{array}{c}-- \\
.0010 \\
<.00460 \\
<.00460 \\
.0119 \\
<.00460 \\
.0124 \\
<.00460 \\
<.00460 \\
<.00460\end{array}$ & $\begin{array}{l}-- \\
- \\
<.0814 \\
.124 \\
.169 \\
<.0814 \\
.145 \\
<.0814 \\
<.0814 \\
<.0814\end{array}$ & $\begin{array}{l}-. \\
.011 \\
.115 \\
.178 \\
.213 \\
.0511 \\
<.0211 \\
.0347 \\
.123 \\
.0469\end{array}$ \\
\hline $\begin{array}{l}\text { I33 (S) } \\
\text { I34 } \\
\text { I34 (R) } \\
\text { I34 (S) } \\
\text { I35 } \\
\text { I36 } \\
\text { I37B } \\
\text { I37B (R) } \\
\text { I38 } \\
\text { I39 }\end{array}$ & $\begin{array}{c}.027 \\
9.23 \\
8.41 \\
7.70 \\
5.34 \\
8.60 \\
15.8 \\
15.9 \\
6.39 \\
6.37\end{array}$ & $\begin{array}{l}<.010 \\
<.00126 \\
<.00126 \\
<.010 \\
<.00126 \\
<.00126 \\
<.00126 \\
<.00126 \\
<.00126 \\
<.00126\end{array}$ & $\begin{array}{l}.370 \\
.190 \\
.216 \\
.220 \\
.336 \\
.212 \\
2.70 \\
2.70 \\
.975 \\
1.52\end{array}$ & $\begin{array}{l}<.0001 \\
-- \\
-- \\
<.0001 \\
-- \\
-- \\
<.000243 \\
<.000243 \\
<.000243 \\
<.000243\end{array}$ & $\begin{array}{l}<.010 \\
<.0343 \\
<.0343 \\
<.010 \\
<.0343 \\
<.0343 \\
<.0343 \\
<.0343 \\
<.0343 \\
<.0343\end{array}$ & $\begin{array}{l}<.001 \\
<.00302 \\
<.00302 \\
<.001 \\
<.00302 \\
<.00302 \\
<.00302 \\
<.00302 \\
<.00302 \\
<.00302\end{array}$ & $\begin{array}{l}<.0010 \\
<.00460 \\
<.00460 \\
<.0010 \\
<.00460 \\
<.00460 \\
.00484 \\
<.00460 \\
<.00460 \\
<.00460\end{array}$ & $\begin{array}{l}-- \\
<.0814 \\
<.0814 \\
-- \\
<.0814 \\
<.0814 \\
<.0814 \\
<.0814 \\
<.0814 \\
<.0814\end{array}$ & $\begin{array}{c}.009 \\
.0370 \\
<.0211 \\
.004 \\
.0548 \\
.0544 \\
<.0211 \\
<.0211 \\
.0406 \\
<.0211\end{array}$ \\
\hline $\begin{array}{l}\text { I } 40 \\
\text { I } 41 \\
\text { I } 42 \\
\text { I43 } \\
\text { I44 } \\
\text { I } 45 \\
\text { I } 46 \\
147 \mathrm{~A} \\
\text { I } 48 \\
\text { I49 }\end{array}$ & $\begin{array}{c}.140 \\
39.4 \\
17.8 \\
38.4 \\
3.89 \\
53.1 \\
16.6 \\
52.9 \\
6.03 \\
.538\end{array}$ & $\begin{array}{c}.00239 \\
.00325 \\
<.00126 \\
.00770 \\
<.00126 \\
<.00126 \\
<.00126 \\
.0133 \\
<.00126 \\
<.00126\end{array}$ & $\begin{array}{c}.267 \\
.952 \\
.506 \\
.999 \\
.415 \\
.788 \\
.166 \\
2.50 \\
.467 \\
.760\end{array}$ & $\begin{array}{r}<.000243 \\
<.000243 \\
<.000243 \\
<.000243 \\
<.000243 \\
<.000243 \\
<.000243 \\
.000403 \\
<.000243 \\
<.000243\end{array}$ & $\begin{array}{r}<.0343 \\
.0657 \\
<.0343 \\
.0657 \\
<.0343 \\
<.0343 \\
<.0343 \\
<.0343 \\
<.0343 \\
<.0343\end{array}$ & $\begin{array}{l}<.00302 \\
<.00302 \\
<.00302 \\
<.00302 \\
<.00302 \\
<.00302 \\
<.00302 \\
<.00302 \\
<.00302 \\
<.00302\end{array}$ & $\begin{array}{c}<.00460 \\
.0101 \\
<.00460 \\
.00781 \\
<.00460 \\
.0118 \\
<.00460 \\
.0118 \\
<.00460 \\
<.00460\end{array}$ & $\begin{array}{c}<.0814 \\
.251 \\
<.0814 \\
.160 \\
<.0814 \\
<.0814 \\
<.0814 \\
.233 \\
<.0814 \\
<.0814\end{array}$ & $\begin{array}{c}<.0211 \\
.169 \\
<.0211 \\
.179 \\
<.0211 \\
<.0211 \\
<.0211 \\
.0497 \\
<.0211 \\
<.0211\end{array}$ \\
\hline $\begin{array}{l}150 \\
\text { I51 } \\
\text { I52 } \\
\text { I53 } \\
\text { I53 (R) } \\
\text { I54A }\end{array}$ & $\begin{array}{l}83.0 \\
57.0 \\
30.2 \\
.068 \\
.095 \\
.093\end{array}$ & $\begin{array}{l}<.00126 \\
<.00126 \\
<.00126 \\
.00336 \\
.00325 \\
.0314\end{array}$ & $\begin{array}{l}1.90 \\
.427 \\
.407 \\
1.18 \\
1.49 \\
.444\end{array}$ & $\begin{array}{l}<.000243 \\
<.000243 \\
<.000243 \\
<.000243 \\
<.000243 \\
<.000243\end{array}$ & $\begin{array}{r}<.0343 \\
<.0343 \\
<.0343 \\
.0442 \\
<.0343 \\
<.0343 \\
\end{array}$ & $\begin{array}{l}<.00302 \\
<.00302 \\
<.00302 \\
<.00302 \\
<.00302 \\
<.00302 \\
\end{array}$ & $\begin{array}{c}.0253 \\
.0177 \\
.00762 \\
<.00460 \\
<.00460 \\
<.00460 \\
\end{array}$ & $\begin{array}{r}.200 \\
.259 \\
.113 \\
<.0814 \\
<.0814 \\
<.0814 \\
\end{array}$ & $\begin{array}{r}.0269 \\
<.0211 \\
<.0211 \\
.0534 \\
.0484 \\
.0978 \\
\end{array}$ \\
\hline
\end{tabular}


Table 12. Results of inorganic-chemical analyses of water from wells in the confined aquifer at Carroll Island, Aberdeen Proving Ground, Md., spring 1989

[All concentrations are for dissolved constituents in units of milligrams per liter; deg $\mathrm{C}$, degrees Celsius; $\mu \mathrm{S} / \mathrm{cm}$, microsiemens per centimeter; (R), replicate sample; (S), split sample; --, missing data; <, less than]

\begin{tabular}{|c|c|c|c|c|c|c|c|c|c|}
\hline $\begin{array}{c}\text { Well } \\
\text { number } \\
\text { (fig. 3) }\end{array}$ & $\begin{array}{l}\text { Sampling } \\
\text { date }\end{array}$ & $\begin{array}{c}\text { Specific } \\
\text { conductance, } \\
\text { field } \\
(\mu \mathrm{S} / \mathrm{cm})\end{array}$ & $\begin{array}{c}\text { pH, } \\
\text { field } \\
\text { (units) }\end{array}$ & $\begin{array}{l}\text { Tempera- } \\
\text { ture, } \\
\text { field } \\
\text { (deg C) }\end{array}$ & $\begin{array}{l}\text { Dissolved } \\
\text { oxygen, } \\
\text { field }\end{array}$ & $\begin{array}{l}\text { Calcium } \\
\text { (as Ca) }\end{array}$ & $\begin{array}{l}\text { Magnesium } \\
\text { (as Mg) }\end{array}$ & $\begin{array}{l}\text { Sodium } \\
\text { (as } \mathrm{Na} \text { ) }\end{array}$ & $\begin{array}{l}\text { Potassium } \\
\text { (as K) }\end{array}$ \\
\hline I16A (S) & $04-24-89$ & 1,270 & 8.83 & 13 & 1.4 & 49.0 & 2.30 & 200 & 22.0 \\
\hline $\mathrm{I} 22 \mathrm{~A}$ & $04-24-89$ & 617 & 6.94 & 14 & 1.3 & 65.0 & 6.64 & 27.7 & 9.60 \\
\hline $\mathrm{I} 22 \mathrm{~A}(\mathrm{~S})$ & $04-24-89$ & 617 & 6.94 & 14 & 1.3 & 80.0 & 8.30 & 34.0 & 9.80 \\
\hline I47B & $04-27-89$ & 687 & 7.70 & 14 & 1.4 & 78.0 & 15.1 & 35.3 & 4.10 \\
\hline I47B (S) & $04-27-89$ & 687 & 7.70 & 14 & 1.4 & -- & -- & -- & -- \\
\hline I54B & $04-27-89$ & 540 & 7.12 & 14 & 1.0 & 45.0 & 3.57 & 41.0 & 7.76 \\
\hline
\end{tabular}

\begin{tabular}{|c|c|c|c|c|c|c|c|c|}
\hline $\begin{array}{c}\text { Well } \\
\text { number } \\
\text { (fig. 3) }\end{array}$ & $\begin{array}{c}\text { Alkalinity } \\
\text { (as } \mathrm{CaCO}_{3} \text { ) }\end{array}$ & $\begin{array}{c}\text { Bicarbonate } \\
\text { (as } \mathrm{HCO}_{3} \text { ) }\end{array}$ & $\begin{array}{c}\text { Sulfate } \\
\text { (as } \mathrm{SO}_{4} \text { ) }\end{array}$ & $\begin{array}{c}\text { Chloride } \\
\text { (as Cl) }\end{array}$ & $\begin{array}{c}\text { Fluoride } \\
\text { (as F) }\end{array}$ & $\begin{array}{c}\text { Bromide } \\
\text { (as Br) }\end{array}$ & $\begin{array}{c}\text { Silica } \\
\left(\text { as SiO }_{2}\right)\end{array}$ & $\begin{array}{c}\text { Nitrogen } \\
\mathrm{NO}_{2}+\mathrm{NO}_{3} \\
\text { (as N) }\end{array}$ \\
\hline II6A & 128 & 156 & 31.2 & 360 & $<1.23$ & $<1.00$ & 12.8 & $<0.010$ \\
\hline $\mathrm{I} 22 \mathrm{~A}$ & 227 & 277 & 38.4 & 44.0 & $<1.23$ & $<1.00$ & 19.2 & .013 \\
\hline $\mathrm{I} 22 \mathrm{~A}(\mathrm{~S})$ & 227 & 277 & 39.0 & 35.0 & .10 & .12 & 41.0 & -- \\
\hline $127 \mathrm{~A}$ & 200 & 244 & $<10.0$ & 10.7 & $<1.23$ & $<1.00$ & 17.5 & $<.010$ \\
\hline I47B (S) & 246 & 300 & -- & - & -- & -- & -- & -- \\
\hline I54B & 111 & 135 & $<10.0$ & 120 & $<1.23$ & $<3.00$ & 13.5 & $<.010$ \\
\hline
\end{tabular}

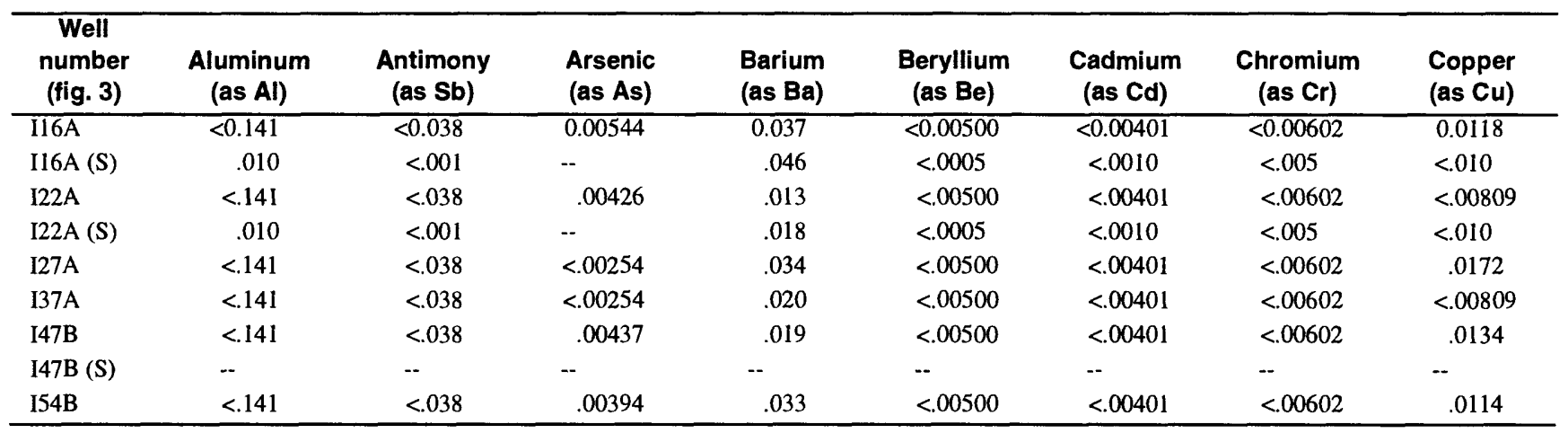

\begin{tabular}{|c|c|c|c|c|c|c|c|c|c|}
\hline $\begin{array}{c}\text { Well } \\
\text { number } \\
\text { (fig. 3) }\end{array}$ & $\begin{array}{c}\text { Iron } \\
\text { (as Fe) }\end{array}$ & $\begin{array}{c}\text { Lead } \\
\text { (as Pb) }\end{array}$ & $\begin{array}{l}\text { Manganese } \\
\text { (as Mn) }\end{array}$ & $\begin{array}{l}\text { Mercury } \\
\text { (as Hg) }\end{array}$ & $\begin{array}{l}\text { Nickel } \\
\text { (as Ni) }\end{array}$ & $\begin{array}{l}\text { Selenium } \\
\text { (as Se) }\end{array}$ & $\begin{array}{l}\text { Silver } \\
\text { (as Ag) }\end{array}$ & $\begin{array}{c}\text { Thallium } \\
\text { (as } \mathrm{TI} \text { ) }\end{array}$ & $\begin{array}{c}\text { Zinc } \\
\text { (as Zn) }\end{array}$ \\
\hline I16A & $<0.043$ & 0.00195 & 0.0475 & $<0.000243$ & $<0.0343$ & $<0.00302$ & $<0.00460$ & $<0.0814$ & $<0.0211$ \\
\hline $\mathrm{I} 22 \mathrm{~A}$ & 1.95 & $<.00126$ & .540 & $<.000243$ & $<.0343$ & $<.00302$ & $<.00460$ & $<.0814$ & $<.0211$ \\
\hline $\mathrm{I} 22 \mathrm{~A}(\mathrm{~S})$ & .340 & $<.010$ & .590 & $<.0001$ & .020 & $<.001$ & $<.0010$ & -. & $<.003$ \\
\hline I27A & 8.25 & $<.00126$ & .639 & $<.000243$ & $<.0343$ & $<.00302$ & $<.00460$ & $<.0814$ & .0259 \\
\hline I47B & .069 & $<.00126$ & .202 & $<.000243$ & $<.0343$ & $<.00302$ & $<.00460$ & $<.0814$ & $<.0211$ \\
\hline I47B (S) & -- & -- & -- & - & -- & - & -- & -- & -- \\
\hline I54B & 5.48 & $<.00126$ & .686 & $<.000243$ & $<.0343$ & $<.00302$ & $<.00460$ & $<.0814$ & $<.0211$ \\
\hline
\end{tabular}


Table 13. Results of organic-chemical analyses of water from selected wells in the surficial aquifer at Carroll Island, Aberdeen Proving Ground, Md., spring 1989

[Concentrations are in micrograms per liter; <, less than; --, missing data; >, greater than; (R), replicate sample; (S), split sample; PCB, polychlorinated biphenyl]

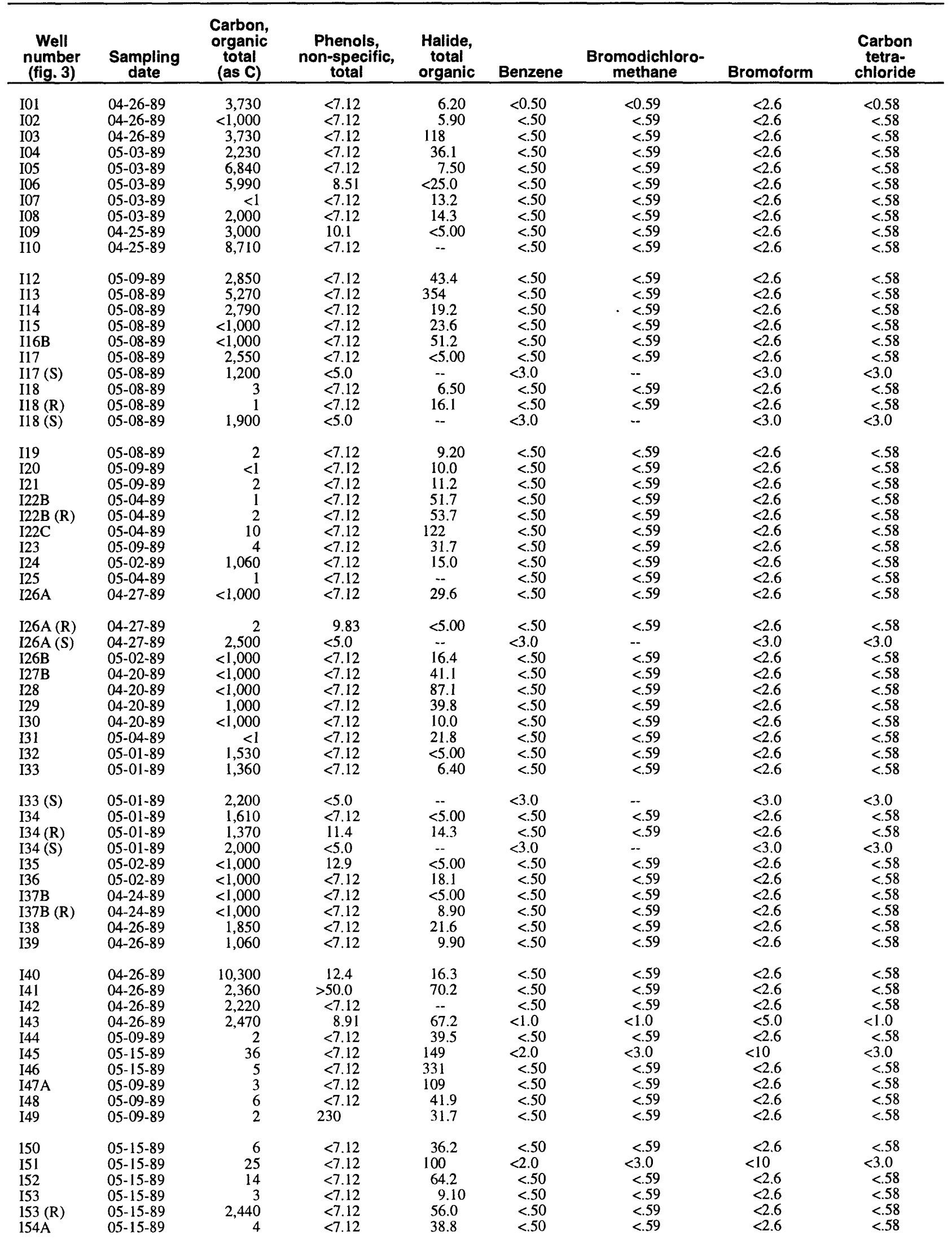


Table 13. Results of organic-chemical analyses of water from selected wells in the surficial aquifer at Carroll Island, Aberdeen Proving Ground, Md., spring 1989--Continued

\begin{tabular}{|c|c|c|c|c|c|c|c|c|c|c|}
\hline $\begin{array}{c}\begin{array}{c}\text { Well } \\
\text { number } \\
\text { (fig. 3) }\end{array} \\
\end{array}$ & $\begin{array}{c}\text { Chloro- } \\
\text { benzene }\end{array}$ & $\begin{array}{l}\text { Chloro- } \\
\text { dibromo- } \\
\text { methane }\end{array}$ & $\begin{array}{l}\text { Chloro- } \\
\text { ethane }\end{array}$ & $\begin{array}{c}\text { 2-Chloro- } \\
\text { ethyl- } \\
\text { vinyl } \\
\text { ether } \\
\end{array}$ & $\begin{array}{c}\begin{array}{c}\text { Chloro- } \\
\text { form }\end{array} \\
\end{array}$ & $\begin{array}{c}\text { Chloro- } \\
\text { methane }\end{array}$ & $\begin{array}{c}\text { 1,2-Di- } \\
\text { chloro- } \\
\text { benzene }\end{array}$ & $\begin{array}{r}\text { 1,3-Di- } \\
\text { chloro- } \\
\text { benzene }\end{array}$ & $\begin{array}{c}\text { 1,4-Di- } \\
\text { chloro- } \\
\text { benzene }\end{array}$ & $\begin{array}{l}\text { 1,1-Di- } \\
\text { chloro- } \\
\text { ethane }\end{array}$ \\
\hline 101 & $<0.50$ & $<0.67$ & $<1.9$ & $<0.71$ & $<0.50$ & $<3.2$ & -- & -- & -- & $<0.68$ \\
\hline 102 & $<.50$ & $<.67$ & $<1.9$ & $<.71$ & $<.50$ & $<3.2$ & -- & -- & -- & $<.68$ \\
\hline I03 & $<.50$ & $<.67$ & $<1.9$ & $<.71$ & $<.50$ & $<3.2$ & -- & -- & -- & $<.68$ \\
\hline I04 & $<.50$ & $<.67$ & $<1.9$ & $<.71$ & $<.50$ & $<3.2$ & $<1.7$ & $<1.7$ & $<1.7$ & $<.68$ \\
\hline 105 & $<.50$ & $<.67$ & $<1.9$ & $<.71$ & $<.50$ & $<3.2$ & $<1.7$ & $<1.7$ & $<1.7$ & $<.68$ \\
\hline I06 & $<.50$ & $<.67$ & $<1.9$ & $<.71$ & $<.50$ & $<3.2$ & $<1.7$ & $<1.7$ & $<1.7$ & $<.68$ \\
\hline I07 & $<.50$ & $<.67$ & $<1.9$ & $<.71$ & $<.50$ & $<3.2$ & $<1.7$ & $<1.7$ & $<1.7$ & $<.68$ \\
\hline I08 & $<.50$ & $<.67$ & $<1.9$ & $<.71$ & $<.50$ & $<3.2$ & $<1.7$ & $<1.7$ & $<1.7$ & $<.68$ \\
\hline 109 & $<.50$ & $<.67$ & $<1.9$ & $<.71$ & $<.50$ & $<3.2$ & -- & -- & -- & $<.68$ \\
\hline I10 & $<.50$ & $<.67$ & $<1.9$ & $<.71$ & $<.50$ & $<3.2$ & -- & -- & -- & $<.68$ \\
\hline $\mathrm{I} 12$ & $<.50$ & $<.67$ & $<1.9$ & $<.71$ & $<.50$ & $<3.2$ & $<1.7$ & $<1.7$ & $<1.7$ & $<.68$ \\
\hline I13 & $<.50$ & $<.67$ & $<1.9$ & $<.71$ & $<.50$ & $<3.6$ & $<1.7$ & $<1.7$ & $<1.7$ & $<.68$ \\
\hline I14 & $<.50$ & $<.67$ & $<1.9$ & $<.71$ & $<.50$ & $<3.6$ & $<1.7$ & $<1.7$ & $<1.7$ & $<.68$ \\
\hline I15 & $<.50$ & $<.67$ & $<1.9$ & $<.71$ & $<.50$ & $<3.6$ & $<1.7$ & $<1.7$ & $<1.7$ & $<.68$ \\
\hline I16B & $<50$ & $<.67$ & $<1.9$ & $<.71$ & $<.50$ & $<3.6$ & $<1.7$ & $<1.7$ & $<1.7$ & $<.68$ \\
\hline I17 & $<.50$ & $<.67$ & $<1.9$ & $<.71$ & $<.50$ & $<3.2$ & $<1.7$ & $<1.7$ & $<1.7$ & $<.68$ \\
\hline I17 (S) & $<3.0$ & $<3.0$ & $<3.0$ & $<3.0$ & $<3.0$ & $<3.0$ & $<5.0$ & $<5.0$ & $<5.0$ & $<3.0$ \\
\hline I18 & $<.50$ & $<.67$ & $<1.9$ & $<.71$ & $<.50$ & $<3.6$ & $<1.7$ & $<1.7$ & $<1.7$ & $<.68$ \\
\hline I18 (R) & $<.50$ & $<.67$ & $<1.9$ & $<.71$ & $<.50$ & $<3.2$ & $<1.7$ & $<1.7$ & $<1.7$ & $<.68$ \\
\hline 118 (S) & $<3.0$ & $<3.0$ & $<3.0$ & $<3.0$ & $<3.0$ & $<3.0$ & $<5.0$ & $<5.0$ & $<5.0$ & $<3.0$ \\
\hline 119 & $<.50$ & $<.67$ & $<1.9$ & $<.71$ & $<.50$ & $<3.6$ & $<1.7$ & $<1.7$ & $<1.7$ & $<.68$ \\
\hline I 20 & $<.50$ & $<.67$ & $<1.9$ & $<.71$ & $<.50$ & $<3.2$ & $<1.7$ & $<1.7$ & $<1.7$ & $<.68$ \\
\hline I 21 & $<.50$ & $<.67$ & $<1.9$ & $<.71$ & $<.50$ & $<3.2$ & $<1.7$ & $<1.7$ & $<1.7$ & $<.68$ \\
\hline I22B & $<.50$ & $<.67$ & $<1.9$ & $<.71$ & $<.50$ & $<3.2$ & $<1.7$ & $<1.7$ & $<1.7$ & $<.68$ \\
\hline I22B (R) & $<.50$ & $<.67$ & $<1.9$ & $<.71$ & $<.50$ & $<3.2$ & $<1.7$ & $<1.7$ & $<1.7$ & $<.68$ \\
\hline $\mathrm{I} 22 \mathrm{C}$ & $<.50$ & $<.67$ & $<1.9$ & $<.71$ & $<.50$ & $<3.2$ & $<1.7$ & $<1.7$ & $<1.7$ & $<.68$ \\
\hline 123 & $<.50$ & $<.67$ & $<1.9$ & $<.71$ & $<.50$ & $<3.2$ & $<1.7$ & $<1.7$ & $<1.7$ & $<.68$ \\
\hline 124 & $<.50$ & $<.67$ & $<1.9$ & $<.71$ & $<.50$ & $<3.2$ & $<1.7$ & $<1.7$ & $<1.7$ & $<.68$ \\
\hline 125 & $<.50$ & $<.67$ & $<1.9$ & $<.71$ & $<.50$ & $<3.2$ & $<1.7$ & $<1.7$ & $<1.7$ & $<.68$ \\
\hline I26A & $<.50$ & $<.67$ & $<1.9$ & $<.71$ & $<.50$ & $<3.2$ & $<1.7$ & $<1.7$ & $<1.7$ & $<.68$ \\
\hline I26A (R) & $<.50$ & $<.67$ & $<1.9$ & $<.71$ & $<.50$ & $<3.2$ & -- & -- & -- & $<.68$ \\
\hline $126 \mathrm{~A}(\mathrm{~S})$ & $<3.0$ & $<3.0$ & $<3.0$ & $<3.0$ & $<3.0$ & $<3.0$ & $<5.0$ & $<5.0$ & $<5.0$ & $<3.0$ \\
\hline $\mathrm{I} 26 \mathrm{~B}$ & $<.50$ & $<.67$ & $<1.9$ & $<.71$ & $<.50$ & $<3.2$ & $<1.7$ & $<1.7$ & $<1.7$ & $<.68$ \\
\hline I27B & $<.50$ & $<.67$ & $<1.9$ & $<.71$ & $<.50$ & $<3.6$ & $<1.7$ & $<1.7$ & $<1.7$ & $<.68$ \\
\hline $\mathrm{I} 28$ & $<.50$ & $<.67$ & $<1.9$ & $<.71$ & $<.50$ & $<3.6$ & $<1.7$ & $<1.7$ & $<1.7$ & $<.68$ \\
\hline I 29 & $<.50$ & $<.67$ & $<1.9$ & $<.71$ & $<.50$ & $<3.6$ & $<1.7$ & $<1.7$ & $<1.7$ & $<.68$ \\
\hline I 30 & $<.50$ & $<.67$ & $<1.9$ & $<.71$ & $<.50$ & $<3.6$ & $<1.7$ & $<1.7$ & $<1.7$ & $<.68$ \\
\hline I31 & $<.50$ & $<.67$ & $<1.9$ & $<.71$ & $<.50$ & $<3.2$ & $<1.7$ & $<1.7$ & $<1.7$ & $<.68$ \\
\hline 132 & $<.50$ & $<.67$ & $<1.9$ & $<.71$ & $<.50$ & $<3.2$ & $<1.7$ & $<1.7$ & $<1.7$ & $<.68$ \\
\hline I33 & $<.50$ & $<.67$ & $<1.9$ & $<.71$ & $<.50$ & $<3.2$ & $<1.7$ & $<1.7$ & $<1.7$ & $<.68$ \\
\hline I33 (S) & $<3.0$ & $<3.0$ & $<3.0$ & $<3.0$ & $<3.0$ & $<3.0$ & $<5.0$ & $<5.0$ & $<5.0$ & $<3.0$ \\
\hline I34 & $<.50$ & $<.67$ & $<1.9$ & $<.71$ & $<.50$ & $<3.2$ & $<1.7$ & $<1.7$ & $<1.7$ & $<.68$ \\
\hline I34 (R) & $<.50$ & $<.67$ & $<1.9$ & $<.71$ & $<.50$ & $<3.2$ & $<1.7$ & $<1.7$ & $<1.7$ & $<.68$ \\
\hline I34 (S) & $<3.0$ & $<3.0$ & $<3.0$ & $<3.0$ & $<3.0$ & $<3.0$ & $<5.0$ & $<5.0$ & $<5.0$ & $<3.0$ \\
\hline 135 & $<.50$ & $<.67$ & $<1.9$ & $<.71$ & $<.50$ & $<3.2$ & $<1.7$ & $<1.7$ & $<1.7$ & $<.68$ \\
\hline I36 & $<.50$ & $<.67$ & $<1.9$ & $<.71$ & $<.50$ & $<3.2$ & $<1.7$ & $<1.7$ & $<1.7$ & $<.68$ \\
\hline I37B & $<.50$ & $<.67$ & $<1.9$ & $<.71$ & $<.50$ & $<3.2$ & -- & -- & -- & $<.68$ \\
\hline I37B (R) & $<.50$ & $<.67$ & $<1.9$ & $<.71$ & $<.50$ & $<3.2$ & -- & -- & -- & $<.68$ \\
\hline I38 & $<.50$ & $<.67$ & $<1.9$ & $<.71$ & $<.50$ & $<3.2$ & -- & -- & -- & $<.68$ \\
\hline I39 & $<.50$ & $<.67$ & $<1.9$ & $<.71$ & $<.50$ & $<3.2$ & -- & -- & -- & $<.68$ \\
\hline 140 & $<.50$ & $<.67$ & $<1.9$ & $<.71$ & $<.50$ & $<3.2$ & - & -- & -- & $<.68$ \\
\hline I41 & $<.50$ & $<.67$ & $<1.9$ & $<.71$ & $<.50$ & $<3.2$ & -. & -- & $\cdot-$ & $<.68$ \\
\hline I 42 & $<.50$ & $<.67$ & $<1.9$ & $<.71$ & $<.50$ & $<3.2$ & -- & -- & -- & $<.68$ \\
\hline I 43 & $<1.0$ & $<.67$ & $<4.0$ & $<1.0$ & $<.50$ & $<6.0$ & -- & -- & - & $<1.0$ \\
\hline I 44 & $<50$ & $<.67$ & $<1.9$ & $<.71$ & $<.50$ & $<3.2$ & $<1.7$ & $<1.7$ & $<1.7$ & $<.68$ \\
\hline 145 & $<2.0$ & $<.67$ & $<100$ & $<4.0$ & $<.50$ & $<20$ & $<1.7$ & $<1.7$ & $<1.7$ & $<3.0$ \\
\hline I 46 & $<.50$ & $<.67$ & $<1.9$ & $<.71$ & $<.50$ & $<3.2$ & $<1.7$ & $<1.7$ & $<1.7$ & $<.68$ \\
\hline I47A & $<.50$ & $<.67$ & $<1.9$ & $<.71$ & $<.50$ & $<3.2$ & $<1.7$ & $<1.7$ & $<1.7$ & $<.68$ \\
\hline I 48 & $<.50$ & $<.67$ & $<1.9$ & $<.71$ & $<.50$ & $<3.2$ & $<1.7$ & $<1.7$ & $<1.7$ & $<.68$ \\
\hline I 49 & $<.50$ & $<.67$ & $<1.9$ & $<.71$ & $<.50$ & $<3.2$ & $<1.7$ & $<1.7$ & $<1.7$ & $<.68$ \\
\hline I50 & $<.50$ & $<.67$ & $<1.9$ & $<.71$ & $<.50$ & $<3.2$ & $<1.7$ & $<1.7$ & $<1.7$ & $<.68$ \\
\hline I51 & $<2.0$ & $<.67$ & $<100$ & $<4.0$ & $<.50$ & $<20$ & $<1.7$ & $<1.7$ & $<1.7$ & $<3.0$ \\
\hline I52 & $<.50$ & $<.67$ & $<1.9$ & $<.71$ & $<.50$ & $<3.2$ & $<1.7$ & $<1.7$ & $<1.7$ & $<.68$ \\
\hline I53 & $<.50$ & $<.67$ & $<1.9$ & $<.71$ & $<.50$ & $<3.2$ & $<1.7$ & $<1.7$ & $<1.7$ & $<.68$ \\
\hline I53 (R) & $<.50$ & $<.67$ & $<1.9$ & $<.71$ & $<.50$ & $<3.2$ & $<1.7$ & $<1.7$ & $<1.7$ & $<.68$ \\
\hline I54A & $<.50$ & $<.67$ & $<1.9$ & $<.71$ & $<.50$ & $<3.2$ & $<1.7$ & $<1.7$ & $<1.7$ & $<.68$ \\
\hline
\end{tabular}


Table 13. Results of organic-chemical analyses of water from selected wells in the surficial aquifer at Carroll Island, Aberdeen Proving Ground, Md., spring 1989--Continued

\begin{tabular}{|c|c|c|c|c|c|c|c|c|c|}
\hline $\begin{array}{c}\text { Well } \\
\text { number } \\
\text { (fig. 3) }\end{array}$ & $\begin{array}{l}\text { 1,2-Di- } \\
\text { chloro- } \\
\text { ethane }\end{array}$ & $\begin{array}{r}\text { 1,1-Di- } \\
\text { chloro- } \\
\text { ethylene } \\
\end{array}$ & $\begin{array}{c}\text { 1,2-Di- } \\
\text { chloro- } \\
\text { ethylene } \\
\text { (cis + trans) }\end{array}$ & $\begin{array}{l}\text { 1,2-Di- } \\
\text { chloro- } \\
\text { propane }\end{array}$ & $\begin{array}{l}\text { cis- } \\
\text { 1,3-Di- } \\
\text { chloro- } \\
\text { propene }\end{array}$ & $\begin{array}{l}\text { trans- } \\
\text { 1,3-Di- } \\
\text { chloro- } \\
\text { propene }\end{array}$ & Ethylbenzene & Fluorene & $\begin{array}{c}\text { Methylene } \\
\text { chloride }\end{array}$ \\
\hline I01 & $<0.50$ & $<0.50$ & $<0.50$ & $<0.50$ & $<0.58$ & $<0.70$ & $<0.50$ & .. & $<2.3$ \\
\hline 102 & $<.50$ & $<.50$ & $<.50$ & $<.50$ & $<.58$ & $<.70$ & $<.50$ & -- & $<2.3$ \\
\hline I03 & $<.50$ & $<.50$ & $<.50$ & $<.50$ & $<.58$ & $<.70$ & $<.50$ & -- & $<2.3$ \\
\hline I04 & $<.50$ & $<.50$ & $<.50$ & $<.50$ & $<.58$ & $<.70$ & $<.50$ & $<3.7$ & $<2.3$ \\
\hline 105 & $<.50$ & $<.50$ & $<.50$ & $<.50$ & $<.58$ & $<.70$ & $<.50$ & $<3.7$ & $<2.3$ \\
\hline 106 & $<.50$ & $<.50$ & $<.50$ & $<.50$ & $<.58$ & $<.70$ & $<.50$ & $<3.7$ & $<2.3$ \\
\hline I07 & $<.50$ & $<.50$ & $<.50$ & $<.50$ & $<.58$ & $<.70$ & $<.50$ & $<3.7$ & $<2.3$ \\
\hline 108 & $<.50$ & $<.50$ & $<.50$ & $<.50$ & $<.58$ & $<.70$ & $<.50$ & $<3.7$ & $<2.3$ \\
\hline I09 & $<.50$ & $<.50$ & $<.50$ & $<.50$ & $<.58$ & $<.70$ & $<.50$ & -- & $<2.3$ \\
\hline $\mathrm{I} 10$ & $<.50$ & $<.50$ & $<.50$ & $<.50$ & $<.58$ & $<.70$ & $<.50$ & -- & $<2.3$ \\
\hline 112 & $<.50$ & $<.50$ & $<.50$ & $<.50$ & $<.58$ & $<.70$ & $<.50$ & $<3.7$ & $<2.3$ \\
\hline I13 & $<.50$ & $<.50$ & $<.50$ & $<.50$ & $<.58$ & $<.70$ & $<.50$ & $<3.7$ & $<2.3$ \\
\hline I14 & $<.50$ & $<.50$ & $<.50$ & $<.50$ & $<.58$ & $<.70$ & $<.50$ & $<3.7$ & $<2.3$ \\
\hline I15 & $<.50$ & $<.50$ & $<.50$ & $<.50$ & $<.58$ & -. & $<.50$ & $<3.7$ & $<2.3$ \\
\hline I16B & $<.50$ & $<.50$ & $<.50$ & $<.50$ & $<.58$ & $<.70$ & $<.50$ & $<3.7$ & $<2.3$ \\
\hline I17 & $<.50$ & $<.50$ & $<.50$ & $<.50$ & $<.58$ & $<.70$ & $<.50$ & $<3.7$ & $<2.3$ \\
\hline $117(S)$ & $<3.0$ & $<3.0$ & $<3.0$ & $<3.0$ & $<3.0$ & $<3.0$ & $<3.0$ & - & $<3.0$ \\
\hline I18 & $<.50$ & $<.50$ & $<.50$ & $<.50$ & $<.58$ & $<.70$ & $<.50$ & $<3.7$ & $<2.3$ \\
\hline I18 (R) & $<.50$ & $<.50$ & $<.50$ & $<.50$ & $<.58$ & $<.70$ & $<.50$ & $<3.7$ & $<2.3$ \\
\hline I18 (S) & $<3.0$ & $<3.0$ & $<3.0$ & $<3.0$ & $<3.0$ & $<3.0$ & $<3.0$ & -- & $<3.0$ \\
\hline I19 & $<.50$ & $<.50$ & $<.50$ & $<.50$ & $<.58$ & $<.70$ & $<.50$ & $<3.7$ & $<2.3$ \\
\hline 120 & $<.50$ & $<.50$ & $<.50$ & $<.50$ & $<.58$ & $<.70$ & $<.50$ & $<3.7$ & $<2.3$ \\
\hline 121 & $<.50$ & $<.50$ & $<.50$ & $<.50$ & $<.58$ & $<.70$ & $<.50$ & $<3.7$ & $<2.3$ \\
\hline I $22 \mathrm{~B}$ & $<.50$ & $<.50$ & $<.50$ & $<.50$ & $<.58$ & $<.70$ & $<.50$ & $<3.7$ & $<2.3$ \\
\hline I22B (R) & $<.50$ & $<.50$ & $<.50$ & $<.50$ & $<.58$ & $<.70$ & $<.50$ & $<3.7$ & $<2.3$ \\
\hline I22C & $<.50$ & $<.50$ & $<.50$ & $<.50$ & $<.58$ & $<70$ & $<.50$ & $<3.7$ & $<2.3$ \\
\hline $\mathrm{I} 23$ & $<.50$ & $<.50$ & $<.50$ & $<.50$ & $<.58$ & $<.70$ & $<.50$ & $<3.7$ & $<2.3$ \\
\hline I 24 & $<.50$ & $<.50$ & $<.50$ & $<.50$ & $<.58$ & $<.70$ & $<.50$ & $<3.7$ & $<2.3$ \\
\hline 125 & $<.50$ & $<.50$ & $<.50$ & $<.50$ & $<.58$ & $<.70$ & $<.50$ & $<3.7$ & $<2.3$ \\
\hline I26A & $<.50$ & $<.50$ & $<.50$ & $<.50$ & $<.58$ & $<.70$ & $<.50$ & $<3.7$ & $<2.3$ \\
\hline I26A (R) & $<.50$ & $<.50$ & $<.50$ & $<.50$ & $<.58$ & $<.70$ & $<.50$ & -- & $<2.3$ \\
\hline I26A (S) & $<3.0$ & $<3.0$ & $<3.0$ & $<3.0$ & $<3.0$ & $<3.0$ & $<3.0$ & -. & $<3.0$ \\
\hline $\mathrm{I} 26 \mathrm{~B}$ & $<.50$ & $<.50$ & $<.50$ & $<.50$ & $<.58$ & $<.70$ & $<.50$ & $<3.7$ & $<2.3$ \\
\hline $127 \mathrm{~B}$ & $<.50$ & $<.50$ & $<.50$ & $<.50$ & $<.58$ & $<.70$ & $<.50$ & $<3.7$ & $<2.3$ \\
\hline 128 & 1.4 & $<.50$ & $<.50$ & $<.50$ & $<.58$ & $<.70$ & $<.50$ & $<3.7$ & $<2.3$ \\
\hline 129 & $<.50$ & $<.50$ & $<.50$ & $<.50$ & $<.58$ & $<70$ & $<.50$ & $<3.7$ & $<2.3$ \\
\hline 130 & $<.50$ & $<.50$ & $<.50$ & $<.50$ & $<.58$ & $<.70$ & $<.50$ & $<3.7$ & $<2.3$ \\
\hline I31 & $<.50$ & $<.50$ & $<.50$ & $<.50$ & $<.58$ & $<.70$ & $<.50$ & $<3.7$ & $<2.3$ \\
\hline I32 & $<.50$ & $<.50$ & $<.50$ & $<.50$ & $<.58$ & $<.70$ & $<.50$ & $<3.7$ & $<2.3$ \\
\hline 133 & $<.50$ & $<.50$ & $<.50$ & $<.50$ & $<.58$ & $<.70$ & $<.50$ & $<3.7$ & $<2.3$ \\
\hline $133(S)$ & $<3.0$ & $<3.0$ & $<3.0$ & $<3.0$ & $<3.0$ & $<3.0$ & $<3.0$ & -.- & $<3.0$ \\
\hline 134 & $<.50$ & $<.50$ & $<.50$ & $<.50$ & $<.58$ & $<.70$ & $<.50$ & $<3.7$ & $<2.3$ \\
\hline I34 (R) & $<.50$ & $<.50$ & $<.50$ & $<.50$ & $<.58$ & $<.70$ & $<.50$ & $<3.7$ & $<2.3$ \\
\hline I34 (S) & $<3.0$ & $<3.0$ & $<3.0$ & $<3.0$ & $<3.0$ & $<3.0$ & $<3.0$ & -- & $<3.0$ \\
\hline 135 & $<.50$ & $<.50$ & $<.50$ & $<.50$ & $<.58$ & $<.70$ & $<.50$ & $<3.7$ & $<2.3$ \\
\hline 136 & $<.50$ & $<.50$ & $<.50$ & $<.50$ & $<.58$ & $<.70$ & $<.50$ & $<3.7$ & $<2.3$ \\
\hline I37B & $<.50$ & $<.50$ & $<.50$ & $<.50$ & $<.58$ & $<.70$ & $<.50$ & -- & $<2.3$ \\
\hline I37B & $<50$ & $<50$ & $<.50$ & $<.50$ & $<.58$ & $<.70$ & $<.50$ & -- & $<2.3$ \\
\hline 138 & $<.50$ & $<.50$ & $<.50$ & $<.50$ & $<.58$ & $<.70$ & $<.50$ & -- & $<2.3$ \\
\hline 139 & $<.50$ & $<.50$ & $<.50$ & $<.50$ & $<.58$ & $<.70$ & $<.50$ & -- & $<2.3$ \\
\hline I 40 & $<.50$ & $<.50$ & $<.50$ & $<.50$ & $<.58$ & $<.70$ & $<.50$ & - & $<2.3$ \\
\hline I41 & $<.50$ & $<.50$ & $<.50$ & $<.50$ & $<.58$ & $<.70$ & $<.50$ & -- & $<2.3$ \\
\hline I 42 & $<.50$ & $<.50$ & $<.50$ & $<.50$ & $<.58$ & $<.70$ & $<.50$ & -. & $<2.3$ \\
\hline I43 & $<1.0$ & $<1.0$ & $<1.0$ & $<1.0$ & $<1.0$ & $<1.0$ & $<1.0$ & -- & $<5.0$ \\
\hline I 44 & $<50$ & $<.50$ & $<.50$ & $<.50$ & $<.58$ & $<.70$ & $<.50$ & $<3.7$ & $<2.3$ \\
\hline I45 & $<2.0$ & $<2.0$ & $<2.0$ & $<2.0$ & $<3.0$ & $<4.0$ & $<2.0$ & $<3.7$ & 50 \\
\hline 146 & $<.50$ & $<.50$ & $<.50$ & $<.50$ & $<.58$ & $<.70$ & $<.50$ & $<3.7$ & 9.3 \\
\hline I $47 \mathrm{~A}$ & $<.50$ & $<.50$ & $<.50$ & $<.50$ & $<.58$ & $<.70$ & $<.50$ & $<3.7$ & $<2.3$ \\
\hline I48 & $<.50$ & $<.50$ & $<.50$ & $<.50$ & $<.58$ & $<.70$ & $<.50$ & $<3.7$ & $<2.3$ \\
\hline I49 & $<.50$ & $<.50$ & $<.50$ & $<.50$ & $<.58$ & $<.70$ & $<.50$ & $<3.7$ & $<2.3$ \\
\hline I50 & $<.50$ & $<.50$ & $<.50$ & $<.50$ & $<.58$ & $<.70$ & $<.50$ & $<3.7$ & $<2.3$ \\
\hline I51 & $<2.0$ & $<2.0$ & $<2.0$ & $<2.0$ & $<3.0$ & $<4.0$ & $<2.0$ & $<3.70$ & 50 \\
\hline 152 & $<.50$ & $<.50$ & $<.50$ & $<.50$ & $<.58$ & $<.70$ & $<.50$ & $<3.7$ & $<2.3$ \\
\hline I53 & $<.50$ & $<.50$ & $<.50$ & $<.50$ & $<.58$ & $<.70$ & $<.50$ & $<3.7$ & $<2.3$ \\
\hline I53 (R) & $<.50$ & $<.50$ & $<.50$ & $<.50$ & $<.58$ & $<.70$ & $<.50$ & $<3.7$ & $<2.3$ \\
\hline I54A & $<.50$ & $<.50$ & $<.50$ & $<.50$ & $<.58$ & $<.70$ & $<.50$ & $<3.7$ & $<2.3$ \\
\hline
\end{tabular}


Table 13. Results of organic-chemical analyses of water from selected wells in the surficial aquifer at Carroll Island, Aberdeen Proving Ground, Md., spring 1989--Continued

\begin{tabular}{|c|c|c|c|c|c|c|c|c|c|}
\hline $\begin{array}{c}\text { Well } \\
\text { number } \\
\text { (fig. 3) }\end{array}$ & $\begin{array}{l}1,1,2,2 \text {-Tetra- } \\
\text { chloroethane }\end{array}$ & $\begin{array}{c}\text { Tetrachloro- } \\
\text { ethylene }\end{array}$ & Toluene & $\begin{array}{l}\text { 1,1,1-Tri- } \\
\text { chloro- } \\
\text { ethane }\end{array}$ & $\begin{array}{l}\text { 1,1,2-Tri- } \\
\text { chloro- } \\
\text { ethane }\end{array}$ & $\begin{array}{l}\text { Trichloro- } \\
\text { ethylene }\end{array}$ & $\begin{array}{c}\text { Trichloro- } \\
\text { fluoro- } \\
\text { methane }\end{array}$ & $\begin{array}{c}\text { Vinyl } \\
\text { chloride }\end{array}$ & Xylenes \\
\hline $\begin{array}{l}101 \\
\mathrm{I} 02 \\
\mathrm{I} 03 \\
104 \\
105 \\
106 \\
107 \\
108 \\
109 \\
110\end{array}$ & $\begin{array}{l}<0.51 \\
<.51 \\
<.51 \\
<.51 \\
<.51 \\
<.51 \\
<.51 \\
<.51 \\
<.51 \\
<.51\end{array}$ & $\begin{array}{l}<1.6 \\
<1.6 \\
<1.6 \\
<1.6 \\
<1.6 \\
<1.6 \\
<1.6 \\
<1.6 \\
<1.6 \\
<1.6\end{array}$ & $\begin{array}{l}<0.50 \\
<.50 \\
<.50 \\
<.50 \\
<.50 \\
<.50 \\
<.50 \\
<.50 \\
<.50 \\
<.50\end{array}$ & $\begin{array}{l}<0.50 \\
<.50 \\
<.50 \\
<.50 \\
<.50 \\
<.50 \\
<.50 \\
<.50 \\
<.50 \\
<.50\end{array}$ & $\begin{array}{l}<1.2 \\
<1.2 \\
<1.2 \\
<1.2 \\
<1.2 \\
<1.2 \\
<1.2 \\
<1.2 \\
<1.2 \\
<1.2\end{array}$ & $\begin{array}{l}<0.50 \\
<.50 \\
<.50 \\
<.50 \\
<.50 \\
<.50 \\
<.50 \\
<.50 \\
<.50 \\
<.50\end{array}$ & $\begin{array}{l}<1.4 \\
<1.4 \\
<1.4 \\
<1.4 \\
<1.4 \\
<1.4 \\
<1.4 \\
<1.4 \\
<1.4 \\
<1.4\end{array}$ & $\begin{array}{l}<2.6 \\
<2.6 \\
<2.6 \\
<2.6 \\
<2.6 \\
<2.6 \\
<2.6 \\
<2.6 \\
<2.6 \\
<2.6\end{array}$ & $\begin{array}{l}<0.84 \\
<.84 \\
<.84 \\
<.84 \\
<.84 \\
<.84 \\
<.84 \\
<.84 \\
<.84 \\
<.84\end{array}$ \\
\hline $\begin{array}{l}\text { I12 } \\
\text { I13 } \\
\text { I14 } \\
\text { I15 } \\
\text { I16B } \\
\text { I17 } \\
\text { I17 (S) } \\
\text { I18 } \\
\text { I18 (R) } \\
\text { I18 (S) }\end{array}$ & $\begin{array}{l}<.51 \\
<.51 \\
<.51 \\
-- \\
<.51 \\
<.51 \\
<3.0 \\
<.51 \\
<.51 \\
<3.0\end{array}$ & $\begin{array}{l}<1.6 \\
<1.6 \\
<1.6 \\
-- \\
<1.6 \\
<1.6 \\
<3.0 \\
<1.6 \\
<1.6 \\
<3.0\end{array}$ & $\begin{array}{l}<.50 \\
<.50 \\
<.50 \\
<.50 \\
<.50 \\
<.50 \\
<3.0 \\
<.50 \\
<.50 \\
<3.0\end{array}$ & $\begin{array}{l}<.50 \\
<.50 \\
<.50 \\
<.50 \\
<.50 \\
<.50 \\
<3.0 \\
<.50 \\
<.50 \\
<3.0\end{array}$ & $\begin{array}{l}<1.2 \\
<1.2 \\
<1.2 \\
<1.2 \\
<1.2 \\
<1.2 \\
<3.0 \\
<1.2 \\
<1.2 \\
<3.0\end{array}$ & $\begin{array}{l}<.50 \\
<.50 \\
<.50 \\
-- \\
<.50 \\
<.50 \\
<3.0 \\
<.50 \\
<.50 \\
<3.0\end{array}$ & $\begin{array}{l}<1.4 \\
<1.4 \\
<1.4 \\
<1.4 \\
<1.4 \\
<1.4 \\
-- \\
<1.4 \\
<1.4 \\
--\end{array}$ & $\begin{array}{l}<2.6 \\
<2.9 \\
<2.9 \\
<2.9 \\
<2.9 \\
<2.6 \\
<1.0 \\
<2.9 \\
<2.6 \\
<1.0\end{array}$ & $\begin{array}{l}<.84 \\
<.84 \\
<.84 \\
-- \\
<.84 \\
<.84 \\
<3.0 \\
<.84 \\
<.84 \\
<3.0\end{array}$ \\
\hline $\begin{array}{l}\text { I19 } \\
\text { I20 } \\
\text { I21 } \\
\text { I22B } \\
\text { I22B (R) } \\
\text { I22C } \\
\text { I23 } \\
124 \\
\text { I25 } \\
\text { I26A }\end{array}$ & $\begin{array}{l}<.51 \\
<.51 \\
<.51 \\
<.51 \\
<.51 \\
<.51 \\
<.51 \\
<.51 \\
<.51 \\
<.51\end{array}$ & $\begin{array}{l}<1.6 \\
<1.6 \\
<1.6 \\
<1.6 \\
<1.6 \\
<1.6 \\
<1.6 \\
<1.6 \\
<1.6 \\
<1.6\end{array}$ & $\begin{array}{l}<.50 \\
<.50 \\
<.50 \\
<.50 \\
<.50 \\
<.50 \\
<.50 \\
<.50 \\
<.50 \\
<.50\end{array}$ & $\begin{array}{l}<.50 \\
<.50 \\
<.50 \\
<.50 \\
<.50 \\
<.50 \\
<.50 \\
<.50 \\
<.50 \\
<.50\end{array}$ & $\begin{array}{l}<1.2 \\
<1.2 \\
<1.2 \\
<1.2 \\
<1.2 \\
<1.2 \\
<1.2 \\
<1.2 \\
<1.2 \\
<1.2\end{array}$ & $\begin{array}{l}<.50 \\
<.50 \\
<.50 \\
<.50 \\
<.50 \\
<.50 \\
<.50 \\
<.50 \\
<.50 \\
<.50\end{array}$ & $\begin{array}{r}<1.4 \\
<1.4 \\
<1.4 \\
<1.4 \\
<1.4 \\
2.1 \\
<1.4 \\
<1.4 \\
<1.4 \\
<1.4\end{array}$ & $\begin{array}{l}<2.9 \\
<2.6 \\
<2.6 \\
<2.6 \\
<2.6 \\
<2.6 \\
<2.6 \\
<2.6 \\
<2.6 \\
<2.6\end{array}$ & $\begin{array}{l}<.84 \\
<.84 \\
<.84 \\
<.84 \\
<.84 \\
<.84 \\
<.84 \\
<.84 \\
<.84 \\
<.84\end{array}$ \\
\hline $\begin{array}{l}\text { I26A (R) } \\
\text { I26A (S) } \\
\text { I26B } \\
\text { I27B } \\
\text { I28 } \\
\text { I29 } \\
\text { I30 } \\
\text { I31 } \\
\text { I32 } \\
\text { I33 }\end{array}$ & $\begin{array}{l}<.51 \\
<3.0 \\
<.51 \\
<.51 \\
<.51 \\
<.51 \\
<.51 \\
<.51 \\
<.51 \\
<.51\end{array}$ & $\begin{array}{l}<1.6 \\
<3.0 \\
<1.6 \\
<1.6 \\
<1.6 \\
<1.6 \\
<1.6 \\
<1.6 \\
<1.6 \\
<1.6\end{array}$ & $\begin{array}{l}<.50 \\
<3.0 \\
<.50 \\
<.50 \\
<.50 \\
<.50 \\
<.50 \\
<.50 \\
<.50 \\
<.50\end{array}$ & $\begin{array}{l}<.50 \\
<3.0 \\
<.50 \\
<.50 \\
<.50 \\
<.50 \\
<.50 \\
<.50 \\
<.50 \\
<.50\end{array}$ & $\begin{array}{l}<1.2 \\
<3.0 \\
<1.2 \\
<1.2 \\
<1.2 \\
<1.2 \\
<1.2 \\
<1.2 \\
<1.2 \\
<1.2\end{array}$ & $\begin{array}{l}<.50 \\
<3.0 \\
<.50 \\
<.50 \\
<.50 \\
<.50 \\
<.50 \\
<.50 \\
<.50 \\
<.50\end{array}$ & $\begin{array}{l}<1.4 \\
-- \\
<1.4 \\
<1.4 \\
<1.4 \\
<1.4 \\
<1.4 \\
<1.4 \\
<1.4 \\
<1.4\end{array}$ & $\begin{array}{l}<2.6 \\
<1.0 \\
<2.6 \\
<2.9 \\
<2.9 \\
<2.9 \\
<2.9 \\
<2.6 \\
<2.6 \\
<2.6\end{array}$ & $\begin{array}{l}<.84 \\
<3.0 \\
<.84 \\
<.84 \\
<.84 \\
<.84 \\
<.84 \\
<.84 \\
<.84 \\
<.84\end{array}$ \\
\hline $\begin{array}{l}\text { I33 (S) } \\
\text { I34 } \\
\text { I34 (R) } \\
\text { I34 (S) } \\
\text { I35 } \\
\text { I36 } \\
\text { I37B } \\
\text { I37B } \\
\text { I38 } \\
\text { I39 }\end{array}$ & $\begin{array}{l}<3.0 \\
<.51 \\
<.51 \\
<3.0 \\
<.51 \\
<.51 \\
<.51 \\
<.51 \\
<.51 \\
<.51\end{array}$ & $\begin{array}{l}<3.0 \\
<1.6 \\
<1.6 \\
<3.0 \\
<1.6 \\
<1.6 \\
<1.6 \\
<1.6 \\
<1.6 \\
<1.6\end{array}$ & $\begin{array}{l}<3.0 \\
<.50 \\
<.50 \\
<3.0 \\
<.50 \\
<.50 \\
<.50 \\
<.50 \\
<.50 \\
<.50\end{array}$ & $\begin{array}{l}<3.0 \\
<.50 \\
<.50 \\
<3.0 \\
<.50 \\
<.50 \\
<.50 \\
<.50 \\
<.50 \\
<.50\end{array}$ & $\begin{array}{l}<3.0 \\
<1.2 \\
<1.2 \\
<3.0 \\
<1.2 \\
<1.2 \\
<1.2 \\
<1.2 \\
<1.2 \\
<1.2\end{array}$ & $\begin{array}{l}<3.0 \\
<.50 \\
<.50 \\
<3.0 \\
<.50 \\
<.50 \\
<.50 \\
<.50 \\
<.50 \\
<.50\end{array}$ & $\begin{array}{l}-\ddot{1} \\
<1.4 \\
<1.4 \\
<1.4 \\
<1.4 \\
<1.4 \\
<1.4 \\
<1.4 \\
<1.4\end{array}$ & $\begin{array}{l}<1.0 \\
<2.6 \\
<2.6 \\
<1.0 \\
<2.6 \\
<2.6 \\
<2.6 \\
<2.6 \\
<2.6 \\
<2.6\end{array}$ & $\begin{array}{l}<3.0 \\
<.84 \\
<.84 \\
<3.0 \\
<.84 \\
<.84 \\
<.84 \\
<.84 \\
<.84 \\
<.84\end{array}$ \\
\hline $\begin{array}{l}\mathrm{I} 40 \\
\mathrm{I} 41 \\
\mathrm{I} 42 \\
\mathrm{I} 43 \\
\mathrm{I} 44 \\
\mathrm{I} 45 \\
\mathrm{I} 46 \\
\mathrm{I} 47 \mathrm{~A} \\
\mathrm{I} 48 \\
\mathrm{I} 49\end{array}$ & $\begin{array}{l}<.51 \\
<.51 \\
<.51 \\
<1.0 \\
<.51 \\
<3.0 \\
<.51 \\
<.51 \\
<.51 \\
<.51\end{array}$ & $\begin{array}{l}<1.6 \\
<1.6 \\
<1.6 \\
<3.0 \\
<1.6 \\
<8.0 \\
<1.6 \\
<1.6 \\
<1.6 \\
<1.6\end{array}$ & $\begin{array}{l}<.50 \\
<.50 \\
<.50 \\
<1.0 \\
<.50 \\
<2.0 \\
<.50 \\
<.50 \\
<.50 \\
<.50\end{array}$ & $\begin{array}{c}<.50 \\
<.50 \\
<.50 \\
<1.0 \\
<.50 \\
<2.0 \\
<.50 \\
<.50 \\
<.50 \\
<.50\end{array}$ & $\begin{array}{l}<1.2 \\
<1.2 \\
<1.2 \\
<2.0 \\
<1.2 \\
<6.0 \\
<1.2 \\
<1.2 \\
<1.2 \\
<1.2\end{array}$ & $\begin{array}{l}<.50 \\
<.50 \\
<.50 \\
<1.0 \\
<.50 \\
<2.0 \\
<.50 \\
<.50 \\
<.50 \\
<.50\end{array}$ & $\begin{array}{l}<1.4 \\
<1.4 \\
<1.4 \\
<3.0 \\
<1.4 \\
<5.0 \\
<1.4 \\
<1.4 \\
<1.4 \\
<1.4\end{array}$ & $\begin{array}{r}<2.6 \\
<2.6 \\
<2.6 \\
5.0 \\
<2.6 \\
<10 \\
<2.6 \\
<2.6 \\
<2.6 \\
<2.6\end{array}$ & $\begin{array}{c}<.84 \\
<.84 \\
<.84 \\
<2.0 \\
<.84 \\
<4.0 \\
<.84 \\
<.84 \\
<.84 \\
<.84\end{array}$ \\
\hline $\begin{array}{l}\text { I50 } \\
\text { I51 } \\
\text { I52 } \\
\text { I53 } \\
\text { I53 (R) } \\
\text { I54A }\end{array}$ & $\begin{array}{l}<.51 \\
<3.0 \\
<8.0 \\
<.51 \\
<.51 \\
<.51\end{array}$ & $\begin{array}{l}<1.6 \\
<8.0 \\
<1.6 \\
<1.6 \\
<1.6 \\
<1.6\end{array}$ & $\begin{array}{l}<.50 \\
<2.0 \\
<.50 \\
<.50 \\
<.50 \\
<.50\end{array}$ & $\begin{array}{c}<.50 \\
<2.0 \\
<.50 \\
<.50 \\
<.50 \\
<.50\end{array}$ & $\begin{array}{l}<1.2 \\
<6.0 \\
<1.2 \\
<1.2 \\
<1.2 \\
<1.2\end{array}$ & $\begin{array}{c}<.50 \\
<2.0 \\
<.50 \\
<.50 \\
<.50 \\
<.50\end{array}$ & $\begin{array}{l}<1.4 \\
<5.0 \\
<1.4 \\
<1.4 \\
<1.4 \\
<1.4\end{array}$ & $\begin{array}{l}<2.6 \\
<10 \\
<2.6 \\
<2.6 \\
<2.6 \\
<2.6\end{array}$ & $\begin{array}{c}<.84 \\
<4.0 \\
<.84 \\
<.84 \\
<.84 \\
<.84\end{array}$ \\
\hline
\end{tabular}


Table 13. Results of organic-chemical analyses of water from selected wells in the surficial aquifer at Carroll /sland, Aberdeen Proving Ground, Md., spring 1989--Continued

\begin{tabular}{|c|c|c|c|c|c|c|c|c|c|}
\hline $\begin{array}{c}\text { Well } \\
\text { number } \\
\text { (fig. 3) }\end{array}$ & $\begin{array}{c}\text { Acenaph- } \\
\text { thene }\end{array}$ & $\begin{array}{l}\text { Acenaph- } \\
\text { thylene }\end{array}$ & $\begin{array}{c}\text { Acetic acid, } \\
\text { vinyl ester }\end{array}$ & Acetone & Acrolein & $\begin{array}{c}\text { Acrylo- } \\
\text { nitrile }\end{array}$ & Aldrin & Anthracene & $\begin{array}{c}\text { alpha- } \\
\text { Benzene- } \\
\text { hexachloride }\end{array}$ \\
\hline 101 & - & -- & $<8.3$ & $<13$ & $<100$ & $<100$ & -- & -- & -- \\
\hline 102 & -- & -- & $<8.3$ & $<13$ & $<100$ & $<100$ & -- & -- & -- \\
\hline 103 & -- & -. & $<8.3$ & $<13$ & $<100$ & $<100$ & -- & -- & -- \\
\hline 104 & $<1.7$ & $<0.50$ & $<8.3$ & $<13$ & $<100$ & $<100$ & $<4.7$ & $<0.50$ & $<4.0$ \\
\hline 105 & $<1.7$ & $<.50$ & $<8.3$ & $<13$ & $<100$ & $<100$ & $<4.7$ & $<.50$ & $<4.0$ \\
\hline 106 & $<1.7$ & $<.50$ & $<8.3$ & $<13$ & $<100$ & $<100$ & $<4.7$ & $<.50$ & $<4.0$ \\
\hline 107 & $<1.7$ & $<.50$ & $<8.3$ & $<13$ & $<100$ & $<100$ & $<4.7$ & $<.50$ & $<4.0$ \\
\hline 108 & $<1.7$ & $<.50$ & $<8.3$ & $<13$ & $<100$ & $<100$ & $<4.7$ & $<.50$ & $<4.0$ \\
\hline 109 & -- & -- & $<8.3$ & $<13$ & $<100$ & $<100$ & -- & -- & -. \\
\hline 110 & -- & -- & $<8.3$ & $<13$ & $<100$ & $<100$ & -- & -. & -- \\
\hline 112 & $<1.7$ & $<.50$ & $<8.3$ & $<13$ & $<100$ & $<100$ & $<4.7$ & $<.50$ & $<4.0$ \\
\hline 113 & $<1.7$ & $<.50$ & $<9.3$ & 31 & $<100$ & $<100$ & $<4,7$ & $<.50$ & $<4.0$ \\
\hline I14 & $<1.7$ & $<.50$ & $<9.3$ & $<13$ & $<100$ & $<100$ & $<4.7$ & $<.50$ & $<4.0$ \\
\hline I15 & $<1.7$ & $<.50$ & $<9.3$ & $<13$ & $<100$ & $<100$ & $<4.7$ & $<.50$ & $<4.0$ \\
\hline II $6 \mathrm{~B}$ & $<1.7$ & $<.50$ & $<9.3$ & $<13$ & $<100$ & $<100$ & $<4.7$ & $<.50$ & $<4.0$ \\
\hline I17 & $<1.7$ & $<.50$ & $<8.3$ & $<13$ & $<100$ & $<100$ & $<4.7$ & $<.50$ & $<4.0$ \\
\hline 117 (S) & $<5.0$ & $<5.0$ & -- & - & -- & -- & $<.01$ & $<5.0$ & $<.0$ \\
\hline I18 & $<1.7$ & $<.50$ & $<8.3$ & $<13$ & $<100$ & $<100$ & $<4.7$ & $<.50$ & $<4.0$ \\
\hline II8 (R) & $<1.7$ & $<.50$ & $<8.3$ & $<13$ & $<100$ & $<100$ & $<4.7$ & $<.50$ & $<4.0$ \\
\hline 118 (S) & $<5.0$ & $<5.0$ & -- & -- & -- & -- & $<.01$ & $<5.0$ & $<.01$ \\
\hline 119 & $<1.7$ & $<.50$ & $<9.3$ & $<13$ & $<100$ & $<100$ & $<4.7$ & $<.50$ & $<4.0$ \\
\hline 120 & $<1.7$ & $<.50$ & $<8.3$ & $<13$ & $<100$ & $<100$ & $<4.7$ & $<.50$ & $<4.0$ \\
\hline 121 & $<1.7$ & $<.50$ & $<8.3$ & $<13$ & $<100$ & $<100$ & $<4.7$ & $<.50$ & $<4.0$ \\
\hline $122 B$ & $<1.7$ & $<.50$ & $<8.3$ & $<13$ & $<100$ & $<100$ & $<4.7$ & $<.50$ & $<4.0$ \\
\hline I22B (R) & $<1.7$ & $<.50$ & $<8.3$ & $<13$ & $<100$ & $<100$ & $<4.7$ & $<.50$ & $<4.0$ \\
\hline $122 \mathrm{C}$ & $<1.7$ & $<.50$ & $<8.3$ & $<13$ & $<100$ & $<100$ & $<4,7$ & $<.50$ & $<4.0$ \\
\hline 123 & $<1.7$ & $<.50$ & $<8.3$ & $<13$ & $<100$ & $<100$ & $<4.7$ & $<.50$ & $<4.0$ \\
\hline $\mathrm{I} 24$ & $<1.7$ & $<.50$ & $<8.3$ & $<13$ & $<100$ & $<100$ & $<4.7$ & $<.50$ & $<4.0$ \\
\hline $\mathrm{I} 25$ & $<1.7$ & $<.50$ & $<8.3$ & $<13$ & $<100$ & $<100$ & $<4.7$ & $<.50$ & $<4.0$ \\
\hline I26A & $<1.7$ & $<.50$ & $<8.3$ & $<13$ & $<100$ & $<100$ & $<4.7$ & $<.50$ & $<4.0$ \\
\hline I26A (R) & $<1.7$ & $<.50$ & $<8.3$ & $<13$ & $<100$ & $<100$ & $<4.7$ & $<.50$ & $<4.0$ \\
\hline $126 \mathrm{~A}(\mathrm{~S})$ & $<5.0$ & $<5.0$ & -- & -- & -- & -. & $<.01$ & $<5.0$ & $<.01$ \\
\hline $126 \mathrm{~B}$ & $<1.7$ & $<.50$ & $<8.3$ & $<13$ & $<100$ & $<100$ & $<4.7$ & $<.50$ & $<4.0$ \\
\hline I $27 \mathrm{~B}$ & $<1.7$ & $<.50$ & $<9.3$ & $<13$ & $<100$ & $<100$ & $<4.7$ & $<.50$ & $<4.0$ \\
\hline $\mathrm{I} 28$ & $<1.7$ & $<.50$ & $<9.3$ & $<13$ & $<100$ & $<100$ & $<4.7$ & $<.50$ & $<4.0$ \\
\hline 129 & $<1.7$ & $<.50$ & $<9.3$ & $<13$ & $<100$ & $<100$ & $<4.7$ & $<.50$ & $<4.0$ \\
\hline 130 & $<1.7$ & $<.50$ & $<9.3$ & $<13$ & $<100$ & $<100$ & $<4.7$ & $<.50$ & $<4.0$ \\
\hline I31 & $<1.7$ & $<.50$ & $<8.3$ & $<13$ & $<100$ & $<100$ & $<4.7$ & $<.50$ & $<4.0$ \\
\hline 132 & $<1.7$ & $<.50$ & $<8.3$ & $<13$ & $<100$ & $<100$ & $<4.7$ & $<.50$ & $<4.0$ \\
\hline $\mathrm{I} 33$ & $<1.7$ & $<.50$ & $<8.3$ & $<13$ & $<100$ & $<100$ & $<4.7$ & $<.50$ & $<4.0$ \\
\hline $\mathrm{I} 33(\mathrm{~S})$ & $<5.0$ & $<5.0$ & -- & -- & -- & -- & $<.01$ & $<5.0$ & $<.01$ \\
\hline 134 & $<1.7$ & $<.50$ & $<8.3$ & $<13$ & $<100$ & $<100$ & $<4.7$ & $<.50$ & $<4.0$ \\
\hline I34 (R) & $<1.7$ & $<.50$ & $<8.3$ & $<13$ & $<100$ & $<100$ & $<4.7$ & $<.50$ & $<4.0$ \\
\hline 134 (S) & $<5.0$ & $<5.0$ & -- & -- & -- & -- & $<.01$ & $<5.0$ & $<.01$ \\
\hline 135 & $<1.7$ & $<.50$ & $<8.3$ & $<13$ & $<100$ & $<100$ & $<4.7$ & $<.50$ & $<4.0$ \\
\hline 136 & $<1.7$ & $<.50$ & $<8.3$ & $<13$ & $<100$ & $<100$ & $<4.7$ & $<.50$ & $<4.0$ \\
\hline I37B & -- & -- & $<8.3$ & $<13$ & $<100$ & $<100$ & -- & -- & -- \\
\hline $\mathrm{I} 37 \mathrm{~B}(\mathrm{R})$ & .. & -- & $<8.3$ & $<13$ & $<100$ & $<100$ & -- & -- & -- \\
\hline I38 & -- & -- & $<8.3$ & $<13$ & $<100$ & $<100$ & -- & .- & -- \\
\hline 139 & -- & -- & $<8.3$ & $<13$ & $<100$ & $<100$ & -- & -- & -- \\
\hline I 40 & -- & -- & $<8.3$ & $<13$ & $<100$ & $<100$ & -- & -- & -- \\
\hline I41 & -- & -- & $<8.3$ & $<13$ & $<100$ & $<100$ & - & -- & -- \\
\hline I42 & -. & -- & $<8.3$ & $<13$ & $<100$ & $<100$ & - & -- & -- \\
\hline I43 & -- & -- & $<20$ & $<30$ & $<200$ & $<200$ & -- & -- & -- \\
\hline I44 & $<1.7$ & $<.50$ & $<8.3$ & $<13$ & $<100$ & $<100$ & $<4.7$ & $<.50$ & $<4.0$ \\
\hline I45 & $<1.7$ & $<.50$ & $<40$ & $<60$ & $<500$ & $<500$ & $<4.7$ & $<.50$ & $<4.0$ \\
\hline I 46 & $<1.7$ & $<.50$ & $<8.3$ & $<13$ & $<100$ & $<100$ & $<4.7$ & $<.50$ & $<4.0$ \\
\hline I $47 \mathrm{~A}$ & $<1.7$ & $<.50$ & $<8.3$ & $<13$ & $<100$ & $<100$ & $<4.7$ & $<.50$ & $<4.0$ \\
\hline I 48 & $<1.7$ & $<.50$ & $<9.3$ & $<13$ & $<100$ & $<100$ & $<4.7$ & $<.50$ & $<4.0$ \\
\hline 149 & $<1.7$ & $<.50$ & $<9.3$ & $<13$ & $<100$ & $<100$ & $<4.7$ & $<.50$ & $<4.0$ \\
\hline 150 & $<1.7$ & $<.50$ & $<8.3$ & $<13$ & $<100$ & $<100$ & $<4.7$ & $<.50$ & $<4.0$ \\
\hline I51 & $<1.7$ & $<.50$ & $<40$ & $<60$ & $<500$ & $<500$ & $<4.7$ & $<.50$ & $<4.0$ \\
\hline I52 & $<1.7$ & $<.50$ & $<8.3$ & $<13$ & $<100$ & $<100$ & $<4.7$ & $<.50$ & $<4.0$ \\
\hline I53 & $<1.7$ & $<.50$ & $<8.3$ & $<13$ & $<100$ & $<100$ & $<4.7$ & $<.50$ & $<4.0$ \\
\hline $153(\mathrm{R})$ & $<1.7$ & $<.50$ & $<8.3$ & $<13$ & $<100$ & $<100$ & $<4.7$ & $<.50$ & $<4.0$ \\
\hline $\mathrm{I} 54 \mathrm{~A}$ & $<1.7$ & $<.50$ & $<8.3$ & $<13$ & $<100$ & $<100$ & $<4.7$ & $<.50$ & $<4.0$ \\
\hline
\end{tabular}


Table 13. Results of organic-chemical analyses of water from selected wells in the surficial aquifer at Carroll Island, Aberdeen Proving Ground, Md., spring 1989--Continued

\begin{tabular}{|c|c|c|c|c|c|c|c|c|c|}
\hline $\begin{array}{c}\text { Well } \\
\text { number } \\
\text { (fig. 3) }\end{array}$ & $\begin{array}{c}\text { beta- } \\
\text { Benzene- } \\
\text { hexachloride }\end{array}$ & $\begin{array}{c}\text { delta- } \\
\text { Benzene- } \\
\text { hexachloride }\end{array}$ & Benzidine & $\begin{array}{c}\text { Benzo [a] } \\
\text { anthracene }\end{array}$ & $\begin{array}{c}\text { Benzo [b] } \\
\text { fluoranthene }\end{array}$ & $\begin{array}{c}\text { Benzo [k] } \\
\text { fluoranthene }\end{array}$ & $\begin{array}{c}\text { Benzoic } \\
\text { acid }\end{array}$ & $\begin{array}{c}\text { Benzo } \\
\text { [g,h,i] } \\
\text { perylene }\end{array}$ & $\begin{array}{c}\text { Benzo [a] } \\
\text { pyrene }\end{array}$ \\
\hline $\mathrm{I} 01$ & -- & -- & -- & -- & -- & -. & -- & -- & -- \\
\hline I02 & -- & -- & -- & -- & -- & .. & -- & -- & - \\
\hline I03 & -- & -. & -- & -- & -- & -- & -- & -- & -- \\
\hline I04 & $<4.0$ & $<4.0$ & $<10.0$ & $<1.6$ & $<5.4$ & $<0.87$ & $<13.0$ & $<6.1$ & $<4.7$ \\
\hline 105 & $<4.0$ & $<4.0$ & $<10.0$ & $<1.6$ & $<5.4$ & $<.87$ & $<13.0$ & $<6.1$ & $<4.7$ \\
\hline I06 & $<4.0$ & $<4.0$ & $<10.0$ & $<1.6$ & $<5.4$ & $<.87$ & $<13.0$ & $<6.1$ & $<4.7$ \\
\hline I07 & $<4.0$ & $<4.0$ & $<10.0$ & $<1.6$ & $<5.4$ & $<.87$ & $<13.0$ & $<6.1$ & $<4.7$ \\
\hline I08 & $<4.0$ & $<4.0$ & $<10.0$ & $<1.6$ & $<5.4$ & $<.87$ & $<13.0$ & $<6.1$ & $<4.7$ \\
\hline 109 & -. & .. & -- & -- & -- & -- & -- & -- & -- \\
\hline 110 & -- & -- & - & $\cdots$ & -- & -- & -- & -- & -- \\
\hline $\mathrm{I1} 2$ & $<4.0$ & $<4.0$ & $<10.0$ & $<1.6$ & $<5.4$ & $<.87$ & $<13.0$ & $<6.1$ & $<4.7$ \\
\hline I13 & $<4.0$ & $<4.0$ & $<10.0$ & $<1.6$ & $<5.4$ & $<.87$ & $<13.0$ & $<6.1$ & $<4.7$ \\
\hline I14 & $<4.0$ & $<4.0$ & $<10.0$ & $<1.6$ & $<5.4$ & $<.87$ & $<13.0$ & $<6.1$ & $<4.7$ \\
\hline I15 & $<4.0$ & $<4.0$ & $<10.0$ & $<1.6$ & $<5.4$ & $<.87$ & $<13.0$ & $<6.1$ & $<4.7$ \\
\hline I16B & $<4.0$ & $<4.0$ & $<10.0$ & $<1.6$ & $<5.4$ & $<.87$ & $<13.0$ & $<6.1$ & $<4.7$ \\
\hline I17 & $<4.0$ & $<4.0$ & $<10.0$ & $<1.6$ & $<5.4$ & $<.87$ & $<13.0$ & $<6.1$ & $<4.7$ \\
\hline $117(\mathrm{~S})$ & $<.01$ & $<.01$ & -- & $<5.0$ & $<10.0$ & $<10.0$ & -. & $<10.0$ & $<10.0$ \\
\hline 118 & $<4.0$ & $<4.0$ & $<10.0$ & $<1.6$ & $<5.4$ & $<.87$ & $<13.0$ & $<6.1$ & $<4.7$ \\
\hline I18 (R) & $<4.0$ & $<4.0$ & $<10.0$ & $<1.6$ & $<5.4$ & $<.87$ & $<13.0$ & $<6.1$ & $<4.7$ \\
\hline I18 (S) & $<.01$ & $<.01$ & -- & $<5.0$ & $<10.0$ & $<10.0$ & .. & $<10.0$ & $<10.0$ \\
\hline I19 & $<4.0$ & $<4.0$ & $<10.0$ & $<1.6$ & $<5.4$ & $<.87$ & $<13.0$ & $<6.1$ & $<4.7$ \\
\hline $\mathrm{I} 20$ & $<4.0$ & $<4.0$ & $<10.0$ & $<1.6$ & $<5.4$ & $<.87$ & $<13.0$ & $<6.1$ & $<4.7$ \\
\hline I2I & $<4.0$ & $<4.0$ & $<10.0$ & $<1.6$ & $<5.4$ & $<.87$ & $<13.0$ & $<6.1$ & $<4.7$ \\
\hline I22B & $<4.0$ & $<4.0$ & $<10.0$ & $<1.6$ & $<5.4$ & $<.87$ & $<13.0$ & $<6.1$ & $<4.7$ \\
\hline I22B (R) & $<4.0$ & $<4.0$ & $<10.0$ & $<1.6$ & $<5.4$ & $<.87$ & $<13.0$ & $<6.1$ & $<4.7$ \\
\hline $\mathrm{I} 22 \mathrm{C}$ & $<4.0$ & $<4.0$ & $<10.0$ & $<1.6$ & $<5.4$ & $<.87$ & $<13.0$ & $<6.1$ & $<4.7$ \\
\hline $\mathrm{I} 23$ & $<4.0$ & $<4.0$ & $<10.0$ & $<1.6$ & $<5.4$ & $<.87$ & $<13.0$ & $<6.1$ & $<4.7$ \\
\hline I 24 & $<4.0$ & $<4.0$ & $<10.0$ & $<1.6$ & $<5.4$ & $<.87$ & $<13.0$ & $<6.1$ & $<4.7$ \\
\hline I 25 & $<4.0$ & $<4.0$ & $<10.0$ & $<1.6$ & $<5.4$ & $<.87$ & $<13.0$ & $<6.1$ & $<4.7$ \\
\hline $\mathrm{I} 26 \mathrm{~A}$ & $<4.0$ & $<4.0$ & $<10.0$ & $<1.6$ & $<5.4$ & $<.87$ & $<13.0$ & $<6.1$ & $<4.7$ \\
\hline $\mathrm{I} 26 \mathrm{~A}(\mathrm{R})$ & $<4.0$ & $<4.0$ & $<10.0$ & $<1.6$ & $<5.4$ & $<.87$ & $<13.0$ & $<6.1$ & $<4.7$ \\
\hline $126 \mathrm{~A}(\mathrm{~S})$ & $<.0$ & $<.01$ & -. & $<5.0$ & $<10.0$ & $<10.0$ & -- & $<10.0$ & $<10.0$ \\
\hline $126 \mathrm{~B}$ & $<4.0$ & $<4.0$ & $<10.0$ & $<1.6$ & $<5.4$ & $<.87$ & $<13.0$ & $<6.1$ & $<4.7$ \\
\hline I $27 \mathrm{~B}$ & $<4.0$ & $<4.0$ & $<10.0$ & $<1.6$ & $<5.4$ & $<.87$ & $<13.0$ & $<6.1$ & $<4.7$ \\
\hline 128 & $<4.0$ & $<4.0$ & $<10.0$ & $<1.6$ & $<5.4$ & $<87$ & $<13.0$ & $<6.1$ & $<4.7$ \\
\hline 129 & $<4.0$ & $<4.0$ & $<10.0$ & $<1.6$ & $<5.4$ & $<.87$ & $<13.0$ & $<6.1$ & $<4.7$ \\
\hline I30 & $<4.0$ & $<4.0$ & $<10.0$ & $<1.6$ & $<5.4$ & $<.87$ & $<13.0$ & $<6.1$ & $<4.7$ \\
\hline I31 & $<4.0$ & $<4.0$ & $<10.0$ & $<1.6$ & $<5.4$ & $<.87$ & $<13.0$ & $<6.1$ & $<4.7$ \\
\hline I32 & $<4.0$ & $<4.0$ & $<10.0$ & $<1.6$ & $<5.4$ & $<.87$ & $<13.0$ & $<6.1$ & $<4.7$ \\
\hline I33 & $<4.0$ & $<4.0$ & $<10.0$ & $<1.6$ & $<5.4$ & $<.87$ & $<13.0$ & $<6.1$ & $<4.7$ \\
\hline $\mathrm{I} 33(\mathrm{~S})$ & $<.0$ & $<.01$ & -- & $<5.0$ & $<10.0$ & $<10.0$ & - & $<10.0$ & $<10.0$ \\
\hline 134 & $<4.0$ & $<4.0$ & $<10.0$ & $<1.6$ & $<5.4$ & $<.87$ & $<13.0$ & $<6.1$ & $<4.7$ \\
\hline $134(\mathrm{R})$ & $<4.0$ & $<4.0$ & $<10.0$ & $<1.6$ & $<5.4$ & $<.87$ & $<13.0$ & $<6.1$ & $<4.7$ \\
\hline 134 (S) & $<.0$ & $<.01$ & -. & $<5.0$ & $<10.0$ & $<10.0$ & -- & $<10.0$ & $<10.0$ \\
\hline I 35 & $<4.0$ & $<4.0$ & $<10.0$ & $<1.6$ & $<5.4$ & $<.87$ & $<13.0$ & $<6.1$ & $<4.7$ \\
\hline 136 & $<4.0$ & $<4.0$ & $<10.0$ & $<1.6$ & $<5.4$ & $<.87$ & $<13.0$ & $<6.1$ & $<4.7$ \\
\hline I37B & -- & -- & - & -- & -- & -- & -- & .. & -- \\
\hline I37B (R) & -- & -- & -- & -- & -. & -- & -. & - & -- \\
\hline I38 & -- & -- & -- & -- & -- & -- & -- & -- & .. \\
\hline 139 & -- & -- & -- & -- & -- & -- & - & -- & -- \\
\hline I 40 & -- & -- & -- & -- & -- & -- & -. & -- & -- \\
\hline I 41 & .- & -- & -- & -- & -. & -- & .. & -- & -- \\
\hline I 42 & -- & - & -- & -- & -- & -- & - & -- & -- \\
\hline I43 & -- & -- & $\ldots$ & -- & -- & -- & $\cdots$ & -- & -- \\
\hline I44 & $<4.0$ & $<4.0$ & $<10.0$ & $<1.6$ & $<5.4$ & $<.87$ & $<13.0$ & $<6.1$ & $<4.7$ \\
\hline I 45 & $<4.0$ & $<4.0$ & $<10.0$ & $<1.6$ & $<5.4$ & $<.87$ & $<13.0$ & $<6.1$ & $<4.7$ \\
\hline I 46 & $<4.0$ & $<4.0$ & $<10.0$ & $<1.6$ & $<5.4$ & $<.87$ & $<13.0$ & $<6.1$ & $<4.7$ \\
\hline I47A & $<4.0$ & $<4.0$ & $<10.0$ & $<1.6$ & $<5.4$ & $<.87$ & $<13.0$ & $<6.1$ & $<4.7$ \\
\hline $\mathrm{I} 48$ & $<4.0$ & $<4.0$ & $<10.0$ & $<1.6$ & $<5.4$ & $<.87$ & $<13.0$ & $<6.1$ & $<4.7$ \\
\hline 149 & $<4.0$ & $<4.0$ & $<10.0$ & $<1.6$ & $<5.4$ & $<.87$ & $<13.0$ & $<6.1$ & $<4.7$ \\
\hline I50 & $<4.0$ & $<4.0$ & $<10.0$ & $<1.6$ & $<5.4$ & $<.87$ & $<13.0$ & $<6.1$ & $<4.7$ \\
\hline I51 & $<4.0$ & $<4.0$ & $<10.0$ & $<1.6$ & $<5.4$ & $<.87$ & $<13.0$ & $<6.1$ & $<4.7$ \\
\hline I52 & $<4.0$ & $<4.0$ & $<10.0$ & $<1.6$ & $<5.4$ & $<.87$ & $<13.0$ & $<6.1$ & $<4.7$ \\
\hline I53 & $<4.0$ & $<4.0$ & $<10.0$ & $<1.6$ & $<5.4$ & $<.87$ & $<13.0$ & $<6.1$ & $<4.7$ \\
\hline $153(\mathrm{R})$ & $<4.0$ & $<4.0$ & $<10.0$ & $<1.6$ & $<5.4$ & $<.87$ & $<13.0$ & $<6.1$ & $<4.7$ \\
\hline I54A & $<4.0$ & $<4.0$ & $<10.0$ & $<1.6$ & $<5.4$ & $<.87$ & $<13.0$ & $<6.1$ & $<4.7$ \\
\hline
\end{tabular}


Table 13. Results of organic-chemical analyses of water from selected wells in the surficial aquifer at Carroll Island, Aberdeen Proving Ground, Md., spring 1989--Continued

\begin{tabular}{|c|c|c|c|c|c|c|c|c|c|}
\hline $\begin{array}{c}\text { Well } \\
\text { number } \\
\text { (fig. 3) }\end{array}$ & $\begin{array}{c}\text { Benzo- } \\
\text { thia- } \\
\text { zole } \\
\end{array}$ & $\begin{array}{l}\text { Benzyl } \\
\text { alcohol }\end{array}$ & 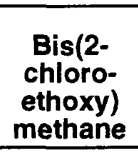 & $\begin{array}{l}\text { Bis(2- } \\
\text { chloro- } \\
\text { ethyl) } \\
\text { ether }\end{array}$ & $\begin{array}{l}\text { Bis(2- } \\
\text { chloro- } \\
\text { iso- } \\
\text { propyl) } \\
\text { ether } \\
\end{array}$ & $\begin{array}{c}\text { 2,2-Bis (para- } \\
\text { chloro-phenyl)- } \\
\text { 1,1-dichloro- } \\
\text { ethane }\end{array}$ & $\begin{array}{c}\text { 2,2-Bis (para- } \\
\text { chloro-phenyl)- } \\
\text { 1,1-dichloro- } \\
\text { ethene }\end{array}$ & $\begin{array}{c}\text { 2,2-Bis (para- } \\
\text { chloro-phenyl)- } \\
\text { 1,1,1-tri- } \\
\text { chloroethane }\end{array}$ & $\begin{array}{c}\text { Bis(2- } \\
\text { ethyl- } \\
\text { hexyl) } \\
\text { phthalate }\end{array}$ \\
\hline I01 & $<2.11$ & -- & -- & -- & -- & -- & $\cdots$ & -. & -- \\
\hline I02 & $<2.11$ & -- & -- & -- & -- & -- & -- & -- & -- \\
\hline I03 & $<2.11$ & -- & -. & -- & -- & -- & -. & .. & -. \\
\hline I04 & $<2.11$ & $<0.72$ & $<1.5$ & $<1.9$ & $<5.3$ & $<4.0$ & $<4.7$ & $<9.2$ & $<4.8$ \\
\hline 105 & $<2.11$ & $<.72$ & $<1.5$ & $<1.9$ & $<5.3$ & $<4.0$ & $<4.7$ & $<9.2$ & $<4.8$ \\
\hline 106 & $<2.11$ & $<.72$ & $<1.5$ & $<1.9$ & $<5.3$ & $<4.0$ & $<4.7$ & $<9.2$ & $<4.8$ \\
\hline 107 & $<2.11$ & $<.72$ & $<1.5$ & $<1.9$ & $<5.3$ & $<4.0$ & $<4.7$ & $<9.2$ & $<4.8$ \\
\hline I08 & $<2.11$ & $<.72$ & $<1.5$ & $<1.9$ & $<5.3$ & $<4.0$ & $<4.7$ & $<9.2$ & $<4.8$ \\
\hline I09 & $<2.11$ & -- & -- & -- & -- & - & -- & -- & -- \\
\hline I10 & $<2.11$ & -- & -- & -- & -- & -- & -- & -- & -- \\
\hline I12 & $<2.11$ & $<.72$ & $<1.5$ & $<1.9$ & $<5.3$ & $<4.0$ & $<4.7$ & $<9.2$ & $<4.8$ \\
\hline I13 & $<2.11$ & $<.72$ & $<1.5$ & $<1.9$ & $<5.3$ & $<4.0$ & $<4.7$ & $<9.2$ & $<4.8$ \\
\hline I14 & $<2.11$ & $<.72$ & $<1.5$ & $<1.9$ & $<.3$ & $<4.0$ & $<4.7$ & $<9.2$ & $<4.8$ \\
\hline I15 & $<2.11$ & $<.72$ & $<1.5$ & $<1.9$ & $<5.3$ & $<4.0$ & $<4.7$ & $<9.2$ & $<4.8$ \\
\hline I16B & $<2.11$ & $<.72$ & $<1.5$ & $<1.9$ & $<5.3$ & $<4.0$ & $<4.7$ & $<9.2$ & $<4.8$ \\
\hline 117 & $<2.11$ & $<.72$ & $<1.5$ & $<1.9$ & $<5.3$ & $<4.0$ & $<4.7$ & $<9.2$ & $<4.8$ \\
\hline $117(S)$ & -- & -- & $<5.0$ & $<5.0$ & $<5.0$ & -. & -- & -- & $<5.0$ \\
\hline 118 & $<2.11$ & $<.72$ & $<1.5$ & $<1.9$ & $<5.3$ & $<4.0$ & $<4.7$ & $<9.2$ & $<4.8$ \\
\hline I18 (R) & $<2.11$ & $<.72$ & $<1.5$ & $<1.9$ & $<5.3$ & $<4.0$ & $<4.7$ & $<9.2$ & $<4.8$ \\
\hline I18 (S) & -- & -- & $<5.0$ & $<5.0$ & $<5.0$ & -- & -- & - & $<5.0$ \\
\hline I19 & $<2.11$ & $<.72$ & $<1.5$ & $<1.9$ & $<5.3$ & $<4.0$ & $<4.7$ & $<9.2$ & $<4.8$ \\
\hline I 20 & $<2.11$ & $<.72$ & $<1.5$ & $<1.9$ & $<5.3$ & $<4.0$ & $<4.7$ & $<9.2$ & $<4.8$ \\
\hline $\mathrm{I} 21$ & $<2.11$ & $<.72$ & $<1.5$ & $<1.9$ & $<5.3$ & $<4.0$ & $<4.7$ & $<9.2$ & $<4.8$ \\
\hline I22B & $<2.11$ & $<.72$ & $<1.5$ & $<1.9$ & $<.3$ & $<4.0$ & $<4.7$ & $<9.2$ & $<4.8$ \\
\hline I22B (R) & $<2.11$ & $<.72$ & $<1.5$ & $<1.9$ & $<5.3$ & $<4.0$ & $<4.7$ & $<9.2$ & $<4.8$ \\
\hline $\mathrm{I} 22 \mathrm{C}$ & $<2.11$ & $<.72$ & $<1.5$ & $<1.9$ & $<5.3$ & $<4.0$ & $<4.7$ & $<9.2$ & $<4.8$ \\
\hline $\mathrm{I} 23$ & $<2.11$ & $<.72$ & $<1.5$ & $<1.9$ & $<5.3$ & $<4.0$ & $<4.7$ & $<9.2$ & $<4.8$ \\
\hline 124 & $<2.11$ & $<.72$ & $<1.5$ & $<1.9$ & $<5.3$ & $<4.0$ & $<4.7$ & $<9.2$ & $<4.8$ \\
\hline $\mathrm{I} 25$ & $<2.11$ & $<.72$ & $<1.5$ & $<1.9$ & $<5.3$ & $<4.0$ & $<4.7$ & $<9.2$ & $<4.8$ \\
\hline $\mathrm{I} 26 \mathrm{~A}$ & $<2.11$ & $<.72$ & $<1.5$ & $<1.9$ & $<5.3$ & $<4.0$ & $<4.7$ & $<9.2$ & $<4.8$ \\
\hline $\mathrm{I} 26 \mathrm{~A}(\mathrm{R})$ & $<2.11$ & $<.72$ & $<1.5$ & $<1.9$ & $<5.3$ & $<4.0$ & $<4.7$ & $<9.2$ & $<4.8$ \\
\hline I26A (S) & -- & -- & $<5.0$ & $<5.0$ & $<5.0$ & -- & -. & - & $<5.0$ \\
\hline $\mathrm{I} 26 \mathrm{~B}$ & $<2.11$ & $<.72$ & $<1.5$ & $<1.9$ & $<5.3$ & $<4.0$ & $<4.7$ & $<9.2$ & $<4.8$ \\
\hline $\mathrm{I} 27 \mathrm{~B}$ & $<2.11$ & $<.72$ & $<1.5$ & $<1.9$ & $<5.3$ & $<4.0$ & $<4.7$ & $<9.2$ & $<4.8$ \\
\hline I 28 & $<2.11$ & $<.72$ & $<1.5$ & $<1.9$ & $<5.3$ & $<4.0$ & $<4.7$ & $<9.2$ & $<4.8$ \\
\hline I 29 & $<2.11$ & $<.72$ & $<1.5$ & $<1.9$ & $<5.3$ & $<4.0$ & $<4.7$ & $<9.2$ & $<4.8$ \\
\hline I30 & $<2.11$ & $<.72$ & $<1.5$ & $<1.9$ & $<5.3$ & $<4.0$ & $<4.7$ & $<9.2$ & $<4.8$ \\
\hline I31 & $<2.11$ & $<.72$ & $<1.5$ & $<1.9$ & $<5.3$ & $<4.0$ & $<4.7$ & $<9.2$ & $<4.8$ \\
\hline $\mathrm{I} 32$ & $<2.11$ & $<.72$ & $<1.5$ & $<1.9$ & $<5.3$ & $<4.0$ & $<4.7$ & $<9.2$ & $<4.8$ \\
\hline $\mathrm{I} 33$ & $<2.11$ & $<.72$ & $<1.5$ & $<1.9$ & $<5.3$ & $<4.0$ & $<4.7$ & $<9.2$ & $<4.8$ \\
\hline I33 (S) & -- & -- & $<5.0$ & $<5.0$ & $<5.0$ & -- & -- & -- & $<5.0$ \\
\hline I34 & $<2.11$ & $<.72$ & $<1.5$ & $<1.9$ & $<5.3$ & $<4.0$ & $<4.7$ & $<9.2$ & $<4.8$ \\
\hline I34 (R) & $<2.11$ & $<.72$ & $<1.5$ & $<1.9$ & $<5.3$ & $<4.0$ & $<4.7$ & $<9.2$ & $<4.8$ \\
\hline I34 (S) & -- & -- & $<5.0$ & $<5.0$ & $<5.0$ & -- & -- & -- & $<5.0$ \\
\hline $\mathrm{I} 35$ & $<2.11$ & $<.72$ & $<1.5$ & $<1.9$ & $<5.3$ & $<4.0$ & $<4.7$ & $<9.2$ & $<4.8$ \\
\hline I36 & $<2.11$ & $<.72$ & $<1.5$ & $<1.9$ & $<5.3$ & $<4.0$ & $<4.7$ & $<9.2$ & $<4.8$ \\
\hline I37B & $<2.11$ & -- & -- & -- & -- & -- & $\ldots$ & -. & -- \\
\hline $\mathrm{I} 37 \mathrm{~B}(\mathrm{R})$ & $<2.11$ & -- & -- & -- & -- & -- & -. & -. & -- \\
\hline I38 & $<2.11$ & -- & .. & -- & -. & -- & -. & -- & -- \\
\hline I39 & $<2.11$ & -- & -- & -- & -- & -- & -- & -- & -- \\
\hline I 40 & $<2.11$ &.- & -- & -- & -- & -- & -- & -- & -- \\
\hline I41 & $<2.11$ & -. & -- & .. & -. & -- & -- & -. & -- \\
\hline I 42 & $<2.11$ & -. & -- & -. & -- & -. & -- & -. & -- \\
\hline I 43 & $<2.11$ & -- & -- & -. & - & -. & .. & -- & .. \\
\hline I44 & $<2.11$ & $<.72$ & $<1.5$ & $<1.9$ & $<5.3$ & $<4.0$ & $<4.7$ & $<9.2$ & $<4.8$ \\
\hline I 45 & $<2.11$ & $<.72$ & $<1.5$ & $<1.9$ & $<5.3$ & $<4.0$ & $<4.7$ & $<9.2$ & $<4.8$ \\
\hline I46 & $<2.11$ & $<72$ & $<1.5$ & $<1.9$ & $<5.3$ & $<4.0$ & $<4.7$ & $<9.2$ & $<4.8$ \\
\hline I $47 \mathrm{~A}$ & $<2.11$ & $<.72$ & $<1.5$ & $<1.9$ & $<5.3$ & $<4.0$ & $<4.7$ & $<9.2$ & $<4.8$ \\
\hline I 48 & $<2.11$ & $<.72$ & $<1.5$ & $<1.9$ & $<5.3$ & $<4.0$ & $<4.7$ & $<9.2$ & $<4.8$ \\
\hline I49 & $<2.11$ & $<.72$ & $<1.5$ & $<1.9$ & $<5.3$ & $<4.0$ & $<4.7$ & $<9.2$ & $<4.8$ \\
\hline I50 & $<2.11$ & $<.72$ & $<1.5$ & $<1.9$ & $<5.3$ & $<4.0$ & $<4.7$ & $<9.2$ & $<4.8$ \\
\hline I51 & $<2.11$ & $<.72$ & $<1.5$ & $<1.9$ & $<5.3$ & $<4.0$ & $<4.7$ & $<9.2$ & $<4.8$ \\
\hline I52 & $<2.11$ & $<.72$ & $<1.5$ & $<1.9$ & $<5.3$ & $<4.0$ & $<4.7$ & $<9.2$ & $<4.8$ \\
\hline I53 & $<2.11$ & $<.72$ & $<1.5$ & $<1.9$ & $<5.3$ & $<4.0$ & $<4.7$ & $<9.2$ & $<4.8$ \\
\hline I53 (R) & $<2.11$ & $<.72$ & $<1.5$ & $<1.9$ & $<5.3$ & $<4.0$ & $<4.7$ & $<9.2$ & $<4.8$ \\
\hline I54A & $<2.11$ & $<.72$ & $<1.5$ & $<1.9$ & $<5.3$ & $<4.0$ & $<4.7$ & $<9.2$ & $<4.8$ \\
\hline
\end{tabular}


Table 13. Results of organic-chemical analyses of water from selected wells in the surficial aquifer at Carroll Island, Aberdeen Proving Ground, Md., spring 1989--Continued

\begin{tabular}{|c|c|c|c|c|c|c|c|c|c|}
\hline $\begin{array}{c}\text { Well } \\
\text { number } \\
\text { (fig. 3) }\end{array}$ & $\begin{array}{l}\text { Bromo- } \\
\text { methane }\end{array}$ & $\begin{array}{c}\text { 4-Bromo- } \\
\text { phenyl- } \\
\text { phenyl ether }\end{array}$ & $\begin{array}{c}\text { Butyl- } \\
\text { benzyl } \\
\text { phthalate }\end{array}$ & $\begin{array}{c}\text { Carbon } \\
\text { disulfide }\end{array}$ & $\begin{array}{c}\text { alpha- } \\
\text { Chlordane }\end{array}$ & $\begin{array}{c}\text { gamma- } \\
\text { Chlordane }\end{array}$ & $\begin{array}{l}\text { 4-Chloro- } \\
\text { aniline }\end{array}$ & $\begin{array}{c}\text { 2-Chloro- } \\
\text { naphthalene }\end{array}$ & $\begin{array}{c}\text { 2-Chloro- } \\
\text { phenol }\end{array}$ \\
\hline I01 & $<5.8$ & -. & -- & $<0.5$ & - & -. & -- & -. & -- \\
\hline 102 & $<5.8$ & -- & -- & $<.5$ & -- & -- & -- & -- & -. \\
\hline 103 & $<5.8$ & -- & -- & $<.5$ & -- & -- & -- & -- & -- \\
\hline I04 & $<5.8$ & $<4.2$ & $<3.4$ & $<.5$ & - & $<5.1$ & $<7.3$ & $<0.50$ & $<0.99$ \\
\hline 105 & $<5.8$ & $<4.2$ & $<3.4$ & $<.5$ & -- & $<5.1$ & $<7.3$ & $<.50$ & $<.99$ \\
\hline 106 & $<5.8$ & $<4.2$ & $<3.4$ & $<.5$ & - & $<5.1$ & $<7.3$ & $<.50$ & $<.99$ \\
\hline 107 & $<5.8$ & $<4.2$ & $<3.4$ & $<.5$ & -- & $<5.1$ & $<7.3$ & $<.50$ & $<.99$ \\
\hline I08 & $<5.8$ & $<4.2$ & $<3.4$ & $<.5$ & -- & $<5.1$ & $<7.3$ & $<.50$ & $<.99$ \\
\hline 109 & $<5.8$ & -- & -- & $<.5$ & -- & -- & -- & - & -- \\
\hline $\mathrm{I} 10$ & $<5.8$ & -- & -- & $<.5$ & - & - & -- & $\cdots$ & -- \\
\hline I12 & $<5.8$ & $<4.2$ & $<3.4$ & $<.5$ & - & $<5.1$ & $<7.3$ & $<.50$ & $<.99$ \\
\hline 113 & $<5.8$ & $<4.2$ & $<3.4$ & $<.5$ & $<5.1$ & $<5.1$ & $<7.3$ & $<.50$ & $<.99$ \\
\hline I14 & $<5.8$ & $<4.2$ & $<3.4$ & $<.5$ & $<5.1$ & $<5.1$ & $<7.3$ & $<.50$ & $<.99$ \\
\hline 115 & $<5.8$ & $<4.2$ & $<3.4$ & $<.5$ & $<5.1$ & $<5.1$ & $<7.3$ & $<.50$ & $<.99$ \\
\hline I16B & $<5.8$ & $<4.2$ & $<3.4$ & $<.5$ & $<5.1$ & $<5.1$ & $<7.3$ & $<.50$ & $<.99$ \\
\hline 117 & $<5.8$ & $<4.2$ & $<3.4$ & $<.5$ & $<5.1$ & $<5.1$ & $<7.3$ & $<.50$ & $<.99$ \\
\hline 117 (S) & -- & $<5.0$ & -- & -- & - & 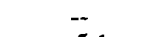 & - & $<5.0$ & $<5.0$ \\
\hline I18 & $<5.8$ & $<4.2$ & $<3.4$ & $<.5$ & $<5.1$ & $<5.1$ & $<7.3$ & $<.50$ & $<.99$ \\
\hline 118 (R) & $<5.8$ & $<4.2$ & $<3.4$ & $<.5$ & $<5.1$ & $<5.1$ & $<7.3$ & $<.50$ & $<.99$ \\
\hline I18 (S) & -- & $<5.0$ & -- & -- & -- & - & -- & $<5.0$ & $<5.0$ \\
\hline I19 & $<5.8$ & $<4.2$ & $<3.4$ & $<.5$ & $<5.1$ & $<5.1$ & $<7.3$ & $<.50$ & $<.99$ \\
\hline 120 & $<5.8$ & $<4.2$ & $<3.4$ & $<.5$ & -- & $<5.1$ & $<7.3$ & $<.50$ & $<.99$ \\
\hline $\mathrm{I} 21$ & $<5.8$ & $<4.2$ & $<3.4$ & $<.5$ & -- & $<5.1$ & $<7.3$ & $<.50$ & $<.99$ \\
\hline $122 \mathrm{~B}$ & $<5.8$ & $<4.2$ & $<3.4$ & $<.5$ & -- & $<5.1$ & $<7.3$ & $<.50$ & $<.99$ \\
\hline I22B (R) & $<5.8$ & $<4.2$ & $<3.4$ & $<.5$ & -- & $<5.1$ & $<7.3$ & $<.50$ & $<.99$ \\
\hline I22C & $<5.8$ & $<4.2$ & $<3.4$ & $<.5$ & -- & $<5.1$ & $<7.3$ & $<.50$ & $<.99$ \\
\hline $\mathrm{I} 23$ & $<5.8$ & $<4.2$ & $<3.4$ & $<.5$ & -- & $<5.1$ & $<7.3$ & $<.50$ & $<.99$ \\
\hline I 24 & $<5.8$ & $<4.2$ & $<3.4$ & $<.5$ & $<5.1$ & $<5.1$ & $<7.3$ & $<.50$ & $<.99$ \\
\hline I25 & $<5.8$ & $<4.2$ & $<3.4$ & $<.5$ & - & $<5.1$ & $<7.3$ & $<.50$ & $<.99$ \\
\hline $\mathrm{I} 26 \mathrm{~A}$ & $<5.8$ & $<4.2$ & $<3.4$ & $<.5$ & $<5.1$ & $<5.1$ & $<7.3$ & $<.50$ & $<.99$ \\
\hline $\mathrm{I} 26 \mathrm{~A}(\mathrm{R})$ & $<5.8$ & $<4.2$ & $<3.4$ & $<.5$ & -- & $<5.1$ & $<7.3$ & $<.50$ & $<.99$ \\
\hline I26A (S) & - & $<5.0$ & - & $\cdots$ & 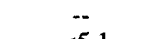 & $\ddot{z}$ & $\bar{z}$ & $<5.0$ & $<5.0$ \\
\hline I26B & $<5.8$ & $<4.2$ & $<3.4$ & $<.5$ & $<5.1$ & $<5.1$ & $<7.3$ & $<.50$ & $<.99$ \\
\hline I27B & $<5.8$ & $<4.2$ & $<3.4$ & $<.5$ & $<5.1$ & $<5.1$ & $<7.3$ & $<.50$ & $<.99$ \\
\hline I 28 & $<5.8$ & $<4.2$ & $<3.4$ & $<.5$ & $<5.1$ & $<5.1$ & $<7.3$ & $<.50$ & $<.99$ \\
\hline I 29 & $<5.8$ & $<4.2$ & $<3.4$ & $<.5$ & $<5.1$ & $<5.1$ & $<7.3$ & $<.50$ & $<.99$ \\
\hline I30 & $<5.8$ & $<4.2$ & $<3.4$ & $<.5$ & $<5.1$ & $<5.1$ & $<7.3$ & $<.50$ & $<.99$ \\
\hline I31 & $<5.8$ & $<4.2$ & $<3.4$ & $<.5$ & $<5.1$ & $<5.1$ & $<7.3$ & $<.50$ & $<.99$ \\
\hline 132 & $<5.8$ & $<4.2$ & $<3.4$ & $<.5$ & $<5.1$ & $<5.1$ & $<7.3$ & $<.50$ & $<.99$ \\
\hline I33 & $<5.8$ & $<4.2$ & $<3.4$ & $<.5$ & $<5.1$ & $<5.1$ & $<7.3$ & $<.50$ & $<.99$ \\
\hline I33 (S) & - & $<5.0$ & -- & - & -- & - & -- & $<5.0$ & $<5.0$ \\
\hline I34 & $<5.8$ & $<4.2$ & $<3.4$ & $<.5$ & $<5.1$ & $<5.1$ & $<7.3$ & $<.50$ & $<.99$ \\
\hline I34 (R) & $<5.8$ & $<4.2$ & $<3.4$ & $<.5$ & $<5.1$ & $<5.1$ & $<7.3$ & $<.50$ & $<.99$ \\
\hline I34 (S) & $-\bar{\sigma}$ & $<5.0$ & -- & -- & $\because$ & $\overline{-}$ & -- & $<5.0$ & $<5.0$ \\
\hline I35 & $<5.8$ & $<4.2$ & $<3.4$ & $<.5$ & $<5.1$ & $<5.1$ & $<7.3$ & $<.50$ & $<.99$ \\
\hline I36 & $<5.8$ & $<4.2$ & $<3.4$ & $<.5$ & $<5.1$ & $<5.1$ & $<7.3$ & $<.50$ & $<.99$ \\
\hline I37B & $<5.8$ & -- & -- & $<.5$ & -- & -- & -- & -- & -- \\
\hline I37B (R) & $<5.8$ & -- & -- & $<.5$ & - & -- & -- & -- & -- \\
\hline I38 & $<5.8$ & -- & -- & $<.5$ & -- & -- & -- & -- & $-\cdot$ \\
\hline 139 & $<5.8$ & -- & -- & $<.5$ & $-\cdot$ & -- & -- & $-\cdot$ & -- \\
\hline I 40 & $<5.8$ & -- & -- & $<.5$ & -- & -- & -- & -- & - \\
\hline I41 & $<5.8$ & -- & -- & $<.5$ & -- & $-\cdot$ & -- & -- & -- \\
\hline I42 & $<5.8$ & -. & -- & $<.5$ & -- & -- & -- & -- & -- \\
\hline I 43 & $<10$ & -- & $\because$ & $<1$ & -- & $\ddot{r}$ & $\ddot{-}$ & -- & -- \\
\hline I44 & $<5.8$ & $<4.2$ & $<3.4$ & $<.5$ & -- & $<5.1$ & $<7.3$ & $<.50$ & $<.99$ \\
\hline I45 & $<30$ & $<4.2$ & $<3.4$ & $<2$ & -- & $<5.1$ & $<7.3$ & $<.50$ & $<.99$ \\
\hline I46 & $<5.8$ & $<4.2$ & $<3.4$ & $<.5$ & -- & $<5.1$ & $<7.3$ & $<.50$ & $<.99$ \\
\hline I47A & $<5.8$ & $<4.2$ & $<3.4$ & $<.5$ & -- & $<5.1$ & $<7.3$ & $<.50$ & $<.99$ \\
\hline I 48 & $<5.8$ & $<4.2$ & $<3.4$ & $<.5$ & -- & $<5.1$ & $<7.3$ & $<.50$ & $<.99$ \\
\hline 149 & $<5.8$ & $<4.2$ & $<3.4$ & $<.5$ & - & $<5.1$ & $<7.3$ & $<.50$ & $<.99$ \\
\hline 150 & $<5.8$ & $<4.2$ & $<3.4$ & $<.5$ & -- & $<5.1$ & $<7.3$ & $<.50$ & $<.99$ \\
\hline 151 & $<30$ & $<4.2$ & $<3.4$ & $<2$ & -- & $<5.1$ & $<7.3$ & $<.50$ & $<.99$ \\
\hline I52 & $<5.8$ & $<4.2$ & $<3.4$ & $<.5$ & -- & $<5.1$ & $<7.3$ & $<.50$ & $<.99$ \\
\hline I53 & $<5.8$ & $<4.2$ & $<3.4$ & $<.5$ & - & $<5.1$ & $<7.3$ & $<.50$ & $<.99$ \\
\hline $153(R)$ & $<5.8$ & $<4.2$ & $<3.4$ & $<.5$ & -- & $<5.1$ & $<7.3$ & $<.50$ & $<.99$ \\
\hline I54A & $<5.8$ & $<4.2$ & $<3.4$ & $<.5$ & $-\cdot$ & $<5.1$ & $<7.3$ & $<.50$ & $<.99$ \\
\hline
\end{tabular}


Table 13. Results of organic-chemical analyses of water from selected wells in the surficial aquifer at Carroll Island, Aberdeen Proving Ground, Md., spring 1989--Continued

\begin{tabular}{|c|c|c|c|c|c|c|c|c|c|}
\hline $\begin{array}{c}\text { Well } \\
\text { number } \\
\text { (fig. 3) }\end{array}$ & $\begin{array}{l}\text { 4-Chloro- } \\
\text { phenyl- } \\
\text { methyl } \\
\text { sulfide } \\
\end{array}$ & $\begin{array}{c}\text { 4-Chloro- } \\
\text { phenyl- } \\
\text { methyl } \\
\text { sulfone } \\
\end{array}$ & $\begin{array}{c}\text { 4-Chloro- } \\
\text { phenyl- } \\
\text { methyl } \\
\text { sulfoxide }\end{array}$ & $\begin{array}{c}\text { 4-Chloro- } \\
\text { phenyl- } \\
\text { phenyl } \\
\text { ether }\end{array}$ & Chrysene & $\begin{array}{c}\text { Diacetone } \\
\text { alcohol }\end{array}$ & $\begin{array}{l}\text { Dibenz [a,h] } \\
\text { anthracene }\end{array}$ & $\begin{array}{c}\text { Dibenzo } \\
\text { furan }\end{array}$ & $\begin{array}{l}\text { Di-n-butyl } \\
\text { phthalate }\end{array}$ \\
\hline I01 & $<1.26$ & $<4.72$ & $<4.23$ & -- & -- & -- & -- & -- & -- \\
\hline I02 & $<1.26$ & $<4.72$ & $<4.23$ & -- & -- & -- & -- & -- & - \\
\hline $\mathrm{I} 03$ & $<1.26$ & $<4.72$ & $<4.23$ & -- & -- & -- & -- & -- & -- \\
\hline I04 & $<1.26$ & $<4.72$ & $<4.23$ & $<5.1$ & $<2.4$ & -- & $<6.5$ & $<1.7$ & $<3.7$ \\
\hline I05 & $<1.26$ & $<4.72$ & $<4.23$ & $<5.1$ & $<2.4$ & -- & $<6.5$ & $<1.7$ & $<3.7$ \\
\hline I06 & $<1.26$ & $<4.72$ & $<4.23$ & $<5.1$ & $<2.4$ & -- & $<6.5$ & $<1.7$ & $<3.7$ \\
\hline I07 & $<1.26$ & $<4.72$ & $<4.23$ & $<5.1$ & $<2.4$ & -. & $<6.5$ & $<1.7$ & $<3.7$ \\
\hline I08 & $<1.26$ & $<4.72$ & $<4.23$ & $<5.1$ & $<2.4$ & -- & $<6.5$ & $<1.7$ & $<3.7$ \\
\hline I09 & $<1.26$ & $<4.72$ & $<4.23$ & -- & -- & -- & -- & -- & -. \\
\hline I10 & $<1.26$ & $<4.72$ & $<4.23$ & -- & -- & -- & - & -- & -- \\
\hline $\mathrm{I} 12$ & $<1.26$ & $<4.72$ & $<4.23$ & $<5.1$ & $<2.4$ & -- & $<6.5$ & $<1.7$ & $<3.7$ \\
\hline I13 & $<1.26$ & $<4.72$ & $<4.23$ & $<5.1$ & $<2.4$ & -- & $<6.5$ & $<1.7$ & $<3.7$ \\
\hline I14 & $<1.26$ & $<4.72$ & $<4.23$ & $<5.1$ & $<2.4$ & -- & $<6.5$ & $<1.7$ & $<3.7$ \\
\hline I15 & $<1.26$ & $<4.72$ & $<4.23$ & $<5.1$ & $<2.4$ & -- & $<6.5$ & $<1.7$ & $<3.7$ \\
\hline I16B & $<1.26$ & $<4.72$ & $<4.23$ & $<5.1$ & $<2.4$ & -- & $<6.5$ & $<1.7$ & $<3.7$ \\
\hline I17 & $<1.26$ & $<4.72$ & $<4.23$ & $<5.1$ & $<2.4$ & 7.0 & $<6.5$ & $<1.7$ & $<3.7$ \\
\hline $117(\mathrm{~S})$ & -- & -- & -- & $<5.0$ & $<10.0$ & -- & -- & -- & $<5.0$ \\
\hline I18 & $<1.26$ & $<4.72$ & $<4.23$ & $<5.1$ & $<2.4$ & -- & $<6.5$ & $<1.7$ & $<3.7$ \\
\hline I18 (R) & $<1.26$ & $<4.72$ & $<4.23$ & $<5.1$ & $<2.4$ & -- & $<6.5$ & $<1.7$ & $<3.7$ \\
\hline I18 (S) & -- & -- & -- & $<5.0$ & $<10.0$ & -- & - & -- & $<5.0$ \\
\hline I19 & $<1.26$ & $<4.72$ & $<4.23$ & $<5.1$ & $<2.4$ & -- & $<6.5$ & $<1.7$ & $<3.7$ \\
\hline 120 & $<1.26$ & $<4.72$ & $<4.23$ & $<5.1$ & $<2.4$ & 4.0 & $<6.5$ & $<1.7$ & $<3.7$ \\
\hline $\mathrm{I} 21$ & $<1.26$ & $<4.72$ & $<4.23$ & $<5.1$ & $<2.4$ & -- & $<6.5$ & $<1.7$ & $<3.7$ \\
\hline I $22 \mathrm{~B}$ & $<1.26$ & $<4.72$ & $<4.23$ & $<5.1$ & $<2.4$ & -. & $<6.5$ & $<1.7$ & $<3.7$ \\
\hline I22B (R) & $<1.26$ & $<4.72$ & $<4.23$ & $<5.1$ & $<2.4$ & -- & $<6.5$ & $<1.7$ & $<3.7$ \\
\hline $\mathrm{I} 22 \mathrm{C}$ & $<1.26$ & $<4.72$ & $<4.23$ & $<5.1$ & $<2.4$ & -- & $<6.5$ & $<1.7$ & $<3.7$ \\
\hline $\mathrm{I} 23$ & $<1.26$ & $<4.72$ & $<4.23$ & $<5.1$ & $<2.4$ & -- & $<6.5$ & $<1.7$ & $<3.7$ \\
\hline $\mathrm{I} 24$ & $<1.26$ & $<4.72$ & $<4.23$ & $<5.1$ & $<2.4$ & -- & $<6.5$ & $<1.7$ & $<3.7$ \\
\hline I25 & $<1.26$ & $<4.72$ & $<4.23$ & $<5.1$ & $<2.4$ & -- & $<6.5$ & $<1.7$ & $<3.7$ \\
\hline $\mathrm{I} 26 \mathrm{~A}$ & $<1.26$ & $<4.72$ & $<4.23$ & $<5.1$ & $<2.4$ & -- & $<6.5$ & $<1.7$ & $<3.7$ \\
\hline $\mathrm{I} 26 \mathrm{~A}(\mathrm{R})$ & $<1.26$ & $<4.72$ & $<4.23$ & $<5.1$ & $<2.4$ & -- & $<6.5$ & $<1.7$ & $<3.7$ \\
\hline $\mathrm{I} 26 \mathrm{~A}(\mathrm{~S})$ & - & -- & -- & $<5.0$ & $<10.0$ & -- & -- & -- & $<5.0$ \\
\hline I26B & $<1.26$ & $<4.72$ & $<4.23$ & $<5.1$ & $<2.4$ & -- & $<6.5$ & $<1.7$ & $<3.7$ \\
\hline $\mathrm{I} 27 \mathrm{~B}$ & $<1.26$ & $<4.72$ & $<4.23$ & $<5.1$ & $<2.4$ & -- & $<6.5$ & $<1.7$ & $<3.7$ \\
\hline 128 & $<1.26$ & $<4.72$ & $<4.23$ & $<5.1$ & $<2.4$ & -- & $<6.5$ & $<1.7$ & $<3.7$ \\
\hline $\mathrm{I} 29$ & $<1.26$ & $<4.72$ & $<4.23$ & $<5.1$ & $<2.4$ & .- & $<6.5$ & $<1.7$ & $<3.7$ \\
\hline I30 & $<1.26$ & $<4.72$ & $<4.23$ & $<5.1$ & $<2.4$ & -- & $<6.5$ & $<1.7$ & $<3.7$ \\
\hline 131 & $<1.26$ & $<4.72$ & $<4.23$ & $<5.1$ & $<2.4$ & -- & $<6.5$ & $<1.7$ & $<3.7$ \\
\hline $\mathrm{I} 32$ & $<1.26$ & $<4.72$ & $<4.23$ & $<5.1$ & $<2.4$ & -- & $<6.5$ & $<1.7$ & $<3.7$ \\
\hline $\mathrm{I} 33$ & $<1.26$ & $<4.72$ & $<4.23$ & $<5.1$ & $<2.4$ & -- & $<6.5$ & $<1.7$ & $<3.7$ \\
\hline I33 (S) & -- & -- & -- & $<5.0$ & $<10.0$ & -. & -- & -. & $<5.0$ \\
\hline I34 & $<1.26$ & $<4.72$ & $<4.23$ & $<5.1$ & $<2.4$ & -- & $<6.5$ & $<1.7$ & $<3.7$ \\
\hline I34 (R) & $<1.26$ & $<4.72$ & $<4.23$ & $<5.1$ & $<2.4$ & -- & $<6.5$ & $<1.7$ & $<3.7$ \\
\hline I34 (S) & -- & -. & -- & $<5.0$ & $<10.0$ & -- & -- & -. & $<5.0$ \\
\hline I35 & $<1.26$ & $<4.72$ & $<4.23$ & $<5.1$ & $<2.4$ & -- & $<6.5$ & $<1.7$ & $<3.7$ \\
\hline I36 & $<1.26$ & $<4.72$ & $<4.23$ & $<5.1$ & $<2.4$ & -- & $<6.5$ & $<1.7$ & $<3.7$ \\
\hline I37B & $<1.26$ & $<4.72$ & $<4.23$ & -- & -- & -- & -- & -- & -- \\
\hline I37B (R) & $<1.26$ & $<4.72$ & $<4.23$ & -- & - & -- & -- & -- & -- \\
\hline $\mathrm{I} 38$ & $<1.26$ & $<4.72$ & $<4.23$ & -- & -- & -- & -- & - & $-\cdot$ \\
\hline I39 & $<1.26$ & $<4.72$ & $<4.23$ & -- & -- & -- & -- & -- & -- \\
\hline I40 & $<1.26$ & $<4.72$ & $<4.23$ & -. & -- & -. & -- & -. & -- \\
\hline I41 & $<1.26$ & $<4.72$ & $<4.23$ & -- & -- & -- & -. & -. & -- \\
\hline I42 & $<1.26$ & $<4.72$ & $<4.23$ & -- & -- & -- & - & -- & -- \\
\hline I43 & $<1.26$ & $<4.72$ & $<4.23$ & -- & -- & -- & -- & -- & -- \\
\hline I 44 & $<1.26$ & $<4.72$ & $<4.23$ & $<5.1$ & $<2.4$ & 4.0 & $<6.5$ & $<1.7$ & $<3.7$ \\
\hline I45 & $<1.26$ & $<4.72$ & $<4.23$ & $<5.1$ & $<2.4$ & -- & $<6.5$ & $<1.7$ & $<3.7$ \\
\hline I 46 & $<1.26$ & $<4.72$ & $<4.23$ & $<5.1$ & $<2.4$ & -- & $<6.5$ & $<1.7$ & $<3.7$ \\
\hline I47A & $<1.26$ & $<4.72$ & $<4.23$ & $<5.1$ & $<2.4$ & -. & $<6.5$ & $<1.7$ & $<3.7$ \\
\hline I 48 & $<1.26$ & $<4.72$ & $<4.23$ & $<5.1$ & $<2.4$ & -- & $<6.5$ & $<1.7$ & $<3.7$ \\
\hline I 49 & $<1.26$ & $<4.72$ & $<4.23$ & $<5.1$ & $<2.4$ & -- & $<6.5$ & $<1.7$ & $<3.7$ \\
\hline I50 & $<1.26$ & $<4.72$ & $<4.23$ & $<5.1$ & $<2.4$ & -- & $<6.5$ & $<1.7$ & $<3.7$ \\
\hline I5I & $<1.26$ & $<4.72$ & $<4.23$ & $<5.1$ & $<2.4$ & -- & $<6.5$ & $<1.7$ & $<3.7$ \\
\hline I52 & $<1.26$ & $<4.72$ & $<4.23$ & $<5.1$ & $<2.4$ & $\cdots$ & $<6.5$ & $<1.7$ & $<3.7$ \\
\hline I53 & $<1.26$ & $<4.72$ & $<4.23$ & $<5.1$ & $<2.4$ & -- & $<6.5$ & $<1.7$ & $<3.7$ \\
\hline I53 (R) & $<1.26$ & $<4.72$ & $<4.23$ & $<5.1$ & $<2.4$ & -- & $<6.5$ & $<1.7$ & $<3.7$ \\
\hline $\mathrm{I} 54 \mathrm{~A}$ & $<1.26$ & $<4.72$ & $<4.23$ & $<5.1$ & $<2.4$ & -- & $<6.5$ & $<1.7$ & $<3.7$ \\
\hline
\end{tabular}


Table 13. Results of organic-chemical analyses of water from selected wells in the surficial aquifer at Carroll Island, Aberdeen Proving Ground, Md., spring 1989--Continued

\begin{tabular}{|c|c|c|c|c|c|c|c|c|}
\hline $\begin{array}{c}\text { Well } \\
\text { number } \\
\text { (fig. 3) }\end{array}$ & $\begin{array}{l}\text { Dichloro- } \\
\text { benzenes }\end{array}$ & $\begin{array}{l}\text { 3,3'-Dichloro- } \\
\text { benzidine }\end{array}$ & $\begin{array}{c}\text { 2,4-Dichloro- } \\
\text { phenol }\end{array}$ & Dieldrin & $\begin{array}{c}\text { Diethyl } \\
\text { phthalate }\end{array}$ & $\begin{array}{l}\text { Dimethyl } \\
\text { disulfide }\end{array}$ & $\begin{array}{c}\text { 2,4-Dimethyl- } \\
\text { phenol }\end{array}$ & $\begin{array}{l}\text { Dimethyl } \\
\text { phthalate }\end{array}$ \\
\hline 101 & $<10.0$ & -- & -- & -- & -. & $<1.14$ & -- & -- \\
\hline 102 & $<10.0$ & -- & -- & -- & -- & $<1.14$ & -- & -. \\
\hline $\mathrm{I} 03$ & $<10.0$ & -- & -- & -- & -- & $<1.14$ & -- & -- \\
\hline 104 & $<10.0$ & $<12.0$ & $<2.9$ & $<4.7$ & $<2.0$ & $<1.14$ & $<5.8$ & $<1.5$ \\
\hline 105 & $<10.0$ & $<12.0$ & $<2.9$ & $<4.7$ & $<2.0$ & $<1.14$ & $<5.8$ & $<1.5$ \\
\hline I06 & $<10.0$ & $<12.0$ & $<2.9$ & $<4.7$ & $<2.0$ & $<1.14$ & $<5.8$ & $<1.5$ \\
\hline I07 & $<10.0$ & $<12.0$ & $<2.9$ & $<4.7$ & $<2.0$ & $<1.14$ & $<5.8$ & $<1.5$ \\
\hline 108 & $<10.0$ & $<12.0$ & $<2.9$ & $<4.7$ & $<2.0$ & $<1.14$ & $<5.8$ & $<1.5$ \\
\hline 109 & $<10.0$ &.- & - & -. & -. & $<1.14$ & -. &.- \\
\hline $\mathrm{I} 10$ & $<10.0$ & -- & -- & - & -- & $<1.14$ & -- & -- \\
\hline $\mathrm{I} 12$ & $<10.0$ & $<12.0$ & $<2.9$ & $<4.7$ & $<2.0$ & $<1.14$ & $<5.8$ & $<1.5$ \\
\hline I13 & $<10.0$ & $<12.0$ & $<2.9$ & $<4.7$ & $<2.0$ & $<1.14$ & $<5.8$ & $<1.5$ \\
\hline I14 & $<10.0$ & $<12.0$ & $<2.9$ & $<4.7$ & $<2.0$ & $<1.14$ & $<5.8$ & $<1.5$ \\
\hline 115 & $<10.0$ & $<12.0$ & $<2.9$ & $<4.7$ & $<2.0$ & $<1.14$ & $<5.8$ & $<1.5$ \\
\hline $116 \mathrm{~B}$ & $<10.0$ & $<12.0$ & $<2.9$ & $<4.7$ & $<2.0$ & $<1.14$ & $<5.8$ & $<1.5$ \\
\hline 117 & $<10.0$ & $<12.0$ & $<2.9$ & $<4.7$ & $<2.0$ & $<1.14$ & $<5.8$ & $<1.5$ \\
\hline I17 (S) & -- & -. & $<5.0$ & $<.01$ & $<5.0$ & -- & $<5.0$ & $<5.0$ \\
\hline I18 & $<10.0$ & $<12.0$ & $<2.9$ & $<4.7$ & $<2.0$ & $<1.14$ & $<5.8$ & $<1.5$ \\
\hline I18 (R) & $<10.0$ & $<12.0$ & $<2.9$ & $<4.7$ & $<2.0$ & $<1.14$ & $<5.8$ & $<1.5$ \\
\hline I18 (S) & - & -- & $<5.0$ & $<.01$ & $<5.0$ & -- & $<5.0$ & $<5.0$ \\
\hline 119 & $<10.0$ & $<12.0$ & $<2.9$ & $<4.7$ & $<2.0$ & $<1.14$ & $<5.8$ & $<1.5$ \\
\hline I 20 & $<10.0$ & $<12.0$ & $<2.9$ & $<4.7$ & $<2.0$ & $<1.14$ & $<5.8$ & $<1.5$ \\
\hline 121 & $<10.0$ & $<12.0$ & $<2.9$ & $<4.7$ & $<2.0$ & $<1.14$ & $<5.8$ & $<1.5$ \\
\hline I22B & $<10.0$ & $<12.0$ & $<2.9$ & $<4.7$ & $<2.0$ & $<1.14$ & $<5.8$ & $<1.5$ \\
\hline I22B (R) & $<10.0$ & $<12.0$ & $<2.9$ & $<4.7$ & $<2.0$ & $<1.14$ & $<5.8$ & $<1.5$ \\
\hline I22C & $<10.0$ & $<12.0$ & $<2.9$ & $<4.7$ & $<2.0$ & $<1.14$ & $<5.8$ & $<1.5$ \\
\hline I 23 & $<10.0$ & $<12.0$ & $<2.9$ & $<4.7$ & $<2.0$ & $<1.14$ & $<5.8$ & $<1.5$ \\
\hline I 24 & $<10.0$ & $<12.0$ & $<2.9$ & $<4.7$ & $<2.0$ & $<1.14$ & $<5.8$ & $<1.5$ \\
\hline I 25 & $<10.0$ & $<12.0$ & $<2.9$ & $<4.7$ & $<2.0$ & $<1.14$ & $<5.8$ & $<1.5$ \\
\hline $126 \mathrm{~A}$ & $<10.0$ & $<12.0$ & $<2.9$ & $<4.7$ & $<2.0$ & $<1.14$ & $<5.8$ & $<1.5$ \\
\hline I26A (R) & $<10.0$ & $<12.0$ & $<2.9$ & $<4.7$ & $<2.0$ & $<1.14$ & $<5.8$ & $<1.5$ \\
\hline I26A (S) & -. & -- & $<5.0$ & $<.01$ & $<5.0$ & -- & $<5.0$ & $<5.0$ \\
\hline $\mathrm{I} 26 \mathrm{~B}$ & $<10.0$ & $<12.0$ & $<2.9$ & $<4.7$ & $<2.0$ & $<1.14$ & $<5.8$ & $<1.5$ \\
\hline $127 \mathrm{~B}$ & $<10.0$ & $<12.0$ & $<2.9$ & $<4.7$ & $<2.0$ & $<1.14$ & $<5.8$ & $<1.5$ \\
\hline I 28 & $<10.0$ & $<12.0$ & $<2.9$ & $<4.7$ & $<2.0$ & $<1.14$ & $<5.8$ & $<1.5$ \\
\hline 129 & $<10.0$ & $<12.0$ & $<2.9$ & $<4.7$ & $<2.0$ & $<1.14$ & $<5.8$ & $<1.5$ \\
\hline 130 & $<10.0$ & $<12.0$ & $<2.9$ & $<4.7$ & $<2.0$ & $<1.14$ & $<5.8$ & $<1.5$ \\
\hline I31 & $<10.0$ & $<12.0$ & $<2.9$ & $<4.7$ & $<2.0$ & $<1.14$ & $<5.8$ & $<1.5$ \\
\hline $\mathrm{I} 32$ & $<10.0$ & $<12.0$ & $<2.9$ & $<4.7$ & $<2.0$ & $<1.14$ & $<5.8$ & $<1.5$ \\
\hline $\mathrm{I} 33$ & $<10.0$ & $<12.0$ & $<2.9$ & $<4.7$ & $<2.0$ & $<1.14$ & $<5.8$ & $<1.5$ \\
\hline I33 (S) & -. & -- & $<5.0$ & $<.01$ & $<5.0$ & -- & $<5.0$ & $<5.0$ \\
\hline I34 & $<10.0$ & $<12.0$ & $<2.9$ & $<4.7$ & $<2.0$ & $<1.14$ & $<5.8$ & $<1.5$ \\
\hline I34 (R) & $<10.0$ & $<12.0$ & $<2.9$ & $<4.7$ & $<2.0$ & $<1.14$ & $<5.8$ & $<1.5$ \\
\hline I34 (S) & -. & -- & $<5.0$ & $<.01$ & $<5.0$ & -- & $<5.0$ & $<5.0$ \\
\hline I35 & $<10.0$ & $<12.0$ & $<2.9$ & $<4.7$ & $<2.0$ & $<1.14$ & $<5.8$ & $<1.5$ \\
\hline I36 & $<10.0$ & $<12.0$ & $<2.9$ & $<4.7$ & $<2.0$ & $<1.14$ & $<5.8$ & $<1.5$ \\
\hline I37B & $<10.0$ & -. & -. & -. & -- & $<1.14$ & -- & -- \\
\hline I37B (R) & $<10.0$ & .. & .. & -. & .. & $<1.14$ & ..- & .. \\
\hline 138 & $<10.0$ & -- & -- & -- & -- & $<1.14$ & -- & -- \\
\hline 139 & $<10.0$ & - & -- & -- & -- & $<1.14$ & -- & -- \\
\hline 140 & $<10.0$ & -_ & -- & -. & -- & $<1.14$ & -- & -- \\
\hline I41 & $<10.0$ & -- & .- & -. & -- & $<1.14$ & .- & -- \\
\hline $\mathrm{I} 42$ & $<10.0$ & -- & .. & -- & ..- & $<1.14$ & -- & -. \\
\hline 143 & $<20.0$ & -.- & -.. & -.- & -- & $<1.14$ & .- & -. \\
\hline I 44 & $<10.0$ & $<12.0$ & $<2.9$ & $<4.7$ & $<2.0$ & $<1.14$ & $<5.8$ & $<1.5$ \\
\hline I45 & $<50.0$ & $<12.0$ & $<2.9$ & $<4.7$ & $<2.0$ & $<1.14$ & $<5.8$ & $<1.5$ \\
\hline 146 & $<10.0$ & $<12.0$ & $<2.9$ & $<4.7$ & $<2.0$ & $<1.14$ & $<5.8$ & $<1.5$ \\
\hline I $47 \mathrm{~A}$ & $<10.0$ & $<12.0$ & $<2.9$ & $<4.7$ & $<2.0$ & $<1.14$ & $<5.8$ & $<1.5$ \\
\hline I 48 & $<10.0$ & $<12.0$ & $<2.9$ & $<4.7$ & $<2.0$ & $<1.14$ & $<5.8$ & $<1.5$ \\
\hline I49 & $<10.0$ & $<12.0$ & $<2.9$ & $<4.7$ & $<2.0$ & $<1.14$ & $<5.8$ & $<1.5$ \\
\hline I50 & $<10.0$ & $<12.0$ & $<2.9$ & $<4.7$ & $<2.0$ & $<1.14$ & $<5.8$ & $<1.5$ \\
\hline 151 & $<50.0$ & $<12.0$ & $<2.9$ & $<4.7$ & $<2.0$ & $<1.14$ & $<5.8$ & $<1.5$ \\
\hline 152 & $<10.0$ & $<12.0$ & $<2.9$ & $<4.7$ & $<2.0$ & $<1.14$ & $<5.8$ & $<1.5$ \\
\hline 153 & $<10.0$ & $<12.0$ & $<2.9$ & $<4.7$ & $<2.0$ & $<1.14$ & $<5.8$ & $<1.5$ \\
\hline I53 (R) & $<10.0$ & $<12.0$ & $<2.9$ & $<4.7$ & $<2.0$ & $<1.14$ & $<5.8$ & $<1.5$ \\
\hline I54A & $<10.0$ & $<12.0$ & $<2.9$ & $<4.7$ & $<2.0$ & $<1.14$ & $<5.8$ & $<1.5$ \\
\hline
\end{tabular}


Table 13. Results of organic-chemical analyses of water from selected wells in the surficial aquifer at Carroll Island, Aberdeen Proving Ground, Md., spring 1989--Continued

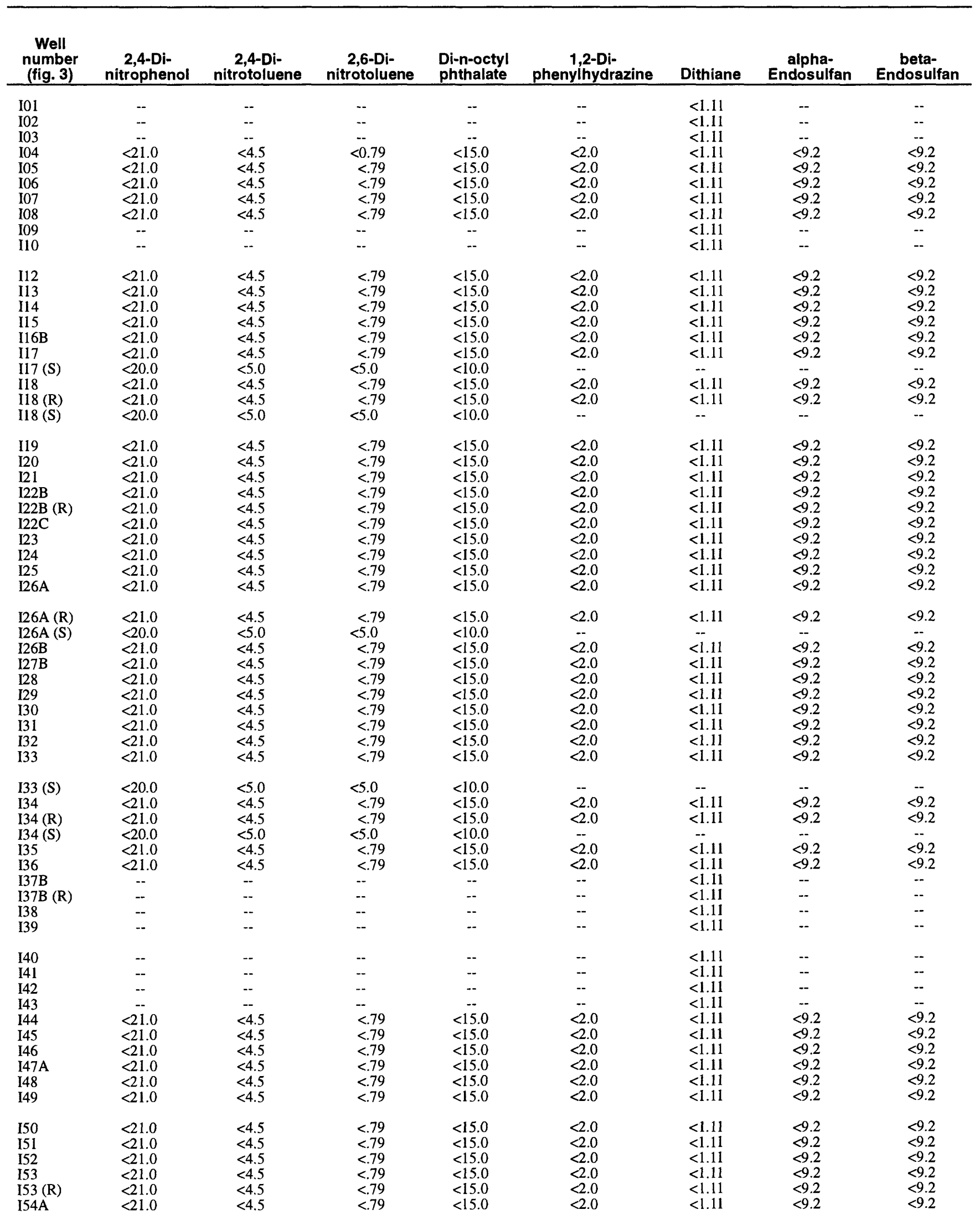


Table 13. Results of organic-chemical analyses of water from selected wells in the surficial aquifer at Carroll Island, Aberdeen Proving Ground, Md., spring 1989--Continued

\begin{tabular}{|c|c|c|c|c|c|c|c|c|c|}
\hline $\begin{array}{c}\text { Well } \\
\text { number } \\
\text { (fig. 3) }\end{array}$ & $\begin{array}{l}\text { Endo- } \\
\text { sulfan } \\
\text { sulfate } \\
\end{array}$ & Endrin & $\begin{array}{c}\begin{array}{c}\text { Endrin } \\
\text { aldehyde }\end{array} \\
\end{array}$ & $\begin{array}{l}\text { Endrin } \\
\text { ketone }\end{array}$ & $\begin{array}{l}\text { 1,2-Epoxy- } \\
\text { cyclohexene }\end{array}$ & Fluoranthene & Heptachlor & $\begin{array}{c}\text { Heptachlor } \\
\text { epoxide }\end{array}$ & $\begin{array}{c}\text { Hexachloro- } \\
\text { benzene }\end{array}$ \\
\hline I01 & -- & -- & -- & -- & -- & -. & -- & -- & -- \\
\hline I02 & -- & -. & -- & -- & -- & -- & -- & -- & -- \\
\hline I03 & -- & -- & -- & -- & -- & -- & -. & -- & -- \\
\hline I04 & $<9.2$ & $<7.6$ & $<8.0$ & $<8.0$ & -. & $<3.3$ & $<2.0$ & $<5.0$ & $<1.6$ \\
\hline 105 & $<9.2$ & $<7.6$ & $<8.0$ & $<8.0$ & -. & $<3.3$ & $<2.0$ & $<5.0$ & $<1.6$ \\
\hline I06 & $<9.2$ & $<7.6$ & $<8.0$ & $<8.0$ & -- & $<3.3$ & $<2.0$ & $<5.0$ & $<1.6$ \\
\hline I07 & $<9.2$ & $<7.6$ & $<8.0$ & $<8.0$ & -- & $<3.3$ & $<2.0$ & $<5.0$ & $<1.6$ \\
\hline I08 & $<9.2$ & $<7.6$ & $<8.0$ & $<8.0$ & -- & $<3.3$ & $<2.0$ & $<5.0$ & $<1.6$ \\
\hline 109 & -- & -- & -- & -- & -- & -- & - & -- & -- \\
\hline 110 & -- & -- & - & -- & -- & - & -- & -- & -- \\
\hline $\mathrm{I} 12$ & $<9.2$ & $<7.6$ & $<8.0$ & $<8.0$ & -- & $<3.3$ & $<2.0$ & $<5.0$ & $<1.6$ \\
\hline I13 & $<9.2$ & $<7.6$ & $<8.0$ & $<8.0$ & -- & $<3.3$ & $<2.0$ & $<5.0$ & $<1.6$ \\
\hline I14 & $<9.2$ & $<7.6$ & $<8.0$ & $<8.0$ & -- & $<3.3$ & $<2.0$ & $<5.0$ & $<1.6$ \\
\hline I15 & $<9.2$ & $<7.6$ & $<8.0$ & $<8.0$ & -- & $<3.3$ & $<2.0$ & $<5.0$ & $<1.6$ \\
\hline I16B & $<9.2$ & $<7.6$ & $<8.0$ & $<8.0$ & 3.0 & $<3.3$ & $<2.0$ & $<5.0$ & $<1.6$ \\
\hline I17 & $<9.2$ & $<7.6$ & $<8.0$ & $<8.0$ & -. & $<3.3$ & $<2.0$ & $<5.0$ & $<1.6$ \\
\hline $\mathrm{I} 17(\mathrm{~S})$ & -- & $<.01$ & -- & -- & -- & $<5.0$ & $<.01$ & $<.01$ & $<5.0$ \\
\hline I18 & $<9.2$ & $<7.6$ & $<8.0$ & $<8.0$ & -- & $<3.3$ & $<2.0$ & $<5.0$ & $<1.6$ \\
\hline I1 8 (R) & $<9.2$ & $<7.6$ & $<8.0$ & $<8.0$ & -. & $<3.3$ & $<2.0$ & $<5.0$ & $<1.6$ \\
\hline I1 8 (S) & -- & $<.01$ & -- & -- & -- & $<5.0$ & $<.01$ & $<.01$ & $<5.0$ \\
\hline I19 & $<9.2$ & $<7.6$ & $<8.0$ & $<8.0$ & -- & $<3.3$ & $<2.0$ & $<5.0$ & $<1.6$ \\
\hline $\mathrm{I} 20$ & $<9.2$ & $<7.6$ & $<8.0$ & $<8.0$ & -- & $<3.3$ & $<2.0$ & $<5.0$ & $<1.6$ \\
\hline $\mathrm{I} 21$ & $<9.2$ & $<7.6$ & $<8.0$ & $<8.0$ & -- & $<3.3$ & $<2.0$ & $<5.0$ & $<1.6$ \\
\hline $122 \mathrm{~B}$ & $<9.2$ & $<7.6$ & $<8.0$ & $<8.0$ & -- & $<3.3$ & $<2.0$ & $<5.0$ & $<1.6$ \\
\hline $\mathrm{I} 22 \mathrm{~B}(\mathrm{R})$ & $<9.2$ & $<7.6$ & $<8.0$ & $<8.0$ & -- & $<3.3$ & $<2.0$ & $<5.0$ & $<1.6$ \\
\hline $\mathrm{I} 22 \mathrm{C}$ & $<9.2$ & $<7.6$ & $<8.0$ & $<8.0$ & 4.0 & $<3.3$ & $<2.0$ & $<5.0$ & $<1.6$ \\
\hline 123 & $<9.2$ & $<7.6$ & $<8.0$ & $<8.0$ & -- & $<3.3$ & $<2.0$ & $<5.0$ & $<1.6$ \\
\hline I 24 & $<9.2$ & $<7.6$ & $<8.0$ & $<8.0$ & -.- & $<3.3$ & $<2.0$ & $<5.0$ & $<1.6$ \\
\hline 125 & $<9.2$ & $<7.6$ & $<8.0$ & $<8.0$ & -- & $<3.3$ & $<2.0$ & $<5.0$ & $<1.6$ \\
\hline $\mathrm{I} 26 \mathrm{~A}$ & $<9.2$ & $<7.6$ & $<8.0$ & $<8.0$ & 5.0 & $<3.3$ & $<2.0$ & $<5.0$ & $<1.6$ \\
\hline $\mathrm{I} 26 \mathrm{~A}(\mathrm{R})$ & $<9.2$ & $<7.6$ & $<8.0$ & $<8.0$ & -- & $<3.3$ & $<2.0$ & $<5.0$ & $<1.6$ \\
\hline $\mathrm{I} 26 \mathrm{~A}(\mathrm{~S})$ & -- & $<.01$ & -- & -. & -- & $<5.0$ & $<.01$ & $<.01$ & $<5.0$ \\
\hline I26B & $<9.2$ & $<7.6$ & $<8.0$ & $<8.0$ & 4.0 & $<3.3$ & $<2.0$ & $<5.0$ & $<1.6$ \\
\hline I27B & $<9.2$ & $<7.6$ & $<8.0$ & -. & -- & $<3.3$ & $<2.0$ & $<5.0$ & $<1.6$ \\
\hline I 28 & $<9.2$ & $<7.6$ & $<8.0$ & -- & -- & $<3.3$ & $<2.0$ & $<5.0$ & $<1.6$ \\
\hline 129 & $<9.2$ & $<7.6$ & $<8.0$ & -- & -- & $<3.3$ & $<2.0$ & $<5.0$ & $<1.6$ \\
\hline $\mathrm{I} 30$ & $<9.2$ & $<7.6$ & $<8.0$ & -- & -- & $<3.3$ & $<2.0$ & $<5.0$ & $<1.6$ \\
\hline I31 & $<9.2$ & $<7.6$ & $<8.0$ & $<8.0$ & .. & $<3.3$ & $<2.0$ & $<5.0$ & $<1.6$ \\
\hline I32 & $<9.2$ & $<7.6$ & $<8.0$ & $<8.0$ & -- & $<3.3$ & $<2.0$ & $<5.0$ & $<1.6$ \\
\hline $\mathrm{I} 33$ & $<9.2$ & $<7.6$ & $<8.0$ & $<8.0$ & -- & $<3.3$ & $<2.0$ & $<5.0$ & $<1.6$ \\
\hline I33 (S) & -- & $<.01$ & - & -- & -- & $<5.0$ & $<.01$ & $<.01$ & $<5.0$ \\
\hline I34 & $<9.2$ & $<7.6$ & $<8.0$ & $<8.0$ & -- & $<3.3$ & $<2.0$ & $<5.0$ & $<1.6$ \\
\hline I34 (R) & $<9.2$ & $<7.6$ & $<8.0$ & $<8.0$ & -- & $<3.3$ & $<2.0$ & $<5.0$ & $<1.6$ \\
\hline 134 (S) & -- & $<.01$ & -- & $\ldots$ & -. & $<5.0$ & $<.01$ & $<.01$ & $<5.0$ \\
\hline I35 & $<9.2$ & $<7.6$ & $<8.0$ & $<8.0$ & -- & $<3.3$ & $<2.0$ & $<5.0$ & $<1.6$ \\
\hline I36 & $<9.2$ & $<7.6$ & $<8.0$ & $<8.0$ & -- & $<3.3$ & $<2.0$ & $<5.0$ & $<1.6$ \\
\hline I37B & -- & -- & -- & -- & -- & -- & -- & -- & - \\
\hline I37B (R) & - & -- & -- & -- & -- & -- & -- & -- & -- \\
\hline I38 & -- & -- & -- & -. & -- & -- & -- & -- & -- \\
\hline 139 & -- & -- & -- & -- & -- & -- & -- & -- & -- \\
\hline 140 & -- & -. & -- & -. & -. & -- & -- & -- & -- \\
\hline I4I & -. & -. & -- &.- & - & -- & -- & -- & - \\
\hline I42 & -. & -- & -. & -- & -- & -- & -- & -- & -- \\
\hline I 43 & -- & -- & -- & -- & -. & -- & -- & - & -. \\
\hline I44 & $<9.2$ & $<7.6$ & $<8.0$ & $<8.0$ & -. & $<3.3$ & $<2.0$ & $<5.0$ & $<1.6$ \\
\hline I45 & $<9.2$ & $<7.6$ & $<8.0$ & $<8.0$ & -- & $<3.3$ & $<2.0$ & $<5.0$ & $<1.6$ \\
\hline 146 & $<9.2$ & $<7.6$ & $<8.0$ & $<8.0$ & -- & $<3.3$ & $<2.0$ & $<5.0$ & $<1.6$ \\
\hline I $47 \mathrm{~A}$ & $<9.2$ & $<7.6$ & $<8.0$ & $<8.0$ & -. & $<3.3$ & $<2.0$ & $<5.0$ & $<1.6$ \\
\hline I 48 & $<9.2$ & $<7.6$ & $<8.0$ & $<8.0$ & -- & $<3.3$ & $<2.0$ & $<5.0$ & $<1.6$ \\
\hline I 49 & $<9.2$ & $<7.6$ & $<8.0$ & $<8.0$ & -- & $<3.3$ & $<2.0$ & $<5.0$ & $<1.6$ \\
\hline I50 & $<9.2$ & $<7.6$ & $<8.0$ & $<8.0$ & -- & $<3.3$ & $<2.0$ & $<5.0$ & $<1.6$ \\
\hline I51 & $<9.2$ & $<7.6$ & $<8.0$ & $<8.0$ & 3.0 & $<3.3$ & $<2.0$ & $<5.0$ & $<1.6$ \\
\hline I52 & $<9.2$ & $<7.6$ & $<8.0$ & $<8.0$ & - & $<3.3$ & $<2.0$ & $<5.0$ & $<1.6$ \\
\hline I53 & $<9.2$ & $<7.6$ & $<8.0$ & $<8.0$ & .- & $<3.3$ & $<2.0$ & $<5.0$ & $<1.6$ \\
\hline $\mathrm{I} 53(\mathrm{R})$ & $<9.2$ & $<7.6$ & $<8.0$ & $<8.0$ & -- & $<3.3$ & $<2.0$ & $<5.0$ & $<1.6$ \\
\hline $\mathrm{I} 54 \mathrm{~A}$ & $<9.2$ & $<7.6$ & $<8.0$ & $<8.0$ & 4.0 & $<3.3$ & $<2.0$ & $<5.0$ & $<1.6$ \\
\hline
\end{tabular}


Table 13. Results of organic-chemical analyses of water from selected wells in the surficial aquifer at Carroll Island, Aberdeen Proving Ground, Md., spring 1989--Continued

\begin{tabular}{|c|c|c|c|c|c|c|c|c|c|}
\hline $\begin{array}{c}\text { Well } \\
\text { number } \\
\text { (fig. 3) }\end{array}$ & $\begin{array}{c}\text { Hexachloro- } \\
\text { butadiene }\end{array}$ & $\begin{array}{c}\text { Hexachloro- } \\
\text { cyclo- } \\
\text { pentadiene }\end{array}$ & $\begin{array}{l}\text { Hexa- } \\
\text { chloro- } \\
\text { ethane } \\
\end{array}$ & $\begin{array}{c}\text { Indeno } \\
{[1,2,3-} \\
\text { c,d] } \\
\text { pyrene }\end{array}$ & Isophorone & Lindane & Methoxychlor & $\begin{array}{l}\text { Methyl- } \\
\text { n-butyl } \\
\text { ketone }\end{array}$ & $\begin{array}{l}\text { 3-Methyl- } \\
\text { 4-chloro- } \\
\text { phenol }\end{array}$ \\
\hline I01 & -- & -- & -- & -- & -- & -- & -- & $<3.6$ & -- \\
\hline I02 & -- & -- & -- & -- & - & -- & -- & $<3.6$ & -- \\
\hline $\mathrm{I} 03$ & -- & -- & -. & -- & -- & -- & - & $<3.6$ & -- \\
\hline I04 & $<3.4$ & $<8.6$ & $<1.5$ & $<8.6$ & $<4.8$ & $<4.0$ & $<5.1$ & $<3.6$ & $<4.0$ \\
\hline I05 & $<3.4$ & $<8.6$ & $<1.5$ & $<8.6$ & $<4.8$ & $<4.0$ & $<5.1$ & $<3.6$ & $<4.0$ \\
\hline 106 & $<3.4$ & $<8.6$ & $<1.5$ & $<8.6$ & $<4.8$ & $<4.0$ & $<5.1$ & $<3.6$ & $<4.0$ \\
\hline 107 & $<3.4$ & $<8.6$ & $<1.5$ & $<8.6$ & $<4.8$ & $<4.0$ & $<5.1$ & $<3.6$ & $<4.0$ \\
\hline I08 & $<3.4$ & $<8.6$ & $<1.5$ & $<8.6$ & $<4.8$ & $<4.0$ & $<5.1$ & $<3.6$ & $<4.0$ \\
\hline 109 & -- & -- & -- & -- & -- & -- & -- & $<3.6$ & -- \\
\hline 110 & -- & -- & -- & -- & -- & -- & - & $<3.6$ & -- \\
\hline I12 & $<3.4$ & $<8.6$ & $<1.5$ & $<8.6$ & $<4.8$ & $<4.0$ & $<5.1$ & $<3.6$ & $<4.0$ \\
\hline 113 & $<3.4$ & $<8.6$ & $<1.5$ & $<8.6$ & $<4.8$ & $<4.0$ & $<5.1$ & $<3.6$ & $<4.0$ \\
\hline I14 & $<3.4$ & $<8.6$ & $<1.5$ & $<8.6$ & $<4.8$ & $<4.0$ & $<5.1$ & $<3.6$ & $<4.0$ \\
\hline I15 & $<3.4$ & $<8.6$ & $<1.5$ & $<8.6$ & $<4.8$ & $<4.0$ & $<5.1$ & $<3.6$ & $<4.0$ \\
\hline I16B & $<3.4$ & $<8.6$ & $<1.5$ & $<8.6$ & $<4.8$ & $<4.0$ & $<5.1$ & $<3.6$ & $<4.0$ \\
\hline I17 & $<3.4$ & $<8.6$ & $<1.5$ & $<8.6$ & $<4.8$ & $<4.0$ & $<5.1$ & $<3.6$ & $<4.0$ \\
\hline $117(\mathrm{~S})$ & $<5.0$ & $<5.0$ & $<5.0$ & $<10$ & $<5.0$ & $<.01$ & $<.01$ & -- & -- \\
\hline I18 & $<3.4$ & $<8.6$ & $<1.5$ & $<8.6$ & $<4.8$ & $<4.0$ & $<5.1$ & $<3.6$ & $<4.0$ \\
\hline I18 (R) & $<3.4$ & $<8.6$ & $<1.5$ & $<8.6$ & $<4.8$ & $<4.0$ & $<5.1$ & $<3.6$ & $<4.0$ \\
\hline 118 (S) & $<5.0$ & $<5.0$ & $<5.0$ & $<10$ & $<5.0$ & $<.01$ & $<.01$ & -- & -- \\
\hline 119 & $<3.4$ & $<8.6$ & $<1.5$ & $<8.6$ & $<4.8$ & $<4.0$ & $<5.1$ & $<3.6$ & $<4.0$ \\
\hline I 20 & $<3.4$ & $<8.6$ & $<1.5$ & $<8.6$ & $<4.8$ & $<4.0$ & $<5.1$ & $<3.6$ & $<4.0$ \\
\hline $\mathrm{I} 21$ & $<3.4$ & $<8.6$ & $<1.5$ & $<8.6$ & $<4.8$ & $<4.0$ & $<5.1$ & $<3.6$ & $<4.0$ \\
\hline I $22 \mathrm{~B}$ & $<3.4$ & $<8.6$ & $<1.5$ & $<8.6$ & $<4.8$ & $<4.0$ & $<5.1$ & $<3.6$ & $<4.0$ \\
\hline $\mathrm{I} 22 \mathrm{~B}(\mathrm{R})$ & $<3.4$ & $<8.6$ & $<1.5$ & $<8.6$ & $<4.8$ & $<4.0$ & $<5.1$ & $<3.6$ & $<4.0$ \\
\hline $\mathrm{I} 22 \mathrm{C}$ & $<3.4$ & $<8.6$ & $<1.5$ & $<8.6$ & $<4.8$ & $<4.0$ & $<5.1$ & $<3.6$ & $<4.0$ \\
\hline $\mathrm{I} 23$ & $<3.4$ & $<8.6$ & $<1.5$ & $<8.6$ & $<4.8$ & $<4.0$ & $<5.1$ & $<3.6$ & $<4.0$ \\
\hline I 24 & $<3.4$ & $<8.6$ & $<1.5$ & $<8.6$ & $<4.8$ & $<4.0$ & $<5.1$ & $<3.6$ & $<4.0$ \\
\hline I 25 & $<3.4$ & $<8.6$ & $<1.5$ & $<8.6$ & $<4.8$ & $<4.0$ & $<5.1$ & $<3.6$ & $<4.0$ \\
\hline $\mathrm{I} 26 \mathrm{~A}$ & $<3.4$ & $<8.6$ & $<1.5$ & $<8.6$ & $<4.8$ & $<4.0$ & $<5.1$ & $<3.6$ & $<4.0$ \\
\hline $\mathrm{I} 26 \mathrm{~A}(\mathrm{R})$ & $<3.4$ & $<8.6$ & $<1.5$ & $<8.6$ & $<4.8$ & $<4.0$ & $<5.1$ & $<3.6$ & $<4.0$ \\
\hline $\mathrm{I} 26 \mathrm{~A}(\mathrm{~S})$ & $<5.0$ & $<5.0$ & $<5.0$ & $<10$ & $<5.0$ & $<.01$ & $<.01$ & -- & -- \\
\hline I26B & $<3.4$ & $<8.6$ & $<1.5$ & $<8.6$ & $<4.8$ & $<4.0$ & $<5.1$ & $<3.6$ & $<4.0$ \\
\hline $\mathrm{I} 27 \mathrm{~B}$ & $<3.4$ & $<8.6$ & $<1.5$ & $<8.6$ & $<4.8$ & $<4.0$ & $<5.1$ & $<3.6$ & $<4.0$ \\
\hline I 28 & $<3.4$ & $<8.6$ & $<1.5$ & $<8.6$ & $<4.8$ & $<4.0$ & $<5.1$ & $<3.6$ & $<4.0$ \\
\hline I 29 & $<3.4$ & $<8.6$ & $<1.5$ & $<8.6$ & $<4.8$ & $<4.0$ & $<5.1$ & $<3.6$ & $<4.0$ \\
\hline I30 & $<3.4$ & $<8.6$ & $<1.5$ & $<8.6$ & $<4.8$ & $<4.0$ & $<5.1$ & $<3.6$ & $<4.0$ \\
\hline I3I & $<3.4$ & $<8.6$ & $<1.5$ & $<8.6$ & $<4.8$ & $<4.0$ & $<5.1$ & $<3.6$ & $<4.0$ \\
\hline 132 & $<3.4$ & $<8.6$ & $<1.5$ & $<8.6$ & $<4.8$ & $<4.0$ & $<5.1$ & $<3.6$ & $<4.0$ \\
\hline $\mathrm{I} 33$ & $<3.4$ & $<8.6$ & $<1.5$ & $<8.6$ & $<4.8$ & $<4.0$ & $<5.1$ & $<3.6$ & $<4.0$ \\
\hline I33 (S) & $<5.0$ & $<5.0$ & $<5.0$ & $<10$ & $<5.0$ & $<.01$ & $<.01$ & -- & -- \\
\hline I34 & $<3.4$ & $<8.6$ & $<1.5$ & $<8.6$ & $<4.8$ & $<4.0$ & $<5.1$ & $<3.6$ & $<4.0$ \\
\hline I34 (R) & $<3.4$ & $<8.6$ & $<1.5$ & $<8.6$ & $<4.8$ & $<4.0$ & $<5.1$ & $<3.6$ & $<4.0$ \\
\hline I34 (S) & $<5.0$ & $<5.0$ & $<5.0$ & $<10$ & $<5.0$ & $<.01$ & $<.01$ & -- & - \\
\hline 135 & $<3.4$ & $<8.6$ & $<1.5$ & $<8.6$ & $<4.8$ & $<4.0$ & $<5.1$ & $<3.6$ & $<4.0$ \\
\hline I36 & $<3.4$ & $<8.6$ & $<1.5$ & $<8.6$ & $<4.8$ & $<4.0$ & $<5.1$ & $<3.6$ & $<4.0$ \\
\hline I37B & $\ldots$ & $\ldots$ & -- & -- & -- & -- & -- & $<3.6$ & -- \\
\hline $\mathrm{I} 37 \mathrm{~B}(\mathrm{R})$ & -- & -- & -- & -- & -- & -- & - & $<3.6$ & -- \\
\hline 138 & -- & -- & -- & -- & -- & -- & -- & $<3.6$ & -- \\
\hline 139 &.- & -- & -- & -. & -- & -- & -- & $<3.6$ & -- \\
\hline 140 & -- & -- & -- & -- & -- & -- & -. & $<3.6$ & -- \\
\hline 141 & -- & -- & -- & -- & -- & -- & -- & $<3.6$ & -- \\
\hline I42 & -- & .. & -- & -- & -- & -- & -- & $<3.6$ & -- \\
\hline I 43 & -- & -- & -- & -- & -- & -- & - & $<7.0$ & -- \\
\hline I 44 & $<3.4$ & $<8.6$ & $<1.5$ & $<8.6$ & $<4.8$ & $<4.0$ & $<5.1$ & $<3.6$ & $<4.0$ \\
\hline I 45 & $<3.4$ & $<8.6$ & $<1.5$ & $<8.6$ & $<4.8$ & $<4.0$ & $<5.1$ & $<20$ & $<4.0$ \\
\hline 146 & $<3.4$ & $<8.6$ & $<1.5$ & $<8.6$ & $<4.8$ & $<4.0$ & $<5.1$ & $<3.6$ & $<4.0$ \\
\hline I $47 \mathrm{~A}$ & $<3.4$ & $<8.6$ & $<1.5$ & $<8.6$ & $<4.8$ & $<4.0$ & $<5.1$ & $<3.6$ & $<4.0$ \\
\hline I48 & $<3.4$ & $<8.6$ & $<1.5$ & $<8.6$ & $<4.8$ & $<4.0$ & $<5.1$ & $<3.6$ & $<4.0$ \\
\hline 149 & $<3.4$ & $<8.6$ & $<1.5$ & $<8.6$ & $<4.8$ & $<4.0$ & $<5.1$ & $<3.6$ & $<4.0$ \\
\hline 150 & $<3.4$ & $<8.6$ & $<1.5$ & $<8.6$ & $<4.8$ & $<4.0$ & $<5.1$ & $<3.6$ & $<4.0$ \\
\hline I5I & $<3.4$ & $<8.6$ & $<1.5$ & $<8.6$ & $<4.8$ & $<4.0$ & $<5.1$ & $<20$ & $<4.0$ \\
\hline I52 & $<3.4$ & $<8.6$ & $<1.5$ & $<8.6$ & $<4.8$ & $<4.0$ & $<5.1$ & $<3.6$ & $<4.0$ \\
\hline I53 & $<3.4$ & $<8.6$ & $<1.5$ & $<8.6$ & $<4.8$ & $<4.0$ & $<5.1$ & $<3.6$ & $<4.0$ \\
\hline $153(\mathrm{R})$ & $<3.4$ & $<8.6$ & $<1.5$ & $<8.6$ & $<4.8$ & $<4.0$ & $<5.1$ & $<3.6$ & $<4.0$ \\
\hline $\mathrm{I} 54 \mathrm{~A}$ & $<3.4$ & $<8.6$ & $<1.5$ & $<8.6$ & $<4.8$ & $<4.0$ & $<5.1$ & $<3.6$ & $<4.0$ \\
\hline
\end{tabular}


Table 13. Results of organic-chemical analyses of water from selected wells in the surficial aquifer at Carroll Island, Aberdeen Proving Ground, Md., spring 1989--Continued

\begin{tabular}{|c|c|c|c|c|c|c|c|c|c|}
\hline $\begin{array}{c}\text { Well } \\
\text { number } \\
\text { (fig. 3) }\end{array}$ & $\begin{array}{l}\text { 2-Methyl- } \\
\text { 4,6-di- } \\
\text { nitrophenol }\end{array}$ & $\begin{array}{l}\text { Methyl- } \\
\text { isobutyl } \\
\text { ketone }\end{array}$ & $\begin{array}{c}\text { Methyl- } \\
\text { ethyl } \\
\text { ketone }\end{array}$ & $\begin{array}{c}\text { 2-Methyl- } \\
\text { naphthalene }\end{array}$ & $\begin{array}{c}\text { 2-Methyl- } \\
\text { phenol }\end{array}$ & $\begin{array}{c}\text { 4-Methyl- } \\
\text { phenol }\end{array}$ & Naphthalene & $\begin{array}{l}\text { 2-Nitro- } \\
\text { aniline }\end{array}$ & $\begin{array}{l}\text { 3-Nitro- } \\
\text { aniline }\end{array}$ \\
\hline I01 & -- & $<3.0$ & $<6.4$ & -- & -- & -- & -. & -- & -. \\
\hline $\mathrm{I} 02$ & -. & $<3.0$ & $<6.4$ & -- & -- & -- & -- & -- & -. \\
\hline 103 & -- & $<3.0$ & $<6.4$ & -- & -- & -- & -- & -- & -- \\
\hline 104 & $<17.0$ & $<3.0$ & $<6.4$ & $<1.7$ & $<3.9$ & $<0.52$ & $<0.5$ & $<4.3$ & $<4.9$ \\
\hline 105 & $<17.0$ & $<3.0$ & $<6.4$ & $<1.7$ & $<3.9$ & $<.52$ & $<.5$ & $<4.3$ & $<4.9$ \\
\hline 106 & $<17.0$ & $<3.0$ & $<6.4$ & $<1.7$ & $<3.9$ & $<.52$ & $<.5$ & $<4.3$ & $<4.9$ \\
\hline 107 & $<17.0$ & $<3.0$ & $<6.4$ & $<1.7$ & $<3.9$ & $<.52$ & $<.5$ & $<4.3$ & $<4.9$ \\
\hline 108 & $<17.0$ & $<3.0$ & $<6.4$ & 2.1 & $<3.9$ & $<.52$ & 15 & $<4.3$ & $<4.9$ \\
\hline I09 & -- & $<3.0$ & $<6.4$ & -. & -- & -- & -- & -- & -- \\
\hline 110 & -- & $<3.0$ & $<6.4$ & -- & -- & -- & -- & - & -- \\
\hline $\mathrm{I} 12$ & $<17.0$ & $<3.0$ & $<6.4$ & $<1.7$ & $<3.9$ & $<.52$ & $<.5$ & $<4.3$ & $<4.9$ \\
\hline 113 & $<17.0$ & $<3.0$ & $<6.4$ & $<1.7$ & $<3.9$ & $<.52$ & $<.5$ & $<4.3$ & $<4.9$ \\
\hline I14 & $<17.0$ & $<3.0$ & $<6.4$ & $<1.7$ & $<3.9$ & $<.52$ & $<.5$ & $<4.3$ & $<4.9$ \\
\hline I15 & $<17.0$ & $<3.0$ & $<6.4$ & $<1.7$ & $<3.9$ & $<.52$ & $<.5$ & $<4.3$ & $<4.9$ \\
\hline I16B & $<17.0$ & $<3.0$ & $<6.4$ & $<1.7$ & $<3.9$ & $<.52$ & $<.5$ & $<4.3$ & $<4.9$ \\
\hline I1 7 & $<17.0$ & $<3.0$ & $<6.4$ & $<1.7$ & $<3.9$ & $<.52$ & $<.5$ & $<4.3$ & $<4.9$ \\
\hline I17 (S) & -. & -- & -- & -- & -- & -- & $<5.0$ & -- & -- \\
\hline 118 & $<17.0$ & $<3.0$ & $<6.4$ & $<1.7$ & $<3.9$ & $<.52$ & $<.5$ & $<4.3$ & $<4.9$ \\
\hline $118(\mathrm{R})$ & $<17.0$ & $<3.0$ & $<6.4$ & $<1.7$ & $<3.9$ & $<.52$ & $<.5$ & $<4.3$ & $<4.9$ \\
\hline I1 8 (S) & -- & -- & -- & -- & -- & -- & $<5.0$ & -- & -- \\
\hline 119 & $<17.0$ & $<3.0$ & $<6.4$ & $<1.7$ & $<3.9$ & $<.52$ & $<.5$ & $<4.3$ & $<4.9$ \\
\hline 120 & $<17.0$ & $<3.0$ & $<6.4$ & $<1.7$ & $<3.9$ & $<.52$ & $<.5$ & $<4.3$ & $<4.9$ \\
\hline I 21 & $<17.0$ & $<3.0$ & $<6.4$ & $<1.7$ & $<3.9$ & $<.52$ & $<.5$ & $<4.3$ & $<4.9$ \\
\hline I $22 \mathrm{~B}$ & $<17.0$ & $<3.0$ & $<6.4$ & $<1.7$ & $<3.9$ & $<.52$ & $<.5$ & $<4.3$ & $<4.9$ \\
\hline $\mathrm{I} 22 \mathrm{~B}(\mathrm{R})$ & $<17.0$ & $<3.0$ & $<6.4$ & $<1.7$ & $<3.9$ & $<.52$ & $<.5$ & $<4.3$ & $<4.9$ \\
\hline I22C & $<17.0$ & $<3.0$ & $<6.4$ & $<1.7$ & $<3.9$ & $<.52$ & $<.5$ & $<4.3$ & $<4.9$ \\
\hline $\mathrm{I} 23$ & $<17.0$ & $<3.0$ & $<6.4$ & $<1.7$ & $<3.9$ & $<.52$ & $<.5$ & $<4.3$ & $<4.9$ \\
\hline 124 & $<17.0$ & $<3.0$ & $<6.4$ & $<1.7$ & $<3.9$ & $<.52$ & $<.5$ & $<4.3$ & $<4.9$ \\
\hline $\mathrm{I} 25$ & $<17.0$ & $<3.0$ & $<6.4$ & $<1.7$ & $<3.9$ & $<.52$ & $<.5$ & $<4.3$ & $<4.9$ \\
\hline $126 \mathrm{~A}$ & $<17.0$ & $<3.0$ & $<6.4$ & $<1.7$ & $<3.9$ & $<.52$ & $<.5$ & $<4.3$ & $<4.9$ \\
\hline $\mathrm{I} 26 \mathrm{~A}(\mathrm{R})$ & $<17.0$ & $<3.0$ & $<6.4$ & $<1.7$ & $<3.9$ & $<.52$ & $<.5$ & $<4.3$ & $<4.9$ \\
\hline $\mathrm{I} 26 \mathrm{~A}(\mathrm{~S})$ & -. & .. & -- & -- & -- & $\ldots$ & $<5.0$ & -. & -- \\
\hline $\mathrm{I} 26 \mathrm{~B}$ & $<17.0$ & $<3.0$ & $<6.4$ & $<1.7$ & $<3.9$ & $<.52$ & $<.5$ & $<4.3$ & $<4.9$ \\
\hline $\mathrm{I} 27 \mathrm{~B}$ & $<17.0$ & $<3.0$ & $<6.4$ & $<1.7$ & $<3.9$ & $<.52$ & $<.5$ & $<4.3$ & $<4.9$ \\
\hline $\mathrm{I} 28$ & $<17.0$ & $<3.0$ & $<6.4$ & $<1.7$ & $<3.9$ & $<.52$ & $<.5$ & $<4.3$ & $<4.9$ \\
\hline 129 & $<17.0$ & $<3.0$ & $<6.4$ & $<1.7$ & $<3.9$ & $<.52$ & $<.5$ & $<4.3$ & $<4.9$ \\
\hline $\mathrm{I} 30$ & $<17.0$ & $<3.0$ & $<6.4$ & $<1.7$ & $<3.9$ & $<.52$ & $<.5$ & $<4.3$ & $<4.9$ \\
\hline I31 & $<17.0$ & $<3.0$ & $<6.4$ & $<1.7$ & $<3.9$ & $<.52$ & $<.5$ & $<4.3$ & $<4.9$ \\
\hline 132 & $<17.0$ & $<3.0$ & $<6.4$ & $<1.7$ & $<3.9$ & $<.52$ & $<.5$ & $<4.3$ & $<4.9$ \\
\hline $\mathrm{I} 33$ & $<17.0$ & $<3.0$ & $<6.4$ & $<1.7$ & $<3.9$ & $<.52$ & $<.5$ & $<4.3$ & $<4.9$ \\
\hline $133(S)$ & -- & -. & -- & -- & -- & -- & $<5.0$ & -- & -- \\
\hline & $<17.0$ & $<3.0$ & $<6.4$ & $<1.7$ & $<3.9$ & $<.52$ & $<.5$ & $<4.3$ & $<4.9$ \\
\hline $\mathrm{I} 34(\mathrm{R})$ & $<17.0$ & $<3.0$ & $<6.4$ & $<1.7$ & $<3.9$ & $<.52$ & $<.5$ & $<4.3$ & $<4.9$ \\
\hline I34 (S) & -. & $\ldots$ & -- & -- & -- & -. & $<5.0$ & -- & -- \\
\hline 135 & $<17.0$ & $<3.0$ & $<6.4$ & $<1.7$ & $<3.9$ & $<.52$ & $<.5$ & $<4.3$ & $<4.9$ \\
\hline I36 & $<17.0$ & $<3.0$ & $<6.4$ & $<1.7$ & $<3.9$ & $<.52$ & $<.5$ & $<4.3$ & $<4.9$ \\
\hline I37B &.- & $<3.0$ & $<6.4$ & -- & -- & -- & -- & -- & -- \\
\hline I37B (R) & -- & $<3.0$ & $<6.4$ & -- & -- & -- & -- & -- & -- \\
\hline 138 & -- & $<3.0$ & $<6.4$ & -- & -- & -- & .- & -- & -- \\
\hline I39 & -- & $<3.0$ & $<6.4$ & -- & -- & -- & -- & - & -- \\
\hline $\mathrm{I} 40$ & -. & $<3.0$ & $<6.4$ & -- & -- & -- & -- & -- & -- \\
\hline I41 & .-. & $<3.0$ & $<6.4$ & --. & -. & -.- & -.- & -.- & -- \\
\hline 142 & -- & $<3.0$ & $<6.4$ & -- & -- & -- & -- & -- & -- \\
\hline 143 & -.. & $<6.0$ & $<10$ & -. & -- & -- & -- & -- & -. \\
\hline 144 & $<17.0$ & $<3.0$ & $<6.4$ & $<1.7$ & $<3.9$ & $<.52$ & $<.5$ & $<4.3$ & $<4.9$ \\
\hline I 45 & $<17.0$ & $<20$ & $<30$ & $<1.7$ & $<3.9$ & $<.52$ & $<.5$ & $<4.3$ & $<4.9$ \\
\hline I 46 & $<17.0$ & $<3.0$ & $<6.4$ & $<1.7$ & $<3.9$ & $<.52$ & $<.5$ & $<4.3$ & $<4.9$ \\
\hline I $47 \mathrm{~A}$ & $<17.0$ & $<3.0$ & $<6.4$ & $<1.7$ & $<3.9$ & $<.52$ & $<.5$ & $<4.3$ & $<4.9$ \\
\hline $\mathrm{I} 48$ & $<17.0$ & $<3.0$ & $<6.4$ & $<1.7$ & $<3.9$ & $<.52$ & $<.5$ & $<4.3$ & $<4.9$ \\
\hline 149 & $<17.0$ & $<3.0$ & $<6.4$ & $<1.7$ & $<3.9$ & $<.52$ & $<.5$ & $<4.3$ & $<4.9$ \\
\hline I50 & $<17.0$ & $<3.0$ & $<6.4$ & $<1.7$ & $<3.9$ & $<.52$ & $<.5$ & $<4.3$ & $<4.9$ \\
\hline I5I & $<17.0$ & $<20$ & $<30$ & $<1.7$ & $<3.9$ & $<.52$ & $<.5$ & $<4.3$ & $<4.9$ \\
\hline I52 & $<17.0$ & $<3.0$ & $<6.4$ & $<1.7$ & $<3.9$ & $<.52$ & $<.5$ & $<4.3$ & $<4.9$ \\
\hline I53 & $<17.0$ & $<3.0$ & $<6.4$ & $<1.7$ & $<3.9$ & $<.52$ & $<.5$ & $<4.3$ & $<4.9$ \\
\hline $\mathrm{I} 53(\mathrm{R})$ & $<17.0$ & $<3.0$ & $<6.4$ & $<1.7$ & $<3.9$ & $<.52$ & $<.5$ & $<4.3$ & $<4.9$ \\
\hline $\mathrm{I} 54 \mathrm{~A}$ & $<17.0$ & $<3.0$ & $<6.4$ & $<1.7$ & $<3.9$ & $<.52$ & $<.5$ & $<4.3$ & $<4.9$ \\
\hline
\end{tabular}


Table 13. Results of organic-chemical analyses of water from selected wells in the surficial aquifer at Carroll Island, Aberdeen Proving Ground, Md., spring 1989--Continued

\begin{tabular}{|c|c|c|c|c|c|c|c|c|c|}
\hline $\begin{array}{c}\text { Well } \\
\text { number } \\
\text { (fig. 3) }\end{array}$ & $\begin{array}{l}\text { 4-Nitro- } \\
\text { aniline }\end{array}$ & $\begin{array}{c}\text { Nitro- } \\
\text { benzene }\end{array}$ & $\begin{array}{l}\text { 2-Nitro- } \\
\text { phenol }\end{array}$ & $\begin{array}{l}\text { 4-Nitro- } \\
\text { phenol }\end{array}$ & $\begin{array}{c}\text { N-Nitroso- } \\
\text { dimethyl- } \\
\text { amine }\end{array}$ & $\begin{array}{c}\text { N-Nitroso- } \\
\text { di-N-propyl- } \\
\text { amine }\end{array}$ & $\begin{array}{c}\text { N-Nitroso- } \\
\text { diphenyl- } \\
\text { amine }\end{array}$ & $\begin{array}{c}\text { 1,4-Oxa- } \\
\text { thiane }\end{array}$ & РCB 1016 \\
\hline 101 & -- & -- & -- & -- & -- & -- & -. & $<1.98$ & -- \\
\hline 102 & -- & -- & -- & -- & -- & -- & -- & $<1.98$ & -- \\
\hline 103 & -- & -- & -- & -- & -- & -- & -- & $<1.98$ & -- \\
\hline 104 & $<5.2$ & $<0.5$ & $<3.7$ & $<12.0$ & $<2.0$ & $<4.4$ & $<3.0$ & $<1.98$ & $<21.0$ \\
\hline I05 & $<5.2$ & $<.5$ & $<3.7$ & $<12.0$ & $<2.0$ & $<4.4$ & $<3.0$ & $<1.98$ & $<21.0$ \\
\hline I06 & $<5.2$ & $<.5$ & $<3.7$ & $<12.0$ & $<2.0$ & $<4.4$ & $<3.0$ & $<1.98$ & $<21.0$ \\
\hline I07 & $<5.2$ & $<.5$ & $<3.7$ & $<12.0$ & $<2.0$ & $<4.4$ & $<3.0$ & $<1.98$ & $<21.0$ \\
\hline 108 & $<5.2$ & $<.5$ & $<3.7$ & $<12.0$ & $<2.0$ & $<4.4$ & $<3.0$ & $<1.98$ & $<21.0$ \\
\hline 109 & -- & -- & -- & -- & -- & -- & -- & $<1.98$ & -- \\
\hline I10 & -- & -- & -- & -- & -- & -- & -- & $<1.98$ & -- \\
\hline $\mathrm{I} 12$ & $<5.2$ & $<.5$ & $<3.7$ & $<12.0$ & $<2.0$ & $<4.4$ & $<3.0$ & $<1.98$ & $<21.0$ \\
\hline I13 & $<5.2$ & $<.5$ & $<3.7$ & $<12.0$ & $<2.0$ & $<4.4$ & $<3.0$ & $<1.98$ & $<21.0$ \\
\hline 114 & $<5.2$ & $<.5$ & $<3.7$ & $<12.0$ & $<2.0$ & $<4.4$ & $<3.0$ & $<1.98$ & $<21.0$ \\
\hline I15 & $<5.2$ & $<.5$ & $<3.7$ & $<12.0$ & $<2.0$ & $<4.4$ & $<3.0$ & $<1.98$ & $<21.0$ \\
\hline I16B & $<5.2$ & $<.5$ & $<3.7$ & $<12.0$ & $<2.0$ & $<4.4$ & $<3.0$ & $<1.98$ & $<21.0$ \\
\hline 117 & $<5.2$ & $<.5$ & $<3.7$ & $<12.0$ & $<2.0$ & $<4.4$ & $<3.0$ & $<1.98$ & $<21.0$ \\
\hline I17 (S) & -- & $<5.0$ & $<5.0$ & $<30.0$ & $<5.0$ & $<5.0$ & $<5.0$ & -- & $<.1$ \\
\hline I18 & $<5.2$ & $<.5$ & $<3.7$ & $<12.0$ & $<2.0$ & $<4.4$ & $<3.0$ & $<1.98$ & $<21.0$ \\
\hline I18 (R) & $<5.2$ & $<.5$ & $<3.7$ & $<12.0$ & $<2.0$ & $<4.4$ & $<3.0$ & $<1.98$ & $<21.0$ \\
\hline I18 (S) & -- & $<5.0$ & $<5.0$ & $<30.0$ & $<5.0$ & $<5.0$ & $<5.0$ & - & $<.1$ \\
\hline I19 & $<5.2$ & $<.5$ & $<3.7$ & $<12.0$ & $<2.0$ & $<4.4$ & $<3.0$ & $<1.98$ & $<21.0$ \\
\hline I 20 & $<5.2$ & $<.5$ & $<3.7$ & $<12.0$ & $<2.0$ & $<4.4$ & $<3.0$ & $<1.98$ & $<21.0$ \\
\hline 121 & $<5.2$ & $<.5$ & $<3.7$ & $<12.0$ & $<2.0$ & $<4.4$ & $<3.0$ & $<1.98$ & $<21.0$ \\
\hline I $22 \mathrm{~B}$ & $<5.2$ & $<.5$ & $<3.7$ & $<12.0$ & $<2.0$ & $<4.4$ & $<3.0$ & $<1.98$ & $<21.0$ \\
\hline $\mathrm{I} 22 \mathrm{~B}(\mathrm{R})$ & $<5.2$ & $<.5$ & $<3.7$ & $<12.0$ & $<2.0$ & $<4.4$ & $<3.0$ & $<1.98$ & $<21.0$ \\
\hline I $22 \mathrm{C}$ & $<5.2$ & $<.5$ & $<3.7$ & $<12.0$ & $<2.0$ & $<4.4$ & $<3.0$ & $<1.98$ & $<21.0$ \\
\hline 123 & $<5.2$ & $<.5$ & $<3.7$ & $<12.0$ & $<2.0$ & $<4.4$ & $<3.0$ & $<1.98$ & $<21.0$ \\
\hline 124 & $<5.2$ & $<.5$ & $<3.7$ & $<12.0$ & $<2.0$ & $<4.4$ & $<3.0$ & $<1.98$ & $<21.0$ \\
\hline 125 & $<5.2$ & $<.5$ & $<3.7$ & $<12.0$ & $<2.0$ & $<4.4$ & $<3.0$ & $<1.98$ & $<21.0$ \\
\hline I26A & $<5.2$ & $<.5$ & $<3.7$ & $<12.0$ & $<2.0$ & $<4.4$ & $<3.0$ & $<1.98$ & $<21.0$ \\
\hline I26A (R) & $<5.2$ & $<.5$ & $<3.7$ & $<12.0$ & $<2.0$ & $<4.4$ & $<3.0$ & $<1.98$ & $<21.0$ \\
\hline $126 \mathrm{~A}(\mathrm{~S})$ & -- & $<5.0$ & $<5.0$ & $<30.0$ & $<5.0$ & $<5.0$ & $<5.0$ & -- & $<.1$ \\
\hline I26B & $<5.2$ & $<.5$ & $<3.7$ & $<12.0$ & $<2.0$ & $<4.4$ & $<3.0$ & $<1.98$ & $<21.0$ \\
\hline I27B & $<5.2$ & $<.5$ & $<3.7$ & $<12.0$ & $<2.0$ & $<4.4$ & $<3.0$ & $<1.98$ & $<21.0$ \\
\hline 128 & $<5.2$ & $<.5$ & $<3.7$ & $<12.0$ & $<2.0$ & $<4.4$ & $<3.0$ & $<1.98$ & $<21.0$ \\
\hline 129 & $<5.2$ & $<.5$ & $<3.7$ & $<12.0$ & $<2.0$ & $<4.4$ & $<3.0$ & $<1.98$ & $<21.0$ \\
\hline 130 & $<5.2$ & $<.5$ & $<3.7$ & $<12.0$ & $<2.0$ & $<4.4$ & $<3.0$ & $<1.98$ & $<21.0$ \\
\hline I31 & $<5.2$ & $<.5$ & $<3.7$ & $<12.0$ & $<2.0$ & $<4.4$ & $<3.0$ & $<1.98$ & $<21.0$ \\
\hline I32 & $<5.2$ & $<.5$ & $<3.7$ & $<12.0$ & $<2.0$ & $<4.4$ & $<3.0$ & $<1.98$ & $<21.0$ \\
\hline 133 & $<5.2$ & $<.5$ & $<3.7$ & $<12.0$ & $<2.0$ & $<4.4$ & $<3.0$ & $<1.98$ & $<21.0$ \\
\hline I33 (S) & -- & $<5.0$ & $<5.0$ & $<30.0$ & $<5.0$ & $<5.0$ & $<5.0$ & -- & $<.1$ \\
\hline 134 & $<5.2$ & $<.5$ & $<3.7$ & $<12.0$ & $<2.0$ & $<4.4$ & $<3.0$ & $<1.98$ & $<21.0$ \\
\hline I34 (R) & $<5.2$ & $<.5$ & $<3.7$ & $<12.0$ & $<2.0$ & $<4.4$ & $<3.0$ & $<1.98$ & $<21.0$ \\
\hline I34 (S) & $\ldots$ & $<5.0$ & $<5.0$ & $<30.0$ & $<5.0$ & $<5.0$ & $<5.0$ & -- & $<.1$ \\
\hline 135 & $<5.2$ & $<.5$ & $<3.7$ & $<12.0$ & $<2.0$ & $<4.4$ & $<3.0$ & $<1.98$ & $<21.0$ \\
\hline I36 & $<5.2$ & $<.5$ & $<3.7$ & $<12.0$ & $<2.0$ & $<4.4$ & $<3.0$ & $<1.98$ & $<21.0$ \\
\hline I37B & -- & -- & -- & -- & -- & -- & -- & $<1.98$ & -- \\
\hline I37B (R) & -- & - & -- & -- & -- & - & -- & $<1.98$ & -- \\
\hline I38 & -- & -- & -- & -- & -- & -- & -- & $<1.98$ & -- \\
\hline I39 & - & $\cdots$ & -- & -- & -- & -- & -- & $<1.98$ & -- \\
\hline I 40 & -- & -- & -- & -- & -- & -- & -- & $<1.98$ & -- \\
\hline I41 & -- & -. & -- & -- & -- & -- & -- & $<1.98$ & -- \\
\hline I42 & - & - & -- & -- & -- & -- & -- & $<1.98$ & -- \\
\hline I43 & -- & -- & -- & -- & -- & -- & -- & $<1.98$ & -- \\
\hline I 44 & $<5.2$ & $<.5$ & $<3.7$ & $<12.0$ & $<2.0$ & $<4.4$ & $<3.0$ & $<1.98$ & $<21.0$ \\
\hline 145 & $<5.2$ & $<.5$ & $<3.7$ & $<12.0$ & $<2.0$ & $<4.4$ & $<3.0$ & $<1.98$ & $<21.0$ \\
\hline I46 & $<5.2$ & $<.5$ & $<3.7$ & $<12.0$ & $<2.0$ & $<4.4$ & $<3.0$ & $<1.98$ & $<21.0$ \\
\hline I $47 \mathrm{~A}$ & $<5.2$ & $<.5$ & $<3.7$ & $<12.0$ & $<2.0$ & $<4.4$ & $<3.0$ & $<1.98$ & $<21.0$ \\
\hline 148 & $<5.2$ & $<.5$ & $<3.7$ & $<12.0$ & $<2.0$ & $<4.4$ & $<3.0$ & $<1.98$ & $<21.0$ \\
\hline I 49 & $<5.2$ & $<.5$ & $<3.7$ & $<12.0$ & $<2.0$ & $<4.4$ & $<3.0$ & $<1.98$ & $<21.0$ \\
\hline 150 & $<5.2$ & $<.5$ & $<3.7$ & $<12.0$ & $<2.0$ & $<4.4$ & $<3.0$ & $<1.98$ & $<21.0$ \\
\hline I51 & $<5.2$ & $<.5$ & $<3.7$ & $<12.0$ & $<2.0$ & $<4.4$ & $<3.0$ & $<1.98$ & $<21.0$ \\
\hline I52 & $<5.2$ & $<.5$ & $<3.7$ & $<12.0$ & $<2.0$ & $<4.4$ & $<3.0$ & $<1.98$ & $<21.0$ \\
\hline 153 & $<5.2$ & $<.5$ & $<3.7$ & $<12.0$ & $<2.0$ & $<4.4$ & $<3.0$ & $<1.98$ & $<21.0$ \\
\hline $153(\mathrm{R})$ & $<5.2$ & $<.5$ & $<3.7$ & $<12.0$ & $<2.0$ & $<4.4$ & $<3.0$ & $<1.98$ & $<21.0$ \\
\hline I54A & $<5.2$ & $<.5$ & $<3.7$ & $<12.0$ & $<2.0$ & $<4.4$ & $<3.0$ & $<1.98$ & $<21.0$ \\
\hline
\end{tabular}


Table 13. Results of organic-chemical analyses of water from selected wells in the surficial aquifer at Carroll Island, Aberdeen Proving Ground, Md., spring 1989--Continued

\begin{tabular}{|c|c|c|c|c|c|c|c|c|c|}
\hline 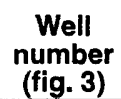 & РCB 1221 & PCB 1232 & РСB 1242 & PCB 1248 & РСВ 1254 & РCB 1260 & $\begin{array}{l}\text { Penta- } \\
\text { chloro- } \\
\text { phenol }\end{array}$ & $\begin{array}{c}\text { Phenan- } \\
\text { threne }\end{array}$ & Phenol \\
\hline I01 & -- & -- & -- & -- & -- & -. & -. & .- & -- \\
\hline 102 & -- & -- & -- & -- & -- & -- & -- & -. & -- \\
\hline I03 & -- &.- & -- & -- & -- & - & - & -- & -- \\
\hline I04 & $<21.0$ & $<21.0$ & $<30.0$ & $<30.0$ & $<36.0$ & $<36.0$ & $<18.0$ & $<0.5$ & $<9.2$ \\
\hline I05 & $<21.0$ & $<21.0$ & $<30.0$ & $<30.0$ & $<36.0$ & $<36.0$ & $<18.0$ & $<.5$ & $<9.2$ \\
\hline 106 & $<21.0$ & $<21.0$ & $<30.0$ & $<30.0$ & $<36.0$ & $<36.0$ & $<18.0$ & $<.5$ & $<9.2$ \\
\hline I07 & $<21.0$ & $<21.0$ & $<30.0$ & $<30.0$ & $<36.0$ & $<36.0$ & $<18.0$ & $<.5$ & $<9.2$ \\
\hline I08 & $<21.0$ & $<21.0$ & $<30.0$ & $<30.0$ & $<36.0$ & $<36.0$ & $<18.0$ & $<.5$ & $<9.2$ \\
\hline 109 & -- & -. & -- & -- & -- & -. & -. & -- & -. \\
\hline IIO & -- & -- & - & -- & -. & -- & -- & -- & -- \\
\hline I12 & $<21.0$ & $<21.0$ & $<30.0$ & $<30.0$ & $<36.0$ & $<36.0$ & $<18.0$ & $<.5$ & $<9.2$ \\
\hline I13 & $<21.0$ & $<21.0$ & $<30.0$ & $<30.0$ & $<36.0$ & $<36.0$ & $<18.0$ & $<.5$ & $<9.2$ \\
\hline I14 & $<21.0$ & $<21.0$ & $<30.0$ & $<30.0$ & $<36.0$ & $<36.0$ & $<18.0$ & $<.5$ & $<9.2$ \\
\hline I15 & $<21.0$ & $<21.0$ & $<30.0$ & $<30.0$ & $<36.0$ & $<36.0$ & $<18.0$ & $<.5$ & $<9.2$ \\
\hline I16B & $<21.0$ & $<21.0$ & $<30.0$ & $<30.0$ & $<36.0$ & $<36.0$ & $<18.0$ & $<.5$ & $<9.2$ \\
\hline I17 & $<21.0$ & $<21.0$ & $<30.0$ & $<30.0$ & $<36.0$ & $<36.0$ & $<18.0$ & $<.5$ & $<9.2$ \\
\hline I17 (S) & $<.1$ & $<.1$ & $<.1$ & $<.1$ & $<.1$ & $<.1$ & $<30.0$ & $<5.0$ & -- \\
\hline I18 & $<21.0$ & $<21.0$ & $<30.0$ & $<30.0$ & $<36.0$ & $<36.0$ & $<18.0$ & $<.5$ & $<9.2$ \\
\hline I18 (R) & $<21.0$ & $<21.0$ & $<30.0$ & $<30.0$ & $<36.0$ & $<36.0$ & $<18.0$ & $<.5$ & $<9.2$ \\
\hline I1 8 (S) & $<.1$ & $<.1$ & $<.1$ & $<.1$ & $<.1$ & $<.1$ & $<30.0$ & $<5.0$ & -- \\
\hline I19 & $<21.0$ & $<21.0$ & $<30.0$ & $<30.0$ & $<36.0$ & $<36.0$ & $<18.0$ & $<.5$ & $<9.2$ \\
\hline I 20 & $<21.0$ & $<21.0$ & $<30.0$ & $<30.0$ & $<36.0$ & $<36.0$ & $<18.0$ & $<.5$ & $<9.2$ \\
\hline I 21 & $<21.0$ & $<21.0$ & $<30.0$ & $<30.0$ & $<36.0$ & $<36.0$ & $<18.0$ & $<.5$ & $<9.2$ \\
\hline I22B & $<21.0$ & $<21.0$ & $<30.0$ & $<30.0$ & $<36.0$ & $<36.0$ & $<18.0$ & $<.5$ & $<9.2$ \\
\hline I22B (R) & $<21.0$ & $<21.0$ & $<30.0$ & $<30.0$ & $<36.0$ & $<36.0$ & $<18.0$ & $<.5$ & $<9.2$ \\
\hline $\mathrm{I} 22 \mathrm{C}$ & $<21.0$ & $<21.0$ & $<30.0$ & $<30.0$ & $<36.0$ & $<36.0$ & $<18.0$ & $<.5$ & $<9.2$ \\
\hline 123 & $<21.0$ & $<21.0$ & $<30.0$ & $<30.0$ & $<36.0$ & $<36.0$ & $<18.0$ & $<.5$ & $<9.2$ \\
\hline I24 & $<21.0$ & $<21.0$ & $<30.0$ & $<30.0$ & $<36.0$ & $<36.0$ & $<18.0$ & $<.5$ & $<9.2$ \\
\hline 125 & $<21.0$ & $<21.0$ & $<30.0$ & $<30.0$ & $<36.0$ & $<36.0$ & $<18.0$ & $<.5$ & $<9.2$ \\
\hline $126 \mathrm{~A}$ & $<21.0$ & $<21.0$ & $<30.0$ & $<30.0$ & $<36.0$ & $<36.0$ & $<18.0$ & $<.5$ & $<9.2$ \\
\hline I26A (R) & $<21.0$ & $<21.0$ & $<30.0$ & $<30.0$ & $<36.0$ & $<36.0$ & $<18.0$ & $<.5$ & -- \\
\hline I26A (S) & $<.1$ & $<.1$ & $<.1$ & $<.1$ & $<.1$ & $<.1$ & $<30.0$ & $<5.0$ & -- \\
\hline I26B & $<21.0$ & $<21.0$ & $<30.0$ & $<30.0$ & $<36.0$ & $<36.0$ & $<18.0$ & $<.5$ & $<9.2$ \\
\hline $127 \mathrm{~B}$ & $<21.0$ & $<21.0$ & $<30.0$ & $<30.0$ & $<36.0$ & $<36.0$ & $<18.0$ & $<.5$ & $<9.2$ \\
\hline $\mathrm{I} 28$ & $<21.0$ & $<21.0$ & $<30.0$ & $<30.0$ & $<36.0$ & $<36.0$ & $<18.0$ & $<.5$ & $<9.2$ \\
\hline I 29 & $<21.0$ & $<21.0$ & $<30.0$ & $<30.0$ & $<36.0$ & $<36.0$ & $<18.0$ & $<.5$ & $<9.2$ \\
\hline I30 & $<21.0$ & $<21.0$ & $<30.0$ & $<30.0$ & $<36.0$ & $<36.0$ & $<18.0$ & $<.5$ & $<9.2$ \\
\hline I31 & $<21.0$ & $<21.0$ & $<30.0$ & $<30.0$ & $<36.0$ & $<36.0$ & $<18.0$ & $<.5$ & $<9.2$ \\
\hline I32 & $<21.0$ & $<21.0$ & $<30.0$ & $<30.0$ & $<36.0$ & $<36.0$ & $<18.0$ & $<.5$ & $<9.2$ \\
\hline I33 & $<21.0$ & $<21.0$ & $<30.0$ & $<30.0$ & $<36.0$ & $<36.0$ & $<18.0$ & $<.5$ & $<9.2$ \\
\hline I33 (S) & $<.1$ & $<$ I & $<1$ & $<.1$ & $<.1$ & $<.1$ & $<30.0$ & $<5.0$ & -- \\
\hline I34 & $<21.0$ & $<21.0$ & $<30.0$ & $<30.0$ & $<36.0$ & $<36.0$ & $<18.0$ & $<.5$ & $<9.2$ \\
\hline I34 (R) & $<21.0$ & $<21.0$ & $<30.0$ & $<30.0$ & $<36.0$ & $<36.0$ & $<18.0$ & $<.5$ & -9.2 \\
\hline I34 (S) & $<.1$ & $<.1$ & $<.1$ & $<.1$ & $<.1$ & $<.1$ & $<30.0$ & $<5.0$ & -- \\
\hline 135 & $<21.0$ & $<21.0$ & $<30.0$ & $<30.0$ & $<36.0$ & $<36.0$ & $<18.0$ & $<.5$ & $<9.2$ \\
\hline I36 & $<21.0$ & $<21.0$ & $<30.0$ & $<30.0$ & $<36.0$ & $<36.0$ & $<18.0$ & $<.5$ & $<9.2$ \\
\hline I37B & -- & -- & -. & -- & -- & -- & .. & .. & -- \\
\hline I37B (R) & -- & -- & -- & -- & -. & -- & -- & -. & -- \\
\hline $\mathrm{I} 38$ & - & -- & - & - & -- & - & -- & -- & -. \\
\hline I39 & -- & -- & -- & -- & -- & -- & -- & -- & -- \\
\hline I40 & -- & .. & -. & -- & -- & -. & -- & -- & -- \\
\hline I41 & .. & .- & .. & .- & -- & -- & -- & .- & -. \\
\hline I 42 & -. & -. & -. & -- & -- & -- & -- & -- & -- \\
\hline I 43 & -- & -- & -. & -- & - & -- & -- & -- & -- \\
\hline I 44 & $<21.0$ & $<21.0$ & $<30.0$ & $<30.0$ & $<36.0$ & $<36.0$ & $<18.0$ & $<.5$ & $<9.2$ \\
\hline I 45 & $<21.0$ & $<21.0$ & $<30.0$ & $<30.0$ & $<36.0$ & $<36.0$ & $<18.0$ & $<.5$ & $<9.2$ \\
\hline I46 & $<21.0$ & $<21.0$ & $<30.0$ & $<30.0$ & $<36.0$ & $<36.0$ & $<18.0$ & $<.5$ & $<9.2$ \\
\hline I $47 \mathrm{~A}$ & $<21.0$ & $<21.0$ & $<30.0$ & $<30.0$ & $<36.0$ & $<36.0$ & $<18.0$ & $<.5$ & $<9.2$ \\
\hline I 48 & $<21.0$ & $<21.0$ & $<30.0$ & $<30.0$ & $<36.0$ & $<36.0$ & $<18.0$ & $<.5$ & $<9.2$ \\
\hline I 49 & $<21.0$ & $<21.0$ & $<30.0$ & $<30.0$ & $<36.0$ & $<36.0$ & $<18.0$ & $<.5$ & $<9.2$ \\
\hline I50 & $<21.0$ & $<21.0$ & $<30.0$ & $<30.0$ & $<36.0$ & $<36.0$ & $<18.0$ & $<.5$ & $<9.2$ \\
\hline I51 & $<21.0$ & $<21.0$ & $<30.0$ & $<30.0$ & $<36.0$ & $<36.0$ & $<18.0$ & $<.5$ & $<9.2$ \\
\hline I52 & $<21.0$ & $<21.0$ & $<30.0$ & $<30.0$ & $<36.0$ & $<36.0$ & $<18.0$ & $<.5$ & $<9.2$ \\
\hline I53 & $<21.0$ & $<21.0$ & $<30.0$ & $<30.0$ & $<36.0$ & $<36.0$ & $<18.0$ & $<.5$ & $<9.2$ \\
\hline I53 (R) & $<21.0$ & $<21.0$ & $<30.0$ & $<30.0$ & $<36.0$ & $<36.0$ & $<18.0$ & $<.5$ & $<9.2$ \\
\hline I54A & $<21.0$ & $<21.0$ & $<30.0$ & $<30.0$ & $<36.0$ & $<36.0$ & $<18.0$ & $<.5$ & $<9.2$ \\
\hline
\end{tabular}


Table 13. Results of organic-chemical analyses of water from selected wells in the surficial aquifer at Carroll Island, Aberdeen Proving Ground, Md., spring 1989--Continued

\begin{tabular}{|c|c|c|c|c|c|c|c|}
\hline $\begin{array}{c}\text { Well } \\
\text { number } \\
\text { (fig. 3) }\end{array}$ & Pyrene & Styrene & Thiodiglycol & Toxaphene & $\begin{array}{c}\text { 1,2,4-Tri- } \\
\text { chlorobenzene }\end{array}$ & $\begin{array}{c}\text { 2,4,5-Tri- } \\
\text { chlorophenol }\end{array}$ & $\begin{array}{c}\text { 2,4,6-Tri- } \\
\text { chlorophenol }\end{array}$ \\
\hline 101 & -.- & $<0.5$ & $<187$ & .. & -- & .- & _- \\
\hline 102 & -. & $<.5$ & $<187$ & -- & -- & -- & $\ldots$ \\
\hline 103 & -- & $<.5$ & $<187$ & -. & -- & -- & -- \\
\hline 104 & $<2.8$ & $<.5$ & $<187$ & $<36.0$ & $<1.8$ & $<5.2$ & $<4.2$ \\
\hline 105 & $<2.8$ & $<.5$ & $<187$ & $<36.0$ & $<1.8$ & $<5.2$ & $<4.2$ \\
\hline 106 & $<2.8$ & $<.5$ & $<187$ & $<36.0$ & $<1.8$ & $<5.2$ & $<4.2$ \\
\hline 107 & $<2.8$ & $<.5$ & $<187$ & $<36.0$ & $<1.8$ & $<5.2$ & $<4.2$ \\
\hline 108 & $<2.8$ & $<.5$ & $<187$ & $<36.0$ & $<1.8$ & $<5.2$ & $<4.2$ \\
\hline I09 & $\ldots$ & $<.5$ & $<65.9$ & -- & -- & -- & -- \\
\hline 110 & -- & $<.5$ & $<65.9$ & -- & -- & -- & - \\
\hline I12 & $<2.8$ & $<.5$ & $<187$ & $<36.0$ & $<1.8$ & $<5.2$ & $<4.2$ \\
\hline I13 & $<2.8$ & $<.5$ & $<65.9$ & $<36.0$ & $<1.8$ & $<5.2$ & $<4.2$ \\
\hline $\mathrm{I} 14$ & $<2.8$ & $<.5$ & $<65.9$ & $<36.0$ & $<1.8$ & $<5.2$ & $<4.2$ \\
\hline I15 & $<2.8$ & $<.5$ & $<65.9$ & $<36.0$ & $<1.8$ & $<5.2$ & $<4.2$ \\
\hline $116 \mathrm{~B}$ & $<2.8$ & $<.5$ & $<65.9$ & $<36.0$ & $<1.8$ & $<5.2$ & $<4.2$ \\
\hline I17 & $<2.8$ & $<.5$ & $<65.9$ & $<36.0$ & $<1.8$ & $<5.2$ & $<4.2$ \\
\hline $117(S)$ & $<5.0$ & -- & -- & $<1.0$ & $<5.0$ & -- & $<20.0$ \\
\hline I18 & $<2.8$ & $<.5$ & $<65.9$ & $<36.0$ & $<1.8$ & $<5.2$ & $<4.2$ \\
\hline I18 (R) & $<2.8$ & $<.5$ & $<65.9$ & $<36.0$ & $<1.8$ & $<5.2$ & $<4.2$ \\
\hline $118(S)$ & $<5.0$ & -- & -- & $<1.0$ & $<5.0$ & -- & $<20.0$ \\
\hline 119 & $<2.8$ & $<.5$ & $<65.9$ & $<36.0$ & $<1.8$ & $<5.2$ & $<4.2$ \\
\hline 120 & $<2.8$ & $<.5$ & $<187$ & $<36.0$ & $<1.8$ & $<5.2$ & $<4.2$ \\
\hline 121 & $<2.8$ & $<.5$ & $<187$ & $<36.0$ & $<1.8$ & $<5.2$ & $<4.2$ \\
\hline $122 \mathrm{~B}$ & $<2.8$ & $<.5$ & $<187$ & $<36.0$ & $<1.8$ & $<5.2$ & $<4.2$ \\
\hline I22B (R) & $<2.8$ & $<.5$ & $<187$ & $<36.0$ & $<1.8$ & $<5.2$ & $<4.2$ \\
\hline $122 \mathrm{C}$ & $<2.8$ & $<.5$ & $<187$ & $<36.0$ & $<1.8$ & $<5.2$ & $<4.2$ \\
\hline 123 & $<2.8$ & $<.5$ & $<187$ & $<36.0$ & $<1.8$ & $<5.2$ & $<4.2$ \\
\hline $\mathrm{I} 24$ & $<2.8$ & $<.5$ & $<187$ & $<36.0$ & $<1.8$ & $<5.2$ & $<4.2$ \\
\hline 125 & $<2.8$ & $<.5$ & $<187$ & $<36.0$ & $<1.8$ & $<5.2$ & $<4.2$ \\
\hline $126 \mathrm{~A}$ & $<2.8$ & $<.5$ & $<187$ & $<36.0$ & $<1.8$ & $<5.2$ & $<4.2$ \\
\hline $\mathrm{I} 26 \mathrm{~A}(\mathrm{R})$ & $<2.8$ & $<.5$ & $<187$ & $<36.0$ & $<1.8$ & $<5.2$ & $<4.2$ \\
\hline $126 \mathrm{~A}(\mathrm{~S})$ & $<5.0$ & -- & -- & $<1.0$ & $<5.0$ & -- & $<20.0$ \\
\hline $\mathrm{I} 26 \mathrm{~B}$ & $<2.8$ & $<.5$ & $<187$ & $<36.0$ & $<1.8$ & $<5.2$ & $<4.2$ \\
\hline $127 \mathrm{~B}$ & $<2.8$ & $<.5$ & $<65.9$ & $<36.0$ & $<1.8$ & $<5.2$ & $<4.2$ \\
\hline I 28 & $<2.8$ & $<.5$ & $<65.9$ & $<36.0$ & $<1.8$ & $<5.2$ & $<4.2$ \\
\hline 129 & $<2.8$ & $<.5$ & $<65.9$ & $<36.0$ & $<1.8$ & $<5.2$ & $<4.2$ \\
\hline $\mathrm{I} 30$ & $<2.8$ & $<.5$ & $<65.9$ & $<36.0$ & $<1.8$ & $<5.2$ & $<4.2$ \\
\hline 131 & $<2.8$ & $<.5$ & $<187$ & $<36.0$ & $<1.8$ & $<5.2$ & $<4.2$ \\
\hline $\mathrm{I} 32$ & $<2.8$ & $<.5$ & $<187$ & $<36.0$ & $<1.8$ & $<5.2$ & $<4.2$ \\
\hline 133 & $<2.8$ & $<.5$ & $<187$ & $<36.0$ & $<1.8$ & $<5.2$ & $<4.2$ \\
\hline $133(S)$ & $<5.0$ & -- & -- & $<1.0$ & $<5.0$ & -- & $<20.0$ \\
\hline I34 & $<2.8$ & $<.5$ & $<187$ & $<36.0$ & $<1.8$ & $<5.2$ & $<4.2$ \\
\hline $134(\mathrm{R})$ & $<2.8$ & $<.5$ & $<187$ & $<36.0$ & $<1.8$ & $<5.2$ & $<4.2$ \\
\hline I34 (S) & $<5.0$ & -- & - & $<1.0$ & $<5.0$ & - & $<20.0$ \\
\hline I35 & $<2.8$ & $<.5$ & $<187$ & $<36.0$ & $<1.8$ & $<5.2$ & $<4.2$ \\
\hline I36 & $<2.8$ & $<.5$ & $<187$ & $<36.0$ & $<1.8$ & $<5.2$ & $<4.2$ \\
\hline I37B & - & $<.5$ & $<65.9$ & .. & -- & -- & -- \\
\hline I37B (R) & -- & $<.5$ & $<65.9$ & -- & -- & -. & -- \\
\hline 138 & -.- & $<.5$ & $<187$ & -- & -- & -- & -- \\
\hline 139 & -- & $<.5$ & $<187$ & -- & -- & -- & -. \\
\hline 140 & - & $<.5$ & $<187$ & $\ldots$ & -. & - & -- \\
\hline 141 & -- & $<.5$ & $<187$ & -- & -- & -- & -- \\
\hline 142 & -. & $<.5$ & $<187$ & -- & -- & -- & -- \\
\hline 143 & -- & $<.5$ & $<187$ & -- & -- & -- & -- \\
\hline 144 & $<2.8$ & $<.5$ & $<187$ & $<36.0$ & $<1.8$ & $<5.2$ & $<4.2$ \\
\hline I 45 & $<2.8$ & $<.5$ & $<187$ & $<36.0$ & $<1.8$ & $<5.2$ & $<4.2$ \\
\hline 146 & $<2.8$ & $<.5$ & $<187$ & $<36.0$ & $<1.8$ & $<5.2$ & $<4.2$ \\
\hline $147 \mathrm{~A}$ & $<2.8$ & $<.5$ & $<187$ & $<36.0$ & $<1.8$ & $<5.2$ & $<4.2$ \\
\hline 148 & $<2.8$ & $<.5$ & $<187$ & $<36.0$ & $<1.8$ & $<5.2$ & $<4.2$ \\
\hline I 49 & $<2.8$ & $<.5$ & $<187$ & $<36.0$ & $<1.8$ & $<5.2$ & $<4.2$ \\
\hline I50 & $<2.8$ & $<.5$ & $<187$ & $<36.0$ & $<1.8$ & $<5.2$ & $<4.2$ \\
\hline 151 & $<2.8$ & $<.5$ & $<187$ & $<36.0$ & $<1.8$ & $<5.2$ & $<4.2$ \\
\hline I52 & $<2.8$ & $<.5$ & $<187$ & $<36.0$ & $<1.8$ & $<5.2$ & $<4.2$ \\
\hline 153 & $<2.8$ & $<.5$ & $<187$ & $<36.0$ & $<1.8$ & $<5.2$ & $<4.2$ \\
\hline I53 (R) & $<2.8$ & $<.5$ & $<187$ & $<36.0$ & $<1.8$ & $<5.2$ & $<4.2$ \\
\hline $154 \mathrm{~A}$ & $<2.8$ & $<.5$ & $<187$ & $<36.0$ & $<1.8$ & $<5.2$ & $<4.2$ \\
\hline
\end{tabular}


Table 14. Results of organic-chemical analyses of water from wells in the confined aquifer at Carroll Island, Aberdeen Proving Ground, Md., spring 1989

[Concentrations are in micrograms per liter; <, less than; --, missing data; (S), split sample; PCB, polychlorinated biphenyl]

\begin{tabular}{|c|c|c|c|c|c|c|c|c|c|}
\hline $\begin{array}{c}\text { Well } \\
\text { number } \\
\text { (fig. 3) }\end{array}$ & $\begin{array}{l}\text { Sampling } \\
\text { date }\end{array}$ & $\begin{array}{c}\text { Carbon, } \\
\text { organic } \\
\text { total } \\
\text { (as C) }\end{array}$ & $\begin{array}{c}\text { Phenols, } \\
\text { non-specific, } \\
\text { total }\end{array}$ & $\begin{array}{l}\text { Halide, } \\
\text { total } \\
\text { organic }\end{array}$ & Benzene & $\begin{array}{l}\text { Bromo- } \\
\text { dichloro- } \\
\text { methane }\end{array}$ & Bromoform & $\begin{array}{c}\text { Carbon } \\
\text { tetrachloride }\end{array}$ & $\begin{array}{l}\text { Chloro- } \\
\text { benzene }\end{array}$ \\
\hline $116 \mathrm{~A}(\mathrm{~S})$ & $04-24-89$ & 2,220 & $<5.0$ & -- & $<3.0$ & -- & $<3.0$ & $<3.0$ & $<3.0$ \\
\hline $122 \mathrm{~A}$ & $04-24-89$ & 2,090 & $<7.12$ & 19.4 & $<.50$ & $<.59$ & $<2.6$ & $<.58$ & $<.50$ \\
\hline $\mathrm{I} 22 \mathrm{~A}(\mathrm{~S})$ & $04-24-89$ & 6,100 & $<5.0$ & -- & $<3.0$ & -- & $<3.0$ & $<3.0$ & $<3.0$ \\
\hline I47B & $04-27-89$ & 2,280 & $<7.12$ & 15.8 & $<.50$ & $<.59$ & $<2.6$ & $<.58$ & $<.50$ \\
\hline I47B (S) & $04-27-89$ & 5,900 & $<5.0$ & -- & $<3.0$ & -- & $<3.0$ & $<3.0$ & $<3.0$ \\
\hline I54B & $04-27-89$ & 1,680 & $<7.12$ & 10.0 & $<.50$ & $<.59$ & $<2.6$ & $<.58$ & $<.50$ \\
\hline $\begin{array}{c}\text { Well } \\
\text { number } \\
\text { (fig. 3) }\end{array}$ & $\begin{array}{l}\text { Chloro- } \\
\text { dibromo- } \\
\text { methane }\end{array}$ & $\begin{array}{l}\text { Chloro- } \\
\text { ethane }\end{array}$ & $\begin{array}{l}\text { 2-Chloro- } \\
\text { ethyl- } \\
\text { vinyl ether }\end{array}$ & Chloroform & $\begin{array}{l}\text { Chloro- } \\
\text { methane }\end{array}$ & $\begin{array}{c}\text { 1,2-Di- } \\
\text { chloro- } \\
\text { benzene }\end{array}$ & $\begin{array}{c}\text { 1,3-Di- } \\
\text { chloro- } \\
\text { benzene }\end{array}$ & $\begin{array}{c}\text { 1,4-Di- } \\
\text { chloro- } \\
\text { benzene }\end{array}$ & $\begin{array}{l}\text { 1,1-Di- } \\
\text { chloro- } \\
\text { ethane }\end{array}$ \\
\hline $122 \mathrm{~A}$ & $<.67$ & $<1.9$ & $<.71$ & $<.50$ & $<3.2$ & -- & - & -- & $<.68$ \\
\hline $\mathrm{I} 22 \mathrm{~A}(\mathrm{~S})$ & $<3.0$ & $<3.0$ & $<3.0$ & $<3.0$ & $<3.0$ & $<5.0$ & $<5.0$ & $<5.0$ & $<3.0$ \\
\hline $127 \mathrm{~A}$ & $<.67$ & $<1.9$ & $<.71$ & $<.50$ & $<3.2$ & -- & -- & -- & $<.68$ \\
\hline I37A & $<.67$ & $<1.9$ & $<.71$ & $<.50$ & $<3.2$ & -- & -- & -- & $<.68$ \\
\hline 147B & $<.67$ & $<1.9$ & $<.71$ & $<.50$ & $<3.2$ & -- & - & -- & $<.68$ \\
\hline I47B (S) & $<3.0$ & $<3.0$ & $<3.0$ & $<3.0$ & $<3.0$ & $<5.0$ & $<5.0$ & $<5.0$ & $<3.0$ \\
\hline I54B & $<.67$ & $<1.9$ & $<.71$ & $<.50$ & $<3.2$ & -. & -- & -- & $<.68$ \\
\hline
\end{tabular}

\begin{tabular}{|c|c|c|c|c|c|c|c|c|c|}
\hline $\begin{array}{c}\text { Well } \\
\text { number } \\
\text { (fig. 3) }\end{array}$ & $\begin{array}{l}\text { 1,2-Di- } \\
\text { chloro- } \\
\text { ethane }\end{array}$ & $\begin{array}{l}\text { 1,1-Di- } \\
\text { chloro- } \\
\text { ethylene }\end{array}$ & $\begin{array}{c}\text { 1,2-Di- } \\
\text { chloro- } \\
\text { ethylene } \\
\text { (cis + trans) }\end{array}$ & $\begin{array}{l}\text { 1,2-Di- } \\
\text { chloro- } \\
\text { propane }\end{array}$ & $\begin{array}{l}\text { cis-1,3-Di- } \\
\text { chloro- } \\
\text { propene }\end{array}$ & $\begin{array}{c}\text { trans-1,3-Di- } \\
\text { chloro- } \\
\text { propene }\end{array}$ & $\begin{array}{l}\text { Ethylben- } \\
\text { zene }\end{array}$ & Fluorene & $\begin{array}{c}\text { Methylene } \\
\text { chloride }\end{array}$ \\
\hline $116 \mathrm{~A}$ & $<0.50$ & $<0.50$ & $<0.50$ & $<0.50$ & $<0.58$ & $<0.70$ & $<0.50$ & - & $<2.3$ \\
\hline $116 \mathrm{~A}(\mathrm{~S})$ & $<3.0$ & $<3.0$ & $<3.0$ & $<3.0$ & $<3.0$ & $<3.0$ & $<3.0$ & -- & $<3.0$ \\
\hline I22A & $<.50$ & $<.50$ & $<.50$ & $<.50$ & $<.58$ & $<.70$ & $<.50$ & -- & $<2.3$ \\
\hline $\mathrm{I} 22 \mathrm{~A}(\mathrm{~S})$ & $<3.0$ & $<3.0$ & $<3.0$ & $<3.0$ & $<3.0$ & $<3.0$ & $<3.0$ & -. & $<3.0$ \\
\hline $127 \mathrm{~A}$ & $<.50$ & $<.50$ & $<.50$ & $<.50$ & $<.58$ & $<.70$ & $<.50$ & -- & $<2.3$ \\
\hline $137 \mathrm{~A}$ & $<.50$ & $<.50$ & $<.50$ & $<.50$ & $<.58$ & $<.70$ & $<.50$ & .. & $<2.3$ \\
\hline I47B & $<.50$ & $<.50$ & $<.50$ & $<.50$ & $<.58$ & $<.70$ & $<.50$ & -- & $<2.3$ \\
\hline I47B (S) & $<3.0$ & $<3.0$ & $<3.0$ & $<3.0$ & $<3.0$ & $<3.0$ & $<3.0$ & -- & $<3.0$ \\
\hline I54B & $<.50$ & $<.50$ & $<.50$ & $<.50$ & $<.58$ & $<.70$ & $<.50$ & -- & $<2.3$ \\
\hline
\end{tabular}

\begin{tabular}{|c|c|c|c|c|c|c|c|c|c|}
\hline $\begin{array}{c}\text { Well } \\
\text { number } \\
\text { (fig. 3) }\end{array}$ & $\begin{array}{c}1,1,2,2-\text { Tetra- } \\
\text { chloro- } \\
\text { ethane }\end{array}$ & $\begin{array}{c}\text { Tetra- } \\
\text { chloro- } \\
\text { ethylene }\end{array}$ & Toluene & $\begin{array}{l}\text { 1,1,1-Tri- } \\
\text { chloro- } \\
\text { ethane }\end{array}$ & $\begin{array}{l}\text { 1,1,2-Tri- } \\
\text { chloro- } \\
\text { ethane }\end{array}$ & $\begin{array}{l}\text { Trichloro- } \\
\text { ethylene }\end{array}$ & $\begin{array}{c}\text { Trichloro- } \\
\text { fluoro- } \\
\text { methane }\end{array}$ & $\begin{array}{c}\text { Vinyl } \\
\text { chloride }\end{array}$ & Xylenes \\
\hline I16A & $<0.51$ & $<1.6$ & $<0.50$ & $<0.50$ & $<1.2$ & $<0.50$ & $<1.4$ & $<2.6$ & $<0.84$ \\
\hline $122 \mathrm{~A}$ & $<.51$ & $<1.6$ & $<.50$ & $<.50$ & $<1.2$ & $<.50$ & $<1.4$ & $<2.6$ & $<.84$ \\
\hline I22A (S) & $<3.0$ & $<3.0$ & $<3.0$ & $<3.0$ & $<3.0$ & $<3.0$ & -- & $<3.0$ & $<3.0$ \\
\hline $127 \mathrm{~A}$ & $<.51$ & $<1.6$ & $<.50$ & $<.50$ & $<1.2$ & $<.50$ & $<1.4$ & $<2.6$ & $<.84$ \\
\hline I47B & $<.51$ & $<1.6$ & $<.50$ & $<.50$ & $<1.2$ & $<.50$ & $<1.4$ & $<2.6$ & $<.84$ \\
\hline 147B (S) & $<3.0$ & $<3.0$ & $<3.0$ & $<3.0$ & $<3.0$ & $<3.0$ & - & $<1.0$ & $<3.0$ \\
\hline I54B & $<.51$ & $<1.6$ & $<.50$ & $<.50$ & $<1.2$ & $<.50$ & $<1.4$ & $<2.6$ & $<.84$ \\
\hline
\end{tabular}


Table 14. Results of organic-chemical analyses of water from wells in the confined aquifer at Carroll Island, Aberdeen Proving Ground, Md., spring 1989--Continued

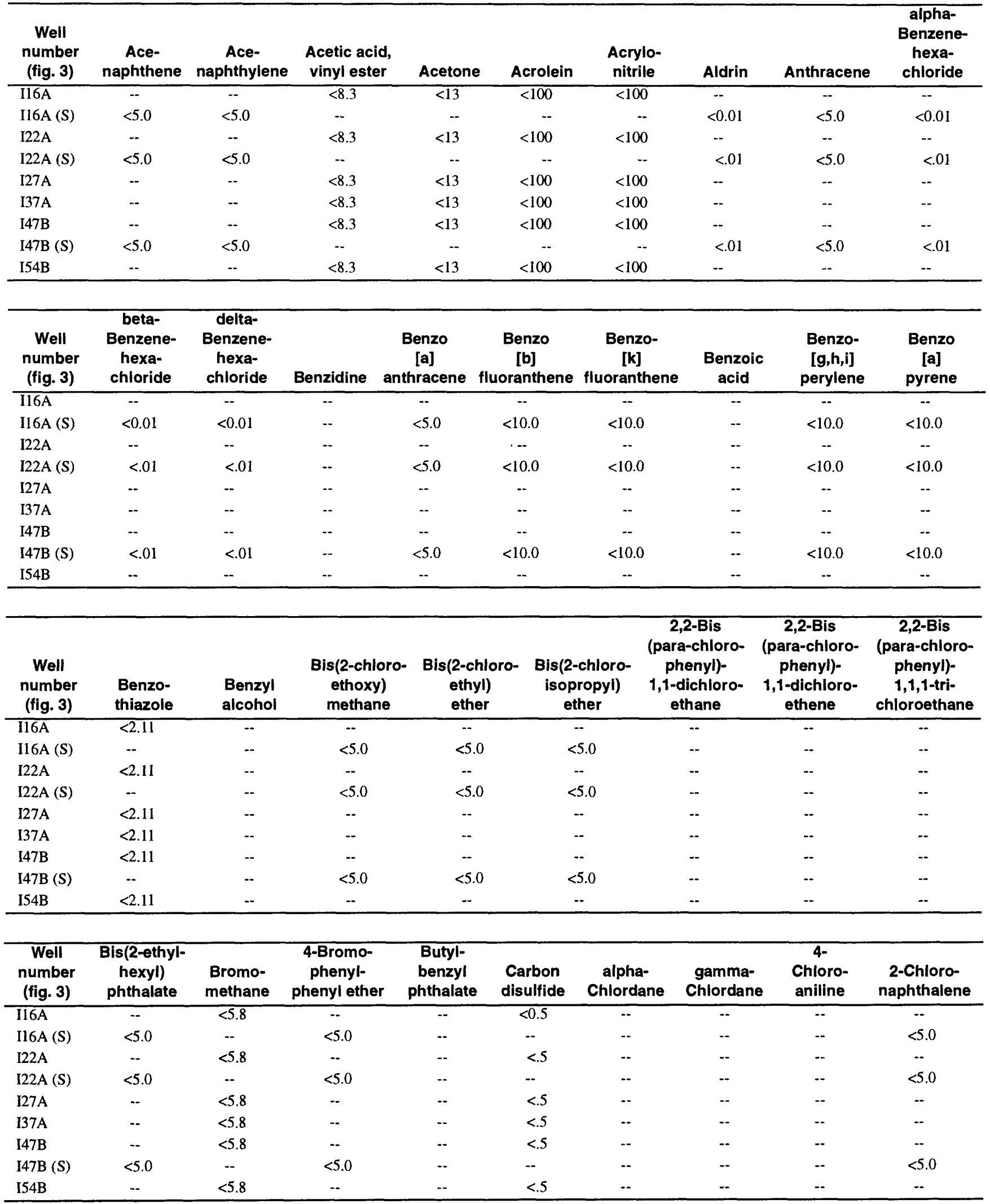


Table 14. Results of organic-chemical analyses of water from wells in the confined aquifer at Carroll Island, Aberdeen Proving Ground, Md., spring 1989--Continued

\begin{tabular}{|c|c|c|c|c|c|c|c|c|c|}
\hline $\begin{array}{c}\text { Well } \\
\text { number } \\
\text { (fig. 3) }\end{array}$ & $\begin{array}{l}\text { 2-Chloro- } \\
\text { phenol }\end{array}$ & $\begin{array}{l}\text { 4-Chloro- } \\
\text { phenyl- } \\
\text { methyl } \\
\text { sulfide }\end{array}$ & $\begin{array}{l}\text { 4-Chloro- } \\
\text { phenyl- } \\
\text { methyl } \\
\text { sulfone }\end{array}$ & $\begin{array}{l}\text { 4-Chloro- } \\
\text { phenyl- } \\
\text { methyl } \\
\text { sulfoxide }\end{array}$ & $\begin{array}{l}\text { 4-Chloro- } \\
\text { phenyl- } \\
\text { phenyl } \\
\text { ether }\end{array}$ & Chrysene & $\begin{array}{c}\text { Dibenz } \\
\text { [a,h] } \\
\text { anthracene }\end{array}$ & $\begin{array}{c}\text { Dibenzo } \\
\text { furan }\end{array}$ & $\begin{array}{l}\text { Di-n-butyl } \\
\text { phthalate }\end{array}$ \\
\hline $116 \mathrm{~A}$ & -- & $<1.26$ & $<4.72$ & $<4.23$ & - & -- & -- & - & -- \\
\hline I16A (S) & $<5.0$ & -- & -- & -- & $<5.0$ & $<10.0$ & -- & -- & $<5.0$ \\
\hline $122 \mathrm{~A}$ & -. & $<1.26$ & $<4.72$ & $<4.23$ & -- & -- & -- & -. & -- \\
\hline $\mathrm{I} 22 \mathrm{~A}(\mathrm{~S})$ & $<5.0$ & - & -- & -- & $<5.0$ & $<10.0$ & -- & -- & $<5.0$ \\
\hline $127 \mathrm{~A}$ & -- & $<1.26$ & $<4.72$ & $<4.23$ & -- & -- & -- & -- & -- \\
\hline I37A & -. & $<1.26$ & $<4.72$ & $<4.23$ & -- & -- & -. & -- & - \\
\hline I47B & -. & $<1.26$ & $<4.72$ & $<4.23$ & -. & -- & -- & -- & - \\
\hline I47B (S) & $<5.0$ & -- & -- & -- & $<5.0$ & $<10.0$ & -- & -- & $<5.0$ \\
\hline I54B & -. & $<1.26$ & $<4.72$ & $<4.23$ & -- & -- & -- & -- & - \\
\hline
\end{tabular}

\begin{tabular}{|c|c|c|c|c|c|c|c|c|}
\hline $\begin{array}{c}\text { Well } \\
\text { number } \\
\text { (fig. 3) }\end{array}$ & $\begin{array}{l}\text { Dichloro- } \\
\text { benzenes }\end{array}$ & $\begin{array}{l}\text { 3,3'-Dichloro- } \\
\text { benzidine }\end{array}$ & $\begin{array}{l}\text { 2,4-Dichloro- } \\
\text { phenol }\end{array}$ & Dieldrin & $\begin{array}{c}\text { Diethyl } \\
\text { phthalate }\end{array}$ & $\begin{array}{l}\text { Dimethyl } \\
\text { disulfide }\end{array}$ & $\begin{array}{l}\text { 2,4-Dimethyl- } \\
\text { phenol }\end{array}$ & $\begin{array}{l}\text { Dimethyl } \\
\text { phthalate }\end{array}$ \\
\hline I16A & $<10.0$ & - & -- & - & -- & $<1.14$ & $\cdots$ & 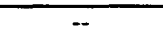 \\
\hline $116 \mathrm{~A}(\mathrm{~S})$ & -- & -. & $<5.0$ & $<0.01$ & $<5.0$ & -- & $<5.0$ & $<5.0$ \\
\hline I $22 \mathrm{~A}$ & $<10.0$ & .- & .- & -- & -- & $<1.14$ & -- & -- \\
\hline $\mathrm{I} 22 \mathrm{~A}(\mathrm{~S})$ & -- & -. & $<5.0$ & $<.01$ & $<5.0$ & -- & $<5.0$ & $<5.0$ \\
\hline $127 \mathrm{~A}$ & $<10.0$ & -- & -. & -- & -- & $<1.14$ & -- & -- \\
\hline $137 \mathrm{~A}$ & $<10.0$ & -- & -- & -- & -- & $<1.14$ & -- & -. \\
\hline I47B & $<10.0$ & -. & -- & -- & -- & $<1.14$ & .. & .- \\
\hline I47B B (S) & -. & .. & $<5.0$ & $<.01$ & $<5.0$ & -- & $<5.0$ & $<5.0$ \\
\hline I54B & $<10.0$ & -- & -. & .- & -- & $<1.14$ & -- & -- \\
\hline $\begin{array}{c}\text { Well } \\
\text { number } \\
\text { (fig. 3) }\end{array}$ & $\begin{array}{l}\text { 2,4-Dinitro- } \\
\text { phenol }\end{array}$ & $\begin{array}{l}\text { 2,4-Dinitro- } \\
\text { toluene }\end{array}$ & $\begin{array}{l}\text { 2,6-Dinitro- } \\
\text { toluene }\end{array}$ & $\begin{array}{l}\text { Di-n-octyl } \\
\text { phthalate }\end{array}$ & $\begin{array}{l}\text { 1,2-Diphenyl- } \\
\text { hydrazine }\end{array}$ & Dithiane & $\begin{array}{c}\text { alpha- } \\
\text { Endosulfan }\end{array}$ & $\begin{array}{c}\text { beta- } \\
\text { Endosulfan }\end{array}$ \\
\hline$\overline{116 A}$ & 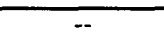 & -- & -. & 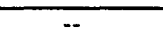 & -- & $<1.11$ & -- & -- \\
\hline I16A (S) & $<20.0$ & $<5.0$ & $<5.0$ & $<10.0$ & -- & -- & -- & -. \\
\hline $\mathrm{I} 22 \mathrm{~A}$ & .. & .- & .. & .. & .. & $<1.11$ & $\ldots$ & .- \\
\hline $\mathrm{I} 22 \mathrm{~A}(\mathrm{~S})$ & $<20.0$ & $<5.0$ & $<5.0$ & $<10.0$ & -- & -- & -- & -- \\
\hline $127 \mathrm{~A}$ & -. & -- & -- & -- & -- & $<1.11$ & -- & -- \\
\hline $137 \mathrm{~A}$ & .- & -- & .. & .- & .- & $<1.11$ & -- & .- \\
\hline I47B & -- & -- & -. & -. & -- & $<1.11$ & -- & -. \\
\hline I47B (S) & $<20.0$ & $<5.0$ & $<5.0$ & $<10.0$ & -- & -- & -- & -- \\
\hline I54B & -- & -- & -- & -- & -- & $<1.11$ & .- & -- \\
\hline
\end{tabular}

\begin{tabular}{|c|c|c|c|c|c|c|c|c|c|}
\hline $\begin{array}{c}\text { Well } \\
\text { number } \\
\text { (fig. 3) }\end{array}$ & $\begin{array}{l}\text { Endosulfan } \\
\text { sulfate }\end{array}$ & Endrin & $\begin{array}{l}\text { Endrin } \\
\text { aldehyde }\end{array}$ & $\begin{array}{l}\text { Endrin } \\
\text { ketone }\end{array}$ & $\begin{array}{l}\text { Fluoran- } \\
\text { thene }\end{array}$ & Heptachlor & $\begin{array}{l}\text { Heptachlor } \\
\text { epoxide }\end{array}$ & $\begin{array}{l}\text { Hexachloro- } \\
\text { benzene }\end{array}$ & $\begin{array}{l}\text { Hexachloro- } \\
\text { butadiene }\end{array}$ \\
\hline $116 \mathrm{~A}$ & -- & - & -- & - & -- & - & - & -- &.- \\
\hline $116 \mathrm{~A}(\mathrm{~S})$ & -- & $<0.01$ & -- & -- & $<5.0$ & $<0.01$ & $<0.01$ & $<5.0$ & $<5.0$ \\
\hline I22A & -. & -- & -- & -- & -- & -- & .- & -- & -- \\
\hline I22A (S) & -- & $<.01$ & -- & -- & $<5.0$ & $<.01$ & $<.01$ & $<5.0$ & $<5.0$ \\
\hline I27A & -- & -. & -- & -. & -. & -- & -- & -- & .- \\
\hline I37A & -- & -- & -- & -- & -- & -- & -- & -- & -. \\
\hline I47B & -- & -- & -- & -- & -- & -- & -- & -. & -- \\
\hline I47B (S) & -- & $<.01$ & -- & -- & $<5.0$ & $<.01$ & $<.01$ & $<5.0$ & $<5.0$ \\
\hline 154B & -. & - & -- & -- & -- & -- & -- & -- & -- \\
\hline
\end{tabular}


Table 14. Results of organic-chemical analyses of water from wells in the confined aquifer at Carroll Island, Aberdeen Proving Ground, Md., spring 1989--Continued

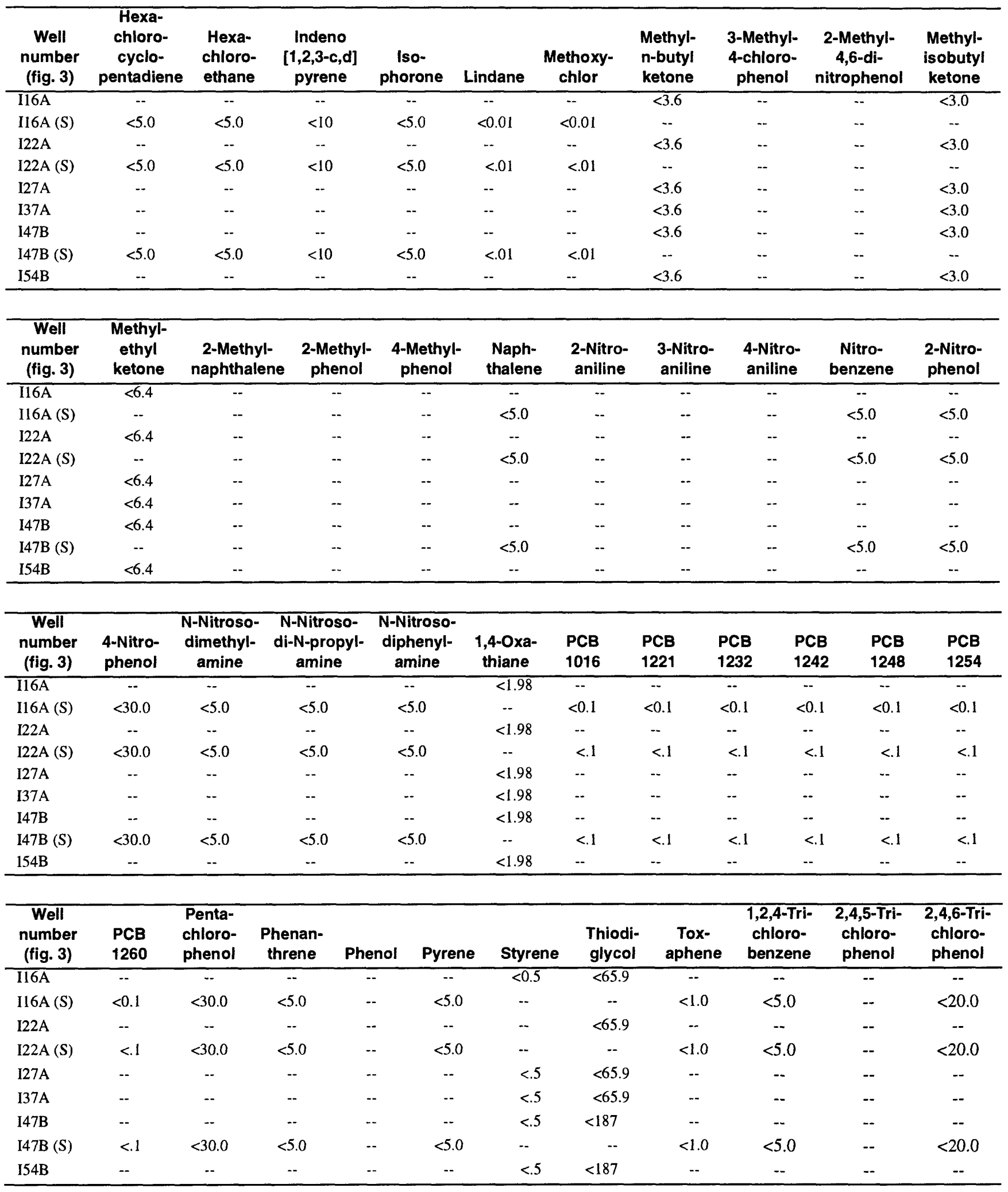


Table 15. Results of inorganic-chemical analyses of surface water from selected sampling sites at Carroll Island, Aberdeen Proving Ground, Md., spring 1989

[Concentrations are for whole water in milligrams per liter; other units are specified; $\mu \mathrm{S} / \mathrm{cm}$, microsiemens per centimeter; deg $\mathrm{C}$, degrees Celsius; <, less than; --, missing data; (R), replicate sample; (S), split sample]

\begin{tabular}{|c|c|c|c|c|c|c|c|c|c|}
\hline $\begin{array}{c}\text { Sampling } \\
\text { site } \\
\text { (fig. 4) }\end{array}$ & $\begin{array}{c}\text { Sampling } \\
\text { date }\end{array}$ & $\begin{array}{c}\text { Specific } \\
\text { conductance, } \\
\text { field } \\
(\mu \mathrm{S} / \mathrm{cm})\end{array}$ & $\begin{array}{c}\mathrm{pH}, \\
\text { field } \\
\text { (units) }\end{array}$ & $\begin{array}{c}\text { Temperature } \\
\text { water, field } \\
\text { (deg C) }\end{array}$ & $\begin{array}{l}\text { Oxygen, } \\
\text { dissolved, } \\
\text { field }\end{array}$ & $\begin{array}{l}\text { Oxygen } \\
\text { demand, } \\
\text { chemical } \\
\text { (low level }\end{array}$ & & $\begin{array}{l}\text { ygen } \\
\text { land, } \\
\text { emical } \\
\text { day) }\end{array}$ & $\begin{array}{l}\text { Calcium } \\
\text { (as Ca) }\end{array}$ \\
\hline \multicolumn{10}{|c|}{ Inland samples: } \\
\hline SW01 & $05-17-89$ & 418 & 6.74 & 20.5 & 5.5 & 35 & & .5 & 5.24 \\
\hline SW02 & $05-17-89$ & 2,010 & 6.75 & 26.5 & 4.1 & 130 & & 0 & 16.1 \\
\hline SW03 & $05-17-89$ & 264 & 7.45 & 17.5 & 6.7 & $<1.0$ & & & 41.0 \\
\hline SW05 & $05-18-89$ & 2,100 & 6.92 & 17.5 & 4.6 & 153 & & 0 & 19.2 \\
\hline SW08 & $05-18-89$ & 481 & 7.39 & 18.5 & 12.5 & 11 & & 6 & 82.0 \\
\hline SW09 & $05-18-89$ & 274 & 6.93 & -- & 5.5 & 119 & & 9 & 18.5 \\
\hline SW09 (R) & $05-18-89$ & 274 & 6.93 & -. & 5.5 & 108 & & 4 & 18.2 \\
\hline SW09 (S) & $05-18-89$ & 274 & 6.93 & -- & 5.5 & -- & & & 2.8 \\
\hline SW12 & $05-17-89$ & 673 & 6.23 & 16.5 & 2.8 & 141 & & 2 & 6.24 \\
\hline SW13 & $05-17-89$ & 141 & 5.53 & -- & -- & 61 & & & 7.19 \\
\hline SW 14 & $05-17-89$ & 87 & 6.07 & 16.0 & 6.0 & 35 & & 5 & 3.99 \\
\hline SW15 & $05-17-89$ & 361 & 6.66 & 16.5 & 4.5 & 66 & & 6 & 25.0 \\
\hline SW16 & $05-17-89$ & 261 & 6.56 & 16.5 & 6.2 & 108 & & 0 & 12.5 \\
\hline SW 17 & $05-17-89$ & 705 & 7.17 & 17.0 & 6.0 & 74 & & 1 & 62.0 \\
\hline SW 18 & $05-18-89$ & 167 & 7.28 & 23.0 & 8.5 & -- & & & 27.0 \\
\hline SW20 & $05-17-89$ & 546 & 7.15 & 20.5 & 1.6 & 153 & & 0 & 13.9 \\
\hline SW21 & $05-17-89$ & 554 & 6.88 & 20.5 & 2.7 & 130 & & 1 & 9.19 \\
\hline \multicolumn{10}{|c|}{ Estuarine samples: } \\
\hline SW04 & $05-18-89$ & 2,210 & 7.04 & 18.5 & 9.9 & 108 & & 4 & 17.8 \\
\hline SW06 & $05-18-89$ & 2,180 & 6.82 & 22.5 & 9.9 & 15 & & & 17.8 \\
\hline SW07 & $05-18-89$ & 1,910 & 6.95 & 21.5 & 10.0 & 8 & & & 17.1 \\
\hline SW10 & $05-18-89$ & 1,430 & 7.35 & 24.5 & 11.6 & $<119$ & & 2 & 17.4 \\
\hline SW11 & $05-17-89$ & 1,800 & 7.33 & 19.0 & 10.9 & 153 & & 8 & 25.0 \\
\hline SW11 (R) & $05-17-89$ & 1,800 & 7.33 & -- & 10.9 & 53 & & 7 & 23.0 \\
\hline SW 19 & $05-18-89$ & 2,000 & 6.81 & 20.5 & 10.0 & $<1.0$ & & & 15.8 \\
\hline $\begin{array}{c}\text { Sampling } \\
\text { site } \\
\text { (fig. 4) }\end{array}$ & $\begin{array}{c}\text { Magnesium } \\
\text { (as Mg) }\end{array}$ & $\begin{array}{c}\text { Sodium } \\
\text { (as Na) }\end{array}$ & $\begin{array}{c}\text { Potassium } \\
\text { (as K) }\end{array}$ & $\begin{array}{l}\text { Alkalinity, } \\
\text { field } \\
\text { (as } \mathrm{CaCO}_{3} \text { ) }\end{array}$ & $\begin{array}{c}\text { Bicarbonate, } \\
\text { field } \\
\text { (as } \mathrm{HCO}_{3} \text { ) }\end{array}$ & $\begin{array}{c}\text { Chloride } \\
\text { (as Cl) }\end{array}$ & $\begin{array}{c}\text { Fluoride } \\
\text { (as F) }\end{array}$ & $\begin{array}{c}\text { Bromide } \\
\text { (as Br) }\end{array}$ & $\begin{array}{c}\text { Silica } \\
\left(\text { as } \mathrm{SiO}_{2}\right) \\
\end{array}$ \\
\hline \multicolumn{10}{|c|}{ Inland samples: } \\
\hline SW01 & 7.85 & 59.0 & 3.64 & 20 & 24 & 140 & $<1.23$ & $<1.00$ & -- \\
\hline SW02 & 35.0 & 340 & 11.0 & 35 & 43 & 640 & $<1.23$ & 1.78 & -- \\
\hline SW03 & 7.76 & 1.86 & 3.97 & 130 & 160 & $<2.12$ & $<1.23$ & $<1.00$ & -- \\
\hline SW05 & 40.0 & 370 & 14.0 & 34 & 42 & 710 & $<1.23$ & 1.93 & -- \\
\hline SW08 & 14.4 & 7.87 & 6.61 & 213 & 260 & 4.95 & $<1.23$ & $<1.00$ & -- \\
\hline SW09 & 8.31 & 27.4 & 5.06 & 65 & 76 & 41.0 & $<1.23$ & $<1.00$ & -. \\
\hline SW09 (R) & 8.02 & 26.4 & 4.57 & 65 & 76 & 38.0 & $<1.23$ & $<1.00$ & -- \\
\hline SW09 (S) & .50 & 2.7 & 1.2 & 65 & 76 & 3.60 & .10 & .030 & 9.7 \\
\hline SW12 & 10.0 & 120 & 8.22 & 31 & 38 & 190 & $<1.23$ & $<1.00$ & - \\
\hline SW13 & 3.17 & 15.1 & 1.80 & 8 & 10 & 25.5 & $<1.23$ & $<1.00$ & -- \\
\hline SW14 & 2.62 & 7.23 & 3.92 & 13 & 16 & 15.7 & $<1.23$ & $<1.00$ & -- \\
\hline SW15 & 11.1 & 36.9 & 4.00 & 84 & 100 & 71.0 & $<1.23$ & $<1.00$ & -- \\
\hline SW16 & 6.86 & 28.7 & 3.45 & 34 & 42 & 55.0 & $<1.23$ & $<1.00$ & -- \\
\hline SW17 & 19.5 & 54.0 & 6.03 & 219 & 270 & 88.0 & $<1.23$ & $<1.00$ & -- \\
\hline SW 18 & 2.52 & 2.75 & 2.08 & 64 & 78 & 3.30 & $<1.23$ & $<1.00$ & -- \\
\hline SW20 & 15.3 & 73.0 & 4.60 & 103 & 130 & 140 & $<1.23$ & $<1.00$ & -- \\
\hline SW21 & 12.0 & 86.0 & 4.73 & 13 & 16 & 190 & $<1.23$ & $<1.00$ & -- \\
\hline \multicolumn{10}{|c|}{ Estuarine samples: } \\
\hline SW04 & 47.0 & 370 & 16.0 & 14 & 17 & 740 & $<1.23$ & 2.09 & -- \\
\hline SW06 & 46.0 & 360 & 15.0 & 13 & 16 & 710 & $<1.23$ & 2.01 & -- \\
\hline SW07 & 39.0 & 300 & 14.2 & 14 & 17 & 600 & $<1.23$ & 1.47 & .. \\
\hline SW10 & 29.0 & 220 & 10.5 & 18 & 22 & 440 & $<1.23$ & $<1.00$ & -- \\
\hline SW11 & 37.0 & 290 & 13.4 & 29 & 35 & 580 & $<1.23$ & $<1.00$ & -- \\
\hline SW11 (R) & 33.0 & 260 & 37.0 & 29 & 35 & 560 & $<1.23$ & $<1.00$ & -- \\
\hline SW19 & 38.0 & 310 & 11.0 & 15 & 18 & 770 & $<1.23$ & 1.60 & -- \\
\hline
\end{tabular}


Table 15. Results of inorganic-chemical analyses of surface water from selected sampling sites at Carroll Island, Aberdeen Proving Ground, Md., spring 1989--Continued

\begin{tabular}{|c|c|c|c|c|c|c|c|c|c|}
\hline $\begin{array}{l}\text { Sampling } \\
\text { site } \\
\text { (fig. 4) }\end{array}$ & $\begin{array}{c}\text { Nitrogen, } \\
\mathrm{NO}_{2}+\mathrm{NO}_{3} \\
\text { (as N) }\end{array}$ & $\begin{array}{c}\text { Phosphorus, } \\
\text { ortho } \\
\text { (as P) }\end{array}$ & $\begin{array}{l}\text { Sulfate } \\
\left.\text { (as } \mathrm{SO}_{4}\right)\end{array}$ & $\begin{array}{c}\text { Aluminum } \\
\text { (as Al) }\end{array}$ & $\begin{array}{l}\text { Antimony } \\
\text { (as Sb) }\end{array}$ & $\begin{array}{l}\text { Barium } \\
\text { (as } \mathrm{Ba} \text { ) }\end{array}$ & $\begin{array}{l}\text { Beryllium } \\
\text { (as Be) }\end{array}$ & $\begin{array}{c}\text { Cadmium } \\
\text { (as Cd) }\end{array}$ & $\begin{array}{l}\text { Chromium } \\
\text { (as } \mathrm{Cr} \text { ) }\end{array}$ \\
\hline \multicolumn{10}{|c|}{ Inland samples: } \\
\hline SW01 & $<0.010$ & -- & $<10.0$ & $<0.141$ & $<0.038$ & 0.0335 & $<0.00500$ & 0.0112 & 0.0200 \\
\hline SW02 & .040 & -- & 76.9 & .402 & .147 & .0125 & .00594 & $<.00401$ & $<.00602$ \\
\hline SW03 & .154 & -- & $<10.0$ & $<.141$ & $<.038$ & .0213 & $<.00500$ & $<.00401$ & $<.00602$ \\
\hline SW05 & .430 & -- & 113 & .531 & $<.038$ & .0150 & $<.00500$ & $<.00401$ & $<.00602$ \\
\hline SW08 & .027 & -- & 32.6 & $<.141$ & $<.038$ & .0406 & $<.00500$ & $<.00401$ & $<.00602$ \\
\hline SW09 & .025 & -- & $<10.0$ & .344 & $<.038$ & .0221 & $<.00500$ & $<.00401$ & $<.00602$ \\
\hline SW09 (R) & .016 & -- & $<10.0$ & .364 & $<.038$ & .0225 & $<.00500$ & $<.00401$ & $<.00602$ \\
\hline SW09 (S) & -- & -- & 3.0 & $<.010$ & $<.001$ & .007 & $<.0005$ & $<.001$ & $<.005$ \\
\hline SW12 & $<.010$ & -- & 10.7 & .594 & $<.038$ & .00935 & $<.00500$ & $<.00401$ & $<.00602$ \\
\hline SW13 & $<.010$ & -- & 18.0 & .637 & $<.038$ & .0314 & $<.00500$ & $<.00401$ & $<.00602$ \\
\hline SW14 & .033 & -- & $<10.0$ & $<.141$ & .0896 & .0111 & $<.00500$ & .00617 & $<.00602$ \\
\hline SW15 & $<.010$ & -- & $<10.0$ & .354 & $<.038$ & .0223 & $<.00500$ & $<.00401$ & $<.00602$ \\
\hline SW16 & .027 & -. & 11.7 & .396 & $<.038$ & .0168 & $<.00500$ & $<.00401$ & $<.00602$ \\
\hline SW17 & .018 & -. & 30.4 & $<.141$ & $<.038$ & .0342 & $<.00500$ & $<.00401$ & $<.00602$ \\
\hline SW18 & $<.010$ & .- & 10.1 & $<.141$ & $<.038$ & .0259 & $<.00500$ & $<.00401$ & $<.00602$ \\
\hline SW20 & $<.030$ & -. & $<10.0$ & .563 & $<.038$ & .0362 & $<.00500$ & $<.00401$ & $<.00602$ \\
\hline SW21 & $<.010$ & -- & $<10.0$ & 2.32 & $<.038$ & .0351 & $<.00500$ & $<.00401$ & $<.00602$ \\
\hline \multicolumn{10}{|c|}{ Estuarine samples: } \\
\hline SW04 & .740 & -- & 108 & .384 & $<.038$ & .0179 & $<.00500$ & $<.00401$ & $<.00602$ \\
\hline SW06 & .880 & -- & 103 & .591 & $<.038$ & .0164 & $<.00500$ & $<.00401$ & $<.00602$ \\
\hline SW07 & .810 & -- & 92.1 & .866 & $<.038$ & .0182 & $<.00500$ & $<.00401$ & $<.00602$ \\
\hline SW10 & .880 & -- & 73.9 & .676 & $<.038$ & .0142 & $<.00500$ & $<.00401$ & $<.00602$ \\
\hline SW11 & .730 & -- & 82.8 & 2.11 & $<.038$ & .0201 & $<.00500$ & $<.00401$ & $<.00602$ \\
\hline SW11 (R) & .800 & -- & 107 & 1.36 & $<.038$ & .0163 & $<.00500$ & $<.00401$ & $<.00602$ \\
\hline SW 19 & .780 & -- & 107 & .441 & $<.038$ & .0147 & $<.00500$ & $<.00401$ & $<.00602$ \\
\hline
\end{tabular}

\begin{tabular}{|c|c|c|c|c|c|c|c|c|c|}
\hline $\begin{array}{c}\text { Sampling } \\
\text { site } \\
\text { (fig. 4) }\end{array}$ & $\begin{array}{l}\text { Copper } \\
\text { (as Cu) }\end{array}$ & $\begin{array}{c}\text { Iron } \\
\text { (as Fe) }\end{array}$ & $\begin{array}{c}\text { Lead } \\
\text { (as Pb) }\end{array}$ & $\begin{array}{c}\text { Manganese } \\
\text { (as Mn) }\end{array}$ & $\begin{array}{l}\text { Nickel } \\
\text { (as Ni) }\end{array}$ & $\begin{array}{l}\text { Selenium } \\
\text { (as Se) }\end{array}$ & $\begin{array}{c}\text { Silver } \\
\text { (as Ag) }\end{array}$ & $\begin{array}{l}\text { Thallium } \\
\text { (as TI) }\end{array}$ & $\begin{array}{c}\text { Zinc } \\
\text { (as Zn) }\end{array}$ \\
\hline \multicolumn{10}{|c|}{ Inland samples: } \\
\hline SW01 & 0.0377 & 0.513 & -- & 0.0565 & 0.0663 & -- & $<0.00460$ & $<0.0814$ & 0.0645 \\
\hline SW02 & .00846 & 1.42 & -. & .128 & $<.0343$ & -- & $<.00460$ & $<.0814$ & $<.0211$ \\
\hline SW03 & .0104 & .334 & -- & .0462 & $<.0343$ & -- & $<.00460$ & $<.0814$ & .0854 \\
\hline SW05 & $<.00809$ & .960 & -- & .274 & $<.0343$ & -- & $<.00460$ & $<.0814$ & .0293 \\
\hline SW08 & .00982 & .338 & -- & .118 & $<.0343$ & -- & $<.00460$ & $<.0814$ & .0282 \\
\hline SW09 & .0200 & 4.37 & -- & .0961 & $<.0343$ & -- & $<.00460$ & $<.0814$ & $<.0211$ \\
\hline SW09 (R) & .0152 & 4.67 & -- & .0952 & $<.0343$ & -- & $<.00460$ & $<.0814$ & $<.0211$ \\
\hline SW09 (S) & $<.010$ & 3.60 & $<0.010$ & .085 & $<.010$ & $<1$ & $<.00100$ & -- & .460 \\
\hline SW12 & .0159 & 5.45 & -- & .446 & $<.0343$ & - & .00564 & $<.0814$ & $<.0211$ \\
\hline SW13 & .0180 & 3.21 & -- & .335 & $<.0343$ & -- & $<.00460$ & $<.0814$ & .0787 \\
\hline SW14 & .0341 & 3.03 & -- & .185 & $<.0343$ & - & $<.00460$ & $<.0814$ & .800 \\
\hline SW15 & .0270 & 4.14 & -- & .0942 & $<.0343$ & -- & $<.00460$ & $<.0814$ & $<.0211$ \\
\hline SW16 & .0149 & 3.91 & -- & .0817 & $<.0343$ & -- & $<.00460$ & $<.0814$ & $<.0211$ \\
\hline SW17 & $<.00809$ & 6.55 & -- & .260 & $<.0343$ & -- & $<.00460$ & .113 & $<.0211$ \\
\hline SW18 & .0357 & .448 & -- & .0122 & $<.0343$ & - & $<.00460$ & $<.0814$ & .0352 \\
\hline SW20 & .0226 & 16.40 & - & 1.21 & $<.0343$ & - & .00546 & $<.0814$ & .0412 \\
\hline SW21 & .0193 & 7.52 & - & .346 & $<.0343$ & -- & $<.00460$ & $<.0814$ & .0354 \\
\hline \multicolumn{10}{|c|}{ Estuarine samples: } \\
\hline SW04 & $<.00809$ & .551 & -- & .126 & $<.0343$ & -- & $<.00460$ & $<.0814$ & $<.0211$ \\
\hline SW06 & $<.00809$ & .850 & -- & .155 & $<.0343$ & -- & $<.00460$ & $<.0814$ & $<.0211$ \\
\hline SW07 & $<.00809$ & 1.29 & -- & .110 & $<.0343$ & -- & $<.00460$ & $<.0814$ & $<.0211$ \\
\hline SW10 & $<.00809$ & .972 & -- & .127 & $<.0343$ & - & $<.00460$ & $<.0814$ & $<.0211$ \\
\hline SW11 & .0442 & 2.89 & -- & .237 & $<.0343$ & -- & $<.00460$ & $<.0814$ & $<.0211$ \\
\hline SW11 (R) & $<.00809$ & 2.00 & -- & .160 & $<.0343$ & -- & $<.00460$ & $<.0814$ & $<.0211$ \\
\hline SW19 & $<.00809$ & .854 & -- & .139 & $<.0343$ & -- & $<.00460$ & $<.0814$ & $<.0211$ \\
\hline
\end{tabular}


Table 16. Results of organic-chemical analyses of surface water from selected sampling sites at Carroll Island, Aberdeen Proving Ground, Md., spring 1989

[Concentrations are in micrograms per liter unless specified; mg/L, milligrams per liter; <, less than; --, missing data; >, greater than; (R), replicate sample; (S), split sample; PCB, polychlorinated biphenyl]

\begin{tabular}{|c|c|c|c|c|c|c|c|c|c|}
\hline $\begin{array}{c}\text { Sampling } \\
\text { site } \\
\text { (fig. 4) }\end{array}$ & $\begin{array}{c}\text { Sampling } \\
\text { date }\end{array}$ & $\begin{array}{c}\text { Carbon, } \\
\text { organic, total } \\
(\mathrm{mg} / \mathrm{L} \text { as } \mathrm{C})\end{array}$ & $\begin{array}{c}\text { Phenols, } \\
\text { non-specific, } \\
\text { total }\end{array}$ & $\begin{array}{c}\text { Halide, } \\
\text { total } \\
\text { organic }\end{array}$ & Benzene & $\begin{array}{l}\text { Bromo- } \\
\text { dichloro- } \\
\text { methane }\end{array}$ & $\begin{array}{c}\text { Bromo- } \\
\text { form }\end{array}$ & $\begin{array}{l}\text { Carbon } \\
\text { tetra- } \\
\text { chloride }\end{array}$ & $\begin{array}{l}\text { Chloro- } \\
\text { benzene }\end{array}$ \\
\hline \multicolumn{10}{|c|}{ Inland samples: } \\
\hline SW01 & $05-17-89$ & 10.5 & -- & 35.0 & $<0.50$ & $<0.59$ & $<2.6$ & $<0.58$ & $<0.50$ \\
\hline SW02 & $05-17-89$ & 19.2 & 24.9 & -- & $<.50$ & $<.59$ & $<2.6$ & $<.58$ & $<.50$ \\
\hline SW03 & $05-17-89$ & 2.44 & 15.7 & 108 & $<.50$ & $<.59$ & $<2.6$ & $<.58$ & $<.50$ \\
\hline SW05 & $05-18-89$ & 13.8 & $<7.12$ & -- & $<.50$ & $<.59$ & $<2.6$ & $<.58$ & $<.50$ \\
\hline SW08 & $05-18-89$ & 29.7 & $<7.12$ & -- & $<.50$ & $<.59$ & $<2.6$ & $<.58$ & $<.50$ \\
\hline SW09 & $05-18-89$ & 26.5 & 21.2 & 68.7 & $<.50$ & $<.59$ & $<2.6$ & $<.58$ & $<.50$ \\
\hline SW09 (R) & $05-18-89$ & 30.0 & 18.1 & -- & $<.50$ & $<.59$ & $<2.6$ & $<.58$ & $<.50$ \\
\hline SW09 (S) & $05-18-89$ & -- & -- & -- & - & -- & -- & -- & -- \\
\hline SW12 & $05-17-89$ & 30.0 & 44.5 & 57.6 & $<.50$ & $<.59$ & $<2.6$ & $<.58$ & $<.50$ \\
\hline SW13 & $05-17-89$ & 24.0 & 27.0 & 50.1 & $<.50$ & $<.59$ & $<2.6$ & $<.58$ & $<.50$ \\
\hline SW14 & $05-17-89$ & 11.4 & 41.0 & 90.5 & $<.50$ & $<.59$ & $<2.6$ & $<.58$ & $<.50$ \\
\hline SW 15 & $05-17-89$ & 18.4 & -- & 87.3 & $<.50$ & $<.59$ & $<2.6$ & $<.58$ & $<.50$ \\
\hline SW16 & $05-17-89$ & 26.4 & 45.8 & 89.9 & .56 & $<.59$ & $<2.6$ & $<.58$ & $<.50$ \\
\hline SW17 & $05-17-89$ & 20.0 & 17.9 & 35.4 & $<.50$ & $<.59$ & $<2.6$ & $<.58$ & $<.50$ \\
\hline SW18 & $05-18-89$ & 5.60 & $<7.12$ & 6.90 & $<.50$ & $<.59$ & $<2.6$ & $<.58$ & $<.50$ \\
\hline SW20 & $05-17-89$ & 39.5 & 18.3 & 57.6 & $<.50$ & $<.59$ & $<2.6$ & $<.58$ & $<.50$ \\
\hline SW21 & $05-17-89$ & 31.2 & 25.6 & 56.7 & $<.50$ & $<.59$ & $<2.6$ & $<.58$ & $<.50$ \\
\hline \multicolumn{10}{|c|}{ Estuarine samples: } \\
\hline SW04 & $05-18-89$ & 4.14 & $<7.12$ & -- & $<.50$ & $<.59$ & $<2.6$ & $<.58$ & $<.50$ \\
\hline SW06 & $05-18-89$ & 4.11 & $>50$ & -- & $<.50$ & $<.59$ & $<2.6$ & $<.58$ & $<.50$ \\
\hline SW07 & $05-18-89$ & 3.86 & 8.84 & -- & $<.50$ & $<.59$ & $<2.6$ & $<.58$ & $<.50$ \\
\hline SW10 & $05-18-89$ & 3.41 & $<7.12$ & 53.2 & $<.50$ & $<.59$ & $<2.6$ & $<.58$ & $<.50$ \\
\hline SW11 & $05-17-89$ & 3.21 & $<7.12$ & 182 & $<.50$ & $<.59$ & $<2.6$ & $<.58$ & $<.50$ \\
\hline SW11 (R) & $05-17-89$ & 3.79 & 16.4 & 13.3 & $<.50$ & $<.59$ & $<2.6$ & $<.58$ & $<.50$ \\
\hline SW19 & 05-18-89 & 5.80 & $<7.12$ & 48.3 & $<.50$ & $<.59$ & $<2.6$ & $<.58$ & $<.50$ \\
\hline $\begin{array}{c}\text { Sampling } \\
\text { site } \\
\text { (fig. 4) }\end{array}$ & $\begin{array}{l}\text { Chloro- } \\
\text { dibromo- } \\
\text { methane }\end{array}$ & $\begin{array}{l}\text { Chloro- } \\
\text { ethane } \\
\end{array}$ & $\begin{array}{l}\text { 2-Chloro- } \\
\text { ethyl- } \\
\text { vinyl } \\
\text { ether }\end{array}$ & $\begin{array}{l}\text { Chloro- } \\
\text { form }\end{array}$ & $\begin{array}{l}\text { Chloro- } \\
\text { methane }\end{array}$ & $\begin{array}{c}\text { 1,2-Di- } \\
\text { chloro- } \\
\text { benzene }\end{array}$ & $\begin{array}{c}\text { 1,3-Di- } \\
\text { chloro- } \\
\text { benzene }\end{array}$ & $\begin{array}{c}\text { 1,4-Di- } \\
\text { chloro- } \\
\text { benzene }\end{array}$ & $\begin{array}{l}\text { 1,1-Di- } \\
\text { chloro- } \\
\text { ethane }\end{array}$ \\
\hline \multicolumn{10}{|c|}{ Inland samples: } \\
\hline SW01 & $<0.67$ & $<1.9$ & $<0.71$ & $<0.50$ & $<3.2$ & $<1.7$ & $<1.7$ & $<1.7$ & $<0.68$ \\
\hline SW02 & $<.67$ & $<1.9$ & $<.71$ & $<.50$ & $<3.2$ & $<1.7$ & $<1.7$ & $<1.7$ & $<.68$ \\
\hline SW03 & $<.67$ & $<1.9$ & $<.71$ & $<.50$ & $<3.2$ & $<1.7$ & $<1.7$ & $<1.7$ & $<.68$ \\
\hline SW05 & $<.67$ & $<1.9$ & $<.71$ & $<.50$ & $<3.2$ & $<1.7$ & $<1.7$ & $<1.7$ & $<.68$ \\
\hline SW08 & $<.67$ & $<1.9$ & $<.71$ & $<.50$ & $<3.2$ & $<5.0$ & $<5.0$ & $<5.0$ & $<.68$ \\
\hline SW09 & $<.67$ & $<1.9$ & $<.71$ & $<.50$ & $<3.2$ & $<1.7$ & $<1.7$ & $<1.7$ & $<.68$ \\
\hline SW09 (R) & $<.67$ & $<1.9$ & $<.71$ & $<.50$ & $<3.2$ & $<1.7$ & $<1.7$ & $<1.7$ & $<.68$ \\
\hline SW09 (S) & -- & -- & -- & -- & -- & $<5.0$ & $<5.0$ & $<5.0$ & -- \\
\hline SW12 & $<.67$ & $<1.9$ & $<.71$ & $<.50$ & $<3.2$ & $<1.7$ & $<1.7$ & $<1.7$ & $<.68$ \\
\hline SW13 & $<.67$ & $<1.9$ & $<.71$ & $<.50$ & $<3.2$ & $<1.7$ & $<1.7$ & $<1.7$ & $<.68$ \\
\hline SW14 & $<.67$ & $<1.9$ & $<.71$ & $<.50$ & $<3.2$ & $<1.7$ & $<1.7$ & $<1.7$ & $<.68$ \\
\hline SW15 & $<.67$ & $<1.9$ & $<.71$ & $<.50$ & $<3.2$ & $<1.7$ & $<1.7$ & $<1.7$ & $<.68$ \\
\hline SW16 & $<.67$ & $<1.9$ & $<.71$ & $<.50$ & $<3.2$ & $<1.7$ & $<1.7$ & $<1.7$ & $<.68$ \\
\hline SW17 & $<.67$ & $<1.9$ & $<.71$ & $<.50$ & $<3.6$ & $<1.7$ & $<1.7$ & $<1.7$ & $<.68$ \\
\hline SW18 & $<.67$ & $<1.9$ & $<.71$ & $<.50$ & $<3.6$ & $<1.7$ & $<1.7$ & $<1.7$ & $<.68$ \\
\hline SW20 & $<.67$ & $<1.9$ & $<.71$ & $<.50$ & $<3.6$ & $<1.7$ & $<1.7$ & $<1.7$ & $<.68$ \\
\hline SW21 & $<.67$ & $<1.9$ & $<.71$ & $<.50$ & $<3.6$ & $<1.7$ & $<1.7$ & $<1.7$ & $<.68$ \\
\hline \multicolumn{10}{|c|}{ Estuarine samples: } \\
\hline SW04 & $<.67$ & $<1.9$ & $<.71$ & $<.50$ & $<3.2$ & $<1.7$ & $<1.7$ & $<1.7$ & $<.68$ \\
\hline SW06 & $<.67$ & $<1.9$ & $<.71$ & $<.50$ & $<3.2$ & $<1.7$ & $<1.7$ & $<1.7$ & $<.68$ \\
\hline SW07 & $<.67$ & $<1.9$ & $<.71$ & $<.50$ & $<3.2$ & $<1.7$ & $<1.7$ & $<1.7$ & $¥ .68$ \\
\hline SW10 & $<.67$ & $<1.9$ & $<.71$ & $<.50$ & $<3.2$ & $<1.7$ & $<1.7$ & $<1.7$ & $<.68$ \\
\hline SW11 & $<.67$ & $<1.9$ & $<.71$ & $<.50$ & $<3.2$ & $<1.7$ & $<1.7$ & $<1.7$ & $<.68$ \\
\hline SW11 (R) & $<.67$ & $<1.9$ & $<.71$ & $<.50$ & $<3.2$ & $<1.7$ & $<1.7$ & $<1.7$ & $<.68$ \\
\hline SW19 & $<.67$ & $<1.9$ & $<.71$ & $<.50$ & $<3.6$ & $<1.7$ & $<1.7$ & $<1.7$ & $<.68$ \\
\hline
\end{tabular}


Table 16. Results of organic-chemical analyses of surface water from selected sampling sites at Carroll Island, Aberdeen Proving Ground, Md., spring 1989--Continued

\begin{tabular}{|c|c|c|c|c|c|c|c|c|c|}
\hline $\begin{array}{c}\text { Sampling } \\
\text { site } \\
\text { (fig. 4) }\end{array}$ & $\begin{array}{l}\text { 1,2-Di- } \\
\text { chloro- } \\
\text { ethane }\end{array}$ & $\begin{array}{c}\text { 1,1-Di- } \\
\text { chloro- } \\
\text { ethylene }\end{array}$ & $\begin{array}{c}\text { 1,2-Di- } \\
\text { chloro- } \\
\text { ethylene } \\
\text { (cis + trans) }\end{array}$ & $\begin{array}{l}\text { 1,2-Di- } \\
\text { chloro- } \\
\text { propane }\end{array}$ & $\begin{array}{l}\text { cis-1,3- } \\
\text { Dichloro- } \\
\text { propene }\end{array}$ & $\begin{array}{l}\text { trans-1,3- } \\
\text { Dichloro- } \\
\text { propene }\end{array}$ & $\begin{array}{c}\text { Ethyl- } \\
\text { benzene }\end{array}$ & Fluorene & $\begin{array}{l}\text { Methylene } \\
\text { chloride }\end{array}$ \\
\hline \multicolumn{10}{|c|}{ Inland samples: } \\
\hline SW01 & $<0.50$ & $<0.50$ & $<0.50$ & $<0.50$ & $<0.58$ & $<0.70$ & $<0.50$ & $<3.7$ & $<2.3$ \\
\hline SW02 & $<.50$ & $<.50$ & $<.50$ & $<.50$ & $<.58$ & $<.70$ & $<.50$ & $<3.7$ & $<2.3$ \\
\hline SW03 & $<.50$ & $<.50$ & $<.50$ & $<.50$ & $<.58$ & $<.70$ & $<.50$ & $<3.7$ & $<2.3$ \\
\hline SW05 & $<.50$ & $<.50$ & $<.50$ & $<.50$ & $<.58$ & $<.70$ & $<.50$ & $<3.7$ & $<2.3$ \\
\hline SW08 & $<.50$ & $<.50$ & $<.50$ & $<.50$ & $<.58$ & $<.70$ & $<.50$ & -- & $<2.3$ \\
\hline SW09 & $<.50$ & $<.50$ & $<.50$ & $<.50$ & $<.58$ & $<.70$ & $<.50$ & $<3.7$ & $<2.3$ \\
\hline SW09 (R) & $<.50$ & $<.50$ & $<.50$ & $<.50$ & $<.58$ & $<.70$ & $<.50$ & $<3.7$ & $<2.3$ \\
\hline SW09 (S) & -- & -- & -. & -- & -- & -- & -- & -- & -- \\
\hline SW12 & $<.50$ & $<.50$ & $<.50$ & $<.50$ & $<.58$ & $<.70$ & $<.50$ & $<3.7$ & $<2.3$ \\
\hline SW13 & $<.50$ & $<.50$ & $<.50$ & $<.50$ & $<.58$ & $<.70$ & $<.50$ & $<3.7$ & $<2.3$ \\
\hline SW14 & $<.50$ & $<.50$ & $<.50$ & $<.50$ & $<.58$ & $<.70$ & $<.50$ & $<3.7$ & $<2.3$ \\
\hline SW15 & $<.50$ & $<.50$ & $<.50$ & $<.50$ & $<.58$ & $<.70$ & $<.50$ & $<3.7$ & $<2.3$ \\
\hline SW16 & $<.50$ & $<.50$ & $<.50$ & $<.50$ & $<.58$ & $<.70$ & $<.50$ & $<3.7$ & $<2.3$ \\
\hline SW17 & $<.50$ & $<.50$ & $<.50$ & $<.50$ & $<.58$ & $<.70$ & $<.50$ & $<3.7$ & $<2.3$ \\
\hline SW18 & $<.50$ & $<.50$ & $<.50$ & $<.50$ & $<.58$ & $<.70$ & $<.50$ & $<3.7$ & $<2.3$ \\
\hline SW20 & $<.50$ & $<.50$ & $<.50$ & $<.50$ & $<.58$ & $<.70$ & $<.50$ & $<3.7$ & $<2.3$ \\
\hline SW21 & $<.50$ & $<.50$ & $<.50$ & $<.50$ & $<.58$ & $<.70$ & $<.50$ & $<3.7$ & $<2.3$ \\
\hline \multicolumn{10}{|c|}{ Estuarine samples: } \\
\hline SW04 & $<.50$ & $<.50$ & $<.50$ & $<.50$ & $<.58$ & $<.70$ & $<.50$ & $<3.7$ & $<2.3$ \\
\hline SW06 & $<.50$ & $<.50$ & $<.50$ & $<.50$ & $<.58$ & $<.70$ & $<.50$ & $<3.7$ & $<2.3$ \\
\hline SW07 & $<.50$ & $<.50$ & $<.50$ & $<.50$ & $<.58$ & $<.70$ & $<.50$ & $<3.7$ & $<2.3$ \\
\hline SW10 & $<.50$ & $<.50$ & $<.50$ & $<.50$ & $<.58$ & $<.70$ & $<.50$ & $<3.7$ & $<2.3$ \\
\hline SW11 & $<.50$ & $<.50$ & $<.50$ & $<.50$ & $<.58$ & $<.70$ & $<.50$ & $<3.7$ & $<2.3$ \\
\hline SW11 (R) & $<.50$ & $<.50$ & $<.50$ & $<.50$ & $<.58$ & $<.70$ & $<.50$ & $<3.7$ & $<2.3$ \\
\hline SW 19 & $<.50$ & $<.50$ & $<.50$ & $<.50$ & $<.58$ & $<.70$ & $<.50$ & $<3.7$ & $<2.3$ \\
\hline
\end{tabular}

\begin{tabular}{|c|c|c|c|c|c|c|c|c|c|}
\hline $\begin{array}{l}\text { Sampling } \\
\text { site } \\
\text { (fig. 4) }\end{array}$ & $\begin{array}{l}1,1,2,2- \\
\text { Tetra- } \\
\text { chloro- } \\
\text { ethane }\end{array}$ & $\begin{array}{c}\text { Tetra- } \\
\text { chloro- } \\
\text { ethylene }\end{array}$ & Toluene & $\begin{array}{l}\text { 1,1,1-Tri- } \\
\text { chloro- } \\
\text { ethane }\end{array}$ & $\begin{array}{l}\text { 1,1,2-Tri- } \\
\text { chloro- } \\
\text { ethane }\end{array}$ & $\begin{array}{l}\text { Trichloro- } \\
\text { ethylene }\end{array}$ & $\begin{array}{l}\text { Trichloro- } \\
\text { fluoro- } \\
\text { methane }\end{array}$ & $\begin{array}{c}\text { Vinyl } \\
\text { chloride }\end{array}$ & Xylenes \\
\hline \multicolumn{10}{|c|}{ Inland samples: } \\
\hline SW01 & $<0.51$ & $<1.6$ & $<0.50$ & $<0.50$ & $<1.2$ & $<0.50$ & $<1.4$ & $<2.6$ & $<0.84$ \\
\hline SW02 & $<.51$ & $<1.6$ & $<.50$ & $<.50$ & $<1.2$ & $<.50$ & $<1.4$ & $<2.6$ & $<.84$ \\
\hline SW03 & $<.51$ & $<1.6$ & $<.50$ & $<.50$ & $<1.2$ & $<.50$ & $<1.4$ & $<2.6$ & $<.84$ \\
\hline SW05 & $<.51$ & $<1.6$ & $<.50$ & $<.50$ & $<1.2$ & $<.50$ & $<1.4$ & $<2.6$ & $<.84$ \\
\hline SW08 & $<.51$ & $<1.6$ & $<.50$ & $<.50$ & $<1.2$ & $<.50$ & $<1.4$ & $<2.6$ & $<.84$ \\
\hline SW09 & $<.51$ & $<1.6$ & $<.50$ & $<.50$ & $<4.0$ & $<.50$ & $<1.4$ & $<2.6$ & $<.84$ \\
\hline SW09 (R) & $<.51$ & $<1.6$ & $<.50$ & $<.50$ & $<4.0$ & $<.50$ & $<1.4$ & $<2.6$ & $<.84$ \\
\hline SW09 (S) & -- & -- & -- & -. & -- & -- & -- & -. & -- \\
\hline SW12 & $<.51$ & $<1.6$ & $<.50$ & $<.50$ & $<1.2$ & $<.50$ & $<1.4$ & $<2.6$ & $<.84$ \\
\hline SW13 & $<.51$ & $<1.6$ & $<.50$ & $<.50$ & $<1.2$ & $<.50$ & $<1.4$ & $<2.6$ & $<.84$ \\
\hline SW14 & $<.51$ & $<1.6$ & $<.50$ & $<.50$ & $<1.2$ & $<.50$ & $<1.4$ & $<2.6$ & $<.84$ \\
\hline SW 15 & $<.51$ & $<1.6$ & $<.50$ & $<.50$ & $<1.2$ & $<.50$ & $<1.4$ & $<2.6$ & $<.84$ \\
\hline SW 16 & $<.51$ & $<1.6$ & .90 & $<.50$ & $<1.2$ & $<.50$ & $<1.4$ & $<2.6$ & $<.84$ \\
\hline SW 17 & $<.51$ & $<1.6$ & $<.50$ & $<.50$ & $<1.2$ & $<.50$ & $<1.4$ & $<2.9$ & $<.84$ \\
\hline SW 18 & $<.51$ & $<1.6$ & $<.50$ & $<.50$ & $<1.2$ & $<.50$ & $<1.4$ & $<2.9$ & $<.84$ \\
\hline SW20 & $<.51$ & $<1.6$ & $<.50$ & $<.50$ & $<1.2$ & $<.50$ & $<1.4$ & $<2.9$ & $<.84$ \\
\hline SW21 & $<.51$ & $<1.6$ & $<.50$ & $<.50$ & $<1.2$ & $<.50$ & $<1.4$ & $<2.9$ & $<.84$ \\
\hline \multicolumn{10}{|c|}{ Estuarine samples: } \\
\hline SW04 & $<.51$ & $<1.6$ & $<.50$ & $<.50$ & $<1.2$ & $<.50$ & $<1.4$ & $<2.6$ & $<.84$ \\
\hline SW06 & $<.51$ & $<1.6$ & $<.50$ & $<.50$ & $<1.2$ & $<.50$ & $<1.4$ & $<2.6$ & $<.84$ \\
\hline SW07 & $<.51$ & $<1.6$ & $<.50$ & $<.50$ & $<1.2$ & $<.50$ & $<1.4$ & $<2.6$ & $<.84$ \\
\hline SW10 & $<.51$ & $<1.6$ & $<.50$ & $<.50$ & $<1.2$ & $<.50$ & $<1.4$ & $<2.6$ & $<.84$ \\
\hline SWII & $<.51$ & $<1.6$ & $<.50$ & $<.50$ & $<1.2$ & $<.50$ & $<1.4$ & $<2.6$ & $<.84$ \\
\hline SW11 (R) & $<.51$ & $<1.6$ & $<.50$ & $<.50$ & $<1.2$ & $<.50$ & $<1.4$ & $<2.7$ & $<.84$ \\
\hline SW 19 & $<.51$ & $<1.6$ & $<.50$ & $<.50$ & $<1.2$ & $<.50$ & $<1.4$ & $<2.9$ & $<.84$ \\
\hline
\end{tabular}


Table 16. Results of organic-chemical analyses of surface water from selected sampling sites at Carroll Island, Aberdeen Proving Ground, Md., spring 1989--Continued

\begin{tabular}{|c|c|c|c|c|c|c|c|c|c|}
\hline $\begin{array}{c}\text { Sampling } \\
\text { site } \\
\text { (fig. 4) }\end{array}$ & $\begin{array}{c}\text { Acenaph- } \\
\text { thene }\end{array}$ & $\begin{array}{c}\text { Acenaph- } \\
\text { thylene }\end{array}$ & $\begin{array}{c}\text { Acetic acid, } \\
\text { vinyl } \\
\text { ester }\end{array}$ & Acetone & Acrolein & $\begin{array}{c}\text { Acrylo- } \\
\text { nitrile }\end{array}$ & Aldrin & $\begin{array}{c}\text { Anthra- } \\
\text { cene }\end{array}$ & $\begin{array}{c}\text { alpha- } \\
\text { Benzene- } \\
\text { hexa- } \\
\text { chloride }\end{array}$ \\
\hline \multicolumn{10}{|c|}{ Inland samples: } \\
\hline SW01 & $<1.7$ & $<0.50$ & $<8.3$ & $<13.0$ & $<100$ & $<100$ & $<4.7$ & $<0.50$ & $<4.0$ \\
\hline SW02 & $<1.7$ & $<.50$ & $<8.3$ & $<13.0$ & $<100$ & $<100$ & $<4.7$ & $<.50$ & $<4.0$ \\
\hline SW03 & $<1.7$ & $<.50$ & $<8.3$ & $<13.0$ & $<100$ & $<100$ & $<4.7$ & $<.50$ & $<4.0$ \\
\hline SW05 & $<1.7$ & $<.50$ & $<8.3$ & $<13.0$ & $<100$ & $<100$ & $<4.7$ & $<.50$ & $<4.0$ \\
\hline SW08 & $<1.7$ & $<.50$ & $<8.3$ & $<13.0$ & $<100$ & $<100$ & $<4.7$ & $<.50$ & $<4.0$ \\
\hline SW09 & $<1.7$ & $<.50$ & $<8.3$ & $<13.0$ & $<100$ & $<100$ & $<4.7$ & $<.50$ & $<4.0$ \\
\hline SW09 (R) & $<1.7$ & $<.50$ & $<8.3$ & $<13.0$ & $<100$ & $<100$ & $<4.7$ & $<.50$ & $<4.0$ \\
\hline SW09 (S) & -- & -- & -- & -- & -- & -- & -- & -- & -- \\
\hline SW12 & $<1.7$ & $<.50$ & $<8.3$ & $<13.0$ & $<100$ & $<100$ & $<4.7$ & $<.50$ & $<4.0$ \\
\hline SW13 & $<1.7$ & $<.50$ & $<8.3$ & $<13.0$ & $<100$ & $<100$ & $<4.7$ & $<.50$ & $<4.0$ \\
\hline SW14 & $<1.7$ & $<.50$ & $<8.3$ & $<13.0$ & $<100$ & $<100$ & $<4.7$ & $<.50$ & $<4.0$ \\
\hline SW15 & $<1.7$ & $<.50$ & $<8.3$ & $<13.0$ & $<100$ & $<100$ & $<4.7$ & $<.50$ & $<4.0$ \\
\hline SW16 & $<1.7$ & $<.50$ & $<8.3$ & $<13.0$ & $<100$ & $<100$ & $<4.7$ & $<.50$ & $<4.0$ \\
\hline SW17 & $<1.7$ & $<.50$ & $<9.3$ & $<13.0$ & $<100$ & $<100$ & $<4.7$ & $<.50$ & $<4.0$ \\
\hline SW18 & $<1.7$ & $<.50$ & $<9.3$ & $<13.0$ & $<100$ & $<100$ & $<4.7$ & $<.50$ & $<4.0$ \\
\hline SW20 & $<1.7$ & $<.50$ & $<9.3$ & $<13.0$ & $<100$ & $<100$ & $<4.7$ & $<.50$ & $<4.0$ \\
\hline SW21 & $<1.7$ & $<.50$ & $<9.3$ & $<13.0$ & $<100$ & $<100$ & $<4.7$ & $<.50$ & $<4.0$ \\
\hline \multicolumn{10}{|c|}{ Estuarine samples: } \\
\hline SW04 & $<1.7$ & $<.50$ & $<8.3$ & $<13.0$ & $<100$ & $<100$ & $<4.7$ & $<.50$ & $<4.0$ \\
\hline SW06 & $<1.7$ & $<.50$ & $<8.3$ & $<13.0$ & $<100$ & $<100$ & $<4.7$ & $<.50$ & $<4.0$ \\
\hline SW07 & $<1.7$ & $<.50$ & $<8.3$ & $<13.0$ & $<100$ & $<100$ & $<4.7$ & $<.50$ & $<4.0$ \\
\hline SW10 & $<1.7$ & $<.50$ & $<8.3$ & $<13.0$ & $<100$ & $<100$ & $<4.7$ & $<.50$ & $<4.0$ \\
\hline SW11 & $<1.7$ & $<.50$ & $<8.3$ & $<13.0$ & $<100$ & $<100$ & $<4.7$ & $<.50$ & $<4.0$ \\
\hline SW11 (R) & $<1.7$ & $<.50$ & $<8.3$ & $<13.0$ & $<100$ & $<100$ & $<4.7$ & $<.50$ & $<4.0$ \\
\hline SW19 & $<1.7$ & $<.50$ & $<9.3$ & $<13.0$ & $<100$ & $<100$ & $<4.7$ & $<.50$ & $<4.0$ \\
\hline
\end{tabular}

\begin{tabular}{|c|c|c|c|c|c|c|c|c|c|c|}
\hline $\begin{array}{l}\text { Sampling } \\
\text { site } \\
\text { (fig. 4) }\end{array}$ & $\begin{array}{c}\text { beta- } \\
\text { Benzene- } \\
\text { hexa- } \\
\text { chloride }\end{array}$ & $\begin{array}{c}\text { delta- } \\
\text { Benzene- } \\
\text { hexa- } \\
\text { chloride }\end{array}$ & Benzidine & $\begin{array}{c}\text { Benzo } \\
\text { [a] } \\
\text { anthra- } \\
\text { cene }\end{array}$ & $\begin{array}{c}\text { Benzo } \\
\text { [b] } \\
\text { fluor- } \\
\text { anthene }\end{array}$ & $\begin{array}{l}\text { Benzo } \\
\text { [k] } \\
\text { fluor- } \\
\text { anthene }\end{array}$ & $\begin{array}{c}\text { Benzoic } \\
\text { acid }\end{array}$ & $\begin{array}{c}\text { Benzo } \\
\text { [g,h,i] } \\
\text { perylene }\end{array}$ & $\begin{array}{c}\text { Benzo } \\
\text { [a] } \\
\text { pyrene }\end{array}$ & $\begin{array}{l}\text { Benzo- } \\
\text { thiazole }\end{array}$ \\
\hline \multicolumn{11}{|c|}{ Inland samples: } \\
\hline SW01 & $<4.0$ & $<4.0$ & $<10.0$ & $<1.6$ & $<5.4$ & $<0.87$ & $<13.0$ & $<6.1$ & $<4.7$ & $<2.11$ \\
\hline SW02 & $<4.0$ & $<4.0$ & $<10.0$ & $<1.6$ & $<5.4$ & $<.87$ & $<13.0$ & $<6.1$ & $<4.7$ & $<2.11$ \\
\hline SW03 & $<4.0$ & $<4.0$ & $<10.0$ & $<1.6$ & $<5.4$ & $<.87$ & $<13.0$ & $<6.1$ & $<4.7$ & $<2.11$ \\
\hline SW05 & $<4.0$ & $<4.0$ & $<10.0$ & $<1.6$ & $<5.4$ & $<.87$ & $<13.0$ & $<6.1$ & $<4.7$ & $<2.11$ \\
\hline SW08 & $<4.0$ & $<4.0$ & $<10.0$ & $<1.6$ & $<5.4$ & $<.87$ & $<13.0$ & $<6.1$ & $<4.7$ & $<2.11$ \\
\hline SW09 & $<4.0$ & $<4.0$ & $<10.0$ & $<1.6$ & $<5.4$ & $<.87$ & $<13.0$ & $<6.1$ & $<4.7$ & $<2.11$ \\
\hline SW09 (R) & $<4.0$ & $<4.0$ & $<10.0$ & $<1.6$ & $<5.4$ & $<.87$ & $<13.0$ & $<6.1$ & $<4.7$ & $<2.11$ \\
\hline SW09 (S) & -- & -. & -- & -. & -. & -- & -. & -- & -- & -- \\
\hline SW12 & $<4.0$ & $<4.0$ & $<10.0$ & $<1.6$ & $<5.4$ & $<.87$ & $<13.0$ & $<6.1$ & $<4.7$ & $<2.11$ \\
\hline SW13 & $<4.0$ & $<4.0$ & $<10.0$ & $<1.6$ & $<5.4$ & $<.87$ & $<13.0$ & $<6.1$ & $<4.7$ & $<2.11$ \\
\hline SW14 & $<4.0$ & $<4.0$ & $<10.0$ & $<1.6$ & $<5.4$ & $<.87$ & $<13.0$ & $<6.1$ & $<4.7$ & $<2.11$ \\
\hline SW15 & $<4.0$ & $<4.0$ & $<10.0$ & $<1.6$ & $<5.4$ & $<.87$ & $<13.0$ & $<6.1$ & $<4.7$ & $<2.11$ \\
\hline SW16 & $<4.0$ & $<4.0$ & $<10.0$ & $<1.6$ & $<5.4$ & $<.87$ & $<13.0$ & $<6.1$ & $<4.7$ & $<2.11$ \\
\hline SW17 & $<4.0$ & $<4.0$ & $<10.0$ & $<1.6$ & $<5.4$ & $<.87$ & $<13.0$ & $<6.1$ & $<4.7$ & $<2.11$ \\
\hline SW18 & $<4.0$ & $<4.0$ & $<10.0$ & $<1.6$ & $<5.4$ & $<.87$ & $<13.0$ & $<6.1$ & $<4.7$ & $<2.11$ \\
\hline SW20 & $<4.0$ & $<4.0$ & $<10.0$ & $<1.6$ & $<5.4$ & $<.87$ & $<13.0$ & $<6.1$ & $<4.7$ & $<2.11$ \\
\hline SW21 & $<4.0$ & $<4.0$ & $<10.0$ & $<1.6$ & $<5.4$ & $<.87$ & $<13.0$ & $<6.1$ & $<4.7$ & $<2.11$ \\
\hline \multicolumn{11}{|c|}{ Estuarine samples: } \\
\hline SW04 & $<4.0$ & $<4.0$ & $<10.0$ & $<1.6$ & $<5.4$ & $<.87$ & $<13.0$ & $<6.1$ & $<4.7$ & $<2.11$ \\
\hline SW06 & $<4.0$ & $<4.0$ & $<10.0$ & $<1.6$ & $<5.4$ & $<.87$ & $<13.0$ & $<6.1$ & $<4.7$ & $<2.11$ \\
\hline SW07 & $<4.0$ & $<4.0$ & $<10.0$ & $<1.6$ & $<5.4$ & $<.87$ & $<13.0$ & $<6.1$ & $<4.7$ & $<2.11$ \\
\hline SW10 & $<4.0$ & $<4.0$ & $<10.0$ & $<1.6$ & $<5.4$ & $<.87$ & $<13.0$ & $<6.1$ & $<4.7$ & $<2.11$ \\
\hline SW11 & $<4.0$ & $<4.0$ & $<10.0$ & $<1.6$ & $<5.4$ & $<.87$ & $<13.0$ & $<6.1$ & $<4.7$ & $<2.11$ \\
\hline SW11 (R) & $<4.0$ & $<4.0$ & $<10.0$ & $<1.6$ & $<5.4$ & $<.87$ & $<13.0$ & $<6.1$ & $<4.7$ & $<2.11$ \\
\hline SW19 & $<4.0$ & $<4.0$ & $<10.0$ & $<1.6$ & $<5.4$ & $<.87$ & $<13.0$ & $<6.1$ & $<4.7$ & $<2.11$ \\
\hline
\end{tabular}


Table 16. Results of organic-chemical analyses of surface water from selected sampling sites at Carroll Island, Aberdeen Proving Ground, Md., spring 1989--Continued

\begin{tabular}{|c|c|c|c|c|c|c|c|c|}
\hline $\begin{array}{c}\text { Sampling } \\
\text { site } \\
\text { (fig. 4) }\end{array}$ & $\begin{array}{l}\text { Benzyl } \\
\text { alcohol }\end{array}$ & $\begin{array}{c}\text { Bis(2- } \\
\text { chloro- } \\
\text { ethoxy) } \\
\text { methane }\end{array}$ & $\begin{array}{c}\text { Bis(2- } \\
\text { chloro- } \\
\text { ethyl) } \\
\text { ether }\end{array}$ & $\begin{array}{c}\text { Bis(2- } \\
\text { chloro- } \\
\text { isopropyl) } \\
\text { ether }\end{array}$ & $\begin{array}{c}\text { 2,2-Bis } \\
\text { (para-chloro- } \\
\text { phenyl)- } \\
\text { 1,1-dichloro- } \\
\text { ethane }\end{array}$ & $\begin{array}{c}\text { 2,2-Bis } \\
\text { (para-chloro- } \\
\text { phenyl)- } \\
\text { 1,1-dichloro- } \\
\text { ethene }\end{array}$ & $\begin{array}{c}\text { 2,2-Bis } \\
\text { (para-chloro- } \\
\text { phenyl)- } \\
\text { 1,1,1-tri- } \\
\text { chloroethane }\end{array}$ & $\begin{array}{c}\text { Bis(2- } \\
\text { ethyl- } \\
\text { hexyl) } \\
\text { phthalate }\end{array}$ \\
\hline \multicolumn{9}{|c|}{ Inland samples: } \\
\hline SW01 & $<0.72$ & $<1.5$ & $<1.9$ & $<5.3$ & $<4.0$ & $<4.7$ & $<9.2$ & $<4.8$ \\
\hline SW02 & $<.72$ & $<1.5$ & $<1.9$ & $<5.3$ & $<4.0$ & $<4.7$ & $<9.2$ & $<4.8$ \\
\hline SW03 & $<.72$ & $<1.5$ & $<1.9$ & $<5.3$ & $<4.0$ & $<4.7$ & $<9.2$ & $<4.8$ \\
\hline SW05 & $<.72$ & $<1.5$ & $<1.9$ & $<5.3$ & $<4.0$ & $<4.7$ & $<9.2$ & $<4.8$ \\
\hline SW08 & $<.72$ & $<1.5$ & $<1.9$ & $<5.3$ & $<4.0$ & $<4.7$ & $<9.2$ & $<4.8$ \\
\hline SW09 & $<.72$ & $<1.5$ & $<1.9$ & $<5.3$ & $<4.0$ & $<4.7$ & $<9.2$ & $<4.8$ \\
\hline SW09 (R) & $<.72$ & $<1.5$ & $<1.9$ & $<5.3$ & $<4.0$ & $<4.7$ & $<9.2$ & $<4.8$ \\
\hline SW09 (S) & -. & -- & -- & -- & -- & -- & -- & -- \\
\hline SW12 & $<.72$ & $<1.5$ & $<1.9$ & $<5.3$ & $<4.0$ & $<4.7$ & $<9.2$ & $<4.8$ \\
\hline SW13 & $<.72$ & $<1.5$ & $<1.9$ & $<5.3$ & $<4.0$ & $<4.7$ & $<9.2$ & $<4.8$ \\
\hline SW14 & $<.72$ & $<1.5$ & $<1.9$ & $<5.3$ & $<4.0$ & $<4.7$ & $<9.2$ & $<4.8$ \\
\hline SW15 & $<.72$ & $<1.5$ & $<1.9$ & $<5.3$ & $<4.0$ & $<4.7$ & $<9.2$ & $<4.8$ \\
\hline SW16 & $<.72$ & $<1.5$ & $<1.9$ & $<5.3$ & $<4.0$ & $<4.7$ & $<9.2$ & $<4.8$ \\
\hline SW17 & $<.72$ & $<1.5$ & $<1.9$ & $<5.3$ & $<4.0$ & $<4.7$ & $<9.2$ & $<4.8$ \\
\hline SW18 & $<.72$ & $<1.5$ & $<1.9$ & $<5.3$ & $<4.0$ & $<4.7$ & $<9.2$ & $<4.8$ \\
\hline SW20 & $<.72$ & $<1.5$ & $<1.9$ & $<5.3$ & $<4.0$ & $<4.7$ & $<9.2$ & $<4.8$ \\
\hline SW21 & $<.72$ & $<1.5$ & $<1.9$ & $<5.3$ & $<4.0$ & $<4.7$ & $<9.2$ & $<4.8$ \\
\hline \multicolumn{9}{|c|}{ Estuarine samples: } \\
\hline SW04 & $<.72$ & $<1.5$ & $<1.9$ & $<5.3$ & $<4.0$ & $<4.7$ & $<9.2$ & $<4.8$ \\
\hline SW06 & $<.72$ & $<1.5$ & $<1.9$ & $<5.3$ & $<4.0$ & $<4.7$ & $<9.2$ & $<4.8$ \\
\hline SW07 & $<.72$ & $<1.5$ & $<1.9$ & $<5.3$ & $<4.0$ & $<4.7$ & $<9.2$ & $<4.8$ \\
\hline SW10 & $<.72$ & $<1.5$ & $<1.9$ & $<5.3$ & $<4.0$ & $<4.7$ & $<9.2$ & $<4.8$ \\
\hline SW11 & $<.72$ & $<1.5$ & $<1.9$ & $<5.3$ & $<4.0$ & $<4.7$ & $<9.2$ & $<4.8$ \\
\hline SW11 (R) & $<.72$ & $<1.5$ & $<1.9$ & $<5.3$ & $<4.0$ & $<4.7$ & $<9.2$ & $<4.8$ \\
\hline SW19 & $<.72$ & $<1.5$ & $<1.9$ & $<5.3$ & $<4.0$ & $<4.7$ & $<9.2$ & $<4.8$ \\
\hline
\end{tabular}

\begin{tabular}{|c|c|c|c|c|c|c|c|c|c|}
\hline $\begin{array}{c}\text { Sampling } \\
\text { site } \\
\text { (fig. 4) }\end{array}$ & $\begin{array}{l}\text { Bromo- } \\
\text { methane }\end{array}$ & $\begin{array}{l}\text { 4-Bromo- } \\
\text { phenyl- } \\
\text { phenyl } \\
\text { ether }\end{array}$ & $\begin{array}{c}\text { Butyl- } \\
\text { benzyl } \\
\text { phthalate }\end{array}$ & $\begin{array}{l}\text { Carbon } \\
\text { disulfide }\end{array}$ & $\begin{array}{c}\text { alpha- } \\
\text { Chlordane }\end{array}$ & $\begin{array}{l}\text { gamma- } \\
\text { Chlordane }\end{array}$ & $\begin{array}{l}\text { 4-Chloro- } \\
\text { aniline }\end{array}$ & $\begin{array}{c}\text { 2-Chloro- } \\
\text { naph- } \\
\text { thalene }\end{array}$ & $\begin{array}{c}\text { 2-Chloro- } \\
\text { phenol }\end{array}$ \\
\hline \multicolumn{10}{|c|}{ Inland samples: } \\
\hline SW01 & $<5.8$ & $<4.2$ & $<3.4$ & $<0.5$ & $<5.1$ & $<5.1$ & $<7.3$ & $<0.50$ & $<0.99$ \\
\hline SW02 & $<5.8$ & $<4.2$ & $<3.4$ & $<.5$ & $<5.1$ & $<5.1$ & $<7.3$ & $<.50$ & $<.99$ \\
\hline SW03 & $<5.8$ & $<4.2$ & $<3.4$ & $<.5$ & $<5.1$ & $<5.1$ & $<7.3$ & $<.50$ & $<.99$ \\
\hline SW05 & $<5.8$ & $<4.2$ & $<3.4$ & $<.5$ & $<5.1$ & $<5.1$ & $<7.3$ & $<.50$ & $<.99$ \\
\hline SW08 & $<5.8$ & $<4.2$ & $<3.4$ & $<.5$ & $<5.1$ & $<5.1$ & $<7.3$ & $<.50$ & $<.99$ \\
\hline SW09 & $<5.8$ & $<4.2$ & $<3.4$ & $<.5$ & $<5.1$ & $<5.1$ & $<7.3$ & $<.50$ & $<.99$ \\
\hline SW09 (R) & $<5.8$ & $<4.2$ & $<3.4$ & $<.5$ & $<5.1$ & $<5.1$ & $<7.3$ & $<.50$ & $<.99$ \\
\hline SW09 (S) & -- & - & -- & -- & -- & -- & -- & -- & -- \\
\hline SW12 & $<5.8$ & $<4.2$ & $<3.4$ & $<.5$ & $<5.1$ & $<5.1$ & $<7.3$ & $<.50$ & $<.99$ \\
\hline SW13 & $<5.8$ & $<4.2$ & $<3.4$ & $<.5$ & $<5.1$ & $<5.1$ & $<7.3$ & $<.50$ & $<.99$ \\
\hline SW14 & $<5.8$ & $<4.2$ & $<3.4$ & $<.5$ & $<5.1$ & $<5.1$ & $<7.3$ & $<.50$ & $<.99$ \\
\hline SW15 & $<5.8$ & $<4.2$ & $<3.4$ & $<.5$ & $<5.1$ & $<5.1$ & $<7.3$ & $<.50$ & $<.99$ \\
\hline SW16 & $<5.8$ & $<4.2$ & $<3.4$ & $<.5$ & $<5.1$ & $<5.1$ & $<7.3$ & $<.50$ & $<.99$ \\
\hline SW17 & $<5.8$ & $<4.2$ & $<3.4$ & $<.5$ & $<5.1$ & $<5.1$ & $<7.3$ & $<.50$ & $<.99$ \\
\hline SW18 & $<5.8$ & $<4.2$ & $<3.4$ & $<.5$ & $<5.1$ & $<5.1$ & $<7.3$ & $<.50$ & $<.99$ \\
\hline SW20 & $<5.8$ & $<4.2$ & $<3.4$ & $<.5$ & $<5.1$ & $<5.1$ & $<7.3$ & $<.50$ & $<.99$ \\
\hline SW21 & $<5.8$ & $<4.2$ & $<3.4$ & $<.5$ & $<5.1$ & $<5.1$ & $<7.3$ & $<.50$ & $<.99$ \\
\hline \multicolumn{10}{|c|}{ Estuarine samples: } \\
\hline SW04 & $<5.8$ & $<4.2$ & $<3.4$ & $<.5$ & $<5.1$ & $<5.1$ & $<7.3$ & $<.50$ & $<.99$ \\
\hline SW06 & $<5.8$ & $<4.2$ & $<3.4$ & $<.5$ & $<5.1$ & $<5.1$ & $<7.3$ & $<.50$ & $<.99$ \\
\hline SW07 & $<5.8$ & $<4.2$ & $<3.4$ & $<.5$ & $<5.1$ & $<5.1$ & $<7.3$ & $<.50$ & $<.99$ \\
\hline SW10 & $<5.8$ & $<4.2$ & $<3.4$ & $<.5$ & $<5.1$ & $<5.1$ & $<7.3$ & $<.50$ & $<.99$ \\
\hline SW11 & $<5.8$ & $<4.2$ & $<3.4$ & $<.5$ & $<5.1$ & $<5.1$ & $<7.3$ & $<.50$ & $<.99$ \\
\hline SW11 (R) & $<5.8$ & $<4.2$ & $<3.4$ & $<.5$ & $<5.1$ & $<5.1$ & $<7.3$ & $<.50$ & $<.99$ \\
\hline SW19 & $<5.8$ & $<4.2$ & $<3.4$ & $<.5$ & $<5.1$ & $<5.1$ & $<7.3$ & $<.50$ & $<.99$ \\
\hline
\end{tabular}


Table 16. Results of organic-chemical analyses of surface water from selected sampling sites at Carroll Island, Aberdeen Proving Ground, Md., spring 1989--Continued

\begin{tabular}{|c|c|c|c|c|c|c|c|c|c|}
\hline $\begin{array}{c}\text { Sampling } \\
\text { site } \\
\text { (fig. 4) }\end{array}$ & $\begin{array}{l}\text { 4-Chloro- } \\
\text { phenyl- } \\
\text { methyl } \\
\text { sulfide }\end{array}$ & $\begin{array}{l}\text { 4-Chাoro- } \\
\text { phenyl- } \\
\text { methyl } \\
\text { sulfone }\end{array}$ & $\begin{array}{l}\text { 4-Chloro- } \\
\text { phenyl- } \\
\text { methyl } \\
\text { sulfoxide }\end{array}$ & $\begin{array}{l}\text { 4-Chloro- } \\
\text { phenyl- } \\
\text { phenyl } \\
\text { ether }\end{array}$ & $\begin{array}{l}\text { Chry- } \\
\text { sene }\end{array}$ & $\begin{array}{c}\text { Di- } \\
\text { acetone } \\
\text { alcohol }\end{array}$ & $\begin{array}{c}\text { Dibenz } \\
\text { [a,h] } \\
\text { anthra- } \\
\text { cene }\end{array}$ & $\begin{array}{l}\text { Di- } \\
\text { benzo } \\
\text { furan }\end{array}$ & $\begin{array}{l}\text { Di-n-butyl } \\
\text { phthalate }\end{array}$ \\
\hline \multicolumn{10}{|c|}{ Inland samples: } \\
\hline SW01 & $<1.26$ & $<4.72$ & $<4.23$ & $<5.1$ & $<2.4$ & -- & $<6.5$ & $<1.7$ & $<3.7$ \\
\hline SW02 & $<1.26$ & $<4.72$ & $<4.23$ & $<5.1$ & $<2.4$ & -. & $<6.5$ & $<1.7$ & $<3.7$ \\
\hline SW03 & $<1.26$ & $<4.72$ & $<4.23$ & $<5.1$ & $<2.4$ & -- & $<6.5$ & $<1.7$ & $<3.7$ \\
\hline SW05 & $<1.26$ & $<4.72$ & $<4.23$ & $<5.1$ & $<2.4$ & - & $<6.5$ & $<1.7$ & $<3.7$ \\
\hline SW08 & $<1.26$ & $<4.72$ & $<4.23$ & $<5.1$ & $<2.4$ & -- & $<6.5$ & $<1.7$ & $<3.7$ \\
\hline SW09 & $<1.26$ & $<4.72$ & $<4.23$ & $<5.1$ & $<2.4$ & -- & $<6.5$ & $<1.7$ & $<3.7$ \\
\hline SW09 (R) & $<1.26$ & $<4.72$ & $<4.23$ & $<5.1$ & $<2.4$ & -- & $<6.5$ & $<1.7$ & $<3.7$ \\
\hline SW09 (S) & - & -. & -- & -- & -- & -- & - & -- & - \\
\hline SW12 & $<1.26$ & $<4.72$ & $<4.23$ & $<5.1$ & $<2.4$ & 2.0 & $<6.5$ & $<1.7$ & $<3.7$ \\
\hline SW13 & $<1.26$ & $<4.72$ & $<4.23$ & $<5.1$ & $<2.4$ & -- & $<6.5$ & $<1.7$ & $<3.7$ \\
\hline SW14 & $<1.26$ & $<4.72$ & $<4.23$ & $<5.1$ & $<2.4$ & .. & $<6.5$ & $<1.7$ & $<3.7$ \\
\hline SW15 & $<1.26$ & $<4.72$ & $<4.23$ & $<5.1$ & $<2.4$ & - & $<6.5$ & $<1.7$ & $<3.7$ \\
\hline SW16 & $<1.26$ & $<4.72$ & $<4.23$ & $<5.1$ & $<2.4$ & -- & $<6.5$ & $<1.7$ & $<3.7$ \\
\hline SW17 & $<1.26$ & $<4.72$ & $<4.23$ & $<5.1$ & $<2.4$ & - & $<6.5$ & $<1.7$ & $<3.7$ \\
\hline SW18 & $<1.26$ & $<4.72$ & $<4.23$ & $<5.1$ & $<2.4$ & -- & $<6.5$ & $<1.7$ & $<3.7$ \\
\hline SW20 & $<1.26$ & $<4.72$ & $<4.23$ & $<5.1$ & $<2.4$ & .. & $<6.5$ & $<1.7$ & $<3.7$ \\
\hline SW21 & $<1.26$ & $<4.72$ & $<4.23$ & $<5.1$ & $<2.4$ & -- & $<6.5$ & $<1.7$ & $<3.7$ \\
\hline \multicolumn{10}{|c|}{ Estuarine samples: } \\
\hline sw04 & $<1.26$ & $<4.72$ & $<4.23$ & $<5.1$ & $<2.4$ & -- & $<6.5$ & $<1.7$ & $<3.7$ \\
\hline Sw06 & $<1.26$ & $<4.72$ & $<4.23$ & $<5.1$ & $<2.4$ & -- & $<6.5$ & $<1.7$ & $<3.7$ \\
\hline SW07 & $<1.26$ & $<4.72$ & $<4.23$ & $<5.1$ & $<2.4$ & -- & $<6.5$ & $<1.7$ & $<3.7$ \\
\hline SW10 & $<1.26$ & $<4.72$ & $<4.23$ & $<5.1$ & $<2.4$ & -- & $<6.5$ & $<1.7$ & $<3.7$ \\
\hline SW11 & $<1.26$ & $<4.72$ & $<4.23$ & $<5.1$ & $<2.4$ & -. & $<6.5$ & $<1.7$ & $<3.7$ \\
\hline SW11 (R) & $<1.26$ & $<4.72$ & $<4.23$ & $<5.1$ & $<2.4$ & -- & $<6.5$ & $<1.7$ & $<3.7$ \\
\hline SW19 & $<1.26$ & $<4.72$ & $<4.23$ & $<5.1$ & $<2.4$ & -- & $<6.5$ & $<1.7$ & $<3.7$ \\
\hline
\end{tabular}

\begin{tabular}{|c|c|c|c|c|c|c|c|c|c|}
\hline $\begin{array}{l}\text { Sampling } \\
\text { site } \\
\text { (fig. 4) }\end{array}$ & $\begin{array}{l}\text { Dichloro- } \\
\text { benzenes }\end{array}$ & $\begin{array}{c}\text { 3,3'-Dichloro- } \\
\text { benzidine }\end{array}$ & $\begin{array}{l}\text { 2,4-Dichloro- } \\
\text { phenol }\end{array}$ & Dieldrin & $\begin{array}{c}\text { Diethyl } \\
\text { phthalate }\end{array}$ & $\begin{array}{l}\text { Dimethyl } \\
\text { disulfide }\end{array}$ & $\begin{array}{l}\text { 2,4-Di- } \\
\text { methyl- } \\
\text { phenol }\end{array}$ & $\begin{array}{l}\text { Dimethyl } \\
\text { phthalate }\end{array}$ & $\begin{array}{l}\text { 2,4-Di- } \\
\text { nitro- } \\
\text { phenol }\end{array}$ \\
\hline \multicolumn{10}{|c|}{ Inland samples: } \\
\hline SW01 & $<10.0$ & $<12.0$ & $<2.9$ & $<4.7$ & $<2.0$ & $<1.14$ & $<5.8$ & $<1.5$ & $<21.0$ \\
\hline SW02 & $<10.0$ & $<12.0$ & $<2.9$ & $<4.7$ & $<2.0$ & $<1.14$ & $<5.8$ & $<1.5$ & $<21.0$ \\
\hline SW03 & $<10.0$ & $<12.0$ & $<2.9$ & $<4.7$ & $<2.0$ & $<1.14$ & $<5.8$ & $<1.5$ & $<21.0$ \\
\hline SW05 & $<10.0$ & $<12.0$ & $<2.9$ & $<4.7$ & $<2.0$ & $<1.14$ & $<5.8$ & $<1.5$ & $<21.0$ \\
\hline SW08 & $<10.0$ & $<12.0$ & $<2.9$ & $<4.7$ & $<2.0$ & $<1.14$ & $<5.8$ & $<1.5$ & $<21.0$ \\
\hline SW09 & $<10.0$ & $<12.0$ & $<2.9$ & $<4.7$ & $<2.0$ & $<1.14$ & $<5.8$ & $<1.5$ & $<21.0$ \\
\hline SW09 (R) & $<10.0$ & $<12.0$ & $<2.9$ & $<4.7$ & $<2.0$ & $<1.14$ & $<5.8$ & $<1.5$ & $<21.0$ \\
\hline SW09 (S) & -- & -- & -- & -. & - & -. & -. & -- & -- \\
\hline SW12 & $<10.0$ & $<12.0$ & $<2.9$ & $<4.7$ & $<2.0$ & $<1.14$ & $<5.8$ & $<1.5$ & $<21.0$ \\
\hline SW13 & $<10.0$ & $<12.0$ & $<2.9$ & $<4.7$ & $<2.0$ & $<1.14$ & $<5.8$ & $<1.5$ & $<21.0$ \\
\hline SW14 & $<10.0$ & $<12.0$ & $<2.9$ & $<4.7$ & $<2.0$ & $<1.14$ & $<5.8$ & $<1.5$ & $<21.0$ \\
\hline SW15 & $<10.0$ & $<12.0$ & $<2.9$ & $<4.7$ & $<2.0$ & $<1.14$ & $<5.8$ & $<1.5$ & $<21.0$ \\
\hline SW16 & $<10.0$ & $<12.0$ & $<2.9$ & $<4.7$ & $<2.0$ & $<1.14$ & $<5.8$ & $<1.5$ & $<21.0$ \\
\hline SW17 & $<10.0$ & $<12.0$ & $<2.9$ & $<4.7$ & $<2.0$ & $<1.14$ & $<5.8$ & $<1.5$ & $<21.0$ \\
\hline SW18 & $<10.0$ & $<12.0$ & $<2.9$ & $<4.7$ & $<2.0$ & $<1.14$ & $<5.8$ & $<1.5$ & $<21.0$ \\
\hline SW20 & $<10.0$ & $<12.0$ & $<2.9$ & $<4.7$ & $<2.0$ & $<1.14$ & $<5.8$ & $<1.5$ & $<21.0$ \\
\hline SW21 & $<10.0$ & $<12.0$ & $<2.9$ & $<4.7$ & $<2.0$ & $<1.14$ & $<5.8$ & $<1.5$ & $<21.0$ \\
\hline \multicolumn{10}{|c|}{ Estuarine samples: } \\
\hline SW04 & $<10.0$ & $<12.0$ & $<2.9$ & $<4.7$ & $<2.0$ & $<1.14$ & $<5.8$ & $<1.5$ & $<21.0$ \\
\hline SW06 & $<10.0$ & $<12.0$ & $<2.9$ & $<4.7$ & $<2.0$ & $<1.14$ & $<5.8$ & $<1.5$ & $<21.0$ \\
\hline SW07 & $<10.0$ & $<12.0$ & $<2.9$ & $<4.7$ & $<2.0$ & $<1.14$ & $<5.8$ & $<1.5$ & $<21.0$ \\
\hline SW10 & $<10.0$ & $<12.0$ & $<2.9$ & $<4.7$ & $<2.0$ & $<1.14$ & $<5.8$ & $<1.5$ & $<21.0$ \\
\hline SW11 & $<10.0$ & $<12.0$ & $<2.9$ & $<4.7$ & $<2.0$ & $<1.14$ & $<5.8$ & $<1.5$ & $<21.0$ \\
\hline SW11 (R) & $<10.0$ & $<12.0$ & $<2.9$ & $<4.7$ & $<2.0$ & $<1.14$ & $<5.8$ & $<1.5$ & $<21.0$ \\
\hline SW19 & $<10.0$ & $<12.0$ & $<2.9$ & $<4.7$ & $<2.0$ & $<1.14$ & $<5.8$ & $<1.5$ & $<21.0$ \\
\hline
\end{tabular}


Table 16. Results of organic-chemical analyses of surface water from selected sampling sites at Carroll Island, Aberdeen Proving Ground, Md., spring 1989--Continued

\begin{tabular}{|c|c|c|c|c|c|c|c|c|c|}
\hline $\begin{array}{c}\text { Sampling } \\
\text { site } \\
\text { (fig. 4) }\end{array}$ & $\begin{array}{l}\text { 2,4-Di- } \\
\text { nitro- } \\
\text { toluene }\end{array}$ & $\begin{array}{c}2,6-D i- \\
\text { nitro- } \\
\text { toluene }\end{array}$ & $\begin{array}{l}\text { Di-n-octyl } \\
\text { phthalate }\end{array}$ & $\begin{array}{c}\text { 1,2-Di- } \\
\text { phenyl- } \\
\text { hydrazine }\end{array}$ & Dithiane & $\begin{array}{l}\text { alpha-Endo- } \\
\text { sulfan }\end{array}$ & $\begin{array}{l}\text { beta-Endo- } \\
\text { sulfan }\end{array}$ & $\begin{array}{l}\text { Endosulfan } \\
\text { sulfate }\end{array}$ & Endrin \\
\hline \multicolumn{10}{|c|}{ Inland samples: } \\
\hline SW01 & $<4.5$ & $<0.79$ & $<15.0$ & $<2.0$ & $<1.11$ & $<9.2$ & $<9.2$ & $<9.2$ & $<7.6$ \\
\hline SW02 & $<4.5$ & $<.79$ & $<15.0$ & $<2.0$ & $<1.11$ & $<9.2$ & $<9.2$ & $<9.2$ & $<7.6$ \\
\hline SW03 & $<4.5$ & $<.79$ & $<15.0$ & $<2.0$ & $<1.11$ & $<9.2$ & $<9.2$ & $<9.2$ & $<7.6$ \\
\hline SW05 & $<4.5$ & $<.79$ & $<15.0$ & $<2.0$ & $<1.11$ & $<9.2$ & $<9.2$ & $<9.2$ & $<7.6$ \\
\hline SW08 & $<4.5$ & $<.79$ & $<15.0$ & $<2.0$ & $<1.11$ & $<9.2$ & $<9.2$ & $<9.2$ & $<7.6$ \\
\hline SW09 & $<4.5$ & $<.79$ & $<15.0$ & $<2.0$ & $<1.11$ & $<9.2$ & $<9.2$ & $<9.2$ & $<7.6$ \\
\hline SW09 (R) & $<4.5$ & $<.79$ & $<15.0$ & $<2.0$ & $<1.11$ & $<9.2$ & $<9.2$ & $<9.2$ & $<7.6$ \\
\hline SW09 (S) & -- & -- & -- & -- & .. & -- & -- & .- & .. \\
\hline SW 12 & $<4.5$ & $<.79$ & $<15.0$ & $<2.0$ & $<1.11$ & $<9.2$ & $<9.2$ & $<9.2$ & $<7.6$ \\
\hline SW13 & $<4.5$ & $<.79$ & $<15.0$ & $<2.0$ & $<1.11$ & $<9.2$ & $<9.2$ & $<9.2$ & $<7.6$ \\
\hline SW14 & $<4.5$ & $<.79$ & $<15.0$ & $<2.0$ & $<1.11$ & $<9.2$ & $<9.2$ & $<9.2$ & $<7.6$ \\
\hline SW15 & $<4.5$ & $<.79$ & $<15.0$ & $<2.0$ & $<1.11$ & $<9.2$ & $<9.2$ & $<9.2$ & $<7.6$ \\
\hline SW16 & $<4.5$ & $<.79$ & $<15.0$ & $<2.0$ & $<1.11$ & $<9.2$ & $<9.2$ & $<9.2$ & $<7.6$ \\
\hline SW17 & $<4.5$ & $<.79$ & $<15.0$ & $<2.0$ & $<1.11$ & $<9.2$ & $<9.2$ & $<9.2$ & $<7.6$ \\
\hline SW 18 & $<4.5$ & $<.79$ & $<15.0$ & $<2.0$ & $<1.11$ & $<9.2$ & $<9.2$ & $<9.2$ & $<7.6$ \\
\hline SW20 & $<4.5$ & $<.79$ & $<15.0$ & $<2.0$ & $<1.11$ & $<9.2$ & $<9.2$ & $<9.2$ & $<7.6$ \\
\hline SW21 & $<4.5$ & $<.79$ & $<15.0$ & $<2.0$ & $<1.11$ & $<9.2$ & $<9.2$ & $<9.2$ & $<7.6$ \\
\hline \multicolumn{10}{|c|}{ Estuarine samples: } \\
\hline SW04 & $<4.5$ & $<.79$ & $<15.0$ & $<2.0$ & $<1.11$ & $<9.2$ & $<9.2$ & $<9.2$ & $<7.6$ \\
\hline SW06 & $<4.5$ & $<.79$ & $<15.0$ & $<2.0$ & $<1.11$ & $<9.2$ & $<9.2$ & $<9.2$ & $<7.6$ \\
\hline SW07 & $<4.5$ & $<.79$ & $<15.0$ & $<2.0$ & $<1.11$ & $<9.2$ & $<9.2$ & $<9.2$ & $<7.6$ \\
\hline SW10 & $<4.5$ & $<.79$ & $<15.0$ & $<2.0$ & $<1.11$ & $<9.2$ & $<9.2$ & $<9.2$ & $<7.6$ \\
\hline SW11 & $<4.5$ & $<.79$ & $<15.0$ & $<2.0$ & $<1.11$ & $<9.2$ & $<9.2$ & $<9.2$ & $<7.6$ \\
\hline SW11 (R) & $<4.5$ & $<.79$ & $<15.0$ & $<2.0$ & $<1.11$ & $<9.2$ & $<9.2$ & $<9.2$ & $<7.6$ \\
\hline SW19 & $<4.5$ & $<79$ & $<15.0$ & $<2.0$ & $<1.11$ & $<9.2$ & $<9.2$ & $<9.2$ & $<7.6$ \\
\hline
\end{tabular}

\begin{tabular}{|c|c|c|c|c|c|c|c|c|c|}
\hline $\begin{array}{c}\text { Sampling } \\
\text { site } \\
\text { (fig. 4) }\end{array}$ & $\begin{array}{l}\text { Endrin } \\
\text { aldehyde }\end{array}$ & $\begin{array}{l}\text { Endrin } \\
\text { ketone }\end{array}$ & $\begin{array}{c}\text { Fluoran- } \\
\text { thene }\end{array}$ & Heptachlor & $\begin{array}{l}\text { Hepta- } \\
\text { chlor } \\
\text { epoxide }\end{array}$ & $\begin{array}{c}\text { Hexa- } \\
\text { chloro- } \\
\text { benzene }\end{array}$ & $\begin{array}{c}\text { Hexa- } \\
\text { chloro- } \\
\text { butadiene }\end{array}$ & $\begin{array}{l}\text { Hexa- } \\
\text { chloro- } \\
\text { cyclo- } \\
\text { penta- } \\
\text { diene }\end{array}$ & $\begin{array}{l}\text { Hexa- } \\
\text { chloro- } \\
\text { ethane }\end{array}$ \\
\hline \multicolumn{10}{|c|}{ Inland samples: } \\
\hline SW01 & $<8.0$ & $<8.0$ & $<3.3$ & $<2.0$ & $<5.0$ & $<1.6$ & $<3.4$ & $<8.6$ & $<1.5$ \\
\hline SW02 & $<8.0$ & $<8.0$ & $<3.3$ & $<2.0$ & $<5.0$ & $<1.6$ & $<3.4$ & $<8.6$ & $<1.5$ \\
\hline SW03 & $<8.0$ & $<8.0$ & $<3.3$ & $<2.0$ & $<5.0$ & $<1.6$ & $<3.4$ & $<8.6$ & $<1.5$ \\
\hline SW05 & $<8.0$ & $<8.0$ & $<3.3$ & $<2.0$ & $<5.0$ & $<1.6$ & $<3.4$ & $<8.6$ & $<1.5$ \\
\hline SW08 & $<8.0$ & $<8.0$ & $<3.3$ & $<2.0$ & $<5.0$ & $<1.6$ & $<3.4$ & $<8.6$ & $<1.5$ \\
\hline SW09 & $<8.0$ & $<8.0$ & $<3.3$ & $<2.0$ & $<5.0$ & $<1.6$ & $<3.4$ & $<8.6$ & $<1.5$ \\
\hline SW09 (R) & $<8.0$ & $<8.0$ & $<3.3$ & $<2.0$ & $<5.0$ & $<1.6$ & $<3.4$ & $<8.6$ & $<1.5$ \\
\hline SW09 (S) & -- & .- & -- & -- &.- & -- & -. & -- & -- \\
\hline SW12 & $<8.0$ & $<8.0$ & $<3.3$ & $<2.0$ & $<5.0$ & $<1.6$ & $<3.4$ & $<8.6$ & $<1.5$ \\
\hline SW13 & $<8.0$ & $<8.0$ & $<3.3$ & $<2.0$ & $<5.0$ & $<1.6$ & $<3.4$ & $<8.6$ & $<1.5$ \\
\hline SW14 & $<8.0$ & $<8.0$ & $<3.3$ & $<2.0$ & $<5.0$ & $<1.6$ & $<3.4$ & $<8.6$ & $<1.5$ \\
\hline SW15 & $<8.0$ & $<8.0$ & $<3.3$ & $<2.0$ & $<5.0$ & $<1.6$ & $<3.4$ & $<8.6$ & $<1.5$ \\
\hline SW16 & $<8.0$ & $<8.0$ & $<3.3$ & $<2.0$ & $<5.0$ & $<1.6$ & $<3.4$ & $<8.6$ & $<1.5$ \\
\hline SW 17 & $<8.0$ & $<8.0$ & $<3.3$ & $<2.0$ & $<5.0$ & $<1.6$ & $<3.4$ & $<8.6$ & $<1.5$ \\
\hline SW 18 & $<8.0$ & $<8.0$ & $<3.3$ & $<2.0$ & $<5.0$ & $<1.6$ & $<3.4$ & $<8.6$ & $<1.5$ \\
\hline SW20 & $<8.0$ & $<8.0$ & $<3.3$ & $<2.0$ & $<5.0$ & $<1.6$ & $<3.4$ & $<8.6$ & $<1.5$ \\
\hline SW21 & $<8.0$ & $<8.0$ & $<3.3$ & $<2.0$ & $<5.0$ & $<1.6$ & $<3.4$ & $<8.6$ & $<1.5$ \\
\hline \multicolumn{10}{|c|}{ Estuarine samples: } \\
\hline SW04 & $<8.0$ & $<8.0$ & $<3.3$ & $<2.0$ & $<5.0$ & $<1.6$ & $<3.4$ & $<8.6$ & $<1.5$ \\
\hline SW06 & $<8.0$ & $<8.0$ & $<3.3$ & $<2.0$ & $<5.0$ & $<1.6$ & $<3.4$ & $<8.6$ & $<1.5$ \\
\hline SW07 & $<8.0$ & $<8.0$ & $<3.3$ & $<2.0$ & $<5.0$ & $<1.6$ & $<3.4$ & $<8.6$ & $<1.5$ \\
\hline SW 10 & $<8.0$ & $<8.0$ & $<3.3$ & $<2.0$ & $<5.0$ & $<1.6$ & $<3.4$ & $<8.6$ & $<1.5$ \\
\hline SW11 & $<8.0$ & $<8.0$ & $<3.3$ & $<2.0$ & $<5.0$ & $<1.6$ & $<3.4$ & $<8.6$ & $<1.5$ \\
\hline SW11 (R) & $<8.0$ & $<8.0$ & $<3.3$ & $<2.0$ & $<5.0$ & $<1.6$ & $<3.4$ & $<8.6$ & $<1.5$ \\
\hline SW19 & $<8.0$ & $<8.0$ & $<3.3$ & $<2.0$ & $<5.0$ & $<1.6$ & $<3.4$ & $<8.6$ & $<1.5$ \\
\hline
\end{tabular}


Table 16. Results of organic-chemical analyses of surface water from selected sampling sites at Carroll Island, Aberdeen Proving Ground, Md., spring 1989--Continued

\begin{tabular}{|c|c|c|c|c|c|c|c|c|c|}
\hline $\begin{array}{l}\text { Sampling } \\
\text { site } \\
\text { (fig. 4) }\end{array}$ & $\begin{array}{l}\text { Hexa- } \\
\text { decanoic } \\
\text { acid }\end{array}$ & $\begin{array}{c}\text { Tndeno } \\
{[1,2,3-c, d]} \\
\text { pyrene }\end{array}$ & Isophorone & Lindane & $\begin{array}{l}\text { Methoxy- } \\
\text { chlor }\end{array}$ & $\begin{array}{l}\text { Methyl- } \\
\text { n-butyl } \\
\text { ketone }\end{array}$ & $\begin{array}{l}\text { 3-Methyl- } \\
\text { 4-chloro- } \\
\text { phenol }\end{array}$ & $\begin{array}{c}\text { 2-Methyl- } \\
\text { 4,6-di- } \\
\text { nitrophenol }\end{array}$ & $\begin{array}{l}\text { Methyl- } \\
\text { isobutyl } \\
\text { ketone }\end{array}$ \\
\hline \multicolumn{10}{|c|}{ Inland samples: } \\
\hline SW01 & -- & $<8.6$ & $<4.8$ & $<4.0$ & $<5.1$ & $<3.6$ & $<4.0$ & $<17.0$ & $<3.0$ \\
\hline SW02 & -- & $<8.6$ & $<4.8$ & $<4.0$ & $<5.1$ & $<3.6$ & $<4.0$ & $<17.0$ & $<3.0$ \\
\hline SW03 & -- & $<8.6$ & $<4.8$ & $<4.0$ & $<5.1$ & $<3.6$ & $<4.0$ & $<17.0$ & $<3.0$ \\
\hline SW05 & -- & $<8.6$ & $<4.8$ & $<4.0$ & $<5.1$ & $<3.6$ & $<4.0$ & $<17.0$ & $<3.0$ \\
\hline SW08 & -- & $<8.6$ & $<4.8$ & $<4.0$ & $<5.1$ & $<3.6$ & $<4.0$ & $<17.0$ & $<3.0$ \\
\hline SW09 & - & $<8.6$ & $<4.8$ & $<4.0$ & $<5.1$ & $<3.6$ & $<4.0$ & $<17.0$ & $<3.0$ \\
\hline SW09 (R) & -. & $<8.6$ & $<4.8$ & $<4.0$ & $<5.1$ & $<3.6$ & $<4.0$ & $<17.0$ & $<3.0$ \\
\hline SW09 (S) & - & -. & -- & -- & -- & -- & -- & $-\cdot$ & -- \\
\hline SW 12 & 2.0 & $<8.6$ & $<4.8$ & $<4.0$ & $<5.1$ & $<3.6$ & $<4.0$ & $<17.0$ & $<3.0$ \\
\hline SW13 & -- & $<8.6$ & $<4.8$ & $<4.0$ & $<5.1$ & $<3.6$ & $<4.0$ & $<17.0$ & $<3.0$ \\
\hline SW14 & 4.0 & $<8.6$ & $<4.8$ & $<4.0$ & $<5.1$ & $<3.6$ & $<4.0$ & $<17.0$ & $<3.0$ \\
\hline SW15 & -- & $<8.6$ & $<4.8$ & $<4.0$ & $<5.1$ & $<3.6$ & $<4.0$ & $<17.0$ & $<3.0$ \\
\hline SW 16 & 2.0 & $<8.6$ & $<4.8$ & $<4.0$ & $<5.1$ & $<3.6$ & $<4.0$ & $<17.0$ & $<3.0$ \\
\hline SW17 & 3.0 & $<8.6$ & $<4.8$ & $<4.0$ & $<5.1$ & $<3.6$ & $<4.0$ & $<17.0$ & $<3.0$ \\
\hline SW 18 & -- & $<8.6$ & $<4.8$ & $<4.0$ & $<5.1$ & $<3.6$ & $<4.0$ & $<17.0$ & $<3.0$ \\
\hline SW20 & 2.0 & $<8.6$ & $<4.8$ & $<4.0$ & $<5.1$ & $<3.6$ & $<4.0$ & $<17.0$ & $<3.0$ \\
\hline SW21 & 3.0 & $<8.6$ & $<4.8$ & $<4.0$ & $<5.1$ & $<3.6$ & $<4.0$ & $<17.0$ & $<3.0$ \\
\hline \multicolumn{10}{|c|}{ Estuarine samples: } \\
\hline Sw04 & -- & $<8.6$ & $<4.8$ & $<4.0$ & $<5.1$ & $<3.6$ & $<4.0$ & $<17.0$ & $<3.0$ \\
\hline SW06 & -- & $<8.6$ & $<4.8$ & $<4.0$ & $<5.1$ & $<3.6$ & $<4.0$ & $<17.0$ & $<3.0$ \\
\hline SW07 & -- & $<8.6$ & $<4.8$ & $<4.0$ & $<5.1$ & $<3.6$ & $<4.0$ & $<17.0$ & $<3.0$ \\
\hline SW10 & -- & $<8.6$ & $<4.8$ & $<4.0$ & $<5.1$ & $<3.6$ & $<4.0$ & $<17.0$ & $<3.0$ \\
\hline SW11 & -- & $<8.6$ & $<4.8$ & $<4.0$ & $<5.1$ & $<3.6$ & $<4.0$ & $<17.0$ & $<3.0$ \\
\hline SW11 (R) & - & $<8.6$ & $<4.8$ & $<4.0$ & $<5.1$ & $<3.6$ & $<4.0$ & $<17.0$ & $<3.0$ \\
\hline SW19 & -- & $<8.6$ & $<4.8$ & $<4.0$ & $<5.1$ & $<3.6$ & $<4.0$ & $<17.0$ & $<3.0$ \\
\hline $\begin{array}{c}\text { Sampling } \\
\text { site } \\
\text { (fig. 4) } \\
\end{array}$ & $\begin{array}{c}\text { Methyl- } \\
\text { ethyl } \\
\text { ketone }\end{array}$ & $\begin{array}{c}\text { 2-Methyl- } \\
\text { naph- } \\
\text { thalene }\end{array}$ & $\begin{array}{c}\text { 2-Methyl- } \\
\text { phenol }\end{array}$ & $\begin{array}{c}\text { 4-Methyl- } \\
\text { phenol }\end{array}$ & $\begin{array}{l}\text { Naph- } \\
\text { thalene }\end{array}$ & $\begin{array}{l}\text { 2-Nitro- } \\
\text { aniline }\end{array}$ & $\begin{array}{l}\text { 3-Nitro- } \\
\text { aniline }\end{array}$ & $\begin{array}{l}\text { 4-Nitro- } \\
\text { aniline }\end{array}$ & $\begin{array}{c}\text { Nitro- } \\
\text { benzene }\end{array}$ \\
\hline \multicolumn{10}{|c|}{ Inland samples: } \\
\hline SW01 & $<6.4$ & $<1.7$ & $<3.9$ & $<0.52$ & $<0.5$ & $<4.3$ & $<4.9$ & $<5.2$ & $<0.5$ \\
\hline SW02 & $<6.4$ & $<1.7$ & $<3.9$ & $<.52$ & $<.5$ & $<4.3$ & $<4.9$ & $<5.2$ & $<.5$ \\
\hline SW03 & $<6.4$ & $<1.7$ & $<3.9$ & $<.52$ & $<.5$ & $<4.3$ & $<4.9$ & $<5.2$ & $<.5$ \\
\hline SW05 & $<6.4$ & $<1.7$ & $<3.9$ & $<.52$ & $<.5$ & $<4.3$ & $<4.9$ & $<5.2$ & $<.5$ \\
\hline SW08 & $<6.4$ & $<1.7$ & $<3.9$ & $<.52$ & $<.5$ & $<4.3$ & $<4.9$ & $<5.2$ & $<.5$ \\
\hline SW09 & $<6.4$ & $<1.7$ & $<3.9$ & $<.52$ & $<.5$ & $<4.3$ & $<4.9$ & $<5.2$ & $<.5$ \\
\hline SW09 (R) & $<6.4$ & $<1.7$ & $<3.9$ & $<.52$ & $<.5$ & $<4.3$ & $<4.9$ & $<5.2$ & $<.5$ \\
\hline SW09 (S) & -- & -- & -- & -. & -- & -- & -- & -- & -- \\
\hline SW12 & $<6.4$ & $<1.7$ & $<3.9$ & $<.52$ & $<.5$ & $<4.3$ & $<4.9$ & $<5.2$ & $<.5$ \\
\hline SW13 & $<6.4$ & $<1.7$ & $<3.9$ & $<.52$ & $<.5$ & $<4.3$ & $<4.9$ & $<5.2$ & $<.5$ \\
\hline SW14 & $<6.4$ & $<1.7$ & $<3.9$ & $<.52$ & $<.5$ & $<4.3$ & $<4.9$ & $<5.2$ & $<.5$ \\
\hline SW15 & $<6.4$ & $<1.7$ & $<3.9$ & $<.52$ & $<.5$ & $<4.3$ & $<4.9$ & $<5.2$ & $<.5$ \\
\hline SW16 & $<6.4$ & $<1.7$ & $<3.9$ & $<.52$ & $<.5$ & $<4.3$ & $<4.9$ & $<5.2$ & $<.5$ \\
\hline SW17 & $<6.4$ & $<1.7$ & $<3.9$ & $<.52$ & $<.5$ & $<4.3$ & $<4.9$ & $<5.2$ & $<.5$ \\
\hline SW18 & $<6.4$ & $<1.7$ & $<3.9$ & $<.52$ & $<.5$ & $<4.3$ & $<4.9$ & $<5.2$ & $<.5$ \\
\hline SW20 & $<6.4$ & $<1.7$ & $<3.9$ & $<.52$ & $<.5$ & $<4.3$ & $<4.9$ & $<5.2$ & $<.5$ \\
\hline SW21 & $<6.4$ & $<1.7$ & $<3.9$ & $<.52$ & $<.5$ & $<4.3$ & $<4.9$ & $<5.2$ & $<.5$ \\
\hline \multicolumn{10}{|c|}{ Estuarine samples: } \\
\hline SW04 & $<6.4$ & $<1.7$ & $<3.9$ & $<.52$ & $<.5$ & $<4.3$ & $<4.9$ & $<5.2$ & $<.5$ \\
\hline SW06 & $<6.4$ & $<1.7$ & $<3.9$ & $<.52$ & $<.5$ & $<4.3$ & $<4.9$ & $<5.2$ & $<.5$ \\
\hline SW07 & $<6.4$ & $<1.7$ & $<3.9$ & $<.52$ & $<.5$ & $<4.3$ & $<4.9$ & $<5.2$ & $<.5$ \\
\hline SW10 & $<6.4$ & $<1.7$ & $<3.9$ & $<.52$ & $<.5$ & $<4.3$ & $<4.9$ & $<5.2$ & $<.5$ \\
\hline SW11 & $<6.4$ & $<1.7$ & $<3.9$ & $<.52$ & $<.5$ & $<4.3$ & $<4.9$ & $<5.2$ & $<.5$ \\
\hline SW11 (R) & $<6.4$ & $<1.7$ & $<3.9$ & $<.52$ & $<.5$ & $<4.3$ & $<4.9$ & $<5.2$ & $<.5$ \\
\hline SW19 & $<6.4$ & $<1.7$ & $<3.9$ & $<.52$ & $<.5$ & $<4.3$ & $<4.9$ & $<5.2$ & $<.5$ \\
\hline
\end{tabular}


Table 16. Results of organic-chemical analyses of surface water from selected sampling sites at Carroll Island, Aberdeen Proving Ground, Md., spring 1989--Continued

\begin{tabular}{|c|c|c|c|c|c|c|c|c|c|}
\hline $\begin{array}{c}\text { Sampling } \\
\text { site } \\
\text { (fig. 4) }\end{array}$ & $\begin{array}{l}\text { 2-Nitro- } \\
\text { phenol }\end{array}$ & $\begin{array}{l}\text { 4-Nitro- } \\
\text { phenol }\end{array}$ & $\begin{array}{c}\text { N-Nitroso- } \\
\text { dimethyl- } \\
\text { amine }\end{array}$ & $\begin{array}{l}\text { N-Nitroso- } \\
\text { di-N-propyl- } \\
\text { amine }\end{array}$ & $\begin{array}{l}\text { N-Nitroso- } \\
\text { diphenyl- } \\
\text { amine }\end{array}$ & $\begin{array}{c}\text { 1,4-Oxa- } \\
\text { thiane }\end{array}$ & $\begin{array}{l}\text { PCB } \\
1016\end{array}$ & $\begin{array}{l}\text { PCB } \\
1221\end{array}$ & $\begin{array}{l}\text { PCB } \\
1232\end{array}$ \\
\hline \multicolumn{10}{|c|}{ Inland samples: } \\
\hline SW01 & $<3.7$ & $<12.0$ & $<2.0$ & $<4.4$ & $<3.0$ & $<1.98$ & $<21.0$ & $<21.0$ & $<21.0$ \\
\hline SW02 & $<3.7$ & $<12.0$ & $<2.0$ & $<4.4$ & $<3.0$ & $<1.98$ & $<21.0$ & $<21.0$ & $<21.0$ \\
\hline SW03 & $<3.7$ & $<12.0$ & $<2.0$ & $<4.4$ & $<3.0$ & $<1.98$ & $<21.0$ & $<21.0$ & $<21.0$ \\
\hline SW05 & $<3.7$ & $<12.0$ & $<2.0$ & $<4.4$ & $<3.0$ & $<1.98$ & $<21.0$ & $<21.0$ & $<21.0$ \\
\hline SW08 & $<3.7$ & $<12.0$ & $<2.0$ & $<4.4$ & $<3.0$ & $<1.98$ & $<21.0$ & $<21.0$ & $<21.0$ \\
\hline SW09 & $<3.7$ & $<12.0$ & $<2.0$ & $<4.4$ & $<3.0$ & $<1.98$ & $<21.0$ & $<21.0$ & $<21.0$ \\
\hline SW09 (R) & $<3.7$ & $<12.0$ & $<2.0$ & $<4.4$ & $<3.0$ & $<1.98$ & $<21.0$ & $<21.0$ & $<21.0$ \\
\hline SW09 (S) & -- & -- & -- & -- & -- & -- & $\cdots$ & -- & -- \\
\hline SW12 & $<3.7$ & $<12.0$ & $<2.0$ & $<4.4$ & $<3.0$ & $<1.98$ & $<21.0$ & $<21.0$ & $<21.0$ \\
\hline SW13 & $<3.7$ & $<12.0$ & $<2.0$ & $<4.4$ & $<3.0$ & $<1.98$ & $<21.0$ & $<21.0$ & $<21.0$ \\
\hline SW14 & $<3.7$ & $<12.0$ & $<2.0$ & $<4.4$ & $<3.0$ & $<1.98$ & $<21.0$ & $<21.0$ & $<21.0$ \\
\hline SW15 & $<3.7$ & $<12.0$ & $<2.0$ & $<4.4$ & $<3.0$ & $<1.98$ & $<21.0$ & $<21.0$ & $<21.0$ \\
\hline SW16 & $<3.7$ & $<12.0$ & $<2.0$ & $<4.4$ & $<3.0$ & $<1.98$ & $<21.0$ & $<21.0$ & $<21.0$ \\
\hline SW17 & $<3.7$ & $<12.0$ & $<2.0$ & $<4.4$ & $<3.0$ & $<1.98$ & $<21.0$ & $<21.0$ & $<21.0$ \\
\hline SW18 & $<3.7$ & $<12.0$ & $<2.0$ & $<4.4$ & $<3.0$ & $<1.98$ & $<21.0$ & $<21.0$ & $<21.0$ \\
\hline SW20 & $<3.7$ & $<12.0$ & $<2.0$ & $<4.4$ & $<3.0$ & $<1.98$ & $<21.0$ & $<21.0$ & $<21.0$ \\
\hline SW21 & $<3.7$ & $<12.0$ & $<2.0$ & $<4.4$ & $<3.0$ & $<1.98$ & $<21.0$ & $<21.0$ & $<21.0$ \\
\hline \multicolumn{10}{|c|}{ Estuarine samples: } \\
\hline SW04 & $<3.7$ & $<12.0$ & $<2.0$ & $<4.4$ & $<3.0$ & $<1.98$ & $<21.0$ & $<21.0$ & $<21.0$ \\
\hline SW06 & $<3.7$ & $<12.0$ & $<2.0$ & $<4.4$ & $<3.0$ & $<1.98$ & $<21.0$ & $<21.0$ & $<21.0$ \\
\hline SW07 & $<3.7$ & $<12.0$ & $<2.0$ & $<4.4$ & $<3.0$ & $<1.98$ & $<21.0$ & $<21.0$ & $<21.0$ \\
\hline SW10 & $<3.7$ & $<12.0$ & $<2.0$ & $<4.4$ & $<3.0$ & $<1.98$ & $<21.0$ & $<21.0$ & $<21.0$ \\
\hline SW11 & $<3.7$ & $<12.0$ & $<2.0$ & $<4.4$ & $<3.0$ & $<1.98$ & $<21.0$ & $<21.0$ & $<21.0$ \\
\hline SW11 (R) & $<3.7$ & $<12.0$ & $<2.0$ & $<4.4$ & $<3.0$ & $<1.98$ & $<21.0$ & $<21.0$ & $<21.0$ \\
\hline SW19 & $<3.7$ & $<12.0$ & $<2.0$ & $<4.4$ & $<3.0$ & $<1.98$ & $<21.0$ & $<21.0$ & $<21.0$ \\
\hline
\end{tabular}

\begin{tabular}{|c|c|c|c|c|c|c|c|c|c|}
\hline $\begin{array}{c}\text { Sampling } \\
\text { site } \\
\text { (fig. 4) }\end{array}$ & $\begin{array}{l}\text { PCB } \\
1242\end{array}$ & $\begin{array}{l}\text { PCB } \\
1248 \\
\end{array}$ & $\begin{array}{l}\text { PCB } \\
1254 \\
\end{array}$ & $\begin{array}{l}\text { PCB } \\
1260\end{array}$ & $\begin{array}{c}\text { Pentachloro- } \\
\text { phenol }\end{array}$ & $\begin{array}{l}\text { Penta- } \\
\text { decanoic } \\
\text { acid }\end{array}$ & $\begin{array}{l}\text { Phenan- } \\
\text { threne }\end{array}$ & Phenol & Pyrene \\
\hline \multicolumn{10}{|c|}{ Inland samples: } \\
\hline SW01 & $<30.0$ & $<30.0$ & $<36.0$ & $<36.0$ & $<18.0$ & - & $<0.5$ & $<9.2$ & $<2.8$ \\
\hline SW02 & $<30.0$ & $<30.0$ & $<36.0$ & $<36.0$ & $<18.0$ & -- & $<.5$ & $<9.2$ & $<2.8$ \\
\hline SW03 & $<30.0$ & $<30.0$ & $<36.0$ & $<36.0$ & $<18.0$ & - & $<.5$ & $<9.2$ & $<2.8$ \\
\hline SW05 & $<30.0$ & $<30.0$ & $<36.0$ & $<36.0$ & $<18.0$ & -- & $<.5$ & $<9.2$ & $<2.8$ \\
\hline SW08 & $<30.0$ & $<30.0$ & $<36.0$ & $<36.0$ & $<18.0$ & - & $<.5$ & - & $<2.8$ \\
\hline SW09 & $<30.0$ & $<30.0$ & $<36.0$ & $<36.0$ & $<18.0$ & -- & $<.5$ & $<9.2$ & $<2.8$ \\
\hline SW09 (R) & $<30.0$ & $<30.0$ & $<36.0$ & $<36.0$ & $<18.0$ & - & $<.5$ & $<9.2$ & $<2.8$ \\
\hline SW09 (S) & -- & -- & -- & -- & -- & - & -- & -- & - \\
\hline SW12 & $<30.0$ & $<30.0$ & $<36.0$ & $<36.0$ & $<18.0$ & -- & $<.5$ & $<9.2$ & $<2.8$ \\
\hline SW13 & $<30.0$ & $<30.0$ & $<36.0$ & $<36.0$ & $<18.0$ & -- & $<.5$ & $<9.2$ & $<2.8$ \\
\hline SW14 & $<30.0$ & $<30.0$ & $<36.0$ & $<36.0$ & $<18.0$ & 3.0 & $<.5$ & $<9.2$ & $<2.8$ \\
\hline SW15 & $<30.0$ & $<30.0$ & $<36.0$ & $<36.0$ & $<18.0$ & -- & $<.5$ & $<9.2$ & $<2.8$ \\
\hline SW16 & $<30.0$ & $<30.0$ & $<36.0$ & $<36.0$ & $<18.0$ & -- & $<.5$ & $<9.2$ & $<2.8$ \\
\hline SW17 & $<30.0$ & $<30.0$ & $<36.0$ & $<36.0$ & $<18.0$ & -- & $<.5$ & $<9.2$ & $<2.8$ \\
\hline SW18 & $<30.0$ & $<30.0$ & $<36.0$ & $<36.0$ & $<18.0$ & -- & $<.5$ & $<9.2$ & $<2.8$ \\
\hline SW20 & $<30.0$ & $<30.0$ & $<36.0$ & $<36.0$ & $<18.0$ & -- & $<.5$ & $<9.2$ & $<2.8$ \\
\hline SW21 & $<30.0$ & $<30.0$ & $<36.0$ & $<36.0$ & $<18.0$ & - & $<.5$ & $<9.2$ & $<2.8$ \\
\hline \multicolumn{10}{|c|}{ Estuarine samples: } \\
\hline SW04 & $<30.0$ & $<30.0$ & $<36.0$ & $<36.0$ & $<18.0$ & -- & $<.5$ & $<9.2$ & $<2.8$ \\
\hline SW06 & $<30.0$ & $<30.0$ & $<36.0$ & $<36.0$ & $<18.0$ & -- & $<.5$ & $<9.2$ & $<2.8$ \\
\hline SW07 & $<30.0$ & $<30.0$ & $<36.0$ & $<36.0$ & $<18.0$ & - & $<.5$ & $<9.2$ & $<2.8$ \\
\hline SW10 & $<30.0$ & $<30.0$ & $<36.0$ & $<36.0$ & $<18.0$ & -- & $<.5$ & $<9.2$ & $<2.8$ \\
\hline SW11 & $<30.0$ & $<30.0$ & $<36.0$ & $<36.0$ & $<18.0$ & -- & $<.5$ & $<9.2$ & $<2.8$ \\
\hline SW11 (R) & $<30.0$ & $<30.0$ & $<36.0$ & $<36.0$ & $<18.0$ & -- & $<.5$ & $<9.2$ & $<2.8$ \\
\hline SW19 & $<30.0$ & $<30.0$ & $<36.0$ & $<36.0$ & $<18.0$ & -- & $<.5$ & $<9.2$ & $<2.8$ \\
\hline
\end{tabular}


Table 16. Results of organic-chemical analyses of surface water from selected sampling sites at Carroll Island, Aberdeen Proving Ground, Md., spring 1989--Continued

\begin{tabular}{|c|c|c|c|c|c|c|c|}
\hline $\begin{array}{l}\text { Sampling } \\
\text { site } \\
\text { (fig. 4) }\end{array}$ & Styrene & $\begin{array}{c}\text { Tetradecanoic } \\
\text { acid }\end{array}$ & Thiodiglycol & Toxaphene & $\begin{array}{c}1,2,4-T r i- \\
\text { chlorobenzene }\end{array}$ & $\begin{array}{c}\text { 2,4,5-Tri- } \\
\text { chlorophenol }\end{array}$ & $\begin{array}{l}\text { 2,4,6-Tri- } \\
\text { chlorophenol }\end{array}$ \\
\hline \multicolumn{8}{|c|}{ Inland samples: } \\
\hline sw01 & $<0.5$ & .- & $<187$ & $<36.0$ & $<1.8$ & $<5.2$ & $<4.2$ \\
\hline SW02 & $<.5$ & -- & $<187$ & $<36.0$ & $<1.8$ & $<5.2$ & $<4.2$ \\
\hline SW03 & $<.5$ & .- & $<187$ & $<36.0$ & $<1.8$ & $<5.2$ & $<4.2$ \\
\hline SW05 & $<.5$ & -- & $<187$ & $<36.0$ & $<1.8$ & $<5.2$ & $<4.2$ \\
\hline SW08 & $<.5$ & .- & $<187$ & $<36.0$ & $<1.8$ & $<5.2$ & $<4.2$ \\
\hline SW09 & $<.5$ & -- & $<187$ & $<36.0$ & $<1.8$ & $<5.2$ & $<4.2$ \\
\hline SW09 (R) & $<.5$ & -- & $<187$ & $<36.0$ & $<1.8$ & $<5.2$ & $<4.2$ \\
\hline SW09 (S) & -- & -. & -- & -- & -. & -- & -- \\
\hline SW12 & $<.5$ & .- & 138 & $<36.0$ & $<1.8$ & $<5.2$ & $<4.2$ \\
\hline SW13 & $<.5$ & -- & $<187$ & $<36.0$ & $<1.8$ & $<5.2$ & $<4.2$ \\
\hline SW14 & $<.5$ & 5.0 & $<187$ & $<36.0$ & $<1.8$ & $<5.2$ & $<4.2$ \\
\hline SW15 & $<.5$ & $\ldots$ & $<187$ & $<36.0$ & $<1.8$ & $<5.2$ & $<4.2$ \\
\hline SW16 & $<.5$ & .. & $<187$ & $<36.0$ & $<1.8$ & $<5.2$ & $<4.2$ \\
\hline SW17 & $<.5$ & .. & $<187$ & $<36.0$ & $<1.8$ & $<5.2$ & $<4.2$ \\
\hline SW18 & $<.5$ & -- & $<187$ & $<36.0$ & $<1.8$ & $<5.2$ & $<4.2$ \\
\hline SW20 & $<.5$ & -- & $<187$ & $<36.0$ & $<1.8$ & $<5.2$ & $<4.2$ \\
\hline SW21 & $<.5$ & -- & $<187$ & $<36.0$ & $<1.8$ & $<5.2$ & $<4.2$ \\
\hline \multicolumn{8}{|c|}{ Estuarine samples: } \\
\hline SW04 & $<.5$ & -- & $<187$ & $<36.0$ & $<1.8$ & $<5.2$ & $<4.2$ \\
\hline SW06 & $<.5$ & -- & $<187$ & $<36.0$ & $<1.8$ & $<5.2$ & $<4.2$ \\
\hline SW07 & $<.5$ & -- & $<187$ & $<36.0$ & $<1.8$ & $<5.2$ & $<4.2$ \\
\hline SW 10 & $<.5$ & - & $<187$ & $<36.0$ & $<1.8$ & $<5.2$ & $<4.2$ \\
\hline SW11 & $<.5$ & .. & $<187$ & $<36.0$ & $<1.8$ & $<5.2$ & $<4.2$ \\
\hline SW11 (R) & $<.5$ & $\ldots$ & $<187$ & $<36.0$ & $<1.8$ & $<5.2$ & $<4.2$ \\
\hline SW19 & $<.5$ & -- & $<187$ & $<36.0$ & $<1.8$ & $<5.2$ & $<4.2$ \\
\hline
\end{tabular}


Table 17. Results of inorganic-chemical analyses of soil from selected sampling sites at Carroll Island, Aberdeen Proving Ground, Md., summer 1990

[Concentrations (except silica) in micrograms per gram; silica concentrations in milligrams per gram; TKN, Total Kjeldahl Nitrogen; --, missing data; <, less than]

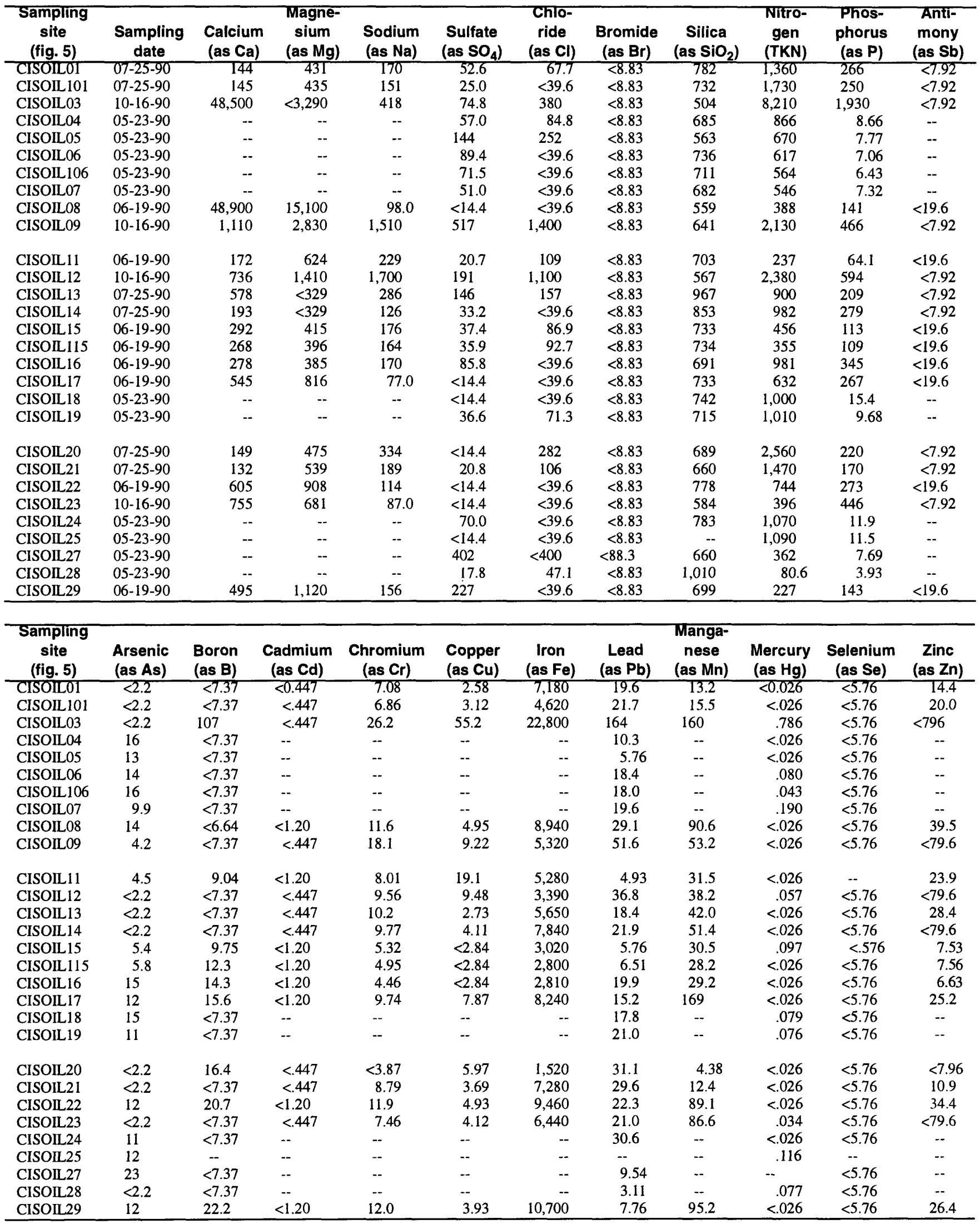


Table 18. Results of organic-chemical analyses of soil from selected sampling sites at Carroll Island, Aberdeen Proving Ground, Md., summer 1990

[Concentrations are in micrograms per gram; $<$, less than; --, missing data]

\begin{tabular}{|c|c|c|c|c|c|c|c|c|c|}
\hline $\begin{array}{c}\text { Sampling } \\
\text { site } \\
\text { (fig. 5) }\end{array}$ & $\begin{array}{c}\text { Sampling } \\
\text { date }\end{array}$ & Benzene & $\begin{array}{l}\text { Bromo- } \\
\text { dichloro- } \\
\text { methane }\end{array}$ & $\begin{array}{c}\text { Bromo- } \\
\text { form }\end{array}$ & $\begin{array}{c}\text { Carbon } \\
\text { tetra- } \\
\text { chloride }\end{array}$ & $\begin{array}{c}\text { Chloro- } \\
\text { benzene }\end{array}$ & $\begin{array}{l}\text { Chloro- } \\
\text { ethane }\end{array}$ & $\begin{array}{l}\text { Chloro- } \\
\text { ethene }\end{array}$ & $\begin{array}{c}\text { 2-Chroro- } \\
\text { ethyl- } \\
\text { vinyl ether }\end{array}$ \\
\hline CISOILOI & $07-25-90$ & $<0.003$ & $<0.003$ & $<0.018$ & $<0.006$ & $<0.003$ & $<0.027$ & $<0.015$ & $<0.048$ \\
\hline CISOIL101 & $07-25-90$ & $<.003$ & $<.003$ & $<.018$ & $<.006$ & $<.003$ & $<.027$ & $<.015$ & $<.048$ \\
\hline CISOIL03 & $10-16-90$ & $<.003$ & $<.003$ & $<.018$ & $<.006$ & $<.003$ & $<.027$ & $<.015$ & $<.048$ \\
\hline CISOIL04 & $05-23-90$ & $<.003$ & $<.003$ & $<.018$ & $<.006$ & $<.003$ & $<.027$ & $<.015$ & $<.048$ \\
\hline CISOIL05 & $05-23-90$ & $<.003$ & $<.003$ & $<.018$ & $<.006$ & $<.003$ & $<.027$ & $<.015$ & $<.048$ \\
\hline CISOIL06 & $05-23-90$ & $<.003$ & $<.003$ & $<.018$ & $<.006$ & $<.003$ & $<.027$ & $<.015$ & $<.048$ \\
\hline CISOILI06 & $05-23-90$ & $<.003$ & $<.003$ & $<.018$ & $<.006$ & $<.003$ & $<.027$ & $<.015$ & $<.048$ \\
\hline CISOIL07 & $05-23-90$ & $<.003$ & $<.003$ & $<.018$ & $<.006$ & $<.003$ & $<.027$ & $<.015$ & $<.048$ \\
\hline CISOIL08 & $06-19-90$ & $<.003$ & $<.003$ & $<.018$ & $<.006$ & $<.003$ & $<.027$ & $<.015$ & $<.048$ \\
\hline CISOIL09 & $10-16-90$ & $<.003$ & $<.003$ & $<.018$ & $<.006$ & $<.003$ & $<.027$ & $<.015$ & $<.048$ \\
\hline CISOILII & $06-19-90$ & $<.003$ & $<.003$ & $<.018$ & $<.006$ & $<.003$ & $<.027$ & $<.015$ & $<.048$ \\
\hline CISOIL 12 & $10-16-90$ & $<.003$ & $<.003$ & $<.018$ & $<.006$ & $<.003$ & $<.027$ & $<.015$ & $<.048$ \\
\hline CISOIL13 & $07-25-90$ & $<.003$ & $<.003$ & $<.018$ & $<.006$ & $<.003$ & $<.027$ & $<.015$ & $<.048$ \\
\hline CISOIL 14 & $07-25-90$ & $<.003$ & $<.003$ & $<.018$ & $<.006$ & $<.003$ & $<.027$ & $<.015$ & $<.048$ \\
\hline CISOIL15 & $06-19-90$ & $<.003$ & $<.003$ & $<.018$ & $<.006$ & $<.003$ & $<.027$ & $<.015$ & $<.048$ \\
\hline CISOIL115 & $06-19-90$ & $<.003$ & $<.003$ & $<.018$ & $<.006$ & $<.003$ & $<.027$ & $<.015$ & $<.048$ \\
\hline CISOIL16 & $06-19-90$ & $<.003$ & $<.003$ & $<.018$ & $<.006$ & $<.003$ & $<.027$ & $<.015$ & $<.048$ \\
\hline CISOIL17 & $06-19-90$ & $<.003$ & $<.003$ & $<.018$ & $<.006$ & $<.003$ & $<.027$ & $<.015$ & $<.048$ \\
\hline CISOIL 18 & $05-23-90$ & $<.003$ & $<.003$ & $<.018$ & $<.006$ & $<.003$ & $<.027$ & $<.015$ & $<.048$ \\
\hline CISOIL19 & $05-23-90$ & $<.003$ & $<.003$ & $<.018$ & $<.006$ & $<.003$ & $<.027$ & $<.015$ & $<.048$ \\
\hline CISOIL20 & $07-25-90$ & $<.003$ & $<.003$ & $<.018$ & $<.006$ & $<.003$ & $<.027$ & $<.015$ & $<.048$ \\
\hline CISOIL21 & $07-25-90$ & $<.003$ & $<.003$ & $<.018$ & $<.006$ & $<.003$ & $<.027$ & $<.015$ & $<.048$ \\
\hline CISOIL22 & $06-19-90$ & $<.003$ & $<.003$ & $<.018$ & $<.006$ & $<.003$ & $<.027$ & $<.015$ & $<.048$ \\
\hline CISOIL 23 & $10-16-90$ & $<.003$ & $<.003$ & $<.018$ & $<.006$ & $<.003$ & $<.027$ & $<.015$ & $<.048$ \\
\hline CISOIL24 & $05-23-90$ & $<.003$ & $<.003$ & $<.018$ & $<.006$ & $<.003$ & $<.027$ & $<.015$ & $<.048$ \\
\hline CISOIL25 & $05-23-90$ & $<.003$ & $<.003$ & $<.018$ & $<.006$ & $<.003$ & $<.027$ & $<.015$ & $<.048$ \\
\hline CISOIL27 & $05-23-90$ & $<.003$ & $<.003$ & $<.018$ & $<.006$ & $<.003$ & $<.027$ & $<.015$ & $<.048$ \\
\hline CISOIL28 & $05-23-90$ & $<.003$ & $<.003$ & $<.018$ & $<.006$ & $<.003$ & $<.027$ & $<.015$ & $<.048$ \\
\hline CISOIL29 & $06-19-90$ & $<.003$ & $<.003$ & $<.018$ & $<.006$ & $<.003$ & $<.027$ & $<.015$ & $<.048$ \\
\hline $\begin{array}{c}\text { Sampling } \\
\text { site } \\
\text { (fig. 5) }\end{array}$ & $\begin{array}{l}\text { Chloro- } \\
\text { form }\end{array}$ & $\begin{array}{l}\text { Chloro- } \\
\text { methane }\end{array}$ & $\begin{array}{l}\text { Dibromo- } \\
\text { chloro- } \\
\text { methane }\end{array}$ & $\begin{array}{c}\text { 1,2-DI- } \\
\text { chloro- } \\
\text { benzene }\end{array}$ & \multicolumn{2}{|c|}{$\begin{array}{l}\text { T,3-DI- } \\
\text { chloro- } \\
\text { benzene }\end{array}$} & $\begin{array}{c}\text { 1,4-DI- } \\
\text { chloro- } \\
\text { benzene }\end{array}$ & $\begin{array}{l}\text { T,1-Di- } \\
\text { chloro- } \\
\text { ethane }\end{array}$ & $\begin{array}{l}\text { T,2-Di- } \\
\text { chloro- } \\
\text { ethane }\end{array}$ \\
\hline CISOILOI & $<0.002$ & $<0.017$ & $<0.014$ & $<0.001$ & \multicolumn{2}{|c|}{$<0.002$} & $<0.001$ & $<0.002$ & $<0.003$ \\
\hline CISOIL101 & $<.002$ & $<.017$ & $<.014$ & $<.001$ & \multicolumn{2}{|c|}{$\begin{array}{l}<.002 \\
<.002\end{array}$} & $<.001$ & $<.002$ & $<.003$ \\
\hline CISOIL03 & $<.002$ & $<.017$ & $<.014$ & $<.001$ & \multicolumn{2}{|c|}{$\begin{array}{l}<.002 \\
<.002\end{array}$} & $<.001$ & $<.002$ & $<.003$ \\
\hline CISOILO4 & $<.002$ & $<.017$ & $<.014$ & $<.001$ & \multirow{2}{*}{\multicolumn{2}{|c|}{$\begin{array}{l}<.002 \\
<.002\end{array}$}} & $<.001$ & $<.002$ & $<.003$ \\
\hline CISOIL05 & $<.002$ & $<.017$ & $<.014$ & $<.001$ & \multirow{2}{*}{\multicolumn{2}{|c|}{$\begin{array}{l}<.002 \\
<.002\end{array}$}} & $<.001$ & $<.002$ & $<.003$ \\
\hline CISOIL06 & $<.002$ & $<.017$ & $<.014$ & $<.001$ & & & $<.001$ & $<.002$ & $<.003$ \\
\hline CISOIL106 & $<.002$ & $<.017$ & $<.014$ & $<.001$ & \multicolumn{2}{|c|}{$\begin{array}{l}<.002 \\
<.002\end{array}$} & & $<.002$ & $<.003$ \\
\hline CISOIL07 & $<.002$ & $<.017$ & $<.014$ & $<.001$ & $<$. & & & $<.002$ & $<.003$ \\
\hline CISOIL08 & $<.002$ & $<.017$ & $<.014$ & $<.001$ & $<$. & & 01 & $<.002$ & $<.003$ \\
\hline CISOIL09 & $<.002$ & $<.017$ & $<.014$ & $<.001$ & $<. C$ & & & $<.002$ & $<.003$ \\
\hline CISOIL11 & $<.002$ & $<.017$ & $<.014$ & $<.001$ & $<$. & & & $<.002$ & $<.003$ \\
\hline CISOIL12 & $<.002$ & $<.017$ & $<.014$ & $<.001$ & $<. c$ & & & $<.002$ & $<.003$ \\
\hline CISOIL13 & $<.002$ & $<.017$ & $<.014$ & $<.001$ & $<$. & & & $<.002$ & $<.003$ \\
\hline CISOIL14 & $<.002$ & $<.017$ & $<.014$ & $<.001$ & $<$. & & & $<.002$ & $<.003$ \\
\hline CISOIL15 & $<.002$ & $<.017$ & $<.014$ & $<.001$ & $<$. & & & $<.002$ & $<.003$ \\
\hline CISOIL115 & $<.002$ & $<.017$ & $<.014$ & $<.001$ & $<$. & & 01 & $<.002$ & $<.003$ \\
\hline CISOIL16 & $<.002$ & $<.017$ & $<.014$ & $<.001$ & $<. C$ & & & $<.002$ & $<.003$ \\
\hline CISOIL17 & $<.002$ & $<.017$ & $<.014$ & $<.001$ & $<$. & & & $<.002$ & $<.003$ \\
\hline CISOIL18 & $<.002$ & $<.017$ & $<.014$ & $<.001$ & $<$. & & & $<.002$ & $<.003$ \\
\hline CISOIL19 & $<.002$ & $<.017$ & $<.014$ & $<.001$ & $<$. & & & $<.002$ & $<.003$ \\
\hline CISOIL20 & $<.002$ & $<.017$ & $<.014$ & $<.001$ & $<$. & & & $<.002$ & $<.003$ \\
\hline CISOIL21 & $<.002$ & $<.017$ & $<.014$ & $<.001$ & $<. C$ & & & $<.002$ & $<.003$ \\
\hline CISOIL22 & $<.002$ & $<.017$ & $<.014$ & $<.001$ & $<C$ & & & $<.002$ & $<.003$ \\
\hline CISOL23 & $<.002$ & $<.017$ & $<.014$ & $<.001$ & $<$. & & & $<.002$ & $<.003$ \\
\hline CISOIL24 & $<.002$ & $<.017$ & $<.014$ & $<.001$ & $<$. & & & $<.002$ & $<.003$ \\
\hline CISOIL25 & $<.002$ & $<.017$ & $<.014$ & $<.001$ & $<$. & & 101 & $<.002$ & $<.003$ \\
\hline CISOIL27 & $<.002$ & $<.017$ & $<.014$ & $<.001$ & $<$. & & 01 & $<.002$ & $<.003$ \\
\hline CISOIL28 & $<.002$ & $<.017$ & $<.014$ & $<.001$ & $<. C$ & & & $<.002$ & $<.003$ \\
\hline CISOIL29 & $<.002$ & $<.017$ & $<.014$ & $<.001$ & $<$. & & & $<.002$ & $<.003$ \\
\hline
\end{tabular}


Table 18. Results of organic-chemical analyses of soil from selected sampling sites at Carroll Island, Aberdeen Proving Ground, Md., summer 1990--Continued

\begin{tabular}{|c|c|c|c|c|c|c|c|c|}
\hline $\begin{array}{c}\text { Sampling } \\
\text { site } \\
\text { (fig. 5) }\end{array}$ & $\begin{array}{l}\text { 1,1-Di- } \\
\text { chloro- } \\
\text { ethylene }\end{array}$ & $\begin{array}{c}\text { 1,2-Di- } \\
\text { chloro- } \\
\text { ethylene }\end{array}$ & $\begin{array}{c}\text { 1,2-Di- } \\
\text { chloro- } \\
\text { propane }\end{array}$ & $\begin{array}{c}\text { 1,3-Di- } \\
\text { chloro- } \\
\text { propane }\end{array}$ & $\begin{array}{c}\text { CIS- } \\
\text { 1,3-Di- } \\
\text { chloro- } \\
\text { propene }\end{array}$ & $\begin{array}{l}\text { trans- } \\
\text { 1,3-Di- } \\
\text { chloro- } \\
\text { propene }\end{array}$ & $\begin{array}{c}\text { 1,2-Di- } \\
\text { methyl- } \\
\text { benzene }\end{array}$ & $\begin{array}{l}\text { 1,3-Di- } \\
\text { methyl- } \\
\text { benzene }\end{array}$ \\
\hline CISOILO & $<0.019$ & $<0.002$ & $<0.002$ & $<0.001$ & $<0.005$ & $<0.005$ & $<0.002$ & $<0.002$ \\
\hline CISOIL101 & $<.019$ & $<.002$ & $<.002$ & $<.001$ & $<.005$ & $<.005$ & $<.002$ & $<.002$ \\
\hline CISOIL03 & $<.019$ & $<.002$ & $<.002$ & $<.001$ & $<5.0$ & $<5.0$ & $<2.0$ & $<2.0$ \\
\hline CISOIL04 & $<.019$ & $<.002$ & $<.002$ & $<.001$ & $<.005$ & $<.005$ & $<.002$ & $<.002$ \\
\hline CISOIL05 & $<.019$ & $<.002$ & $<.002$ & $<.001$ & $<.005$ & $<.005$ & $<.002$ & $<.002$ \\
\hline CISOIL06 & $<.019$ & $<.002$ & $<.002$ & $<.001$ & $<.005$ & $<.005$ & $<.002$ & $<.002$ \\
\hline CISOIL106 & $<.019$ & $<.002$ & $<.002$ & $<.001$ & $<.005$ & $<.005$ & $<.002$ & $<.002$ \\
\hline CISOIL07 & $<.019$ & $<.002$ & $<.002$ & $<.001$ & $<.005$ & $<.005$ & $<.002$ & $<.002$ \\
\hline CISOIL08 & $<.019$ & $<.002$ & $<.002$ & $<.001$ & $<.005$ & $<.005$ & $<.002$ & $<.002$ \\
\hline CISOIL09 & $<.019$ & $<.002$ & $<.002$ & $<.001$ & $<5.0$ & $<5.0$ & $<2.0$ & $<2.0$ \\
\hline CISOIL11 & $<.019$ & $<.002$ & $<.002$ & $<.001$ & $<.005$ & $<.005$ & $<.002$ & $<.002$ \\
\hline CISOIL12 & $<.019$ & $<.002$ & $<.002$ & $<.001$ & $<5.0$ & $<5.0$ & $<2.0$ & $<2.0$ \\
\hline CISOIL13 & $<.019$ & $<.002$ & $<.002$ & $<.001$ & $<.005$ & $<.005$ & $<.002$ & $<.002$ \\
\hline CISOIL14 & $<.019$ & $<.002$ & $<.002$ & $<.001$ & $<.005$ & $<.005$ & $<.002$ & $<.002$ \\
\hline CISOIL15 & $<.019$ & $<.002$ & $<.002$ & $<.001$ & $<.005$ & $<.005$ & $<.002$ & $<.002$ \\
\hline CISOIL115 & $<.019$ & $<.002$ & $<.002$ & $<.001$ & $<.005$ & $<.005$ & $<.002$ & $<.002$ \\
\hline CISOIL16 & $<.019$ & $<.002$ & $<.002$ & $<.001$ & $<.005$ & $<.005$ & $<.002$ & $<.002$ \\
\hline CISOIL17 & $<.019$ & $<.002$ & $<.002$ & $<.001$ & $<.005$ & $<.005$ & $<.002$ & $<.002$ \\
\hline CISOIL18 & $<.019$ & $<.002$ & $<.002$ & $<.001$ & $<.005$ & $<.005$ & $<.002$ & $<.002$ \\
\hline CISOIL19 & $<.019$ & $<.002$ & $<.002$ & $<.001$ & $<.005$ & $<.005$ & $<.002$ & $<.002$ \\
\hline CISOIL20 & $<.019$ & $<.002$ & $<.002$ & $<.001$ & $<.005$ & $<.005$ & $<.002$ & $<.002$ \\
\hline CISOIL21 & $<.019$ & $<.002$ & $<.002$ & $<.001$ & $<.005$ & $<.005$ & $<.002$ & $<.002$ \\
\hline CISOIL22 & $<.019$ & $<.002$ & $<.002$ & $<.001$ & $<.005$ & $<.005$ & $<.002$ & $<.002$ \\
\hline CISOIL23 & $<.019$ & $<.002$ & $<.002$ & $<.001$ & $<5.0$ & $<5.0$ & $<2.0$ & $<2.0$ \\
\hline CISOIL24 & $<.019$ & $<.002$ & $<.002$ & $<.001$ & $<.005$ & $<.005$ & $<.002$ & $<.002$ \\
\hline CISOIL25 & $<.019$ & $<.002$ & $<.002$ & $<.001$ & $<.005$ & $<.005$ & $<.002$ & $<.002$ \\
\hline CISOIL27 & $<.019$ & $<.002$ & $<.002$ & $<.001$ & $<.005$ & $<.005$ & $<.002$ & $<.002$ \\
\hline CISOIL28 & $<.019$ & $<.002$ & $<.002$ & $<.001$ & $<.005$ & $<.005$ & $<.002$ & $<.002$ \\
\hline CISOIL29 & $<.019$ & $<.002$ & $<.002$ & $<.001$ & $<.005$ & $<.005$ & $<.002$ & $<.002$ \\
\hline $\begin{array}{c}\text { Sampling } \\
\text { site } \\
\text { (fig. 5) }\end{array}$ & $\begin{array}{l}\text { Ethyl- } \\
\text { benzene }\end{array}$ & Fluorene & $\begin{array}{l}\text { Methylene } \\
\text { chloride }\end{array}$ & $\begin{array}{c}\text { 1,1,2,2- } \\
\text { Tetra- } \\
\text { chloro- } \\
\text { ethane }\end{array}$ & $\begin{array}{l}\text { Tetra- } \\
\text { chloro- } \\
\text { ethylene }\end{array}$ & Toluene & $\begin{array}{c}\text { 1,1,1- } \\
\text { Trichloro- } \\
\text { ethane }\end{array}$ & $\begin{array}{c}\text { 1,1,2- } \\
\text { Trichloro- } \\
\text { ethane }\end{array}$ \\
\hline CISOILOI & $<0.003$ & $<0.33$ & $<0.006$ & $<0.002$ & $<0.002$ & $<0.008$ & $<0.004$ & $<0.020$ \\
\hline CISOIL101 & $<.003$ & $<.33$ & $<.006$ & $<.002$ & $<.002$ & $<.008$ & $<.004$ & $<.020$ \\
\hline CISOIL03 & $<.003$ & $<.33$ & $<.006$ & $<.002$ & $<.002$ & $<.008$ & $<.004$ & $<.020$ \\
\hline CISOIL04 & $<.003$ & $<.33$ & $<.006$ & .23 & $<.002$ & $<.008$ & $<.004$ & $<.020$ \\
\hline CISOIL05 & $<.003$ & $<.33$ & $<.006$ & $<.002$ & $<.002$ & $<.008$ & $<.004$ & $<.020$ \\
\hline CISOIL06 & $<.003$ & $<.33$ & $<.006$ & $<.002$ & $<.002$ & $<.008$ & $<.004$ & $<.020$ \\
\hline CISOIL106 & $<.003$ & $<.33$ & $<.006$ & $<.002$ & $<.002$ & $<.008$ & $<.004$ & $<.020$ \\
\hline CISOIL07 & $<.003$ & $<.33$ & $<.006$ & $<.002$ & $<.002$ & $<.008$ & $<.004$ & $<.020$ \\
\hline CISOIL08 & $<.003$ & $<.33$ & $<.006$ & $<.002$ & $<.002$ & $<.008$ & $<.004$ & $<.020$ \\
\hline CISOIL09 & $<.003$ & $<.33$ & $<.006$ & $<.002$ & $<.002$ & $<.008$ & $<.004$ & $<.020$ \\
\hline CISOIL11 & $<.003$ & $<.33$ & .016 & $<.002$ & $<.002$ & $<.008$ & $<.004$ & $<.020$ \\
\hline CISOIL 12 & $<.003$ & $<.33$ & $<.006$ & $<.002$ & $<.002$ & $<.008$ & $<.004$ & $<.020$ \\
\hline CISOIL13 & $<.003$ & $<.33$ & $<.006$ & $<.002$ & $<.002$ & $<.008$ & $<.004$ & $<.020$ \\
\hline CISOIL 14 & $<.003$ & $<.33$ & $<.006$ & $<.002$ & $<.002$ & $<.008$ & $<.004$ & $<.020$ \\
\hline CISOIL15 & $<.003$ & $<.33$ & $<.006$ & $<.002$ & $<.002$ & $<.008$ & $<.004$ & $<.020$ \\
\hline CISOLL115 & $<.003$ & $<.33$ & $<.006$ & $<.002$ & $<.002$ & $<.008$ & $<.004$ & $<.020$ \\
\hline CISOIL16 & $<.003$ & $<.33$ & $<.006$ & $<.002$ & $<.002$ & $<.008$ & $<.004$ & $<.020$ \\
\hline CISOIL17 & $<.003$ & $<.33$ & $<.006$ & .24 & $<.002$ & $<.008$ & $<.004$ & $<.020$ \\
\hline CISOIL 18 & $<.003$ & $<.33$ & $<.006$ & $<.002$ & $<.002$ & $<.008$ & $<.004$ & $<.020$ \\
\hline CISOIL19 & $<.003$ & $<.33$ & $<.006$ & .26 & $<.002$ & $<.008$ & $<.004$ & $<.020$ \\
\hline CISOIL20 & $<.003$ & $<.33$ & $<.006$ & $<.002$ & $<.002$ & $<.008$ & $<.004$ & $<.020$ \\
\hline CISOIL21 & $<.003$ & $<.33$ & $<.006$ & $<.002$ & $<.002$ & $<.008$ & $<.004$ & $<.020$ \\
\hline CISOIL22 & $<.003$ & $<.33$ & $<.006$ & $<.002$ & $<.002$ & $<.008$ & $<.004$ & $<.020$ \\
\hline CISOIL23 & $<.003$ & $<.33$ & $<.006$ & $<.002$ & $<.002$ & $<.008$ & $<.004$ & $<.002$ \\
\hline CISOIL24 & $<.003$ & $<.33$ & $<.006$ & $<.002$ & $<.002$ & $<.008$ & $<.004$ & $<.020$ \\
\hline CISOIL25 & $<.003$ & $<.33$ & $<.006$ & .39 & $<.002$ & $<.008$ & $<.004$ & $<.020$ \\
\hline CISOIL27 & $<.003$ & $<.33$ & $<.006$ & $<.002$ & $<.002$ & $<.008$ & $<.004$ & $<.020$ \\
\hline CISOIL28 & $<.003$ & $<.33$ & $<.006$ & $<.002$ & $<.002$ & $<.008$ & $<.004$ & $<.020$ \\
\hline CISOIL29 & $<.003$ & $<.33$ & $<.006$ & $<.002$ & $<.002$ & $<.008$ & $<.004$ & $<.020$ \\
\hline
\end{tabular}


Table 18. Results of organic-chemical analyses of soil from selected sampling sites at Carroll Island, Aberdeen Proving Ground, Md., summer 1990--Continued

\begin{tabular}{|c|c|c|c|c|c|c|c|c|c|}
\hline $\begin{array}{c}\text { Sampling } \\
\text { site } \\
\text { (fig. 5) }\end{array}$ & $\begin{array}{c}\text { Tri- } \\
\text { chloro- } \\
\text { ethylene }\end{array}$ & $\begin{array}{l}\text { Tri- } \\
\text { chloro- } \\
\text { fluoro- } \\
\text { methane }\end{array}$ & $\begin{array}{l}\text { Ace- } \\
\text { naph- } \\
\text { thene }\end{array}$ & $\begin{array}{c}\text { Ace- } \\
\text { naph- } \\
\text { thylene }\end{array}$ & $\begin{array}{c}\text { Acetic } \\
\text { acid }\end{array}$ & Acetone & Aldrin & $\begin{array}{c}\text { Anthra- } \\
\text { cene }\end{array}$ & $\begin{array}{c}\text { alpha- } \\
\text { Benzene- } \\
\text { hexachloride }\end{array}$ \\
\hline CISOॉLOI & $<0.004$ & $<0.005$ & $<0.41$ & $<0.46$ & $<0.01$ & \multirow{2}{*}{$\begin{array}{l}0.014 \\
<.010\end{array}$} & $<0.29$ & $<0.54$ & $<0.46$ \\
\hline CISOIL 101 & $<.004$ & $<.005$ & $<.41$ & $<.46$ & $<.01$ & & $<.29$ & $<.54$ & $<46$ \\
\hline CISOIL03 & $<.004$ & $<5.0$ & $<.41$ & $<.46$ & $<10$ & $\begin{array}{l}<.010 \\
<10\end{array}$ & $<.29$ & $<.54$ & $<.46$ \\
\hline CISOIL04 & $<.004$ & $<.005$ & $<41$ & $<.46$ & $<.01$ & $<.010$ & $<.29$ & $<.54$ & $<.46$ \\
\hline CISOIL05 & $<.004$ & $<.005$ & $<.41$ & $<.46$ & $<.01$ & .014 & $<.29$ & $<.54$ & $<.46$ \\
\hline CISOIL06 & $<.004$ & $<.005$ & $<.41$ & $<.46$ & $<.01$ & $<.010$ & $<.29$ & $<.54$ & $<.46$ \\
\hline CISOIL106 & $<.004$ & $<.005$ & $<.41$ & $<.46$ & $<.01$ & $<.010$ & $<.29$ & $<.54$ & $<.46$ \\
\hline CISOIL07 & $<.004$ & $<.005$ & $<.41$ & $<.46$ & $<.01$ & $<.010$ & $<.29$ & $<.54$ & $<.46$ \\
\hline CISOIL08 & $<.004$ & $<.005$ & $<.41$ & $<.46$ & $<.01$ & .018 & $<.29$ & $<.54$ & $<.46$ \\
\hline CISOIL09 & $<.004$ & $<5.0$ & $<.41$ & $<.46$ & $<10$ & $<10$ & $<.29$ & $<.54$ & $<.46$ \\
\hline CISOIL11 & $<.004$ & $<.005$ & $<.41$ & $<.46$ & $<.01$ & .022 & $<.29$ & $<.54$ & $<.46$ \\
\hline CISOIL 12 & $<.004$ & $<5.0$ & $<.41$ & $<.46$ & $<10$ & .016 & $<.29$ & $<.54$ & $<.46$ \\
\hline CISOIL13 & $<.004$ & $<.005$ & $<.41$ & $<.46$ & $<.01$ & .014 & $<.29$ & $<.54$ & $<.46$ \\
\hline CISOIL14 & $<.004$ & $<.005$ & $<.41$ & $<.46$ & $<.01$ & \multirow{2}{*}{$\begin{array}{l}.013 \\
.019\end{array}$} & $<.29$ & $<.54$ & $<.46$ \\
\hline CISOIL15 & $<.004$ & $<.005$ & $<.41$ & $<.46$ & $<.01$ & & $<.29$ & $<.54$ & $<.46$ \\
\hline CISOIL115 & $<.004$ & $<.005$ & $<.41$ & $<.46$ & $<.01$ & .018 & $<.29$ & $<.54$ & $<.46$ \\
\hline CISOIL16 & $<.004$ & $<.005$ & $<.41$ & $<.46$ & $<.01$ & .027 & $<.29$ & $<.54$ & $<.46$ \\
\hline CISOIL17 & $<.004$ & $<.005$ & $<.41$ & $<.46$ & $<.01$ & .017 & $<.29$ & $<.54$ & $<.46$ \\
\hline CISOIL 18 & $<.004$ & $<.005$ & $<.41$ & $<.46$ & $<.01$ & $<.010$ & $<.29$ & $<.54$ & $<.46$ \\
\hline CISOIL19 & $<.004$ & $<.005$ & $<.41$ & $<.46$ & $<.01$ & $<.010$ & $<.29$ & $<.54$ & $<.46$ \\
\hline CISOLL20 & $<.004$ & $<.005$ & $<.41$ & $<.46$ & $<.01$ & .26 & $<.29$ & $<.54$ & $<.46$ \\
\hline CISOIL21 & $<.004$ & $<.005$ & $<.41$ & $<.46$ & $<.01$ & $<.010$ & $<.29$ & $<.54$ & $<.46$ \\
\hline CISOIL22 & $<.004$ & $<.005$ & $<.41$ & $<.46$ & $<.01$ & .025 & $<.29$ & $<.54$ & $<.46$ \\
\hline CISOIL 23 & $<.004$ & $<5.0$ & $<.41$ & $<.46$ & $<10$ & $<10$ & $<.29$ & $<.54$ & $<.46$ \\
\hline CISOIL24 & $<.004$ & $<.005$ & $<.41$ & $<.46$ & $<.01$ & $<.010$ & $<.29$ & $<.54$ & $<46$ \\
\hline CISOLL25 & $<.004$ & $<.005$ & $<.41$ & $<.46$ & $<.01$ & $<.010$ & $<.29$ & $<.54$ & $<.46$ \\
\hline CISOIL27 & $<.004$ & $<.005$ & $<.41$ & $<.46$ & $<.01$ & $<.010$ & $<.29$ & $<.54$ & $<.46$ \\
\hline CISOIL28 & $<.004$ & $<.005$ & $<.41$ & $<.46$ & $<.01$ & $<.010$ & $<.29$ & $<.54$ & $<.46$ \\
\hline CISOLL29 & $<.004$ & $<.005$ & $<.41$ & $<.46$ & $<.01$ & .019 & $<.29$ & $<.54$ & $<.46$ \\
\hline $\begin{array}{c}\text { Sampling } \\
\text { site } \\
\text { (fig. 5) }\end{array}$ & $\begin{array}{c}\text { beta- } \\
\text { Benzene- } \\
\text { hexachloride }\end{array}$ & $\begin{array}{r}\text { d } \\
\text { Ber } \\
\text { hexa }\end{array}$ & $\begin{array}{l}\text { en- } \\
\text { ene- } \\
\text { loride }\end{array}$ & $\begin{array}{c}\text { Benzo } \\
\text { [a] } \\
\text { anthracene }\end{array}$ & $\begin{array}{r}\text { Be } \\
\text { fluora }\end{array}$ & thene & $\begin{array}{c}\text { Benzo } \\
\text { [k] } \\
\text { uoranthene }\end{array}$ & $\begin{array}{c}\text { Benzoic } \\
\text { acid }\end{array}$ & $\begin{array}{c}\text { Benzo } \\
\text { [g,h,i] } \\
\text { perylene }\end{array}$ \\
\hline CISOILO & $<0.36$ & $<0$ & & $<0.30$ & $<0.3$ & & $<0.80$ & 4.6 & $<0.24$ \\
\hline CISOIL 101 & $<.36$ & & & $<.30$ & $<.3$ & & $<.80$ & 2.9 & $<.24$ \\
\hline CISOIL03 & $<.36$ & & & $<.30$ & $<3$ & & $<.80$ & $<1.7$ & $<.24$ \\
\hline CISOIL04 & $<.36$ & & & $<.30$ & $<3$ & & $<.80$ & 1.1 & $<.24$ \\
\hline CISOIL05 & $<.36$ & & & $<.30$ & $<3$ & & $<.80$ & .14 & $<.24$ \\
\hline CISOIL06 & $<.36$ & & & $<.30$ & $<3$ & & $<.80$ & .12 & $<.24$ \\
\hline CISOIL 106 & $<.36$ & & & $<.30$ & $<3$ & & $<.80$ & .12 & $<.24$ \\
\hline CISOIL07 & $<.36$ & & & $<.30$ & $<3$ & & $<.80$ & .31 & $<.24$ \\
\hline CISOIL08 & $<.36$ & & & $<.30$ & $<3$ & & $<.80$ & $<.33$ & $<.24$ \\
\hline CISOIL09 & $<.36$ & & & $<.30$ & $<3$ & & $<.80$ & $<1.7$ & $<.24$ \\
\hline CISOIL11 & $<.36$ & & & $<.30$ & $<3$ & & $<.80$ & .062 & $<.24$ \\
\hline CISOIL12 & $<.36$ & & & $<.30$ & $<.3$ & & $<.80$ & $<1.7$ & $<.24$ \\
\hline CISOIL 13 & $<.36$ & & & $<.30$ & $<.3$ & & $<.80$ & 2.0 & $<.24$ \\
\hline CISOIL14 & $<.36$ & & & $<.30$ & $<.3$ & & $<.80$ & 1.5 & $<.24$ \\
\hline CISOIL 15 & $<.36$ & & & $<.30$ & $<.3$ & & $<.80$ & $<3.3$ & $<.24$ \\
\hline CISOIL115 & $<.36$ & & & $<.30$ & $<3$ & & $<.80$ & $<.33$ & $<.24$ \\
\hline CISOIL16 & $<.36$ & & & $<.30$ & $<.3$ & & $<.80$ & .13 & $<.24$ \\
\hline CISOIL17 & $<.36$ & & & $<.30$ & $<.3$ & & $<.80$ & $<1.7$ & $<.24$ \\
\hline CISOIL18 & $<.36$ & & & $<.30$ & $<.3$ & & $<.80$ & $<1.7$ & $<.24$ \\
\hline ClSOIL19 & $<.36$ & & & $<.30$ & $<.3$ & & $<.80$ & $<1.7$ & $<.24$ \\
\hline CISOIL20 & $<.36$ & & & $<.30$ & $<.3$ & & $<.80$ & 6.9 & $<.24$ \\
\hline CISOIL21 & $<.36$ & & & $<.30$ & $<.3$ & & $<.80$ & 5.0 & $<.24$ \\
\hline CISOIL22 & $<.36$ & & & $<.30$ & $<.3$ & & $<.80$ & $<1.7$ & $<.24$ \\
\hline CISOIL 23 & $<.36$ & & & $<.30$ & $<3$ & & $<.80$ & $<1.7$ & $<.24$ \\
\hline CISOIL24 & $<.36$ & & & $<.30$ & $<3$ & & $<.80$ & .14 & $<.24$ \\
\hline CISOIL25 & $<.36$ & & & $<.30$ & $<.3$ & & $<.80$ & .13 & $<.24$ \\
\hline CISOIL27 & $<.36$ & & & $<.30$ & $<.3$ & & $<.80$ & .21 & $<.24$ \\
\hline CISOIL28 & $<.36$ & & & $<.30$ & $<3$ & & $<.80$ & .063 & $<.24$ \\
\hline CISOIL29 & $<.36$ & & & $<.30$ & $<.3$ & & $<.80$ & .12 & $<.24$ \\
\hline
\end{tabular}


Table 18. Results of organic-chemical analyses of soil from selected sampling sites at Carroll Island, Aberdeen Proving Ground, Md., summer 1990--Continued

\begin{tabular}{|c|c|c|c|c|c|c|c|c|c|}
\hline $\begin{array}{c}\text { Sampling } \\
\text { site } \\
\text { (fig. 5) }\end{array}$ & $\begin{array}{c}\text { Benzo } \\
\text { [a] } \\
\text { pyrene }\end{array}$ & $\begin{array}{l}\text { Benzyl } \\
\text { alcohol }\end{array}$ & $\begin{array}{l}\text { Bis(2- } \\
\text { chloro- } \\
\text { ethoxy) } \\
\text { methane }\end{array}$ & $\begin{array}{l}\text { Bis(2- } \\
\text { chloro- } \\
\text { ethyl) } \\
\text { ether }\end{array}$ & $\begin{array}{l}\text { Bis(2- } \\
\text { chloro- } \\
\text { sopropyl) } \\
\text { ether }\end{array}$ & $\begin{array}{c}\text { 2,2-Bis } \\
\text { (para-chloro- } \\
\text { phenyl)- } \\
\text { 1,1-dj- } \\
\text { chloroethane }\end{array}$ & $\begin{array}{c}\text { 2,2-Bis } \\
\text { (para-chloro- } \\
\text { phenyl)- } \\
\text { 1,1-di- } \\
\text { chloroethene }\end{array}$ & $\begin{array}{c}\text { 2,2-Bis } \\
\text { (para-chloro- } \\
\text { phenyl)- } \\
\text { 1,1,1-tri- } \\
\text { chloroethane }\end{array}$ & $\begin{array}{c}\text { Bis(2- } \\
\text { ethyl- } \\
\text { hexyl) } \\
\text { phthalate }\end{array}$ \\
\hline CISOILOI & $<0.38$ & $<0.33$ & $<0.33$ & $<0.33$ & $<0.33$ & $<0.18$ & $<0.22$ & $<0.41$ & $<0.39$ \\
\hline CISOIL101 & $<.38$ & $<.33$ & $<.33$ & $<.33$ & $<.33$ & $<.18$ & $<.22$ & $<.41$ & $<.39$ \\
\hline CISOIL03 & $<.38$ & $<.33$ & $<.33$ & $<.33$ & $<.33$ & $<.18$ & $<.22$ & $<.41$ & $<.39$ \\
\hline CISOIL04 & $<38$ & $<.33$ & $<.33$ & $<.33$ & $<.33$ & $<.18$ & $<.22$ & $<.41$ & $<.39$ \\
\hline CISOIL05 & $<.38$ & $<.33$ & $<.33$ & $<.33$ & $<.33$ & $<.18$ & $<.22$ & $<.41$ & $<.39$ \\
\hline CISOIL06 & $<.38$ & $<.33$ & $<.33$ & $<.33$ & $<.33$ & $<.18$ & $<.22$ & $<.41$ & $<.39$ \\
\hline CISOIL106 & $<.38$ & $<.33$ & $<.33$ & $<.33$ & $<.33$ & $<.18$ & $<.22$ & $<.41$ & $<.39$ \\
\hline CISOIL07 & $<.38$ & $<.33$ & $<.33$ & $<.33$ & $<.33$ & $<.18$ & $<.22$ & $<.41$ & $<.39$ \\
\hline CISOIL08 & $<.38$ & $<.33$ & $<.33$ & $<.33$ & $<.33$ & $<.18$ & $<.22$ & $<.41$ & $<.39$ \\
\hline CISOIL09 & $<.38$ & $<.33$ & $<.33$ & $<.33$ & $<.33$ & $<.18$ & $<.22$ & $<.41$ & $<.39$ \\
\hline CISOIL11 & $<.38$ & $<.33$ & $<.33$ & $<.33$ & $<.33$ & $<.18$ & $<.22$ & $<.41$ & $<.39$ \\
\hline CISOIL12 & $<.38$ & $<.33$ & $<.33$ & $<.33$ & $<.33$ & $<.18$ & $<.22$ & $<.41$ & $<.39$ \\
\hline CISOIL13 & $<.38$ & $<.33$ & $<.33$ & $<.33$ & $<.33$ & $<.18$ & $<.22$ & $<41$ & $<.39$ \\
\hline CISOIL 14 & $<.38$ & $<.33$ & $<.33$ & $<.33$ & $<.33$ & $<.18$ & $<.22$ & $<.41$ & $<.39$ \\
\hline CISOIL15 & $<.38$ & $<.33$ & $<.33$ & $<.33$ & $<.33$ & $<.18$ & $<.22$ & $<.41$ & $<.39$ \\
\hline CISOIL115 & $<.38$ & $<.33$ & $<.33$ & $<.33$ & $<.33$ & $<.18$ & $<.22$ & $<.41$ & $<.39$ \\
\hline CISOIL16 & $<.38$ & $<.33$ & $<.33$ & $<.33$ & $<.33$ & $<.18$ & $<.22$ & $<.41$ & $<.39$ \\
\hline CISOIL17 & $<.38$ & $<.33$ & $<.33$ & $<.33$ & $<.33$ & $<.18$ & $<.22$ & $<.41$ & $<.39$ \\
\hline CISOIL 18 & $<.38$ & $<.33$ & $<.33$ & $<.33$ & $<.33$ & $<.18$ & $<.22$ & $<.4 \mathrm{I}$ & $<.39$ \\
\hline CISOIL19 & $<.38$ & $<.33$ & $<.33$ & $<.33$ & $<.33$ & $<.18$ & $<.22$ & $<.41$ & $<.39$ \\
\hline CISOIL20 & $<.38$ & $<.33$ & $<.33$ & $<.33$ & $<.33$ & $<.18$ & $<.22$ & $<.41$ & $<.39$ \\
\hline CISOIL21 & $<.38$ & $<.33$ & $<.33$ & $<.33$ & $<.33$ & $<.18$ & $<.22$ & $<.41$ & $<.39$ \\
\hline CISOIL22 & $<.38$ & $<.33$ & $<.33$ & $<.33$ & $<.33$ & $<.18$ & $<.22$ & $<.41$ & $<.39$ \\
\hline CISOIL23 & $<.38$ & $<.33$ & $<.33$ & $<.33$ & $<.33$ & $<.18$ & $<.22$ & $<41$ & $<.39$ \\
\hline CISOIL24 & $<.38$ & $<33$ & $<.33$ & $<.33$ & $<.33$ & $<.18$ & $<.22$ & $<.41$ & $<.39$ \\
\hline CISOIL25 & $<.38$ & $<.33$ & $<.33$ & $<33$ & $<.33$ & $<.18$ & $<.22$ & $<.41$ & $<.39$ \\
\hline CISOIL27 & $<.38$ & $<.33$ & $<.33$ & $<.33$ & $<.33$ & $<.18$ & $<.22$ & $<.41$ & $<.39$ \\
\hline CISOIL28 & $<.38$ & $<.33$ & $<.33$ & $<.33$ & $<.33$ & $<.18$ & $<.22$ & $<.41$ & $<.39$ \\
\hline CISOIL29 & $<.38$ & $<.33$ & $<.33$ & $<.33$ & $<.33$ & $<.18$ & $<.22$ & $<.41$ & $<39$ \\
\hline $\begin{array}{l}\text { Sampling } \\
\text { site } \\
\text { (fig. 5) }\end{array}$ & $\begin{array}{l}\text { Bromo- } \\
\text { methane }\end{array}$ & $\begin{array}{c}\text { 4-Bromo- } \\
\text { phenyl- } \\
\text { phenyl ether }\end{array}$ & $\begin{array}{c}\text { Butyl- } \\
\text { benzyl } \\
\text { phthalate }\end{array}$ & $\begin{array}{c}\text { Carbon } \\
\text { disulfide }\end{array}$ & $\begin{array}{l}\text { alpha- } \\
\text { Chlor } \\
\text { dane }\end{array}$ & $\begin{array}{l}\text { gamma- } \\
\text { Chlor- } \\
\text { dane }\end{array}$ & $\begin{array}{l}\text { 4-Chloro- } \\
\text { aniline }\end{array}$ & $\begin{array}{c}\text { 4-Chloro- } \\
\text { cresol }\end{array}$ & $\begin{array}{l}\text { 2-Chioro- } \\
\text { naphtha- } \\
\text { lene }\end{array}$ \\
\hline CISOILó & $<0.01$ & $<0.33$ & 0.13 & $<0.005$ & $<1.0$ & $<1.0$ & $<0.33$ & $<0.33$ & $<0.32$ \\
\hline CISOIL101 & $<.01$ & $<.33$ & .095 & $<.005$ & $<1.0$ & $<1.0$ & $<.33$ & $<.33$ & $<.32$ \\
\hline CISOIL03 & $<10$ & $<.33$ & $<.33$ & $<5.0$ & $<1.0$ & $<1.0$ & $<.33$ & $<.33$ & $<.32$ \\
\hline CISOIL04 & $<.01$ & $<.33$ & $<.33$ & $<.005$ & $<1.0$ & $<1.0$ & $<.33$ & $<.33$ & $<.32$ \\
\hline CISOIL05 & $<.01$ & $<.33$ & .21 & $<.005$ & $<1.0$ & $<1.0$ & $<.33$ & $<.33$ & $<.32$ \\
\hline CISOIL06 & $<.01$ & $<.33$ & .080 & $<.005$ & $<1.0$ & $<1.0$ & $<.33$ & $<.33$ & $<.32$ \\
\hline CISOIL106 & $<.01$ & $<.33$ & $<.33$ & $<.005$ & $<1.0$ & $<1.0$ & $<.33$ & $<.33$ & $<.32$ \\
\hline CISOIL07 & $<.01$ & $<.33$ & .10 & $<.005$ & $<1.0$ & $<1.0$ & $<.33$ & $<.33$ & $<.32$ \\
\hline CISOIL08 & $<.01$ & $<.33$ & $<.033$ & $<.005$ & $<1.0$ & $<1.0$ & $<.33$ & $<.33$ & $<.32$ \\
\hline CISOIL09 & $<10$ & $<.33$ & .70 & $<5.0$ & $<1.0$ & $<1.0$ & $<.33$ & $<.33$ & $<.32$ \\
\hline CISOIL11 & $<.01$ & $<.33$ & .049 & $<.005$ & $<1.0$ & $<1.0$ & $<.33$ & $<.33$ & $<.32$ \\
\hline CISOIL12 & $<10$ & $<.33$ & $<.33$ & $<5.0$ & $<1.0$ & $<1.0$ & $<.33$ & $<.33$ & $<.32$ \\
\hline CISOIL13 & $<.01$ & $<.33$ & .20 & $<.005$ & $<1.0$ & $<1.0$ & $<.33$ & $<.33$ & $<.32$ \\
\hline CISOIL14 & $<.01$ & $<.33$ & .19 & $<.005$ & $<1.0$ & $<1.0$ & $<.33$ & $<.33$ & $<.32$ \\
\hline CISOIL15 & $<.01$ & $<.33$ & $<.33$ & $<.005$ & $<1.0$ & $<1.0$ & $<.33$ & $<.33$ & $<.32$ \\
\hline CISOIL115 & $<.01$ & $<.33$ & $<.033$ & $<.005$ & $<1.0$ & $<1.0$ & $<.33$ & $<.33$ & $<.32$ \\
\hline CISOILI6 & $<.01$ & $<.33$ & .20 & $<.005$ & $<1.0$ & $<1.0$ & $<.33$ & $<.33$ & $<.32$ \\
\hline CISOIL17 & $<.01$ & $<.33$ & $<.33$ & $<.005$ & $<1.0$ & $<1.0$ & $<.33$ & $<.33$ & $<.32$ \\
\hline CISOIL 18 & $<.01$ & $<.33$ & $<.33$ & $<.005$ & $<1.0$ & $<1.0$ & $<.33$ & $<.33$ & $<.32$ \\
\hline CISOIL19 & $<.01$ & $<.33$ & $<.33$ & $<.005$ & $<1.0$ & $<1.0$ & $<.33$ & $<.33$ & $<.32$ \\
\hline CISOIL20 & $<.01$ & $<.33$ & .26 & $<.005$ & $<1.0$ & $<1.0$ & $<.33$ & $<.33$ & $<.32$ \\
\hline CISOIL2I & $<.01$ & $<.33$ & .27 & $<.005$ & $<1.0$ & $<1.0$ & $<.33$ & $<.33$ & $<.32$ \\
\hline CISOIL22 & $<.01$ & $<.33$ & $<.33$ & $<.005$ & $<1.0$ & $<1.0$ & $<.33$ & $<.33$ & $<.32$ \\
\hline CISOIL23 & $<10$ & $<33$ & .51 & $<5.0$ & $<1.0$ & $<1.0$ & $<.33$ & $<.33$ & $<.32$ \\
\hline CISOIL24 & $<.01$ & $<.33$ & .19 & $<.005$ & $<1.0$ & $<1.0$ & $<.33$ & $<.33$ & $<.32$ \\
\hline CISOIL25 & $<.01$ & $<.33$ & .094 & $<.005$ & $<1.0$ & $<1.0$ & $<.33$ & $<.33$ & $<.32$ \\
\hline CISOIL27 & $<.01$ & $<.33$ & .10 & $<.005$ & $<1.0$ & $<1.0$ & $<.33$ & $<.33$ & $<.32$ \\
\hline CISOIL28 & $<.01$ & $<.33$ & .15 & $<.005$ & $<1.0$ & $<1.0$ & $<.33$ & $<.33$ & $<.32$ \\
\hline CISOIL29 & $<.01$ & $<.33$ & .060 & $<.005$ & $<1.0$ & $<1.0$ & $<.33$ & $<.33$ & $<.32$ \\
\hline
\end{tabular}


Table 18. Results of organic-chemical analyses of soil from selected sampling sites at Carroll Island, Aberdeen Proving Ground, Md., summer 1990--Continued

\begin{tabular}{|c|c|c|c|c|c|c|c|c|c|}
\hline $\begin{array}{c}\text { Sampling } \\
\text { site } \\
\text { (fig. 5) }\end{array}$ & $\begin{array}{c}\text { 2-Chloro- } \\
\text { phenol }\end{array}$ & $\begin{array}{l}\text { 4-Chioro- } \\
\text { phenyl- } \\
\text { methyl } \\
\text { sulfide }\end{array}$ & $\begin{array}{l}\text { 4-Chioro } \\
\text { phenyl- } \\
\text { methyl } \\
\text { sulfone }\end{array}$ & $\begin{array}{c}\text { 4-Chloro- } \\
\text { phenyl- } \\
\text { methyl } \\
\text { sulfoxide }\end{array}$ & $\begin{array}{l}\text { 4-Chloro- } \\
\text { phenyl- } \\
\text { phenyl } \\
\text { ether }\end{array}$ & $\begin{array}{l}\text { Chry- } \\
\text { sene }\end{array}$ & $\begin{array}{c}\text { Dibenz- } \\
{[a, h]} \\
\text { antha- } \\
\text { cene }\end{array}$ & $\begin{array}{c}\text { Di- } \\
\text { benzo- } \\
\text { furan }\end{array}$ & $\begin{array}{c}\text { Di-n- } \\
\text { butyl } \\
\text { phthalate }\end{array}$ \\
\hline CISOILÓ & $<0.33$ & $<0.37$ & $<0.69$ & $<0.27$ & $<0.33$ & $<0.45$ & $<0.20$ & $<0.33$ & $<0.33$ \\
\hline CISOIL101 & $<.33$ & $<.37$ & $<.69$ & $<.27$ & $<.33$ & $<.45$ & $<.20$ & $<.33$ & $<.33$ \\
\hline CISOIL03 & $<.33$ & $<.37$ & $<.69$ & $<.27$ & $<.33$ & $<.45$ & $<.20$ & $<.33$ & $<.33$ \\
\hline CISOIL04 & $<.33$ & $<.37$ & $<.69$ & $<.27$ & $<.33$ & $<.45$ & $<.20$ & $<.33$ & $<.33$ \\
\hline CISOIL05 & $<.33$ & $<.37$ & $<.69$ & $<.27$ & $<.33$ & $<.45$ & $<.20$ & $<.33$ & $<.33$ \\
\hline CISOIL06 & $<.33$ & $<.37$ & $<.69$ & $<.27$ & $<.33$ & $<.45$ & $<.20$ & $<.33$ & $<.33$ \\
\hline CISOIL106 & $<.33$ & $<.37$ & $<.69$ & $<.27$ & $<.33$ & $<.45$ & $<.20$ & $<.33$ & $<.33$ \\
\hline CISOIL07 & $<.33$ & $<.37$ & $<.69$ & $<.27$ & $<.33$ & $<.45$ & $<.20$ & $<.33$ & $<.33$ \\
\hline CISOIL08 & $<.33$ & $<.37$ & $<.69$ & $<.27$ & $<.33$ & $<.45$ & $<.20$ & $<.33$ & $<.33$ \\
\hline CISOIL09 & $<.33$ & $<.37$ & $<.69$ & $<.27$ & $<.33$ & $<.45$ & $<.20$ & $<.33$ & $<.33$ \\
\hline CISOIL11 & $<.33$ & $<.37$ & $<.69$ & $<.27$ & $<.33$ & $<.45$ & $<.20$ & $<.33$ & $<33$ \\
\hline ClSOIL12 & $<.33$ & $<.37$ & $<.69$ & $<.27$ & $<.33$ & $<.45$ & $<.20$ & $<33$ & $<.33$ \\
\hline CISOIL13 & $<.33$ & $<.37$ & $<.69$ & $<.27$ & $<.33$ & $<.45$ & $<.20$ & $<.33$ & $<.33$ \\
\hline CISOIL14 & $<.33$ & $<.37$ & $<.69$ & $<.27$ & $<.33$ & $<.45$ & $<.20$ & $<.33$ & $<.33$ \\
\hline CISOIL15 & $<.33$ & $<.37$ & $<.69$ & $<.27$ & $<.33$ & $<.45$ & $<.20$ & $<.33$ & $<.33$ \\
\hline CISOIL115 & $<.33$ & $<.37$ & $<.69$ & $<.27$ & $<.33$ & $<.45$ & $<.20$ & $<.33$ & $<.33$ \\
\hline CISOIL16 & $<.33$ & $<.37$ & $<.69$ & $<.27$ & $<.33$ & $<.45$ & $<.20$ & $<.33$ & $<.33$ \\
\hline CISOIL17 & $<.33$ & $<.37$ & $<.69$ & $<.27$ & $<.33$ & $<.45$ & $<.20$ & $<.33$ & $<.33$ \\
\hline CISOIL18 & $<.33$ & $<.37$ & $<.69$ & $<.27$ & $<.33$ & $<.45$ & $<.20$ & $<.33$ & $<.33$ \\
\hline CISOIL 19 & $<.33$ & $<.37$ & $<.69$ & $<.27$ & $<.33$ & $<.45$ & $<.20$ & $<.33$ & $<.33$ \\
\hline C1SOIL20 & $<.33$ & $<.37$ & $<.69$ & $<.27$ & $<.33$ & $<.45$ & $<.20$ & $<.33$ & $<.33$ \\
\hline CISOIL21 & $<.33$ & $<.37$ & $<.69$ & $<.27$ & $<.33$ & $<.45$ & $<.20$ & $<.33$ & $<.33$ \\
\hline C1SOIL22 & $<.33$ & $<.37$ & $<.69$ & $<.27$ & $<.33$ & $<.45$ & $<.20$ & $<.33$ & $<.33$ \\
\hline CISOIL23 & $<.33$ & $<.37$ & $<.69$ & $<.27$ & $<.33$ & $<.45$ & $<.20$ & $<.33$ & $<.33$ \\
\hline CISOIL24 & $<.33$ & $<.37$ & $<.69$ & $<.27$ & $<.33$ & $<.45$ & $<.20$ & $<.33$ & $<.33$ \\
\hline CISOIL25 & $<.33$ & $<.37$ & $<.69$ & $<.27$ & $<.33$ & $<.45$ & $<.20$ & $<.33$ & $<.33$ \\
\hline CISOIL27 & $<.33$ & $<.37$ & $<.69$ & $<.27$ & $<.33$ & $<.45$ & $<.20$ & $<.33$ & $<.33$ \\
\hline CISOIL28 & $<.33$ & $<.37$ & $<.69$ & $<.27$ & $<.33$ & $<.45$ & $<.20$ & $<.33$ & $<.33$ \\
\hline CISOIL29 & $<.33$ & $<.37$ & $<.69$ & $<.27$ & $<.33$ & $<.45$ & $<.20$ & $<.33$ & $<.33$ \\
\hline $\begin{array}{l}\text { Sampling } \\
\text { site } \\
\text { (fig. 5) }\end{array}$ & $\begin{array}{c}\text { 3,3'-Di- } \\
\text { chloro- } \\
\text { benzidine }\end{array}$ & $\begin{array}{l}\text { 2,4-Di- } \\
\text { chloro- } \\
\text { phenol }\end{array}$ & Dieldrin & $\begin{array}{c}\text { Diethyl } \\
\text { phthalate }\end{array}$ & $\begin{array}{l}\text { 2,4-Di- } \\
\text { methyl- } \\
\text { phenol }\end{array}$ & $\begin{array}{l}\text { Dimethyl } \\
\text { phthalate }\end{array}$ & $\begin{array}{c}\text { 2,4-Di- } \\
\text { nitro- } \\
\text { phenol }\end{array}$ & $\begin{array}{c}\text { 2,4-Di- } \\
\text { nitro- } \\
\text { toluene }\end{array}$ & $\begin{array}{c}\text { 2,6-Di- } \\
\text { nitro- } \\
\text { toluene }\end{array}$ \\
\hline CISOILOI & $<0.20$ & $<0.33$ & $<0.30$ & $<0.33$ & $<0.33$ & $<0.33$ & $<1.7$ & $<0.39$ & $<0.53$ \\
\hline CISOIL 101 & $<.20$ & $<.33$ & $<.30$ & $<.33$ & $<.33$ & $<.33$ & $<1.7$ & $<.39$ & $<.53$ \\
\hline CISOIL03 & $<.20$ & $<.33$ & $<.30$ & $<.33$ & $<.33$ & $<.33$ & $<1.7$ & $<.39$ & $<.53$ \\
\hline CISOIL04 & $<.20$ & $<.33$ & $<.30$ & $<.33$ & $<.33$ & $<.33$ & $<1.7$ & $<.39$ & $<.53$ \\
\hline CISOIL05 & $<.20$ & $<.33$ & $<.30$ & $<.33$ & $<.33$ & $<.33$ & $<1.7$ & $<.39$ & $<.53$ \\
\hline CISOIL06 & $<.20$ & $<.33$ & $<.30$ & $<.33$ & $<.33$ & $<.33$ & $<\mathrm{I} .7$ & $<.39$ & $<.53$ \\
\hline CISOILl06 & $<.20$ & $<.33$ & $<.30$ & $<.33$ & $<.33$ & $<.33$ & $<1.7$ & $<.39$ & $<.53$ \\
\hline CISOIL07 & $<.20$ & $<.33$ & $<.30$ & $<.33$ & $<.33$ & $<.33$ & $<1.7$ & $<.39$ & $<.53$ \\
\hline CISOIL08 & $<.20$ & $<.33$ & $<.30$ & $<.033$ & $<.33$ & $<.33$ & $<1.7$ & $<.39$ & $<.53$ \\
\hline CISOIL09 & $<.20$ & $<.33$ & $<.30$ & $<.33$ & $<.33$ & $<.33$ & $<1.7$ & $<.39$ & $<.53$ \\
\hline CISOIL11 & $<.20$ & $<.33$ & $<.30$ & $<.033$ & $<.33$ & $<.33$ & $<1.7$ & $<.39$ & $<.53$ \\
\hline CISOILI2 & $<.20$ & $<.33$ & $<.30$ & $<.33$ & $<.33$ & $<.33$ & $<1.7$ & $<.39$ & $<.53$ \\
\hline CISOILI3 & $<.20$ & $<.33$ & $<.30$ & $<.33$ & $<.33$ & $<.33$ & $<1.7$ & $<.39$ & $<.53$ \\
\hline CISOIL14 & $<.20$ & $<.33$ & $<.30$ & $<.33$ & $<.33$ & $<.33$ & $<1.7$ & $<.39$ & $<.53$ \\
\hline CISOILI5 & $<.20$ & $<.33$ & $<.30$ & $<.33$ & $<.33$ & $<.33$ & $<1.7$ & $<.39$ & $<.53$ \\
\hline CISOILII5 & $<.20$ & $<.33$ & $<.30$ & $<.033$ & $<.33$ & $<.33$ & $<\mathrm{I} .7$ & $<.39$ & $<.53$ \\
\hline CISOIL16 & $<.20$ & $<.33$ & $<.30$ & $<.33$ & $<.33$ & $<.33$ & $<1.7$ & $<.39$ & $<.53$ \\
\hline CISOILI7 & $<.20$ & $<.33$ & $<.30$ & $<.033$ & $<.33$ & $<.33$ & $<1.7$ & $<.39$ & $<.53$ \\
\hline CISOILI8 & $<.20$ & $<.33$ & $<.30$ & $<.33$ & $<.33$ & $<.33$ & $<1.7$ & $<.39$ & $<.53$ \\
\hline CISOILI9 & $<.20$ & $<.33$ & $<.30$ & $<.33$ & $<.33$ & $<.33$ & $<\mathrm{I} .7$ & $<.39$ & $<.53$ \\
\hline C1SOLL20 & $<.20$ & $<.33$ & $<.30$ & $<.33$ & $<.33$ & $<.33$ & $<\mathrm{I} .7$ & $<.39$ & $<.53$ \\
\hline CISO1L2I & $<.20$ & $<.33$ & $<.30$ & $<.33$ & $<.33$ & $<.33$ & $<1.7$ & $<.39$ & $<.53$ \\
\hline CISOIL22 & $<.20$ & $<.33$ & $<.30$ & $<.33$ & $<.33$ & $<.33$ & $<1.7$ & $<.39$ & $<.53$ \\
\hline CISOIL23 & $<.20$ & $<.33$ & $<.30$ & $<.33$ & $<.33$ & $<.33$ & $<1.7$ & $<.39$ & $<.53$ \\
\hline C1SOIL24 & $<.20$ & $<.33$ & $<.30$ & $<.33$ & $<.33$ & $<.33$ & $<\mathrm{I} .7$ & $<.39$ & $<.53$ \\
\hline CISOIL25 & $<.20$ & $<.33$ & $<.30$ & $<.33$ & $<.33$ & $<.33$ & $<1.7$ & $<.39$ & $<.53$ \\
\hline CISOIL27 & $<.20$ & $<.33$ & $<.30$ & $<.33$ & $<.33$ & $<.33$ & $<1.7$ & $<.39$ & $<.53$ \\
\hline CISOIL28 & $<.20$ & $<.33$ & $<.30$ & $<.33$ & $<.33$ & $<.33$ & $<\mathrm{I} .7$ & $<.39$ & $<.53$ \\
\hline CISOIL29 & $<.20$ & $<.33$ & $<.30$ & $<.033$ & $<.33$ & $<.33$ & $<1.7$ & $<.39$ & $<.53$ \\
\hline
\end{tabular}


Table 18. Results of organic-chemical analyses of soil from selected sampling sites at Carroll Island, Aberdeen Proving Ground, Md., summer 1990--Continued

\begin{tabular}{|c|c|c|c|c|c|c|c|c|c|}
\hline $\begin{array}{l}\text { Sampling } \\
\text { site } \\
\text { (fig. 5) }\end{array}$ & $\begin{array}{c}\text { Di-n- } \\
\text { octyl } \\
\text { phthalate }\end{array}$ & Dithiane & $\begin{array}{l}\text { alpha- } \\
\text { Endo- } \\
\text { sulfan }\end{array}$ & $\begin{array}{l}\text { beta- } \\
\text { Endo- } \\
\text { sulfan }\end{array}$ & $\begin{array}{l}\text { Endo- } \\
\text { sulfan } \\
\text { sulfate }\end{array}$ & Endrin & $\begin{array}{l}\text { Endrin } \\
\text { ketone }\end{array}$ & $\begin{array}{c}\text { Fluor- } \\
\text { anthene }\end{array}$ & $\begin{array}{l}\text { Hepta- } \\
\text { chlor }\end{array}$ \\
\hline CISOॉLOI & $<0.59$ & $<0.24$ & $<0.10$ & $<0.20$ & $<0.20$ & $<0.41$ & $<0.20$ & $<0.52$ & $<0.28$ \\
\hline CISOIL101 & $<.59$ & $<.24$ & $<.10$ & $<.20$ & $<.20$ & $<.41$ & $<20$ & $<.52$ & $<.28$ \\
\hline CISOIL03 & $<.59$ & $<.24$ & $<1.0$ & $<.20$ & $<.20$ & $<.41$ & $<.20$ & $<.52$ & $<.28$ \\
\hline CISOILO4 & $<.59$ & $<.24$ & $<.10$ & $<.20$ & $<.20$ & $<.41$ & $<.20$ & $<.52$ & $<.28$ \\
\hline CISOIL05 & $<.59$ & $<.24$ & $<.10$ & $<.20$ & $<.20$ & $<.41$ & $<.20$ & $<.52$ & $<.28$ \\
\hline CISOIL06 & $<.59$ & $<.24$ & $<.10$ & $<.20$ & $<.20$ & $<.41$ & $<.20$ & $<.52$ & $<.28$ \\
\hline CISOIL106 & $<.59$ & $<.24$ & $<.10$ & $<.20$ & $<.20$ & $<.41$ & $<20$ & $<.52$ & $<.28$ \\
\hline CISOIL07 & $<.59$ & $<.24$ & $<.10$ & $<.20$ & $<.20$ & $<.41$ & $<.20$ & $<.52$ & $<.28$ \\
\hline CISOIL08 & $<.59$ & $<.24$ & $<.10$ & $<.20$ & $<20$ & $<.41$ & $<.20$ & $<.52$ & $<.28$ \\
\hline ClSOIL09 & $<.59$ & $<.24$ & $<1.0$ & $<.20$ & $<.20$ & $<.41$ & $<.20$ & $<.52$ & $<.28$ \\
\hline ClSOILII & $<.59$ & $<.24$ & $<.10$ & $<.20$ & $<.20$ & $<41$ & $<.20$ & $<.52$ & $<.28$ \\
\hline CISOIL12 & $<.59$ & $<.24$ & $<1.0$ & $<.20$ & $<.20$ & $<.41$ & $<.20$ & $<.52$ & $<.28$ \\
\hline CISOIL13 & $<.59$ & $<.24$ & $<.10$ & $<.20$ & $<.20$ & $<.41$ & $<.20$ & $<.52$ & $<.28$ \\
\hline C1SOIL14 & $<.59$ & $<24$ & $<.10$ & $<.20$ & $<.20$ & $<.41$ & $<.20$ & $<.52$ & $<.28$ \\
\hline CISOIL15 & $<.59$ & $<24$ & $<.10$ & $<.20$ & $<.20$ & $<.41$ & $<.20$ & $<.52$ & $<.28$ \\
\hline CISOIL115 & $<.59$ & $<.24$ & $<.10$ & $<.20$ & $<.20$ & $<.41$ & $<.20$ & $<.52$ & $<.28$ \\
\hline CISOIL16 & $<.59$ & $<.24$ & $<.10$ & $<.20$ & $<.20$ & $<.41$ & $<20$ & $<.52$ & $<.28$ \\
\hline CISOIL17 & $<.59$ & $<.24$ & $<.10$ & $<.20$ & $<.20$ & $<.41$ & $<.20$ & $<.52$ & $<28$ \\
\hline CISOIL18 & $<.59$ & $<.24$ & $<.10$ & $<.20$ & $<.20$ & $<.41$ & $<.20$ & $<.52$ & $<28$ \\
\hline CISOIL19 & $<.59$ & $<.24$ & $<.10$ & $<.20$ & $<.20$ & $<.41$ & $<.20$ & $<.52$ & $<.28$ \\
\hline CISOIL20 & $<.59$ & $<.24$ & $<.10$ & $<.20$ & $<.20$ & $<.41$ & $<.20$ & $<.52$ & $<.28$ \\
\hline CISOIL21 & $<.59$ & $<.24$ & $<.10$ & $<.20$ & $<.20$ & $<.41$ & $<.20$ & $<.52$ & $<.28$ \\
\hline CISOIL22 & $<.59$ & $<.24$ & $<.10$ & $<.20$ & $<.20$ & $<.41$ & $<.20$ & $<.52$ & $<.28$ \\
\hline CISOIL23 & $<.59$ & $<.24$ & $<1.0$ & $<.20$ & $<.20$ & $<.41$ & $<.20$ & $<.52$ & $<.28$ \\
\hline CISOIL24 & $<.59$ & $<.24$ & $<.10$ & $<.20$ & $<.20$ & $<.41$ & $<.20$ & $<.52$ & $<.28$ \\
\hline CISOIL25 & $<.59$ & $<.24$ & $<.10$ & $<.20$ & $<20$ & $<.41$ & $<20$ & $<.52$ & $<.28$ \\
\hline CISOIL27 & $<.59$ & $<.24$ & $<.10$ & $<20$ & $<.20$ & $<.41$ & $<.20$ & $<.52$ & $<.28$ \\
\hline CISOIL28 & $<.59$ & $<.24$ & $<.10$ & $<.20$ & $<.20$ & $<.41$ & $<.20$ & $<.52$ & $<.28$ \\
\hline CISOIL29 & $<.59$ & $<24$ & $<.10$ & $<20$ & $<.20$ & $<41$ & $<.20$ & $<.52$ & $<.28$ \\
\hline $\begin{array}{l}\text { Sampling } \\
\text { site } \\
\text { (fig. 5) }\end{array}$ & $\begin{array}{l}\text { Hepta- } \\
\text { chlor } \\
\text { epoxide }\end{array}$ & $\begin{array}{c}\text { Hepta- } \\
\text { decanoic } \\
\text { acid }\end{array}$ & $\begin{array}{c}\text { Hexa- } \\
\text { chloro- } \\
\text { benzene }\end{array}$ & $\begin{array}{c}\begin{array}{c}\text { Hexa- } \\
\text { chloro- } \\
\text { butadiene }\end{array} \\
\end{array}$ & $\begin{array}{c}\text { Hexa- } \\
\text { chloro- } \\
\text { cyclo- } \\
\text { pentadiene }\end{array}$ & $\begin{array}{l}\text { Hexa- } \\
\text { chloro- } \\
\text { ethane }\end{array}$ & $\begin{array}{c}\begin{array}{c}\text { Hexa- } \\
\text { decanoic } \\
\text { acid }\end{array} \\
\end{array}$ & $\begin{array}{c}\text { Tndeno } \\
{[1,2,3-} \\
c, d] \\
\text { pyrene } \\
\end{array}$ & $\begin{array}{c}\text { Iso- } \\
\text { phorone }\end{array}$ \\
\hline CISOILO1 & $<0.36$ & -- & $<0.26$ & $<0.42$ & $<0.33$ & $<0.40$ & 0.26 & $<0.21$ & $<0.33$ \\
\hline CISOIL101 & $<.36$ & -- & $<.26$ & $<.42$ & $<.33$ & $<.40$ & .41 & $<.21$ & $<.33$ \\
\hline CISOIL03 & $<.36$ & -- & $<.26$ & $<.42$ & $<.33$ & $<.40$ & -- & $<.21$ & $<.33$ \\
\hline CISOIL04 & $<.36$ & -- & $<.26$ & $<.42$ & $<.33$ & $<.40$ & .57 & $<.21$ & $<.33$ \\
\hline CISOIL05 & $<.36$ & -- & $<.26$ & $<.42$ & $<.33$ & $<.40$ & .65 & $<.21$ & $<.33$ \\
\hline CISOIL06 & $<.36$ & 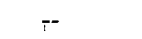 & $<.26$ & $<.42$ & $<.33$ & $<.40$ & .49 & $<.21$ & $<.33$ \\
\hline CISOIL106 & $<.36$ & -- & $<.26$ & $<.42$ & $<.33$ & $<.40$ & -- & $<.21$ & $<.33$ \\
\hline CISOIL07 & $<.36$ & -- & $<.26$ & $<.42$ & $<.33$ & $<.40$ & .61 & $<.21$ & $<.33$ \\
\hline CISOIL08 & $<.36$ & -- & $<.26$ & $<.42$ & $<.33$ & $<.40$ & -- & $<.21$ & $<.33$ \\
\hline CISOIL09 & $<.36$ & -- & $<.26$ & $<.42$ & $<.33$ & $<.40$ & -- & $<.21$ & $<.33$ \\
\hline CISOIL11 & $<.36$ & -- & $<.26$ & $<.42$ & $<.33$ & $<.40$ & -- & $<.21$ & $<.33$ \\
\hline CISOIL12 & $<.36$ & -- & $<.26$ & $<.42$ & $<.33$ & $<.40$ & -- & $<.21$ & $<.33$ \\
\hline CISOIL13 & $<.36$ & -- & $<.26$ & $<.42$ & $<.33$ & $<.40$ & .26 & $<.21$ & $<.33$ \\
\hline CISOIL14 & $<.36$ & 0.64 & $<.26$ & $<.42$ & $<.33$ & $<.40$ & 13 & $<.21$ & $<.33$ \\
\hline CISOIL 15 & $<.36$ & -- & $<.26$ & $<.42$ & $<.33$ & $<.40$ & - & $<.21$ & $<.33$ \\
\hline CISOIL 115 & $<.36$ & -- & $<.26$ & $<.42$ & $<.33$ & $<.40$ & -- & $<.21$ & $<.33$ \\
\hline CISOIL16 & $<.36$ & -- & $<.26$ & $<.42$ & $<.33$ & $<.40$ & -- & $<.21$ & $<.33$ \\
\hline CISOIL17 & $<.36$ & -- & $<.26$ & $<.42$ & $<.33$ & $<.40$ & $\cdots$ & $<.21$ & $<.33$ \\
\hline CISOIL18 & $<.36$ & -- & $<.26$ & $<.42$ & $<.33$ & $<.40$ & -- & $<.21$ & $<.33$ \\
\hline CISOIL 19 & $<.36$ & -- & $<.26$ & $<.42$ & $<.33$ & $<.40$ & -- & $<.21$ & $<.33$ \\
\hline CISOIL20 & $<.36$ & -- & $<.26$ & $<.42$ & $<.33$ & $<.40$ & -- & $<.21$ & $<.33$ \\
\hline CISOIL21 & $<.36$ & -- & $<.26$ & $<.42$ & $<.33$ & $<.40$ & .40 & $<.21$ & $<.33$ \\
\hline CISOIL22 & $<.36$ & -- & $<26$ & $<.42$ & $<.33$ & $<40$ & .. & $<.21$ & $<.33$ \\
\hline CISOIL23 & $<.36$ & -. & $<.26$ & $<.42$ & $<.33$ & $<.40$ & -- & $<.21$ & $<.33$ \\
\hline CISOIL24 & $<.36$ & -- & $<.26$ & $<.42$ & $<.33$ & $<.40$ & .84 & $<.21$ & $<.33$ \\
\hline CISOIL25 & $<.36$ & -- & $<.26$ & $<.42$ & $<.33$ & $<.40$ & .77 & $<.21$ & $<.33$ \\
\hline CISOIL27 & $<.36$ & -- & $<.26$ & $<.42$ & $<.33$ & $<.40$ & .48 & $<.21$ & $<.33$ \\
\hline CISOIL28 & $<.36$ & -- & $<.26$ & $<.42$ & $<.33$ & $<.40$ & .32 & $<.21$ & $<.33$ \\
\hline CISOIL29 & $<.36$ & -- & $<.26$ & $<.42$ & $<.33$ & $<.40$ & - & $<.21$ & $<.33$ \\
\hline
\end{tabular}


Table 18. Results of organic-chemical analyses of soil from selected sampling sites at Carroll Island, Aberdeen Proving Ground, Md., summer 1990--Continued

\begin{tabular}{|c|c|c|c|c|c|c|c|c|c|}
\hline $\begin{array}{l}\text { Sampling } \\
\text { site } \\
\text { (fig. } 5 \text { ) }\end{array}$ & Lindane & Malathion & $\begin{array}{l}\text { Meth- } \\
\text { oxy- } \\
\text { chlor }\end{array}$ & $\begin{array}{l}\text { Methyl- } \\
\text { n-butyl } \\
\text { ketone }\end{array}$ & $\begin{array}{l}\text { Methyl- } \\
\text { ethyl } \\
\text { ketone }\end{array}$ & $\begin{array}{l}\text { Methyl- } \\
\text { isobutyl } \\
\text { ketone }\end{array}$ & $\begin{array}{c}\text { T-Methyl- } \\
\text { naph- } \\
\text { thalene }\end{array}$ & $\begin{array}{c}\text { 2-Methyl- } \\
\text { naph- } \\
\text { thalene }\end{array}$ & $\begin{array}{c}\text { 2-Methyl- } \\
\text { phenol }\end{array}$ \\
\hline CISOILOI & $<0.43$ & $<0.48$ & $<1.0$ & $<0.01$ & $<0.010$ & $<0.01$ & -- & -- & $<0.33$ \\
\hline CISOIL101 & $<.43$ & $<.48$ & $<1.0$ & $<.01$ & $<.010$ & $<.01$ & -- & -- & $<.33$ \\
\hline CISOIL03 & $<.43$ & $<.48$ & $<1.0$ & $<10$ & $<10$ & $<10$ & -- & $<0.33$ & $<.33$ \\
\hline CISOILO4 & $<.43$ & $<.48$ & $<1.0$ & $<.01$ & $<.010$ & $<.01$ & $<0.33$ & - & $<.33$ \\
\hline CISOIL05 & $<.43$ & $<.48$ & $<1.0$ & $<.01$ & $<.010$ & $<.01$ & $<.33$ & -- & $<.33$ \\
\hline CISOIL06 & $<.43$ & $<.48$ & $<1.0$ & $<.01$ & $<.010$ & $<.01$ & $<.33$ & -- & $<.33$ \\
\hline CISOIL106 & $<.43$ & $<.48$ & $<1.0$ & $<.01$ & $<.010$ & $<.01$ & -- & -- & $<.33$ \\
\hline CISOIL07 & $<.43$ & $<.48$ & $<1.0$ & $<.01$ & $<.010$ & $<.01$ & $<.33$ & -- & $<.33$ \\
\hline CISOIL08 & $<.43$ & $<.48$ & $<1.0$ & $<.01$ & $<.010$ & $<.01$ & -- & $<.33$ & $<.33$ \\
\hline CISOIL09 & $<.43$ & $<.48$ & $<1.0$ & $<10$ & $<10$ & $<10$ & -- & $<.33$ & $<.33$ \\
\hline CISOIL11 & $<.43$ & $<.48$ & $<1.0$ & $<.01$ & $<.010$ & $<.01$ & -- & $<.33$ & $<.33$ \\
\hline CISOIL12 & $<.43$ & $<.48$ & $<1.0$ & $<10$ & $<10$ & $<10$ & -- & $<.33$ & $<.33$ \\
\hline CISOIL13 & $<.43$ & $<.48$ & $<1.0$ & $<.01$ & $<.010$ & $<.01$ & -- & -- & $<.33$ \\
\hline CISOIL14 & $<.43$ & $<.48$ & $<1.0$ & $<.01$ & $<.010$ & $<.01$ & -- & -- & $<.33$ \\
\hline CISOIL15 & $<.43$ & $<.48$ & $<1.0$ & $<.01$ & $<.010$ & $<.01$ & - & $<.33$ & $<.33$ \\
\hline CISOIL115 & $<.43$ & $<.48$ & $<1.0$ & $<.01$ & $<.010$ & $<.01$ & -- & $<.33$ & $<.33$ \\
\hline CISOIL16 & $<.43$ & $<.48$ & $<1.0$ & $<.01$ & $<.010$ & $<.01$ & -- & $<.33$ & $<.33$ \\
\hline CISOIL17 & $<.43$ & $<.48$ & $<1.0$ & $<.01$ & $<.010$ & $<.01$ & -- & $<.33$ & $<.33$ \\
\hline CISOIL18 & $<.43$ & $<.48$ & $<1.0$ & $<.01$ & $<.010$ & $<.01$ & -- & -- & $<.33$ \\
\hline CISOIL19 & $<.43$ & $<.48$ & $<1.0$ & $<.01$ & $<.010$ & $<.01$ & -- & -- & $<.33$ \\
\hline CISOIL20 & $<.43$ & $<.48$ & $<1.0$ & $<.01$ & .13 & $<.01$ & -- & -- & $<.33$ \\
\hline CISOIL21 & $<.43$ & $<.48$ & $<1.0$ & $<.01$ & $<.010$ & $<.01$ & -- & -- & $<.33$ \\
\hline CISOIL22 & $<.43$ & $<.48$ & $<1.0$ & $<.01$ & $<.010$ & $<.01$ & - & $<.33$ & $<.33$ \\
\hline CISOIL23 & $<.43$ & $<.48$ & $<1.0$ & $<10$ & $<10$ & $<10$ & -- & $<.33$ & $<.33$ \\
\hline CISOIL24 & $<.43$ & $<.48$ & $<1.0$ & $<.01$ & $<.010$ & $<.01$ & $<.33$ & -- & $<.33$ \\
\hline CISOIL25 & $<.43$ & $<.48$ & $<1.0$ & $<.01$ & $<.010$ & $<.01$ & $<.33$ & -- & $<.33$ \\
\hline CISOIL27 & $<.43$ & $<.48$ & $<1.0$ & $<.01$ & $<.010$ & $<.01$ & $<.33$ & -- & $<.33$ \\
\hline CISOIL28 & $<.43$ & $<.48$ & $<1.0$ & $<.01$ & $<.010$ & $<.01$ & $<.33$ & -- & $<.33$ \\
\hline CISOIL29 & $<.43$ & $<.48$ & $<1.0$ & $<.01$ & $<.010$ & $<.01$ & - & $<.33$ & $<.33$ \\
\hline $\begin{array}{c}\text { Sampling } \\
\text { site } \\
\text { (fig. 5) }\end{array}$ & $\begin{array}{c}\text { 4-Methyl- } \\
\text { phenol }\end{array}$ & $\begin{array}{l}\text { Naph- } \\
\text { thalene }\end{array}$ & $\begin{array}{l}\text { 2-Nitro- } \\
\text { aniline }\end{array}$ & $\begin{array}{l}\text { 3-Nitro- } \\
\text { aniline }\end{array}$ & $\begin{array}{l}\text { 4-Nitro } \\
\text { aniline }\end{array}$ & $\begin{array}{l}\text { Nitro- } \\
\text { ben- } \\
\text { zene }\end{array}$ & $\begin{array}{l}\text { 2-Nitro- } \\
\text { phenol }\end{array}$ & $\begin{array}{l}\text { 4-Nitro- } \\
\text { phenol }\end{array}$ & $\begin{array}{l}\text { N- } \\
\text { Nitroso- } \\
\text { diphenyl- } \\
\text { amine }\end{array}$ \\
\hline CISOাLO1 & $<0.33$ & $<0.42$ & $<1.7$ & $<1.7$ & $<1.7$ & $<0.33$ & $<0.33$ & $<1.7$ & $<0.33$ \\
\hline CISOIL101 & $<.33$ & $<.42$ & $<1.7$ & $<1.7$ & $<1.7$ & $<.33$ & $<.33$ & $<1.7$ & $<.33$ \\
\hline CISOIL03 & $<.33$ & $<.42$ & $<.33$ & $<1.7$ & $<1.7$ & $<.33$ & $<.33$ & $<1.7$ & $<.33$ \\
\hline CISOIL04 & $<.33$ & $<.42$ & $<1.7$ & $<1.7$ & $<1.7$ & $<.33$ & $<.33$ & $<1.7$ & $<.33$ \\
\hline CISOIL05 & $<.33$ & $<.42$ & $<1.7$ & $<1.7$ & $<1.7$ & $<.33$ & $<.33$ & $<1.7$ & $<.33$ \\
\hline CISOIL06 & $<.33$ & $<.42$ & $<1.7$ & $<1.7$ & $<1.7$ & $<.33$ & $<.33$ & $<1.7$ & $<.33$ \\
\hline CISOIL106 & $<.33$ & $<.42$ & $<1.7$ & $<1.7$ & $<1.7$ & $<.33$ & $<.33$ & $<1.7$ & $<.33$ \\
\hline CISOIL07 & $<.33$ & $<.42$ & $<1.7$ & $<1.7$ & $<1.7$ & $<.33$ & $<.33$ & $<1.7$ & $<.33$ \\
\hline CISOIL08 & $<.33$ & $<.42$ & $<3.3$ & $<1.7$ & $<1.7$ & $<.33$ & $<.33$ & $<1.7$ & $<.33$ \\
\hline CISOIL09 & $<.33$ & $<.42$ & $<.33$ & $<1.7$ & $<1.7$ & $<.33$ & $<.33$ & $<1.7$ & $<.33$ \\
\hline CISOIL11 & $<.33$ & $<42$ & $<3.3$ & $<1.7$ & $<1.7$ & $<.33$ & $<.33$ & $<.17$ & $<.33$ \\
\hline CISOIL12 & $<.33$ & $<.42$ & $<.33$ & $<1.7$ & $<1.7$ & $<.33$ & $<.33$ & $<1.7$ & $<.33$ \\
\hline CISOIL13 & $<.33$ & $<.42$ & $<1.7$ & $<1.7$ & $<1.7$ & $<.33$ & $<.33$ & $<1.7$ & $<.33$ \\
\hline CISOIL14 & $<.33$ & $<.42$ & $<1.7$ & $<1.7$ & $<1.7$ & $<.33$ & $<.33$ & $<1.7$ & $<.33$ \\
\hline CISOIL15 & $<.33$ & $<.42$ & $<3.3$ & $<1.7$ & $<1.7$ & $<.33$ & $<.33$ & $<1.7$ & $<.33$ \\
\hline CISOIL115 & $<.33$ & $<.42$ & $<3.3$ & $<1.7$ & $<1.7$ & $<.33$ & $<.33$ & $<1.7$ & $<.33$ \\
\hline CISOIL16 & $<.33$ & $<.42$ & $<1.7$ & $<1.7$ & $<1.7$ & $<.33$ & $<.33$ & $<1.7$ & $<.33$ \\
\hline CISOIL17 & $<.33$ & $<.42$ & $<3.3$ & $<1.7$ & $<1.7$ & $<.33$ & $<.33$ & $<1.7$ & $<.33$ \\
\hline CISOIL18 & $<.33$ & $<.42$ & $<1.7$ & $<1.7$ & $<1.7$ & $<.33$ & $<.33$ & $<1.7$ & $<.33$ \\
\hline CISOIL19 & $<.33$ & $<.42$ & $<1.7$ & $<1.7$ & $<1.7$ & $<.33$ & $<.33$ & $<1.7$ & $<.33$ \\
\hline CISOIL20 & .98 & $<.42$ & $<1.7$ & $<1.7$ & $<1.7$ & $<.33$ & $<.33$ & $<1.7$ & $<.33$ \\
\hline CISOIL21 & $<.33$ & $<.42$ & $<1.7$ & $<1.7$ & $<1.7$ & $<.33$ & $<.33$ & $<1.7$ & $<.33$ \\
\hline CISOIL22 & $<.33$ & $<.42$ & $<1.7$ & $<1.7$ & $<1.7$ & $<.33$ & $<.33$ & $<1.7$ & $<.33$ \\
\hline CISOIL23 & $<.33$ & $<.42$ & $<.33$ & $<1.7$ & $<1.7$ & $<.33$ & $<.33$ & $<1.7$ & $<.33$ \\
\hline CISOIL24 & $<.33$ & $<.42$ & $<1.7$ & $<1.7$ & $<1.7$ & $<.33$ & $<.33$ & $<1.7$ & $<.33$ \\
\hline CISOIL25 & $<.33$ & $<.42$ & $<1.7$ & $<1.7$ & $<1.7$ & $<.33$ & $<.33$ & $<1.7$ & $<.33$ \\
\hline CISOIL27 & $<.33$ & $<.42$ & $<1.7$ & $<1.7$ & $<1.7$ & $<.33$ & $<.33$ & $<1.7$ & $<.33$ \\
\hline CISOIL28 & $<.33$ & $<42$ & $<1.7$ & $<1.7$ & $<1.7$ & $<.33$ & $<.33$ & $<1.7$ & $<.33$ \\
\hline CISOIL29 & $<.33$ & $<.42$ & $<3.30$ & $<1.7$ & $<1.7$ & $<.33$ & $<.33$ & $<1.7$ & $<.33$ \\
\hline
\end{tabular}


Table 18. Results of organic-chemical analyses of soil from selected sampling sites at Carroll Island, Aberdeen Proving Ground, Md., summer 1990--Continued

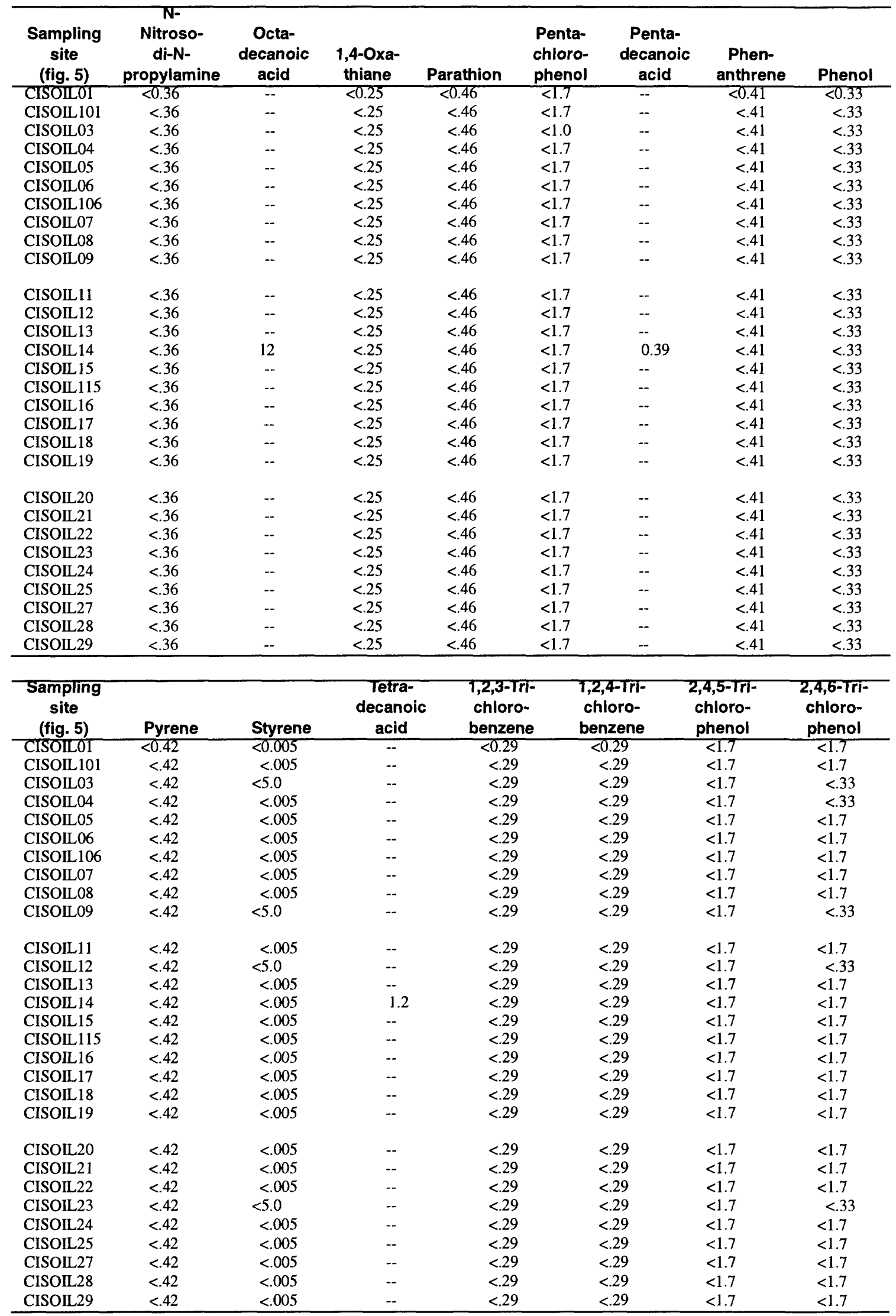


Table 19. Results of inorganic-chemical analyses of equipment blanks at Carroll Island, Aberdeen Proving Ground, Md., spring 1989

[All concentrations are for dissolved constituents in units of milligrams per liter unless noted; $\mu \mathrm{S} / \mathrm{cm}$, microsiemens per centimeter; --, missing data; $<$, less than]

\begin{tabular}{|c|c|c|c|c|c|c|c|c|}
\hline $\begin{array}{c}\text { Lab } \\
\text { identifier }\end{array}$ & Date & $\begin{array}{c}\text { Specific } \\
\text { conductance, } \\
\text { laboratory } \\
(\mu S / \mathrm{cm})\end{array}$ & $\begin{array}{c}\text { Calcium } \\
\text { (as Ca) }\end{array}$ & $\begin{array}{c}\text { Magnesium } \\
\text { (as Mg) }\end{array}$ & $\begin{array}{l}\text { Sodium } \\
\text { (as Na) }\end{array}$ & $\begin{array}{c}\text { Potassium } \\
\text { (as K) }\end{array}$ & $\begin{array}{l}\text { Sulfate } \\
\text { (as } \mathrm{SO}_{4} \text { ) }\end{array}$ & $\begin{array}{c}\text { Chloride } \\
\text { (as Cl) }\end{array}$ \\
\hline LS37*131 & $04-27-89$ & 1.44 & -- & -- & -- & - & $<10.0$ & $<2.12$ \\
\hline LS37*137 & $05-09-89$ & 1.80 & -- & .. & -. & -- & -- & -- \\
\hline
\end{tabular}

\begin{tabular}{ccccccccc}
\hline $\begin{array}{c}\text { Lab } \\
\text { identifier }\end{array}$ & Date & $\begin{array}{c}\text { Fluoride } \\
\text { (as F) }\end{array}$ & $\begin{array}{c}\text { Bromide } \\
\text { (as Br) }\end{array}$ & $\begin{array}{c}\text { Silica } \\
\text { (as SiO })\end{array}$ & $\begin{array}{c}\text { Nitrogen } \\
\mathrm{NO}_{2}+\mathrm{NO}_{3} \\
(\text { as N) }\end{array}$ & $\begin{array}{c}\text { Aluminum } \\
\text { (as Al) }\end{array}$ & $\begin{array}{c}\text { Antimony } \\
\text { (as Sb) }\end{array}$ & $\begin{array}{c}\text { Arsenic } \\
\text { (as As) }\end{array}$ \\
\hline $\mathrm{LS}_{37} 7^{*} 131$ & $04-27-89$ & $<1.23$ & $<3.00$ & $<0.050$ & $<0.010$ & -- & -- & $<0.00254$ \\
$\mathrm{LS} 37^{*} 137$ & $05-09-89$ & -- & -- & $<.050$ & $<.010$ & -- & -- & $<.00254$ \\
\hline
\end{tabular}

\begin{tabular}{ccccccccc}
\hline $\begin{array}{c}\text { Lab } \\
\text { identifier }\end{array}$ & Date & $\begin{array}{c}\text { Barium } \\
\text { (as Ba) }\end{array}$ & $\begin{array}{c}\text { Beryllium } \\
\text { (as Be) }\end{array}$ & $\begin{array}{c}\text { Cadmium } \\
\text { (as Cd) }\end{array}$ & $\begin{array}{c}\text { Chromium } \\
\text { (as Cr) }\end{array}$ & $\begin{array}{c}\text { Copper } \\
\text { (as Cu) }\end{array}$ & $\begin{array}{c}\text { Iron } \\
\text { (as Fe) }\end{array}$ & $\begin{array}{c}\text { Lead } \\
\text { (as Pb) }\end{array}$ \\
\hline LS37*131 & $04-27-89$ & -- & -- & -- & -- & -- & - & $<0.00126$ \\
LS37*137 & $05-09-89$ & -- & -- & - & - & -- & -- & $<.00126$ \\
\hline
\end{tabular}

\begin{tabular}{ccccccccc}
\hline $\begin{array}{c}\text { Lab } \\
\text { identifier }\end{array}$ & Date & $\begin{array}{c}\text { Manganese } \\
\text { (as Mn) }\end{array}$ & $\begin{array}{c}\text { Mercury } \\
\text { (as Hg) }\end{array}$ & $\begin{array}{c}\text { Nickel } \\
\text { (as Ni) }\end{array}$ & $\begin{array}{c}\text { Selenium } \\
\text { (as Se) }\end{array}$ & $\begin{array}{c}\text { Silver } \\
\text { (as Ag) }\end{array}$ & $\begin{array}{c}\text { Thallium } \\
\text { (as TI) }\end{array}$ & $\begin{array}{c}\text { Zinc } \\
\text { (as Zn) }\end{array}$ \\
\hline $\mathrm{LS} 37^{*} 131$ & $04-27-89$ & -- & $<0.000243$ & -- & $<0.00302$ & -- & -- & - \\
$\mathrm{LS} 37^{*} 137$ & $05-09-89$ & -- & $<.000243$ & - & $<.00302$ & -- & -- & -- \\
\hline
\end{tabular}


Table 20. Results of organic-chemical analyses of equipment blanks at Carroll Island, Aberdeen Proving Ground, Md., spring 1989

[Concentrations are in micrograms per liter; <, less than; --, missing data; PCB, polychlorinated biphenyl]

\begin{tabular}{|c|c|c|c|c|c|c|c|c|}
\hline $\begin{array}{c}\text { Lab } \\
\text { identifier }\end{array}$ & Date & Benzene & $\begin{array}{l}\text { Bromo- } \\
\text { dichloro- } \\
\text { methane }\end{array}$ & $\begin{array}{l}\text { Bromo- } \\
\text { form }\end{array}$ & $\begin{array}{c}\text { Carbon } \\
\text { tetra- } \\
\text { chloride }\end{array}$ & $\begin{array}{l}\text { Chloro- } \\
\text { benzene }\end{array}$ & $\begin{array}{l}\text { Chloro- } \\
\text { ethane }\end{array}$ & $\begin{array}{l}\text { Chloro- } \\
\text { form }\end{array}$ \\
\hline LS37*137 & $05-09-89$ & $<0.50$ & $<0.59$ & $<2.6$ & $<0.58$ & $<0.50$ & $<1.9$ & $<0.50$ \\
\hline $\begin{array}{c}\text { Lab } \\
\text { identifier }\end{array}$ & Date & $\begin{array}{l}\text { Chloro- } \\
\text { methane }\end{array}$ & $\begin{array}{l}\text { Chloro- } \\
\text { dibromo- } \\
\text { methane }\end{array}$ & $\begin{array}{c}\text { 1,2- } \\
\text { Dichloro- } \\
\text { benzene }\end{array}$ & $\begin{array}{c}\text { 1,3- } \\
\text { Dichloro- } \\
\text { benzene }\end{array}$ & $\begin{array}{c}\text { 1,4- } \\
\text { Dichloro- } \\
\text { benzene }\end{array}$ & $\begin{array}{c}\text { 1,1- } \\
\text { Dichloro- } \\
\text { ethane }\end{array}$ & $\begin{array}{c}1,2- \\
\text { Dichloro- } \\
\text { ethane }\end{array}$ \\
\hline LS37*129 & $05-02-89$ & -- & -- & $<1.7$ & $<1.7$ & $<1.7$ & -- & - \\
\hline LS $37 * 137$ & $05-09-89$ & $<3.2$ & $<0.67$ & $<1.7$ & $<1.7$ & $<1.7$ & $<0.68$ & $<0.50$ \\
\hline
\end{tabular}

\begin{tabular}{|c|c|c|c|c|c|c|c|c|}
\hline $\begin{array}{c}\text { Lab } \\
\text { identifier }\end{array}$ & Date & $\begin{array}{l}\text { 1,1-Dichloro- } \\
\text { ethylene }\end{array}$ & $\begin{array}{l}\text { 1,2-Dichloro- } \\
\text { ethylene } \\
\text { (cis+trans) }\end{array}$ & $\begin{array}{c}\text { 1,2-Di- } \\
\text { chloro- } \\
\text { propane }\end{array}$ & $\begin{array}{l}\text { cis-1,3-Di- } \\
\text { chloro- } \\
\text { propylene }\end{array}$ & $\begin{array}{c}\text { trans-1,3-Di- } \\
\text { chloro- } \\
\text { propylene }\end{array}$ & $\begin{array}{c}\text { Ethyl- } \\
\text { benzene }\end{array}$ & Fluorene \\
\hline $\mathrm{LS} 7^{*} 129$ & $05-02-89$ & $\bar{m}$ & $\cdots$ & - & $\cdots$ & - & -- & $<3.7$ \\
\hline LS37*137 & $05-09-89$ & $<0.50$ & $<0.50$ & $<0.50$ & $<0.58$ & $<0.70$ & $<0.50$ & $<3.7$ \\
\hline
\end{tabular}

\begin{tabular}{ccccccccc}
\hline $\begin{array}{c}\text { Lab } \\
\text { identifier }\end{array}$ & Date & $\begin{array}{c}\text { Methylene } \\
\text { chloride }\end{array}$ & Phenol & $\begin{array}{c}\text { 1,1,2,2-Tetra- } \\
\text { chloroethane }\end{array}$ & $\begin{array}{c}\text { Tetra- } \\
\text { chloroethylene }\end{array}$ & Toluene & $\begin{array}{c}\text { 1,1,1-Tri- } \\
\text { chloroethane }\end{array}$ & $\begin{array}{c}\text { Trichloro- } \\
\text { ethylene }\end{array}$ \\
\hline LS37*129 & $05-02-89$ & -- & $<9.2$ & -- & -- & -- & -- & -- \\
LS37*137 & $05-09-89$ & $<2.3$ & $<9.2$ & $<0.51$ & $<1.6$ & $<0.50$ & $<0.50$ & $<0.50$ \\
\hline
\end{tabular}

\begin{tabular}{ccccccc}
\hline $\begin{array}{c}\text { Lab } \\
\text { identifier }\end{array}$ & Date & $\begin{array}{c}\text { 1,1,2-Trichloro- } \\
\text { ethane }\end{array}$ & $\begin{array}{c}\text { Trichloro- } \\
\text { fluoromethane }\end{array}$ & Vinyl chloride & Xylenes & $\begin{array}{c}\text { Halogens, } \\
\text { total organic }\end{array}$ \\
\hline LS37*121 & $05-04-89$ & -- & - & -- & - & $<5.00$ \\
LS37*129 & $05-02-89$ & -- & - & -- & - & 9.00 \\
LS37*131 & $04-27-89$ & -- & - & - & - & $<5.00$ \\
LS37*133 & $04-27-89$ & -- & - & - & - & $<5.00$ \\
LS37*137 & $05-09-89$ & $<1.2$ & $<1.4$ & $<2.6$ & $<0.84$ & 116 \\
\hline
\end{tabular}

\begin{tabular}{ccccccccc}
\hline $\begin{array}{c}\text { Lab } \\
\text { identifier }\end{array}$ & Date & $\begin{array}{c}\text { Acetic acid } \\
\text { vinyl ester }\end{array}$ & $\begin{array}{c}\text { Acenaph- } \\
\text { thene }\end{array}$ & $\begin{array}{c}\text { Acenaph- } \\
\text { thylene }\end{array}$ & Acetone & Acrolein & $\begin{array}{c}\text { Acryloni- } \\
\text { trile }\end{array}$ & Aldrin \\
\hline LS37*129 & $05-02-89$ & -- & $<1.70$ & $<0.500$ & -- & -- & -- & $<4.70$ \\
LS37*137 & $05-09-89$ & $<8.30$ & $<1.70$ & $<.500$ & $<13.0$ & $<100$ & $<100$ & $<4.70$ \\
\hline
\end{tabular}

\begin{tabular}{|c|c|c|c|c|c|c|c|c|}
\hline $\begin{array}{c}\text { Lab } \\
\text { identifier }\end{array}$ & Date & Anthracene & $\begin{array}{c}\text { alpha- } \\
\text { Benzene- } \\
\text { hexachloride }\end{array}$ & $\begin{array}{c}\text { beta- } \\
\text { Benzene- } \\
\text { hexachloride }\end{array}$ & $\begin{array}{c}\text { delta- } \\
\text { Benzene- } \\
\text { hexachloride }\end{array}$ & Benzidene & $\begin{array}{c}\text { Benzo } \\
\text { [a] } \\
\text { anthracene }\end{array}$ & $\begin{array}{l}\text { Benzo } \\
\text { [a] } \\
\text { pyrene }\end{array}$ \\
\hline LS37*129 & $05-02-89$ & $<0.500$ & $<4.00$ & $<4.00$ & $<4.00$ & $<10.0$ & $<1.60$ & $<4.70$ \\
\hline LS37*137 & $05-09-89$ & $<.500$ & $<4.00$ & $<4.00$ & $<4.00$ & $<10.0$ & $<1.60$ & $<4.70$ \\
\hline
\end{tabular}

\begin{tabular}{ccccccccc}
\hline $\begin{array}{c}\text { Lab } \\
\text { identifier }\end{array}$ & Date & $\begin{array}{c}\text { Benzo } \\
{[\mathbf{b}]} \\
\text { fluoranthene }\end{array}$ & $\begin{array}{c}\text { Benzo } \\
{[\mathrm{g}, \mathrm{h}, \mathrm{i}]} \\
\text { perylene }\end{array}$ & $\begin{array}{c}\text { Benzoic } \\
\text { acid }\end{array}$ & $\begin{array}{c}\text { Benzo } \\
{[\mathbf{k}]} \\
\text { fluoranthene }\end{array}$ & $\begin{array}{c}\text { Benzo- } \\
\text { thiazole }\end{array}$ & $\begin{array}{c}\text { Benzyl } \\
\text { alcohol }\end{array}$ & $\begin{array}{c}\text { Bis(2-chloro- } \\
\text { ethoxy) } \\
\text { methane }\end{array}$ \\
\hline LS37*121 & $05-04-89$ & -- & -- & -- & -- & $<2.11$ & -- & -- \\
LS37*129 & $05-02-89$ & $<5.40$ & $<6.10$ & $<13.0$ & $<0.870$ & $<2.11$ & $<0.720$ & $<1.50$ \\
LS37*131 & $04-27-89$ & -- & -- & -- & -- & $<2.11$ & -- & -- \\
LS37*133 & $04-27-89$ & -- & -- & -- & -- & $<2.11$ & -- & - \\
LS37*137 & $05-09-89$ & $<5.40$ & $<6.10$ & $<13.0$ & $<.870$ & $<2.11$ & $<.720$ & $<1.50$ \\
\hline
\end{tabular}


Table 20. Results of organic-chemical analyses of equipment blanks at Carroll Island, Aberdeen Proving Ground, Md., spring 1989--Continued

\begin{tabular}{|c|c|c|c|c|c|c|c|c|}
\hline $\begin{array}{c}\text { Lab } \\
\text { identifier }\end{array}$ & Date & $\begin{array}{l}\text { Bis(2- } \\
\text { chloro- } \\
\text { ethyl) } \\
\text { ether }\end{array}$ & $\begin{array}{c}\text { Bis(2- } \\
\text { chloro- } \\
\text { isopropyl) } \\
\text { ether }\end{array}$ & $\begin{array}{c}\text { 2,2-Bis } \\
\text { (p-chloro- } \\
\text { phenyl)- } \\
\text { 1,1-dichloro- } \\
\text { ethane }\end{array}$ & $\begin{array}{c}\text { 2,2-Bis } \\
\text { (p-chloro- } \\
\text { phenyl)- } \\
\text { 1,1-dichloro- } \\
\text { ethene }\end{array}$ & $\begin{array}{c}\text { 2,2-Bis } \\
\text { (p-chloro- } \\
\text { phenyl)- } \\
\text { 1,1,1-trichloro- } \\
\text { ethane }\end{array}$ & $\begin{array}{c}\text { Bis(2- } \\
\text { ethyl- } \\
\text { hexyl) } \\
\text { phthalate }\end{array}$ & $\begin{array}{l}\text { Bromo- } \\
\text { methane }\end{array}$ \\
\hline LS37*129 & $05-02-89$ & $<1.90$ & $<5.30$ & $<4.00$ & $<4.70$ & $<9.20$ & $<4.80$ & - \\
\hline LS37*137 & $05-09-89$ & $<1.90$ & $<5.30$ & $<4.00$ & $<4.70$ & $<9.20$ & $<4.80$ & $<5.80$ \\
\hline $\begin{array}{c}\text { Lab } \\
\text { identifier }\end{array}$ & Date & $\begin{array}{c}\text { 4-Bromo- } \\
\text { phenyl- } \\
\text { phenyl ether }\end{array}$ & $\begin{array}{c}\text { Butyl- } \\
\text { benzyl } \\
\text { phthalate }\end{array}$ & $\begin{array}{l}\text { Carbon } \\
\text { di- } \\
\text { sulfide }\end{array}$ & $\begin{array}{c}\text { alpha- } \\
\text { Chlordane }\end{array}$ & $\begin{array}{l}\text { gamma- } \\
\text { Chlordane }\end{array}$ & $\begin{array}{l}\text { 4-Chloro- } \\
\text { aniline }\end{array}$ & $\begin{array}{c}\text { 2-Chloro- } \\
\text { ethyl- } \\
\text { vinyl ether }\end{array}$ \\
\hline LS37*129 & $05-02-89$ & $<4.20$ & $<3.40$ & -- & $<5.10$ & $<5.10$ & $<7.30$ & - \\
\hline LS37*137 & $05-09-89$ & $<4.20$ & $<3.40$ & $<0.500$ & $<5.10$ & $<5.10$ & $<7.30$ & $<0.710$ \\
\hline $\begin{array}{c}\text { Lab } \\
\text { identifier }\end{array}$ & Date & $\begin{array}{l}\text { 2-Chloro- } \\
\text { naph- } \\
\text { thalene }\end{array}$ & $\begin{array}{l}\text { 2-Chloro- } \\
\text { phenol }\end{array}$ & $\begin{array}{l}\text { 4-Chloro- } \\
\text { phenyl- } \\
\text { methyl } \\
\text { sulfide }\end{array}$ & $\begin{array}{l}\text { 4-Chloro- } \\
\text { phenyl- } \\
\text { methyl } \\
\text { sulfone }\end{array}$ & $\begin{array}{l}\text { 4-Chloro- } \\
\text { phenyl- } \\
\text { methyl } \\
\text { sulfoxide }\end{array}$ & $\begin{array}{l}\text { 4-Chloro- } \\
\text { phenyl- } \\
\text { phenyl } \\
\text { ether }\end{array}$ & Chrysene \\
\hline LS37*121 & $05-04-89$ & - & - & $<1.26$ & $<4.72$ & $<4.23$ & -- & -- \\
\hline LS37*129 & $05-02-89$ & $<0.500$ & $<0.990$ & $<1.26$ & $<4.72$ & $<4.23$ & $<5.10$ & $<2.40$ \\
\hline $\mathrm{LS} 37 * 131$ & $04-27-89$ & - & -- & $<1.26$ & $<4.72$ & $<4.23$ & - & - \\
\hline LS37*133 & $04-27-89$ & -- & - & $<1.26$ & $<4.72$ & $<4.23$ & -- & - \\
\hline LS37*137 & $05-09-89$ & $<.500$ & $<.990$ & $<1.26$ & $<4.72$ & $<4.23$ & $<5.10$ & $<2.40$ \\
\hline
\end{tabular}

\begin{tabular}{|c|c|c|c|c|c|c|c|c|}
\hline $\begin{array}{c}\text { Lab } \\
\text { identifier }\end{array}$ & Date & $\begin{array}{c}\text { Dibenz } \\
{[\mathrm{a}, \mathrm{h}]} \\
\text { anthracene }\end{array}$ & $\begin{array}{c}\text { Dibenzo } \\
\text { furan }\end{array}$ & $\begin{array}{l}\text { Di-n-butyl } \\
\text { phthalate }\end{array}$ & $\begin{array}{l}\text { Dichloro- } \\
\text { benzenes }\end{array}$ & $\begin{array}{l}\text { 3,3'-Dichloro- } \\
\text { benzidine }\end{array}$ & $\begin{array}{c}\text { 2,4-Dichloro- } \\
\text { phenol }\end{array}$ & Dieldrin \\
\hline LS37*129 & $05-02-89$ & $<6.50$ & $<1.70$ & $<3.70$ & - & $<12.0$ & $<2.90$ & $<4.70$ \\
\hline LS37*137 & $05-09-89$ & $<6.50$ & $<1.70$ & $<3.70$ & $<10.0$ & $<12.0$ & $<2.90$ & $<4.70$ \\
\hline
\end{tabular}

\begin{tabular}{|c|c|c|c|c|c|c|c|c|}
\hline $\begin{array}{c}\text { Lab } \\
\text { identifier }\end{array}$ & Date & $\begin{array}{c}\text { Diethyl } \\
\text { phthalate }\end{array}$ & $\begin{array}{l}\text { Dimethyl } \\
\text { disulfide }\end{array}$ & $\begin{array}{l}\text { 2,4-Di- } \\
\text { methyl- } \\
\text { phenol }\end{array}$ & $\begin{array}{l}\text { Dimethyl } \\
\text { phthalate }\end{array}$ & $\begin{array}{c}\text { 2,4-Dinitro- } \\
\text { phenol }\end{array}$ & $\begin{array}{l}\text { 2,4-Dinitro- } \\
\text { toluene }\end{array}$ & $\begin{array}{l}\text { 2,6-Dinitro- } \\
\text { toluene }\end{array}$ \\
\hline $\mathrm{LS} 37 * 121$ & $05-04-89$ & -- & $<1.14$ & $\cdots$ & $\cdots$ & 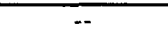 & $\cdots$ & $\cdots$ \\
\hline $\mathrm{LS} 37 * 129$ & $05-02-89$ & $<2.00$ & $<1.14$ & $<5.80$ & $<1.50$ & $<21.0$ & $<4.50$ & $<0.790$ \\
\hline $\mathrm{LS} 37 * 131$ & $04-27-89$ & - & $<1.14$ & -- & - & -- & -- & -- \\
\hline $\mathrm{LS} 37 * 133$ & $04-27-89$ & -- & $<1.14$ & -- & - & - & - & -- \\
\hline LS37*137 & $05-09-89$ & $<2.00$ & $<1.14$ & $<5.80$ & $<1.50$ & $<21.0$ & $<4.50$ & $<.790$ \\
\hline
\end{tabular}

\begin{tabular}{|c|c|c|c|c|c|c|c|c|}
\hline $\begin{array}{c}\text { Lab } \\
\text { identifier }\end{array}$ & Date & $\begin{array}{l}\text { Di-n-octyl } \\
\text { phthalate }\end{array}$ & $\begin{array}{l}\text { 1,2-Diphenyl- } \\
\text { hydrazine }\end{array}$ & Dithiane & $\begin{array}{c}\text { alpha- } \\
\text { Endosulfan }\end{array}$ & $\begin{array}{c}\text { beta- } \\
\text { Endosulfan }\end{array}$ & $\begin{array}{c}\text { Endosulfan } \\
\text { sulfate }\end{array}$ & Endrin \\
\hline $\mathrm{LS} 37^{*} 121$ & $05-04-89$ & - & -- & $<1.11$ & -- & -- & -- & - \\
\hline LS37*129 & $05-02-89$ & $<15.0$ & $<2.00$ & $<1.11$ & $<9.20$ & $<9.20$ & $<9.20$ & $<7.60$ \\
\hline $\mathrm{LS} 37 * 131$ & $04-27-89$ & -- & -- & $<1.11$ & - & - & -- & -- \\
\hline LS37*133 & $04-27-89$ & -- & -- & $<1.11$ & -- & - & -- & -- \\
\hline $\mathrm{LS} 37 * 137$ & $05-09-89$ & $<15.0$ & $<2.00$ & $<1.11$ & $<9.20$ & $<9.20$ & $<9.20$ & $<7.60$ \\
\hline
\end{tabular}

\begin{tabular}{|c|c|c|c|c|c|c|c|c|}
\hline $\begin{array}{c}\text { Lab } \\
\text { identifier }\end{array}$ & Date & $\begin{array}{c}\text { Endrin } \\
\text { aldehyde }\end{array}$ & $\begin{array}{l}\text { Endrin } \\
\text { ketone }\end{array}$ & $\begin{array}{l}\text { Fluor- } \\
\text { anthene }\end{array}$ & $\begin{array}{l}\text { Hepta- } \\
\text { chlor }\end{array}$ & $\begin{array}{l}\text { Heptachlor } \\
\text { epoxide }\end{array}$ & $\begin{array}{c}\text { Hexachloro- } \\
\text { benzene }\end{array}$ & $\begin{array}{l}\text { Hexachloro- } \\
\text { butadiene }\end{array}$ \\
\hline $\mathrm{LS} 37^{*} 129$ & $05-02-89$ & $<8.00$ & $<8.00$ & $<3.30$ & $<2.00$ & $<5.00$ & $<1.60$ & $<3.40$ \\
\hline
\end{tabular}


Table 20. Results of organic-chemical analyses of equipment blanks at Carroll Island, Aberdeen Proving Ground, Md., spring 1989--Continued

\begin{tabular}{|c|c|c|c|c|c|c|c|c|}
\hline $\begin{array}{c}\text { Lab } \\
\text { identifier }\end{array}$ & Date & $\begin{array}{c}\text { Hexachloro- } \\
\text { cyclo- } \\
\text { pentadiene }\end{array}$ & $\begin{array}{l}\text { Hexachloro- } \\
\text { ethane }\end{array}$ & $\begin{array}{c}\text { Indeno } \\
{[1,2,3-c, d]} \\
\text { pyrene }\end{array}$ & Isophorone & Lindane & $\begin{array}{l}\text { Meth- } \\
\text { oxychlor }\end{array}$ & $\begin{array}{l}\text { Methyl- } \\
\text { n-butyl } \\
\text { ketone }\end{array}$ \\
\hline LS37*129 & $05-02-89$ & $<8.60$ & $<1.50$ & $<8.60$ & $<4.80$ & $<4.00$ & $<5.10$ & - \\
\hline LS37*137 & $05-09-89$ & $<8.60$ & $<1.50$ & $<8.60$ & $<4.80$ & $<4.00$ & $<5.10$ & $<3.60$ \\
\hline $\begin{array}{c}\text { Lab } \\
\text { identifier }\end{array}$ & Date & $\begin{array}{l}\text { 3-Methyl- } \\
\text { 4-chloro- } \\
\text { phenol }\end{array}$ & $\begin{array}{l}\text { 2-Methyl- } \\
\text { 4,6-dinitro- } \\
\text { phenol }\end{array}$ & $\begin{array}{l}\text { Methyl- } \\
\text { ethyl } \\
\text { ketone }\end{array}$ & $\begin{array}{l}\text { Methyl- } \\
\text { isobutyl } \\
\text { ketone }\end{array}$ & $\begin{array}{l}\text { 2-Methyl- } \\
\text { naph- } \\
\text { thalene }\end{array}$ & $\begin{array}{l}\text { 2-Methyl- } \\
\text { phenol }\end{array}$ & $\begin{array}{l}\text { 4-Methyl- } \\
\text { phenol }\end{array}$ \\
\hline LS37*129 & $05-02-89$ & $<4.00$ & $<17.0$ & -- & -- & $<1.70$ & $<3.90$ & $<0.520$ \\
\hline LS37*137 & 05-09-89 & $<4.00$ & $<17.0$ & $<6.40$ & $<3.00$ & $<1.70$ & $<3.90$ & $<.520$ \\
\hline $\begin{array}{c}\text { Lab } \\
\text { identifier }\end{array}$ & Date & $\begin{array}{l}\text { Naph- } \\
\text { thalene }\end{array}$ & $\begin{array}{l}\text { 2-Nitro- } \\
\text { aniline }\end{array}$ & $\begin{array}{l}\text { 3-Nitro- } \\
\text { aniline }\end{array}$ & $\begin{array}{l}\text { 4-Nitro- } \\
\text { aniline }\end{array}$ & $\begin{array}{c}\text { Nitro- } \\
\text { benzene }\end{array}$ & $\begin{array}{l}\text { 2-Nitro- } \\
\text { phenol }\end{array}$ & $\begin{array}{l}\text { 4-Nitro- } \\
\text { phenol }\end{array}$ \\
\hline LS37*129 & $05-02-89$ & $<0.500$ & $<4.30$ & $<4.90$ & $<5.20$ & $<0.500$ & $<3.70$ & $<12.0$ \\
\hline LS37*137 & $05-09-89$ & $<.500$ & $<4.30$ & $<4.90$ & $<5.20$ & $<.500$ & $<3.70$ & $<12.0$ \\
\hline $\begin{array}{c}\text { Lab } \\
\text { identifier }\end{array}$ & Date & $\begin{array}{l}\text { N-Nitroso- } \\
\text { dimethyl- } \\
\text { amine }\end{array}$ & $\begin{array}{l}\text { N-Nitroso-di- } \\
\text { N-propyl- } \\
\text { amine }\end{array}$ & $\begin{array}{l}\text { N-Nitroso- } \\
\text { diphenyl- } \\
\text { amine }\end{array}$ & $\begin{array}{c}\text { 1,4-Oxa- } \\
\text { thiane }\end{array}$ & $\begin{array}{l}\text { PCB } \\
1016\end{array}$ & $\begin{array}{l}\text { PCB } \\
1221\end{array}$ & $\begin{array}{l}\text { PCB } \\
1232\end{array}$ \\
\hline LS37*121 & $05-04-89$ & - & -- & $\overline{--}$ & $<1.98$ & - & -- & - \\
\hline LS $37 * 129$ & $05-02-89$ & $<2.00$ & $<4.40$ & $<3.00$ & $<1.98$ & $<21.0$ & $<21.0$ & $<21.0$ \\
\hline LS37*131 & $04-27-89$ & -- & - & -- & $<1.98$ & -. & -- & -- \\
\hline $\mathrm{LS} 37^{*} 133$ & $04-27-89$ & - & -- & - & $<1.98$ & $-\cdot$ & -- & -- \\
\hline $\mathrm{LS} 37 * 137$ & $05-09-89$ & $<2.00$ & $<4.40$ & $<3.00$ & $<1.98$ & $<21.0$ & $<21.0$ & $<21.0$ \\
\hline
\end{tabular}

\begin{tabular}{|c|c|c|c|c|c|c|c|c|}
\hline $\begin{array}{c}\text { Lab } \\
\text { identifier }\end{array}$ & Date & $\begin{array}{l}\text { PCB } \\
1242\end{array}$ & $\begin{array}{l}\text { PCB } \\
1248\end{array}$ & $\begin{array}{l}\text { PCB } \\
1254\end{array}$ & $\begin{array}{l}\text { PCB } \\
1260\end{array}$ & $\begin{array}{c}\text { Pentachloro- } \\
\text { phenol }\end{array}$ & $\begin{array}{c}\text { Phenan- } \\
\text { threne }\end{array}$ & $\begin{array}{c}\text { Phenolics } \\
\text { (non- } \\
\text { specific) }\end{array}$ \\
\hline LS37*121 & $05-04-89$ & -- & -- & - & - & - & -- & $<7.12$ \\
\hline LS $37 * 129$ & $05-02-89$ & $<30.0$ & $<30.0$ & $<36.0$ & $<36.0$ & $<18.0$ & $<0.500$ & $<7.12$ \\
\hline $\mathrm{LS} 37 * 131$ & $04-27-89$ & -- & -- & -. & -- & -- & -- & $<7.12$ \\
\hline LS $37 * 133$ & $04-27-89$ & -- & -- & -. & -- & -- & -. & 8.46 \\
\hline LS $37 * 137$ & $05-09-89$ & $<30.0$ & $<30.0$ & $<36.0$ & $<36.0$ & $<18.0$ & $<.500$ & -- \\
\hline
\end{tabular}

\begin{tabular}{ccccccccc}
\hline $\begin{array}{c}\text { Lab } \\
\text { identifier }\end{array}$ & Date & Pyrene & Styrene & $\begin{array}{c}\text { Thio- } \\
\text { di- } \\
\text { glycol }\end{array}$ & Toxaphene & $\begin{array}{c}\text { 1,2,4-Tri- } \\
\text { chloro- } \\
\text { benzene }\end{array}$ & $\begin{array}{c}\text { 2,4,5-Tri- } \\
\text { chloro- } \\
\text { phenol }\end{array}$ & $\begin{array}{c}\text { 2,4,6-Tri- } \\
\text { chloro- } \\
\text { phenol }\end{array}$ \\
\hline LS37*121 & $05-04-89$ & -- & -- & $<272$ & -- & -- & -- & -- \\
LS37*129 & $05-02-89$ & $<2.80$ & -- & -- & $<36.0$ & $<1.80$ & $<5.20$ & $<4.20$ \\
LS37*137 & $05-09-89$ & $<2.80$ & $<0.500$ & $<272$ & $<36.0$ & $<1.80$ & $<5.20$ & $<4.20$ \\
\hline
\end{tabular}


Table 21. Tentative identification of unknown organic compounds in water from wells and blank samples at Carroll Island, Aberdeen Proving Ground, Md., spring 1989

[Concentrations are approximate, in micrograms per liter; --, unknowns not reported; R, duplicate sample. UNK number is a laboratory code used to designate unknown compounds]

\begin{tabular}{|c|c|c|c|c|}
\hline $\begin{array}{c}\text { Well number (fig. 3) } \\
\text { or type } \\
\text { of blank sample }\end{array}$ & Sampling date & UNK number & Concentration & Tentative identification \\
\hline \multirow[t]{3}{*}{ I03 } & $4-26-89$ & UNK533 & 4 & Unknown \\
\hline & & UNK561 & 38 & Iodocyclohexanol \\
\hline & & UNK565 & 2 & Chloroiodocyclohexanol \\
\hline \multirow[t]{2}{*}{107} & 5-03-89 & UNK616 & 4 & Unknown \\
\hline & & UNK637 & 4 & Unknown \\
\hline I08 & 5-03-89 & UNK561 & 4 & Iodocyclohexanol \\
\hline \multirow[t]{2}{*}{109} & $4-25-89$ & UNK561 & 12 & Iodocyclohexanol \\
\hline & & UNK616 & 4 & Unknown \\
\hline 110 & $4-25-89$ & UNK561 & 5 & Iodocyclohexanol \\
\hline \multirow[t]{2}{*}{112} & $5-09-89$ & UNK552 & 6 & cis-2-Bromocyclohexanol \\
\hline & & UNK561 & 10 & Iodocyclohexanol \\
\hline \multirow[t]{2}{*}{ I14 } & $5-08-89$ & UNK533 & 3 & Unknown \\
\hline & & UNK616 & 2 & Unknown \\
\hline \multirow[t]{4}{*}{ I15 } & $5-08-89$ & UNK547 & 7 & Unknown \\
\hline & & UNK561 & 18 & Iodocyclohexanol \\
\hline & & UNK616 & 3 & Unknown \\
\hline & & UNK648 & 5 & Unknown hydrocarbon \\
\hline Trip blank & $5-01-89$ & -- & & \\
\hline Trip blank & $5-08-89$ & -- & & \\
\hline \multirow[t]{2}{*}{$116 \mathrm{~A}$} & $4-24-89$ & UNK557 & 9 & Unknown \\
\hline & & UNK616 & 2 & Unknown \\
\hline \multirow[t]{4}{*}{ I16B } & $5-08-89$ & UNK533 & 5 & Unknown \\
\hline & & UNK534 & 8 & Unknown \\
\hline & & UNK552 & 5 & cis-2-Bromocyclohexanol \\
\hline & & UNK561 & 20 & Iodocyclohexanol \\
\hline \multirow[t]{3}{*}{ I17 } & $5-08-89$ & UNK533 & 4 & Unknown \\
\hline & & UNK534 & 4 & Unknown \\
\hline & & UNK561 & 3 & Iodocyclohexanol \\
\hline I18 & $5-08-89$ & -- & & \\
\hline I18 (R) & $5-08-89$ & -- & & \\
\hline \multirow[t]{2}{*}{119} & $5-08-89$ & UNK561 & 10 & Iodocyclohexanol \\
\hline & & UNK616 & 2 & Unknown \\
\hline $120 \mathrm{~A}$ & $5-09-89$ & UNK588 & 2 & Unknown \\
\hline 121 & $5-09-89$ & UNK533 & 4 & Unknown \\
\hline I22A & $4-24-89$ & UNK616 & 3 & Unknown \\
\hline I22B & $5-04-89$ & UNK599 & 70 & Tris(2-chloroethyl)ester phosphoric acid \\
\hline I22B (R) & $5-04-89$ & UNK599 & 70 & Tris(2-chloroethyl)ester phosphoric acid \\
\hline \multirow[t]{4}{*}{$\mathrm{I} 22 \mathrm{C}$} & $5-04-89$ & UNK533 & 4 & Unknown \\
\hline & & UNK547 & 10 & Unknown \\
\hline & & UNK548 & 5 & Unknown \\
\hline & & UNK561 & 10 & Iodocyclohexanol \\
\hline Equipment blank & $5-04-89$ & UNK591 & 21 & Diphenylmethanone \\
\hline \multirow[t]{4}{*}{123} & $5-09-89$ & UNK533 & 4 & Unknown \\
\hline & & UNK534 & 5 & Unknown \\
\hline & & UNK561 & 30 & Iodocyclohexanol \\
\hline & & UNK588 & 20 & Unknown \\
\hline \multirow[t]{2}{*}{$\mathrm{I} 25$} & 5-04-89 & UNK533 & 5 & Unknown \\
\hline & & UNK561 & 3 & lodocyclohexanol \\
\hline $126 \mathrm{~A}$ & $4-27-89$ & UNK561 & 4 & Iodocyclohexanol \\
\hline I26A (R) & $4-27-89$ & UNK561 & 4 & lodocyclohexanol \\
\hline I26B & $5-02-89$ & -- & & \\
\hline
\end{tabular}


Table 21. Tentative identification of unknown organic compounds in water from wells and blank samples at Carroll Island, Aberdeen Proving Ground, Md., spring 1989--Continued

\begin{tabular}{|c|c|c|c|c|}
\hline $\begin{array}{c}\text { Well number (fig. } 3 \text { ) } \\
\text { or type } \\
\text { of blank sample }\end{array}$ & Sampling date & UNK number & Concentration & Tentative identification \\
\hline \multirow[t]{4}{*}{$\overline{127 \mathrm{~A}}$} & $4-25-89$ & UNK599 & 2 & Unknown \\
\hline & & UNK616 & 4 & Unknown \\
\hline & & UNK642 & 3 & Unknown \\
\hline & & UNK650 & 6 & Unknown \\
\hline I27B & $4-20-89$ & UNK533 & 7 & Unknown \\
\hline I27B (R) & $4-20-89$ & -- & & \\
\hline \multirow[t]{3}{*}{$\mathrm{I} 28$} & $4-20-89$ & UNK511 & 10 & Chloroiodomethane \\
\hline & & UNK561 & 67 & Iodocyclohexanol \\
\hline & & UNK565 & 8 & Unknown \\
\hline 129 & $4-20-89$ & UNK533 & 4 & Unknown \\
\hline \multirow{2}{*}{130} & $4-20-89$ & UNK511 & 4 & Chloroiodomethane \\
\hline & & UNK599 & 3 & Tris(2-chloroethyl)ester phosphoric acid \\
\hline Trip blank & $5-04-89$ & -- & & \\
\hline $\mathrm{I} 32$ & $5-01-89$ & UNK561 & 30 & Iodocyclohexanol \\
\hline 135 & $5-02-89$ & UNK533 & 4 & Unknown \\
\hline $\mathrm{I} 36$ & $5-02-89$ & UNK648 & 4 & 10-Demethylsqualene \\
\hline Equipment blank & $5-02-89$ & UNK591 & 8 & Diphenylmethanone \\
\hline \multirow[t]{3}{*}{$137 \mathrm{~A}$} & $4-24-89$ & UNK561 & 2 & Iodocyclohexanol \\
\hline & & UNK599 & 3 & Unknown \\
\hline & & UNK616 & 4 & Unknown \\
\hline I37B & $4-24-89$ & UNK561 & 11 & Iodocyclohexanol \\
\hline I37B (R) & $4-24-89$ & UNK561 & 13 & Iodocyclohexanol \\
\hline Trip blank & $4-25-89$ & -- & & \\
\hline $\mathrm{I} 38 \mathrm{~A}$ & $4-26-89$ & UNK561 & 13 & Iodocyclohexanol \\
\hline 139 & $4-26-89$ & UNK561 & 10 & Iodocyclohexanol \\
\hline \multirow[t]{4}{*}{ I41 } & $4-26-89$ & UNK511 & 3 & Chloroiodomethane \\
\hline & & UNK533 & 3 & Unknown \\
\hline & & UNK561 & 32 & Iodocyclohexanol \\
\hline & & UNK565 & 6 & Chloroiodocyclohexanol \\
\hline \multirow[t]{2}{*}{ I42 } & $4-26-89$ & UNK561 & 9 & Iodocyclohexanol \\
\hline & & UNK565 & 2 & Chloroiodocyclohexanol \\
\hline \multirow[t]{2}{*}{ I43 } & $4-26-89$ & UNK533 & 3 & Unknown \\
\hline & & UNK565 & 5 & Chloroiodocyclohexanol \\
\hline \multirow[t]{3}{*}{ I44 } & $5-09-89$ & UNK561 & 10 & Iodocyclohexanol \\
\hline & & UNK588 & 10 & Unknown \\
\hline & & UNK599 & 8 & $\begin{array}{l}\text { Tris(2-chloroethyl)ester phos- } \\
\text { phoric acid }\end{array}$ \\
\hline I45 & 5-15-89 & UNK589 & 3 & $\begin{array}{l}\text { 2-Methyl,1-(1,1-dimethylethyl)-2-methyl-1,3- } \\
\text { propanediylester propanoic acid }\end{array}$ \\
\hline \multirow[t]{6}{*}{ I47A } & $5-09-89$ & UNK552 & 3 & cis-2-Bromocyclohexanol \\
\hline & & UNK561 & 40 & Iodocyclohexanol \\
\hline & & UNK565 & 6 & Chloroiodocyclohexanol \\
\hline & & UNK581 & 5 & Dodecanol \\
\hline & & UNK587 & 7 & Unknown alcohol \\
\hline & & UNK602 & 3 & Unknown \\
\hline \multirow[t]{2}{*}{ I47B } & $4-27-89$ & UNK616 & 4 & Unknown \\
\hline & & UNK637 & 3 & Unknown \\
\hline I 48 & $5-09-89$ & -- & & \\
\hline \multirow[t]{2}{*}{ I49 } & $5-09-89$ & UNK533 & 4 & Unknown \\
\hline & & UNK561 & 30 & Iodocyclohexanol \\
\hline \multirow[t]{3}{*}{150} & $5-15-89$ & UNK533 & 4 & Unknown \\
\hline & & UNK552 & 6 & cis-2-Bromocyclohexanol \\
\hline & & UNK561 & 10 & Iodocyclohexanol \\
\hline
\end{tabular}


Table 21. Tentative identification of unknown organic compounds in water from wells and blank samples at Carroll Island, Aberdeen Proving Ground, Md., spring 1989--Continued

\begin{tabular}{lcccl}
\hline $\begin{array}{c}\text { Well number (fig. 3) } \\
\text { or type } \\
\text { of blank sample }\end{array}$ & Sampling date & UNK number & Concentration & \multicolumn{1}{c}{ Tentative identification } \\
\hline I51 & $5-15-89$ & -- & & Unknown \\
I52 & $5-15-89$ & UNK616 & 2 & Unknown \\
I53 & $5-15-89$ & UNK533 & 7 & Unknown \\
& & UNK534 & 7 & cis-2-Bromocyclohexanol \\
& & UNK552 & 7 & Iodocyclohexanol \\
& & UNK561 & 8 & Unknown \\
I53 (R) & $5-15-89$ & UNK533 & 6 & cis-2-Bromocyclohexanol \\
& & UNK552 & 7 & Iodocyclohexanol \\
& & UNK561 & 7 & Unknown \\
I54A & $5-15-89$ & UNK533 & 6 & Unknown \\
& & UNK534 & 5 & Iodocyclohexanol \\
& & UNK561 & 3 & Unknown \\
I54B & $4-27-89$ & UNK555 & 2 & Unknown \\
& & UNK616 & 3 & Diphenylmethanone \\
Equipment blank & $4-27-89$ & UNK591 & 8 & Diphenylmethanone \\
Equipment blank & $5-09-89$ & UNK591 & 12 & \\
Equipment blank & $4-27-89$ & -- & & \\
Trip blank & $5-15-89$ & -- & & \\
\hline
\end{tabular}


Table 22. Tentative identification of unknown organic compounds in surface water from selected sampling sites at Carroll Island, Aberdeen Proving Ground, Md., spring 1989

[Concentrations are approximate, in micrograms per liter; --, unknowns not reported; $R$, duplicate sample. UNK number is a laboratory designation for unknown compounds]

\begin{tabular}{|c|c|c|c|c|}
\hline $\begin{array}{l}\text { Sampling site } \\
\text { (fig. 4) }\end{array}$ & Sampling date & UNK number & Concentration & Tentative identification \\
\hline SW01 & $5-17-89$ & -. & & \\
\hline SW03 & $5-17-89$ & .. & & \\
\hline SW08 & $5-18-89$ & -- & & \\
\hline \multirow[t]{2}{*}{ SW09 } & $5-18-89$ & UNK512 & 5 & Unknown \\
\hline & & UNK646 & 10 & Unknown \\
\hline \multirow[t]{3}{*}{ SW11 } & $5-19-89$ & UNK603 & 2 & Unknown \\
\hline & & UNK614 & 4 & Unknown \\
\hline & & UNK666 & 6 & Unknown \\
\hline \multirow[t]{3}{*}{ SW11 (R) } & $5-19-89$ & UNK603 & 2 & Unknown \\
\hline & & UNK614 & 4 & Unknown \\
\hline & & UNK667 & 5 & Unknown \\
\hline SW12 & $5-17-89$ & UNK646 & 30 & 4,4'-Thiobis[2-(1,1-dimethyethyl)]-5-methylphenol \\
\hline SW13 & $5-17-89$ & -- & & \\
\hline \multirow[t]{7}{*}{ SW14 } & $5-17-89$ & UNK593 & 3 & Tridecanoic acid \\
\hline & & UNK603 & 3 & Unknown \\
\hline & & UNK614 & 2 & Unknown \\
\hline & & UNK615 & 5 & Unknown \\
\hline & & UNK617 & 4 & Unknown \\
\hline & & UNK674 & 20 & Stigmasta-5,22-dien-3 $\beta$-ol \\
\hline & & UNK679 & 9 & Unknown \\
\hline SW15 & $5-17-89$ & -- & & \\
\hline SW16 & 5-17-89 & UNK616 & 2 & Unknown \\
\hline SW17 & $5-17-89$ & -. & & \\
\hline SW18 (R) & $5-18-89$ & UNK646 & 5 & 4,4'-Thiobis[2-(1,1-dimethyethyl)]-5-methylphenol \\
\hline SW20 & $5-17-89$ & -- & & \\
\hline SW21 & $5-17-89$ & UNK588 & 2 & Unknown \\
\hline Equipment blank & $5-18-89$ & UNK646 & 5 & 4,4'-Thiobis[2-(1,1-dimethyethyl)]-5-methylphenol \\
\hline
\end{tabular}


Table 23. Tentative identification of unknown organic compounds in soil from selected sampling sites at Carroll Island, Aberdeen Proving Ground, Md., summer 1990

[UNK number is a laboratory designation for an unknown compound; UNK numbers less than 500 indicate volatile compounds; UNK numbers greater than 500 indicate semivolatile compounds; Concentrations are approximate and are reported in micrograms per gram; Tentative identification is the library compound chosen by the computer model; $\mathrm{R}$ is a value assigned by the computer to evaluate the match; Compound names truncated by the computer are indicated with an ellipsis (...) at the truncation point]

\begin{tabular}{|c|c|c|c|c|}
\hline $\begin{array}{l}\text { Sampling site } \\
\text { (fig. 5) }\end{array}$ & UNK number & Concentration & Tentative identification & $\mathbf{R}$ \\
\hline \multirow[t]{18}{*}{ CISOIL01 } & UNK217 & 0.005 & 4-Methyl-1-(1-methylethyl)-bicyclo[3.1.0]hexane & 0.897 \\
\hline & UNK320 & .004 & Decanal & .870 \\
\hline & UNK528 & .392 & Acetic acid methyl ester & .755 \\
\hline & UNK530 & 5.22 & 2,4-Dimethyl-1,3-dioxolane-2-methanol & .826 \\
\hline & UNK536 & .392 & Hexanedoic acid & .913 \\
\hline & UNK537 & 1.31 & 2,4-Pentanedione & .873 \\
\hline & UNK539 & .783 & Missing data & \\
\hline & UNK540 & .261 & 5-Methyl-5-hexen-2-one & .842 \\
\hline & UNK542 & .653 & trans-Diacetate tetrahydro- $2 \mathrm{H}$-pyran-2,3-diol & .848 \\
\hline & UNK552 & .261 & 2-Ethyl-hexanoic acid & .749 \\
\hline & UNK576 & .261 & 4,11,11-Trimethyl-8-me...bicyclo[7.2.0]undec-4-ene & .991 \\
\hline & UNK577 & .522 & [Copy illegible. Could not be determined.] & \\
\hline & UNK580 & .392 & 2,3-Octanediol & .778 \\
\hline & UNK631 & 1.31 & 1-(Chloromethyl)-4-(2-propenyl)-benzene & .741 \\
\hline & UNK633 & .653 & (E)-9-Eicosene & .952 \\
\hline & UNK638 & .131 & 1-Hexadecanol & .641 \\
\hline & UNK650 & 1.31 & (E)-9-Eicosene & .968 \\
\hline & UNK657 & .392 & Decanoic acid decyl ester & .737 \\
\hline \multirow[t]{23}{*}{ CISOIL101 } & UNK217 & .272 & $\alpha$-Pinene & .980 \\
\hline & UNK223 & .014 & Camphene & .961 \\
\hline & UNK234 & .004 & $\beta$-Myrcene & .860 \\
\hline & UNK253 & .004 & 1,2-Diethenyl-3-methyl-cyclobutane & .715 \\
\hline & UNK320 & .005 & Decanal & .897 \\
\hline & UNK334 & .068 & 4,11,11-Trimethyl-8-me... bicyclo[7.2.0]undec-4-ene & .958 \\
\hline & UNK528 & .272 & Acetic acid 1-methylethyl ester & .777 \\
\hline & UNK530 & .272 & 2,4-Dimethyl-1,3-dioxolane-2-methanol & .841 \\
\hline & UNK530 & 4.08 & 2,3-Dimethyl-heptane & .989 \\
\hline & UNK537 & .815 & 2,4-Pentanedione & .868 \\
\hline & UNK538 & .272 & 3,6,6-Trimethylbicyclo[3.1.1]hept-2-ene & .931 \\
\hline & UNK539 & 679 & 5-Methyl-5-hexen-2-one & .794 \\
\hline & UNK543 & .543 & trans-Diacetate tetrahydro- $2 H$-pyran-2,3-diol & .854 \\
\hline & UNK576 & .272 & 4,11,11-Trimethyl-8-me...bicyclo[7.2.0]undec-4-ene & .987 \\
\hline & UNK577 & .272 & Caryophyllene & .989 \\
\hline & UNK577 & 1.09 & Octahyd...1H-cyclopenta 1,3 cyclopropa 1,2 benzene & .980 \\
\hline & UNK581 & .272 & Octahyd...1H-cyclopenta 1,3 cyclopropa 1,2 benzene & .955 \\
\hline & UNK583 & .136 & 1,2,4a,5,8,8a-Hexahydro-4,7-dimethyl-naphthalene & .966 \\
\hline & UNK591 & .272 & $1,2,3,4,4 \mathrm{a}, 7,8,8 \mathrm{a}$-Octahydro-1,6-d...1-naphthalenol & .974 \\
\hline & UNK621 & .272 & 4-Methyl-1-phenyl-1-penten-3-one & 678 \\
\hline & UNK631 & 2.72 & [Copy illegible. Could not be determined.] & \\
\hline & UNK634 & .543 & (E)-9-Eicosene & .935 \\
\hline & UNK650 & .408 & (E)-9-Eicosene & .896 \\
\hline \multirow[t]{9}{*}{ C1SO1L03 } & UNK528 & 1.12 & 1,1-Dipropoxy-propane & .824 \\
\hline & UNK528 & 22.4 & 3-Hydroxy-3,5-dimethyl-2-hexanone & .710 \\
\hline & UNK530 & 1.12 & 4-Methyl octane & .985 \\
\hline & UNK530 & 1.12 & 2,3-Dimethyl-heptane & .966 \\
\hline & UNK530 & 1.49 & 3,4-Dimethyl-heptane & .983 \\
\hline & UNK531 & 1.12 & 3-Methyl-octane & .986 \\
\hline & UNK536 & .373 & 2-Bromo-hexane & .892 \\
\hline & UNK536 & 1.49 & 1-(Ethenyloxy)-pentane & .900 \\
\hline & UNK538 & 3.36 & 2,5-Dihydro-2,2,4-trimethyl-furan & .822 \\
\hline
\end{tabular}


Table 23. Tentative identification of unknown organic compounds in soil from selected sampling sites at Carroll Island, Aberdeen Proving Ground, Md., summer 1990--Continued

\begin{tabular}{|c|c|c|c|c|}
\hline $\begin{array}{l}\text { Sampling site } \\
\text { (fig. 5) }\end{array}$ & UNK number & Concentration & Tentative identification & $\mathbf{R}$ \\
\hline \multirow[t]{6}{*}{ CISOIL03--Continued } & UNK541 & 3.36 & trans-Diacetate tetrahydro- $2 \mathrm{H}$-pyran-2,3-diol & 0.846 \\
\hline & UNK547 & 1.12 & $\mathrm{~N}$-acetyl-dl-alloisoleucine & .702 \\
\hline & UNK633 & .373 & 2-(Octadecyloxy)-ethanol & .833 \\
\hline & UNK660 & 1.12 & (Z)-2-(9-Octadecenyloxy)-ethanol & .929 \\
\hline & UNK667 & .746 & Pentatriacontane & .971 \\
\hline & UNK687 & .373 & Hexadecanal & .935 \\
\hline \multirow[t]{13}{*}{ CISOIL04 } & UNK 136 & .003 & Cyanoacetic acid & .965 \\
\hline & UNK250 & .003 & 2,2-Dimethyl-1-propanol benzoate & .904 \\
\hline & UNK276 & .006 & Decanal & .975 \\
\hline & UNK 528 & 2.29 & 2,4-Dimethyl-1,3-dioxolane-2-methanol & .847 \\
\hline & UNK536 & 2.29 & 2,4-Pentanedione & .872 \\
\hline & UNK538 & .687 & 5-Methyl-5-hexen-2-one & .820 \\
\hline & UNK540 & .344 & Acetate 7-oxabicyclo[4.1.0]heptan-1-ol & .520 \\
\hline & UNK541 & 1.15 & trans-Diacetate tetrahydro- $2 \mathrm{H}$-pyran-2,3-diol & .857 \\
\hline & UNK616 & .344 & (Z)-9-Octadecenoic acid & .960 \\
\hline & UNK617 & .344 & Octadecanoic acid & .924 \\
\hline & UNK626 & .115 & (1-Propylheptadecyl)-cyclohexane & .713 \\
\hline & UNK633 & .344 & Phosphonic acid dioctadecyl ester & .703 \\
\hline & UNK647 & .229 & Phosphonic acid dioctadecyl ester & .865 \\
\hline \multirow[t]{14}{*}{ CISOIL05 } & UNK020 & .007 & Missing data & \\
\hline & UNK250 & .004 & 2-Chloroheptane & .731 \\
\hline & UNK276 & .009 & Decanal & .983 \\
\hline & UNK529 & 2.62 & 2,4-Dimethyl-2-pentanol & .790 \\
\hline & UNK536 & 2.62 & 2-Bromo-hexane & .864 \\
\hline & UNK538 & .393 & 5-Methyl-5-hexen-2-one & .777 \\
\hline & UNK541 & .393 & 2,3-Dihydro-3,5-dihydroxy-6-methy...4H-pyran-4-one & .511 \\
\hline & UNK542 & 2.62 & trans-Diacetate tetrahydro- $2 \mathrm{H}$-pyran-2,3-diol & .858 \\
\hline & UNK547 & 1.05 & 2-Methyl-3-heptanone & .631 \\
\hline & UNK616 & .131 & (E)-9-Eicosene & .816 \\
\hline & UNK616 & .262 & N-Methyl-N-(1-oxododecyl)-glycine & .751 \\
\hline & UNK625 & .262 & 4-Ethyl-5-octyl-2,2-bis(trifluorom...1,3-dioxolane & .499 \\
\hline & UNK630 & .262 & 4-Ethyl-5-octyl-2,2-bis(trifluorom...1,3-dioxolane & .634 \\
\hline & UNK636 & .393 & 4-Ethyl-5-octyl-2,2-bis(trifluorom...1,3-dioxolane & 689 \\
\hline \multirow[t]{7}{*}{ CISOIL06 } & UNK019 & .005 & Methylhydrazine oxalate (1:1) & .756 \\
\hline & UNK250 & .010 & (Z)-5-Methyl-2-decene & .700 \\
\hline & UNK276 & .012 & 5-Methyl-1-heptene & .714 \\
\hline & UNK528 & .737 & Missing data & \\
\hline & UNK536 & 1.23 & Missing data & \\
\hline & UNK538 & .86 & Missing data & \\
\hline & UNK542 & .369 & Missing data & \\
\hline \multirow[t]{10}{*}{ CISOIL106 } & UNK020 & .005 & Methylhydrazine oxalate (1:1) & .759 \\
\hline & UNK249 & .005 & 5-Methyl-1-hexene & .662 \\
\hline & UNK275 & .005 & 2-Octen-1-ol & .945 \\
\hline & UNK529 & .959 & Missing data & \\
\hline & UNK536 & 2.4 & Missing data & \\
\hline & UNK538 & .6 & Missing data & \\
\hline & UNK541 & .24 & Missing data & \\
\hline & UNK542 & 2.4 & Missing data & \\
\hline & UNK543 & .24 & Missing data & \\
\hline & UNK547 & .24 & Missing data & \\
\hline \multirow[t]{3}{*}{ CISOIL07 } & UNK014 & .005 & Methylhydrazine oxalate (1:1) & .869 \\
\hline & UNK020 & .005 & Methylhydrazine oxalate (1:1) & .668 \\
\hline & UNK250 & .005 & 2,4-Dimethyl-1-pentene & .602 \\
\hline
\end{tabular}


Table 23. Tentative identification of unknown organic compounds in soil from selected sampling sites at Carroll Island, Aberdeen Proving Ground, Md., summer 1990--Continued

\begin{tabular}{|c|c|c|c|c|}
\hline $\begin{array}{l}\text { Sampling site } \\
\text { (fig. 5) }\end{array}$ & UNK number & Concentration & Tentative identification & $\mathbf{R}$ \\
\hline \multirow[t]{10}{*}{ CISOIL07--Continued } & UNK276 & 0.005 & 2-Octen-1-ol & 0.944 \\
\hline & UNK529 & 3.67 & 2,4-Dimethyl-2-pentanol & .792 \\
\hline & UNK536 & .49 & 2-Bromo-hexane & .913 \\
\hline & UNK538 & .612 & 5-Methyl-5-hexen-2-one & .780 \\
\hline & UNK542 & 3.67 & trans-Diacetate tetrahydro- $2 H$-pyran-2,3-diol & .856 \\
\hline & UNK543 & .245 & trans-Diacetate tetrahydro- $2 H$-pyran-2,3-diol & .908 \\
\hline & UNK568 & .122 & 2-Methyl-2-propenoic acid propyl ester & .739 \\
\hline & UNK602 & .612 & 3-Pentadecyl-phenol & .895 \\
\hline & UNK615 & .245 & Phosphonic acid dioctadecyl ester & .781 \\
\hline & UNK637 & 2.45 & 1 Benzothieno 3,2-b 1 benzothiophene & .681 \\
\hline \multirow[t]{7}{*}{ CISOIL08 } & UNK257 & .004 & Nonanal & .995 \\
\hline & UNK284 & .006 & Decanal & .993 \\
\hline & UNK528 & 3.64 & Missing data & \\
\hline & UNK536 & 2.42 & Missing data & \\
\hline & UNK538 & 1.21 & Missing data & \\
\hline & UNK541 & 1.21 & Missing data & \\
\hline & UNK547 & .727 & Missing data & \\
\hline \multirow[t]{16}{*}{ CISOIL09 } & UNK022 & .008 & 3-Hydroxy-butanal & .712 \\
\hline & UNK528 & .333 & 1,1-Dipropoxy-propane & .924 \\
\hline & UNK528 & 9.98 & (Z)-5,5-Dimethyl-2-hexene & .897 \\
\hline & UNK530 & .499 & 2,3-Dimethyl-heptane & .857 \\
\hline & UNK530 & .832 & 4-Methyl-octane & .986 \\
\hline & UNK530 & .998 & 3,4-Dimethyl-heptane & .976 \\
\hline & UNK531 & .499 & 6-Methyl-undecane & .972 \\
\hline & UNK536 & .333 & 2-Bromo-hexane & .914 \\
\hline & UNK536 & .333 & 2,5-Hexanedione & .938 \\
\hline & UNK537 & 1.33 & Missing data & \\
\hline & UNK538 & .333 & 5-Methyl-3-hexen-2-one & .783 \\
\hline & UNK 540 & .333 & Octyl-silane & .637 \\
\hline & UNK541 & 1.66 & trans-Diacetate tetrahydro- $2 H$-pyran-2,3-diol & .846 \\
\hline & UNK547 & .333 & 1-(Trimethyloxiranyl)-ethanone & .685 \\
\hline & UNK599 & .166 & Benzenesulfonamide & .940 \\
\hline & UNK629 & .333 & Hexadecanal & .964 \\
\hline \multirow[t]{9}{*}{ CISOIL11 } & UNK034 & .004 & Missing data & \\
\hline & UNK078 & .004 & Missing data & \\
\hline & UNK257 & .006 & Missing data & \\
\hline & UNK284 & .011 & Missing data & \\
\hline & UNK528 & 2.47 & Missing data & \\
\hline & UNK536 & .986 & Missing data & \\
\hline & UNK538 & .863 & Missing data & \\
\hline & UNK541 & .74 & Missing data & \\
\hline & UNK547 & .247 & 5-Hexyldihydro-2( $3 H)$-furanone & .625 \\
\hline \multirow[t]{11}{*}{ CISOIL12 } & UNK022 & .014 & Amphetamine & .706 \\
\hline & UNK528 & .283 & 1,1-Dipropoxy-propane & .821 \\
\hline & UNK528 & 7.07 & 5,5-Dimethyl-1-hexene & .884 \\
\hline & UNK530 & .424 & 4-Methyl-octane & .980 \\
\hline & UNK530 & .707 & 2,3-Dimethyl heptane & .855 \\
\hline & UNK530 & .707 & 3,4-Dimethyl-heptane & .973 \\
\hline & UNK531 & .424 & 3-Methyl-octane & .986 \\
\hline & UNK535 & .141 & (E)-2-methyl-2-butenoic acid & .871 \\
\hline & UNK536 & .424 & 2,7-Dimethyl-octane & .763 \\
\hline & UNK536 & .141 & 2-Bromo-hexane & .894 \\
\hline & UNK536 & .99 & 5,5-Dimethyl-2(5H)-furanone & .901 \\
\hline
\end{tabular}


Table 23. Tentative identification of unknown organic compounds in soil from selected sampling sites at Carroll Island, Aberdeen Proving Ground, Md., summer 1990--Continued

\begin{tabular}{|c|c|c|c|c|}
\hline $\begin{array}{l}\text { Sampling site } \\
\text { (fig. 5) }\end{array}$ & UNK number & Concentration & Tentative identification & $\mathbf{R}$ \\
\hline \multirow[t]{12}{*}{ CISOIL12--Continued } & UNK538 & 1.41 & 5-Methyl-3-hexen-2-one & 0.785 \\
\hline & UNK538 & .707 & 2,5-Dihydro-2,2,4-trimethyl furan & .824 \\
\hline & UNK541 & .707 & trans-Diacetate tetrahydro- $2 \mathrm{H}$-pyran-2,3-diol & .847 \\
\hline & UNK547 & .424 & 1-(Trimethyloxiranyl)-ethanone & .667 \\
\hline & UNK551 & .141 & 2,3-Dimethyl-heptane & .726 \\
\hline & UNK633 & 1.13 & 11-Decyl-tetracosane & .970 \\
\hline & UNK638 & .424 & Octanoic acid 1-methyltridecyl ester & .766 \\
\hline & UNK646 & 4.24 & Docosane & .913 \\
\hline & UNK653 & .566 & 2-Methyl-1-hexadecanol & .726 \\
\hline & UNK666 & .849 & 11-Decyl-tetracosane & .975 \\
\hline & UNK697 & .424 & Heptacosane & .959 \\
\hline & UNK729 & .283 & 11-Octadecenal & .908 \\
\hline \multirow[t]{12}{*}{ CISOIL13 } & UNK019 & .003 & 4-Pentyn-2-ol & .342 \\
\hline & UNK319 & .003 & Decanal & .880 \\
\hline & UNK528 & .263 & Acetic acid 1-methylethyl ester & .763 \\
\hline & UNK530 & 3.94 & 2,4-Dimethyl-1,3-dioxolane-2-methanol & .819 \\
\hline & UNK537 & 1.18 & 2,4-Pentanedione & .867 \\
\hline & UNK538 & .263 & 3,6,6-Trimethylbicyclo[3.1.1]hept-2-ene & .916 \\
\hline & UNK539 & 1.18 & 5-Methyl 3-hexen-2-one & .815 \\
\hline & UNK540 & .394 & 5-Methyl 3-hexen-2-one & .852 \\
\hline & UNK542 & .526 & trans-Diacetate tetrahydro- $2 \mathrm{H}$-pyran-2,3-diol & .852 \\
\hline & UNK631 & .788 & 1,2,3,4-Tetrahydro-1-methyl-naphthalene & .710 \\
\hline & UNK634 & .263 & (E)-9-Eicosene & .926 \\
\hline & UNK650 & .657 & (E)-9-Eicosene & .894 \\
\hline \multirow[t]{26}{*}{ CISOIL14 } & UNK017 & .004 & Missing data & \\
\hline & UNK319 & .010 & Decanal & .880 \\
\hline & UNK530 & 3.86 & 2,4-Dimethyl-1,3-dioxolane-2-methanol & .837 \\
\hline & UNK537 & .643 & 2-Bromo-hexane & .860 \\
\hline & UNK539 & .514 & 5-Methyl-3-hexen-2-one & .803 \\
\hline & UNK541 & .257 & Missing data & \\
\hline & UNK542 & .386 & trans-Diacetate tetrahydro- $2 \mathrm{H}$-pyran-2,3-diol & .863 \\
\hline & UNK549 & 2.57 & 2-Ethyl-hexanoic acid & .935 \\
\hline & UNK556 & 64.3 & 2-Ethyl-hexanoic acid & .971 \\
\hline & UNK557 & .129 & 2-Methyl-2-hexenoic acid methyl ester & .813 \\
\hline & UNK560 & .386 & 2-Dodecenal & .653 \\
\hline & UNK568 & .257 & Missing data & \\
\hline & UNK583 & .257 & N,N-bis(2-hydroxyethyl)-dodecanamide & .939 \\
\hline & UNK613 & .129 & Missing data & \\
\hline & UNK613 & .129 & Missing data & \\
\hline & UNK614 & .129 & Missing data & \\
\hline & UNK623 & .257 & Missing data & \\
\hline & UNK624 & .129 & Missing data & \\
\hline & UNK633 & .386 & 1-Cyclopentyl-4-(3-cyclopentylpropyl)-dodecane & .643 \\
\hline & UNK641 & .257 & 2'-Dodecyl-1,1' 3' 1'"-tercyclopentane & .736 \\
\hline & UNK649 & .257 & 2'-Dodecyl-1,1' 3' '"'-tercyclopentane & .711 \\
\hline & UNK662 & .129 & Missing data & \\
\hline & UNK662 & .514 & Missing data & \\
\hline & UNK672 & .129 & Missing data & \\
\hline & UNK683 & .129 & Missing data & \\
\hline & UNK683 & .129 & Missing data & \\
\hline \multirow[t]{3}{*}{ CISOIL15 } & UNK034 & .004 & Carbamic acid 2-propenyl ester & .845 \\
\hline & UNK257 & .008 & Nonanol & .991 \\
\hline & UNK283 & .012 & Dimethyl-1-octanol & .810 \\
\hline
\end{tabular}


Table 23. Tentative identification of unknown organic compounds in soil from selected sampling sites at Carroll Island, Aberdeen Proving Ground, Md., summer 1990--Continued

\begin{tabular}{|c|c|c|c|c|}
\hline $\begin{array}{l}\text { Sampling site } \\
\text { (fig. 5) }\end{array}$ & UNK number & Concentration & Tentative identification & $\mathbf{R}$ \\
\hline \multirow[t]{5}{*}{ CISOIL15--Continued } & UNK528 & 2.4 & Missing data & \\
\hline & UNK536 & 2.4 & Missing data & \\
\hline & UNK538 & 2.4 & Missing data & \\
\hline & UNK541 & 1.2 & Missing data & \\
\hline & UNK547 & .24 & Missing data & \\
\hline \multirow[t]{9}{*}{ CISOIL115 } & UNK034 & .002 & Pentanal & 0.845 \\
\hline & UNK257 & .006 & Nonanal & .993 \\
\hline & UNK284 & .011 & Decanal & .989 \\
\hline & UNK528 & 2.37 & Missing data & \\
\hline & UNK536 & 2.37 & Missing data & \\
\hline & UNK538 & 2.37 & Missing data & \\
\hline & UNK541 & 1.07 & Missing data & \\
\hline & UNK547 & .473 & Missing data & \\
\hline & UNK650 & .237 & Missing data & \\
\hline \multirow[t]{8}{*}{ CISOIL16 } & UNK034 & .003 & Carbamic acid 2-propenyl ester & .876 \\
\hline & UNK257 & .004 & Nonanal & .993 \\
\hline & UNK284 & .007 & Decanal & .994 \\
\hline & UNK528 & 2.65 & Missing data & \\
\hline & UNK536 & 2.65 & Missing data & \\
\hline & UNK538 & 2.65 & Missing data & \\
\hline & UNK541 & 1.19 & Missing data & \\
\hline & UNK547 & .398 & Missing data & \\
\hline \multirow[t]{9}{*}{ CISOIL17 } & UNK034 & .005 & Pentanal & .815 \\
\hline & UNK257 & .005 & Nonanal & .993 \\
\hline & UNK284 & .009 & Decanal & .987 \\
\hline & UNK528 & 2.43 & Missing data & \\
\hline & UNK536 & 2.43 & Missing data & \\
\hline & UNK538 & 2.43 & Missing data & \\
\hline & UNK541 & .851 & Missing data & \\
\hline & UNK547 & .608 & Missing data & \\
\hline & UNK747 & 3.65 & Missing data & \\
\hline \multirow[t]{6}{*}{ CISOIL18 } & UNK019 & .007 & Methylhydrazine oxalate (1:1) & .773 \\
\hline & UNK135 & .002 & Cyanoacetic acid & .927 \\
\hline & UNK250 & .004 & Benzoic acid hydrazide & .868 \\
\hline & UNK276 & .005 & Heptanal & .859 \\
\hline & UNK528 & .491 & 2,4-Dimethyl-1,3-dioxolane-2-methanol & .840 \\
\hline & UNK541 & .246 & 2,4-Dimethyl-3-heptanone & .743 \\
\hline \multirow[t]{14}{*}{ CISOIL19 } & UNK019 & .005 & Trinitro-methane & .639 \\
\hline & UNK250 & .009 & Nonanal & .910 \\
\hline & UNK275 & .011 & Decanal & .975 \\
\hline & UNK528 & 3.94 & Missing data & \\
\hline & UNK529 & .263 & 2-Methyl-heptane & .745 \\
\hline & UNK529 & .263 & 2,4-Dimethyl-2-pentanol & .775 \\
\hline & UNK535 & .394 & 1,1,2,2-Tetrachloroethane & .976 \\
\hline & UNK535 & .394 & 4-Chloro-4,4-difluoro-4-butanone & .790 \\
\hline & UNK536 & 2.63 & 2,4-Pentanedione & .864 \\
\hline & UNK536 & 2.63 & 1-(3-Ethyloxyranyl) & .874 \\
\hline & UNK538 & .92 & 5-Methyl-5-hexen-2-one & .787 \\
\hline & UNK541 & 1.31 & trans-Diacetate tetrahydro- $2 \mathrm{H}$-pyran-2,3-diol & .846 \\
\hline & UNK547 & 2.63 & Hydroxy-hexanoic acid methyl ester & .789 \\
\hline & UNK641 & .263 & Octadecanal & .931 \\
\hline \multirow[t]{2}{*}{ CISOIL20 } & UNK 127 & .007 & 3-Methyl-2-butanone & .971 \\
\hline & UNK217 & .016 & 2-Methyl-5-(1-methylethyl)-bicyclo[3.1.0]hex-2-ene & .925 \\
\hline
\end{tabular}


Table 23. Tentative identification of unknown organic compounds in soil from selected sampling sites at Carroll Island, Aberdeen Proving Ground, Md., summer 1990--Continued

\begin{tabular}{|c|c|c|c|c|}
\hline $\begin{array}{l}\text { Sampling site } \\
\text { (fig. 5) }\end{array}$ & UNK number & Concentration & Tentative identification & $\mathbf{R}$ \\
\hline \multirow[t]{36}{*}{ CISOIL20--Continued } & UNK223 & 0.005 & Missing data & \\
\hline & UNK227 & .082 & 2-Propenyl benzene & 0.986 \\
\hline & UNK254 & .033 & 1-Methyl-3-(1-methylethyl)-benzene & .961 \\
\hline & UNK258 & .016 & 1,1'-(1-Ethenyl-1,3-propanediyl)bis-benzene & .970 \\
\hline & UNK319 & .007 & Missing data & \\
\hline & UNK334 & .131 & Missing data & \\
\hline & UNK 528 & 4.92 & 2,4-Dimethyl-2-pentanol & .778 \\
\hline & UNK531 & .984 & Heptanoic acid & .949 \\
\hline & UNK535 & .82 & Missing data & \\
\hline & UNK537 & 1.48 & 5-Methyl-3-hexen-2-one & .821 \\
\hline & UNK537 & 1.64 & 3,6,6-Trimethylbicyclo[3.1.1]hept-2-ene & .982 \\
\hline & UNK569 & .82 & Missing data & \\
\hline & UNK 583 & .82 & Missing data & \\
\hline & UNK590 & 4.92 & Decahydro-4a-methyl-8-methylene-2...1-naphthalenol & .827 \\
\hline & UNK591 & 1.64 & $1,2,3,4,4 \mathrm{a}, 7,8,8 \mathrm{a}$-Octahydro-1,6-d...1-naphthalenol & .971 \\
\hline & UNK598 & .82 & Missing data & \\
\hline & UNK623 & 3.28 & Phosphonic acid dioctadecyl ester & .812 \\
\hline & UNK630 & 6.56 & (2-Methyl-1-methylenepropyl)-benzene & .661 \\
\hline & UNK633 & 11.5 & (E)-9-Eicosene & .976 \\
\hline & UNK634 & .82 & Missing data & \\
\hline & UNK639 & 1.64 & Phosphonic acid dioctadecyl ester & .946 \\
\hline & UNK647 & 32.8 & (E)-9-Eicosene & .976 \\
\hline & UNK653 & .82 & Missing data & \\
\hline & UNK655 & 1.48 & Decanedioic acid didecyl ester & .896 \\
\hline & UNK656 & 1.48 & Phosphonic acid dioctadecyl ester & .940 \\
\hline & UNK660 & 1.64 & Missing data & \\
\hline & UNK667 & 16.4 & Tricarbonyl N-(phenyl-2-pyridinylmethylene) iron & .971 \\
\hline & UNK667 & 32.8 & 5-Cyclohexyl-5-cyclohexyl-dodecane & .913 \\
\hline & UNK669 & 1.64 & 5-Cyclohexyl-5-cyclohexyl-undecane & .840 \\
\hline & UNK680 & 1.64 & Decanedioic acid didecyl ester & .891 \\
\hline & UNK687 & 16.4 & Hexadecanal & .969 \\
\hline & UNK697 & 6.56 & Tetratetracontane & .989 \\
\hline & UNK698 & 1.64 & Decanedioic acid didecyl ester & .892 \\
\hline & UNK 7,28 & 1.64 & Octadecanal & .962 \\
\hline & UNK742 & 1.48 & Missing data & \\
\hline & UNK750 & 1.48 & Missing data & \\
\hline \multirow[t]{15}{*}{ CISOIL21 } & UNK320 & .004 & Decanal & .880 \\
\hline & UNK334 & .005 & $(Z, E)$ 3,7,11-Trimethyl-1,3,6,10-dodecatetraene & .764 \\
\hline & UNK528 & .27 & Acetic acid 1-methylethyl ester & .656 \\
\hline & UNK530 & 4.04 & 2,4-Dimethyl-1,3-dioxolane-2-methanol & .839 \\
\hline & UNK537 & .539 & 1-(3-Ethyloxyranyl)-ethanone & .861 \\
\hline & UNK539 & .809 & 5-Methyl 5-hexen-2-one & .815 \\
\hline & UNK540 & .27 & 5-Methyl 3-hexen-2-one & .847 \\
\hline & UNK542 & .404 & trans-Diacetate tetrahydro- $2 H$-pyran-2,3-diol & .841 \\
\hline & UNK552 & .135 & 2-Ethyl-hexanoic acid & .526 \\
\hline & UNK569 & .135 & (2-Hydroxy-5-methylphenyl)-ethanone & .767 \\
\hline & UNK577 & .135 & 4,11,11-Trimethyl-8-me...bicyclo[7.2.0]undec-4-ene & .950 \\
\hline & UNK591 & .135 & 2-Dodecenal & .699 \\
\hline & UNK622 & .27 & 1,2-Octanediol & .744 \\
\hline & UNK633 & 1.35 & Missing data & \\
\hline & UNK650 & 2.7 & Missing data & \\
\hline \multirow[t]{2}{*}{ CISOIL22 } & UNK258 & .005 & Nonanal & .994 \\
\hline & UNK284 & .007 & Decanal & .990 \\
\hline
\end{tabular}


Table 23. Tentative identification of unknown organic compounds in soil from selected sampling sites at Carroll Island, Aberdeen Proving Ground, Md., summer 1990--Continued

\begin{tabular}{|c|c|c|c|c|}
\hline $\begin{array}{l}\text { Sampling site } \\
\text { (fig. 5) }\end{array}$ & UNK number & Concentration & Tentative identification & $\mathbf{R}$ \\
\hline \multirow[t]{6}{*}{ C1SOIL22--Continued } & UNK528 & 2.48 & 2,4-Dimethyl-1,3-dioxolane-2-methanol & 0.840 \\
\hline & UNK529 & .124 & 3,4-Dimethyl heptane & .890 \\
\hline & UNK536 & 2.48 & 2,4-Pentanedione & .877 \\
\hline & UNK538 & 1.24 & 5-Methyl 5-hexen-2-one & .774 \\
\hline & UNK541 & 1.12 & trans-Diacetate tetrahydro- $2 \mathrm{H}$-pyran-2,3-diol & .849 \\
\hline & UNK547 & .868 & 1-Oxiranyl-ethanone & .675 \\
\hline \multirow[t]{23}{*}{ CISOIL23 } & UNK023 & .010 & Amphetamine & .741 \\
\hline & UNK 186 & .012 & $\alpha$-pinene & .956 \\
\hline & UNK528 & .248 & 1,I-Dipropoxy-propane & .844 \\
\hline & UNK528 & 6.19 & 2,6,8-Trimethyl-decane & .888 \\
\hline & UNK530 & .248 & 2-Methyl-octane & .962 \\
\hline & UNK530 & .495 & 2,3-Dimethyl-heptane & .953 \\
\hline & UNK530 & .495 & 3,4-Dimethyl-heptane & .983 \\
\hline & UNK531 & .371 & 3-Methyl-octane & .986 \\
\hline & UNK536 & 1.11 & 2-Bromo-hexane & .865 \\
\hline & UNK537 & .743 & 5-Methyl-3-hexen-2-one & .788 \\
\hline & UNK538 & .124 & 5-Methyl-3-hexen-2-one & .852 \\
\hline & UNK541 & .866 & trans-Diacetate tetrahydro- $2 H$-pyran-2,3-diol & .843 \\
\hline & UNK547 & .248 & $\mathrm{~N}$-acetyl-dl-alloisoleucine & .715 \\
\hline & UNK581 & .371 & Octahyd...1H-cyclopenta 1,3 cyclopropa 1,2 benzene & .948 \\
\hline & UNK604 & .371 & 10-Octadecenoic acid methyl ester & .947 \\
\hline & UNK605 & .248 & 12-(Acetyloxy)-9-octadecenoic acid methyl este... & .948 \\
\hline & UNK614 & .248 & 9-Octadecenoic acid $(Z)$-methyl ester & .964 \\
\hline & UNK630 & 2.48 & (2-Methyl-1-methylenepropyl)-benzene & .742 \\
\hline & UNK642 & .248 & Octadecanal & .975 \\
\hline & UNK660 & .248 & $(Z, Z)-9,12$-Octadecadienoic acid & .837 \\
\hline & UNK667 & .248 & Heptacosane & .967 \\
\hline & UNK697 & .124 & Heptacosane & .967 \\
\hline & UNK740 & .743 & Decahydro-1,4a-dimethyl-7-(1-meth...1-napthalenol & .721 \\
\hline \multirow[t]{11}{*}{ C1SOIL24 } & UNK019 & .006 & Methylhydrazine oxalate $(1: 1)$ & .719 \\
\hline & UNK135 & .003 & Cyclobutanol & .905 \\
\hline & UNK250 & .006 & Nonanal & .827 \\
\hline & UNK276 & .006 & Decanal & .985 \\
\hline & UNK529 & 2.79 & 2,4-Dimethyl-2-pentanol & .787 \\
\hline & UNK536 & 2.79 & 2-Bromo-hexane & .872 \\
\hline & UNK538 & .557 & 5-Methyl-5-hexen-2-one & .786 \\
\hline & UNK 542 & 2.79 & trans-Diacetate tetrahydro- $2 \mathrm{H}$-pyran-2,3-diol & .864 \\
\hline & UNK548 & .279 & Meth...Methyl $\alpha$-d-glucopyranosiduronic acid & .678 \\
\hline & UNK615 & .279 & (Z)-9-Octadecenoic acid & .912 \\
\hline & UNK616 & .279 & Octadecanoic acid & .863 \\
\hline \multirow[t]{10}{*}{ C1SOIL25 } & UNK019 & .004 & Cyanoacetic acid & .819 \\
\hline & UNK249 & .004 & 5-Methyl-1-hexene & .730 \\
\hline & UNK275 & .005 & Decanal & .978 \\
\hline & UNK529 & 3.86 & 2,4-Dimethyl-2-pentanol & .793 \\
\hline & UNK536 & 2.57 & 2-Bromo-hexane & .866 \\
\hline & UNK538 & .386 & 5-Methyl-5-hexen-2-one & .791 \\
\hline & UNK542 & 1.29 & trans-Diacetate tetrahydro- $2 \mathrm{H}$-pyran-2,3-diol & .860 \\
\hline & UNK548 & .386 & 1,2-Ethanediol monoacetate & .730 \\
\hline & UNK615 & .257 & 1,1'-(2-Ethyl-1,3-propanediyl)bis-cyclohexane & .793 \\
\hline & UNK616 & .129 & Octadecanoic acid & .878 \\
\hline \multirow[t]{3}{*}{ CISOIL27 } & UNK020 & .005 & Methylhydrazine oxalate $(1: 1)$ & .728 \\
\hline & UNK250 & .004 & 1-Heptene & .657 \\
\hline & UNK275 & .004 & Decanal & .978 \\
\hline
\end{tabular}


Table 23. Tentative identification of unknown organic compounds in soil from selected sampling sites at Carroll Island, Aberdeen Proving Ground, Md., summer 1990--Continued

\begin{tabular}{|c|c|c|c|c|}
\hline $\begin{array}{l}\text { Sampling site } \\
\text { (fig. 5) }\end{array}$ & UNK number & Concentration & Tentative identification & $\mathbf{R}$ \\
\hline \multirow[t]{14}{*}{ CISOIL27--Continued } & UNK528 & 2.38 & 2,4-Dimethyl-2-pentanol & 0.783 \\
\hline & UNK536 & .715 & Missing data & \\
\hline & UNK538 & 1.07 & Missing data & \\
\hline & UNK542 & 3.58 & trans-Diacetate tetrahydro- $2 \mathrm{H}$-pyran-2,3-diol & .857 \\
\hline & UNK543 & .238 & Missing data & \\
\hline & UNK610 & .119 & Missing data & \\
\hline & UNK615 & .238 & Missing data & \\
\hline & UNK622 & .238 & Missing data & \\
\hline & UNK622 & .477 & Missing data & \\
\hline & UNK623 & .238 & Missing data & \\
\hline & UNK624 & .954 & Bis(4-methylpentyl) 1,2-benzenedicarboxylic acid & .989 \\
\hline & UNK625 & .477 & Bis(4-methylpentyl) 1,2-benzenedicarboxylic acid & .983 \\
\hline & UNK625 & .715 & Missing data & \\
\hline & UNK626 & .596 & Bis(4-methylpentyl) 1,2-benzenedicarboxylic acid & .955 \\
\hline \multirow[t]{8}{*}{ CISOIL28 } & UNK013 & .002 & Methylhydrazine oxalate (1:1) & .650 \\
\hline & UNK025 & .002 & N,3-Dimethyl 1-butanamine & .505 \\
\hline & UNK250 & .002 & Benzoic acid hydrazide & .929 \\
\hline & UNK529 & 2.14 & 2,4-Dimethyl-2-pentanol & .790 \\
\hline & UNK536 & .214 & 2-Bromo-hexane & .922 \\
\hline & UNK538 & 2.14 & 5-Methyl-3-hexen-2-one & .787 \\
\hline & UNK539 & .214 & 5-Methyl-3-hexen-2-one & .846 \\
\hline & UNK542 & 2.14 & trans-Diacetate tetrahydro- $2 \mathrm{H}$-pyran-2,3-diol & .807 \\
\hline \multirow[t]{11}{*}{ CISOIL29 } & UNK034 & .004 & Pentanal & .861 \\
\hline & UNK078 & .004 & Acetamide & .829 \\
\hline & UNK 163 & .002 & Hexanal & .990 \\
\hline & UNK228 & .004 & Missing data & \\
\hline & UNK257 & .012 & Nonanal & .991 \\
\hline & UNK283 & .024 & Decanal & .990 \\
\hline & UNK528 & 2.39 & Missing data & \\
\hline & UNK536 & 2.39 & 2-Bromo-hexane & \\
\hline & UNK538 & 2.39 & Missing data & \\
\hline & UNK541 & 1.19 & Missing data & \\
\hline & UNK547 & .478 & Missing data & \\
\hline
\end{tabular}

